Comparative Effectiveness Review

Number 192

\title{
Anxiety in Children
}
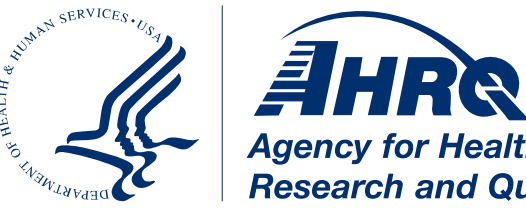

Agency for Healthcare

Research and Quality
Effective Health

Care Program 


\section{Comparative Effectiveness Review}

Number 192

\section{Anxiety in Children}

Prepared for:

Agency for Healthcare Research and Quality

U.S. Department of Health and Human Services

5600 Fishers Lane

Rockville, MD 20857

www.ahrq.gov

Contract No. 290-2015-00013-I

Prepared by:

Mayo Clinic Evidence-based Practice Center

Rochester, MN

Investigators:

Zhen Wang, Ph.D.

Stephen Whiteside, Ph.D., L.P.

Leslie Sim, Ph.D., L.P.

Wigdan Farah, M.B.B.S.

Allison Morrow, B.A.

Mouaz Alsawas, M.D., M.Sc.

Patricia Barrionuevo Moreno, M.D.

Mouaffaa Tello, M.D.

Noor Asi, M.D.

Bradley Beuschel, B.S.P.H.

Lubna Daraz, Ph.D.

Jehad Almasri, M.D.

Feras Zaiem, M.D.

Shalak Gunjal, M.S.

Laura Larrea Mantilla, M.D.

Oscar Ponce Ponte, M.D.

Annie LeBlanc, Ph.D.

Larry J. Prokop, M.L.S.

M. Hassan Murad, M.D., M.P.H.

AHRQ Publication No. 17-EHC023-EF

August 2017

Erratum July 2018 


\section{Erratum}

The following corrections were made to this report.

The sentence in the Structured Abstract, CBT “was more likely to increase remission than sertraline,” was deleted.

On page 16, under Results, Drugs Versus CBT, Key Points and Discussion, “CBT was more likely to increase remission than sertraline (moderate SOE)," was deleted.

In Table 8, Sertraline (class: SSRI) vs. CBT, relative risk (RR) for response was changed to 0.92 (95\%

CI: 0.75 to 1.13 ). RR for remission was changed to 1.00 (95\% CI: 0.77 to 1.29 ). Overall evidence strength was changed to low (no difference).

Here is Table 8 with the changes highlighted in yellow and also indicated with an asterisk in the cell. 
Table 8. Strength of evidence for drugs versus CBT

\begin{tabular}{|c|c|c|c|c|c|}
\hline Comparison & Outcome & Conclusion & $\begin{array}{l}\text { Study Design and } \\
\text { Sample Size }\end{array}$ & $\begin{array}{l}\text { Factors That } \\
\text { Affect the } \\
\text { Strength of } \\
\text { Evidence }^{b}\end{array}$ & $\begin{array}{c}\text { Overall } \\
\text { Evidence } \\
\text { Strength } \\
\text { (Direction of } \\
\text { Effect) }\end{array}$ \\
\hline \multirow[t]{5}{*}{$\begin{array}{l}\text { Fluoxetine } \\
\text { (class: SSRI) } \\
\text { vs. CBT }\end{array}$} & $\begin{array}{l}\text { Primary } \\
\text { anxiety, child } \\
\text { report }\end{array}$ & $\begin{array}{l}\text { SMD:-0.16; } \\
95 \% \mathrm{Cl}:-0.55 \\
\text { to } 0.24 ; \\
\mathrm{I}^{2}=\mathrm{N} / \mathrm{A}\end{array}$ & 1 RCT (102 Patients) ${ }^{51}$ & $\begin{array}{l}\text { Severe } \\
\text { imprecision (wide } \\
\text { Cls and small } \\
\text { sample size) }\end{array}$ & $\begin{array}{l}\text { Low } \\
\text { (no difference) }\end{array}$ \\
\hline & $\begin{array}{l}\text { Primary } \\
\text { anxiety, } \\
\text { clinician } \\
\text { report }\end{array}$ & $\begin{array}{l}\text { SMD:0.78; } \\
95 \% \mathrm{Cl}: 0.37 \\
\text { to } 1.18 ; \\
\text { l2}^{2}=\mathrm{N} / \mathrm{A}\end{array}$ & 1 RCT (102 Patients) ${ }^{51}$ & $\begin{array}{l}\text { Imprecision } \\
\text { (small sample } \\
\text { size) }\end{array}$ & $\begin{array}{l}\text { Moderate } \\
\text { (increased } \\
\text { anxiety) }\end{array}$ \\
\hline & Function & $\begin{array}{l}\text { SMD: } 0.54 ; \\
95 \% \mathrm{Cl}: 0.14 \\
\text { to } 0.94 ; \\
\mathrm{I}^{2}=\mathrm{N} / \mathrm{A}\end{array}$ & 1 RCT (102 Patients) ${ }^{51}$ & $\begin{array}{l}\text { Imprecision } \\
\text { (small sample } \\
\text { size) }\end{array}$ & $\begin{array}{l}\text { Moderate } \\
\text { (reduced } \\
\text { function) }\end{array}$ \\
\hline & $\begin{array}{l}\text { Secondary } \\
\text { measure }\end{array}$ & $\begin{array}{l}\text { SMD: } 0.51 ; \\
95 \% \mathrm{Cl}: 0.11 \\
\text { to } 0.90 ; \\
\text { I2}^{2}=\mathrm{N} / \mathrm{A}\end{array}$ & 1 RCT (102 Patients) ${ }^{51}$ & $\begin{array}{l}\text { Imprecision } \\
\text { (small sample } \\
\text { size) }\end{array}$ & $\begin{array}{l}\text { Moderate } \\
\text { (increased } \\
\text { anxiety) }\end{array}$ \\
\hline & $\begin{array}{l}\text { Social } \\
\text { function }\end{array}$ & $\begin{array}{l}\text { SMD: }-0.19 ; \\
95 \% \mathrm{Cl}:-0.58 \\
\text { to } 0.21 ; \\
\text { I2=N/A }\end{array}$ & 1 RCT (102 Patients) ${ }^{51}$ & $\begin{array}{l}\text { Severe } \\
\text { imprecision (wide } \\
\text { Cls and small } \\
\text { sample size) }\end{array}$ & $\begin{array}{l}\text { Low } \\
\text { (no difference) }\end{array}$ \\
\hline \multirow[t]{4}{*}{$\begin{array}{l}\text { Sertraline } \\
\text { (class: SSRI) } \\
\text { vs. } \\
\text { CBT }\end{array}$} & $\begin{array}{l}\text { Primary } \\
\text { anxiety, } \\
\text { clinician } \\
\text { report }\end{array}$ & $\begin{array}{l}\text { SMD: }-0.15 ; \\
95 \% \mathrm{Cl}:-0.31 \\
\text { to } 0.02 ; I^{2}= \\
\text { N/A }\end{array}$ & $\begin{array}{l}1 \text { RCT (272 Patients) } \\
67,69-73\end{array}$ & $\begin{array}{l}\text { Severe } \\
\text { imprecision (wide } \\
\text { Cls and small } \\
\text { sample size) }\end{array}$ & $\begin{array}{l}\text { Low } \\
\text { (no difference) }\end{array}$ \\
\hline & Function & $\begin{array}{l}\text { SMD: }-0.12 ; \\
95 \% \mathrm{Cl}:-0.35 \\
\text { to } 0.12 ; I^{2}= \\
\text { N/A }\end{array}$ & $\begin{array}{l}1 \text { RCT (272 Patients) } \\
67,69-73\end{array}$ & $\begin{array}{l}\text { Severe } \\
\text { imprecision (wide } \\
\text { Cls and small } \\
\text { sample size) }\end{array}$ & $\begin{array}{l}\text { Low } \\
\text { (no difference) }\end{array}$ \\
\hline & Remission & $\begin{array}{l}\text { RR: } 1.00 ; \\
95 \% \mathrm{Cl}: \\
0.77 \text { to } 1.29 ; * \\
\text { I² }^{2} \text { N/A }\end{array}$ & $\begin{array}{l}1 \text { RCT (272 Patients) } \\
67,69-73\end{array}$ & $\begin{array}{l}\text { Severe } \\
\text { imprecision (wide } \\
\text { Cls and small } \\
\text { sample size)* }\end{array}$ & $\begin{array}{l}\text { Low } \\
\text { (no difference)* }\end{array}$ \\
\hline & Response & $\begin{array}{l}\text { RR: } 0.92 ; \\
95 \% \mathrm{Cl}: 0.75 \\
\text { to } 1.13 ; * \\
\mathrm{I}^{2}=\mathrm{N} / \mathrm{A}\end{array}$ & $\begin{array}{l}\text { 1 RCT (272 Patients) } \\
67,69-73\end{array}$ & $\begin{array}{l}\text { Severe } \\
\text { imprecision (wide } \\
\text { Cls and small } \\
\text { sample size) }\end{array}$ & $\begin{array}{l}\text { Low } \\
\text { (no difference) }\end{array}$ \\
\hline
\end{tabular}


On page 21, under Results, CBT Combined with Drugs, Discussion, the sentence, "One RCT of 272 patients compared the combination of CBT and sertraline to CBT, or to sertraline" was changed to "One RCT compared the combination of CBT and sertraline to CBT (279 patients), or to sertraline (273 patients)."

In Table 10, CBT + sertraline (class: SSRI) vs CBT, the number of patients was changed to 279. Relative risk (RR) of remission was changed to 1.51 (95\% CI: 1.22-1.86). Overall evidence strength was changed to moderate (improved remission). RR for response was changed to 1.35 (95\% CI: 1.15-1.58). CBT+ Sertraline (class: SSRI) vs. Sertraline (class: SSRI), RR of remission was changed to 1.51 (95\% CI: $1.22-$ 1.87). Overall evidence strength was changed to moderate (improved remission). RR for response was changed to 1.47 (95\% CI: 1.24-1.75).

Here is Table 10 with the changes highlighted in yellow.

Table 10. Strength of evidence for CBT combined with drugs

\begin{tabular}{|c|c|c|c|c|c|}
\hline Comparison & Outcome & Conclusion & $\begin{array}{l}\text { Study Design and } \\
\text { Sample Size }\end{array}$ & $\begin{array}{l}\text { Factors That } \\
\text { Affect the } \\
\text { Strength of } \\
\text { Evidence }^{b}\end{array}$ & $\begin{array}{l}\text { Overall } \\
\text { Evidence } \\
\text { Strength } \\
\text { (Direction of } \\
\text { Effect) }\end{array}$ \\
\hline \multirow[t]{3}{*}{$\begin{array}{l}\text { Imipramine } \\
\text { (class: TCA) + } \\
\text { CBT vs. CBT }\end{array}$} & $\begin{array}{l}\text { Primary } \\
\text { anxiety, child } \\
\text { report }\end{array}$ & $\begin{array}{l}\text { SMD: }-0.74 ; \\
95 \% \mathrm{Cl}:-1.26 \\
\text { to }-0.23 ; \\
\mathrm{I}^{2}=\mathrm{N} / \mathrm{A}\end{array}$ & 1 RCT (63 Patients) ${ }^{159}$ & $\begin{array}{l}\text { Imprecision (small } \\
\text { sample size) }\end{array}$ & $\begin{array}{l}\text { Moderate } \\
\text { (reduced anxiety) }\end{array}$ \\
\hline & $\begin{array}{l}\text { Primary } \\
\text { anxiety. } \\
\text { clinician report }\end{array}$ & $\begin{array}{l}\text { SMD: }-0.61 ; \\
95 \% \mathrm{Cl}:-1.11 \\
\text { to } 0.10 ; \\
1^{2}=\mathrm{N} / \mathrm{A}\end{array}$ & 1 RCT (63 Patients) ${ }^{159}$ & $\begin{array}{l}\text { Severe } \\
\text { imprecision (small } \\
\text { sample size and } \\
\text { wide } \mathrm{Cl} \text { ) }\end{array}$ & $\begin{array}{l}\text { Low } \\
\text { (no difference) }\end{array}$ \\
\hline & Function & $\begin{array}{l}\text { SMD: }-1.27 ; \\
95 \% \mathrm{Cl}:-1.81 \\
\text { to }-0.73 ; \\
1^{2}=\mathrm{N} / \mathrm{A}\end{array}$ & 1 RCT (63 Patients) ${ }^{159}$ & $\begin{array}{l}\text { Imprecision (small } \\
\text { sample size) }\end{array}$ & $\begin{array}{l}\text { Moderate } \\
\text { (improved } \\
\text { function) }\end{array}$ \\
\hline \multirow[t]{4}{*}{$\begin{array}{l}\text { Fluoxetine } \\
\text { (class: SSRI) + } \\
\text { CBT vs. CBT }\end{array}$} & Function & $\begin{array}{l}\text { SMD: }-0.13 ; \\
95 \% \mathrm{Cl}:-0.74 \\
\text { to } 0.48 ; \\
1^{2}=\mathrm{N} / \mathrm{A}\end{array}$ & 1 RCT (41 Patients) ${ }^{160}$ & $\begin{array}{l}\text { Severe } \\
\text { imprecision (small } \\
\text { sample size and } \\
\text { wide } \mathrm{Cl} \text { ) }\end{array}$ & $\begin{array}{l}\text { Low } \\
\text { (no difference) }\end{array}$ \\
\hline & $\begin{array}{l}\text { Secondary } \\
\text { measure }\end{array}$ & $\begin{array}{l}\text { SMD: }-0.03 ; \\
95 \% \mathrm{Cl}:-0.59 \\
\text { to } 0.64 ; \\
\mathrm{I}^{2}=\mathrm{N} / \mathrm{A}\end{array}$ & 1 RCT (41 Patients) ${ }^{160}$ & $\begin{array}{l}\text { Severe } \\
\text { imprecision (small } \\
\text { sample size and } \\
\text { wide } \mathrm{Cl} \text { ) }\end{array}$ & $\begin{array}{l}\text { Low } \\
\text { (no difference) }\end{array}$ \\
\hline & Response & $\begin{array}{l}\text { RR: } 1.71 ; \\
96 \% \mathrm{Cl}: 0.69 \\
\text { to } 4.24 ; \\
\mathrm{l}^{2}=\mathrm{N} / \mathrm{A}\end{array}$ & 1 RCT (41 Patients) ${ }^{160}$ & $\begin{array}{l}\text { Severe } \\
\text { imprecision (small } \\
\text { sample size and } \\
\text { wide } \mathrm{Cl} \text { ) }\end{array}$ & $\begin{array}{l}\text { Low } \\
\text { (no difference) }\end{array}$ \\
\hline & Remission & $\begin{array}{l}\text { RR: } 0.24 ; \\
95 \% \mathrm{Cl}: 0.06 \\
\text { to } 0.99 ; \\
\mathrm{l}^{2}=\mathrm{N} / \mathrm{A}\end{array}$ & 1 RCT (41 Patients) ${ }^{160}$ & $\begin{array}{l}\text { Severe } \\
\text { imprecision (small } \\
\text { sample size and } \\
\text { wide } \mathrm{Cl} \text { ) }\end{array}$ & $\begin{array}{l}\text { Low } \\
\text { (reduced } \\
\text { remission) }\end{array}$ \\
\hline \multirow[t]{2}{*}{$\begin{array}{l}\text { CBT + } \\
\text { Sertraline } \\
\text { (class: SSRI) } \\
\text { vs. CBT }\end{array}$} & $\begin{array}{l}\text { Primary } \\
\text { anxiety, } \\
\text { clinician report }\end{array}$ & $\begin{array}{l}\text { SMD: }-0.69 ; \\
95 \% \mathrm{Cl}:-0.93 \\
\text { to }-0.45 ; \\
\mathrm{I}^{2}=\mathrm{N} / \mathrm{A}\end{array}$ & $\begin{array}{l}\text { 1 RCT (279 Patients) } \\
67,69-73\end{array}$ & $\begin{array}{l}\text { Imprecision (small } \\
\text { sample size) }\end{array}$ & $\begin{array}{l}\text { Moderate } \\
\text { (reduced anxiety) }\end{array}$ \\
\hline & Function & $\begin{array}{l}\text { SMD: }-0.47 ; \\
95 \% \text { Cl: }-0.70 \\
\text { to }-0.23 ; \\
1^{2}=N / A\end{array}$ & ${ }_{67,69-73}^{1}$ RCT (279 Patients) & $\begin{array}{l}\text { Imprecision (small } \\
\text { sample size) }\end{array}$ & $\begin{array}{l}\text { Moderate } \\
\text { (improved } \\
\text { function) }\end{array}$ \\
\hline
\end{tabular}




\begin{tabular}{|c|c|c|c|c|c|}
\hline Comparison & Outcome & Conclusion & $\begin{array}{l}\text { Study Design and } \\
\text { Sample Size }\end{array}$ & $\begin{array}{l}\text { Factors That } \\
\text { Affect the } \\
\text { Strength of } \\
\text { Evidence }^{b}\end{array}$ & $\begin{array}{c}\text { Overall } \\
\text { Evidence } \\
\text { Strength } \\
\text { (Direction of } \\
\text { Effect) }\end{array}$ \\
\hline & Remission & $\begin{array}{l}\text { RR: } 1.51 ; \\
95 \% \mathrm{Cl}: 1.22 \\
\text { to } 1.86 ; \\
\mathrm{I}^{2}=\mathrm{N} / \mathrm{A}\end{array}$ & $\begin{array}{l}1 \text { RCT (279 Patients) } \\
67,69-73\end{array}$ & $\begin{array}{l}\text { Imprecision (small } \\
\text { sample size) }\end{array}$ & $\begin{array}{l}\text { Moderate } \\
\text { (improved } \\
\text { remission) }\end{array}$ \\
\hline & Response & $\begin{array}{l}\text { RR: } 1.35 ; \\
95 \% \mathrm{Cl}: 1.15 \\
\text { to } 1.58 ; \\
\mathrm{I}^{2}=\mathrm{N} / \mathrm{A}\end{array}$ & $\begin{array}{l}1 \text { RCT (279 Patients) } \\
67,69-73\end{array}$ & $\begin{array}{l}\text { Imprecision (small } \\
\text { sample size) }\end{array}$ & $\begin{array}{l}\text { Moderate } \\
\text { (improved } \\
\text { response) }\end{array}$ \\
\hline \multirow[t]{4}{*}{$\begin{array}{l}\text { CBT+ } \\
\text { Sertraline } \\
\text { (class: SSRI) } \\
\text { vS. Sertraline } \\
\text { (class: SSRI) }\end{array}$} & $\begin{array}{l}\text { Primary } \\
\text { anxiety, } \\
\text { clinician report }\end{array}$ & $\begin{array}{l}\text { SMD: }-0.46 ; \\
95 \% \text { Cl: }-0.70 \\
\text { to }-0.22 ; \\
\mathrm{I}^{2}=\mathrm{N} / \mathrm{A}\end{array}$ & $\begin{array}{l}\text { 1 RCT (273 Patients) } \\
67,69-73\end{array}$ & $\begin{array}{l}\text { Imprecision (small } \\
\text { sample size) }\end{array}$ & $\begin{array}{l}\text { Moderate } \\
\text { (reduced anxiety) }\end{array}$ \\
\hline & Function & $\begin{array}{l}\text { SMD: }-0.34 ; \\
95 \% \text { Cl: }-0.58 \\
\text { to }-0.10 ; \\
I^{2}=N / A\end{array}$ & $\begin{array}{l}\text { 1 RCT (273 Patients) } \\
67,69-73\end{array}$ & $\begin{array}{l}\text { Imprecision (small } \\
\text { sample size) }\end{array}$ & $\begin{array}{l}\text { Moderate } \\
\text { (improved } \\
\text { function) }\end{array}$ \\
\hline & Remission & $\begin{array}{l}\text { RR: } 1.51 ; \\
95 \% \mathrm{Cl}: 1.22, \\
1.87 ; \mathrm{I}^{2}=\mathrm{N} / \mathrm{A}\end{array}$ & $\begin{array}{l}\text { 1 RCT (273 Patients) } \\
67,69-73\end{array}$ & $\begin{array}{l}\text { Severe } \\
\text { imprecision (wide } \\
\text { Cls and small } \\
\text { sample size) }\end{array}$ & $\begin{array}{l}\text { Moderate } \\
\text { (improved } \\
\text { remission) }\end{array}$ \\
\hline & Response & $\begin{array}{l}\text { RR: } 1.47 ; \\
95 \% \text { Cl: } 1.24 \\
\text { to } 1.75 ; \\
I^{2}=N / A\end{array}$ & $\begin{array}{l}1 \text { RCT (273 Patients) } \\
67,69-73\end{array}$ & $\begin{array}{l}\text { Imprecision (small } \\
\text { sample size) }\end{array}$ & $\begin{array}{l}\text { Moderate } \\
\text { (improved } \\
\text { response) }\end{array}$ \\
\hline
\end{tabular}


This report is based on research conducted by the Mayo Clinic Evidence-based Practice Center (EPC) under contract to the Agency for Healthcare Research and Quality (AHRQ), Rockville, MD (Contract No. 290-2015-00013-I). The findings and conclusions in this document are those of the authors, who are responsible for its contents; the findings and conclusions do not necessarily represent the views of AHRQ. Therefore, no statement in this report should be construed as an official position of AHRQ or of the U.S. Department of Health and Human Services.

\section{None of the investigators have any affiliations or financial involvement that conflicts with the material presented in this report.}

The information in this report is intended to help health care decisionmakers - patients and clinicians, health system leaders, and policymakers, among others-make well-informed decisions and thereby improve the quality of health care services. This report is not intended to be a substitute for the application of clinical judgment. Anyone who makes decisions concerning the provision of clinical care should consider this report in the same way as any medical reference and in conjunction with all other pertinent information, i.e., in the context of available resources and circumstances presented by individual patients.

This report is made available to the public under the terms of a licensing agreement between the author and the Agency for Healthcare Research and Quality. This report may be used and reprinted without permission except those copyrighted materials that are clearly noted in the report. Further reproduction of those copyrighted materials is prohibited without the express permission of copyright holders.

AHRQ or U.S. Department of Health and Human Services endorsement of any derivative products that may be developed from this report, such as clinical practice guidelines, other quality enhancement tools, or reimbursement or coverage policies, may not be stated or implied.

This report may periodically be assessed for the currency of conclusions. If an assessment is done, the resulting surveillance report describing the methodology and findings will be found on the Effective Health Care Program Web site at www.effectivehealthcare.ahrq.gov. Search on the title of the report.

Persons using assistive technology may not be able to fully access information in this report. For assistance contact EffectiveHealthCare@ahrq.hhs.gov.

Suggested citation: Wang Z, Whiteside S, Sim L, Farah W, Morrow A, Alsawas M, Barrionuevo Moreno P, Tello M, Asi N, Beuschel B, Daraz L, Almasri J, Zaiem F, Gunjal S, Larrea Mantilla L, Ponce Ponte O, LeBlanc A, Prokop LJ, Murad MH. Anxiety in Children. Comparative Effectiveness Review No. 192. (Prepared by the Mayo Clinic Evidence-based Practice Center under Contract No. 290-2015-00013-I.) AHRQ Publication No. 17-EHC023EF. Rockville, MD: Agency for Healthcare Research and Quality; August 2017. Erratum July 2018. www.effectivehealthcare.ahrq.gov/reports/final.cfm.

DOI: https://doi.org/10.23970/AHRQEPCCER192. 


\section{Preface}

The Agency for Healthcare Research and Quality (AHRQ), through its Evidence-based Practice Centers (EPCs), sponsors the development of systematic reviews to assist public- and private-sector organizations in their efforts to improve the quality of health care in the United States. These reviews provide comprehensive, science-based information on common, costly medical conditions, and new health care technologies and strategies.

Systematic reviews are the building blocks underlying evidence-based practice; they focus attention on the strength and limits of evidence from research studies about the effectiveness and safety of a clinical intervention. In the context of developing recommendations for practice, systematic reviews can help clarify whether assertions about the value of the intervention are based on strong evidence from clinical studies. For more information about AHRQ EPC systematic reviews, see www.effectivehealthcare.ahrq.gov/reference/purpose.cfm.

AHRQ expects that these systematic reviews will be helpful to health plans, providers, purchasers, government programs, and the health care system as a whole. Transparency and stakeholder input are essential to the Effective Health Care Program. Please visit the Web site (www.effectivehealthcare.ahrq.gov) to see draft research questions and reports or to join an email list to learn about new program products and opportunities for input.

If you have comments on this systematic review, they may be sent by mail to the Task Order Officers named below at: Agency for Healthcare Research and Quality, 5600 Fishers Lane, Rockville, MD 20857, or by email to epc@ahrq.hhs.gov.

Gopal Khanna, M.B.A.

Director

Agency for Healthcare Research and Quality

Stephanie Chang, M.D., M.P.H.

Director

Evidence-based Practice Center Program

Center for Evidence and Practice

Improvement

Agency for Healthcare Research and Quality

David W. Niebuhr, M.D., M.P.H., M.Sc.

Task Order Officer

Center for Evidence and Practice

Improvement

Agency for Healthcare Research and Quality
Arlene S. Bierman, M.D., M.S.

Director

Center for Evidence and Practice Improvement

Agency for Healthcare Research and Quality

Suchitra Iyer, Ph.D.

Task Order Officer

Center for Evidence and Practice

Improvement

Agency for Healthcare Research and Quality 


\section{Key Informants}

In designing the study questions, the EPC consulted several Key Informants who represent the end-users of research. The EPC sought the Key Informant input on the priority areas for research and synthesis. Key Informants are not involved in the analysis of the evidence or the writing of the report. Therefore, in the end, study questions, design, methodological approaches, and/or conclusions do not necessarily represent the views of individual Key Informants.

Key Informants must disclose any financial conflicts of interest greater than $\$ 10,000$ and any other relevant business or professional conflicts of interest. Because of their role as end-users, individuals with potential conflicts may be retained. The TOO and the EPC work to balance, manage, or mitigate any conflicts of interest.

The list of Key Informants who provided input to this report follows:

Lynn F. Bufka, Ph.D.

American Psychological Association

Washington, DC

Lauren G. Caldwell, J.D., Ph.D.

American Psychological Association

Washington, DC

Elizabeth Edgerton, M.D.

Health Resources and Services

Administration

Rockville, MD

Stephanie C. Eken, M.D., FAAP

Rogers Behavioral Health

Tampa, FL

Raquel Halfond, Ph.D.*

American Psychological Association

Washington, DC

Adrienne Kennedy, M.A.

National Alliance on Mental Illness

Austin, TX

Anna E. Ordóñez, M.D., M.A.S.

National Institute of Mental Health

Bethesda, MD

*Provided input on Draft Report.
Judith L. Rapoport, M.D.

National Institute of Mental Health

Bethesda, MD

Moira A. Rynn, M.D.*

Chair of Department of Psychiatry \&

Behavioral Sciences

Duke University Medical Center

Durham, NC

Joel Sherrill, Ph.D.

National Institute of Mental Health

Bethesda, MD

Elizabeth Sweet, M.Ed.

Substance Abuse and Mental Health

Services Administration

Rockville, MD

Jing Zhang, M.D., Ph.D.

Food and Drug Administration

Silver Spring, MD 


\section{Technical Expert Panel}

In designing the study questions and methodology at the outset of this report, the EPC consulted several technical and content experts. Broad expertise and perspectives were sought. Divergent and conflicted opinions are common and perceived as healthy scientific discourse that results in a thoughtful, relevant systematic review. Therefore, in the end, study questions, design, methodologic approaches, and/or conclusions do not necessarily represent the views of individual technical and content experts.

Technical Experts must disclose any financial conflicts of interest greater than $\$ 10,000$ and any other relevant business or professional conflicts of interest. Because of their unique clinical or content expertise, individuals with potential conflicts may be retained. The TOO and the EPC work to balance, manage, or mitigate any potential conflicts of interest identified.

The list of Technical Experts who provided input to this report follows:

Jonathan Comer, Ph.D.

Florida International University

Miami, FL

Stephanie C. Eken, M.D., FAAP

Rogers Behavioral Health

Tampa, FL

Abbe Garcia, Ph.D.*

The Warren Alpert Medical School of

Brown University

East Providence, RI

Amie E. Grills, Ph.D.*

Boston University

Boston, MA

*Provided input on Draft Report.
Jill Ehrenreich May, Ph.D.

University of Miami

Coral Gables, FL

Moira A. Rynn, M.D.*

Chair of Department of Psychiatry \&

Behavioral Sciences

Duke University Medical Center

Durham, NC 


\section{Peer Reviewers}

Prior to publication of the final evidence report, EPCs sought input from independent Peer Reviewers without financial conflicts of interest. However, the conclusions and synthesis of the scientific literature presented in this report do not necessarily represent the views of individual reviewers.

Peer Reviewers must disclose any financial conflicts of interest greater than $\$ 10,000$ and any other relevant business or professional conflicts of interest. Because of their unique clinical or content expertise, individuals with potential nonfinancial conflicts may be retained. The TOO and the EPC work to balance, manage, or mitigate any potential nonfinancial conflicts of interest identified.

The list of Peer Reviewers follows:

Jennie M. Kuckertz, M.S.

SDSU/UC San Diego Joint Doctoral

Program in Clinical Psychology

San Diego, CA

Eli Lebowitz, Ph.D.

Yale School of Medicine

New Haven, CT

David Rettew, M.D.

University of Vermont Larner College of

Medicine

Burlington, VT
Karen T. G. Schwartz, M.S.

SDSU/UC San Diego Joint Doctoral

Program in Clinical Psychology

San Diego, CA

John T. Walkup, M.D.

Weill Cornell Medicine and New York-

Presbyterian

New York, NY

V. Robin Weersing, Ph.D.

SDSU/UC San Diego Joint Doctoral

Program in Clinical Psychology

San Diego, CA 


\section{Anxiety in Children}

\section{Structured Abstract}

Objectives. To evaluate the comparative effectiveness and safety of treatments for childhood anxiety disorders, including panic disorder, social anxiety disorder, specific phobias, generalized anxiety disorder, and separation anxiety.

Data sources. We searched MEDLINE ${ }^{\circledR}$, Embase ${ }^{\circledR}$, PsycINFO ${ }^{\circledR}$, Cochrane Central Register of Controlled Trials, Cochrane Database of Systematic Reviews, and SciVerse Scopus through February 1, 2017, and reviewed bibliographies and the gray literature.

Review methods. We included randomized and non-randomized comparative studies that compared psychotherapy, pharmacotherapy, or a combination in children ages 3 to 18 years with panic disorder, social anxiety disorder, specific phobias, generalized anxiety disorder, or separation anxiety. Pairs of independent reviewers selected studies using pre-specified inclusion and exclusion criteria.

Results. We included 206 studies. Compared with pill placebo, selective serotonin reuptake inhibitors and serotonin-norepinephrine reuptake inhibitors improved primary anxiety symptoms (moderate to high strength of evidence [SOE]). Tricyclic antidepressants marginally improved clinical response (low SOE). Benzodiazepines did not show significant improvement in primary anxiety symptoms (low SOE). Data on head-to-head comparisons across drugs were sparse (only 2 RCTs; low SOE). Compared with waitlisting or no treatment, cognitive behavioral therapy (CBT) improved primary anxiety symptoms (clinician, child, and parent report), function, remission, and clinical response (low to moderate SOE). Compared with other therapies (attention control or treatment as usual), CBT reduced primary anxiety symptoms (child report; moderate SOE). Compared with CBT alone, the combination of imipramine and CBT reduced primary anxiety symptoms (child report) and function (moderate SOE). The combination of sertraline and CBT reduced primary anxiety symptoms (clinician report), improved function, and increased clinical response compared with CBT alone or sertraline alone (moderate SOE). CBT reduced primary anxiety symptoms and improved function more than fluoxetine. Medications increased short-term adverse events that were mostly not serious (low or moderate SOE). Studies were too small or too short to assess suicidality with SSRI or SNRI. One trial showed a statistically nonsignificant increase in suicidal ideation with venlafaxine (low SOE).

Conclusions. CBT is effective in reducing anxiety symptoms and improving function. Medications, primarily those targeting serotonin, are also effective and were associated with various short-term adverse events, which were mostly not serious, but studies were too small or too short to assess suicidality with SSRI or SNRI. The combination of medications and CBT is likely more effective than either treatment alone. Comparative effectiveness evidence between various medications and comparing CBT versus medications, or the combination, is limited and represents a need for research in this field. Future research is needed to evaluate components of CBT, effect modifiers of treatment, and long-term safety of drugs, and needs to be more inclusive of underserved populations and minorities. 


\section{Contents}

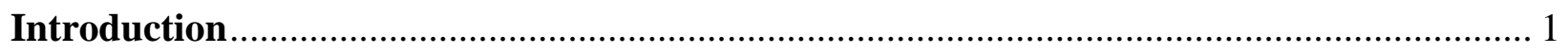

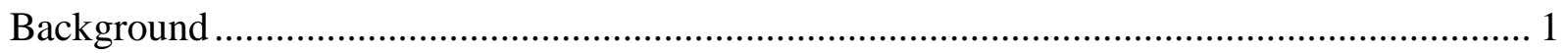

Scope and Key Questions ................................................................................................... 2

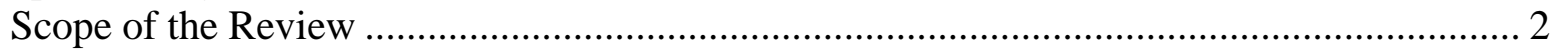

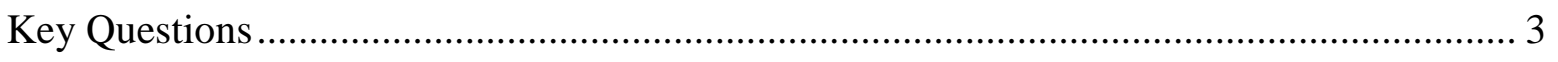

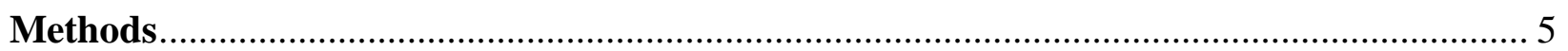

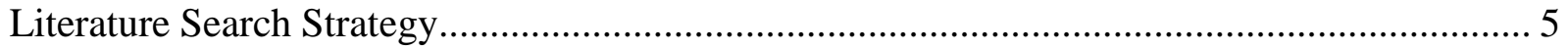

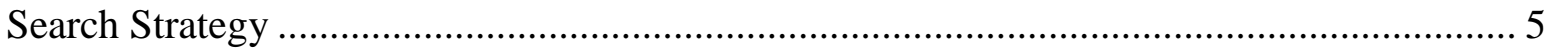

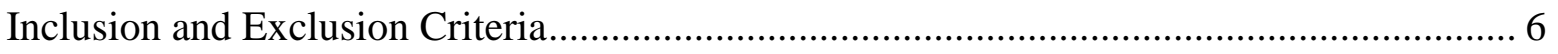

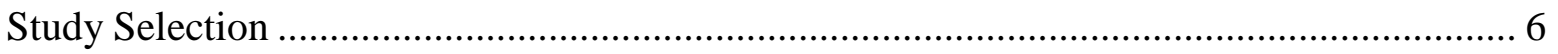

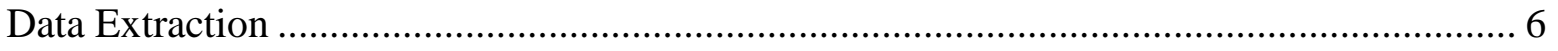

Assessment of Methodological Risk of Bias of Individual Studies....................................... 6

Data Synthesis....................................................................................................... 7

Grading the Strength of Evidence .......................................................................................... 8

Assessing Applicability ......................................................................................... 9

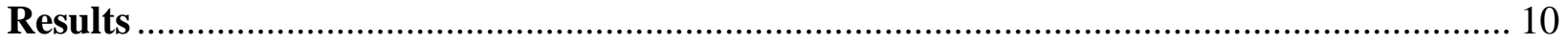

Literature Searches and Evidence Base ............................................................................. 10

Analysis Results................................................................................................................ 10

KQ 1: What is the comparative effectiveness of the available treatments for childhood anxiety disorders, including panic disorder, social anxiety disorder, specific phobias, generalized anxiety disorder, and separation anxiety? ........................................................ 10

KQ 2: What are the comparative harms and safety concerns regarding the available treatments for childhood anxiety disorders, including panic disorder, social anxiety disorder, specific phobias, generalized anxiety disorder, and separation anxiety?............................... 24

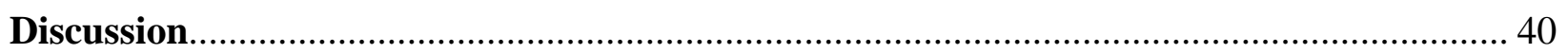

Findings in Relation to What Is Known ............................................................................. 40

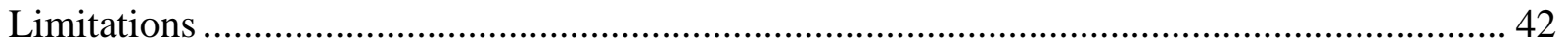

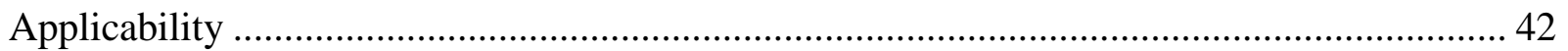

A Guide To Aid in Applicability ................................................................................ 42

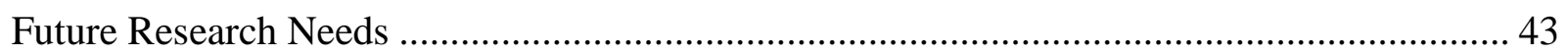

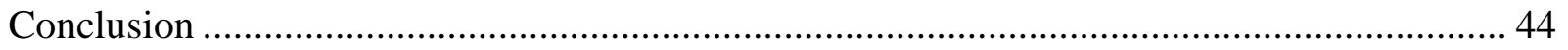

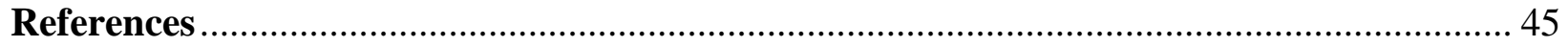

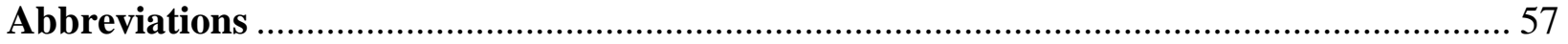

Tables

Table 1. Psychotherapy used to treat childhood anxiety................................................................2 
Table 2. Medications used to treat childhood anxiety ...........................................................2

Table 3. PICOTS (population, interventions, comparisons, outcomes, timing, and setting)...........4

Table 4. Categories of standardized outcome measures .........................................................8

Table 5. Strength of evidence for drug classes versus pill placebo ..........................................11

Table 6. Strength of evidence for individual drugs versus pill placebo....................................12

Table 7. Strength of evidence for drugs versus drugs.........................................................15

Table 8. Strength of evidence for drugs versus CBT ..............................................................16

Table 9. Strength of evidence for CBT versus pill placebo, waitlisting/no treatment, or attention

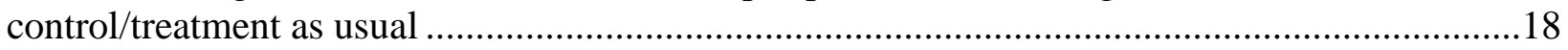

Table 10. Strength of evidence for CBT combined with drugs .............................................21

Table 11. Strength of evidence for adverse events of drugs versus pill placebo ..........................24

Table 12. Strength of evidence for adverse events reported in other comparisons, including combination treatments

Table 13. Average standard deviations for commonly used scales that can be multiplied by SMD

for conversion

\section{Figure}

Figure 1. Analytic framework........................................................... 5

\section{Appendixes}

Appendix A. Flow Chart

Appendix B. Search Strategy

Appendix C. Criteria for Inclusion/Exclusion of Studies

Appendix D. Excluded Studies

Appendix E. Description of Included Studies

Appendix F. Risk of Bias

Appendix G. Subgroup Analysis

Appendix H. Figures

Appendix I. References for Appendixes 


\section{Introduction}

\section{Background}

Childhood anxiety disorders are very common, affecting one in eight children. ${ }^{1}$ The National Institute of Mental Health estimates a prevalence between the ages 13 and 18 years of 25.1 percent and a lifetime prevalence of 5.9 percent for severe anxiety disorder. ${ }^{2}$ Anxiety disorders in childhood generally follow an impairing course leading to additional psychopathology and often interfere with social, emotional, and academic development. ${ }^{3,4}$

Multiple treatment options are available, including psychotherapy, pharmacotherapy, and combined treatment approaches. Cognitive behavioral therapy (CBT) and selective serotonin reuptake inhibitor (SSRIs) are considered by many to be first line treatments. ${ }^{5-9}$ CBT is generally recommended as the first-line treatment by World Health Organization (WHO), National Institute for Health and Care Excellence (NICE), and British Columbia Medical Services Commission. ${ }^{10-12}$ In addition to CBT, other psychotherapy approaches include: psychoanalysis, family therapy, and education support. Pharmacotherapy is also widely used, including SSRIs, serotonin-norepinephrine reuptake inhibitors (SNRIs), benzodiazepines, and others.

Pharmacotherapy is commonly used when psychotherapy is not available, does not lead to adequate response, or for moderate or severe symptoms at initial presentation.

There is a great deal of uncertainty regarding comparative effectiveness and safety of all treatments for childhood anxiety disorders. The potential advantage of psychotherapy is related to being safe and noninvasive. ${ }^{5,6}$ The potential disadvantages are that it has limited availability, ${ }^{13}$ requires multiple appointments, ${ }^{14}$ and requires behavioral changes by children and families. The potential disadvantages of pharmacotherapy are that it has unknown effect on brain chemistry, has the potential for adverse events (AEs), ${ }^{15,16}$ and that its benefits may not persist after treatment has been discontinued. ${ }^{17,18}$ Currently, existing treatment guidelines provide inconsistent and at times conflicting advice. ${ }^{10,11,19}$ Regarding SSRIs, one guideline specifically recommends that SSRIs should not be used in children, ${ }^{11}$ while another recommends they be used if CBT is not sufficient, ${ }^{10}$ and the third recommends their use for more severe presentations or if CBT is not available. ${ }^{19}$ Furthermore, despite the fact that all guidelines recommended CBT as a first line treatment, the components that comprise CBT differ between guidelines. In addition, one guideline suggested mild severity be treated with general health promotion, ${ }^{10}$ another recommended CBT regardless of severity, ${ }^{11}$ and the third recommended CBT as a sole intervention only for mild to moderate symptoms. ${ }^{19}$ Regarding other behavioral interventions, one organization specifically recommended that they should not be used, ${ }^{11}$ another did not comment, ${ }^{10}$ and the third recommended that multiple different interventions be considered including modalities that were later in the guidelines described as having little to no empirical support. ${ }^{19}$ In addition, there were inconsistency between several recommendations and the supporting data, particularly when discussing the role of symptom severity in treatment decisions, the comparative effectiveness of different SSRIs, the use of SSRIs in preschool age youth, and the use of non-SSRIs medications. ${ }^{20-22}$ Finally, additional inconsistencies exists between guidelines, such as the level of empirical support ascribed to an intervention, the relative value of different treatment modalities, or the specifics of treatment protocols.

Many factors have been proposed to interfere with participation or adherence to treatment and/or response to treatments, including severity of illness, comorbid conditions, family socioeconomic status (SES), externalizing symptoms, patient age, family dysfunction or stressor, and others. For example, treatment for children under six usually involves primarily parent 
training/behavior management interventions; while treatment with children 6 and up is more likely to involve working directly with children. Evidence reviews and randomized controlled trials (RCTs) reported conflicting results regarding differential response rates by age groups. ${ }^{23}$ Severity of symptoms is generally believed to be associated with worse outcomes and guidelines suggest a different treatment approach for these children. ${ }^{11,19}$ Despite many available treatments, the majority of children with anxiety disorders do not receive treatment. ${ }^{24}$

The objectives of this systematic review are to evaluate the comparative effectiveness of psychotherapy and pharmacotherapy for childhood anxiety disorders and to evaluate the harms and safety concerns associated with these treatments.

Based on the Fifth Edition of the Diagnostic and Statistical Manual of Mental Disorders (DSM-5), we plan to study the following types of anxiety: panic disorder, social anxiety disorder, specific phobias, generalized anxiety disorder, and separation anxiety. Obsessive compulsive disorder (OCD) and post-traumatic stress disorder will be excluded as their treatment approaches are generally different from other types of anxiety.

\section{Scope and Key Questions}

\section{Scope of the Review}

This systematic review addresses the comparative effectiveness and harms of commonly used types of psychotherapy and pharmacotherapy as listed in Tables 1 and 2.

Table 1. Psychotherapy used to treat childhood anxiety

\begin{tabular}{|l|l|}
\hline \multicolumn{1}{|c|}{ Psychotherapy } & \multicolumn{1}{c|}{ Subtype } \\
\hline Cognitive behavioral therapy (CBT): & Exposure therapy/systematic desensitization: contingency \\
Attempts to change cognition and & management exposure therapy; self-control exposure therapy \\
\cline { 2 - 2 } $\begin{array}{l}\text { behavior, generally consisting of some } \\
\text { combination of cognitive restructuring, } \\
\text { relaxation training, and exposure } \\
\text { therapy. Delivered during face-to-face }\end{array}$ & Family focused cognitive behavior therapy \\
\cline { 2 - 2 } $\begin{array}{l}\text { appointment with the child and typically } \\
\text { some degree of parent involvement. }\end{array}$ & Child focused cognitive behavior therapy \\
\hline $\begin{array}{l}\text { Other psychotherapies: Any other } \\
\text { intervention that included child or } \\
\text { parents working with a therapist to } \\
\text { address anxiety. Included parent- } \\
\text { directed behavioral interventions, } \\
\text { mindfulness interventions, as well as } \\
\text { non-cognitive behavioral therapies. This }\end{array}$ & Parent child interaction therapy \\
\cline { 2 - 2 } $\begin{array}{l}\text { was not considered a homogeneous } \\
\text { group. }\end{array}$ & Problem solving therapy \\
\cline { 2 - 2 } & Third wave (mindfulness) therapies \\
\cline { 2 - 2 } & Psychodynamic psychotherapy \\
\cline { 2 - 2 } & Attention modification program \\
\cline { 2 - 2 } & Motivational interviewing \\
\cline { 2 - 2 } & Eye movement desensitization reprocessing therapy (EMDR) \\
\hline
\end{tabular}

Table 2. Medications used to treat childhood anxiety

\begin{tabular}{|l|l|}
\hline \multicolumn{1}{|c|}{ Drug Class } & \multicolumn{1}{|c|}{ Medication (Brand Name) } \\
\hline \multirow{4}{*}{$\begin{array}{l}\text { Serotonin reuptake inhibitor } \\
\text { inhibitor (SSRI) }\end{array}$} & Sertraline (Zoloft) \\
\cline { 2 - 2 } & Citalopram (Celexa) \\
\cline { 2 - 2 } & Escitalopram (Lexapro) \\
\cline { 2 - 2 } & Fluoxetine (Prozac) \\
\cline { 2 - 2 } & Fluvoxamine (Luvox) \\
\cline { 2 - 2 } & Paroxetine (Paxil) \\
\hline
\end{tabular}




\begin{tabular}{|l|l|}
\hline \multicolumn{1}{|c|}{ Drug Class } & \multicolumn{1}{c|}{ Medication (Brand Name) } \\
\hline \multirow{4}{*}{$\begin{array}{l}\text { Serotonin-norepinephrine reuptake } \\
\text { inhibitors (SNRI) }\end{array}$} & Venlafaxine (Effexor) \\
\cline { 2 - 2 } & Atomoxetine (Strattera) \\
\cline { 2 - 2 } & Reboxetine (Edronax) \\
\cline { 2 - 2 } & Duloxetine (Cymbalta) \\
\hline Benzodiazepine & Alprazolam (Xanax, Niravam) \\
\cline { 2 - 2 } & Chlordiazepoxide (Librium) \\
\cline { 2 - 2 } & Clonazepam (Klonopin) \\
\hline Tricyclic antidepressant (TCA) & Imipramine (Tofranil) \\
\cline { 2 - 2 } & Clomipramine (Anafranil) \\
\hline Others & Mebicarum (Mebicar) \\
\cline { 2 - 2 } & Buspirone (Buspar) \\
\cline { 2 - 2 } & Mirtazapine (Remeron) \\
\cline { 2 - 2 } & Nefazodone (Dutonin, Nefadar, Serzone) \\
\hline
\end{tabular}

\section{Key Questions}

The following Key Questions (KQs) were determined based on input from multiple key informants and members of a Technical Expert Panel. The related PICOTS (population, interventions, comparisons, outcomes, timing, and setting) are listed in Table 3.

KQ 1: What is the comparative effectiveness of the available treatments for childhood anxiety disorders, including panic disorder, social anxiety disorder, specific phobias, generalized anxiety disorder, and separation anxiety?

a. What is the evidence for the comparative effectiveness of psychotherapy, pharmacotherapy, and combined treatment approaches for childhood anxiety disorders?

b. What is the evidence of differential effectiveness of different classes of medication, and for different medications within classes?

c. What is the evidence of differential effectiveness of different psychotherapy approaches, delivery mode, and components of psychotherapy for childhood anxiety disorders that are necessary and sufficient for improvement (including number of treatments and intensity of psychotherapy)?

d. How does comparative effectiveness of interventions vary according to child/family characteristics, and disease characteristics, including age, sex, race, ethnicity, SES, diagnosis, child maltreatment, parent/family comorbidity, duration, maltreatment?

e. How does comparative effectiveness of interventions vary according to child comorbid conditions, including attention deficit hyperactivity disorder (ADHD), depression, substance abuse, autism spectrum disorder, behavioral disorders, and somatic medical conditions? 
f. What are the treatment burdens (for patients, providers, and health systems) and contextual factors (patient/family preference, time associated with psychotherapy) that influence treatment choices for childhood anxiety disorders?

KQ 2: What are the comparative harms and safety concerns regarding the available treatments for childhood anxiety disorders, including panic disorder, social anxiety disorder, specific phobias, generalized anxiety disorder, and separation anxiety?

\section{a. What is the evidence for short-term and long-term patient experienced harms associated with treatments for childhood anxiety disorders?}

Table 3. PICOTS (population, interventions, comparisons, outcomes, timing, and setting)

\begin{tabular}{|l|l|}
\hline \multicolumn{1}{|c|}{ PICOTS Element } & \multicolumn{1}{c|}{ Description } \\
\hline Population & $\begin{array}{l}\text { Children and adolescents ages 3 to 18 years with panic disorder, social anxiety } \\
\text { disorder, specific phobias, generalized anxiety disorder, and separation anxiety. }\end{array}$ \\
\hline Interventions & Any psychotherapy, pharmacotherapy, alone or combined. \\
\hline Comparisons & $\begin{array}{l}\text { Other treatment, waitlisting or no treatment, pill placebo, attention control, or treatment } \\
\text { as usual }\end{array}$ \\
\hline & $\begin{array}{l}\text { Intermediate outcomes (standardized measures with child, parent, school, and } \\
\text { clinician report) such as SCARED, RCMAS, Beck Anxiety Inventory, MASC, Liebowitz } \\
\text { Social Anxiety Scale, Social Phobia and Anxiety Inventory for Children, SCAS, Fear } \\
\text { Survey Schedule for Children - revised, STAIC, Anxiety Disorder Interview Schedule - } \\
\text { child version. } \\
\text { Patient centered outcomes such as remission, anxiety symptoms, diagnosis free, } \\
\text { behavioral problems (Behavior Assessment System for Children, Achenbach Child } \\
\text { Behavior Checklist), parent distress, therapeutic alliance, school attendance, reduction } \\
\text { in impairment (Child Sheehan Disability Scale), quality of life (Multidimensional Child } \\
\text { Health Questionnaire, and Youth Quality of Life Instrument - research version), } \\
\text { avoiding hospitalization, length of treatment, availability of treatment, peer relationship. }\end{array}$ \\
AEs, dropout from therapy. \\
\hline Timing & Studies with any duration of followup. \\
\hline Setting & Outpatient and hospital. \\
\hline
\end{tabular}

AEs: adverse events, MASC: multidimensional anxiety scale for children, RCMAS: revised children's manifest anxiety scale, SCARED: screen for anxiety-related emotional disorders, SCAS: Spence children's anxiety scale, STAIC: state trait anxiety inventory - child. 


\section{Methods}

We developed an analytic framework to guide the whole process of the systematic review (Figure.1). We followed the established methodologies of systematic reviews as outlined in the Agency for Healthcare Research and Quality (AHRQ) Methods Guide for Comparative Effectiveness Reviews. ${ }^{25}$ The reporting complies with the Preferred Reporting Items for Systematic Reviews and Meta-Analyses (PRISMA) statements. ${ }^{26}$ The study protocol is registered in the international prospective register of systematic reviews (PROSPERO \#: CRD42016046542) and published on AHRQ Web site.

Figure 1. Analytic framework

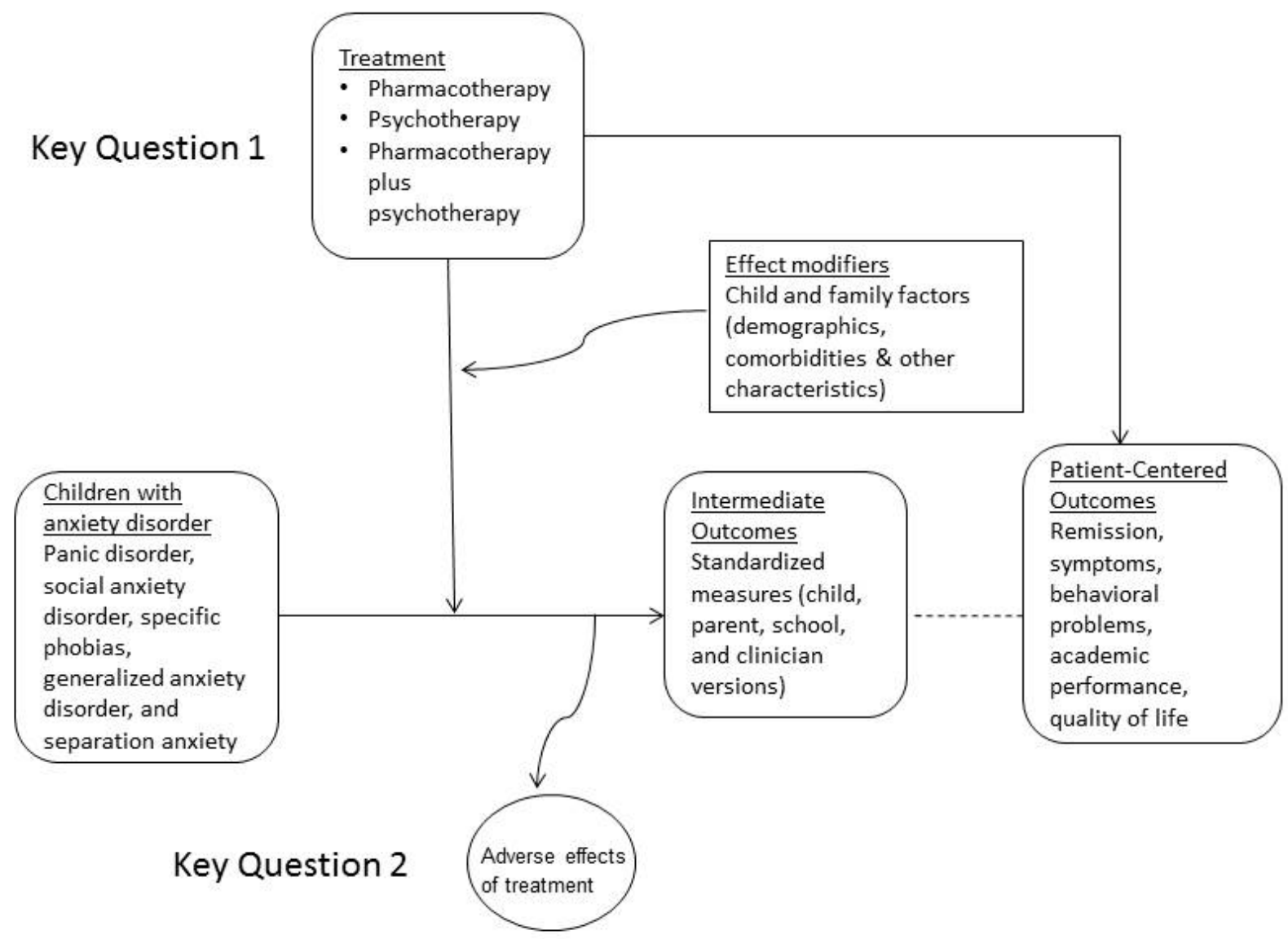

\section{Literature Search Strategy}

\section{Search Strategy}

We conducted a comprehensive literature search of eight databases, including Ovid MEDLINE $^{\circledR}$ In-Process \& Other Non-Indexed Citations, Ovid MEDLINE ${ }^{\circledR}$, Embase ${ }^{\circledR}$, 
PsycINFO $^{\circledR}$, Cochrane Central Register of Controlled Trials, Ovid Cochrane Database of Systematic Reviews, and SciVerse Scopus from databases inception to February 1, 2017. We also searched U.S. Food and Drug Administration (FDA) new drug applications, ClinicalTrials.gov, Health Canada, Medicines and Healthcare Products Regulatory Agency (MHRA), AHRQ’s Horizon Scanning System, conference proceedings, patient advocate group Web sites, and medical society Web sites. Relevant systematic reviews and meta-analysis, as well as reference mining of relevant publications, were used to identify additional existing and new literature. An experienced librarian, with the inputs from the study investigators, developed the search strategy (Appendix B). An independent experienced librarian peer-reviewed the search strategy.

\section{Inclusion and Exclusion Criteria}

The eligible studies had to meet all the following criteria: 1) children and adolescents between 3 and 18 years old with confirmed diagnosis of panic disorder, social anxiety disorder, specific phobias, generalized anxiety disorder, or separation anxiety; 2) received any psychotherapy, pharmacotherapy, alone or combined; 3) reported outcomes of interest (standardized measures, patient centered outcomes, or safety outcomes). We included randomized controlled trials (RCTs), and comparative observational studies. Case reports or case series were used to identify additional adverse events (AEs). We did not restrict publication time, or study location. The detailed inclusion and exclusion criteria are attached in Appendix C.

\section{Study Selection}

Independent reviewers, working in duplicate and in pairs, screened the titles and abstracts of all citations using the inclusion and exclusion criteria. Studies included by either reviewer were retrieved for full-text screening. Independent reviewers, working in pairs, screened the full-text version of eligible references (Appendix Figure A.1). Discrepancies between the reviewers were resolved through discussions and consensus. If consensus was not reached, a third reviewer was added to resolve the difference.

\section{Data Extraction}

At the beginning of data extraction, we developed a standardized data extraction form to extract study characteristics (author, study design, inclusion and exclusion criteria, patient characteristics, interventions, comparisons, outcomes, and related items for assessing study quality and applicability). The standardized form was pilot-tested by all study team members using 10 randomly selected studies. We iteratively continued testing the form until no additional items or unresolved questions existed. A second reviewer verified data extraction. When there was missing information, we contacted the authors.

\section{Assessment of Methodological Risk of Bias of Individual Studies}

We evaluated the risk of bias of each included study using predefined criteria. For RCTs, we applied the Cochrane Collaboration's Risk of Bias tool (scored as high, low, unclear) to assess sequence generation; allocation concealment; participant, personnel, and outcome assessor blinding; attrition bias; incomplete outcome data; selective outcome reporting; and other sources of bias (e.g. imbalance of baseline characteristics, conflict of interest). ${ }^{27} \mathrm{~A}$ judgment of overall risk of bias across the various domains was made focusing on random allocation, allocation 
concealment and blinding (high risk of bias in any of these domains led to a high overall rating). We did not consider industry funding as an automatic indicator of high risk of bias. For observational studies, we selected appropriate items from the Newcastle-Ottawa Scale (i.e. high, moderate, low, unclear), focusing on the representativeness of the population, selection of the cohorts, ascertainment of exposure and outcomes, adequacy of follow-up land possible conflicts of interest. $^{28}$

\section{Data Synthesis}

We summarized key features/characteristics (e.g. study populations, design, intervention, outcomes, and conclusions) of the included studies and presented data qualitatively in evidence tables for each Key Question.

We conducted meta-analyses to quantitatively summarize study findings. The main analyses were based on the effects measured post intervention, though length of followup (less than 6 months versus longer than 6 months) was evaluated in the subgroup analyses. We defined length of follow up as the time from the end of treatments to the time of outcome assessment. We used the intention-to-treat (ITT) principle. To facilitate the analyses, we categorized the standardized measures into groups: primary anxiety measure; secondary related measure; function related outcome; satisfaction with treatment; and social function (Table 4). For binary treatment response, we define it as 1) loss of principal anxiety diagnosis, or 2) Clinical Global Impression - Severity scale (CGI-S) 1 or 2; for remission, we define it as 1) loss of all anxiety diagnoses, or 2) Clinical Global Impression - Improvement scale (CGI-I) 1 or 2 . We grouped AEs into symptoms related to abdominal/GI/appetite, behavior change, cold/infection/allergies, headache/dizzy/vision problems, fatigue/somnolence, difficulty sleeping, accidental injury, and suicide/suicidal ideation/self-harm. AEs were deemed to be serious if they were described as serious by the included studies, or led to discontinuation of treatment, significant morbidity, or mortality. We calculated relative risk (RR) and corresponding 95-percent confidence intervals (CIs) for binary outcomes and standardized mean difference (SMD) and related 95 percent confidence intervals for continuous outcomes. For count data (i.e. a single patient may experience more than one event), we calculated rate ratios, instead of RRs. The DerSimonian and Laird random effect method with the Knapp and Hartung adjustment of the variance was used when the number of the comparison was larger than two $(n>2) .^{29}$ The fixed effect model based on the Mantel and Haenszel method was used when there were only two studies $(n=2)$. We evaluated heterogeneity between studies using the $\mathrm{I}^{2}$ indicator.

To further explore heterogeneity, we planned to stratify analysis conducting these subgroup analyses (based on a priori defined factors):
- Age
- Sex
- Race/ethnicity
- Household income
- Parent education level
- Family dysfunction/stressor
- Diagnosis
- Severity
- Length of follow-up
- Treatment sequence 
- Comorbidities

- Provider

- Delivery mode

- Component of psychotherapy

- Cognitive behavioral therapy intensity

- Study settings

The statistical difference between subgroups was evaluated using one-way ANOVA tests

We evaluated potential publication bias by evaluating funnel plots symmetry and using the Egger linear regression test when the number of studies included in a direct comparison is large ( $\mathrm{n}>=20$ ). Two tailed $\mathrm{p}$ value $<0.05$ was considered as statistically significant. All statistical analyses were conducted using Stata version 14.2 (StataCorp LP, College Station, Texas).

Table 4. Categories of standardized outcome measures

\begin{tabular}{|l|l|}
\hline \multicolumn{1}{|c|}{ Category } & \multicolumn{1}{c|}{ Description } \\
\hline Primary anxiety symptoms & $\begin{array}{l}\text { All measures of child anxiety symptoms completed by the child, parent, or an } \\
\text { examiner. }\end{array}$ \\
\hline $\begin{array}{l}\text { Secondary anxiety } \\
\text { measures }\end{array}$ & $\begin{array}{l}\text { Symptoms related to anxiety, but not the primary measure, such as coping, } \\
\text { avoidance, or anxious thoughts. }\end{array}$ \\
\hline Function & $\begin{array}{l}\text { Measure of interference from symptoms or dysfunction in daily behaviors, such as } \\
\text { school. }\end{array}$ \\
\hline Satisfaction & Satisfaction with treatment or therapeutic alliance. \\
\hline Social function & Measures of social skills or success with peer relationships. \\
\hline
\end{tabular}

\section{Grading the Strength of Evidence}

We graded strength of evidence (SOE) following the Methods Guide on assessing the strength of evidence. ${ }^{25}$ The ratings were made via a consensus process among team members with expertise in evidence appraisal and guideline methodology. Randomized studies start with an initial level of high and observational studies start at a level of low. For each comparison and for the critical outcomes, we assessed the following domains for the total body of evidence addressing each outcome (all relevant studies in a particular comparison):

1) The methodological limitations of the studies (i.e., risk of bias): We lowered SOE one or two levels based on how serious the limitations in terms of their impact on inference.

2) Precision: We lowered SOE one or two levels based on the confidence intervals and sample size. If confidence intervals included appreciable benefits and harms (crossing no effect), or the total sample size was lower than 400 (an arbitrary cutoff that corresponds to a standardized small effect of 0.20 with significance of 0.05 and power of 0.80$),{ }^{30}$ we rated SOE down by one level. When both of these situations were encountered simultaneously, we rated SOE down twice for imprecision and labeled this scenario as "severe imprecision".

3) Directness: We lowered SOE one level if the outcomes were surrogate and not patientimportant.

4) Consistency: We lowered SOE one or two levels based on qualitative and statistical measures of heterogeneity (arbitrary cutoff of I-squared value of $60 \%$ or more was used as an indication for substantial heterogeneity).

5) The likelihood of publication bias: We lowered SOE one level if we suspected publication bias based on study reporting or statistical tests for publication bias. 
Evidence derived from observational studies could be rated up if we observe a large effect, a dose response gradient, or if plausible confounding suggested a stronger association ${ }^{31}$. When judgment about two domains were borderline (for example, unclear risk of bias and possible publication bias), we opted to rate down once for both domains. Based on this assessment and the initial study design, we assigned SOE rating as high, moderate, low, or 'insufficient evidence to estimate an effect'. We produced summary of evidence tables for each comparison and for each outcome including data source, effect size and SOE rating with rationale for judgments that affected rating. We did not consider consistency in results across informants (child, parent and clinician) as a factor in rating SOE because we considered these as independent outcomes.

\section{Assessing Applicability}

Overall judgments about applicability were qualitatively made using the PICOTS framework. We focused on whether the populations, interventions, and comparisons in existing studies were representative of current practice. We reported any limitations in applicability of individual studies in evidence tables and limitations of applicability of the whole body of evidence in the discussion section. To further enhance applicability and considering that relative association measures and standardized effects are challenging to apply, we provided: 1 ) an approach to convert RRs to absolute effects (using baseline risks derived from the current data), and 2) an approach to convert SMDs to measures with units of scales commonly used in evaluating anxiety disorders in children (using standard deviations if such scales derived from the current data). 


\section{Results}

\section{Literature Searches and Evidence Base}

The electronic search, grey literature and reference mining identified 32,156 citations. After title and abstract screening, 3,288 studies were retrieved for full text review. A total of 206 studies met eligibility criteria and were included in the analyses (Appendix A, Figure A.1).

For Key Question (KQ) 1, we identified a total of 110 randomized controlled trials (RCTs) and 4 non-randomized comparative studies. 19 RCTs compared drugs to pill placebo. 2 RCTs compared drugs to drugs. 2 RCTs compared cognitive behavioral therapy (CBT) to drugs. 88 studies (84 RCTs and 4 non-randomized comparative studies studies) compared CBT to pill placebo, waitlisting/no treatment, or attention control/treatment as usual. 3 RCTs compared combination treatment to drugs or CBT alone.

For KQ 2, 20 RCTs and non-randomized comparative studies reported adverse events (AEs). Majority of these studies compared drugs to pill placebo, while head-to-head comparisons were rare. In addition, 18 single cohort observational studies reported AEs related to different drugs.

We identified 51 studies (44 RCTs and 7 non-randomized comparative studies) that evaluated non-CBT psychotherapies. We did not quantitatively combine these studies due to the heterogeneity of the interventions. However, these studies are summarized in Appendix Table E.8-19. 52 studies (47 RCTs and 5 non-randomized comparative studies) compared different CBTs in terms of components (exposure session, cognitive strategy, and/or relaxation strategy), treatment intensity, parent involvement, and delivery mode (individual-based versus groupbased).

We included 193 studies published in English, 10 studies in Spanish, ${ }^{32-41}$ and 3 studies in German. ${ }^{42-44}$ We excluded one study published in Turkish ${ }^{45-47}$ and three in Persian. ${ }^{48}$ In addition, we identified 225 relevant ongoing trials through clinicaltrials.gov.

Risk of bias in the majority of the included studies was rated as moderate to high (Appendix Table F.1 and F.2). We did not rate down strength of evidence (SOE) due to lack of blinding as this is not feasible in CBT and other psychotherapies.

\section{Analysis Results}

$\mathrm{KQ} \mathrm{1:} \mathrm{What} \mathrm{is} \mathrm{the} \mathrm{comparative} \mathrm{effectiveness} \mathrm{of} \mathrm{the} \mathrm{available} \mathrm{treatments} \mathrm{for}$ childhood anxiety disorders, including panic disorder, social anxiety disorder, specific phobias, generalized anxiety disorder, and separation anxiety?

\section{Drugs Versus Pill Placebo}

\section{Key Points}

- $\quad$ Selective serotonin reuptake inhibitor (SSRIs) improved primary anxiety symptoms (clinician and parent report), function, remission, and clinical response, compared to pill placebo (moderate to high SOE).

- Serotonin-norepinephrine reuptake inhibitors (SNRIs) improved primary anxiety symptoms, compared to pill placebo (only clinician report) (high SOE). 
- Tricyclic antidepressants marginally improved clinical response, compared to pill placebo (low SOE).

- Benzodiazepines did not show significant improvement in anxiety symptoms over pill placebo (low SOE).

\section{Discussion}

Nineteen RCTs ${ }^{7,22,49-72}$ compared medications to pill placebo, including atomoxetine, clonazepam, clomipramine, duloxetine, fluvoxamine, fluoxetine, imipramine, paroxetine, sertraline, and venlafaxine. Overall, 2,498 patients were included with a mean age of 11.6 years old and 54.1 percent male. 13 studies ${ }^{49-52,54,56,58,60-65}(68.4 \%)$ included patients without any comorbidity. 6 studies ${ }^{7,22,53-55,57,66,67,69-73}$ included children with anxiety and comorbidity (attention deficit hyperactivity disorder (ADHD), autism, ODD, obsessive compulsive disorder (OCD) and other internalizing disorders). Details of the included studies can be found in Appendix Table E.1. We were unable to evaluate publication bias due to small number of studies $(\mathrm{n}<20)$ included in each comparisons.

As a class, SSRIs improved primary anxiety symptoms (clinician and parent report), function, remission, and clinical response, compared to pill placebo (moderate to high SOE). SNRIs improved primary anxiety symptoms (clinician report, high SOE). TCAs marginally improved clinical response (low SOE), whereas benzodiazepines did not show significant improvement in anxiety symptoms over pill placebo (low SOE). Results of the comparisons of drug classes with pill placebo and associated SOE are presented in Table 5. Results of the individual drugs comparisons with pill placebo are presented in Table 6.

Table 5. Strength of evidence for drug classes versus pill placebo

\begin{tabular}{|c|c|c|c|c|c|}
\hline Comparison & Outcome & Conclusion & $\begin{array}{l}\text { Study Design and } \\
\text { Sample Size }^{a}\end{array}$ & $\begin{array}{l}\text { Factors That Affect } \\
\text { the Strength of } \\
\text { Evidence }^{b}\end{array}$ & $\begin{array}{l}\text { Overall } \\
\text { Evidence } \\
\text { Strength } \\
\text { (Direction of } \\
\text { Effect) }\end{array}$ \\
\hline $\begin{array}{l}\text { Benzodiazepine } \\
\text { vs. Pill Placebo }\end{array}$ & $\begin{array}{l}\text { Primary } \\
\text { anxiety, } \\
\text { clinician } \\
\text { report }\end{array}$ & $\begin{array}{l}\text { SMD: } 0.30 ; \\
95 \% \mathrm{Cl}:-0.72 \\
\text { to } 1.32 ; I^{2}=\mathrm{N} / \mathrm{A}\end{array}$ & 1 RCT (15 Patients) ${ }^{57}$ & $\begin{array}{l}\text { Severe imprecision } \\
\text { (small sample size } \\
\text { and wide Cls) }\end{array}$ & $\begin{array}{l}\text { Low } \\
\text { (no difference) }\end{array}$ \\
\hline \multirow[t]{4}{*}{$\begin{array}{l}\text { SNRI vs. Pill } \\
\text { Placebo }\end{array}$} & $\begin{array}{l}\text { Primary } \\
\text { anxiety, } \\
\text { child report }\end{array}$ & $\begin{array}{l}\text { SMD: }-2.14 ; \\
95 \% \mathrm{Cl}:-9.75 \\
\text { to } 5.48 ; \mathrm{I}^{2}= \\
99.4 \%\end{array}$ & $\begin{array}{l}3 \text { RCTs (622 } \\
\text { Patients) }\end{array}$ & $\begin{array}{l}\text { Severe imprecision } \\
\text { (very wide Cls) and } \\
\text { inconsistency }\end{array}$ & Insufficient \\
\hline & $\begin{array}{l}\text { Primary } \\
\text { anxiety, } \\
\text { parent } \\
\text { report }\end{array}$ & $\begin{array}{l}\text { SMD: }-0.32 ; \\
95 \% \mathrm{Cl}:-0.63 \\
\text { to } 0.00 ; I^{2}=\mathrm{N} / \mathrm{A}\end{array}$ & 1 RCT (153 Patients) ${ }^{62}$ & $\begin{array}{l}\text { Severe imprecision } \\
\text { (small sample size } \\
\text { and wide Cls) }\end{array}$ & $\begin{array}{l}\text { Low } \\
\text { (no difference) }\end{array}$ \\
\hline & $\begin{array}{l}\text { Primary } \\
\text { anxiety, } \\
\text { clinician } \\
\text { report }\end{array}$ & $\begin{array}{l}\text { SMD: }-0.45 ; \\
95 \% \mathrm{Cl}:-0.81 \\
\text { to }-0.10 ; \\
I^{2}=0.0 \%\end{array}$ & $\begin{array}{l}3 \text { RCTs (601 } \\
\text { Patients) }\end{array}$ & None & $\begin{array}{l}\text { High } \\
\text { (reduced } \\
\text { anxiety) }\end{array}$ \\
\hline & Function & $\begin{array}{l}\text { SMD: }-0.05 \\
95 \% \text { Cl: }-0.24 \\
\text { to } 0.13 \\
I^{2}=93.4 \%\end{array}$ & $\begin{array}{l}2 \text { RCTs (448 } \\
\text { Patients) }\end{array}$ & $\begin{array}{l}\text { Severe imprecision } \\
\text { (wide Cls) and } \\
\text { inconsistency }\end{array}$ & $\begin{array}{l}\text { Low } \\
\text { (no difference) }\end{array}$ \\
\hline $\begin{array}{l}\text { SSRI vs. Pill } \\
\text { Placebo }\end{array}$ & $\begin{array}{l}\text { Primary } \\
\text { anxiety, } \\
\text { child report }\end{array}$ & $\begin{array}{l}\text { SMD: }-0.42 ; \\
95 \% \mathrm{Cl}:-0.96 \\
\text { to } 0.12 ; \\
I^{2}=27.5 \%\end{array}$ & $\begin{array}{l}4 \text { RCTs (197 } \\
\text { Patients) }\end{array}$ & $\begin{array}{l}\text { Severe imprecision } \\
\text { (small sample size } \\
\text { and wide Cls) }\end{array}$ & $\begin{array}{l}\text { Low } \\
\text { (no difference) }\end{array}$ \\
\hline
\end{tabular}




\begin{tabular}{|c|c|c|c|c|c|}
\hline Comparison & Outcome & Conclusion & $\begin{array}{l}\text { Study Design and } \\
\text { Sample Size }^{a}\end{array}$ & $\begin{array}{l}\text { Factors That Affect } \\
\text { the Strength of } \\
\text { Evidence }^{b}\end{array}$ & $\begin{array}{l}\text { Overall } \\
\text { Evidence } \\
\text { Strength } \\
\text { (Direction of } \\
\text { Effect) } \\
\end{array}$ \\
\hline & $\begin{array}{l}\text { Primary } \\
\text { anxiety, } \\
\text { parent } \\
\text { report }\end{array}$ & $\begin{array}{l}\text { SMD: }-0.61 ; \\
95 \% \mathrm{Cl}:-1.03 \\
\text { to }-0.20 ; \\
\mathrm{I}^{2}=55.1 \%\end{array}$ & $\begin{array}{l}2 \text { RCTs (96 } \\
\text { Patients) }\end{array}$ & $\begin{array}{l}\text { Imprecision (small } \\
\text { sample size) }\end{array}$ & $\begin{array}{l}\text { Moderate } \\
\text { (reduced } \\
\text { anxiety) }\end{array}$ \\
\hline & $\begin{array}{l}\text { Primary } \\
\text { anxiety, } \\
\text { clinician } \\
\text { report }\end{array}$ & $\begin{array}{l}\text { SMD: }-0.65 ; \\
95 \% \mathrm{Cl}:-1.10 \\
\text { to }-0.21 ; \\
\mathrm{I}^{2}=73.4 \%\end{array}$ & $\begin{array}{l}7 \text { RCTs (675 } \\
\text { Patients), 22, 49, 51, 53, 54, } \\
61,65,67,69-73\end{array}$ & Inconsistency & $\begin{array}{l}\text { Moderate } \\
\text { (reduced } \\
\text { anxiety) }\end{array}$ \\
\hline & Function & $\begin{array}{l}\text { SMD: }-0.59 \\
95 \% \text { Cl: to }- \\
0.85 \text { to }-0.34 \\
I^{2}=0.0 \%\end{array}$ & $\begin{array}{l}4 \text { RCTs }(680 \\
\text { Patients) } 7,51,53,65,67,69- \\
73\end{array}$ & None & $\begin{array}{l}\text { High } \\
\text { (improved } \\
\text { function) }\end{array}$ \\
\hline & $\begin{array}{l}\text { Secondary } \\
\text { measure }\end{array}$ & $\begin{array}{l}\text { SMD: }-0.19 ; \\
95 \% \mathrm{Cl}:-0.55 \\
\text { to } 0.17 ; I^{2}=75.1\end{array}$ & $\begin{array}{l}1 \text { RCT }(124 \\
\text { Patients) }\end{array}$ & $\begin{array}{l}\text { Severe imprecision } \\
\text { (small sample size } \\
\text { and wide Cls) }\end{array}$ & $\begin{array}{l}\text { Low } \\
\text { (no difference) }\end{array}$ \\
\hline & $\begin{array}{l}\text { Social } \\
\text { function }\end{array}$ & $\begin{array}{l}\text { SMD: } 0.18 ; \\
95 \% \mathrm{Cl}:-0.26 \\
\text { to } 0.62 ; I^{2}= \\
\text { N/A }\end{array}$ & 1 RCT (80 Patients) ${ }^{51}$ & $\begin{array}{l}\text { Severe imprecision } \\
\text { (small sample size } \\
\text { and wide Cls) }\end{array}$ & $\begin{array}{l}\text { Low } \\
\text { (no difference) }\end{array}$ \\
\hline & Remission & $\begin{array}{l}\text { RR: } 2.04 ; 95 \% \\
\mathrm{Cl}: 1.37 \text { to } \\
3.04 ; I^{2}=\mathrm{N} / \mathrm{A}\end{array}$ & $\begin{array}{l}2 \text { RCTs (95 } \\
\text { Patients) }\end{array}$ & $\begin{array}{l}\text { Imprecision small } \\
\text { sample size) }\end{array}$ & $\begin{array}{l}\text { Moderate } \\
\text { (improved } \\
\text { remission) }\end{array}$ \\
\hline & Response & $\begin{array}{l}\text { RR: } 1.96 ; 95 \% \\
\mathrm{Cl}: 1.60 \text { to } \\
2.40 ; I^{2}=0.0 \%\end{array}$ & $\begin{array}{l}2 \text { RCTs (396 } \\
\text { Patients) }\end{array}$ & $\begin{array}{l}\text { Imprecision (small } \\
\text { sample size) }\end{array}$ & $\begin{array}{l}\text { Moderate } \\
\text { (improved } \\
\text { response) }\end{array}$ \\
\hline \multirow[t]{4}{*}{$\begin{array}{l}\text { TCA vs. Pill } \\
\text { Placebo }\end{array}$} & $\begin{array}{l}\text { Primary } \\
\text { anxiety, } \\
\text { child report }\end{array}$ & $\begin{array}{l}\text { SMD: } 0.36 ; \\
95 \% \mathrm{Cl}:-0.27 \\
\text { to } 0.99 ; \\
\mathrm{I}^{2}=45.6 \%\end{array}$ & $\begin{array}{l}2 \text { RCTs (41 } \\
\text { Patients) }\end{array}$ & $\begin{array}{l}\text { Severe imprecision } \\
\text { (small sample size } \\
\text { and wide Cls). }\end{array}$ & $\begin{array}{l}\text { Low } \\
\text { (no difference) }\end{array}$ \\
\hline & $\begin{array}{l}\text { Primary } \\
\text { anxiety, } \\
\text { parent } \\
\text { report }\end{array}$ & $\begin{array}{l}\text { SMD: } 0.46 ; \\
95 \% \mathrm{Cl}:-0.41 \\
\text { to } 1.33 ; I^{2}=\mathrm{N} / \mathrm{A}\end{array}$ & 1 RCT (21 Patients) ${ }^{74}$ & $\begin{array}{l}\text { Methodological } \\
\text { limitations, severe } \\
\text { imprecision (small } \\
\text { sample size and wide } \\
\mathrm{Cl} \text { ) }\end{array}$ & Insufficient \\
\hline & Remission & $\begin{array}{l}\text { RR: } 1.83 ; 95 \% \\
\mathrm{Cl}: 0.74 \text { to } \\
4.55 ; I^{2}=\mathrm{N} / \mathrm{A}\end{array}$ & 1 RCT (20 Patients) ${ }^{54}$ & $\begin{array}{l}\text { Severe imprecision } \\
\text { (small sample size } \\
\text { and wide Cls) }\end{array}$ & $\begin{array}{l}\text { Low } \\
\text { (no difference) }\end{array}$ \\
\hline & Response & $\begin{array}{l}\text { RR: } 1.72 ; 95 \% \\
\mathrm{Cl}: 1.01 \text { to } \\
2.91 ; I^{2}=\mathrm{N} / \mathrm{A}\end{array}$ & 1 RCT (35 Patients) ${ }^{56}$ & $\begin{array}{l}\text { Severe imprecision } \\
\text { (small sample size } \\
\text { and wide Cls) }\end{array}$ & $\begin{array}{l}\text { Low } \\
\text { (improved } \\
\text { response) }\end{array}$ \\
\hline
\end{tabular}

CI: confidence interval, N/A: not applicable, RCT: randomized control trial, RR: relative risk, SMD: standardized mean difference, SNRI: serotonin-norepinephrine reuptake inhibitor, SSRI: selective serotonin reuptake inhibitor, TCA: tricyclic antidepressants.

${ }^{\mathrm{a}}$ The sample size includes the number of patients from each comparison.

${ }^{\mathrm{b}}$ Only SOE domains that led to rating down SOE are reported in this column. Domains that are not reported were satisfactory.

Table 6. Strength of evidence for individual drugs versus pill placebo

\begin{tabular}{|l|l|l|l|l|l|}
\hline Comparison & Outcome & Conclusion & $\begin{array}{l}\text { Study Design and } \\
\text { Sample Size }\end{array}$ & $\begin{array}{l}\text { Factors That } \\
\text { Affect the } \\
\text { Strength of } \\
\text { Evidence }^{\mathbf{b}}\end{array}$ & $\begin{array}{c}\text { Overall } \\
\text { Evidence } \\
\text { Strength } \\
\text { (Direction of } \\
\text { Effect) }\end{array}$ \\
\hline $\begin{array}{l}\text { Atomoxetine } \\
\text { (class: SNRI) }\end{array}$ & $\begin{array}{l}\text { Primary anxiety, } \\
\text { child report }\end{array}$ & $\begin{array}{l}\text { SMD: }-0.29 ; \\
95 \% \mathrm{Cl}:-0.51\end{array}$ & $\begin{array}{l}2 \mathrm{RCTS}(331 \\
\text { Patients) }\end{array}$ & $\begin{array}{l}\text { Imprecision (small } \\
\text { sample size) }\end{array}$ & $\begin{array}{l}\text { Moderate } \\
\text { (reduced }\end{array}$ \\
\hline
\end{tabular}




\begin{tabular}{|c|c|c|c|c|c|}
\hline Comparison & Outcome & Conclusion & $\begin{array}{l}\text { Study Design and } \\
\text { Sample Size }{ }^{a}\end{array}$ & $\begin{array}{l}\text { Factors That } \\
\text { Affect the } \\
\text { Strength of } \\
\text { Evidence }^{b}\end{array}$ & $\begin{array}{c}\text { Overall } \\
\text { Evidence } \\
\text { Strength } \\
\text { (Direction of } \\
\text { Effect) }\end{array}$ \\
\hline \multirow[t]{4}{*}{ vs. Pill Placebo } & & $\begin{array}{l}\text { to }-0.08 ; \\
\mathrm{I}^{2}=0.0 \%\end{array}$ & & & anxiety) \\
\hline & $\begin{array}{l}\text { Primary anxiety, } \\
\text { clinician report }\end{array}$ & $\begin{array}{l}\text { SMD: }-0.56 ; \\
95 \% \mathrm{Cl}:-0.78 \\
\text { to }-0.34 ; \\
\mathrm{I}^{2}=0.0 \%\end{array}$ & $\begin{array}{l}2 \text { RCTs (331 } \\
\text { Patients) })^{55,62}\end{array}$ & $\begin{array}{l}\text { Imprecision (small } \\
\text { sample size) }\end{array}$ & $\begin{array}{l}\text { Moderate } \\
\text { (reduced } \\
\text { anxiety) }\end{array}$ \\
\hline & $\begin{array}{l}\text { Primary anxiety, } \\
\text { parent report }\end{array}$ & $\begin{array}{l}\text { SMD: }-0.23 ; \\
95 \% \mathrm{Cl}:-0.55 \\
\text { to } 0.08 ; I^{2}= \\
\text { N/A }\end{array}$ & $\begin{array}{l}1 \text { RCT (155 } \\
\text { Patients) }\end{array}$ & $\begin{array}{l}\text { Severe } \\
\text { imprecision (small } \\
\text { sample size and } \\
\text { wide Cls) }\end{array}$ & $\begin{array}{l}\text { Low } \\
\text { (no difference) }\end{array}$ \\
\hline & Function & $\begin{array}{l}\text { SMD: }-0.46 ; \\
95 \% \mathrm{Cl}:-0.76 \\
\text { to }-0.16 ; I^{2}= \\
\text { N/A }\end{array}$ & $\begin{array}{l}1 \text { RCT (176 } \\
\text { Patients) }\end{array}$ & $\begin{array}{l}\text { Imprecision (small } \\
\text { sample size) }\end{array}$ & $\begin{array}{l}\text { Moderate } \\
\text { (improved } \\
\text { function) }\end{array}$ \\
\hline $\begin{array}{l}\text { Clomipramine } \\
\text { (class: TCA) vs. } \\
\text { Pill Placebo }\end{array}$ & $\begin{array}{l}\text { Primary anxiety, } \\
\text { child report }\end{array}$ & $\begin{array}{l}\text { SMD: }-0.07 ; \\
95 \% \mathrm{Cl}:-0.95 \\
\text { to } 0.81 ; I^{2}=\mathrm{N} / \mathrm{A}\end{array}$ & $\begin{array}{l}1 \text { RCT (19 } \\
\text { Patients) }\end{array}$ & $\begin{array}{l}\text { Severe } \\
\text { imprecision (small } \\
\text { sample size and } \\
\text { wide Cls) }\end{array}$ & $\begin{array}{l}\text { Low } \\
\text { (no difference) }\end{array}$ \\
\hline \multirow[t]{2}{*}{$\begin{array}{l}\text { Duloxetine } \\
\text { (class: SNRI) } \\
\text { vs. Pill Placebo }\end{array}$} & $\begin{array}{l}\text { Primary anxiety, } \\
\text { clinician report }\end{array}$ & $\begin{array}{l}\text { SMD: }-0.43 ; \\
\text { 95\% Cl: }-0.67 \\
\text { to }-0.19 ; \\
I^{2}=N / A\end{array}$ & $\begin{array}{l}1 \text { RCT (272 } \\
\text { Patients) }\end{array}$ & $\begin{array}{l}\text { Imprecision (small } \\
\text { sample size) }\end{array}$ & $\begin{array}{l}\text { Moderate } \\
\text { (reduced } \\
\text { anxiety) }\end{array}$ \\
\hline & Function & $\begin{array}{l}\text { SMD: }-0.35 ; \\
95 \% \mathrm{Cl}:-0.59 \\
\text { to }-0.11 ; \\
I^{2}=\mathrm{N} / \mathrm{A}\end{array}$ & $\begin{array}{l}1 \text { RCT (272 } \\
\text { Patients) }\end{array}$ & $\begin{array}{l}\text { Imprecision (small } \\
\text { sample size) }\end{array}$ & $\begin{array}{l}\text { Moderate } \\
\text { (improved } \\
\text { function) }\end{array}$ \\
\hline \multirow[t]{8}{*}{$\begin{array}{l}\text { Fluoxetine } \\
\text { (class: SSRI) vs. } \\
\text { Pill Placebo }\end{array}$} & $\begin{array}{l}\text { Primary anxiety, } \\
\text { child report }\end{array}$ & $\begin{array}{l}\text { SMD:-0.38; } \\
\text { 95\% Cl: }-1.26 \\
\text { to 0.50; } \\
\mathrm{I}^{2}=43.3 \%\end{array}$ & $\begin{array}{l}2 \text { RCTs (154 } \\
\text { Patients) })^{51,53,54}\end{array}$ & $\begin{array}{l}\text { Severe } \\
\text { imprecision (wide } \\
\text { Cls and small } \\
\text { sample size) }\end{array}$ & $\begin{array}{l}\text { Low } \\
\text { (no difference) }\end{array}$ \\
\hline & $\begin{array}{l}\text { Primary anxiety, } \\
\text { parent report }\end{array}$ & $\begin{array}{l}\text { SMD:-0.46; } \\
95 \% \mathrm{Cl}:-0.92 \\
\text { to } 0.01 ; I^{2}=\mathrm{N} / \mathrm{A}\end{array}$ & $\begin{array}{l}1 \text { RCT (74 } \\
\text { Patients) }\end{array}$ & $\begin{array}{l}\text { Severe } \\
\text { imprecision (wide } \\
\text { Cls and small } \\
\text { sample size) }\end{array}$ & $\begin{array}{l}\text { Low } \\
\text { (no difference) }\end{array}$ \\
\hline & $\begin{array}{l}\text { Primary anxiety, } \\
\text { clinician report }\end{array}$ & $\begin{array}{l}\text { SMD:-0.40; } \\
95 \% \text { Cl: }-0.72 \\
\text { to }-0.01 ; \\
I^{2}=\text { N/A }\end{array}$ & $\begin{array}{l}2 \text { RCTs (154 } \\
\text { Patients) })^{51,53}\end{array}$ & $\begin{array}{l}\text { Severe } \\
\text { imprecision (wide } \\
\text { Cls and small } \\
\text { sample size) }\end{array}$ & $\begin{array}{l}\text { Low } \\
\text { (reduced } \\
\text { anxiety) }\end{array}$ \\
\hline & Function & $\begin{array}{l}\text { SMD: }-0.75 ; \\
95 \% \text { Cl: }-1.07 \\
\text { to }-0.42 ; I^{2}= \\
0.0 \%\end{array}$ & $\begin{array}{l}2 \text { RCTs (154 } \\
\text { Patients) }\end{array}$ & $\begin{array}{l}\text { Imprecision (small } \\
\text { sample size) }\end{array}$ & $\begin{array}{l}\text { Moderate } \\
\text { (improved } \\
\text { function) }\end{array}$ \\
\hline & $\begin{array}{l}\text { Secondary } \\
\text { measure }\end{array}$ & $\begin{array}{l}\text { SMD: }-0.19 ; \\
95 \% \mathrm{Cl}:-0.55 \\
\text { to } 0.17 ; \\
\mathrm{I}^{2}=75.1 \%\end{array}$ & $\begin{array}{l}1 \text { RCT (124 } \\
\text { Patients) })^{51,54}\end{array}$ & $\begin{array}{l}\text { Severe } \\
\text { imprecision (wide } \\
\text { Cls and small } \\
\text { sample size) }\end{array}$ & $\begin{array}{l}\text { Low } \\
\text { (no difference) }\end{array}$ \\
\hline & Social function & $\begin{array}{l}\text { SMD: } 0.18 ; \\
95 \% \mathrm{Cl}:-0.26 \\
\text { to } 0.62 ; I^{2}=\mathrm{N} / \mathrm{A}\end{array}$ & $\begin{array}{l}1 \text { RCT (80 } \\
\text { Patients) }\end{array}$ & $\begin{array}{l}\text { Severe } \\
\text { imprecision (wide } \\
\text { Cls and small } \\
\text { sample size) }\end{array}$ & $\begin{array}{l}\text { Low } \\
\text { (no difference) }\end{array}$ \\
\hline & Remission & $\begin{array}{l}\text { RR: } 2.04 ; 95 \% \\
\mathrm{Cl}: 1.32 \text { to } \\
3.04 ; I^{2}=N / A\end{array}$ & $\begin{array}{l}2 \text { RCTs (95 } \\
\text { Patients) }\end{array}$ & $\begin{array}{l}\text { Imprecision (small } \\
\text { sample size) }\end{array}$ & $\begin{array}{l}\text { Moderate } \\
\text { (improved } \\
\text { remission) }\end{array}$ \\
\hline & Response & $\begin{array}{l}\text { RR: } 1.70 ; 95 \% \\
\mathrm{Cl}: 1.01 \text { to } \\
2.82 ; I^{2}=0.0 \%\end{array}$ & $\begin{array}{l}1 \text { RCT (74 } \\
\text { Patients) }\end{array}$ & $\begin{array}{l}\text { Severe } \\
\text { imprecision (wide } \\
\text { Cls and small }\end{array}$ & $\begin{array}{l}\text { Low } \\
\text { (improved } \\
\text { response) }\end{array}$ \\
\hline
\end{tabular}




\begin{tabular}{|c|c|c|c|c|c|}
\hline Comparison & Outcome & Conclusion & $\begin{array}{l}\text { Study Design and } \\
\text { Sample Size }\end{array}$ & $\begin{array}{l}\text { Factors That } \\
\text { Affect the } \\
\text { Strength of } \\
\text { Evidence }^{b}\end{array}$ & $\begin{array}{c}\text { Overall } \\
\text { Evidence } \\
\text { Strength } \\
\text { (Direction of } \\
\text { Effect) }\end{array}$ \\
\hline & & & & sample size) & \\
\hline $\begin{array}{l}\text { Fluvoxamine } \\
\text { (class: SSRI) vs. } \\
\text { Pill Placebo }\end{array}$ & $\begin{array}{l}\text { Primary anxiety, } \\
\text { clinician report }\end{array}$ & $\begin{array}{l}\text { SMD: }-0.97 ; \\
95 \% \mathrm{Cl}:-1.31 \\
\text { to }-0.63 ; \\
\mathrm{I}^{2}=69.1 \%\end{array}$ & $\begin{array}{l}2 \text { RCTs (153 } \\
\text { Patients) })^{22,49}\end{array}$ & $\begin{array}{l}\text { Imprecision (small } \\
\text { sample size) and } \\
\text { inconsistency }\end{array}$ & $\begin{array}{l}\text { Low } \\
\text { (reduced } \\
\text { anxiety) }\end{array}$ \\
\hline \multirow[t]{2}{*}{$\begin{array}{l}\text { Imipramine } \\
\text { (class: TCA) vs. } \\
\text { Pill Placebo }\end{array}$} & $\begin{array}{l}\text { Primary anxiety, } \\
\text { child report }\end{array}$ & $\begin{array}{l}\text { SMD: } 0.80 ; \\
95 \% \mathrm{Cl}:-0.10 \\
\text { to } 1.70 ; I^{2}=\mathrm{N} / \mathrm{A}\end{array}$ & $\begin{array}{l}1 \text { RCT (21 } \\
\text { Patients) }\end{array}$ & $\begin{array}{l}\text { Methodological } \\
\text { limitations, severe } \\
\text { imprecision (small } \\
\text { sample size and } \\
\text { wide Cl) }\end{array}$ & Insufficient \\
\hline & $\begin{array}{l}\text { Primary anxiety, } \\
\text { parent report }\end{array}$ & $\begin{array}{l}\text { SMD: } 0.46 ; \\
95 \% \text { Cl: }- \\
0.41 \text { to 1.33; } \\
I^{2}=\text { N/A }\end{array}$ & $\begin{array}{l}1 \text { RCT (21 } \\
\text { Patients) }\end{array}$ & $\begin{array}{l}\text { Methodological } \\
\text { limitations, severe } \\
\text { imprecision (small } \\
\text { sample size and } \\
\text { wide } \mathrm{Cl} \text { ) }\end{array}$ & Insufficient \\
\hline \multirow[t]{3}{*}{$\begin{array}{l}\text { Paroxetine } \\
\text { (class: SSRI) vs. } \\
\text { Pill Placebo }\end{array}$} & $\begin{array}{l}\text { Primary anxiety, } \\
\text { clinician report }\end{array}$ & $\begin{array}{l}\text { SMD: }-0.71 ; \\
95 \% \mathrm{Cl}:-1.06 \\
\text { to }-0.37 ; \\
I^{2}=\mathrm{N} / \mathrm{A}\end{array}$ & $\begin{array}{l}1 \text { RCT }(137 \\
\text { Patients })^{65}\end{array}$ & $\begin{array}{l}\text { Imprecision (small } \\
\text { sample size) }\end{array}$ & $\begin{array}{l}\text { Moderate } \\
\text { (reduced } \\
\text { anxiety) }\end{array}$ \\
\hline & Function & $\begin{array}{l}\text { SMD: }-0.61 ; \\
95 \% \text { Cl: }-0.83 \\
\text { to }-0.38 ; \\
I^{2}=\text { N/A }\end{array}$ & $\begin{array}{l}1 \text { RCT (317 } \\
\text { Patients) }{ }^{65}\end{array}$ & $\begin{array}{l}\text { Imprecision (small } \\
\text { sample size) }\end{array}$ & $\begin{array}{l}\text { Moderate } \\
\text { (improved } \\
\text { function) }\end{array}$ \\
\hline & Response & $\begin{array}{l}\text { RR: } 2.02 ; 95 \% \\
\mathrm{Cl}: 1.62 \text { to } \\
2.51 ; I^{2}=\mathrm{N} / \mathrm{A}\end{array}$ & $\begin{array}{l}1 \text { RCT (322 } \\
\text { Patients) }\end{array}$ & $\begin{array}{l}\text { Imprecision (small } \\
\text { sample size) }\end{array}$ & $\begin{array}{l}\text { Moderate } \\
\text { (improved } \\
\text { response) }\end{array}$ \\
\hline \multirow[t]{4}{*}{$\begin{array}{l}\text { Sertraline } \\
\text { (class: SSRI) vs. } \\
\text { Pill Placebo }\end{array}$} & $\begin{array}{l}\text { Primary anxiety, } \\
\text { child report }\end{array}$ & $\begin{array}{l}\text { SMD: }-0.75 ; \\
95 \% \mathrm{Cl}:-1.62 \\
\text { to } 0.12 ; I^{2}=\mathrm{N} / \mathrm{A}\end{array}$ & $\begin{array}{l}1 \text { RCT (22 } \\
\text { patients) }^{61}\end{array}$ & $\begin{array}{l}\text { Severe } \\
\text { imprecision (wide } \\
\text { Cls and small } \\
\text { sample size) }\end{array}$ & $\begin{array}{l}\text { Low } \\
\text { (no difference) }\end{array}$ \\
\hline & $\begin{array}{l}\text { Primary anxiety, } \\
\text { parent report }\end{array}$ & $\begin{array}{l}\text { SMD: }-0.24 ; \\
95 \% \mathrm{Cl}:-2.16 \\
\text { to }-0.32 ; \\
I^{2}=\mathrm{N} / \mathrm{A}\end{array}$ & $\begin{array}{l}1 \text { RCT (22 } \\
\text { Patients) }\end{array}$ & $\begin{array}{l}\text { Severe } \\
\text { imprecision (wide } \\
\text { Cls and small } \\
\text { sample size) }\end{array}$ & $\begin{array}{l}\text { Low } \\
\text { (reduced } \\
\text { anxiety) }\end{array}$ \\
\hline & $\begin{array}{l}\text { Primary anxiety, } \\
\text { clinician report }\end{array}$ & $\begin{array}{l}\text { SMD: }-71 ; 95 \% \\
\mathrm{Cl}:-0.99 \text { to }- \\
0.42 ; 1^{2}=89.9 \%\end{array}$ & $\begin{array}{l}2 \text { RCTs }(231 \\
\text { Patients) })^{7,61,67,69-73}\end{array}$ & $\begin{array}{l}\text { Imprecision (small } \\
\text { sample size), } \\
\text { inconsistency }\end{array}$ & $\begin{array}{l}\text { Low } \\
\text { (reduced } \\
\text { anxiety) }\end{array}$ \\
\hline & Function & $\begin{array}{l}\text { SMD: }-0.46 ; \\
95 \% \mathrm{Cl}:-0.74 \\
\text { to }-0.17 ; \\
I^{2}=\mathrm{N} / \mathrm{A}\end{array}$ & $\begin{array}{l}1 \text { RCT (209 } \\
\text { Patients) }\end{array}$ & $\begin{array}{l}\text { Imprecision (small } \\
\text { sample size) }\end{array}$ & $\begin{array}{l}\text { Moderate } \\
\text { (improved } \\
\text { function) }\end{array}$ \\
\hline \multirow[t]{3}{*}{$\begin{array}{l}\text { Venlafaxine } \\
\text { (class: SNRI) } \\
\text { vs. Pill Placebo }\end{array}$} & $\begin{array}{l}\text { Primary anxiety, } \\
\text { child report }\end{array}$ & $\begin{array}{l}\text { SMD: }-1.96 ; \\
95 \% \mathrm{Cl}:-2.23 \\
\text { to }-1.64 ; \\
\mathrm{I}^{2}=99.6 \%\end{array}$ & $\begin{array}{l}2 \text { RCTs }(443 \\
\text { Patients) })^{58,62}\end{array}$ & Inconsistency & $\begin{array}{l}\text { Moderate } \\
\text { (reduced } \\
\text { anxiety) }\end{array}$ \\
\hline & $\begin{array}{l}\text { Primary anxiety, } \\
\text { parent report }\end{array}$ & $\begin{array}{l}\text { SMD: }-0.32 ; \\
95 \% \mathrm{Cl}:-0.63 \\
\text { to } 0.00 ; I^{2}=\mathrm{N} / \mathrm{A}\end{array}$ & $\begin{array}{l}1 \text { RCT (153 } \\
\text { Patients) }{ }^{62}\end{array}$ & $\begin{array}{l}\text { Severe } \\
\text { imprecision (wide } \\
\text { Cls and small } \\
\text { sample size) }\end{array}$ & $\begin{array}{l}\text { Low } \\
\text { (no difference) }\end{array}$ \\
\hline & $\begin{array}{l}\text { Primary anxiety, } \\
\text { clinician report }\end{array}$ & $\begin{array}{l}\text { SMD: }-0.42 ; \\
95 \% \mathrm{Cl}:-0.74 \\
\text { to }-0.10 ; \\
I^{2}=\mathrm{N} / \mathrm{A}\end{array}$ & $\begin{array}{l}1 \text { RCT (153 } \\
\text { Patients) }{ }^{62}\end{array}$ & $\begin{array}{l}\text { Imprecision (small } \\
\text { sample size) }\end{array}$ & $\begin{array}{l}\text { Moderate } \\
\text { (reduced } \\
\text { anxiety) }\end{array}$ \\
\hline $\begin{array}{l}\text { Clonazepam } \\
\text { (class: } \\
\text { Benzodiazepine }\end{array}$ & $\begin{array}{l}\text { Primary anxiety, } \\
\text { clinician report }\end{array}$ & $\begin{array}{l}\text { SMD: } 0.30 ; \\
95 \% \mathrm{Cl}:-0.72 \\
\text { to } 1.32 ; I^{2}=\mathrm{N} / \mathrm{A}\end{array}$ & $\begin{array}{l}1 \text { RCT (15 } \\
\text { Patients) }\end{array}$ & $\begin{array}{l}\text { Severe } \\
\text { imprecision (wide } \\
\text { Cls and small }\end{array}$ & $\begin{array}{l}\text { Low } \\
\text { (no difference) }\end{array}$ \\
\hline
\end{tabular}




\begin{tabular}{|c|c|c|c|c|c|}
\hline Comparison & Outcome & Conclusion & $\begin{array}{l}\text { Study Design and } \\
\text { Sample Size }^{a}\end{array}$ & $\begin{array}{l}\text { Factors That } \\
\text { Affect the } \\
\text { Strength of } \\
\text { Evidence }^{b}\end{array}$ & $\begin{array}{c}\text { Overall } \\
\text { Evidence } \\
\text { Strength } \\
\text { (Direction of } \\
\text { Effect) }\end{array}$ \\
\hline ) vs. Pill Placebo & & & & sample size) & \\
\hline \multirow{3}{*}{$\begin{array}{l}\text { Venlafaxine } \\
\text { (class: SNRI) } \\
\text { vs. Attention } \\
\text { Control or } \\
\text { Treatment As } \\
\text { Usual }\end{array}$} & $\begin{array}{l}\text { Primary anxiety, } \\
\text { child report }\end{array}$ & $\begin{array}{l}\text { SMD: }-0.40 ; \\
95 \% \mathrm{Cl}:-0.72 \\
\text { to }-0.09 ; \\
I^{2}=\mathrm{N} / \mathrm{A}\end{array}$ & $\begin{array}{l}1 \text { RCT (158 } \\
\text { Patients) }\end{array}$ & $\begin{array}{l}\text { Imprecision (small } \\
\text { sample size) }\end{array}$ & $\begin{array}{l}\text { Moderate } \\
\text { (reduced } \\
\text { anxiety) }\end{array}$ \\
\hline & $\begin{array}{l}\text { Primary anxiety, } \\
\text { parent report }\end{array}$ & $\begin{array}{l}\text { SMD: }-0.42 ; \\
95 \% \mathrm{Cl}:-0.73 \\
\text { to }-0.10 ; \\
I^{2}=\mathrm{N} / \mathrm{A}\end{array}$ & $\begin{array}{l}1 \text { RCT (158 } \\
\text { Patients) }\end{array}$ & $\begin{array}{l}\text { Imprecision (small } \\
\text { sample size) }\end{array}$ & $\begin{array}{l}\text { Moderate } \\
\text { (reduced } \\
\text { anxiety) }\end{array}$ \\
\hline & $\begin{array}{l}\text { Primary anxiety, } \\
\text { clinician report }\end{array}$ & $\begin{array}{l}\text { SMD: }-0.09 ; \\
95 \% \mathrm{Cl}:-0.40 \\
\text { to } 0.22 ; 1^{2}=\mathrm{N} / \mathrm{A}\end{array}$ & $\begin{array}{l}1 \text { RCT (158 } \\
\text { Patients) }\end{array}$ & $\begin{array}{l}\text { Severe } \\
\text { imprecision (wide } \\
\text { Cls and small } \\
\text { sample size) }\end{array}$ & $\begin{array}{l}\text { Low } \\
\text { (no difference) }\end{array}$ \\
\hline \multirow{3}{*}{$\begin{array}{l}\text { Atomoxetine } \\
\text { (class: SNRI) } \\
\text { vs. Attention } \\
\text { Control or } \\
\text { Treatment As } \\
\text { Usual }\end{array}$} & $\begin{array}{l}\text { Primary anxiety, } \\
\text { child report }\end{array}$ & $\begin{array}{l}\text { SMD: }-0.26 ; \\
95 \% \mathrm{Cl}:-0.57 \\
\text { to } 0.05 ; 1^{2}=\mathrm{N} / \mathrm{A}\end{array}$ & $\begin{array}{l}1 \text { RCT (154 } \\
\text { Patients) }\end{array}$ & $\begin{array}{l}\text { Severe } \\
\text { imprecision (wide } \\
\text { Cls and small } \\
\text { sample size) }\end{array}$ & $\begin{array}{l}\text { Low } \\
\text { (no difference) }\end{array}$ \\
\hline & $\begin{array}{l}\text { Primary anxiety, } \\
\text { parent report }\end{array}$ & $\begin{array}{l}\text { SMD: }-0.34 ; \\
95 \% \mathrm{Cl}:-0.65 \\
\text { to }-0.03 ; \\
\mathrm{I}^{2}=\mathrm{N} / \mathrm{A}\end{array}$ & $\begin{array}{l}1 \text { RCT (154 } \\
\text { Patients) }\end{array}$ & $\begin{array}{l}\text { Severe } \\
\text { imprecision (wide } \\
\text { Cls and small } \\
\text { sample size) }\end{array}$ & $\begin{array}{l}\text { Low } \\
\text { (reduced } \\
\text { anxiety) }\end{array}$ \\
\hline & $\begin{array}{l}\text { Primary anxiety, } \\
\text { clinician report }\end{array}$ & $\begin{array}{l}\text { SMD: }-0.33 ; \\
95 \% \mathrm{Cl}:-0.65 \\
\text { to }-0.02 ; \\
I^{2}=\mathrm{N} / \mathrm{A}\end{array}$ & $\begin{array}{l}1 \text { RCT (154 } \\
\text { Patients) }\end{array}$ & $\begin{array}{l}\text { Severe } \\
\text { imprecision (wide } \\
\text { Cls and small } \\
\text { sample size) }\end{array}$ & $\begin{array}{l}\text { Low } \\
\text { (reduced } \\
\text { anxiety) }\end{array}$ \\
\hline
\end{tabular}

CI: confidence interval, N/A: not applicable, RCT: randomized control trial, RR: relative risk, SMD: standardized mean difference, SNRI: serotonin-norepinephrine reuptake inhibitor, SSRI: selective serotonin reuptake inhibitor, TCA: tricyclic antidepressants.

${ }^{\mathrm{a}}$ The sample size includes the number of patients from each comparison.

${ }^{\mathrm{b}}$ Only SOE domains that led to rating down SOE are reported in this column. Domains that are not reported were satisfactory.

\section{Drugs Versus Drugs}

\section{Key Points}

- Only two RCTs conducted head-to-head comparison.

- Compared to clomipramine, fluoxetine was more effective in improving primary anxiety symptoms (child report) (low SOE).

- No significant difference was found between venlafaxine and atomoxetine on primary anxiety symptoms (child, parent, and clinician reports) (low SOE).

\section{Discussion}

One RCT ${ }^{54,62}$ compared fluoxetine to clomipramine ${ }^{54}$ and another RCT compared venlafaxine to atomoxetine. ${ }^{62}$ Overall, 39 patients were included with age range of 6-17 years old and $52.2 \%$ male. These 2 studies $^{54,62}$ included patients without any comorbidity. Details of the included studies can be found in Appendix Table E.2. We were unable to evaluate publication bias due to small number of studies $(\mathrm{n}<20)$ included in each comparisons.

Compared to clomipramine, fluoxetine was more effective in improving primary anxiety symptoms (child report, low SOE); while venlafaxine and atomoxetine were not significantly 
different in improving primary anxiety symptoms (low SOE). Results of the individual drugs comparisons with drugs are presented in Table 7.

Table 7. Strength of evidence for drugs versus drugs

\begin{tabular}{|c|c|c|c|c|c|}
\hline Comparison & Outcome & Conclusion & $\begin{array}{l}\text { Study Design and } \\
\text { Sample Size }\end{array}$ & $\begin{array}{l}\text { Factors That } \\
\text { Affect the } \\
\text { Strength of } \\
\text { evidence }^{b}\end{array}$ & $\begin{array}{c}\text { Overall } \\
\text { Evidence } \\
\text { Strength } \\
\text { (Direction } \\
\text { of Effect) }\end{array}$ \\
\hline \multirow[t]{2}{*}{$\begin{array}{l}\text { Fluoxetine (class: } \\
\text { SSRI) vs. } \\
\text { Clomipramine } \\
\text { (class: TCA) }\end{array}$} & $\begin{array}{l}\text { Primary anxiety, } \\
\text { child report }\end{array}$ & $\begin{array}{l}\text { SMD: }-1.01 ; \\
95 \% \mathrm{Cl}:-2.02 \text { to } \\
-0.09 ; I^{2}=\mathrm{N} / \mathrm{A}\end{array}$ & 1 RCT (19 Patients) ${ }^{54}$ & $\begin{array}{l}\text { Severe } \\
\text { imprecision } \\
\text { (wide Cls and } \\
\text { small sample } \\
\text { size) }\end{array}$ & $\begin{array}{l}\text { Low } \\
\text { (reduced } \\
\text { anxiety) }\end{array}$ \\
\hline & Remission & $\begin{array}{l}\text { RR: } 1.20 ; 95 \% \\
\text { Cl: } 0.69 \text { to } 2.09 \\
I^{2}=N / A\end{array}$ & 1 RCT (19 Patients) ${ }^{54}$ & $\begin{array}{l}\text { Severe } \\
\text { imprecision } \\
\text { (wide Cls and } \\
\text { small sample } \\
\text { size) }\end{array}$ & $\begin{array}{l}\text { Low } \\
\text { (no } \\
\text { difference) }\end{array}$ \\
\hline \multirow[t]{3}{*}{$\begin{array}{l}\text { Venlafaxine } \\
\text { (class: SNRI) vs. } \\
\text { Atomoxetine } \\
\text { (class: SNRI) }\end{array}$} & $\begin{array}{l}\text { Primary anxiety, } \\
\text { child report }\end{array}$ & $\begin{array}{l}\text { SMD: }-0.12 ; \\
95 \% \mathrm{Cl}:-0.43 \text { to } \\
0.20 ; I^{2}=\mathrm{N} / \mathrm{A}\end{array}$ & 1 RCT (154 Patients) ${ }^{62}$ & $\begin{array}{l}\text { Severe } \\
\text { imprecision } \\
\text { (wide Cls and } \\
\text { small sample } \\
\text { size) }\end{array}$ & $\begin{array}{l}\text { Low } \\
\text { (no } \\
\text { difference) }\end{array}$ \\
\hline & $\begin{array}{l}\text { Primary anxiety, } \\
\text { parent report }\end{array}$ & $\begin{array}{l}\text { SMD: }-0.08 ; \\
95 \% \mathrm{Cl}:-0.39 \text { to } \\
0.24 ; I^{2}=\mathrm{N} / \mathrm{A}\end{array}$ & 1 RCT (154 Patients) ${ }^{62}$ & $\begin{array}{l}\text { Severe } \\
\text { imprecision } \\
\text { (wide Cls and } \\
\text { small sample } \\
\text { size) }\end{array}$ & $\begin{array}{l}\text { Low } \\
\text { (no } \\
\text { difference) }\end{array}$ \\
\hline & $\begin{array}{l}\text { Primary anxiety, } \\
\text { clinician report }\end{array}$ & $\begin{array}{l}\text { SMD: } 0.25 ; 95 \% \\
\text { Cl: }-0.07 \text { to } 0.57 \\
I^{2}=N / A\end{array}$ & 1 RCT (154 Patients) ${ }^{62}$ & $\begin{array}{l}\text { Severe } \\
\text { imprecision } \\
\text { (wide Cls and } \\
\text { small sample } \\
\text { size) }\end{array}$ & $\begin{array}{l}\text { Low } \\
\text { (no } \\
\text { difference) }\end{array}$ \\
\hline
\end{tabular}

CI: confidence interval, N/A: not applicable, RCT: randomized control trial, RR: relative risk, SMD: standardized mean difference, SNRI: serotonin-norepinephrine reuptake inhibitor, SSRI: selective serotonin reuptake inhibitor, TCA: tricyclic antidepressants.

${ }^{\mathrm{a}}$ The sample size includes the number of patients from each comparison.

${ }^{\mathrm{b}}$ Only SOE domains that led to rating down SOE are reported in this column. Domains that are not reported were satisfactory.

\section{Drugs Versus CBT}

\section{Key Points}

- Only two RCTs compared CBT to SSRIs.

- CBT reduced primary anxiety symptoms and improved function more than fluoxetine (moderate SOE).

\section{Discussion}

One RCT compared CBT to fluoxetine. ${ }^{51,63}$ Overall, 102 patients were included with a mean age of 11.6 years old and 51.5 percent male. Details of the included study can be found in Appendix Table E.3. CBT was more effective in improving primary anxiety symptoms (clinician report), function, and secondary anxiety measures (moderate SOE). Table 8 includes summary of the results and assessment of SOE. 
One RCT of 272 patients with a primary diagnosis of social anxiety disorder, generalized anxiety disorder, or social anxiety disorder (mean age: 10.7 years), compared CBT to sertraline. ${ }^{7}$ 67, 69-73 Patients were randomized to receive either 14 sessions of CBT or sertraline (up to $200 \mathrm{mg}$

per day). Details of the included study can be found in Appendix Table E.3. There were no other significant differences in other outcomes (low SOE) (Table 8).

Table 8. Strength of evidence for drugs versus CBT

\begin{tabular}{|c|c|c|c|c|c|}
\hline Comparison & Outcome & Conclusion & $\begin{array}{l}\text { Study Design and } \\
\text { Sample Size }^{a}\end{array}$ & $\begin{array}{l}\text { Factors That } \\
\text { Affect the } \\
\text { Strength of } \\
\text { Evidence }^{b}\end{array}$ & $\begin{array}{c}\text { Overall } \\
\text { Evidence } \\
\text { Strength } \\
\text { (Direction of } \\
\text { Effect) }\end{array}$ \\
\hline \multirow[t]{5}{*}{$\begin{array}{l}\text { Fluoxetine } \\
\text { (class: SSRI) } \\
\text { vs. CBT }\end{array}$} & $\begin{array}{l}\text { Primary } \\
\text { anxiety, child } \\
\text { report }\end{array}$ & $\begin{array}{l}\text { SMD:-0.16; } \\
95 \% \mathrm{Cl}:-0.55 \\
\text { to } 0.24 ; \\
I^{2}=\mathrm{N} / \mathrm{A}\end{array}$ & 1 RCT (102 Patients) & $\begin{array}{l}\text { Severe } \\
\text { imprecision (wide } \\
\text { Cls and small } \\
\text { sample size) }\end{array}$ & $\begin{array}{l}\text { Low } \\
\text { (no difference) }\end{array}$ \\
\hline & $\begin{array}{l}\text { Primary } \\
\text { anxiety, } \\
\text { clinician } \\
\text { report }\end{array}$ & $\begin{array}{l}\text { SMD:0.78; } \\
95 \% \mathrm{Cl}: 0.37 \\
\text { to } 1.18 ; \\
I^{2}=\mathrm{N} / \mathrm{A}\end{array}$ & 1 RCT (102 Patients) & $\begin{array}{l}\text { Imprecision } \\
\text { (small sample } \\
\text { size) }\end{array}$ & $\begin{array}{l}\text { Moderate } \\
\text { (increased } \\
\text { anxiety) }\end{array}$ \\
\hline & Function & $\begin{array}{l}\text { SMD: } 0.54 ; \\
95 \% \mathrm{Cl}: 0.14 \\
\text { to } 0.94 ; \\
I^{2}=\mathrm{N} / \mathrm{A}\end{array}$ & 1 RCT (102 Patients) ${ }^{51}$ & $\begin{array}{l}\text { Imprecision } \\
\text { (small sample } \\
\text { size) }\end{array}$ & $\begin{array}{l}\text { Moderate } \\
\text { (reduced } \\
\text { function) }\end{array}$ \\
\hline & $\begin{array}{l}\text { Secondary } \\
\text { measure }\end{array}$ & $\begin{array}{l}\text { SMD: } 0.51 ; \\
95 \% \mathrm{Cl}: 0.11 \\
\text { to } 0.90 ; \\
1^{2}=\mathrm{N} / \mathrm{A}\end{array}$ & 1 RCT (102 Patients) & $\begin{array}{l}\text { Imprecision } \\
\text { (small sample } \\
\text { size) }\end{array}$ & $\begin{array}{l}\text { Moderate } \\
\text { (increased } \\
\text { anxiety) }\end{array}$ \\
\hline & $\begin{array}{l}\text { Social } \\
\text { function }\end{array}$ & $\begin{array}{l}\text { SMD: }-0.19 ; \\
95 \% \mathrm{Cl}:-0.58 \\
\text { to } 0.21 ; \\
\text { I2=N/A }\end{array}$ & 1 RCT (102 Patients) & $\begin{array}{l}\text { Severe } \\
\text { imprecision (wide } \\
\text { Cls and small } \\
\text { sample size) }\end{array}$ & $\begin{array}{l}\text { Low } \\
\text { (no difference) }\end{array}$ \\
\hline \multirow[t]{4}{*}{$\begin{array}{l}\text { Sertraline } \\
\text { (class: SSRI) } \\
\text { vS. } \\
\text { CBT }\end{array}$} & $\begin{array}{l}\text { Primary } \\
\text { anxiety, } \\
\text { clinician } \\
\text { report }\end{array}$ & $\begin{array}{l}\text { SMD: }-0.15 ; \\
95 \% \mathrm{Cl}:-0.31 \\
\text { to } 0.02 ; I^{2}= \\
\text { N/A }\end{array}$ & $\begin{array}{l}1 \text { RCT (272 Patients) } \\
67,69-73\end{array}$ & $\begin{array}{l}\text { Severe } \\
\text { imprecision (wide } \\
\text { Cls and small } \\
\text { sample size) }\end{array}$ & $\begin{array}{l}\text { Low } \\
\text { (no difference) }\end{array}$ \\
\hline & Function & $\begin{array}{l}\text { SMD: }-0.12 ; \\
95 \% \mathrm{Cl}:-0.35 \\
\text { to } 0.12 ; I^{2}= \\
\text { N/A }\end{array}$ & $\underset{67,69-73}{1 \text { RCT (272 Patients) }}$ & $\begin{array}{l}\text { Severe } \\
\text { imprecision (wide } \\
\text { Cls and small } \\
\text { sample size) }\end{array}$ & $\begin{array}{l}\text { Low } \\
\text { (no difference) }\end{array}$ \\
\hline & Remission & $\begin{array}{l}\text { RR: } 1.00 ; \\
95 \% \mathrm{Cl} \\
0.77 \text { to } 1.29 \\
\text { I }^{2}=\mathrm{N} / \mathrm{A}\end{array}$ & $\begin{array}{l}1 \text { RCT (272 Patients) } \\
67,69-73\end{array}$ & $\begin{array}{l}\text { Severe } \\
\text { imprecision (wide } \\
\text { Cls and small } \\
\text { sample size) }\end{array}$ & $\begin{array}{l}\text { Low } \\
\text { (no difference) }\end{array}$ \\
\hline & Response & $\begin{array}{l}\text { RR: } 0.92 ; \\
95 \% \mathrm{Cl}: 0.75 \\
\text { to } 1.13 ; \\
\mathrm{I}^{2}=\mathrm{N} / \mathrm{A}\end{array}$ & $\begin{array}{l}1 \text { RCT (272 Patients) } \\
67,69-73\end{array}$ & $\begin{array}{l}\text { Severe } \\
\text { imprecision (wide } \\
\text { Cls and small } \\
\text { sample size) }\end{array}$ & $\begin{array}{l}\text { Low } \\
\text { (no difference) }\end{array}$ \\
\hline
\end{tabular}

CI: confidence interval, CBT: cognitive behavioral therapy, N/A: not applicable, RCT: randomized control trial, RR: relative risk, SMD: standardized mean difference, SNRI: serotonin-norepinephrine reuptake inhibitor, SSRI: selective serotonin reuptake inhibitor, TCA: Tricyclic antidepressants

${ }^{\mathrm{a}}$ The sample size includes the number of patients from each comparison.

${ }^{\mathrm{b}}$ Only SOE domains that led to rating down SOE are reported in this column. Domains that are not reported were satisfactory. 


\section{CBT Versus Control (Pill Placebo, Waitlisting/No Treatment, or Attention Control/Treatment as Usual)}

\section{Key Points}

- Compared to pill placebo, CBT improved secondary anxiety measures (low SOE).

- Compared to waitlisting or no treatment, CBT improved primary anxiety symptoms (clinician, child, and parent report), function, remission, and clinical response (low to moderate SOE).

- Compared to attention control or treatment as usual, CBT reduced primary anxiety symptoms (child report) (moderate SOE).

\section{Discussion}

Eighty-four RCTs and 4 non-randomized comparative studies compared CBT to controls. 29 RCTs $^{7,33,38,41,63,67-72,75-101}$ and 1 non-randomized comparative study ${ }^{102}$ compared CBT to attention control/treatment as usual, 60 RCTs $33,34,36,39-42,44,84,86,89,100,101,103-153$ and 3 nonrandomized comparative study ${ }^{154-156}$ compared CBT versus waitlisting/no treatment, and 3 RCTs compared CBT versus pill placebo. $7,51,63,67-72$ Overall, 6,978 patients were included with a

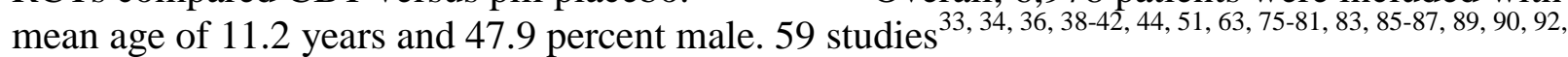
$94,96,100,102-105,107-109,110,113,117,118,120,123-126,130,131,133,135,137,139-145,147,154-156$

(67.0\%) of included patients without any comorbidity. 30 studies $^{7,}$ 67-73, 82, 84, 88, 91, 93, 95, 97-99, 101, 106, 111, 112, 114-116, 119, 121, 122, 127-129, 134, 136, 138, 146, 148-150, 152, 153 included children with anxiety and other comorbidities. 8

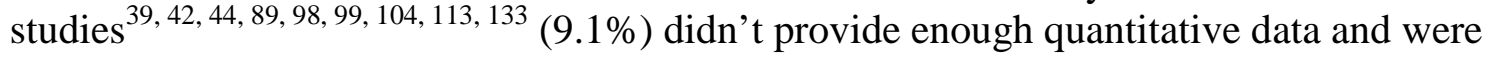
excluded from meta-analyses. Details of the included studies can be found in Appendix Tables E.4 to E.6. We found indications of potential publication bias when CBT was compared to waitlisting on primary anxiety symptoms (Appendix Figures H.1 to H.3). We were unable to evaluate publication bias due to small number of studies $(n<20)$ included in other comparisons.

Compared to pill placebo, CBT improved secondary anxiety measures (low SOE). Compared to waitlisting or no treatment, CBT improved primary anxiety symptoms (clinician, child, and parent report), function, remission, and clinical response (low to moderate SOE). Compared to attention control or treatment as usual, CBT reduced primary anxiety symptoms (child report, moderate SOE). Table 9 includes summary of the results and assessment of SOE.

Table 9. Strength of evidence for CBT versus pill placebo, waitlisting/no treatment, or attention control/treatment as usual

\begin{tabular}{|c|c|c|c|c|c|}
\hline $\begin{array}{c}\text { Compariso } \\
\mathbf{n}\end{array}$ & Outcome & Conclusion & $\begin{array}{l}\text { Study Design and } \\
\text { Sample Size }\end{array}$ & $\begin{array}{c}\text { Factors That Affect } \\
\text { the Strength of } \\
\text { Evidence }^{b}\end{array}$ & $\begin{array}{c}\text { Overall } \\
\text { Evidence } \\
\text { Strength } \\
\text { (Direction of } \\
\text { Effect) }\end{array}$ \\
\hline \multirow[t]{3}{*}{$\begin{array}{l}\text { CBT vs. Pill } \\
\text { Placebo }\end{array}$} & $\begin{array}{l}\text { Primary anxiety, } \\
\text { child report }\end{array}$ & $\begin{array}{l}\text { SMD: }-0.22 ; \\
95 \% \mathrm{Cl}:-0.64 \\
\text { to } 0.19 ; \\
\mathrm{I}^{2}=\mathrm{N} / \mathrm{A}\end{array}$ & $\begin{array}{l}1 \text { RCT (96 } \\
\text { Patients) }\end{array}$ & $\begin{array}{l}\text { Severe imprecision } \\
\text { (wide Cls and small } \\
\text { sample size) }\end{array}$ & $\begin{array}{l}\text { Low } \\
\text { (no difference) }\end{array}$ \\
\hline & $\begin{array}{l}\text { Primary anxiety, } \\
\text { clinician report }\end{array}$ & $\begin{array}{l}\text { SMD: }-0.61 ; \\
95 \% \text { Cl: }-0.85 \\
\text { to }-0.37 ; \\
I^{2}=89.1 \%\end{array}$ & $\begin{array}{l}2 \text { RCTs (311 } \\
\text { Patients) } \\
\text { 7, 51, 67, 69-73 }\end{array}$ & $\begin{array}{l}\text { Methodological } \\
\text { limitations, } \\
\text { inconsistency, } \\
\text { imprecision (small } \\
\text { sample size) }\end{array}$ & Insufficient \\
\hline & Function & SMD:-0.60; & 2 RCTs (311 & Methodological & Insufficient \\
\hline
\end{tabular}




\begin{tabular}{|c|c|c|c|c|c|}
\hline $\begin{array}{c}\text { Compariso } \\
n\end{array}$ & Outcome & Conclusion & $\begin{array}{l}\text { Study Design and } \\
\text { Sample Size }\end{array}$ & $\begin{array}{c}\text { Factors That Affect } \\
\text { the Strength of } \\
\text { Evidence }^{b}\end{array}$ & $\begin{array}{c}\text { Overall } \\
\text { Evidence } \\
\text { Strength } \\
\text { (Direction of } \\
\text { Effect) } \\
\end{array}$ \\
\hline & & $\begin{array}{l}95 \% \mathrm{Cl}:-0.84 \\
\text { to }-0.36 ; \\
\mathrm{I}^{2}=90.5 \%\end{array}$ & Patients) ${ }^{7,51,67,69-73}$ & $\begin{array}{l}\text { limitations, } \\
\text { inconsistency, } \\
\text { imprecision (small } \\
\text { sample size) }\end{array}$ & \\
\hline & Social function & $\begin{array}{l}\text { SMD: } 0.35 \\
95 \% \mathrm{Cl}:- \\
0.07,0.76 \\
I^{2}=\mathrm{N} / \mathrm{A}\end{array}$ & $\begin{array}{l}1 \text { RCT (96 } \\
\text { Patients) }\end{array}$ & $\begin{array}{l}\text { Methodological } \\
\text { limitations, severe } \\
\text { imprecision (small } \\
\text { sample size and wide } \\
\mathrm{Cl} \text { ) }\end{array}$ & Insufficient \\
\hline & $\begin{array}{l}\text { Secondary } \\
\text { measure }\end{array}$ & $\begin{array}{l}\text { SMD: }-0.02 ; \\
95 \% \mathrm{Cl}:-0.42 \\
\text { to } 0.37 ; \\
\mathrm{I}^{2}=99.1 \%\end{array}$ & $\begin{array}{l}1 \text { RCT (96 } \\
\text { Patients) }\end{array}$ & $\begin{array}{l}\text { Imprecision (small } \\
\text { sample size) and } \\
\text { inconsistency }\end{array}$ & $\begin{array}{l}\text { Low } \\
\text { (no difference) }\end{array}$ \\
\hline \multirow[t]{7}{*}{$\begin{array}{l}\text { CBT vs. } \\
\text { Waitlisting } \\
\text { or No } \\
\text { Treatment }\end{array}$} & $\begin{array}{l}\text { Primary anxiety, } \\
\text { child report }\end{array}$ & $\begin{array}{l}\text { SMD: }-0.77 ; \\
95 \% \mathrm{Cl}:-1.06 \\
\text { to }-0.47 ; \\
\mathrm{I}^{2}=86.5 \%\end{array}$ & $\begin{array}{l}41 \text { RCTs, } 2 \text { non- } \\
\text { randomized } \\
\text { comparative studies } \\
(2,297 \text { Patients) })^{33,36}, \\
40,86,105-112,114-117,119 \\
120,122-130,134-139,141-146, \\
150,151,153-155,157,158\end{array}$ & Inconsistency $^{\mathrm{c}}$ & $\begin{array}{l}\text { Moderate } \\
\text { (reduced } \\
\text { anxiety) }\end{array}$ \\
\hline & $\begin{array}{l}\text { Primary anxiety, } \\
\text { parent report }\end{array}$ & $\begin{array}{l}\text { SMD: }-0.88 ; \\
95 \% \mathrm{Cl}:-1.23 \\
\text { to }-0.54 ; \\
\mathrm{I}^{2}=81.2 \%\end{array}$ & $\begin{array}{l}27 \text { RCTs } 2 \text { non- } \\
\text { randomized } \\
\text { comparative studies } \\
(1,540 \text { Patients })^{33,103,} \\
105,106,110,111,114-116,121- \\
124,126-128,131,132,134,136- \\
138,141,143,145,146,150,151 \text {, } \\
153,155,158\end{array}$ & Inconsistency $^{\mathrm{C}}$ & $\begin{array}{l}\text { Moderate } \\
\text { (reduced } \\
\text { anxiety) }\end{array}$ \\
\hline & $\begin{array}{l}\text { Primary anxiety, } \\
\text { clinician report }\end{array}$ & $\begin{array}{l}\text { SMD: }-1.38 ; \\
95 \% \mathrm{Cl}:-1.95 \\
\text { to }-0.81 ; \\
\mathrm{I}^{2}=88.3 \%\end{array}$ & $\begin{array}{l}32 \text { RCTs, } 2 \text { non- } \\
\text { randomized } \\
\text { comparative studies } \\
(1,926 \text { Patients) })^{33,36,} \\
40,86,106,107,109,111,112, \\
114,117-122,126,127,129,131 \text {, } \\
132,136,137,139,143-146,148- \\
150,152-154,158\end{array}$ & Inconsistency $^{\mathrm{C}}$ & $\begin{array}{l}\text { Moderate } \\
\text { (reduced } \\
\text { anxiety) }\end{array}$ \\
\hline & Function & $\begin{array}{l}\text { SMD: }-0.80 \text {, } \\
95 \% \mathrm{Cl} ;-1.41 \\
\text { to }-0.20 ; \\
\mathrm{I}^{2}=91.6 \%\end{array}$ & $\begin{array}{l}18 \mathrm{RCTs}, 1 \text { non } \\
\text { randomized control } \\
\text { trial }(937 \text { Patients) } \\
36,106,108,114,117,119,122, \\
126,128,129,132,134,136,141, \\
146,148,152,154\end{array}$ & Inconsistency & $\begin{array}{l}\text { Moderate } \\
\text { (improved } \\
\text { function) }\end{array}$ \\
\hline & Social function & $\begin{array}{l}\text { SMD: }-0.02 ; \\
95 \% \mathrm{Cl} ;-0.77 \\
\text { to } 0.74 ; \\
\mathrm{I}^{2}=86.1 \%\end{array}$ & $\begin{array}{l}9 \text { RCTs, } 1 \text { non- } \\
\text { randomized control } \\
\text { trial }(385 \text { Patients })^{36,} \\
41,114-117,119,122,123,144, \\
154\end{array}$ & $\begin{array}{l}\text { Severe imprecision } \\
\text { (wide } \mathrm{Cl} \text { and small } \\
\text { sample size), } \\
\text { inconsistency }\end{array}$ & Insufficient \\
\hline & Satisfaction & $\begin{array}{l}\text { SMD: } 0.90 ; \\
95 \% \mathrm{Cl}:-0.58 \\
\text { to } 1.21 ; \\
\mathrm{I}^{2}=0.0 \%\end{array}$ & $\begin{array}{l}2 \text { RCTs (146 } \\
\text { Patients) }\end{array}$ & $\begin{array}{l}\text { Severe imprecision } \\
\text { (wide } \mathrm{Cl} \text { and small } \\
\text { sample size) }\end{array}$ & $\begin{array}{l}\text { Low } \\
\text { (no difference) }\end{array}$ \\
\hline & $\begin{array}{l}\text { Secondary } \\
\text { measure }\end{array}$ & $\begin{array}{l}\text { SMD: } 0.37 ; \\
95 \% \mathrm{Cl}:-0.32 \\
\text { to } 1.05 ; \\
92.4 \%\end{array}$ & $\begin{array}{l}16 \text { RCTs, } 2 \text { non- } \\
\text { randomized control } \\
(1,111 \text { Patients) } 33,36 \\
40,86,108,110,115,116,119 \\
121-125,130,135,137,144,147\end{array}$ & $\begin{array}{l}\text { Imprecision (wide } \mathrm{Cl} \text { ), } \\
\text { inconsistency }\end{array}$ & $\begin{array}{l}\text { Low } \\
\text { (no difference) }\end{array}$ \\
\hline
\end{tabular}




\begin{tabular}{|c|c|c|c|c|c|}
\hline $\begin{array}{c}\text { Compariso } \\
n\end{array}$ & Outcome & Conclusion & $\begin{array}{l}\text { Study Design and } \\
\text { Sample Size }\end{array}$ & $\begin{array}{c}\text { Factors That Affect } \\
\text { the Strength of } \\
\text { Evidence }\end{array}$ & $\begin{array}{c}\text { Overall } \\
\text { Evidence } \\
\text { Strength } \\
\text { (Direction of } \\
\text { Effect) } \\
\end{array}$ \\
\hline & & & 154 & & \\
\hline & Remission & $\begin{array}{l}\text { RR: } 4.08 ; \\
95 \% \mathrm{Cl}: 1.05 \\
\text { to } 15.80 ; \\
\mathrm{I}^{2}=80.8 \%\end{array}$ & $\begin{array}{l}7 \text { RCTs (307 } \\
\text { Patients) } 33,34,108,111, \\
122,134,149\end{array}$ & $\begin{array}{l}\text { Methodological } \\
\text { limitations, } \\
\text { imprecision (small } \\
\text { sample size), } \\
\text { inconsistency }\end{array}$ & $\begin{array}{l}\text { Low } \\
\text { (improved } \\
\text { remission) }\end{array}$ \\
\hline & Response & $\begin{array}{l}\text { RR: } 4.72 ; \\
95 \% \mathrm{Cl}: 2.39 \\
\text { to } 9.32 ; \\
\mathrm{I}^{2}=80.4 \%\end{array}$ & $\begin{array}{l}14 \text { RCTs }(733 \\
\text { Patients) }{ }^{36,81,86,115,} \\
116,120-122,124,126-128,136 \\
143,144,148,149\end{array}$ & Inconsistency & $\begin{array}{l}\text { Moderate } \\
\text { (improved } \\
\text { response) }\end{array}$ \\
\hline \multirow[t]{9}{*}{$\begin{array}{l}\text { CBT vs. } \\
\text { Attention } \\
\text { Control or } \\
\text { Treatment } \\
\text { As Usual }\end{array}$} & $\begin{array}{l}\text { Primary anxiety, } \\
\text { child report }\end{array}$ & $\begin{array}{l}\text { SMD:-0.36; } \\
95 \% \mathrm{Cl}:-0.67 \\
\text { to }-0.05 ; \\
\mathrm{I}^{2}=60.5 \%\end{array}$ & $\begin{array}{l}12 \text { RCTs, } 1 \text { non- } \\
\text { randomized } \\
\text { comparative study } \\
(704 \text { Patients) })^{38,76,79} \\
80,82,83,87,88,92,94-96,102\end{array}$ & $\begin{array}{l}\text { Borderline } \\
\text { imprecision and } \\
\text { inconsistency }\end{array}$ & $\begin{array}{l}\text { Moderate } \\
\text { (reduced } \\
\text { anxiety) }\end{array}$ \\
\hline & $\begin{array}{l}\text { Primary anxiety } \\
\text { clinician report }\end{array}$ & $\begin{array}{l}\text { SMD:-0.11; } \\
95 \% \mathrm{Cl}:-0.36 \\
\text { to } 0.14 ; \\
\mathrm{I}^{2}=28.6 \%\end{array}$ & $\begin{array}{l}9 \text { RCTs (486 } \\
\text { Patients) } \\
94-79,97,100\end{array}$ & $\begin{array}{l}\text { Methodological } \\
\text { limitations, } \\
\text { imprecision (wide } \\
\text { Cls) }\end{array}$ & $\begin{array}{l}\text { Low } \\
\text { (no difference) }\end{array}$ \\
\hline & $\begin{array}{l}\text { Primary anxiety, } \\
\text { parent report }\end{array}$ & $\begin{array}{l}\text { SMD: } 0.04 ; \\
95 \% \mathrm{Cl}:-0.17 \\
\text { to } 0.24 ; \\
\mathrm{I}^{2}=0.0 \%\end{array}$ & $\begin{array}{l}7 \text { RCTs, } 1 \text { non- } \\
\text { randomized } \\
\text { comparative study } \\
(533 \text { Patients) })^{78-81,92,} \\
94,96,97,102\end{array}$ & $\begin{array}{l}\text { Methodological } \\
\text { limitations, } \\
\text { imprecision (wide } \\
\text { Cls) }\end{array}$ & $\begin{array}{l}\text { Low } \\
\text { (no difference) }\end{array}$ \\
\hline & Function & $\begin{array}{l}\text { SMD: }-0.70 \text {, } \\
95 \% \mathrm{Cl}:-1.76 \\
\text { to }-0.36 ; \\
\mathrm{I}^{2}=83.5 \%\end{array}$ & $\begin{array}{l}5 \text { RCTs (293 } \\
\text { Patients) } \\
\text { P8, 82, 95, 96, } 101\end{array}$ & $\begin{array}{l}\text { Methodological } \\
\text { limitations, } \\
\text { imprecision (small } \\
\text { sample size), } \\
\text { inconsistency }\end{array}$ & Insufficient \\
\hline & Social function & $\begin{array}{l}\text { SMD: }-0.23 \text {, } \\
95 \% \mathrm{Cl}:-0.66 \\
\text { to } 0.21 ; \\
\mathrm{I}^{2}=40.9 \%\end{array}$ & $\begin{array}{l}5 \text { RCTs }(330 \\
\text { Patients) } \\
38,78,92,101,102\end{array}$ & $\begin{array}{l}\text { Methodological } \\
\text { limitations, severe } \\
\text { imprecision (small } \\
\text { sample size and wide } \\
\text { Cls) }\end{array}$ & Insufficient \\
\hline & Satisfaction & $\begin{array}{l}\text { SMD: }-0.03, \\
95 \% \mathrm{Cl}:-0.71 \\
\text { to } 0.65 ; \\
\mathrm{I}^{2}=\mathrm{N} / \mathrm{A}\end{array}$ & $\begin{array}{l}1 \text { RCT ( } 33 \\
\text { Patients) }\end{array}$ & $\begin{array}{l}\text { Severe imprecision } \\
\text { (small sample size } \\
\text { and wide Cls) }\end{array}$ & $\begin{array}{l}\text { Low } \\
\text { (no difference) }\end{array}$ \\
\hline & $\begin{array}{l}\text { Secondary } \\
\text { measure }\end{array}$ & $\begin{array}{l}\text { SMD: }-0.50 ; \\
95 \% \mathrm{Cl}:-1.28 \\
\text { to } 0.29 ; \\
\mathrm{I}^{2}=\mathrm{N} / \mathrm{A}\end{array}$ & $\begin{array}{l}\text { R RCTs (156 } \\
\text { Patients) }\end{array}$ & $\begin{array}{l}\text { Severe imprecision } \\
\text { (small sample size } \\
\text { and wide Cls) }\end{array}$ & $\begin{array}{l}\text { Low } \\
\text { (no difference) }\end{array}$ \\
\hline & Remission & $\begin{array}{l}\text { RR: } 1.51 ; \\
95 \% \mathrm{Cl}: 0.95 \\
\text { to } 2.40 ; \\
\mathrm{I}^{2}=0.0 \%\end{array}$ & $\begin{array}{l}4 \text { RCTs (366 } \\
\text { Patients\} }\end{array}$ & $\begin{array}{l}\text { Severe imprecision } \\
\text { (small sample size } \\
\text { and wide Cls) }\end{array}$ & $\begin{array}{l}\text { Low } \\
\text { (no difference) }\end{array}$ \\
\hline & Response & $\begin{array}{l}\text { RR: } 1.90,95 \% \\
\text { Cl: } 0.68 \text { to } \\
5.30 ; \\
I^{2}=67.2 \%\end{array}$ & $\begin{array}{l}5 \text { RCTs (374 } \\
\text { Patients) }\end{array}$ & $\begin{array}{l}\text { Methodological } \\
\text { limitations, severe } \\
\text { imprecision (small } \\
\text { sample size and wide } \\
\text { Cls), inconsistency }\end{array}$ & Insufficient \\
\hline
\end{tabular}

CI: confidence interval, CBT: cognitive behavioral therapy, N/A: not applicable, RCT: randomized control trial, RR: relative risk, SMD: standardized mean difference.

${ }^{\text {a }}$ The sample size includes the number of patients from each comparison.

${ }^{\mathrm{b}}$ Only SOE domains that led to rating down SOE are reported in this column. Domains that are not reported were satisfactory.

${ }^{\mathrm{c}}$ There was a suggestion of publication bias; however, we did not rate down SOE. 


\section{CBT Combined With Drugs}

\section{Key Points}

- Compared to CBT alone, the combination of imipramine and CBT reduced primary anxiety symptoms (child report) and function (moderate SOE).

- The combination of fluoxetine and CBT was found to have lower remission rate compared to CBT alone (low SOE).

- The combination of sertraline and CBT reduced primary anxiety symptoms (clinician report), improved function, and increased clinical response, compared to CBT alone (moderate SOE).

- The combination of sertraline and CBT improved primary anxiety symptoms (clinician report), function, and clinical response (moderate SOE), compared to sertraline alone (moderate SOE).

\section{Discussion}

One RCT with 63 patients compared the combination of imipramine and CBT to CBT alone $^{159}$. All patients had major depressive disorder and at least one anxiety disorder. The mean age of the included patients was 13.9 years and 90.5 percent were Caucasians. Details of the included study can be found in Appendix Table E.7. Compared with CBT alone, adding imipramine to CBT reduced primary anxiety symptoms (child report) and improved function (moderate SOE).

One RCT of 41 anxious school refusing adolescents compared fluoxetine plus CBT to $\mathrm{CBT}^{160}$. Details of the included study can be found in Appendix Table E.7. Patients in the CBT and fluoxetine group had lower remission than CBT alone (low SOE).

One RCT compared the combination of CBT and sertraline to CBT (279 patients), or to sertraline (273 patients) ${ }^{\text {7, 67, 69-73 }}$. Patients (7-17 years old; mean age: 10.7; primary diagnosis of social anxiety disorder, generalized anxiety disorder, or social anxiety disorder) were randomized to receive either 14 sessions of CBT or sertraline (up to $200 \mathrm{mg}$ per day). Details of the included study can be found in Appendix Table E.7. Compared to CBT alone, adding sertraline reduced primary anxiety symptoms (clinician report), improved function, and improved clinical response (moderate SOE). The addition of CBT to sertraline (compared to sertraline alone) improved primary anxiety symptoms (clinician report), function, and likelihood of clinical response (moderate SOE) (Table 10).

Table 10. Strength of evidence for CBT combined with drugs

\begin{tabular}{|c|c|c|c|c|c|}
\hline Comparison & Outcome & Conclusion & $\begin{array}{l}\text { Study Design and } \\
\text { Sample Size }\end{array}$ & $\begin{array}{l}\text { Factors That } \\
\text { Affect the } \\
\text { Strength of } \\
\text { Evidence }^{b}\end{array}$ & $\begin{array}{c}\text { Overall } \\
\text { Evidence } \\
\text { Strength } \\
\text { (Direction of } \\
\text { Effect) }\end{array}$ \\
\hline \multirow[t]{3}{*}{$\begin{array}{l}\text { Imipramine } \\
\text { (class: TCA) + } \\
\text { CBT vs. CBT }\end{array}$} & $\begin{array}{l}\text { Primary } \\
\text { anxiety, child } \\
\text { report }\end{array}$ & $\begin{array}{l}\text { SMD: }-0.74 ; \\
95 \% \mathrm{Cl}:-1.26 \\
\text { to }-0.23 ; \\
\text { I }^{2}=\mathrm{N} / \mathrm{A}\end{array}$ & 1 RCT (63 Patients) ${ }^{159}$ & $\begin{array}{l}\text { Imprecision (small } \\
\text { sample size) }\end{array}$ & $\begin{array}{l}\text { Moderate } \\
\text { (reduced anxiety) }\end{array}$ \\
\hline & $\begin{array}{l}\text { Primary } \\
\text { anxiety. } \\
\text { clinician report }\end{array}$ & $\begin{array}{l}\text { SMD: }-0.61 ; \\
95 \% \mathrm{Cl}:-1.11 \\
\text { to } 0.10 ; \\
\mathrm{I}^{2}=\mathrm{N} / \mathrm{A}\end{array}$ & 1 RCT (63 Patients) ${ }^{159}$ & $\begin{array}{l}\text { Severe } \\
\text { imprecision (small } \\
\text { sample size and } \\
\text { wide } \mathrm{Cl} \text { ) }\end{array}$ & $\begin{array}{l}\text { Low } \\
\text { (no difference) }\end{array}$ \\
\hline & Function & $\begin{array}{l}\text { SMD: -1.27; } \\
95 \% \text { Cl: }-1.81\end{array}$ & 1 RCT (63 Patients) ${ }^{159}$ & $\begin{array}{l}\text { Imprecision (small } \\
\text { sample size) }\end{array}$ & $\begin{array}{l}\text { Moderate } \\
\text { (improved }\end{array}$ \\
\hline
\end{tabular}




\begin{tabular}{|c|c|c|c|c|c|}
\hline Comparison & Outcome & Conclusion & $\begin{array}{l}\text { Study Design and } \\
\text { Sample Size }^{a}\end{array}$ & $\begin{array}{l}\text { Factors That } \\
\text { Affect the } \\
\text { Strength of } \\
\text { Evidence }^{b}\end{array}$ & $\begin{array}{c}\text { Overall } \\
\text { Evidence } \\
\text { Strength } \\
\text { (Direction of } \\
\text { Effect) }\end{array}$ \\
\hline & & $\begin{array}{l}\text { to }-0.73 ; \\
1^{2}=N / A\end{array}$ & & & function) \\
\hline \multirow[t]{4}{*}{$\begin{array}{l}\text { Fluoxetine } \\
\text { (class: SSRI) + } \\
\text { CBT vs. CBT }\end{array}$} & Function & $\begin{array}{l}\text { SMD: }-0.13 ; \\
95 \% \mathrm{Cl}:-0.74 \\
\text { to } 0.48 ; \\
\text { I }^{2}=\mathrm{N} / \mathrm{A}\end{array}$ & 1 RCT (41 Patients) ${ }^{160}$ & $\begin{array}{l}\text { Severe } \\
\text { imprecision (small } \\
\text { sample size and } \\
\text { wide } \mathrm{Cl} \text { ) }\end{array}$ & $\begin{array}{l}\text { Low } \\
\text { (no difference) }\end{array}$ \\
\hline & $\begin{array}{l}\text { Secondary } \\
\text { measure }\end{array}$ & $\begin{array}{l}\text { SMD: }-0.03 ; \\
95 \% \mathrm{Cl}:-0.59 \\
\text { to } 0.64 ; \\
\mathrm{I}^{2}=\mathrm{N} / \mathrm{A}\end{array}$ & 1 RCT (41 Patients) ${ }^{160}$ & $\begin{array}{l}\text { Severe } \\
\text { imprecision (small } \\
\text { sample size and } \\
\text { wide } \mathrm{Cl} \text { ) }\end{array}$ & $\begin{array}{l}\text { Low } \\
\text { (no difference) }\end{array}$ \\
\hline & Response & $\begin{array}{l}\text { RR: } 1.71 ; \\
96 \% \mathrm{Cl}: 0.69 \\
\text { to 4.24; } \\
\text { I }^{2}=\mathrm{N} / \mathrm{A}\end{array}$ & 1 RCT (41 Patients) ${ }^{160}$ & $\begin{array}{l}\text { Severe } \\
\text { imprecision (small } \\
\text { sample size and } \\
\text { wide } \mathrm{Cl} \text { ) }\end{array}$ & $\begin{array}{l}\text { Low } \\
\text { (no difference) }\end{array}$ \\
\hline & Remission & $\begin{array}{l}\text { RR: } 0.24 ; \\
95 \% \mathrm{Cl}: 0.06 \\
\text { to } 0.99 ; \\
I^{2}=\mathrm{N} / \mathrm{A}\end{array}$ & 1 RCT (41 Patients) ${ }^{160}$ & $\begin{array}{l}\text { Severe } \\
\text { imprecision (small } \\
\text { sample size and } \\
\text { wide } \mathrm{Cl} \text { ) }\end{array}$ & $\begin{array}{l}\text { Low } \\
\text { (reduced } \\
\text { remission) }\end{array}$ \\
\hline \multirow[t]{4}{*}{$\begin{array}{l}\text { CBT + } \\
\text { Sertraline } \\
\text { (class: SSRI) } \\
\text { vs. CBT }\end{array}$} & $\begin{array}{l}\text { Primary } \\
\text { anxiety, } \\
\text { clinician report }\end{array}$ & $\begin{array}{l}\text { SMD: }-0.69 ; \\
95 \% \mathrm{Cl}:-0.93 \\
\text { to }-0.45 ; \\
\text { I }^{2}=\mathrm{N} / \mathrm{A}\end{array}$ & $\frac{1}{67,69-73}(279$ Patients) & $\begin{array}{l}\text { Imprecision (small } \\
\text { sample size) }\end{array}$ & $\begin{array}{l}\text { Moderate } \\
\text { (reduced anxiety) }\end{array}$ \\
\hline & Function & $\begin{array}{l}\text { SMD: }-0.47 ; \\
95 \% \mathrm{Cl}:-0.70 \\
\text { to }-0.23 ; \\
\text { I }^{2}=\mathrm{N} / \mathrm{A}\end{array}$ & $\underset{67,69-73}{1} \underset{6 C T}{R C}(279$ Patients) & $\begin{array}{l}\text { Imprecision (small } \\
\text { sample size) }\end{array}$ & $\begin{array}{l}\text { Moderate } \\
\text { (improved } \\
\text { function) }\end{array}$ \\
\hline & Remission & $\begin{array}{l}\text { RR: } 1.51 ; \\
95 \% \mathrm{Cl}: 1.22 \\
\text { to } 1.86 ; \\
\text { I }^{2}=\mathrm{N} / \mathrm{A}\end{array}$ & $\underset{67,69-73}{1} \underset{2 C T}{R C}(279$ Patients) & $\begin{array}{l}\text { Imprecision (small } \\
\text { sample size) }\end{array}$ & $\begin{array}{l}\text { Moderate } \\
\text { (improved } \\
\text { remission) }\end{array}$ \\
\hline & Response & $\begin{array}{l}\text { RR: } 1.35 ; \\
95 \% \mathrm{Cl}: 1.15 \\
\text { to } 1.58 ; \\
\text { I }^{2}=\mathrm{N} / \mathrm{A}\end{array}$ & $\underset{67,69-73}{1} \underset{6 C T}{R C}(279$ Patients) & $\begin{array}{l}\text { Imprecision (small } \\
\text { sample size) }\end{array}$ & $\begin{array}{l}\text { Moderate } \\
\text { (improved } \\
\text { response) }\end{array}$ \\
\hline \multirow[t]{4}{*}{$\begin{array}{l}\text { CBT+ } \\
\text { Sertraline } \\
\text { (class: SSRI) } \\
\text { vs. Sertraline } \\
\text { (class: SSRI) }\end{array}$} & $\begin{array}{l}\text { Primary } \\
\text { anxiety, } \\
\text { clinician report }\end{array}$ & $\begin{array}{l}\text { SMD: }-0.46 ; \\
95 \% \mathrm{Cl}:-0.70 \\
\text { to }-0.22 ; \\
\text { I }^{2}=\mathrm{N} / \mathrm{A}\end{array}$ & $\underset{67,69-73}{1 \text { RCT }}(273$ Patients) & $\begin{array}{l}\text { Imprecision (small } \\
\text { sample size) }\end{array}$ & $\begin{array}{l}\text { Moderate } \\
\text { (reduced anxiety) }\end{array}$ \\
\hline & Function & $\begin{array}{l}\text { SMD: }-0.34 ; \\
95 \% \mathrm{Cl}:-0.58 \\
\text { to }-0.10 ; \\
I^{2}=\mathrm{N} / \mathrm{A}\end{array}$ & $\underset{67,69-73}{1 \text { RCT }}(273$ Patients) & $\begin{array}{l}\text { Imprecision (small } \\
\text { sample size) }\end{array}$ & $\begin{array}{l}\text { Moderate } \\
\text { (improved } \\
\text { function) }\end{array}$ \\
\hline & Remission & $\begin{array}{l}\text { RR: } 1.51 ; \\
95 \% \mathrm{Cl}: 1.22 \\
\text { to } 1.87 ; \\
\text { I }^{2}=\mathrm{N} / \mathrm{A}\end{array}$ & $\underset{67,69-73}{1 \text { RCT }}(273$ Patients) & $\begin{array}{l}\text { Severe } \\
\text { imprecision (wide } \\
\text { Cls and small } \\
\text { sample size) }\end{array}$ & $\begin{array}{l}\text { Moderate } \\
\text { (improved } \\
\text { remission) }\end{array}$ \\
\hline & Response & $\begin{array}{l}\text { RR: } 1.47 ; \\
95 \% \mathrm{Cl}: 1.24 \\
\text { to } 1.75 ; \\
\text { I }^{2}=\mathrm{N} / \mathrm{A}\end{array}$ & $\begin{array}{l}1 \text { RCT (273 Patients) } \\
67,69-73\end{array}$ & $\begin{array}{l}\text { Imprecision (small } \\
\text { sample size) }\end{array}$ & $\begin{array}{l}\text { Moderate } \\
\text { (improved } \\
\text { response) }\end{array}$ \\
\hline
\end{tabular}

CI: confidence interval, CBT: cognitive behavioral therapy, N/A: not applicable, RCT: randomized control trial, RR: relative risk, SMD: standardized mean difference, SSRI: selective serotonin reuptake inhibitor, TCA: tricyclic antidepressants ${ }^{\mathrm{a}}$ The sample size includes the number of patients from each comparison.

${ }^{\mathrm{b}}$ Only SOE domains that led to rating down SOE are reported in this column. Domains that are not reported were satisfactory. 


\section{Subgroup Analysis}

\section{Key Points}

- Treatment effects observed immediately post intervention were larger than those observed after a period of followup.

- Individual-based CBT had statistically significantly more improvement on function than group-based CBT.

- Relaxation and cognitive strategies in CBT were not associated with improvements on primary anxiety symptoms, function, secondary measures, social function, and clinical response; while exposure statistically significantly reduced primary anxiety symptoms (parent report).

- Compared to waitlisting or no treatment, CBT was found to have more improvement on functioning in age group 13-18 than age group 7-12.

\section{Discussion}

We were not able to conduct a large number of the planned subgroup analyses, including those based on race/ethnicity, parent education level, family income, disease severity (measured by CGI), treatment sequence, and provider. This was due to studies not providing sufficient stratified data per subgroup variable. The results of the feasible exploratory analyses are reported in Appendix Tables G.1 to G.12 and were summarized as follows:

- Age: when CBT compared to waitlisting or no treatment, we found statistically significantly more improvement in function in age group 13-18 than age group 7-12.

- Comorbidity: when CBT compared to pill placebo, patients without comorbidity had statistically significantly more improvement in secondary anxiety measures than patient with any comorbidity. However, the finding was limited by the fact that CBT delivered to children with comorbidities was different in children without comorbidities. Inference from subgroup analyses evaluating comorbidities is less reliable.

- ADHD: when fluvoxamine compared to pill placebo, we found no statistically significant difference on primary anxiety symptoms (clinician report).

- Autism: When CBT was compared to waitlisting or no treatment, we did not find statistically significant difference in outcomes (primary anxiety symptoms, clinician, child, and parent report), function, or clinical response in patients with autism than patients without autism.

- School refusal: when CBT compared to pill placebo, patients without school refusal were found to have statistically significant better outcome (secondary anxiety measures) than patient with school refusal.

- Diagnosis: when CBT compared to attention control/treatment as usual, patients with social anxiety disorder were found to have more improvement on secondary anxiety measures than patients with panic disorder.

- Treatment settings: when CBT compared to attention control or treatment as usual, we found statistically significantly more improvement in secondary anxiety measures in school settings than mental health clinic.

- Length of follow-up: when CBT compared to waitlisting or no treatment, post intervention response rate was significantly higher than those reported at less than 6month followup. Post intervention reduction of primary anxiety symptoms (child report) 
and remission rate were also significantly larger than those reported after more than 6 month followup.

- Exposure sessions in CBT: Compared with non-exposure CBT, exposure sessions statistically significant reduced primary anxiety symptoms (parent report only).

- Cognitive strategies in CBT: CBT with cognitive strategies were found to have statistically significant less improvement in primary anxiety symptoms (parent report) than CBT without cognitive strategies. No other significant differences were found on primary anxiety symptoms (clinician and child report), function, secondary measures, social function, or clinical response.

- Relaxation strategies in CBT: We found no statistically significant differences between CBT with relaxation and CBT without relaxation on primary anxiety symptoms (clinician, child, and parent report), function, secondary measures, social function, and clinical response.

- Individual-based CBT versus group-based CBT: we found that individual-based CBT had statistically significantly more improvement on function than group-based CBT.

- Treatment intensity: we found no statistically significant difference in any outcome based on treatment intensity.

KQ 2: What are the comparative harms and safety concerns regarding the available treatments for childhood anxiety disorders, including panic disorder, social anxiety disorder, specific phobias, generalized anxiety disorder, and separation anxiety?

\section{Key Points}

- SSRIs and SNRIs were associated with increased risk of various short-term AEs that were overall not serious (low to moderate SOE).

- Studies were generally too small or too short to assess the effect of SSRIs on suicidal behavior. One study found that venlafaxine was associated with a statistically nonsignificant increase in the risk of suicidal ideation (low SOE).

- No differences or fewer dropout rates were found when CBT was compared to pill placebo, waitlisting, or active control therapies (low SOE).

\section{Discussion}

Twenty RCTs 7 , 22, 49-51, 53-58, 60-62, 64-72, 74, 161 compared medications to pill placebo, including atomoxetine, clonazepam, clomipramine, duloxetine, fluvoxamine fluoxetine, imipramine, sertraline, and venlafaxine, and reported AEs. Overall, 2,610 patients were included with a mean age of 11.6 years old and 53.4 percent male. 14 studies $49-52,56,58,60-65$ 49-52, 54, 56, 58, 60-65 (70.0\%)

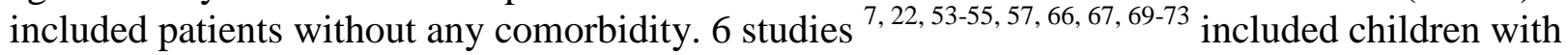
anxiety and comorbidity (ADHD, autism, ODD, OCD and other internalizing disorder). Details of the included studies can be found in Appendix Table E.1. We were unable to evaluate publication bias due to small number of studies $(n<20)$ included in each comparisons.

Compared with pill placebo, SSRIs as a class was not significantly different on number of dropouts, dropouts due to any AEs, or any AEs. In terms of specific SSRIs, AEs that were associated with low to moderate SOE were any AEs (fluoxetine, paroxetine), AEs related to gastrointestinal symptoms (fluvoxamine), behavior change (paroxetine), cold/infection/allergies 
(paroxetine), and difficulties in sleeping (paroxetine). In terms of SNRIs, AEs that were associated with moderate SOE included atomoxetine (any AE and GI AEs) and venlafaxine (gastrointestinal AE and somnolence). These adverse effects were not serious (i.e., were not described as severe by the included trials, or did not lead to discontinuation of treatment or significant morbidity or mortality). Imipramine (class: TCA) was found to have higher risk of AEs related to oral symptoms (moderate SOE). Evidence on AE of benzodiazepines was sparse and of lower quality.

CBT was associated with fewer dropouts than pill placebo or sertraline (class: SSRI) (low SOE). Compared to sertraline, CBT was found to have lower risk of any AEs, AEs related to behavior change, and difficulties in sleeping.

Three studies reported suicide/suicidal ideation/self-harm. ${ }^{\text {7, 58, 67-72, } 162}$ The CAMS trial ${ }^{\text {7, 67-72 }}$ compared CBT, sertraline, CBT plus sertraline, and pill placebo. The study found no suicide attempts in any group and no statistical difference between groups on suicide ideation. In a RCT of 293 children with generalized social anxiety disorder, March et al. ${ }^{58}$ compared venlafaxine ER to pill placebo and found 3 cases of suicide ideation (3/140) in the venlafaxine group and no incidence in the pill placebo group $(\mathrm{p}=0.18)$. In an observational study ${ }^{162}$, Renaud et al. found no suicide attempts or ideation among 12 children treated by SSRIs and benzodiazepines.

Eighteen single-cohort observational studies reported AEs related to different drugs. Those AEs included gastrointestinal symptoms, behavior change, difficulties in sleeping, headache, fatigue, and somnolence. No serious AEs were reported. The characteristics of these studies are summarized in Appendix Table E.21.

In summary, SOE supporting specific AE for specific drugs was low in general. However, as a class, SSRIs and SNRIs increased the risk of short-term AEs that were mostly not serious with the exception of increased suicidal ideation with venlafaxine. Studies were generally too small or too short to assess the effect of SSRIs on suicidal behavior, but one study found increased suicidal behavior with venlafaxine (low SOE). Results of the AEs are presented in Tables 11 and 12.

Table 11. Strength of evidence for adverse events of drugs versus pill placebo

\begin{tabular}{|c|c|c|c|c|c|}
\hline Comparison & Outcome & $\begin{array}{l}\text { Conclusi } \\
\text { on }\end{array}$ & $\begin{array}{l}\text { Study Design and Sample } \\
\text { Size }^{a}\end{array}$ & $\begin{array}{l}\text { Factors That } \\
\text { Affect the } \\
\text { Strength of } \\
\text { Evidence }^{b}\end{array}$ & $\begin{array}{c}\text { Overall } \\
\text { Evidence } \\
\text { Strength } \\
\text { (Direction } \\
\text { of Effect) }\end{array}$ \\
\hline $\begin{array}{l}\text { Benzodiazepi } \\
\text { ne vs. Pill } \\
\text { Placebo }\end{array}$ & Dropouts & $\begin{array}{l}\text { RR: } 6.22 ; \\
95 \% \text { Cl: } \\
0.38 \text { to } \\
102.94 ; \\
\text { I }^{2}=\text { N/A }\end{array}$ & $1 \mathrm{RCT}$ (15 Patients) ${ }^{57}$ & $\begin{array}{l}\text { Severe } \\
\text { imprecision } \\
\text { (small sample } \\
\text { size and wide } \\
\mathrm{Cl} \text { ) }\end{array}$ & $\begin{array}{l}\text { Low } \\
\text { (no } \\
\text { difference) }\end{array}$ \\
\hline \multirow[t]{3}{*}{$\begin{array}{l}\text { SNRI vs. Pill } \\
\text { Placebo }\end{array}$} & Dropouts & $\begin{array}{l}\text { RR: } 0.93 ; \\
95 \% \text { Cl: } \\
0.70 \text { to } \\
1.25 \\
I^{2}=0.0 \%\end{array}$ & $\begin{array}{l}4 \text { RCTs (786 Patients) } \\
64\end{array}$ & $\begin{array}{l}\text { Methodological } \\
\text { limitations, } \\
\text { imprecision } \\
\text { (wide Cls) }\end{array}$ & $\begin{array}{l}\text { Low } \\
\text { (no } \\
\text { difference) }\end{array}$ \\
\hline & Dropouts due to AEs & $\begin{array}{l}\text { RR: } 0.99 ; \\
95 \% \mathrm{Cl} \text {; } \\
0.39 \text { to } \\
2.47 \\
\left.\right|^{2}=7.9 \%\end{array}$ & $\begin{array}{l}{ }_{64}^{4} \text { RCTs (786 Patients) } \\
\text { 62 55, 58, }\end{array}$ & $\begin{array}{l}\text { Methodological } \\
\text { limitations, } \\
\text { imprecision } \\
\text { (wide Cls) }\end{array}$ & $\begin{array}{l}\text { Low } \\
\text { (no } \\
\text { difference) }\end{array}$ \\
\hline & Any AEs & $\begin{array}{l}\text { Rate ratio: } \\
1.55 ; 95 \% \\
\text { Cl: } 0.35 \text { to } \\
6.77 ;\end{array}$ & 3 RCTs (786 Patients) ${ }^{55,58,62}$ & $\begin{array}{l}\text { Methodological } \\
\text { limitations, } \\
\text { imprecision } \\
\text { (wide Cls) }\end{array}$ & $\begin{array}{l}\text { Low } \\
\text { (no } \\
\text { difference) }\end{array}$ \\
\hline
\end{tabular}




\begin{tabular}{|c|c|c|c|c|c|}
\hline Comparison & Outcome & $\begin{array}{l}\text { Conclusi } \\
\text { on }\end{array}$ & $\begin{array}{c}\text { Study Design and Sample } \\
\text { Size }^{\mathrm{a}}\end{array}$ & $\begin{array}{l}\text { Factors That } \\
\text { Affect the } \\
\text { Strength of } \\
\text { Evidence }^{b}\end{array}$ & $\begin{array}{c}\text { Overall } \\
\text { Evidence } \\
\text { Strength } \\
\text { (Direction } \\
\text { of Effect) } \\
\end{array}$ \\
\hline & & $\mathrm{I}^{2}=94.8 \%$ & & & \\
\hline & $\begin{array}{l}\text { AEs related to } \\
\text { abdominal/GI/appetite }\end{array}$ & $\begin{array}{l}\text { Rate ratio: } \\
2.15 ; 95 \% \\
\text { Cl: } 0.63 \text { to } \\
7.34 ; \\
I^{2}=78.8 \%\end{array}$ & 3 RCTs (786 Patients) ${ }^{55,58,62}$ & $\begin{array}{l}\text { Methodological } \\
\text { limitations, } \\
\text { imprecision } \\
\text { (wide Cls) }\end{array}$ & $\begin{array}{l}\text { Low } \\
\text { (no } \\
\text { difference) }\end{array}$ \\
\hline & $\begin{array}{l}\text { AEs related to } \\
\text { accidental injury }\end{array}$ & $\begin{array}{l}\text { Rate ratio: } \\
1.16,95 \% \\
\text { Cl: } 0.58 \text { to } \\
2.29 ; \\
I^{2}=\mathrm{N} / \mathrm{A}\end{array}$ & 21 RCTs (320 Patients) ${ }^{62}$ & $\begin{array}{l}\text { Methodological } \\
\text { limitations, } \\
\text { imprecision } \\
\text { (wide Cls) }\end{array}$ & $\begin{array}{l}\text { Low } \\
\text { (no } \\
\text { difference) }\end{array}$ \\
\hline & $\begin{array}{l}\text { AEs related to } \\
\text { behavior change }\end{array}$ & $\begin{array}{l}\text { Rate ratio: } \\
1.48 ; 95 \% \\
\text { Cl: } 0.71 \text { to } \\
3.10 ; \\
I^{2}=0.0 \%\end{array}$ & 2 RCTs (466 Patients) ${ }^{55,58}$ & $\begin{array}{l}\text { Methodological } \\
\text { limitations, } \\
\text { imprecision } \\
\text { (wide Cls) }\end{array}$ & $\begin{array}{l}\text { Low } \\
\text { (no } \\
\text { difference) }\end{array}$ \\
\hline & $\begin{array}{l}\text { AEs related to } \\
\text { cold/infection/allergie } \\
\mathrm{s}\end{array}$ & $\begin{array}{l}\text { Rate ratio: } \\
1.05 ; 95 \% \\
\text { Cl: } 0.16 \text { to } \\
7.10 ; \\
\mathrm{I}^{2}=83.6 \%\end{array}$ & 3 RCTs (786 Patients) ${ }^{55,58,62}$ & $\begin{array}{l}\text { Methodological } \\
\text { limitations, } \\
\text { imprecision } \\
\text { (wide Cls), } \\
\text { inconsistency }\end{array}$ & Insufficient \\
\hline & $\begin{array}{l}\text { AEs related to } \\
\text { fatigue/somnolence }\end{array}$ & $\begin{array}{l}\text { Rate ratio: } \\
2.14 ; 95 \% \\
\text { Cl: } 1.13 \text { to } \\
4.07 ; \\
I^{2}=\mathrm{N} / \mathrm{A}\end{array}$ & 1 RCT (290 Patients) $)^{58}$ & $\begin{array}{l}\text { Imprecision } \\
\text { (small sample } \\
\text { size) }\end{array}$ & $\begin{array}{l}\text { Moderate } \\
\text { (increased } \\
\text { AEs) }\end{array}$ \\
\hline & $\begin{array}{l}\text { AEs related to } \\
\text { headache/dizzy/vision } \\
\text { problems }\end{array}$ & $\begin{array}{l}\text { Rate ratio: } \\
0.76 ; 95 \% \\
\text { Cl: } 0.52 \text { to } \\
1.11 ; \\
I^{2}=60.2 \%\end{array}$ & 2 RCTs (496 Patients) ${ }^{55,62}$ & $\begin{array}{l}\text { Methodological } \\
\text { limitations, } \\
\text { imprecision } \\
\text { (wide Cls) }\end{array}$ & $\begin{array}{l}\text { Low } \\
\text { (no } \\
\text { difference) }\end{array}$ \\
\hline & $\begin{array}{l}\text { AEs related to } \\
\text { suicide/ideation/self- } \\
\text { harm }\end{array}$ & $\begin{array}{l}\text { Rate ratio: } \\
4.29 ; 95 \% \\
\text { Cl: } 0.48 \text { to } \\
38.44 ; \\
I^{2}=\mathrm{N} / \mathrm{A}\end{array}$ & 1 RCT (290 Patients) $)^{58}$ & $\begin{array}{l}\text { Severe } \\
\text { imprecision } \\
\text { (small sample } \\
\text { size and wide } \\
\text { Cls) }\end{array}$ & $\begin{array}{l}\text { Low } \\
\text { (no } \\
\text { difference) }\end{array}$ \\
\hline \multirow[t]{4}{*}{$\begin{array}{l}\text { SSRI vs. Pill } \\
\text { Placebo }\end{array}$} & Dropouts & $\begin{array}{l}\text { RR: } 0.82 ; \\
95 \% \mathrm{Cl} \text { : } \\
0.59 \text { to } \\
1.13 \\
\mathrm{I}^{2}=0.0 \%\end{array}$ & $\begin{array}{l}7 \text { RCTs (856 Patients) }{ }^{7,22,51,} \\
53,54,61,65,67-72\end{array}$ & $\begin{array}{l}\text { Imprecision } \\
\text { (wide CIs) }\end{array}$ & $\begin{array}{l}\text { Moderate } \\
\text { (no } \\
\text { difference) }\end{array}$ \\
\hline & Dropouts due to AEs & $\begin{array}{l}\text { RR: } 2.60 \\
95 \% \text { Cl: } \\
0.64 \text { to } \\
10.65 \\
I^{2}=0.0 \%\end{array}$ & $\begin{array}{l}\text { 4 RCTs (733 Patients) } \\
65,67-72\end{array}$ & $\begin{array}{l}\text { Severe } \\
\text { imprecision } \\
\text { (extremely } \\
\text { wide Cls) }\end{array}$ & $\begin{array}{l}\text { Low } \\
\text { (no } \\
\text { difference) }\end{array}$ \\
\hline & Any AEs & $\begin{array}{l}\text { Rate ratio: } \\
1.28 ; 95 \% \\
\text { Cl: } 0.71 \text { to } \\
2.30 ; \\
I^{2}=79.1 \%\end{array}$ & $\begin{array}{l}8 \text { RCTs (930 Patients) } \\
50,53,54,60,61,65,67-72\end{array}$ & $\begin{array}{l}\text { Imprecision } \\
\text { (wide Cls), } \\
\text { inconsistency }\end{array}$ & $\begin{array}{l}\text { Low } \\
\text { (no } \\
\text { difference) }\end{array}$ \\
\hline & $\begin{array}{l}\text { AEs related to } \\
\text { abdominal/GI/appetite }\end{array}$ & $\begin{array}{l}\text { Rate ratio: } \\
1.40 ; 95 \% \\
\text { Cl: } 0.68 \text { to } \\
2.87 ; \\
I^{2}=54.8 \%\end{array}$ & $\begin{array}{l}6 \text { RCTs (780 Patients) }{ }^{7,22,49,} \\
53,61,65,67-72\end{array}$ & $\begin{array}{l}\text { Imprecision } \\
\text { (wide CIs) }\end{array}$ & $\begin{array}{l}\text { Moderate } \\
\text { (no } \\
\text { difference) }\end{array}$ \\
\hline
\end{tabular}




\begin{tabular}{|c|c|c|c|c|c|}
\hline Comparison & Outcome & $\begin{array}{l}\text { Conclusi } \\
\text { on }\end{array}$ & $\begin{array}{c}\text { Study Design and Sample } \\
\text { Size }^{a}\end{array}$ & $\begin{array}{l}\text { Factors That } \\
\text { Affect the } \\
\text { Strength of } \\
\text { Evidence }^{\mathbf{b}}\end{array}$ & $\begin{array}{c}\text { Overall } \\
\text { Evidence } \\
\text { Strength } \\
\text { (Direction } \\
\text { of Effect) }\end{array}$ \\
\hline & $\begin{array}{l}\text { AEs related to } \\
\text { behavior change }\end{array}$ & $\begin{array}{l}\text { Rate ratio: } \\
1.66 ; 95 \% \\
\text { Cl: } 0.92 \text { to } \\
2.98 ; \\
I^{2}=48.2 \%\end{array}$ & $\begin{array}{l}7 \text { RCTs ( } 823 \text { Patients) } \\
53,60,61,65,67-72 \\
7,49,\end{array}$ & $\begin{array}{l}\text { Imprecision } \\
\text { (wide Cls) }\end{array}$ & $\begin{array}{l}\text { Moderate } \\
\text { (no } \\
\text { difference) }\end{array}$ \\
\hline & $\begin{array}{l}\text { AEs related to } \\
\text { cold/infection/allergie } \\
\mathrm{s}\end{array}$ & $\begin{array}{l}\text { Rate ratio: } \\
1.09 ; 95 \% \\
\text { Cl: } 0.67 \text { to } \\
1.79 ; \\
1^{2}=36.0 \%\end{array}$ & $\begin{array}{l}4 \text { 4 RCTs (684 Patients) } \\
65,-72\end{array}$ & $\begin{array}{l}\text { Imprecision } \\
\text { (wide Cls) }\end{array}$ & $\begin{array}{l}\text { Moderate } \\
\text { (no } \\
\text { difference) }\end{array}$ \\
\hline & $\begin{array}{l}\text { AEs related to } \\
\text { difficulties sleeping }\end{array}$ & $\begin{array}{l}\text { Rate ratio: } \\
1.24 ; 95 \% \\
\text { Cl: } 0.42 \text { to } \\
3.69 ; \\
\mathrm{I}^{2}=80.5 \%\end{array}$ & $\begin{array}{l}5 \text { RCTs (739 Patients) } \\
50,65,67-72\end{array}$ & $\begin{array}{l}\text { Imprecision } \\
\text { (wide Cls), } \\
\text { inconsistency }\end{array}$ & $\begin{array}{l}\text { Low } \\
\text { (no } \\
\text { difference) }\end{array}$ \\
\hline & $\begin{array}{l}\text { AEs related to } \\
\text { fatigue/somnolence }\end{array}$ & $\begin{array}{l}\text { Rate ratio: } \\
1.61 ; 95 \% \\
\text { Cl: } 0.83 \text { to } \\
3.11 ; \\
I^{2}=0.0 \%\end{array}$ & $\begin{array}{l}4 \text { RC RCTS (679 Patients) } \\
6, \text {, 22, 61, }\end{array}$ & $\begin{array}{l}\text { Methodological } \\
\text { limitations, } \\
\text { imprecision } \\
\text { (wide Cls) }\end{array}$ & $\begin{array}{l}\text { Low } \\
\text { (no } \\
\text { difference) }\end{array}$ \\
\hline & $\begin{array}{l}\text { AEs related to } \\
\text { headache/dizzy/vision } \\
\text { problem }\end{array}$ & $\begin{array}{l}\text { Rate ratio: } \\
1.24 ; 95 \% \\
\text { Cl: } 0.57 \text { to } \\
2.67 ; \\
I^{2}=21.3 \%\end{array}$ & $\underset{61,67-72}{4 \text { RCTS (384 Patients) }}$ & $\begin{array}{l}\text { Methodological } \\
\text { limitations, } \\
\text { severe } \\
\text { imprecision } \\
\text { (small sample } \\
\text { size and wide } \\
\text { Cls) } \\
\end{array}$ & Insufficient \\
\hline & $\begin{array}{l}\text { AEs related to } \\
\text { accidental injury }\end{array}$ & $\begin{array}{l}\text { Rate ratio: } \\
2.29 ; 95 \% \\
\text { Cl: } 0.26 \text { to } \\
20.45 ; \\
\mathrm{I}^{2}=\mathrm{N} / \mathrm{A}\end{array}$ & 1 RCT (209 Patients) ${ }^{7,67-72}$ & $\begin{array}{l}\text { Severe } \\
\text { imprecision } \\
\text { (small sample } \\
\text { size and wide } \\
\text { Cls) }\end{array}$ & $\begin{array}{l}\text { Low } \\
\text { (no } \\
\text { difference) }\end{array}$ \\
\hline & $\begin{array}{l}\text { AEs related to } \\
\text { suicide/ideation/self- } \\
\text { harm }\end{array}$ & $\begin{array}{l}0 \text { case in } \\
\text { each } \\
\text { group }\end{array}$ & 1 RCT (209 Patients), 67-72 & No data & Insufficient \\
\hline & $\begin{array}{l}\text { AEs related to dry } \\
\text { mouth/bad taste/oral } \\
\text { symptoms }\end{array}$ & $\begin{array}{l}\text { Rate ratio: } \\
\text { 1.10; } 95 \% \\
\text { Cl: } 0.34 \text { to } \\
3.58 ; \\
I^{2}=62.0 \%\end{array}$ & 2 RCTs (47 Patients) ${ }^{49,61}$ & $\begin{array}{l}\text { Severe } \\
\text { imprecision } \\
\text { (wide } \mathrm{Cl} \text {, small } \\
\text { sample size), } \\
\text { inconsistency }\end{array}$ & Insufficient \\
\hline \multirow[t]{3}{*}{$\begin{array}{l}\text { TCA vs. Pill } \\
\text { Placebo }\end{array}$} & Any AEs & $\begin{array}{l}\text { Rate ratio: } \\
1.39 ; 95 \% \\
\text { Cl: } 0.82 \text { to } \\
2.63 ; \\
I^{2}=86.6 \%\end{array}$ & 2 RCTs (56 Patients) $)^{56,74}$ & $\begin{array}{l}\text { Severe } \\
\text { imprecision } \\
\text { (small sample } \\
\text { size and wide } \\
\mathrm{Cl} \text { ), } \\
\text { inconsistency }\end{array}$ & Insufficient \\
\hline & $\begin{array}{l}\text { AEs related to } \\
\text { abdominal/GI/appetite }\end{array}$ & $\begin{array}{l}\text { Rate ratio: } \\
0.62 ; 95 \% \\
\text { Cl: } 0.21 \text { to } \\
1.86 ; \\
\mathrm{I}^{2}=0.0 \%\end{array}$ & 2 RCTs (56 Patients) ${ }^{56,74}$ & $\begin{array}{l}\text { Severe } \\
\text { imprecision } \\
\text { (small sample } \\
\text { size and wide } \\
\mathrm{Cl} \text { ) }\end{array}$ & $\begin{array}{l}\text { Low } \\
\text { (no } \\
\text { difference) }\end{array}$ \\
\hline & $\begin{array}{l}\text { AEs related to } \\
\text { behavior change }\end{array}$ & $\begin{array}{l}\text { Rate ratio: } \\
5.45 ; 95 \% \\
\text { Cl: } 0.66 \text { to } \\
45.30 ; \\
I^{2}=0.0 \%\end{array}$ & 2 RCTs (56 Patients) ${ }^{56,74}$ & $\begin{array}{l}\text { Severe } \\
\text { imprecision } \\
\text { (small sample } \\
\text { size and wide } \\
\mathrm{Cl} \text { ) }\end{array}$ & $\begin{array}{l}\text { Low } \\
\text { (no } \\
\text { difference) }\end{array}$ \\
\hline
\end{tabular}




\begin{tabular}{|c|c|c|c|c|c|}
\hline Comparison & Outcome & $\begin{array}{l}\text { Conclusi } \\
\text { on }\end{array}$ & $\begin{array}{c}\text { Study Design and Sample } \\
\text { Size }^{a}\end{array}$ & $\begin{array}{l}\text { Factors That } \\
\text { Affect the } \\
\text { Strength of } \\
\text { Evidence }^{b}\end{array}$ & $\begin{array}{l}\text { Overall } \\
\text { Evidence } \\
\text { Strength } \\
\text { (Direction } \\
\text { of Effect) }\end{array}$ \\
\hline & $\begin{array}{l}\text { AEs related to } \\
\text { difficulties sleeping }\end{array}$ & $\begin{array}{l}\text { Rate ratio: } \\
0.34 ; 95 \% \\
\text { Cl: } 0.07 \text { to } \\
1.63 ; \\
\mathrm{I}^{2}=0.0 \%\end{array}$ & 2 RCTs (56 Patients) ${ }^{56,74}$ & $\begin{array}{l}\text { Severe } \\
\text { imprecision } \\
\text { (small sample } \\
\text { size and wide } \\
\mathrm{Cl} \text { ) }\end{array}$ & $\begin{array}{l}\text { Low } \\
\text { (no } \\
\text { difference) }\end{array}$ \\
\hline & $\begin{array}{l}\text { AEs related to } \\
\text { fatigue/somnolence }\end{array}$ & $\begin{array}{l}\text { Rate ratio: } \\
2.73 ; 95 \% \\
\mathrm{Cl}: 0.28 \text { to } \\
26.22 ; \\
\mathrm{I}^{2}=\mathrm{N} / \mathrm{A}\end{array}$ & 1 RCT (21 Patients) $)^{74}$ & $\begin{array}{l}\text { Severe } \\
\text { imprecision } \\
\text { (small sample } \\
\text { size and wide } \\
\text { Cl) }\end{array}$ & $\begin{array}{l}\text { Low } \\
\text { (no } \\
\text { difference) }\end{array}$ \\
\hline & $\begin{array}{l}\text { AEs related to } \\
\text { difficulties sleeping }\end{array}$ & $\begin{array}{l}\text { Rate ratio: } \\
0.34 ; 95 \% \\
\text { Cl: } 0.07 \text { to } \\
1.63 ; \\
\mathrm{I}^{2}=0.0 \%\end{array}$ & 2 RCTs (56 Patients) $)^{56,74}$ & $\begin{array}{l}\text { Severe } \\
\text { imprecision } \\
\text { (small sample } \\
\text { size and wide } \\
\mathrm{Cl} \text { ) }\end{array}$ & $\begin{array}{l}\text { Low } \\
\text { (no } \\
\text { difference) }\end{array}$ \\
\hline & $\begin{array}{l}\text { AEs related to dry } \\
\text { mouth/bad taste/oral } \\
\text { symptoms }\end{array}$ & $\begin{array}{l}\text { Rate ratio: } \\
3.81 ; 95 \% \\
\mathrm{Cl}: 1.25 \\
\text { to } 11.62 ; \\
\mathrm{I}^{2}=0.0 \%\end{array}$ & 2 RCTs (56 Patients) ) 56,74 & $\begin{array}{l}\text { Imprecision } \\
\text { (small sample } \\
\text { size) }\end{array}$ & $\begin{array}{l}\text { Moderate } \\
\text { (increased } \\
\text { AEs) }\end{array}$ \\
\hline \multirow[t]{7}{*}{$\begin{array}{l}\text { Atomoxetine } \\
\text { (class: SNRI) } \\
\text { vs. Pill } \\
\text { Placebo }\end{array}$} & Dropouts & $\begin{array}{l}\text { RR: } 1.07, \\
95 \% \mathrm{Cl} \text { : } \\
0.64 \text { to } \\
1.79 ; \\
\mathrm{I}^{2}=\mathrm{N} / \mathrm{A}\end{array}$ & 1 RCT (176 Patients) $)^{55}$ & $\begin{array}{l}\text { Severe } \\
\text { imprecision } \\
\text { (small sample } \\
\text { size and wide } \\
\mathrm{Cl} \text { ) }\end{array}$ & $\begin{array}{l}\text { Low } \\
\text { (no } \\
\text { difference) }\end{array}$ \\
\hline & Dropouts due to AEs & $\begin{array}{l}\text { RR: } 0.98, \\
95 \% \mathrm{Cl} \text { : } \\
0.06 \text { to } \\
15.38 ; \\
\mathrm{I}^{2}=\mathrm{N} / \mathrm{A}\end{array}$ & 1 RCT (176 Patients) $)^{55}$ & $\begin{array}{l}\text { Severe } \\
\text { imprecision } \\
\text { (small sample } \\
\text { size and wide } \\
\mathrm{Cl} \text { ) }\end{array}$ & $\begin{array}{l}\text { Low } \\
\text { (no } \\
\text { difference) }\end{array}$ \\
\hline & Any AEs & $\begin{array}{l}\text { Rate ratio: } \\
1.74 ; 95 \% \\
\text { Cl: } 1.17 \text { to } \\
2.61 ; \\
\mathrm{I}^{2}=\mathrm{N} / \mathrm{A}\end{array}$ & 1 RCT (176 Patients) ${ }^{55}$ & $\begin{array}{l}\text { Imprecision } \\
\text { (small sample } \\
\text { size) }\end{array}$ & $\begin{array}{l}\text { Moderate } \\
\text { (increased } \\
\text { AEs) }\end{array}$ \\
\hline & $\begin{array}{l}\text { AEs related to } \\
\text { abdominal/GI/appetite }\end{array}$ & $\begin{array}{l}\text { Rate ratio: } \\
2.48 ; 95 \% \\
\text { Cl: } 1.31 \text { to } \\
4.71 ; \\
I^{2}=\mathrm{N} / \mathrm{A}\end{array}$ & 1 RCT (176 Patients) ${ }^{55}$ & $\begin{array}{l}\text { Imprecision } \\
\text { (small sample } \\
\text { size) }\end{array}$ & $\begin{array}{l}\text { Moderate } \\
\text { (increased } \\
\text { AEs) }\end{array}$ \\
\hline & $\begin{array}{l}\text { AEs related to } \\
\text { behavior change }\end{array}$ & $\begin{array}{l}\text { Rate ratio: } \\
1.63 ; 95 \% \\
\mathrm{Cl}: 0.39 \text { to } \\
6.82 ; \\
\mathrm{I}^{2}=\mathrm{N} / \mathrm{A}\end{array}$ & 1 RCT (176 Patients) $)^{55}$ & $\begin{array}{l}\text { Severe } \\
\text { imprecision } \\
\text { (small sample } \\
\text { size and wide } \\
\mathrm{Cl} \text { ) }\end{array}$ & $\begin{array}{l}\text { Low } \\
\text { (no } \\
\text { difference) }\end{array}$ \\
\hline & $\begin{array}{l}\text { AEs related to } \\
\text { Cold/Infection/Allergie } \\
\mathrm{s}\end{array}$ & $\begin{array}{l}\text { Rate } \\
\text { Ratio: } \\
1.19 ; 95 \% \\
\text { Cl: } 0.59 \text { to } \\
2.41 ; \\
\left.\right|^{2}=\text { N/A }\end{array}$ & 1 RCT (176 Patients) $)^{55}$ & $\begin{array}{l}\text { Severe } \\
\text { imprecision } \\
\text { (small sample } \\
\text { size and wide } \\
\mathrm{Cl} \text { ) }\end{array}$ & $\begin{array}{l}\text { Low } \\
\text { (no } \\
\text { difference) }\end{array}$ \\
\hline & $\begin{array}{l}\text { AEs related to } \\
\text { headache/dizzy/vision }\end{array}$ & $\begin{array}{l}\text { Rate ratio: } \\
1.54 ; 95 \% \\
\mathrm{Cl} \text { : } \\
0.60 \text { to } \\
3.96 ;\end{array}$ & 1 RCT (176 Patients) $)^{55}$ & $\begin{array}{l}\text { Severe } \\
\text { imprecision } \\
\text { (small sample } \\
\text { size and wide } \\
\mathrm{Cl} \text { ) }\end{array}$ & $\begin{array}{l}\text { Low } \\
\text { (no } \\
\text { difference) }\end{array}$ \\
\hline
\end{tabular}




\begin{tabular}{|c|c|c|c|c|c|}
\hline Comparison & Outcome & $\begin{array}{l}\text { Conclusi } \\
\text { on }\end{array}$ & $\begin{array}{l}\text { Study Design and Sample } \\
\text { Size }^{\mathrm{a}}\end{array}$ & $\begin{array}{l}\text { Factors That } \\
\text { Affect the } \\
\text { Strength of } \\
\text { Evidence }^{b}\end{array}$ & $\begin{array}{c}\text { Overall } \\
\text { Evidence } \\
\text { Strength } \\
\text { (Direction } \\
\text { of Effect) }\end{array}$ \\
\hline & & $I^{2}=N / A$ & & & \\
\hline \multirow[t]{2}{*}{$\begin{array}{l}\text { Clomipramine } \\
\text { (class: TCA) } \\
\text { vs. Pill } \\
\text { Placebo }\end{array}$} & Dropouts & $\begin{array}{l}\text { RR: } 3.60 ; \\
95 \% \text { Cl: } \\
0.16 \text { to } \\
79.00 ; \\
I^{2}=\mathrm{N} / \mathrm{A}\end{array}$ & 1 RCT (20 Patients) $)^{54}$ & $\begin{array}{l}\text { Severe } \\
\text { imprecision } \\
\text { (small sample } \\
\text { size and wide } \\
\mathrm{Cl} \text { ) }\end{array}$ & $\begin{array}{l}\text { Low } \\
\text { (no } \\
\text { difference) }\end{array}$ \\
\hline & Any AEs & $\begin{array}{l}\text { Rate ratio: } \\
0.52 ; 95 \% \\
\mathrm{Cl}: 0.14 \text { to } \\
2.03 ; \\
\mathrm{I}^{2}=\mathrm{N} / \mathrm{A}\end{array}$ & 1 RCT (19 Patients) $)^{54}$ & $\begin{array}{l}\text { Severe } \\
\text { imprecision } \\
\text { (small sample } \\
\text { size and wide } \\
\mathrm{Cl} \text { ) }\end{array}$ & $\begin{array}{l}\text { Low } \\
\text { (no } \\
\text { difference) }\end{array}$ \\
\hline $\begin{array}{l}\text { Clonazepam } \\
\text { (class: } \\
\text { Benzodiazepi } \\
\text { ne) vs. Pill } \\
\text { Placebo }\end{array}$ & Dropouts & $\begin{array}{l}\text { RR: } 6.22 ; \\
95 \% \mathrm{Cl} \text { : } \\
0.38 \text { to } \\
102.94 \\
\mathrm{I}^{2}=\mathrm{N} / \mathrm{A}\end{array}$ & 1 RCT (15 Patients) ${ }^{57}$ & $\begin{array}{l}\text { Severe } \\
\text { imprecision } \\
\text { (small sample } \\
\text { size and wide } \\
\mathrm{Cl} \text { ) }\end{array}$ & $\begin{array}{l}\text { Low } \\
\text { (no } \\
\text { difference) }\end{array}$ \\
\hline \multirow[t]{2}{*}{$\begin{array}{l}\text { Duloxetine } \\
\text { (class: SNRI) } \\
\text { vs. Pill } \\
\text { Placebo }\end{array}$} & Dropouts & $\begin{array}{l}\text { RR: } 1.02 ; \\
95 \% \mathrm{Cl} \text {; } \\
0.76 \text { to } \\
1.35 ; \\
\mathrm{I}^{2}=\mathrm{N} / \mathrm{A}\end{array}$ & 1 RCT (272 Patients) ${ }^{64}$ & $\begin{array}{l}\text { Severe } \\
\text { imprecision } \\
\text { (small sample } \\
\text { size and wide } \\
\mathrm{Cl} \text { ) }\end{array}$ & $\begin{array}{l}\text { Low } \\
\text { (no } \\
\text { difference) }\end{array}$ \\
\hline & Dropouts due to AEs & $\begin{array}{l}\text { RR: } 1.17 ; \\
95 \% \mathrm{Cl} \text {; } \\
0.58 \text { to } \\
2.37 ; \\
\mathrm{I}^{2}=\mathrm{N} / \mathrm{A}\end{array}$ & 1 RCT (272 Patients) $)^{64}$ & $\begin{array}{l}\text { Severe } \\
\text { imprecision } \\
\text { (small sample } \\
\text { size and wide } \\
\mathrm{Cl} \text { ) }\end{array}$ & $\begin{array}{l}\text { Low } \\
\text { (no } \\
\text { difference) }\end{array}$ \\
\hline \multirow[t]{5}{*}{$\begin{array}{l}\text { Fluoxetine } \\
\text { (class: SSRI) } \\
\text { vs. Pill } \\
\text { Placebo }\end{array}$} & Dropouts & $\begin{array}{l}\text { RR: } 1.39 ; \\
95 \% \mathrm{Cl} \text {; } \\
0.38 \text { to } \\
5.09 ; \\
I^{2}=0.0\end{array}$ & 3 RCTs (175 Patients) ${ }^{51,53,54}$ & $\begin{array}{l}\text { Methodological } \\
\text { limitations, } \\
\text { severe } \\
\text { imprecision } \\
\text { (small sample } \\
\text { size and wide } \\
\text { Cls) }\end{array}$ & Insufficient \\
\hline & Dropouts due to AEs & $\begin{array}{l}\text { RR: } 3.00 ; \\
95 \% \mathrm{Cl} \text { : } \\
0.13 \text { to } \\
71.34 ; \\
\text { I }^{2}=\mathrm{N} / \mathrm{A}\end{array}$ & $1 \mathrm{RCT}$ (74 Patients) $)^{53}$ & $\begin{array}{l}\text { Methodological } \\
\text { limitations, } \\
\text { severe } \\
\text { imprecision } \\
\text { (small sample } \\
\text { size and wide } \\
\text { Cls) }\end{array}$ & Insufficient \\
\hline & Any AEs & $\begin{array}{l}\text { Rate ratio: } \\
2.77 ; 95 \% \\
\text { Cl: } 1.71 \text { to } \\
4.47 ; \\
\mathrm{I}^{2}=0.0 \%\end{array}$ & 2 RCTs (95 Patients) & $\begin{array}{l}\text { Methodological } \\
\text { limitations, } \\
\text { imprecision } \\
\text { (small sample } \\
\text { size) } \\
\end{array}$ & $\begin{array}{l}\text { Low } \\
\text { (increased } \\
\text { AEs) }\end{array}$ \\
\hline & $\begin{array}{l}\text { AEs related to } \\
\text { abdominal/GI/appetite }\end{array}$ & $\begin{array}{l}\text { Rate ratio: } \\
\text { 2.29; } 95 \% \\
\text { Cl: } 0.94 \text { to } \\
5.56 ; \\
I^{2}=\text { N/A }\end{array}$ & 1 RCT (74 Patients) $)^{53}$ & $\begin{array}{l}\text { Methodological } \\
\text { limitations, } \\
\text { severe } \\
\text { imprecision } \\
\text { (small sample } \\
\text { size and wide } \\
\text { Cls) }\end{array}$ & Insufficient \\
\hline & $\begin{array}{l}\text { AEs related to } \\
\text { behavior Change }\end{array}$ & $\begin{array}{l}\text { Rate ratio: } \\
1.75 ; 95 \% \\
\text { Cl: } 0.51 \text { to } \\
5.98 ;\end{array}$ & 1 RCT (74 Patients) ${ }^{53}$ & $\begin{array}{l}\text { Methodological } \\
\text { limitations, } \\
\text { severe } \\
\text { imprecision }\end{array}$ & Insufficient \\
\hline
\end{tabular}




\begin{tabular}{|c|c|c|c|c|c|}
\hline Comparison & Outcome & $\begin{array}{l}\text { Conclusi } \\
\text { on }\end{array}$ & $\begin{array}{c}\text { Study Design and Sample } \\
\text { Size }^{a}\end{array}$ & $\begin{array}{l}\text { Factors That } \\
\text { Affect the } \\
\text { Strength of } \\
\text { Evidence }^{b}\end{array}$ & $\begin{array}{c}\text { Overall } \\
\text { Evidence } \\
\text { Strength } \\
\text { (Direction } \\
\text { of Effect) }\end{array}$ \\
\hline & & $\mathrm{I}^{2}=\mathrm{N} / \mathrm{A}$ & & $\begin{array}{l}\text { (small sample } \\
\text { size and wide } \\
\text { Cls) }\end{array}$ & \\
\hline \multirow[t]{10}{*}{$\begin{array}{l}\text { Fluvoxamine } \\
\text { (class: SSRI) } \\
\text { vs. Pill } \\
\text { Placebo }\end{array}$} & Dropouts & $\begin{array}{l}\text { RR: } 0.74 ; \\
95 \% \text { Cl: } \\
0.35 \text { to } \\
1.54 ; \\
I^{2}=\text { N/A }\end{array}$ & 1 RCT (128 Patients) ${ }^{22}$ & $\begin{array}{l}\text { Severe } \\
\text { imprecision } \\
\text { (small sample } \\
\text { size and wide } \\
\mathrm{Cl} \text { ) }\end{array}$ & $\begin{array}{l}\text { Low } \\
\text { (no } \\
\text { difference) }\end{array}$ \\
\hline & Dropouts due to AEs & $\begin{array}{l}\text { RR: } 5.16 ; \\
95 \% \mathrm{Cl} \text {; } \\
0.62 \text { to } \\
42.93 ; \\
\mathrm{I}^{2}=\mathrm{N} / \mathrm{A}\end{array}$ & 1 RCT (128 Patients) ${ }^{22}$ & $\begin{array}{l}\text { Severe } \\
\text { imprecision } \\
\text { (small sample } \\
\text { size and wide } \\
\mathrm{Cl} \text { ) }\end{array}$ & $\begin{array}{l}\text { Low } \\
\text { (no } \\
\text { difference) }\end{array}$ \\
\hline & Any AEs & $\begin{array}{l}\text { Rate ratio: } \\
\text { 1.18; } 95 \% \\
\text { Cl: } 0.15 \text { to } \\
9.45 ; \\
I^{2}=83.5 \%\end{array}$ & $\begin{array}{l}\text { 4 RCTs (303 Patients) } \\
50,60\end{array}$ & $\begin{array}{l}\text { Severe } \\
\text { imprecision } \\
\text { (small sample } \\
\text { size and wide } \\
\mathrm{Cl} \text { ) }\end{array}$ & $\begin{array}{l}\text { Low } \\
\text { (no } \\
\text { difference) }\end{array}$ \\
\hline & $\begin{array}{l}\text { AEs related to } \\
\text { abdominal/GI/appetite }\end{array}$ & $\begin{array}{l}\text { Rate ratio: } \\
\text { 1.58; } 95 \% \\
\text { Cl: } 1.13 \text { to } \\
2.20 ; \\
\mathrm{I}^{2}=0.0 \%\end{array}$ & 2 RCTs (153 Patients) ${ }^{22,49}$ & $\begin{array}{l}\text { Imprecision } \\
\text { (small sample } \\
\text { size) }\end{array}$ & $\begin{array}{l}\text { Moderate } \\
\text { (increased } \\
\text { AEs) }\end{array}$ \\
\hline & $\begin{array}{l}\text { AEs related to } \\
\text { behavior change }\end{array}$ & $\begin{array}{l}\text { Rate ratio: } \\
2.12 ; 95 \% \\
\text { Cl: } 0.08 \text { to } \\
54.36 ; \\
I^{2}=79.0 \%\end{array}$ & 3 RCTs (198 Patients) ${ }^{22,49,60}$ & $\begin{array}{l}\text { Severe } \\
\text { imprecision } \\
\text { (small sample } \\
\text { size and wide } \\
\mathrm{Cl} \text { ), } \\
\text { inconsistency }\end{array}$ & Insufficient \\
\hline & $\begin{array}{l}\text { AEs related to } \\
\text { cold/infection/allergie } \\
\mathrm{s}\end{array}$ & $\begin{array}{l}\text { Rate ratio: } \\
1.05 ; 95 \% \\
\text { Cl: } 0.75 \text { to } \\
1.47 ; I^{2}= \\
53.1 \%\end{array}$ & 2 RCTs (153 Patients) $)^{22,49}$ & $\begin{array}{l}\text { Severe } \\
\text { imprecision } \\
\text { (small sample } \\
\text { size and wide } \\
\mathrm{Cl} \text { ) } \\
\end{array}$ & $\begin{array}{l}\text { Low } \\
\text { (no } \\
\text { difference) }\end{array}$ \\
\hline & $\begin{array}{l}\text { AEs related to } \\
\text { difficulties sleeping }\end{array}$ & $\begin{array}{l}\text { Rate ratio: } \\
0.76 ; 95 \% \\
\text { Cl: } 0.14 \text { to } \\
3.86 ; \\
I^{2}=55.2 \%\end{array}$ & 3 RCTs (258 Patients) ${ }^{22,49,50}$ & $\begin{array}{l}\text { Severe } \\
\text { imprecision } \\
\text { (small sample } \\
\text { size and wide } \\
\mathrm{Cl} \text { ) }\end{array}$ & $\begin{array}{l}\text { Low } \\
\text { (no } \\
\text { difference) }\end{array}$ \\
\hline & $\begin{array}{l}\text { AEs related to } \\
\text { headache/dizzy/vision }\end{array}$ & $\begin{array}{l}\text { Rate ratio: } \\
1.22 ; 95 \% \\
\mathrm{Cl}: 0.74 \text { to } \\
2.00 ; I^{2}= \\
0.0 \%\end{array}$ & 2 RCTs (153 Patients) ${ }^{22,49}$ & $\begin{array}{l}\text { Severe } \\
\text { imprecision } \\
\text { (small sample } \\
\text { size and wide } \\
\mathrm{Cl} \text { ) } \\
\end{array}$ & $\begin{array}{l}\text { Low } \\
\text { (no } \\
\text { difference) }\end{array}$ \\
\hline & $\begin{array}{l}\text { AEs related to } \\
\text { fatigue/somnolence }\end{array}$ & $\begin{array}{l}\text { Rate ratio: } \\
1.65 ; 95 \% \\
\text { Cl: } 0.87 \text { to } \\
3.15 ; \\
\mathrm{I}^{2}=\mathrm{N} / \mathrm{A}\end{array}$ & 1 RCT (128 Patients) ${ }^{22}$ & $\begin{array}{l}\text { Severe } \\
\text { imprecision } \\
\text { (small sample } \\
\text { size and wide } \\
\mathrm{Cl} \text { ) }\end{array}$ & $\begin{array}{l}\text { Low } \\
\text { (no } \\
\text { difference) }\end{array}$ \\
\hline & $\begin{array}{l}\text { AEs related to dry } \\
\text { mouth/bad taste/oral } \\
\text { symptoms }\end{array}$ & $\begin{array}{l}\text { Rate ratio: } \\
0.22 ; 95 \% \\
\text { Cl: } 0.02 \text { to } \\
2.13 ; \\
\mathrm{I}^{2}=\mathrm{N} / \mathrm{A}\end{array}$ & 1 RCT (25 Patients) ${ }^{49}$ & $\begin{array}{l}\text { Severe } \\
\text { imprecision } \\
\text { (small sample } \\
\text { size and wide } \\
\mathrm{Cl} \text { ) }\end{array}$ & $\begin{array}{l}\text { Low } \\
\text { (no } \\
\text { difference) }\end{array}$ \\
\hline $\begin{array}{l}\text { Imipramine } \\
\text { (class: TCA) }\end{array}$ & Any AEs & $\begin{array}{l}\text { Rate ratio: } \\
1.40 ; 95 \%\end{array}$ & 2 RCTs (56 Patients) ${ }^{56,74}$ & $\begin{array}{l}\text { Severe } \\
\text { imprecision }\end{array}$ & Insufficient \\
\hline
\end{tabular}




\begin{tabular}{|c|c|c|c|c|c|}
\hline Comparison & Outcome & $\begin{array}{l}\text { Conclusi } \\
\text { on }\end{array}$ & $\begin{array}{c}\text { Study Design and Sample } \\
\text { Size }^{a}\end{array}$ & $\begin{array}{l}\text { Factors That } \\
\text { Affect the } \\
\text { Strength of } \\
\text { Evidence }^{b}\end{array}$ & $\begin{array}{l}\text { Overall } \\
\text { Evidence } \\
\text { Strength } \\
\text { (Direction } \\
\text { of Effect) }\end{array}$ \\
\hline \multirow[t]{7}{*}{$\begin{array}{l}\text { vs. Pill } \\
\text { Placebo }\end{array}$} & & $\begin{array}{l}\mathrm{Cl}: 0.82 \text { to } \\
2.63 ; \\
\mathrm{I}^{2}=86.6 \%\end{array}$ & & $\begin{array}{l}\text { (small sample } \\
\text { size and wide } \\
\mathrm{Cl} \text { ), } \\
\text { inconsistency }\end{array}$ & \\
\hline & $\begin{array}{l}\text { AEs related to } \\
\text { abdominal/GI/appetite }\end{array}$ & $\begin{array}{l}\text { Rate ratio: } \\
0.62 ; 95 \% \\
\text { Cl: } 0.21 \text { to } \\
1.86 ; \\
\mathrm{I}^{2}=0.0 \%\end{array}$ & 2 RCTs (56 Patients) $)^{56,74}$ & $\begin{array}{l}\text { Severe } \\
\text { imprecision } \\
\text { (small sample } \\
\text { size and wide } \\
\mathrm{Cl} \text { ) }\end{array}$ & $\begin{array}{l}\text { Low } \\
\text { (no } \\
\text { difference) }\end{array}$ \\
\hline & $\begin{array}{l}\text { AEs related to } \\
\text { behavior change }\end{array}$ & $\begin{array}{l}\text { Rate ratio: } \\
5.45 ; 95 \% \\
\text { Cl: } 0.66 \text { to } \\
45.30 ; \\
I^{2}=0.0 \%\end{array}$ & 2 RCTs (56 Patients) $)^{56,74}$ & $\begin{array}{l}\text { Severe } \\
\text { imprecision } \\
\text { (small sample } \\
\text { size and wide } \\
\mathrm{Cl} \text { ) }\end{array}$ & $\begin{array}{l}\text { Low } \\
\text { (no } \\
\text { difference) }\end{array}$ \\
\hline & $\begin{array}{l}\text { AEs related to } \\
\text { difficulties sleeping }\end{array}$ & $\begin{array}{l}\text { Rate ratio: } \\
0.34 ; 95 \% \\
\text { Cl: } 0.07 \\
\text { to1.63; } \\
\mathrm{I}^{2}=0.0 \%\end{array}$ & 2 RCTs (56 Patients) $)^{56,74}$ & $\begin{array}{l}\text { Severe } \\
\text { imprecision } \\
\text { (small sample } \\
\text { size and wide } \\
\mathrm{Cl} \text { ) }\end{array}$ & $\begin{array}{l}\text { Low } \\
\text { (no } \\
\text { difference) }\end{array}$ \\
\hline & $\begin{array}{l}\text { AEs related to } \\
\text { fatigue/somnolence }\end{array}$ & $\begin{array}{l}\text { Rate ratio: } \\
2.73 ; 95 \% \\
\text { Cl: } 0.28 \text { to } \\
26.22 ; \\
\mathrm{I}^{2}=\mathrm{N} / \mathrm{A}\end{array}$ & 1 RCT (21 Patients) ${ }^{74}$ & $\begin{array}{l}\text { Severe } \\
\text { imprecision } \\
\text { (small sample } \\
\text { size and wide } \\
\mathrm{Cl} \text { ) }\end{array}$ & $\begin{array}{l}\text { Low } \\
\text { (no } \\
\text { difference) }\end{array}$ \\
\hline & $\begin{array}{l}\text { AEs related to } \\
\text { difficulties sleeping }\end{array}$ & $\begin{array}{l}\text { Rate } \\
\text { Ratio: } \\
0.34 ; 95 \% \\
\text { Cl: } 0.07 \text { to } \\
1.63 ; \\
\left.\right|^{2}=0.0 \%\end{array}$ & 2 RCTs (56 Patients) ${ }^{56,74}$ & $\begin{array}{l}\text { Severe } \\
\text { imprecision } \\
\text { (small sample } \\
\text { size and wide } \\
\mathrm{Cl} \text { ) }\end{array}$ & $\begin{array}{l}\text { Low } \\
\text { (no } \\
\text { difference) }\end{array}$ \\
\hline & $\begin{array}{l}\text { AEs related to dry } \\
\text { mouth/bad taste/oral } \\
\text { symptoms }\end{array}$ & $\begin{array}{l}\text { Rate } \\
\text { Ratio: } \\
3.81 ; 95 \% \\
\text { Cl: } 1.25 \text { to } \\
11.62 ; \\
\left.\right|^{2}=0.0 \%\end{array}$ & 2 RCTs (56 Patients) $)^{56,74}$ & $\begin{array}{l}\text { Imprecision } \\
\text { (small number } \\
\text { of patients) }\end{array}$ & $\begin{array}{l}\text { Moderate } \\
\text { (increased } \\
\text { AEs) }\end{array}$ \\
\hline \multirow[t]{4}{*}{$\begin{array}{l}\text { Paroxetine } \\
\text { (class: SSRI) } \\
\text { vs. Pill } \\
\text { Placebo }\end{array}$} & Dropouts & $\begin{array}{l}\text { RR: } 0.71 ; \\
95 \% \text { Cl: } \\
0.50 \text { to } \\
1.02 ; \\
I^{2}=\mathrm{N} / \mathrm{A}\end{array}$ & 1 RCT (322 Patients) (55 $^{65}$ & $\begin{array}{l}\text { Severe } \\
\text { imprecision } \\
\text { (small sample } \\
\text { size and wide } \\
\mathrm{Cl} \text { ) }\end{array}$ & $\begin{array}{l}\text { Low } \\
\text { (no } \\
\text { difference) }\end{array}$ \\
\hline & Dropouts due to AEs & $\begin{array}{l}\text { RR: } 4.28 ; \\
95 \% \text { Cl: } \\
0.94 \text { to } \\
19.51 ; \\
I^{2}=\mathrm{N} / \mathrm{A}\end{array}$ & 1 RCT (322 Patients) $)^{65}$ & $\begin{array}{l}\text { Severe } \\
\text { imprecision } \\
\text { (small sample } \\
\text { size and wide } \\
\mathrm{Cl} \text { ) }\end{array}$ & $\begin{array}{l}\text { Low } \\
\text { (no } \\
\text { difference) }\end{array}$ \\
\hline & Any AEs & $\begin{array}{l}\text { Rate ratio: } \\
1.85 ; 95 \% \\
\mathrm{Cl}: 1.45 \text { to } \\
2.35 ; \\
\mathrm{I}^{2}=\mathrm{N} / \mathrm{A}\end{array}$ & 1 RCT (210 Patients) $)^{65}$ & $\begin{array}{l}\text { Imprecision } \\
\text { (small sample } \\
\text { size) }\end{array}$ & $\begin{array}{l}\text { Moderate } \\
\text { (increased } \\
\text { AEs) }\end{array}$ \\
\hline & $\begin{array}{l}\text { AEs related to } \\
\text { abdominal/GI/appetite }\end{array}$ & $\begin{array}{l}\text { Rate ratio: } \\
3.49 ; 95 \% \\
\text { Cl: } 0.97 \text { to } \\
12.51 ; \\
\mathrm{I}^{2}=\mathrm{N} / \mathrm{A}\end{array}$ & 1 RCT (322 Patients) ${ }^{65}$ & $\begin{array}{l}\text { Severe } \\
\text { imprecision } \\
\text { (small sample } \\
\text { size and wide } \\
\mathrm{Cl} \text { ) }\end{array}$ & $\begin{array}{l}\text { Low } \\
\text { (no } \\
\text { difference) }\end{array}$ \\
\hline
\end{tabular}




\begin{tabular}{|c|c|c|c|c|c|}
\hline Comparison & Outcome & $\begin{array}{l}\text { Conclusi } \\
\text { on }\end{array}$ & $\begin{array}{c}\text { Study Design and Sample } \\
\text { Size }^{a}\end{array}$ & $\begin{array}{l}\text { Factors That } \\
\text { Affect the } \\
\text { Strength of } \\
\text { Evidence }^{b}\end{array}$ & $\begin{array}{c}\text { Overall } \\
\text { Evidence } \\
\text { Strength } \\
\text { (Direction } \\
\text { of Effect) }\end{array}$ \\
\hline & $\begin{array}{l}\text { AEs related to } \\
\text { behavior change }\end{array}$ & $\begin{array}{l}\text { Rate ratio: } \\
2.16 ; 95 \% \\
\mathrm{Cl}: 1.06 \text { to } \\
4.40 ; \\
I^{2}=\mathrm{N} / \mathrm{A}\end{array}$ & 1 RCT (322 Patients) ${ }^{65}$ & $\begin{array}{l}\text { Severe } \\
\text { imprecision } \\
\text { (small sample } \\
\text { size and wide } \\
\mathrm{Cl} \text { ) }\end{array}$ & $\begin{array}{l}\text { Low } \\
\text { (increased } \\
\text { AEs) }\end{array}$ \\
\hline & $\begin{array}{l}\text { AEs related to } \\
\text { cold/infection/allergie } \\
\mathrm{s}\end{array}$ & $\begin{array}{l}\text { Rate ratio: } \\
2.00 ; 95 \% \\
\mathrm{Cl}: 1.39 \text { to } \\
2.89 ; \\
\mathrm{I}^{2}=\mathrm{N} / \mathrm{A}\end{array}$ & 1 RCT (274 Patients) ${ }^{65}$ & $\begin{array}{l}\text { Imprecision } \\
\text { (small sample } \\
\text { size) }\end{array}$ & $\begin{array}{l}\text { Moderate } \\
\text { (increased } \\
\text { AEs) }\end{array}$ \\
\hline & $\begin{array}{l}\text { AEs related to } \\
\text { difficulties sleeping }\end{array}$ & $\begin{array}{l}\text { Rate ratio: } \\
6.17 ; 95 \% \\
\mathrm{Cl}: 3.58 \text { to } \\
10.63 ; \\
\mathrm{I}^{2}=\mathrm{N} / \mathrm{A}\end{array}$ & 1 RCT (157 Patients) ${ }^{65}$ & $\begin{array}{l}\text { Imprecision } \\
\text { (small sample } \\
\text { size) }\end{array}$ & $\begin{array}{l}\text { Moderate } \\
\text { (increased } \\
\text { AEs) }\end{array}$ \\
\hline & $\begin{array}{l}\text { AEs related to } \\
\text { fatigue/somnolence }\end{array}$ & $\begin{array}{l}\text { Rate ratio: } \\
1.52 ; 95 \% \\
\mathrm{Cl}: 0.76 \text { to } \\
3.03 ; \\
\text { I }^{2}=\mathrm{N} / \mathrm{A}\end{array}$ & 1 RCT (320 Patients) ${ }^{65}$ & $\begin{array}{l}\text { Severe } \\
\text { imprecision } \\
\text { (small sample } \\
\text { size and wide } \\
\mathrm{Cl} \text { ) }\end{array}$ & $\begin{array}{l}\text { Low } \\
\text { (no } \\
\text { difference) }\end{array}$ \\
\hline \multirow[t]{7}{*}{$\begin{array}{l}\text { Sertraline } \\
\text { (class: SSRI) } \\
\text { Vs. Pill } \\
\text { Placebo }\end{array}$} & Dropouts & $\begin{array}{l}\text { RR: } 0.73 ; \\
95 \% \mathrm{Cl} \text { : } \\
0.38 \text { to } \\
1.42 ; \\
\mathrm{I}^{2}=0.0 \%\end{array}$ & ${ }_{67-72}^{2 \text { RCTs (231 Patients) }}$ & $\begin{array}{l}\text { Methodological } \\
\text { limitations, } \\
\text { severe } \\
\text { imprecision } \\
\text { (small sample } \\
\text { size and wide } \\
\text { Cls) }\end{array}$ & Insufficient \\
\hline & Dropouts due to AEs & $\begin{array}{l}\text { RR: } 1.33 ; \\
95 \% \text { Cl: } \\
0.36 \text { to } \\
5.00 ; \\
\text { I }^{2}=\text { N/A }\end{array}$ & 1 RCT (209 Patients) ${ }^{7,67-72}$ & $\begin{array}{l}\text { Severe } \\
\text { imprecision } \\
\text { (small sample } \\
\text { size and wide } \\
\mathrm{Cl} \text { ) }\end{array}$ & $\begin{array}{l}\text { Low } \\
\text { (no } \\
\text { difference) }\end{array}$ \\
\hline & Any AEs & $\begin{array}{l}\text { Rate ratio: } \\
1.295 \% \\
\mathrm{Cl}: 0.94 \text { to } \\
1.55 ; \\
\mathrm{I}^{2}=50.1 \%\end{array}$ & $\underset{67-72}{2}$ RCTs (231 Patients) ${ }^{7,61,}$ & $\begin{array}{l}\text { Methodological } \\
\text { limitations, } \\
\text { severe } \\
\text { imprecision } \\
\text { (small sample } \\
\text { size and wide } \\
\text { Cls) }\end{array}$ & Insufficient \\
\hline & $\begin{array}{l}\text { AEs related to } \\
\text { abdominal/Gl/appetite }\end{array}$ & $\begin{array}{l}\text { Rate ratio: } \\
0.88 ; 95 \% \\
\text { Cl: } 0.50 \text { to } \\
1.53 ; \\
I^{2}=78.6 \%\end{array}$ & $\underset{67-72}{2 \text { RCTs (231 Patients) }}$ & $\begin{array}{l}\text { Severe } \\
\text { imprecision } \\
\text { (small sample } \\
\text { size and wide } \\
\mathrm{Cl} \text { ) }\end{array}$ & $\begin{array}{l}\text { Low } \\
\text { (no } \\
\text { difference) }\end{array}$ \\
\hline & $\begin{array}{l}\text { AEs related to } \\
\text { behavior change }\end{array}$ & $\begin{array}{l}\text { Rate ratio: } \\
1.57 ; 95 \% \\
\mathrm{Cl}: 0.88 \text { to } \\
2.81 ; \\
\mathrm{I}^{2}=0.00 \%\end{array}$ & ${ }_{72}^{2}$ RCTs (231 Patients) & $\begin{array}{l}\text { Severe } \\
\text { imprecision } \\
\text { (small sample } \\
\text { size and wide } \\
\mathrm{Cl} \text { ) }\end{array}$ & $\begin{array}{l}\text { Low } \\
\text { (no } \\
\text { difference) }\end{array}$ \\
\hline & $\begin{array}{l}\text { AEs related to } \\
\text { cold/infection/allergie } \\
\mathrm{s}\end{array}$ & $\begin{array}{l}\text { Rate ratio: } \\
0.86 ; 95 \% \\
\mathrm{Cl}: 0.49 \text { to } \\
1.51 ; \\
\mathrm{I}^{2}=\mathrm{N} / \mathrm{A}\end{array}$ & 1 RCT (209 Patients) ${ }^{7,67-72}$ & $\begin{array}{l}\text { Severe } \\
\text { imprecision } \\
\text { (small sample } \\
\text { size and wide } \\
\mathrm{Cl} \text { ) }\end{array}$ & $\begin{array}{l}\text { Low } \\
\text { (no } \\
\text { difference) }\end{array}$ \\
\hline & $\begin{array}{l}\text { AEs related to } \\
\text { difficulties sleeping }\end{array}$ & $\begin{array}{l}\text { Rate ratio: } \\
1.94 ; 95 \%\end{array}$ & 1 RCT (209 Patients) ${ }^{7,67-72}$ & $\begin{array}{l}\text { Severe } \\
\text { imprecision }\end{array}$ & $\begin{array}{l}\text { Low } \\
\text { (no }\end{array}$ \\
\hline
\end{tabular}




\begin{tabular}{|c|c|c|c|c|c|}
\hline Comparison & Outcome & $\begin{array}{l}\text { Conclusi } \\
\text { on }\end{array}$ & $\begin{array}{c}\text { Study Design and Sample } \\
\text { Size }^{a}\end{array}$ & $\begin{array}{l}\text { Factors That } \\
\text { Affect the } \\
\text { Strength of } \\
\text { Evidence }^{b}\end{array}$ & $\begin{array}{l}\text { Overall } \\
\text { Evidence } \\
\text { Strength } \\
\text { (Direction } \\
\text { of Effect) }\end{array}$ \\
\hline & & $\begin{array}{l}\mathrm{Cl}: 0.72 \\
\text { to } 5.27 \\
\mathrm{I}^{2}=\mathrm{N} / \mathrm{A}\end{array}$ & & $\begin{array}{l}\text { (small sample } \\
\text { size and wide } \\
\mathrm{Cl} \text { ) }\end{array}$ & difference) \\
\hline & $\begin{array}{l}\text { AEs related to } \\
\text { fatigue/somnolence }\end{array}$ & $\begin{array}{l}\text { Rate ratio: } \\
1.68 ; 95 \% \\
\text { Cl: } 0.76 \text { to } \\
3.74 ; \\
\mathrm{I}^{2}=0.0 \%\end{array}$ & ${ }_{72}^{2}$ RCTs (231 Patients) & $\begin{array}{l}\text { Severe } \\
\text { imprecision } \\
\text { (small sample } \\
\text { size and wide } \\
\mathrm{Cl} \text { ) }\end{array}$ & $\begin{array}{l}\text { Low } \\
\text { (no } \\
\text { difference) }\end{array}$ \\
\hline & $\begin{array}{l}\text { AEs related to } \\
\text { headache/dizzy/vision }\end{array}$ & $\begin{array}{l}\text { Rate ratio: } \\
1.29 ; 95 \% \\
\text { Cl: } 0.59 \text { to } \\
2.85 ; \\
I^{2}=72.6 \%\end{array}$ & ${ }_{72}^{2}$ RCTs (231 Patients) & $\begin{array}{l}\text { Severe } \\
\text { imprecision } \\
\text { (small sample } \\
\text { size and wide } \\
\mathrm{Cl} \text { ) }\end{array}$ & $\begin{array}{l}\text { Low } \\
\text { (no } \\
\text { difference) }\end{array}$ \\
\hline & $\begin{array}{l}\text { AEs related to } \\
\text { accidental injury }\end{array}$ & $\begin{array}{l}\text { Rate ratio: } \\
2.29 ; 95 \% \\
\mathrm{Cl}: 0.26 \\
\text { to } 20.45 ; \\
\mathrm{I}^{2}=\mathrm{N} / \mathrm{A}\end{array}$ & 1 RCT (209 patients) $)^{7,67-72}$ & $\begin{array}{l}\text { Severe } \\
\text { imprecision } \\
\text { (small sample } \\
\text { size and wide } \\
\mathrm{Cl} \text { ) }\end{array}$ & $\begin{array}{l}\text { Low } \\
\text { (no } \\
\text { difference) }\end{array}$ \\
\hline & $\begin{array}{l}\text { AEs related to } \\
\text { suicide/ideation/self- } \\
\text { harm }\end{array}$ & $\begin{array}{l}0 \text { case in } \\
\text { each } \\
\text { group }\end{array}$ & 1 RCT (209 patients) $)^{7,67-72}$ & No data & Insufficient \\
\hline & $\begin{array}{l}\text { AEs related to dry } \\
\text { mouth/bad taste/oral } \\
\text { symptoms }\end{array}$ & $\begin{array}{l}\text { Rate ratio: } \\
2.0 ; 95 \% \\
\text { Cl: } \\
0.50 \text { to } \\
8.00 ; \\
\left.\right|^{2}=\mathrm{N} / \mathrm{A}\end{array}$ & 1 RCT (22 patients) ${ }^{61}$ & $\begin{array}{l}\text { Severe } \\
\text { imprecision } \\
\text { (small sample } \\
\text { size and wide } \\
\mathrm{Cl} \text { ) }\end{array}$ & $\begin{array}{l}\text { Low } \\
\text { (no } \\
\text { difference) }\end{array}$ \\
\hline \multirow[t]{6}{*}{$\begin{array}{l}\text { Venlafaxine } \\
\text { (class: SNRI) } \\
\text { vs. Pill } \\
\text { Placebo }\end{array}$} & Dropouts & $\begin{array}{l}\text { RR: } 0.84 ; \\
95 \% \text { Cl: } \\
0.65 \text { to } \\
1.09 ; \\
I^{2}=0.0 \%\end{array}$ & 2 RCTs (610 Patients) & $\begin{array}{l}\text { Imprecision } \\
\text { (wide Cls) }\end{array}$ & $\begin{array}{l}\text { Moderate } \\
\text { (no } \\
\text { difference) }\end{array}$ \\
\hline & Dropouts due to AEs & $\begin{array}{l}\text { RR: } 0.78 ; \\
95 \% \text { Cl: } \\
0.36 \text { to } \\
1.66 ; \\
I^{2}=64.9 \%\end{array}$ & 2 RCTs (610 Patients) ${ }^{58,62}$ & $\begin{array}{l}\text { Imprecision } \\
\text { (wide Cls), } \\
\text { inconsistency }\end{array}$ & $\begin{array}{l}\text { Low } \\
\text { (no } \\
\text { difference) }\end{array}$ \\
\hline & Any AEs & $\begin{array}{l}\text { Rate ratio: } \\
1.13 ; 95 \% \\
\text { Cl: } 0.98 \text { to } \\
1.31 ; \\
\mathrm{I}^{2}=97.5 \%\end{array}$ & 2 RCTs (610 Patients) ${ }^{58,62}$ & $\begin{array}{l}\text { Imprecision } \\
\text { (wide Cls), } \\
\text { inconsistency }\end{array}$ & $\begin{array}{l}\text { Low } \\
\text { (no } \\
\text { difference) }\end{array}$ \\
\hline & $\begin{array}{l}\text { AEs related to } \\
\text { abdominal/GI/appetite }\end{array}$ & $\begin{array}{l}\text { Rate ratio: } \\
1.92 ; 95 \% \\
\text { Cl: } 1.44 \text { to } \\
2.57 ; \\
\mathrm{I}^{2}=88.8 \%\end{array}$ & 2 RCTs (610 Patients) ${ }^{58,62}$ & Inconsistency & $\begin{array}{l}\text { Moderate } \\
\text { (increased } \\
\text { AEs) }\end{array}$ \\
\hline & $\begin{array}{l}\text { AEs related to } \\
\text { behavior change }\end{array}$ & $\begin{array}{l}\text { Rate ratio: } \\
\text { 1.43; } 95 \% \\
\text { Cl: } 0.60 \text { to } \\
3.39 ; \\
\mathrm{I}^{2}=\mathrm{N} / \mathrm{A}\end{array}$ & 1 RCT (290 Patients) $)^{58}$ & $\begin{array}{l}\text { Severe } \\
\text { imprecision } \\
\text { (small sample } \\
\text { size and wide } \\
\mathrm{Cl} \text { ) }\end{array}$ & $\begin{array}{l}\text { Low } \\
\text { (no } \\
\text { difference) }\end{array}$ \\
\hline & $\begin{array}{l}\text { AEs related to } \\
\text { cold/Infection/allergie } \\
\mathrm{s}\end{array}$ & $\begin{array}{l}\text { Rate ratio: } \\
0.87 ; 95 \% \\
\text { Cl: } 0.57 \text { to } \\
1.32 ; 1^{2}=\end{array}$ & 2 RCTs (610 Patients) ${ }^{58,62}$ & $\begin{array}{l}\text { Severe } \\
\text { imprecision } \\
\text { (small sample } \\
\text { size and wide }\end{array}$ & Insufficient \\
\hline
\end{tabular}




\begin{tabular}{|c|c|c|c|c|c|}
\hline Comparison & Outcome & $\begin{array}{l}\text { Conclusi } \\
\text { on }\end{array}$ & $\begin{array}{l}\text { Study Design and Sample } \\
\text { Size }^{a}\end{array}$ & $\begin{array}{l}\text { Factors That } \\
\text { Affect the } \\
\text { Strength of } \\
\text { Evidence }^{b}\end{array}$ & $\begin{array}{c}\text { Overall } \\
\text { Evidence } \\
\text { Strength } \\
\text { (Direction } \\
\text { of Effect) }\end{array}$ \\
\hline & & $91.4 \%$ & & $\begin{array}{l}\mathrm{Cl}), \\
\text { inconsistency }\end{array}$ & \\
\hline & $\begin{array}{l}\text { AEs related to } \\
\text { fatigue/somnolence }\end{array}$ & $\begin{array}{l}\text { Rate ratio: } \\
2.14 ; 95 \% \\
\text { Cl: } 1.13 \text { to } \\
4.07 ; \\
\text { I }^{2}=\text { N/A }\end{array}$ & 1 RCT (290 Patients) $)^{58}$ & $\begin{array}{l}\text { Imprecision } \\
\text { (small sample } \\
\text { size) }\end{array}$ & $\begin{array}{l}\text { Moderate } \\
\text { (increased } \\
\text { AEs) }\end{array}$ \\
\hline & $\begin{array}{l}\text { AEs related to } \\
\text { headache/dizzy/vision }\end{array}$ & $\begin{array}{l}\text { Rate ratio: } \\
0.67 ; 95 \% \\
\text { Cl: } 0.44 \text { to } \\
1.01 ; \\
\text { I }^{2}=\text { N/A }\end{array}$ & 1 RCT (320 Patients) ${ }^{62}$ & $\begin{array}{l}\text { Severe } \\
\text { imprecision } \\
\text { (small sample } \\
\text { size and wide } \\
\mathrm{Cl} \text { ) }\end{array}$ & $\begin{array}{l}\text { Low } \\
\text { (no } \\
\text { difference) }\end{array}$ \\
\hline & $\begin{array}{l}\text { AEs related to } \\
\text { suicide/ideation/self- } \\
\text { harm }\end{array}$ & $\begin{array}{l}\text { Rate ratio: } \\
4.29 ; 95 \% \\
\text { Cl: } 0.48 \text { to } \\
38.34 ; \\
\text { I }^{2}=\mathrm{N} / \mathrm{A}\end{array}$ & 1 RCT (290 Patients) ${ }^{58}$ & $\begin{array}{l}\text { Severe } \\
\text { imprecision } \\
\text { (small sample } \\
\text { size and wide } \\
\mathrm{Cl} \text { ) }\end{array}$ & $\begin{array}{l}\text { Low } \\
\text { (no } \\
\text { difference) }\end{array}$ \\
\hline & $\begin{array}{l}\text { AEs related to } \\
\text { accidental injury }\end{array}$ & $\begin{array}{l}\text { Rate ratio: } \\
1.16 ; 95 \% \\
\text { Cl: } 0.58 \text { to } \\
2.29 ; \\
I^{2}=\text { N/A }\end{array}$ & 1 RCT (320 Patients) ${ }^{62}$ & $\begin{array}{l}\text { Severe } \\
\text { imprecision } \\
\text { (small sample } \\
\text { size and wide } \\
\mathrm{Cl} \text { ) }\end{array}$ & $\begin{array}{l}\text { Low } \\
\text { (no } \\
\text { difference) }\end{array}$ \\
\hline
\end{tabular}

AE: adverse event, CI: confidence interval, GI: gastrointestinal, N/A: not applicable, RCT: randomized controlled trial, RR: relative risk, SNRI: serotonin-norepinephrine reuptake inhibitor, SMD: standardized mean difference, SSRI: selective serotonin reuptake inhibitor, TCA: tricyclic antidepressants

${ }^{\mathrm{a}}$ The sample size includes the number of patients from each comparison.

${ }^{b}$ Only SOE domains that led to rating down SOE are reported in this column. Domains that are not reported were satisfactory.

Table 12. Strength of evidence for adverse events reported in other comparisons, including combination treatments

\begin{tabular}{|c|c|c|c|c|c|}
\hline Comparison & Outcome & $\underset{n}{\text { Conclusio }}$ & $\begin{array}{l}\text { Study Design and } \\
\text { Sample Size }\end{array}$ & $\begin{array}{l}\text { Factors That } \\
\text { Affect the } \\
\text { Strength of } \\
\text { Evidence }^{b}\end{array}$ & $\begin{array}{c}\text { Overall } \\
\text { Evidence } \\
\text { Strength } \\
\text { (Direction of } \\
\text { Effect) }\end{array}$ \\
\hline \multirow[t]{2}{*}{ TCA vs. SSRI } & Dropouts & $\begin{array}{l}\text { RR: } 0.56 ; \\
95 \% \mathrm{Cl} \text { : } \\
0.06 \text { to } \\
5.14 ; \\
\mathrm{I}^{2}=\mathrm{N} / \mathrm{A}\end{array}$ & $\begin{array}{l}\text { 1 RCT (19 } \\
\text { Patients })^{54}\end{array}$ & $\begin{array}{l}\text { Severe imprecision } \\
\text { (small sample size } \\
\text { and wide } \mathrm{Cl} \text { ) }\end{array}$ & $\begin{array}{l}\text { Low } \\
\text { (no difference) }\end{array}$ \\
\hline & Any AEs & $\begin{array}{l}\text { Rate ratio: } \\
6.90 ; 95 \% \\
\text { Cl: } 2.10 \text { to } \\
22.98 ; \\
I^{2}=\mathrm{N} / \mathrm{A}\end{array}$ & $\begin{array}{l}\text { 1 RCT (19 } \\
\text { Patients) })^{54}\end{array}$ & $\begin{array}{l}\text { Severe imprecision } \\
\text { (small sample size } \\
\text { and wide } \mathrm{Cl} \text { ) }\end{array}$ & $\begin{array}{l}\text { Low } \\
\text { (increased AEs) }\end{array}$ \\
\hline \multirow[t]{2}{*}{$\begin{array}{l}\text { Clomipramine } \\
\text { (class: TCA) } \\
\text { vs. Fluoxetine } \\
\text { (class: SSRI) }\end{array}$} & Dropouts & $\begin{array}{l}\text { RR: } 0.56 ; \\
95 \% \mathrm{Cl} \text {; } \\
0.06 \text { to } \\
5.14 ; \\
\mathrm{I}^{2}=\mathrm{N} / \mathrm{A}\end{array}$ & $\begin{array}{l}1 \text { RCT (19 } \\
\text { Patients) }\end{array}$ & $\begin{array}{l}\text { Severe imprecision } \\
\text { (small sample size } \\
\text { and wide } \mathrm{Cl} \text { ) }\end{array}$ & $\begin{array}{l}\text { Low } \\
\text { (no difference) }\end{array}$ \\
\hline & Any AEs & $\begin{array}{l}\text { Rate ratio: } \\
6.90 ; 95 \% \\
\mathrm{Cl}: 2.10 \text { to } \\
22.98 ; \\
\mathrm{I}^{2}=\mathrm{N} / \mathrm{A}\end{array}$ & $\begin{array}{l}1 \text { RCT (19 } \\
\text { Patients) }\end{array}$ & $\begin{array}{l}\text { Severe imprecision } \\
\text { (small sample size } \\
\text { and wide } \mathrm{Cl} \text { ) }\end{array}$ & $\begin{array}{l}\text { Low } \\
\text { (increased AEs) }\end{array}$ \\
\hline
\end{tabular}




\begin{tabular}{|c|c|c|c|c|c|}
\hline Comparison & Outcome & $\underset{n}{\text { Conclusio }}$ & $\begin{array}{l}\text { Study Design and } \\
\text { Sample Size }^{\mathrm{a}}\end{array}$ & $\begin{array}{l}\text { Factors That } \\
\text { Affect the } \\
\text { Strength of } \\
\text { Evidence }^{b}\end{array}$ & $\begin{array}{c}\text { Overall } \\
\text { Evidence } \\
\text { Strength } \\
\text { (Direction of } \\
\text { Effect) }\end{array}$ \\
\hline $\begin{array}{l}\text { Sertraline } \\
\text { (class: SSRI) } \\
\text { vs Paroxetine } \\
\text { (class: SSRI) }\end{array}$ & Any AEs & $\begin{array}{l}\text { Rate ratio: } \\
5.00 ; \\
95 \% \mathrm{Cl} \\
0.31 \text { to } \\
79.94 ; \\
\mathrm{I}^{2}=\mathrm{N} / \mathrm{A}\end{array}$ & $\begin{array}{l}1 \text { RCT (19 } \\
\text { patients) }\end{array}$ & $\begin{array}{l}\text { Severe imprecision } \\
\text { (small sample size } \\
\text { and wide } \mathrm{Cl} \text { ) }\end{array}$ & $\begin{array}{l}\text { Low } \\
\text { (no difference) }\end{array}$ \\
\hline $\begin{array}{l}\text { Fluoxetine } \\
\text { (class: SSRI) } \\
\text { vs. CBT }\end{array}$ & Dropouts & $\begin{array}{l}\text { RR: } 1.26 ; \\
95 \% \mathrm{Cl} \text { : } \\
0.61 \text { to } \\
2.58 ; \\
\mathrm{I}^{2}=\mathrm{N} / \mathrm{A}\end{array}$ & $\begin{array}{l}1 \mathrm{RCT}(102 \\
\text { Patients) }\end{array}$ & $\begin{array}{l}\text { Severe imprecision } \\
\text { (small sample size } \\
\text { and wide } \mathrm{Cl} \text { ) }\end{array}$ & $\begin{array}{l}\text { Low } \\
\text { (no difference) }\end{array}$ \\
\hline \multirow[t]{9}{*}{$\begin{array}{l}\text { Sertraline } \\
\text { (class: SSRI) } \\
\text { vs CBT }\end{array}$} & Dropouts & $\begin{array}{l}\text { RR: } 2.79 ; \\
95 \% \mathrm{Cl}: \\
1.12 \text { to } \\
6.91 ; \\
\mathrm{I}^{2}=\mathrm{N} / \mathrm{A}\end{array}$ & $\begin{array}{l}1 \text { RCT }(272 \\
\text { Patients) }\end{array}$ & $\begin{array}{l}\text { Methodological } \\
\text { limitations, } \\
\text { imprecision (small } \\
\text { sample size) }\end{array}$ & $\begin{array}{l}\text { Low } \\
\text { (increased } \\
\text { dropouts) }\end{array}$ \\
\hline & $\begin{array}{l}\text { Dropouts due to } \\
\text { AEs }\end{array}$ & $\begin{array}{l}\text { RR: } 15.67 ; \\
95 \% \mathrm{Cl} ; \\
0.90 \text { to } \\
271.71 ; \\
1^{2}=\mathrm{N} / \mathrm{A}\end{array}$ & $\begin{array}{l}1 \text { RCT }(272 \\
\text { Patients) }\end{array}$ & $\begin{array}{l}\text { Methodological } \\
\text { limitations, severe } \\
\text { imprecision (small } \\
\text { sample size and } \\
\text { wide CI) }\end{array}$ & Insufficient \\
\hline & Any AEs & $\begin{array}{l}\text { Rate ratio: } \\
1.39 ; 95 \% \\
\text { CI: } 1.09 \text { to } \\
1.77 ; \\
1^{2}=\mathrm{N} / \mathrm{A}\end{array}$ & $\begin{array}{l}1 \text { RCT }(272 \\
\text { Patients) }\end{array}$ & $\begin{array}{l}\text { Methodological } \\
\text { limitations, } \\
\text { imprecision (small } \\
\text { sample size) }\end{array}$ & $\begin{array}{l}\text { Low } \\
\text { (increased AEs) }\end{array}$ \\
\hline & $\begin{array}{l}\text { AEs related to } \\
\text { abdominal/GI/app } \\
\text { etite }\end{array}$ & $\begin{array}{l}\text { Rate ratio: } \\
0.71 ; 95 \% \\
\text { Cl: } 0.41 \text { to } \\
1.20 ; \\
I^{2}=0.0 \%\end{array}$ & $\begin{array}{l}2 \mathrm{RCT}(274 \\
\text { Patients), 67-72, } 161\end{array}$ & $\begin{array}{l}\text { Methodological } \\
\text { limitations, severe } \\
\text { imprecision (small } \\
\text { sample size and } \\
\text { wide Cl) }\end{array}$ & Insufficient \\
\hline & $\begin{array}{l}\text { AEs related to } \\
\text { behavior change }\end{array}$ & $\begin{array}{l}\text { Rate ratio: } \\
2.09 ; 95 \% \\
\text { Cl: } 1.17 \text { to } \\
3.74 ; \\
I^{2}=0.0 \%\end{array}$ & $\begin{array}{l}2 \text { RCT (321 } \\
\text { Patients) }\end{array}$ & $\begin{array}{l}\text { Methodological } \\
\text { limitations, } \\
\text { imprecision (small } \\
\text { sample size) }\end{array}$ & $\begin{array}{l}\text { Low } \\
\text { (increased AEs) }\end{array}$ \\
\hline & $\begin{array}{l}\text { AEs related to } \\
\text { cold/infection/alle } \\
\text { rgies }\end{array}$ & $\begin{array}{l}\text { Rate ratio: } \\
0.64 ; 95 \% \\
\text { Cl: } 0.41 \text { to } \\
1.01 ; \\
I^{2}=\mathrm{N} / \mathrm{A}\end{array}$ & $\begin{array}{l}1 \text { RCT }(272 \\
\text { Patients) }\end{array}$ & $\begin{array}{l}\text { Severe imprecision } \\
\text { (small sample size } \\
\text { and wide } \mathrm{Cl} \text { ) }\end{array}$ & $\begin{array}{l}\text { Low } \\
\text { (no difference) }\end{array}$ \\
\hline & $\begin{array}{l}\text { AEs related to } \\
\text { difficulties } \\
\text { sleeping }\end{array}$ & $\begin{array}{l}\text { Rate ratio: } \\
4.44 ; 95 \% \\
\mathrm{Cl}: 1.50 \text { to } \\
13.20 ; \\
\mathrm{I}^{2}=\mathrm{N} / \mathrm{A}\end{array}$ & $\begin{array}{l}1 \text { RCT }(272 \\
\text { Patients) }\end{array}$ & $\begin{array}{l}\text { Imprecision (small } \\
\text { sample size) }\end{array}$ & $\begin{array}{l}\text { Moderate } \\
\text { (increased AEs) }\end{array}$ \\
\hline & $\begin{array}{l}\text { AEs related to } \\
\text { headache/dizzy/v } \\
\text { ision }\end{array}$ & $\begin{array}{l}\text { Rate ratio: } \\
1.83 ; 95 \% \\
\text { Cl: } 0.90 \text { to } \\
3.72 ; \\
I^{2}=\mathrm{N} / \mathrm{A}\end{array}$ & $\begin{array}{l}1 \text { RCT }(272 \\
\text { Patients) })^{7,67-72}\end{array}$ & $\begin{array}{l}\text { Severe imprecision } \\
\text { (small sample size } \\
\text { and wide } \mathrm{Cl} \text { ) }\end{array}$ & $\begin{array}{l}\text { Low } \\
\text { (no difference) }\end{array}$ \\
\hline & $\begin{array}{l}\text { AEs related to } \\
\text { accidental injury }\end{array}$ & $\begin{array}{l}\text { Rate ratio: } \\
1.05 ; 95 \% \\
\text { Cl: } 0.26 \text { to } \\
4.18 ; \\
\end{array}$ & $\begin{array}{l}1 \mathrm{RCT}(272 \\
\text { Patients) })^{7,67-72}\end{array}$ & $\begin{array}{l}\text { Severe imprecision } \\
\text { (small sample size } \\
\text { and wide } \mathrm{Cl} \text { ) }\end{array}$ & $\begin{array}{l}\text { Low } \\
\text { (no difference) }\end{array}$ \\
\hline
\end{tabular}




\begin{tabular}{|c|c|c|c|c|c|}
\hline Comparison & Outcome & $\underset{n}{\text { Conclusio }}$ & $\begin{array}{l}\text { Study Design and } \\
\text { Sample Size }^{\mathrm{a}}\end{array}$ & $\begin{array}{l}\text { Factors That } \\
\text { Affect the } \\
\text { Strength of } \\
\text { Evidence }^{b}\end{array}$ & $\begin{array}{c}\text { Overall } \\
\text { Evidence } \\
\text { Strength } \\
\text { (Direction of } \\
\text { Effect) }\end{array}$ \\
\hline & & $\mathrm{I}^{2}=\mathrm{N} / \mathrm{A}$ & & & \\
\hline & $\begin{array}{l}\text { AEs related to } \\
\text { suicide/ideation/s } \\
\text { elf-harm }\end{array}$ & 0 events & $\begin{array}{l}1 \text { RCT (272 } \\
\text { Patients) })^{7,67-72}\end{array}$ & No data & Insufficient \\
\hline \multirow[t]{10}{*}{$\begin{array}{l}\text { CBT vs. Pill } \\
\text { Placebo }\end{array}$} & Dropouts & $\begin{array}{l}\text { RR: } 0.53 \text {; } \\
95 \% \mathrm{Cl} \text { : } \\
0.30 \text { to } \\
0.95 ; \\
I^{2}=74.4 \%\end{array}$ & $\begin{array}{l}2 \text { RCTs (311 } \\
\text { Patients) })^{7,51,67-72}\end{array}$ & $\begin{array}{l}\text { Severe imprecision } \\
\text { (small sample size } \\
\text { and wide } \mathrm{Cl} \text { ) }\end{array}$ & $\begin{array}{l}\text { Low } \\
\text { (reduced } \\
\text { dropouts) }\end{array}$ \\
\hline & $\begin{array}{l}\text { Dropouts due to } \\
\text { AEs }\end{array}$ & $\begin{array}{l}\text { RR: } 0.08 ; \\
95 \% \mathrm{Cl} \text {; } \\
0.00 \text { to } \\
1.50 ; \\
\text { I }^{2}=\mathrm{N} / \mathrm{A}\end{array}$ & $\begin{array}{l}1 \text { RCT (215 } \\
\text { Patients) })^{7,67-72}\end{array}$ & $\begin{array}{l}\text { Severe imprecision } \\
\text { (small sample size } \\
\text { and wide } \mathrm{Cl} \text { ) }\end{array}$ & $\begin{array}{l}\text { Low } \\
\text { (no difference) }\end{array}$ \\
\hline & Any AEs & $\begin{array}{l}\text { Rate ratio: } \\
0.97 ; 95 \% \\
\text { Cl: } 0.71 \text { to } \\
1.30 ; \\
1^{2}=\mathrm{N} / \mathrm{A}\end{array}$ & $\begin{array}{l}1 \text { RCT (215 } \\
\text { Patients) })^{7,67-72}\end{array}$ & $\begin{array}{l}\text { Severe imprecision } \\
\text { (small sample size } \\
\text { and wide } \mathrm{Cl} \text { ) }\end{array}$ & $\begin{array}{l}\text { Low } \\
\text { (no difference) }\end{array}$ \\
\hline & $\begin{array}{l}\text { AEs related to } \\
\text { abdominal/GI/app } \\
\text { etite }\end{array}$ & $\begin{array}{l}\text { Rate ratio: } \\
0.84 ; 95 \% \\
\text { Cl: } 0.44 \text { to } \\
1.61 ; \\
\mathrm{I}^{2}=\mathrm{N} / \mathrm{A}\end{array}$ & $\begin{array}{l}1 \text { RCT (215 } \\
\text { Patients) })^{7,67-72}\end{array}$ & $\begin{array}{l}\text { Severe imprecision } \\
\text { (small sample size } \\
\text { and wide } \mathrm{Cl} \text { ) }\end{array}$ & $\begin{array}{l}\text { Low } \\
\text { (no difference) }\end{array}$ \\
\hline & $\begin{array}{l}\text { AEs related to } \\
\text { behavior change }\end{array}$ & $\begin{array}{l}\text { Rate ratio: } \\
0.72 ; 95 \% \\
\text { Cl: } 0.35 \text { to } \\
1.47 ; \\
1^{2}=\mathrm{N} / \mathrm{A}\end{array}$ & $\begin{array}{l}1 \text { RCT (215 } \\
\text { Patients) })^{7,67-72}\end{array}$ & $\begin{array}{l}\text { Severe imprecision } \\
\text { (small sample size } \\
\text { and wide } \mathrm{Cl} \text { ) }\end{array}$ & $\begin{array}{l}\text { Low } \\
\text { (no difference) }\end{array}$ \\
\hline & $\begin{array}{l}\text { AEs related to } \\
\text { cold/infection/alle } \\
\text { rgies }\end{array}$ & $\begin{array}{l}\text { Rate ratio: } \\
1.34 ; 95 \% \\
\text { Cl: } 0.80 \text { to } \\
2.25 ; \\
\mathrm{I}^{2}=\mathrm{N} / \mathrm{A}\end{array}$ & $\begin{array}{l}1 \text { RCT (215 } \\
\text { Patients) })^{7,67-72}\end{array}$ & $\begin{array}{l}\text { Severe imprecision } \\
\text { (small sample size } \\
\text { and wide } \mathrm{Cl} \text { ) }\end{array}$ & $\begin{array}{l}\text { Low } \\
\text { (no difference) }\end{array}$ \\
\hline & $\begin{array}{l}\text { AEs related to } \\
\text { difficulties } \\
\text { sleeping }\end{array}$ & $\begin{array}{l}\text { Rate ratio: } \\
0.44 ; 95 \% \\
\text { Cl: } 0.12 \text { to } \\
1.63 ; \\
\mathrm{I}^{2}=\mathrm{N} / \mathrm{A}\end{array}$ & $\begin{array}{l}1 \text { RCT (215 } \\
\text { Patients) })^{7,67-72}\end{array}$ & $\begin{array}{l}\text { Severe imprecision } \\
\text { (small sample size } \\
\text { and wide } \mathrm{Cl} \text { ) }\end{array}$ & $\begin{array}{l}\text { Low } \\
\text { (no difference) }\end{array}$ \\
\hline & $\begin{array}{l}\text { AEs related to } \\
\text { headache/dizzy/v } \\
\text { ision }\end{array}$ & $\begin{array}{l}\text { Rate ratio: } \\
1.09 ; 95 \% \\
\text { Cl: } 0.41 \text { to } \\
2.92 ; \\
\mathrm{I}^{2}=\mathrm{N} / \mathrm{A}\end{array}$ & $\begin{array}{l}1 \text { RCT (215 } \\
\text { Patients) })^{7,67-72}\end{array}$ & $\begin{array}{l}\text { Severe imprecision } \\
\text { (small sample size } \\
\text { and wide } \mathrm{Cl} \text { ) }\end{array}$ & $\begin{array}{l}\text { Low } \\
\text { (no difference) }\end{array}$ \\
\hline & $\begin{array}{l}\text { AEs related to } \\
\text { suicide/ideation/s } \\
\text { elf-harm }\end{array}$ & $\begin{array}{l}\text { Rate ratio: } \\
2.73 ; 95 \% \\
\text { Cl: } 0.32 \text { to } \\
23.40 ; \\
\mathrm{I}^{2}=\mathrm{N} / \mathrm{A}\end{array}$ & $\begin{array}{l}1 \text { RCT (215 } \\
\text { Patients) })^{7,67-72}\end{array}$ & $\begin{array}{l}\text { Severe imprecision } \\
\text { (small sample size } \\
\text { and wide } \mathrm{Cl} \text { ) }\end{array}$ & $\begin{array}{l}\text { Low } \\
\text { (no difference) }\end{array}$ \\
\hline & $\begin{array}{l}\text { AEs related to } \\
\text { accidental injury }\end{array}$ & $\begin{array}{l}\text { Rate ratio: } \\
2.19 ; 95 \% \\
\mathrm{Cl}: 0.24 \text { to } \\
19.57 ; \\
\mathrm{I}^{2}=\mathrm{N} / \mathrm{A}\end{array}$ & $\begin{array}{l}1 \text { RCT (215 } \\
\text { Patients) })^{7,67-72}\end{array}$ & $\begin{array}{l}\text { Severe imprecision } \\
\text { (small sample size } \\
\text { and wide } \mathrm{Cl} \text { ) }\end{array}$ & $\begin{array}{l}\text { Low } \\
\text { (no difference) }\end{array}$ \\
\hline $\begin{array}{l}\text { CBT vs. } \\
\text { Waitlisting or }\end{array}$ & Dropouts & $\begin{array}{l}\text { RR: 1.19; } \\
\text { 95\% Cl: }\end{array}$ & $\begin{array}{l}29 \text { RCTs }(1345 \\
\text { Patients) } \\
84,105-108,110,\end{array}$ & $\begin{array}{l}\text { Methodological } \\
\text { limitations, }\end{array}$ & $\begin{array}{l}\text { Low } \\
\text { (no difference) }\end{array}$ \\
\hline
\end{tabular}




\begin{tabular}{|c|c|c|c|c|c|}
\hline Comparison & Outcome & $\underset{n}{\text { Conclusio }}$ & $\begin{array}{l}\text { Study Design and } \\
\text { Sample Size }\end{array}$ & $\begin{array}{l}\text { Factors That } \\
\text { Affect the } \\
\text { Strength of } \\
\text { Evidence }^{b}\end{array}$ & $\begin{array}{c}\text { Overall } \\
\text { Evidence } \\
\text { Strength } \\
\text { (Direction of } \\
\text { Effect) }\end{array}$ \\
\hline \multirow[t]{2}{*}{ No Treatment } & & $\begin{array}{l}0.81 \text { to } \\
1.73 ; \\
\left.\right|^{2}=14.52 \%\end{array}$ & $\begin{array}{l}111,114-116,120-122,126,127 \\
129,136-138,140-144,146,149 \\
152,153\end{array}$ & $\begin{array}{l}\text { imprecision (wide } \\
\mathrm{Cl} \text { ) }\end{array}$ & \\
\hline & $\begin{array}{l}\text { Dropouts due to } \\
\text { AEs }\end{array}$ & $\begin{array}{l}\text { RR: } 0.31 ; \\
95 \% \text { Cl: } \\
0.12 \text { to } \\
0.79 ; I^{2}=N A\end{array}$ & $\begin{array}{l}1 \text { RCT (125 } \\
\text { Patients) }\end{array}$ & $\begin{array}{l}\text { Methodological } \\
\text { limitations, } \\
\text { imprecision (small } \\
\text { sample size) } \\
\end{array}$ & $\begin{array}{l}\text { Low } \\
\text { (reduced } \\
\text { dropouts) }\end{array}$ \\
\hline $\begin{array}{l}\text { CBT vs. } \\
\text { Attention } \\
\text { Control or } \\
\text { Treatment As } \\
\text { Usual }\end{array}$ & Dropouts & $\begin{array}{l}\text { RR: } 0.87 ; \\
\text { 95\% Cl: } \\
0.65 \text { to } 1.16 \\
I^{2}=0.0 \%\end{array}$ & $\begin{array}{l}16 \text { RCTs and } 1 \text { non- } \\
\text { randomized } \\
\text { comparative study } \\
(1053 \text { Patients) } \\
80,82-84,86,88,90,92,94-97 \\
100,102\end{array}$ & $\begin{array}{l}\text { Methodological } \\
\text { limitations, } \\
\text { imprecision (wide } \\
\mathrm{Cl} \text { ) }\end{array}$ & $\begin{array}{l}\text { Low } \\
\text { (no difference) }\end{array}$ \\
\hline \multirow[t]{9}{*}{$\begin{array}{l}\text { CBT+ } \\
\text { Sertraline } \\
\text { (class: SSRI) } \\
\text { vs. CBT }\end{array}$} & Dropouts & $\begin{array}{l}\text { RR: } 1.99 ; \\
95 \% \mathrm{Cl} \text {; } \\
0.77 \text { to } \\
5.14 ; \\
1^{2}=\mathrm{N} / \mathrm{A}\end{array}$ & $\begin{array}{l}1 \mathrm{RCT} \text { and } 1 \text { non- } \\
\text { randomized } \\
\text { comparative study } \\
(327 \text { patients), 67-72, } \\
163\end{array}$ & $\begin{array}{l}\text { Severe imprecision } \\
\text { (small sample size } \\
\text { and wide Cls) }\end{array}$ & $\begin{array}{l}\text { Low } \\
\text { (no difference) }\end{array}$ \\
\hline & $\begin{array}{l}\text { Dropouts due to } \\
\text { AEs }\end{array}$ & $\begin{array}{l}\text { RR: } 2.98 ; \\
95 \% \text { Cl: } \\
0.12 \text { to } \\
72.50 ; \\
I^{2}=\mathrm{N} / \mathrm{A}\end{array}$ & $\begin{array}{l}1 \text { RCT }(279 \\
\text { patients) }\end{array}$ & $\begin{array}{l}\text { Severe imprecision } \\
\text { (small sample size } \\
\text { and wide Cls) }\end{array}$ & $\begin{array}{l}\text { Low } \\
\text { (no difference) }\end{array}$ \\
\hline & Any AEs & $\begin{array}{l}\text { Rate } \\
\text { ratio:1.67; } \\
95 \% \text { Cl: } \\
1.32 \text { to } 2.07 \\
I^{2}=\text { N/A }\end{array}$ & $\begin{array}{l}\text { 1 RCT }(279 \\
\text { Patients) }\end{array}$ & $\begin{array}{l}\text { Severe imprecision } \\
\text { (small sample size } \\
\text { and wide Cls) }\end{array}$ & $\begin{array}{l}\text { Low } \\
\text { (increased AEs) }\end{array}$ \\
\hline & $\begin{array}{l}\text { AEs related to } \\
\text { abdominal/GI/app } \\
\text { etite }\end{array}$ & $\begin{array}{l}\text { Rate ratio: } \\
1.42 ; 95 \% \\
\mathrm{Cl}: 0.84 \text { to } \\
2.42 ; \\
\mathrm{I}^{2}=\mathrm{N} / \mathrm{A}\end{array}$ & $\begin{array}{l}\text { 1 RCT }(279 \\
\text { Patients) }\end{array}$ & $\begin{array}{l}\text { Severe imprecision } \\
\text { (small sample size } \\
\text { and wide Cls) }\end{array}$ & $\begin{array}{l}\text { Low } \\
\text { (no difference) }\end{array}$ \\
\hline & $\begin{array}{l}\text { AEs related to } \\
\text { behavior change }\end{array}$ & $\begin{array}{l}\text { Rate ratio: } \\
3.80 ; 95 \% \\
\text { Cl: } 2.23 \text { to } \\
6.48 ; \\
\mathrm{I}^{2}=\mathrm{N} / \mathrm{A}\end{array}$ & $\begin{array}{l}1 \text { RCT (279 } \\
\text { Patients) })^{7,67-72}\end{array}$ & $\begin{array}{l}\text { Imprecision (small } \\
\text { sample size) }\end{array}$ & $\begin{array}{l}\text { Moderate } \\
\text { (increased AEs) }\end{array}$ \\
\hline & $\begin{array}{l}\text { AEs related to } \\
\text { cold/infection/alle } \\
\text { rgies }\end{array}$ & $\begin{array}{l}\text { Rate ratio: } \\
0.95 ; 95 \% \\
\text { Cl: } 0.64 \text { to } \\
1.42 ; \\
\mathrm{I}^{2}=\mathrm{N} / \mathrm{A}\end{array}$ & $\begin{array}{l}1 \text { RCT (279 } \\
\text { Patients) })^{7,67-72}\end{array}$ & $\begin{array}{l}\text { Severe imprecision } \\
\text { (small sample size } \\
\text { and wide Cls) }\end{array}$ & $\begin{array}{l}\text { Low } \\
\text { (no difference) }\end{array}$ \\
\hline & $\begin{array}{l}\text { AEs related to } \\
\text { difficulties } \\
\text { sleeping }\end{array}$ & $\begin{array}{l}\text { Rate ratio: } \\
3.23 ; 95 \% \\
\text { Cl: } 1.05 \text { to } \\
9.90 ; \\
1^{2}=\mathrm{N} / \mathrm{A}\end{array}$ & $\begin{array}{l}1 \text { RCT }(279 \\
\text { Patients) }\end{array}$ & $\begin{array}{l}\text { Severe imprecision } \\
\text { (small sample size } \\
\text { and wide Cls) }\end{array}$ & $\begin{array}{l}\text { Low } \\
\text { (increased AEs) }\end{array}$ \\
\hline & $\begin{array}{l}\text { AEs related to } \\
\text { headache/dizzy/v } \\
\text { ision }\end{array}$ & $\begin{array}{l}\text { Rate ratio: } \\
1.49 ; 95 \% \\
\text { Cl: } 0.72 \text { to } \\
3.09 ; \\
1^{2}=\mathrm{N} / \mathrm{A}\end{array}$ & $\begin{array}{l}1 \text { RCT (279 } \\
\text { Patients) }\end{array}$ & $\begin{array}{l}\text { Severe imprecision } \\
\text { (small sample size } \\
\text { and wide Cls) }\end{array}$ & $\begin{array}{l}\text { Low } \\
\text { (no difference) }\end{array}$ \\
\hline & $\begin{array}{l}\text { AEs related to } \\
\text { suicide/ideation/s }\end{array}$ & $\begin{array}{l}\text { Rate ratio: } \\
0.99 ; 95 \%\end{array}$ & $\begin{array}{l}1 \text { RCT (279 } \\
\text { Patients) })^{7,67-72}\end{array}$ & $\begin{array}{l}\text { Severe imprecision } \\
\text { (small sample size }\end{array}$ & $\begin{array}{l}\text { Low } \\
\text { (no difference) }\end{array}$ \\
\hline
\end{tabular}




\begin{tabular}{|c|c|c|c|c|c|}
\hline Comparison & Outcome & $\begin{array}{c}\text { Conclusio } \\
\mathbf{n}\end{array}$ & $\begin{array}{l}\text { Study Design and } \\
\text { Sample Size }{ }^{a}\end{array}$ & $\begin{array}{l}\text { Factors That } \\
\text { Affect the } \\
\text { Strength of } \\
\text { Evidence }^{b}\end{array}$ & $\begin{array}{c}\text { Overall } \\
\text { Evidence } \\
\text { Strength } \\
\text { (Direction of } \\
\text { Effect) }\end{array}$ \\
\hline & elf-harm & $\begin{array}{l}\mathrm{Cl}: 0.29 \text { to } \\
3.43 ; \\
\mathrm{I}^{2}=\mathrm{N} / \mathrm{A}\end{array}$ & & and wide Cls) & \\
\hline & $\begin{array}{l}\text { AEs related to } \\
\text { accidental injury }\end{array}$ & $\begin{array}{l}\text { Rate ratio: } \\
1.00 ; \\
95 \% \mathrm{Cl} \text { : } \\
0.25 \text { to } \\
3.80 ; \\
\mathrm{I}^{2}=\mathrm{N} / \mathrm{A}\end{array}$ & $\begin{array}{l}\text { 1 RCT (279 } \\
\text { Patients) }\end{array}$ & $\begin{array}{l}\text { Severe imprecision } \\
\text { (small sample size } \\
\text { and wide Cls) }\end{array}$ & $\begin{array}{l}\text { Low } \\
\text { (no difference) }\end{array}$ \\
\hline \multirow[t]{10}{*}{$\begin{array}{l}\text { CBT+ } \\
\text { Sertraline } \\
\text { (class: SSRI) } \\
\text { vs. Sertraline } \\
\text { (class: SSRI) }\end{array}$} & Dropouts & $\begin{array}{l}\text { RR: } 0.71 ; \\
95 \% \mathrm{Cl} \text { : } \\
0.35 \text { to } \\
1.45 ; \\
\text { I }^{2}=\mathrm{N} / \mathrm{A}\end{array}$ & $\begin{array}{l}1 \text { RCT }(273 \\
\text { Patients) }\end{array}$ & $\begin{array}{l}\text { Severe imprecision } \\
\text { (small sample size } \\
\text { and wide Cls) }\end{array}$ & $\begin{array}{l}\text { Low } \\
\text { (no difference) }\end{array}$ \\
\hline & $\begin{array}{l}\text { Dropouts due to } \\
\text { AEs }\end{array}$ & $\begin{array}{l}\text { RR: } 0.14 ; \\
95 \% \mathrm{Cl} \text {; } \\
0.02 \text { to } \\
1.09 ; \\
\text { I }^{2}=\mathrm{N} / \mathrm{A}\end{array}$ & $\begin{array}{l}1 \text { RCT (273 } \\
\text { Patients), } 67-72\end{array}$ & $\begin{array}{l}\text { Severe imprecision } \\
\text { (small sample size } \\
\text { and wide Cls) }\end{array}$ & $\begin{array}{l}\text { Low } \\
\text { (no difference) }\end{array}$ \\
\hline & Any AEs & $\begin{array}{l}\text { Rate ratio: } \\
1.2 ; 95 \% \\
\mathrm{Cl}: 0.97 \text { to } \\
1.45 ; \\
\mathrm{I}^{2}=\mathrm{N} / \mathrm{A}\end{array}$ & $\begin{array}{l}1 \mathrm{RCT}(273 \\
\text { Patients) }\end{array}$ & $\begin{array}{l}\text { Severe imprecision } \\
\text { (small sample size } \\
\text { and wide Cls) }\end{array}$ & $\begin{array}{l}\text { Low } \\
\text { (no difference) }\end{array}$ \\
\hline & $\begin{array}{l}\text { AEs related to } \\
\text { abdominal/GI/app } \\
\text { etite }\end{array}$ & $\begin{array}{l}\text { Rate ratio: } \\
1.01 ; 95 \% \\
\mathrm{Cl}: 0.62 \text { to } \\
1.65 ; \\
\mathrm{I}^{2}=\mathrm{N} / \mathrm{A}\end{array}$ & $\begin{array}{l}1 \mathrm{RCT}(273 \\
\text { Patients) }\end{array}$ & $\begin{array}{l}\text { Severe imprecision } \\
\text { (small sample size } \\
\text { and wide Cls) }\end{array}$ & $\begin{array}{l}\text { Low } \\
\text { (no difference) }\end{array}$ \\
\hline & $\begin{array}{l}\text { AEs related to } \\
\text { behavior change }\end{array}$ & $\begin{array}{l}\text { Rate ratio: } \\
1.82 ; 95 \% \\
\mathrm{Cl}: 1.20 \text { to } \\
2.75 ; \\
\mathrm{I}^{2}=\mathrm{N} / \mathrm{A}\end{array}$ & $\begin{array}{l}1 \mathrm{RCT}(273 \\
\text { Patients) }\end{array}$ & $\begin{array}{l}\text { Imprecision (small } \\
\text { sample size) }\end{array}$ & $\begin{array}{l}\text { Moderate } \\
\text { (increased AEs) }\end{array}$ \\
\hline & $\begin{array}{l}\text { AEs related to } \\
\text { cold/infection/alle } \\
\text { rgies }\end{array}$ & $\begin{array}{l}\text { Rate ratio: } \\
1.49 ; 95 \% \\
\text { Cl: } 0.94 \text { to } \\
2.35 ; \\
\mathrm{I}^{2}=\mathrm{N} / \mathrm{A}\end{array}$ & $\begin{array}{l}1 \text { RCT }(273 \\
\text { Patients) }\end{array}$ & $\begin{array}{l}\text { Severe imprecision } \\
\text { (small sample size } \\
\text { and wide Cls) }\end{array}$ & $\begin{array}{l}\text { Low } \\
\text { (no difference) }\end{array}$ \\
\hline & $\begin{array}{l}\text { AEs related to } \\
\text { difficulties } \\
\text { Sleeping }\end{array}$ & $\begin{array}{l}\text { Rate ratio: } \\
0.73 ; 95 \% \\
\mathrm{Cl}: 0.35 \text { to } \\
1.50 ; \\
\mathrm{I}^{2}=\mathrm{N} / \mathrm{A}\end{array}$ & $\begin{array}{l}1 \text { RCT }(273 \\
\text { Patients) }\end{array}$ & $\begin{array}{l}\text { Severe imprecision } \\
\text { (small sample size } \\
\text { and wide Cls) }\end{array}$ & $\begin{array}{l}\text { Low } \\
\text { (no difference) }\end{array}$ \\
\hline & $\begin{array}{l}\text { AEs related to } \\
\text { fatigue/somnolen } \\
\text { ce }\end{array}$ & $\begin{array}{l}\text { Rate ratio: } \\
0.20 ; 95 \% \\
\mathrm{Cl}: 0.06 \text { to } \\
0.71 ; \\
\mathrm{I}^{2}=\mathrm{N} / \mathrm{A}\end{array}$ & $\begin{array}{l}1 \text { RCT }(273 \\
\text { Patients) }\end{array}$ & $\begin{array}{l}\text { Imprecision (small } \\
\text { sample size) }\end{array}$ & $\begin{array}{l}\text { Moderate } \\
\text { (reduced AEs) }\end{array}$ \\
\hline & $\begin{array}{l}\text { AEs related to } \\
\text { headache/dizzy/v } \\
\text { ision }\end{array}$ & $\begin{array}{l}\text { Rate ratio: } \\
0.81 ; 95 \% \\
\mathrm{Cl}: 0.43 \text { to } \\
1.53 ; \\
\mathrm{I}^{2}=\mathrm{N} / \mathrm{A}\end{array}$ & $\begin{array}{l}1 \text { RCT }(273 \\
\text { Patients) }\end{array}$ & $\begin{array}{l}\text { Severe imprecision } \\
\text { (small sample size } \\
\text { and wide } \mathrm{Cl} \text { ) }\end{array}$ & $\begin{array}{l}\text { Low(no } \\
\text { difference) }\end{array}$ \\
\hline & $\begin{array}{l}\text { AEs related to } \\
\text { suicide/ideation/s }\end{array}$ & $\begin{array}{l}0 \text { case in } \\
\text { each group }\end{array}$ & $\begin{array}{l}1 \text { RCT }(273 \\
\text { Patients) }\end{array}$ & No data & Insufficient \\
\hline
\end{tabular}




\begin{tabular}{|c|c|c|c|c|c|}
\hline Comparison & Outcome & $\begin{array}{c}\text { Conclusio } \\
n\end{array}$ & $\begin{array}{l}\text { Study Design and } \\
\text { Sample Size }\end{array}$ & $\begin{array}{l}\text { Factors That } \\
\text { Affect the } \\
\text { Strength of } \\
\text { Evidence }^{b}\end{array}$ & $\begin{array}{c}\text { Overall } \\
\text { Evidence } \\
\text { Strength } \\
\text { (Direction of } \\
\text { Effect) }\end{array}$ \\
\hline & elf-harm & & & & \\
\hline & $\begin{array}{l}\text { AEs related to } \\
\text { accidental injury }\end{array}$ & $\begin{array}{l}\text { Rate ratio: } \\
0.95 ; 95 \% \\
\mathrm{Cl}: 0.24 \text { to } \\
3.80 ; \\
1^{2}=\mathrm{N} / \mathrm{A}\end{array}$ & $\begin{array}{l}1 \mathrm{RCT}(273 \\
\text { Patients) })^{7,67-72}\end{array}$ & $\begin{array}{l}\text { Severe imprecision } \\
\text { (small sample size } \\
\text { and wide } \mathrm{Cl} \text { ) }\end{array}$ & $\begin{array}{l}\text { Low } \\
\text { (no difference) }\end{array}$ \\
\hline $\begin{array}{l}\text { CBT+ } \\
\text { Imipramine } \\
\text { (class: TCA) } \\
\text { vs. CBT }\end{array}$ & Dropouts & $\begin{array}{l}\text { RR: 0.80; } \\
95 \% \mathrm{Cl} \text { : } \\
0.34 \text { to } \\
1.89 ; \\
\text { I }^{2}=\mathrm{N} / \mathrm{A}\end{array}$ & $\begin{array}{l}1 \text { RCT (63 } \\
\text { Patients) }\end{array}$ & $\begin{array}{l}\text { Severe imprecision } \\
\text { (small sample size } \\
\text { and wide } \mathrm{Cl} \text { ) }\end{array}$ & $\begin{array}{l}\text { Low } \\
\text { (no difference) }\end{array}$ \\
\hline $\begin{array}{l}\text { CBT+ } \\
\text { Fluoxetine } \\
\text { (class: SSRI) } \\
\text { vs. CBT }\end{array}$ & Dropouts & $\begin{array}{l}\text { RR: } 1.54 ; \\
95 \% \mathrm{Cl} \text {; } \\
0.60 \text { to } \\
3.88 ; \\
\mathrm{I}^{2}=\mathrm{N} / \mathrm{A}\end{array}$ & $\begin{array}{l}1 \text { RCT(41 } \\
\text { Patients) }\end{array}$ & $\begin{array}{l}\text { Severe imprecision } \\
\text { (small sample size } \\
\text { and wide } \mathrm{Cl} \text { ) }\end{array}$ & $\begin{array}{l}\text { Low } \\
\text { (no difference) }\end{array}$ \\
\hline
\end{tabular}

AE: adverse event, CBT: cognitive behavioral therapy, CI: confidence interval, GI: Gastrointestinal, N/A: not applicable, RCT: randomized controlled trial, RR: relative risk, SNRI: serotonin-norepinephrine reuptake inhibitor, SMD: standardized mean difference, SSRI: selective serotonin reuptake inhibitor, TCA: tricyclic antidepressants

${ }^{\text {a }}$ The sample size includes the number of patients from each comparison.

${ }^{\mathrm{b}}$ Only SOE domains that led to rating down SOE are reported in this column. Domains that are not reported were satisfactory. 


\section{Discussion}

We conducted a systematic review and meta-analysis to examine the effectiveness and safety of treatments for anxiety disorders (i.e., separation anxiety disorder, generalized anxiety disorder, social anxiety disorder, panic disorder, and specific phobia) in children (i.e. ages 3 to 18). The systematic review examined medications (primarily selective serotonin reuptake inhibitors and selective norepinephrine reuptake inhibitors, tricyclic antidepressant, and anxiolytics) as well as psychotherapies (primarily cognitive behavioral therapy). This review constitutes the largest and most comprehensive review of the treatment literature for child anxiety disorders. In total, we examined 206 studies including 19 studies comparing medication to placebo with 2,498 patients and 88 studies comparing cognitive behavioral therapy (CBT) to a control group with 6,978 patients. To our knowledge, there has not been a systematic review of pharmacotherapy for childhood anxiety disorders since 2010. In the current review, by far, CBT was the most extensively examined intervention with over 40 studies providing outcome data for comparisons against waitlisting or no treatment.

No individual medication had evidence for significant reduction in anxiety symptoms across all three reporters (child, parent, and clinician). The finding regarding inconsistent effectiveness across reporters in trials of medications might be related to artifacts of study design including issues with blinding or may reflect that medication treatment of child anxiety is not as robust as $\mathrm{CBT}^{164}$. Compared to pill placebo, selective serotonin reuptake inhibitor (SSRIs) and serotoninnorepinephrine reuptake inhibitors (SNRIs) improved anxiety symptoms (evidence was available for paroxetine, fluoxetine, sertraline, fluvoxamine, duloxetine, atomoxetine, and venlafaxine). The effect of benzodiazepines and TCAs on anxiety symptoms, function and remission was only supported by insufficient or low strength of evidence. Data on head-to-head comparisons across drugs were sparse. Compared to waitlisting or no treatment, CBT significantly reduced primary anxiety symptoms based on child, parent, and clinician reports, improved function, and improved remission and clinical response. The combination of SSRIs and CBT reduced primary anxiety symptoms and improved clinical response, compared to either approach alone. Short-term AEs (mostly not serious) were common with medications but not psychotherapy. Studies were generally too small or too short to assess suicidality with SSRI or SNRIs, with the exception of venlafaxine. Exploratory subgroup analyses showed that 1) post intervention effective sizes were larger than those reported in followup, 2) individual-based CBT had statistically significantly more improvement in function than group-based CBT, 3) relaxation and cognitive strategies in CBT were not associated with improvements; while exposure statistically significantly reduced primary anxiety symptoms, and 4) CBT was found to have more improvement on functioning in age group 13-18 than age group 7-12. However, such results from subgroup analyses should be considered hypothesis generating.

\section{Findings in Relation to What Is Known}

In regards to the CBT, the current analysis is consistent with previous ones, such as a Cochrane systematic review, concluding that CBT is an effective treatment for childhood and adolescent anxiety disorders. However, the current review extends the empirical support for CBT, by finding moderate support for the superiority of CBT over treatment as usual or attention control. The current analyses also contribute additional information to the understanding of the necessary and sufficient components of CBT. Specifically, the data suggest that relaxation and cognitive-restructuring do not increase effectiveness above exposure. In fact the presence of 
cognitive-restructuring was associated with worse outcomes in terms of functioning. Moreover, the current analyses found no differences or fewer dropout rates between CBT and pill placebo, waitlisting, or active control therapies. This finding refutes the belief that patients find CBT (particularly exposure) aversive and unacceptable. Finally, the current report highlights factors that may reduce the effectiveness of CBT including younger age. As such, the current review bolsters the empirical support for CBT by supporting its incremental effectiveness over common therapeutic factors, elucidating some of its active ingredients, and demonstrating its acceptability.

In regards to medication, the current analyses are consistent with previous systematic reviews of psychopharmacologic interventions suggesting that SSRIs and SNRIs have demonstrated effectiveness in the reduction of anxiety symptoms. However, the evidence support for SSRIs is somewhat lessened by the fact that superiority over pill placebo was not found with child report. This issue of inconsistent report is more concerning for SNRIs where support for effectiveness was only found through clinician report, and not through parent or child report of symptoms, or on measures of functioning. In terms of adverse events (AEs), the current review provides the most comprehensive evaluation to date and suggests that short-term AEs tended to be not serious and generally did not lead to discontinuation. Studies were generally of small sizes and short duration and did not report the incidence of serious AEs. There was no evidence of suicidal behavior or ideation associated with the use of SSRIs in children with anxiety, although one trial showed a nonsignificant increase in suicidal ideation with venlafaxine. This contrasted with the well reported two fold increase in suicidal behavior and/or suicidal thoughts associated with SSRIs used for the treatment of depression in children and adolescents, a finding which led to the black box warning. Besides the small sample sizes and short duration, this discrepancy could also be due to the lack of a standardized mechanism for coding and assessing akathisia, aggression, hostility, and suicidal events in pediatric trials and the resulting underreporting of harm events ${ }^{165}$. Evidence on the effectiveness of benzodiazepines and tricyclic antidepressants remains minimal and insufficient to recommend their routine use. ${ }^{15,166}$

The current analysis also contributes to the understanding of effectiveness in terms of patient centered outcomes. Whereas previous analyses typically focused exclusively on reduction of anxiety symptoms, the current analyses also examined effects on functioning, anxiety related constructs (such as coping skills), social functioning, and AEs. The results suggested that both CBT and SSRIs improve functioning. The current analyses are also the first to our knowledge to examine the symptom improvement from the perspectives of each stakeholder. Specifically, rather than selecting a single outcome measure from each study, we examined the parent, child, and clinician/evaluator reported outcomes.

Overall, our findings are consistent with existing evidence synthesis reports in terms of demonstrating effectiveness of CBT, SSRIs and SNRIs and pointing out to the need for comparative effectiveness evidence and concerns about long term safety of medications. In terms of existing guidelines, the World Health Organization (WHO), National Institute for Health and Care Excellence (NICE), and British Columbia Medical Services Commission ${ }^{10-12}$ are congruent with the current findings in that they recommend CBT as the first-line treatment with medication treatment as a reasonable alternative if preferred by the patient or if CBT was unavailable. In contrast, the American Academy of Child and Adolescent Psychiatry (AACAP) guideline recommends that treatment be multimodal (including a variety of education, psychotherapy interventions, and medications) and informed by the severity of the symptoms and level of impairment. ${ }^{19}$ The current findings provide some data to address the need acknowledged in the 
AACAP guidelines for comparative effectiveness by supporting the superiority of CBT over treatment as usual.

\section{Limitations}

Despite anxiety being a common disorder in children, the body of evidence was relatively small and had short followup. A large number of scales were used across studies in overlapping domains, which created a challenge for evidence synthesis, interpretation and translation. Components of interventions and description of participants comorbidities, demographics and social support was either lacking or was provided without stratification per intervention. This rendered numerous subgroup analyses unfeasible. Results of such subgroup analyses would have been most helpful to guideline developers, practitioners and patients because it could have led to nuanced and personalized recommendations. We found indications of potential publication bias when CBT was compared to waitlisting on primary anxiety symptoms. We were unable to statistically evaluate publication bias for most of the comparisons due to small numbers of studies $(n<20)$. The synthesis of data on AEs in particular is limited by the fact that the vast majority of CBT studies do not evaluate AEs and by the lack of a structured consistent approach to measurement in medication studies.

\section{Applicability}

The results of this review are likely widely applicable to a heterogeneous population of children with separation anxiety disorder, generalized anxiety disorder, social anxiety disorder, panic disorder, and specific phobia; with minimal psychiatric comorbidities, who are on average 8-18 years old and have ready access to mental health professionals who can provide CBT or have access to psychiatrists or pediatricians who are willing to prescribe SSRIs and SNRIs. Studies published in foreign languages (Spanish and German) demonstrated similar or larger effect size (the effect was in the same direction), compared to studies published in English.

Children of younger ages (3-6) were less presented in the current literature. The majority of the studies were conducted with populations that were predominately Caucasian with limited comorbidity. As such, it is unclear how the results would apply to more diverse populations, patients with comorbidity (especially disruptive behavior), or families with significant additional psychosocial stressors. Most studies also studied treatment naïve children. Thus it is unclear how the results apply to practitioners working with children that have received previous ineffective treatments.

\section{A Guide To Aid in Applicability}

To facilitate analysis, data had to be standardized (i.e., expressed in multiples of standard deviations and presented as a standardized mean difference called SMD) or combined using a relative association measure (e.g., relative risk). Such measures may be challenging to interpret by guideline developers or practicing clinicians and can be translated to become more clinically meaningful. ${ }^{167}$

One way to make SMD more clinically relevant is to translate it back to scales with which clinicians have familiarity. In Table 13, we provide the average standard deviations for commonly used scales that can be multiplied by SMD for conversion. 
Table 13. Average standard deviations for commonly used scales that can be multiplied by SMD for conversion

\begin{tabular}{|l|l|l|}
\hline \multicolumn{1}{|c|}{ Domain } & \multicolumn{1}{|c|}{$\begin{array}{c}\text { Commonly Used } \\
\text { Scales }\end{array}$} & \multicolumn{1}{c|}{$\begin{array}{c}\text { Average Standard } \\
\text { Deviation }^{\mathbf{a}}\end{array}$} \\
\hline \multirow{2}{*}{$\begin{array}{l}\text { Primary Anxiety Symptoms } \\
\text { (Clinician report) }\end{array}$} & ADIS & 1.73 \\
\cline { 2 - 3 } & CGI-Severity & 1.16 \\
\cline { 2 - 3 } $\begin{array}{l}\text { Primary Anxiety Symptoms } \\
\text { (Child report) }\end{array}$ & SARS & 5.53 \\
\cline { 2 - 3 } & SPAI & 16.54 \\
\cline { 2 - 3 } $\begin{array}{l}\text { Primary Anxiety Symptoms } \\
\text { (Parent report) }\end{array}$ & SSSCR & 14.37 \\
\cline { 2 - 3 } & SCAS & 18.61 \\
\cline { 2 - 3 } & SCARED & 12.88 \\
\cline { 2 - 3 } & STAI & 10.43 \\
\hline
\end{tabular}

ADIS: anxiety disorder interview schedule, CGI-Severity: clinical global impressions- severity, FSSCR: fear survey schedule for children - revised, PARS: pediatric anxiety rating scale, SCARED: screen for child anxiety related emotional disorders, SCAS: Spence children's anxiety scale, SPAI: social phobia and anxiety inventory, STAI: state-trait anxiety inventory.

a The standard deviation of other scales can be obtained from studies that used such scales and can be used for conversion of SMD to any scale following the same approach.

As an example of this conversion; compared with pill placebo, fluoxetine reduced primary anxiety symptoms by SMD=-0.40. Multiplying this SMD by the average standard deviation of ADIS scale (1.73) results in -0.69 (which is the expected improvement in anxiety symptoms using ADIS scale). Another approach to aid in the interpretation of the SMD is to consider the magnitude of the effect. SMD cutoffs of $0.20,0.50$, and 0.80 are considered to represent small, moderate, and large effect, respectively.

For binary outcomes presented using a relative effect measure, the effect can be multiplied by the baseline risk to produce an absolute effect and number needed to treat. Using the same example, fluoxetine improved remission by $\mathrm{RR}=1.75$. Using the average risk in the placebo arms of the included studies (36\%), we obtain the absolute effect of 270 patients per 1000 achieving remission (number needed to treat $=4$ ). Such conversion can be done in each local setting differently (using a baseline risk appropriate for the setting of the stakeholder) and facilitates the applicability of the findings of this review.

\section{Future Research Needs}

Interventions for anxiety in children are complex interventions with multiple components and effect modifiers. However, few studies provided sufficient information to determine the relative effectiveness of such components (e.g. relaxation, exposure, and cognitive-restructuring) or to explore contextual factors that can modify the effectiveness of these complex interventions. Research needs to move away from the simple question of 'does this work?" to "under what circumstances do medications and psychotherapy work best for children with anxiety?” Therefore, studies need to explore the most beneficial components of CBT and the impact of comorbidities, family demographics and stressors as effect modifiers that can change the effectiveness of treatment. Knowing these effect modifiers would help in providing more individualized treatment. Further research is also needed on long term safety of drugs, treatment of refractory anxiety symptoms, and needs to be more inclusive of underserved populations and minorities. Since anxiety outcomes are measured using a variety of scales without established minimally clinically important differences, studies that establish such differences are needed to better enable clinicians and patients gauge the effectiveness of interventions and balance benefits and harms during a shared decision making process. A large number of analyses, when stratified by an individual intervention, had a small number of included patients leading to imprecise 
estimates. Considering that anxiety in children is a fairly common condition, larger trials ( $>400$ participants) with follow up that exceeds 2-3 years are likely feasible and are needed to advance patient care.

\section{Conclusion}

CBT is effective in reducing anxiety symptoms and improving function. Medications, primarily those targeting serotonin, are also effective but were associated with various short-term AEs, which were mostly not serious, but studies were too small or too short to assess suicidality with SSRI or SNRI. One trial showed a statistically nonsignificant increase in suicidal ideation with venlafaxine. The combination of medications and CBT is likely more effective than either treatment alone. Comparative effectiveness evidence between various medications and comparing CBT versus medications, or the combination, is limited and represents a need for research in this field. Future research is needed to evaluate components of CBT, effect modifiers of treatment, and long-term safety of drugs, and needs to be more inclusive of underserved populations and minorities. 


\section{References}

1. Anxiety and Depression Association of America. Facts \& Statistics. 2014. http://www.adaa.org/about-adaa/pressroom/facts-statistics.

2. National Institute of Mental Health. Any Anxiety Disorder Among Children. 2016. http://www.nimh.nih.gov/health/statistics/pr evalence/any-anxiety-disorder-amongchildren.shtml.

3. Bittner A, Egger HL, Erkanli A, et al. What do childhood anxiety disorders predict? J Child Psychol Psychiatry. 2007 Dec;48(12):1174-83. doi: 10.1111/j.14697610.2007.01812.x. PMID: 18093022.

4. Ezpeleta L, Keeler G, Erkanli A, et al. Epidemiology of psychiatric disability in childhood and adolescence. J Child Psychol Psychiatry. 2001 Oct;42(7):901-14. doi: 10.1017/S0021963001007740. PMID: 11693585.

5. Chorpita BF, Daleiden EL, Ebesutani C, et al. Evidence-Based Treatments for Children and Adolescents: An Updated Review of Indicators of Efficacy and Effectiveness. Clinical Psychology Science and Practice. 2011;18:154-72. doi: 10.1111/j.14682850.2011.01247.x.

6. James A, Soler A, Weatherall R. Cognitive behavioural therapy for anxiety disorders in children and adolescents. Cochrane Database of Systematic Reviews. 2009; Issue 4. Art. No.: CD004690. DOI: 10.1002/14651858.CD004690.pub2.doi: 10.1002/14651858.CD004690.pub3.

7. Walkup JT, Albano AM, Piacentini J, et al. Cognitive behavioral therapy, sertraline, or a combination in childhood anxiety. N Engl J Med. 2008 Dec 25;359(26):2753-66. doi: 10.1056/NEJMoa0804633. PMID: 18974308.

8. Chambless DL, Ollendick TH. Empirically supported psychological interventions: controversies and evidence. Annu Rev Psychol. 2001;52:685-716. doi: 10.1146/annurev.psych.52.1.685. PMID: 11148322.

9. Manassis K, Russell K, Newton AS. The Cochrane Library and the treatment of childhood and adolescent anxiety disorders: and overview of reviews. Evidence-Base Child Health: A Cochrane Review Journal. 2010;5:541-54. doi: 10.1002/ebch.508.

10. Medical Services Commission. Anxiety and depression in children and youth -- diagnosis and treatment. Victoria (BC): British Columbia Medical Services Commission; 2010 Jan 1.

11. National Institute for Health and Clinical Excellence (NICE), ed Social anxiety disorder: Recognition, assessment and treatment. ; 2013.

12. Tol WA, Barbui C, van Ommeren M. Management of acute stress, PTSD, and bereavement: WHO recommendations. JAMA. 2013 Aug 07;310(5):477-8. doi: 10.1001/jama.2013.166723. PMID: 23925613.

13. Whiteside SP, Deacon BJ, Benito K, et al. Factors associated with practitioners' use of exposure therapy for childhood anxiety disorders. J Anxiety Disord. 2016 May;40:29-36. doi: 10.1016/j.janxdis.2016.04.001. PMID: 27085463.

14. Ale CM, McCarthy DM, Rothschild LM, et al. Components of Cognitive Behavioral Therapy Related to Outcome in Childhood Anxiety Disorders. Clin Child Fam Psychol Rev. 2015 Sep;18(3):240-51. doi: 10.1007/s10567-015-0184-8. PMID: 26001645.

15. Ipser JC, Stein DJ, Hawkridge S, et al. Pharmacotherapy for anxiety disorders in children and adolescents. Cochrane Database Syst Rev. 2009 Jul 08(3):CD005170. doi: 10.1002/14651858.CD005170.pub2. PMID: 19588367. 
16. Bridge JA, Iyengar S, Salary CB, et al. Clinical response and risk for reported suicidal ideation and suicide attempts in pediatric antidepressant treatment: a metaanalysis of randomized controlled trials. JAMA. 2007 Apr 18;297(15):1683-96. doi: 10.1001/jama.297.15.1683. PMID: 17440145 .

17. Birmaher B, Yelovich AK, Renaud J. Pharmacologic treatment for children and adolescents with anxiety disorders. Pediatr Clin North Am. 1998 Oct;45(5):1187-204. doi: 10.1016/S0031-3955(05)70069-9. PMID: 9884682.

18. Blanco C, Antia SX, Liebowitz MR. Pharmacotherapy of social anxiety disorder. Biol Psychiatry. 2002 Jan 01;51(1):109-20. doi: 10.1016/S0006-3223(01)01294-X. PMID: 11801236.

19. Connolly SD, Bernstein GA, Work Group on Quality I. Practice parameter for the assessment and treatment of children and adolescents with anxiety disorders. J Am Acad Child Adolesc Psychiatry. 2007 Feb;46(2):267-83. doi: 10.1097/01.chi.0000246070.23695.06. PMID: 17242630.

20. Barterian JA, Rappuhn E, Seif EL, et al. Current state of evidence for medication treatment of preschool internalizing disorders. ScientificWorldJournal. 2014;2014:286085. doi: 10.1155/2014/286085. PMID: 24600324.

21. Ivarsson T, Skarphedinsson G, Kornor H, et al. The place of and evidence for serotonin reuptake inhibitors (SRIs) for obsessive compulsive disorder (OCD) in children and adolescents: Views based on a systematic review and meta-analysis. Psychiatry Res. 2015 May 30;227(1):93-103. doi: 10.1016/j.psychres.2015.01.015. PMID: 25769521.

22. Pine, D S, Walkup, et al. Fluvoxamine for the treatment of anxiety disorders in children and adolescents. New England Journal of Medicine. 200126 Apr;344(17):1279-85. doi: 10.1056/NEJM200104263441703.

PMID: 2001155341.

23. Kendall PC, Peterman JS. CBT for Adolescents With Anxiety: Mature Yet Still Developing. Am J Psychiatry. 2015 Jun;172(6):519-30. doi: 10.1176/appi.ajp.2015.14081061. PMID: 26029805.

24. Merikangas KR, He JP, Burstein M, et al. Service utilization for lifetime mental disorders in U.S. adolescents: results of the National Comorbidity Survey-Adolescent Supplement (NCS-A). J Am Acad Child Adolesc Psychiatry. 2011 Jan;50(1):32-45. doi: 10.1016/j.jaac.2010.10.006. PMID: 21156268.

25. Methods Guide for Effectiveness and Comparative Effectiveness Reviews. AHRQ Publication No. 10(14)-EHC063-EF. Rockville, MD: Agency for Healthcare Research and Quality; January 2014. Chapters available at: www.effectivehealthcare.ahrq.gov.

26. Moher D, Liberati A, Tetzlaff J, et al. Preferred reporting items for systematic reviews and meta-analyses: the PRISMA statement. BMJ. 2009 Jul 21;339:b2535. doi: 10.1136/bmj.b2535. PMID: 19622551.

27. Higgins JPT, Green S, eds. Cochrane handbook for systematic reviews of interventions Version 5.1.0 [updated March 2011]: The Cochrane Collaboration; 2011.

28. Wells G, Shea B, O'connell D, et al. The Newcastle-Ottawa Scale (NOS) for assessing the quality of nonrandomised studies in meta-analyses. 2000.

29. Knapp G, Hartung J. Improved tests for a random effects meta-regression with a single covariate. Stat Med. 2003 Sep 15;22(17):2693-710. doi: 10.1002/sim.1482. PMID: 12939780.

30. Guyatt GH, Oxman AD, Kunz R, et al. GRADE guidelines 6. Rating the quality of evidence--imprecision. J Clin Epidemiol. 2011 Dec;64(12):1283-93. doi: 
10.1016/j.jclinepi.2011.01.012. PMID: 21839614.

31. Guyatt GH, Oxman AD, Sultan S, et al. GRADE guidelines: 9. Rating up the quality of evidence. J Clin Epidemiol. 2011

Dec;64(12):1311-6. doi:

10.1016/j.jclinepi.2011.06.004. PMID: 21802902.

32. Rosa-Alcazar A, I, Boix M, et al. Contributions of cognitive restructuring in the treatment of social phobia in adolescents. Behavioral Psychology / Psicologia Conductual: Revista Internacional Clinica y de la Salud Psicologia Conductual Revista Internacional de Psicologia Clinica de la Salud. 2013;21(1):6-23. PMID: CN-01038693 NEW.

33. Rosa A, Ana I, Olivares O, et al. The role of non-specific effects in the psychological treatment of adolescents with social phobia. Anuario de Psicologia. 2009 Apr;40(1):4361. PMID: 2009-08210-003.

34. Gil B, F, Hernandez G, et al. [Cognitivebehavioural treatment in Mexican children with social phobia]. Anuario de Psicologia. 2009;40(1):89-104. PMID: CN-00753537 UPDATE.

35. Olivares R, Jose, Rosa-Alcazar A, et al. The relevance of the individualized attention in the treatment with adolescents under generalized social phobia. International journal of clinical and health psychology. 2006;6(3):565-80. PMID: CN-00634079 UPDATE.

36. Rodriguez, J O, Alcazar, et al. Early detection and treatment of adolescents with generalized social phobia. Psicothema. 2005;17(1):1-8. PMID: CN-00596495 UPDATE.

37. Amoros-Boix M, Rosa-Alcazar AI, Olivares-Olivares PJ. Role of the focus of attention in the treatment of generalized social phobia in adolescents. Anales De Psicologia. 2011 Oct;27(3):718-28. PMID: WOS:000293716800017.
38. Rosa A, Ana I, Olivares R, et al. The role of planned interaction in the treatment of generalized social phobia. Terapia Psicologica. 2007;25(2):205-12. PMID: 2008-02112-012.

39. Mendez, Xavier, Orgiles, et al. Psychological treatment of the phobia of the dark in a game situation: A controlled essay. Revista de Psicopatologia y Psicologia Clinica. 2003 Dec;8(3):199-210. PMID: 2004-12003-002.

40. Sanchez-Garcia R, Olivares J. Effectiveness of a program for early detection/intervention in children/adolescents with generalized social phobia. Anales De Psicologia. 2009 Dec;25(2):241-9. PMID: WOS:000272061800006.

41. Arándiga, Antonio V, Rodríguez, et al. Competencia social y autoestima en adolescentes con fobia social. Investigar el cambio curricular en el espacio europeo de educación superior. 2014:459-79.

42. Moller, C, Petermann, et al. Short- and longterm effects of a cognitive-behavioural training programme for children with social anxiety. [German]. Verhaltenstherapie. 2011 March;21(1):15-22. PMID: 2011134836.

43. Joormann, J, Unnewehr, et al. The efficacy of a cognitive-behavioral group treatment for children and adolescents with social phobia: A controlled trial. [German]. Zeitschrift fur Klinische Psychologie und Psychotherapie. 2002;31(4):284-90. PMID: 2002363778.

44. Ortbandt, C, Petermann, et al. Effects of a cognitive behavioral training program for children with social anxiety. Kindheit und Entwicklung. 2009;18(1):21-9.

45. Sheykhan R, Mohamadkhani S, Hasanabadi H. Self-Focused Attention in Treatment of Social Anxiety: A Controlled Clinical Trial. Journal of Mazandaran University of Medical Sciences. 2013;23(106):120-8.

46. ÃÈ Í. The Effectiveness of Cognitive Behavior Treatment Based on Kendall's 
Coping Program on Anxiety Disorders: A Transdiagnostic Approach.

47. Dadsetan P, Anari A, Sedghpour BS. Social anxiety disorders and drama-therapy. Journal of Iranian Psychologists. 2008;4(14):115-23.

48. Aydin A, Tekinsav Sutcu S, Sorias O. [Evaluation of the effectiveness of a cognitive-behavioral therapy program for alleviating the symptoms of social anxiety in adolescents]. Turk Psikiyatri Derg. 2010 Spring;21(1):25-36. PMID: 20204902.

49. Abikoff H, McGough J, Vitiello B, et al. Sequential pharmacotherapy for children with comorbid attentiondeficit/hyperactivity and anxiety disorders. J Am Acad Child Adolesc Psychiatry. 2005 May;44(5):418-27. doi: 10.1097/01.chi.0000155320.52322.37. PMID: 15843763.

50. Alfano CA, Ginsburg GS, Kingery JN. Sleep-related problems among children and adolescents with anxiety disorders. J Am Acad Child Adolesc Psychiatry. 2007 Feb;46(2):224-32. doi: 10.1097/01.chi.0000242233.06011.8e. PMID: 17242626.

51. Beidel DC, Turner SM, Sallee FR, et al. SET-C versus fluoxetine in the treatment of childhood social phobia. J Am Acad Child Adolesc Psychiatry. 2007 Dec;46(12):162232. doi: 10.1097/chi.0b013e318154bb57. PMID: 18030084.

52. Black B, Uhde TW. Treatment of elective mutism with fluoxetine: a double-blind, placebo-controlled study. J Am Acad Child Adolesc Psychiatry. 1994 Sep;33(7):1000-6. doi: 10.1097/00004583-199409000-00010. PMID: 7961338.

53. Birmaher B, Axelson DA, Monk K, et al. Fluoxetine for the treatment of childhood anxiety disorders. J Am Acad Child Adolesc Psychiatry. 2003 Apr;42(4):415-23. doi: 10.1097/01.CHI.0000037049.04952.9F. PMID: 12649628.
54. da Costa CZ, de Morais RM, Zanetta DM, et al. Comparison among clomipramine, fluoxetine, and placebo for the treatment of anxiety disorders in children and adolescents. J Child Adolesc Psychopharmacol. 2013 Dec;23(10):687-92. doi: 10.1089/cap.2012.0110. PMID: 24350814.

55. Geller D, Donnelly C, Lopez F, et al. Atomoxetine treatment for pediatric patients with attention-deficit/hyperactivity disorder with comorbid anxiety disorder. J Am Acad Child Adolesc Psychiatry. 2007

Sep;46(9):1119-27. doi: 10.1097/chi.0b013e3180ca8385. PMID: 17712235.

56. Gittelman K, Rachel, Klein, et al. School phobia: Diagnostic considerations in the light of imipramine effects. Journal of Nervous and Mental Disease. 1973 Mar;156(3):199-215. PMID: 1974-01582001.

57. Graae F, Milner J, Rizzotto L, et al. Clonazepam in childhood anxiety disorders. J Am Acad Child Adolesc Psychiatry. 1994 Mar-Apr;33(3):372-6. doi: 10.1097/00004583-199403000-00011. PMID: 8169182.

58. March JS, Entusah AR, Rynn M, et al. A Randomized controlled trial of venlafaxine ER versus placebo in pediatric social anxiety disorder. Biol Psychiatry. 2007 Nov 15;62(10):1149-54. doi: 10.1016/j.biopsych.2007.02.025. PMID: 17553467.

59. Reinblatt SP, Riddle MA. Selective serotonin reuptake inhibitor-induced apathy: a pediatric case series. J Child Adolesc Psychopharmacol. 2006 Feb-Apr;16(12):227-33. doi: 10.1089/cap.2006.16.227. PMID: 16553543.

60. Reinblatt SP, DosReis S, Walkup JT, et al. Activation adverse events induced by the selective serotonin reuptake inhibitor fluvoxamine in children and adolescents. J Child Adolesc Psychopharmacol. 2009 Apr;19(2):119-26. doi: 10.1089/cap.2008.040. PMID: 19364290. 
61. Rynn MA, Siqueland L, Rickels K. Placebocontrolled trial of sertraline in the treatment of children with generalized anxiety disorder. Am J Psychiatry. 2001 Dec;158(12):2008-14. doi: 10.1176/appi.ajp.158.12.2008. PMID: 11729017.

62. Rynn MA, Riddle MA, Yeung PP, et al. Efficacy and safety of extended-release venlafaxine in the treatment of generalized anxiety disorder in children and adolescents: two placebo-controlled trials. Am J Psychiatry. 2007 Feb;164(2):290-300. doi: 10.1176/ajp.2007.164.2.290. PMID: 17267793.

63. Scharfstein LA, Beidel DC, Finnell LR, et al. Do pharmacological and behavioral interventions differentially affect treatment outcome for children with social phobia? Behav Modif. 2011 Sep;35(5):451-67. doi: 10.1177/0145445511408590. PMID: 21586501.

64. Strawn JR, Prakash A, Zhang Q, et al. A randomized, placebo-controlled study of duloxetine for the treatment of children and adolescents with generalized anxiety disorder. J Am Acad Child Adolesc Psychiatry. 2015 Apr;54(4):283-93. doi: 10.1016/j.jaac.2015.01.008. PMID: 25791145.

65. Wagner, K, Berard, et al. A multicenter, randomized, double-blind, placebocontrolled trial ofparoxetine in children and adolescents with social anxiety disorder. Archives of General Psychiatry. 2004;61(11):1153-62. doi: 10.1001/archpsyc.61.11.1153.

66. Walkup J, Labellarte M, Riddle MA, et al. Treatment of pediatric anxiety disorders: an open-label extension of the research units on pediatric psychopharmacology anxiety study. J Child Adolesc Psychopharmacol. 2002 Fall;12(3):175-88. doi: 10.1089/104454602760386879. PMID: 12427292.

67. Ginsburg GS, Kendall PC, Sakolsky D, et al. Remission after acute treatment in children and adolescents with anxiety disorders: findings from the CAMS. J Consult Clin Psychol. 2011 Dec;79(6):806-13. doi: 10.1037/a0025933. PMID: 22122292.

68. Gonzalez A, Peris TS, Vreeland A, et al. Parental anxiety as a predictor of medication and CBT response for anxious youth. Child Psychiatry Hum Dev. 2015 Feb;46(1):84-93. doi: 10.1007/s10578-014-0454-6. PMID: 24610431.

69. Keeton CP, Ginsburg GS, Drake KL, et al. Benefits of child-focused anxiety treatments for parents and family functioning. Depress Anxiety. 2013 Sep;30(9):865-72. doi: 10.1002/da.22055. PMID: 23390005.

70. Nail, Jennifer E, Christofferson, et al. Academic impairment and impact of treatments among youth with anxiety disorders. Child \& Youth Care Forum. 2015 Jun;44(3):327-42. doi: 10.1007/s10566-0149290-x. PMID: 2014-51382-001.

71. Piacentini J, Bennett S, Compton SN, et al. 24- and 36-week outcomes for the Child/Adolescent Anxiety Multimodal Study (CAMS). J Am Acad Child Adolesc Psychiatry. 2014 Mar;53(3):297-310. doi: 10.1016/j.jaac.2013.11.010. PMID: 24565357.

72. Rynn MA, Walkup JT, Compton SN, et al. Child/Adolescent anxiety multimodal study: evaluating safety. J Am Acad Child Adolesc Psychiatry. 2015 Mar;54(3):180-90. doi: 10.1016/j.jaac.2014.12.015. PMID: 25721183.

73. Gonzalez, A, Peris, et al. Parental Anxiety as a Predictor of Medication and CBT Response for Anxious Youth. Child Psychiatry and Human Development. 2014:1-10. doi: 10.1007/s10578-014-04546.

74. Klein RG, Koplewicz HS, Kanner A. Imipramine treatment of children with separation anxiety disorder. J Am Acad Child Adolesc Psychiatry. 1992 Jan;31(1):21-8. doi: 10.1097/00004583199201000-00005. PMID: 1347039. 
75. Beidel DC, Turner SM, Morris TL. Behavioral treatment of childhood social phobia. J Consult Clin Psychol. 2000 Dec;68(6):1072-80. doi: 10.1037//0022006X.68.6.1072. PMID: 11142541.

76. Ginsburg GS, Drake KL. School-based treatment for anxious african-american adolescents: a controlled pilot study. J Am Acad Child Adolesc Psychiatry. 2002 Jul;41(7):768-75. doi: 10.1097/00004583200207000-00007. PMID: 12108800.

77. Halldorsdottir T, Ollendick TH. Long-term outcomes of brief, intensive CBT for specific phobias: The negative impact of ADHD symptoms. J Consult Clin Psychol. 2016 May;84(5):465-71. doi: 10.1037/сcp0000088. PMID: 26900895.

78. Herbert JD, Gaudiano BA, Rheingold AA, et al. Cognitive behavior therapy for generalized social anxiety disorder in adolescents: a randomized controlled trial. J Anxiety Disord. 2009 Mar;23(2):167-77. doi: 10.1016/j.janxdis.2008.06.004. PMID: 18653310 .

79. Hudson JL, Rapee RM, Deveney C, et al. Cognitive-behavioral treatment versus an active control for children and adolescents with anxiety disorders: a randomized trial. $\mathrm{J}$ Am Acad Child Adolesc Psychiatry. 2009 May;48(5):533-44. doi: 10.1097/CHI.0b013e31819c2401. PMID: 19318990.

80. Kendall PC, Hudson JL, Gosch E, et al. Cognitive-behavioral therapy for anxiety disordered youth: a randomized clinical trial evaluating child and family modalities. J Consult Clin Psychol. 2008 Apr;76(2):28297. doi: 10.1037/0022-006X.76.2.282. PMID: 18377124.

81. Khanna MS, Kendall PC. Exploring the role of parent training in the treatment of childhood anxiety. J Consult Clin Psychol. 2009 Oct;77(5):981-6. doi: 10.1037/a0016920. PMID: 19803577.

82. Khanna MS, Kendall PC. Computer-assisted cognitive behavioral therapy for child anxiety: results of a randomized clinical trial. J Consult Clin Psychol. 2010

Oct;78(5):737-45. doi: 10.1037/a0019739. PMID: 20873909.

83. Last CG, Hansen C, Franco N. Cognitivebehavioral treatment of school phobia. J Am Acad Child Adolesc Psychiatry. 1998 Apr;37(4):404-11. doi: 10.1097/00004583199804000-00018. PMID: 9549961.

84. Menzies RG, Clarke JC. A comparison of in vivo and vicarious exposure in the treatment of childhood water phobia. Behav Res Ther. 1993 Jan;31(1):9-15. doi: 10.1016/00057967(93)90037-U. PMID: 8093340.

85. Muris, P, Meesters, et al. Cognitive coping vs emotional disclosure in the treatment of anxious children: A pilot-study. Cognitive Behaviour Therapy. 2002;31(2):59-67. doi: 10.1080/16506070252959490. PMID: 2003069119.

86. Ollendick TH, Ost LG, Reuterskiold L, et al. One-session treatment of specific phobias in youth: a randomized clinical trial in the United States and Sweden. J Consult Clin Psychol. 2009 Jun;77(3):504-16. doi: 10.1037/a0015158. PMID: 19485591.

87. Pincus DB, May JE, Whitton SW, et al. Cognitive-behavioral treatment of panic disorder in adolescence. J Clin Child Adolesc Psychol. 2010;39(5):638-49. doi: 10.1080/15374416.2010.501288. PMID: 20706917.

88. Reigada, Laura C, Polokowski, et al. Treatment for comorbid pediatric gastrointestinal and anxiety disorders: A pilot study of a flexible health sensitive cognitive-behavioral therapy program. Clinical Practice in Pediatric Psychology. 2015 Dec;3(4):314-26. doi: 10.1037/cpp0000116 PMID: 2015-55574002.

89. Ritter B. The group desensitization of children's snake phobias using vicarious and contact desensitization procedures. Behav Res Ther. 1968 Feb;6(1):1-6. doi: 10.1016/0005-7967(68)90033-8. PMID: 5689466. 
90. Silk JS, Tan PZ, Ladouceur CD, et al. A Randomized Clinical Trial Comparing Individual Cognitive Behavioral Therapy and Child-Centered Therapy for Child Anxiety Disorders. J Clin Child Adolesc Psychol. 2016 Mar 16:1-13. doi: 10.1080/15374416.2016.1138408. PMID: 26983904.

91. Van S, F. J A, Dirksen, et al. Costeffectiveness of cognitive-behavioral therapy versus treatment as usual for anxiety disorders in children with autism spectrum disorder. Research in Autism Spectrum Disorders. 2014 February;8(2):127-37. doi: 10.1016/j.rasd.2013.11.001. PMID: 2013783128.

92. Masia W, Carrie, Colognori, et al. Can school counselors deliver cognitivebehavioral treatment for social anxiety effectively? A randomized controlled trial. Journal of Child Psychology and Psychiatry. 2016 Mar:No Pagination Specified. doi: 10.1111/jcpp.12550. PMID: 2016-14653001.

93. Fujii, Cori, Renno, et al. Intensive cognitive behavioral therapy for anxiety disorders in school-aged children with autism: A preliminary comparison with treatment-asusual. School Mental Health. 2013;5(1):2537. doi: 10.1007/s12310-012-9090-0. PMID: CN-01000510 UPDATE.

94. Ginsburg GS, Becker KD, Drazdowski TK, et al. Treating Anxiety Disorders in Inner City Schools: Results from a Pilot Randomized Controlled Trial Comparing CBT and Usual Care. Child Youth Care Forum. 2012 Feb;41(1):1-19. doi: 10.1007/s10566-011-9156-4. PMID: 22701295.

95. Ingul JM, Aune T, Nordahl HM. A randomized controlled trial of individual cognitive therapy, group cognitive behaviour therapy and attentional placebo for adolescent social phobia. Psychother Psychosom. 2014;83(1):54-61. doi: 10.1159/000354672. PMID: 24281563.

96. Masia Warner C, Fisher PH, Shrout PE, et al. Treating adolescents with social anxiety disorder in school: an attention control trial.
J Child Psychol Psychiatry. 2007 Jul;48(7):676-86. doi: 10.1111/j.14697610.2007.01737.x. PMID: 17593148.

97. Southam-Gerow MA, Weisz JR, Chu BC, et al. Does cognitive behavioral therapy for youth anxiety outperform usual care in community clinics? An initial effectiveness test. J Am Acad Child Adolesc Psychiatry. 2010 Oct;49(10):1043-52. doi: 10.1016/j.jaac.2010.06.009. PMID: 20855049.

98. Storch EA, Arnold EB, Lewin AB, et al. The effect of cognitive-behavioral therapy versus treatment as usual for anxiety in children with autism spectrum disorders: a randomized, controlled trial. J Am Acad Child Adolesc Psychiatry. 2013

Feb;52(2):132-42 e2. doi: 10.1016/j.jaac.2012.11.007. PMID: 23357440.

99. Storch EA, Salloum A, King MA, et al. A Randomized Controlled Trial in Community Mental Health Centers of ComputerAssisted Cognitive Behavioral Therapy Versus Treatment as Usual for Children with Anxiety. Depress Anxiety. 2015 Nov;32(11):843-52. doi: 10.1002/da.22399. PMID: 26366886.

100. O'Brien, F, Olden, et al. Group cognitive behavioural therapy for children with anxiety disorder - An evaluation of the 'Friends for Youth' programme. Irish Journal of Psychological Medicine. 2007

March;24(1):5-12. doi: doi.org/10.1017/S0790966700010065. PMID: 2007447394.

101. Suveg C, Hudson JL, Brewer G, et al. Cognitive-behavioral therapy for anxietydisordered youth: secondary outcomes from a randomized clinical trial evaluating child and family modalities. J Anxiety Disord. 2009 Apr;23(3):341-9. doi: 10.1016/j.janxdis.2009.01.003. PMID: 19216048.

102. Yen CF, Chen YM, Cheng JW, et al. Effects of cognitive-behavioral therapy on improving anxiety symptoms, behavioral problems and parenting stress in Taiwanese children with anxiety disorders and their 
mothers. Child Psychiatry Hum Dev. 2014

Jun;45(3):338-47. doi: 10.1007/s10578-0130403-9. PMID: 24002227.

103. Abbasi, Z, Amiri, et al. The effective comparison between modular cognitive behavioral therapy (MCBT) and child-parent relationship training (CPRT) in children with separation anxiety symptoms. Social Sciences (Pakistan). 2016;11(6):890-902. doi: 10.3923/sscience.2016.890.902.

104. Adler Nevo GW, Avery D, Fiksenbaum L, et al. Eight years later: outcomes of CBTtreated versus untreated anxious children. Brain Behav. 2014 Sep;4(5):765-74. doi: 10.1002/brb3.274. PMID: 25328851.

105. Afshari A, Neshat-Doost HT, Maracy MR, et al. The effective comparison between emotion-focused cognitive behavioral group therapy and cognitive behavioral group therapy in children with separation anxiety disorder. J Res Med Sci. 2014 Mar;19(3):221-7. PMID: 24949029.

106. Arendt K, Thastum M, Hougaard E. Efficacy of a Danish version of the Cool Kids program: a randomized wait-list controlled trial. Acta Psychiatr Scand. 2015 May 27;133(2):109-21. doi: 10.1111/acps.12448. PMID: 26016532.

107. Baer S, Garland EJ. Pilot study of community-based cognitive behavioral group therapy for adolescents with social phobia. J Am Acad Child Adolesc Psychiatry. 2005 Mar;44(3):258-64. doi: 10.1097/00004583-200503000-00010. PMID: 15725970.

108. Barrett PM, Dadds MR, Rapee RM. Family treatment of childhood anxiety: a controlled trial. J Consult Clin Psychol. 1996 Apr;64(2):333-42. doi: 10.1037//0022006X.64.2.333. PMID: 8871418.

109. Barrett PM. Evaluation of cognitivebehavioral group treatments for childhood anxiety disorders. J Clin Child Psychol. 1998 Dec;27(4):459-68. doi: 10.1207/s15374424jccp2704_10. PMID: 9866083.
110. Chalfant AM, Rapee R, Carroll L. Treating anxiety disorders in children with high functioning autism spectrum disorders: a controlled trial. J Autism Dev Disord. 2007 Nov;37(10):1842-57. doi: 10.1007/s10803006-0318-4. PMID: 17171539.

111. Chiu AW, Langer DA, McLeod BD, et al. Effectiveness of modular CBT for child anxiety in elementary schools. Sch Psychol Q. 2013 Jun;28(2):141-53. doi: 10.1037/spq0000017. PMID: 23750860.

112. Cobham VE. Do anxiety-disordered children need to come into the clinic for efficacious treatment? J Consult Clin Psychol. 2012 Jun;80(3):465-76. doi: 10.1037/a0028205. PMID: 22545740.

113. Dewis LM, Kirkby KC, Martin F, et al. Computer-aided vicarious exposure versus live graded exposure for spider phobia in children. J Behav Ther Exp Psychiatry. 2001 Mar;32(1):17-27. doi: 10.1016/S00057916(01)00019-2. PMID: 11729943.

114. Donovan CL, Cobham V, Waters AM, et al. Intensive group-based CBT for child social phobia: a pilot study. Behav Ther. 2015 May;46(3):350-64. doi: 10.1016/j.beth.2014.12.005. PMID: 25892171.

115. Flannery S, E C, Kendall, et al. Group and individual cognitive-behavioral treatments for youth with anxiety disorders: A randomized clinical trial. Cognitive Therapy and Research. 2000 June;24(3):251-78. doi: 10.1023/A:1005500219286. PMID: 2000223577.

116. Flannery S, E, Choudhury, et al. Group and individual cognitive-behavioral treatments for youth with anxiety disorders: 1-Year follow-up. Cognitive Therapy and Research. 2005 April;29(2):253-9. doi: 10.1007/s10608-005-3168-z. PMID: 2005221485.

117. Gallagher HM, Rabian BA, McCloskey MS. A brief group cognitive-behavioral intervention for social phobia in childhood. J Anxiety Disord. 2004;18(4):459-79. doi: 
10.1016/S0887-6185(03)00027-6. PMID: 15149708 .

118. Gallo KP, Chan PT, Buzzella BA, et al. The impact of an 8-day intensive treatment for adolescent panic disorder and agoraphobia on comorbid diagnoses. Behav Ther. 2012 Mar;43(1):153-9. doi: 10.1016/j.beth.2011.05.002. PMID: 22304887.

119. Hancock KM, Swain J, Hainsworth CJ, et al. Acceptance and Commitment Therapy versus Cognitive Behavior Therapy for Children With Anxiety: Outcomes of a Randomized Controlled Trial. J Clin Child Adolesc Psychol. 2016 Mar 21:1-16. doi: 10.1080/15374416.2015.1110822. PMID: 26998803.

120. Hayward C, Varady S, Albano AM, et al. Cognitive-behavioral group therapy for social phobia in female adolescents: results of a pilot study. J Am Acad Child Adolesc Psychiatry. 2000 Jun;39(6):721-6. doi: 10.1097/00004583-200006000-00010. PMID: 10846306.

121. Hirshfeld-Becker DR, Masek B, Henin A, et al. Cognitive behavioral therapy for 4- to 7year-old children with anxiety disorders: a randomized clinical trial. J Consult Clin Psychol. 2010 Aug;78(4):498-510. doi: 10.1037/a0019055. PMID: 20658807.

122. Holmes MC, Donovan CL, Farrell LJ, et al. The efficacy of a group-based, disorderspecific treatment program for childhood GAD--a randomized controlled trial. Behav Res Ther. 2014 Oct;61:122-35. doi: 10.1016/j.brat.2014.08.002. PMID: 25193003.

123. Kendall, P C. Treating anxiety disorders in children: results of a randomized clinical trial. Annual Progress in Child Psychiatry and Child Development. 1995doi: 10.1037/0022-006X.62.1.100 • PMID: CN00216211 UPDATE.

124. Kendall PC, Flannery-Schroeder E, Panichelli-Mindel SM, et al. Therapy for youths with anxiety disorders: a second randomized clinical trial. J Consult Clin
Psychol. 1997 Jun;65(3):366-80. doi: 10.1037/0022-006X.65.3.366. PMID: 9170760.

125. Leutgeb V, Schienle A. Changes in facial electromyographic activity in spider-phobic girls after psychotherapy. J Psychiatr Res. 2012 Jun;46(6):805-10. doi: 10.1016/j.jpsychires.2012.02.017. PMID: 22424962.

126. Masia-Warner C, Klein RG, Dent HC, et al. School-based intervention for adolescents with social anxiety disorder: results of a controlled study. J Abnorm Child Psychol. 2005 Dec;33(6):707-22. doi: 10.1007/s10802-005-7649-z. PMID: 16328746.

127. McConachie H, McLaughlin E, Grahame V, et al. Group therapy for anxiety in children with autism spectrum disorder. Autism. 2014 Aug;18(6):723-32. doi: 10.1177/1362361313488839. PMID: 24101715.

128. McNally Keehn RH, Lincoln AJ, Brown MZ, et al. The Coping Cat program for children with anxiety and autism spectrum disorder: a pilot randomized controlled trial. J Autism Dev Disord. 2013 Jan;43(1):57-67. doi: 10.1007/s10803-012-1541-9. PMID: 22588377.

129. Melfsen S, Kuhnemund M, Schwieger J, et al. Cognitive behavioral therapy of socially phobic children focusing on cognition: a randomised wait-list control study. Child Adolesc Psychiatry Ment Health. 2011 Feb 28;5(1):5. doi: 10.1186/1753-2000-5-5. PMID: 21356037.

130. Mendlowitz SL, Manassis K, Bradley S, et al. Cognitive-behavioral group treatments in childhood anxiety disorders: the role of parental involvement. J Am Acad Child Adolesc Psychiatry. 1999 Oct;38(10):12239. doi: 10.1097/00004583-19991000000010. PMID: 10517054.

131. Miller LC, Barrett CL, Hampe E, et al. Comparison of reciprocal inhibition, psychotherapy, and waiting list control for 
phobic children. J Abnorm Psychol. 1972 Jun;79(3):269-79. PMID: 5033367.

132. Hampe E, Noble H, Miller LC, et al. Phobic children one and two years posttreatment. J Abnorm Psychol. 1973 Dec;82(3):446-53. PMID: 4770914.

133. Obler M, Terwilliger RF. Pilot study on the effectiveness of systematic desensitization with neurologically impaired children with phobic disorders. J Consult Clin Psychol. 1970 Jun;34(3):314-8. doi:

10.1037/h0029367. PMID: 5523436.

134. Olivares J, Olivares-Olivares PJ, RosaAlcazar AI, et al. The contribution of the therapist's competence in the treatment of adolescents with generalized social phobia. Psicothema. 2014;26(4):483-9. doi: 10.7334/psicothema2014.69. PMID: 25340895.

135. Ost LG, Svensson L, Hellstrom K, et al. One-Session treatment of specific phobias in youths: a randomized clinical trial. J Consult Clin Psychol. 2001 Oct;69(5):814-24. doi: 10.1037/0022-006X.69.5.814. PMID: 11680558.

136. Ost, L G, Cederlund, et al. Behavioral treatment of social phobia in youth: Does parent education training improve the outcome? Behaviour Research and Therapy. 2015 April 01;67:19-29. doi: 10.1016/j.brat.2015.02.001. PMID: 2015788786.

137. Rapee RM, Abbott MJ, Lyneham HJ. Bibliotherapy for children with anxiety disorders using written materials for parents: A randomized controlled trial. J Consult Clin Psychol. 2006 Jun;74(3):436-44. doi: 10.1037/0022-006X.74.3.436. PMID: 16822101.

138. Reaven, J A, Blakeley S, et al. Cognitivebehavioral group treatment for anxiety symptoms in children with high-functioning autism spectrum disorders: A pilot study. Focus on Autism and Other Developmental Disabilities. 2009 March;24(1):27-37. doi: 10.1177/1088357608327666. PMID: 2009069887.
139. Sánchez G, Raquel, Rodríguez, et al. Intervención temprana en niños y adolescentes con fobia social. Anuario de psicología/The UB Journal of psychology. 2009;40(1):75-88.

140. Santucci LC, Ehrenreich-May J. A randomized controlled trial of the child anxiety multi-day program (CAMP) for separation anxiety disorder. Child Psychiatry Hum Dev. 2013 Jun;44(3):43951. doi: 10.1007/s10578-012-0338-6. PMID: 23053618.

141. Schneider S, Blatter-Meunier J, Herren C, et al. Disorder-specific cognitive-behavioral therapy for separation anxiety disorder in young children: a randomized waiting-listcontrolled trial. Psychother Psychosom. 2011;80(4):206-15. doi: 10.1159/000323444. PMID: 21494062.

142. Shortt AL, Barrett PM, Fox TL. Evaluating the FRIENDS program: a cognitivebehavioral group treatment for anxious children and their parents. J Clin Child Psychol. 2001 Dec;30(4):525-35. doi: 10.1207/S15374424JCCP3004_09. PMID: 11708240 .

143. Silverman WK, Kurtines WM, Ginsburg GS, et al. Treating anxiety disorders in children with group cognitive-behaviorial therapy: a randomized clinical trial. $\mathrm{J}$ Consult Clin Psychol. 1999 Dec;67(6):9951003. doi: 10.1037/0022-006X.67.6.995 PMID: 10596522.

144. Spence SH, Donovan C, BrechmanToussaint M. The treatment of childhood social phobia: the effectiveness of a social skills training-based, cognitive-behavioural intervention, with and without parental involvement. J Child Psychol Psychiatry. 2000 Sep;41(6):713-26. doi: 10.1111/14697610.00659. PMID: 11039684.

145. Spence SH, Holmes JM, March S, et al. The feasibility and outcome of clinic plus internet delivery of cognitive-behavior therapy for childhood anxiety. J Consult Clin Psychol. 2006 Jun;74(3):614-21. doi: 
10.1037/0022-006X.74.3.614. PMID: 16822117.

146. Spence SH, Donovan CL, March S, et al. A randomized controlled trial of online versus clinic-based CBT for adolescent anxiety. J Consult Clin Psychol. 2011 Oct;79(5):62942. doi: 10.1037/a0024512. PMID: 21744945.

147. Treadwell KR, Kendall PC. Self-talk in youth with anxiety disorders: states of mind, content specificity, and treatment outcome. J Consult Clin Psychol. 1996 Oct;64(5):94150. doi: 10.1037//0022-006X.64.5.941 PMID: 8916623.

148. Warner CM, Colognori D, Kim RE, et al. Cognitive-behavioral treatment of persistent functional somatic complaints and pediatric anxiety: an initial controlled trial. Depress Anxiety. 2011 Jul;28(7):551-9. doi: 10.1002/da.20821. PMID: 21681863.

149. Waters AM, Ford LA, Wharton TA, et al. Cognitive-behavioural therapy for young children with anxiety disorders: Comparison of a Child + Parent condition versus a Parent Only condition. Behav Res Ther. 2009

Aug;47(8):654-62. doi: 10.1016/j.brat.2009.04.008. PMID: 19457471.

150. Wergeland GJ, Fjermestad KW, Marin CE, et al. An effectiveness study of individual vs. group cognitive behavioral therapy for anxiety disorders in youth. Behav Res Ther. 2014 Jun;57:1-12. doi: 10.1016/j.brat.2014.03.007. PMID: 24727078.

151. Wergeland GJ, Fjermestad KW, Marin CE, et al. Predictors of treatment outcome in an effectiveness trial of cognitive behavioral therapy for children with anxiety disorders. Behav Res Ther. 2016 Jan;76:1-12. doi: 10.1016/j.brat.2015.11.001. PMID: 26583954.

152. White SW, Ollendick T, Albano AM, et al. Randomized controlled trial: Multimodal Anxiety and Social Skill Intervention for adolescents with autism spectrum disorder. J Autism Dev Disord. 2013 Feb;43(2):382-94. doi: 10.1007/s10803-012-1577-x. PMID: 22735897.

153. Wood JJ, Drahota A, Sze K, et al. Cognitive behavioral therapy for anxiety in children with autism spectrum disorders: a randomized, controlled trial. J Child Psychol Psychiatry. 2009 Mar;50(3):224-34. doi: 10.1111/j.1469-7610.2008.01948.x. PMID: 19309326.

154. Olivares, J, Garcia L, et al. Results at longterm among three psychological treatments for adolescents with generalized social phobia (I): Statistical significance. Psicologia Conductual. 2002;10(1):147-64. PMID: 2002236025.

155. Rapee, Ronald M. Group treatment of children with anxiety disorders: Outcome and predictors of treatment response. Australian Journal of Psychology. 2000;52(3):125-9. doi: 10.1080/00049530008255379.

156. Van S, F. J A, Bogels, et al. CBT for anxiety disorders in children with and without autism spectrum disorders. Journal of Consulting and Clinical Psychology. 2015 01 Jun;83(3):512-23. doi: 10.1037/a0039108. PMID: 2015938821.

157. Muris P, Meesters C, van Melick M.

Treatment of childhood anxiety disorders: a preliminary comparison between cognitivebehavioral group therapy and a psychological placebo intervention. J Behav Ther Exp Psychiatry. 2002 Sep-Dec;33(34):143-58. doi: 10.1016/S00057916(02)00025-3. PMID: 12628633.

158. Lee SS, Victor AM, James MG, et al. School-Based Interventions for Anxious Children: Long-Term Follow-Up. Child Psychiatry Hum Dev. 2016 Apr;47(2):18393. doi: 10.1007/s10578-015-0555-X. PMID: 26003419.

159. Bernstein GA, Borchardt CM, Perwien AR, et al. Imipramine plus cognitive-behavioral therapy in the treatment of school refusal. J Am Acad Child Adolesc Psychiatry. 2000 Mar;39(3):276-83. doi: 10.1097/00004583200003000-00008. PMID: 10714046. 
160. Melvin GA, Dudley AL, Gordon MS, et al. Augmenting Cognitive Behavior Therapy for School Refusal with Fluoxetine: A Randomized Controlled Trial. Child Psychiatry Hum Dev. 2016 Aug 02doi: 10.1007/s10578-016-0675-y. PMID: 27485100 .

161. Mancini C, Van Ameringen M, Oakman JM, et al. Serotonergic agents in the treatment of social phobia in children and adolescents: a case series. Depress Anxiety. 1999;10(1):339. doi: 10.1002/(SICI)15206394(1999)10:1<33::AID-DA6>3.0.CO;2H. PMID: 10499188.

162. Renaud J, Birmaher B, Wassick SC, et al. Use of selective serotonin reuptake inhibitors for the treatment of childhood panic disorder: a pilot study. J Child Adolesc Psychopharmacol. 1999;9(2):73-83. doi: 10.1089/cap.1999.9.73. PMID:

10461817.

163. Eichstedt JA, Tobon JI, Phoenix E, et al. Worried no more: The effects of medication status on treatment response to a CBT group for children with anxiety in a community setting. Clin Child Psychol Psychiatry. 2011 Apr;16(2):265-77. doi:
10.1177/1359104510366282. PMID: 21059669.

164. Moncrieff J, Wessely S, Hardy R. Active placebos versus antidepressants for depression. Cochrane Database Syst Rev. 2004(1):CD003012. doi: 10.1002/14651858.CD003012.pub2. PMID: 14974002.

165. Sharma T, Guski LS, Freund N, et al. Suicidality and aggression during antidepressant treatment: systematic review and meta-analyses based on clinical study reports. BMJ. 2016 Jan 27;352:i65. doi: 10.1136/bmj.i65. PMID: 26819231.

166. Dobson ET, Strawn JR. Pharmacotherapy for Pediatric Generalized Anxiety Disorder: A Systematic Evaluation of Efficacy, Safety and Tolerability. Paediatr Drugs. 2016 Feb;18(1):45-53. doi: 10.1007/s40272-0150153-1. PMID: 26660158.

167. Murad MH, Montori VM, Ioannidis JP, et al. How to read a systematic review and meta-analysis and apply the results to patient care: users' guides to the medical literature. JAMA. 2014 Jul;312(2):171-9. doi: 10.1001/jama.2014.5559. PMID: 25005654. 


\section{Abbreviations}

\begin{tabular}{|l|l|}
\hline AACAP & American Academy of Child and Adolescent Psychiatry \\
\hline ADHD & Attention Deficit Hyperactivity Disorder \\
\hline ADIS & Anxiety Disorder Interview Schedule \\
\hline AE & Adverse Event \\
\hline CBT & Cognitive Behavioral Therapy \\
\hline CGAS & Children's Global Assessment Scale \\
\hline CGI-I & Clinical Global Impression - Improvement Scale \\
\hline CGI-S & Clinical Global Impressions Scale - Severity Scale \\
\hline Cl & Confidence Interval \\
\hline CMAS & Children's Manifest Anxiety Scale \\
\hline DSM-5 & Diagnostic and Statistical Manual of Mental Disorders \\
\hline EAS Temperament & Emotionality-Activity-Sociability Temperament Survey \\
\hline Survey & \\
\hline FSSCR & Fear Survey Schedule for Children - Revised \\
\hline ITT & Intention-to-treat \\
\hline MASC & Multidimensional Anxiety Scale for Children \\
\hline N/A & Not Applicable \\
\hline NICE & National Institute for Health and Care Excellence \\
\hline NIMH & The National Institute of Mental Health \\
\hline OCD & Obsessive Compulsive Disorder \\
\hline ODD & Oppositional Defiant Disorder \\
\hline PARS & Pediatric Anxiety Rating Scale \\
\hline PICOTS & Population, Interventions, Comparisons, Outcomes, Timing, and Setting \\
\hline PRISMA & Preferred Reporting Items for Systematic Reviews and Meta-Analyses \\
\hline PST & Problem Solving Therapy \\
\hline RCMAS & Revised Children's Manifest Anxiety Scale \\
\hline RCT & Randomized Controlled Trial \\
\hline SCARED & Screen for Child Anxiety Related Emotional Disorders \\
\hline SCAS & Spence Children's Anxiety Scale \\
\hline SES & Socioeconomic Status \\
\hline SMD & Standardized Mean Difference \\
\hline SNRI & Serotonin-Norepinephrine Reuptake Inhibitor \\
\hline SOE & Strength of Evidence \\
\hline SPAI & Social Phobia and Anxiety Inventory \\
\hline SRI & Serotonin Reuptake Inhibitor \\
\hline SSRI & Selective Serotonin Reuptake Inhibitor \\
\hline STAI & State-Trait Anxiety Inventory \\
\hline TCA & Tricyclic Antidepressant \\
\hline & \\
\hline
\end{tabular}




\section{Appendixes Contents}

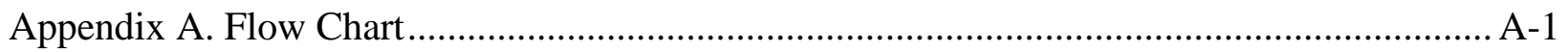

Appendix B. Search Strategy ……………………….................................................... B-1

Appendix C. Criteria for Inclusion/Exclusion of Studies ......................................................... C-1

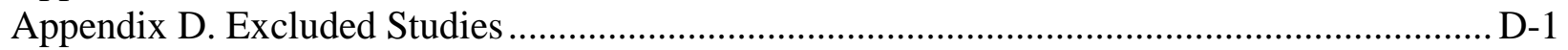

Appendix E. Description of Included Studies......................................................................

Appendix F. Risk of Bias...................................................................................................

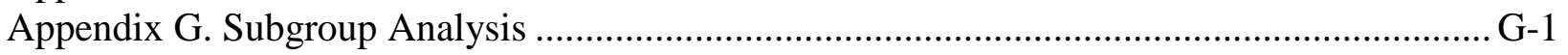

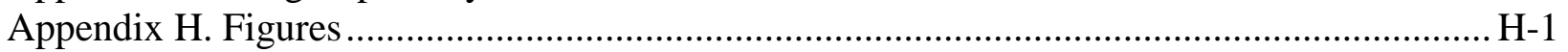

Appendix I. References for Appendixes .....................................................................................

\section{Tables}

Table C.1. Inclusion and exclusion criteria ..............................................................................

Table E.1. Characteristics of the included studies comparing drugs versus pill placebo .............E-1

Table E.2. Characteristics of the included studies comparing drugs versus drugs ........................E-8

Table E.3. Characteristics of the included studies comparing CBT versus drugs .........................E-9

Table E.4. Characteristics of the included studies comparing CBT versus waitlisting or no

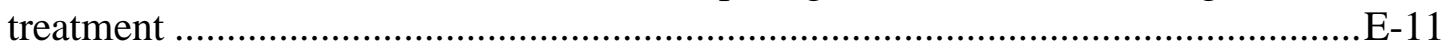

Table E.5. Characteristics of the included studies comparing CBT versus pill placebo ............E-41

Table E.6. Characteristics of the included studies comparing CBT versus attention control or

treatment as usual..............................................................................................................

Table E.7. Characteristics of studies evaluating combination of CBT with drugs versus CBT E-58

Table E.8. Characteristics of studies comparing parent only intervention versus waitlisting ...E-61

Table E.9. Characteristics of studies comparing different components of parent only

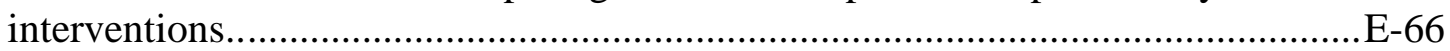

Table E.10. Characteristics of studies comparing distance therapy versus waitlisting ..............E-68

Table E.11. Characteristics of studies comparing different components of distance therapy ...E-77

Table E.12. Characteristics of studies comparing attention bias modification versus waitlisting or pill placebo E-79

Table E.13. Characteristics of studies comparing combined attention bias modification intervention and other therapy versus other therapy …………………………......E-80

Table E.14. Characteristics of studies comparing mindfulness-based CBT to waitlisting.........E-81

Table E.15. Characteristics of studies comparing acceptance and commitment therapy versus

waitlist or no treatment .................................................................................... E-82

Table E.16. Characteristics of studies comparing non-CBT psychoanalysis versus wait listing.E-83

Table E.17. Characteristics of studies comparing other therapy versus waitlisting or attention control or treatment as usual

Table E.18. Characteristics of studies comparing different non-CBT psychotherapies .............E-87

Table E.19. Characteristics of studies comparing CBT versus other psychotherapy ..................E-89

Table E.20. Characteristics of studies comparing different CBTs................................................

Table E.21. Characteristics of single-cohort observational studies with adverse events..........E-122

Table F.1. Risk of bias in randomized controlled trials (Cochrane ROB tool) ............................F-1 
Table F.2. Risk of bias in non-randomized comparative studies (Newcastle-Ottawa Quality Assessment Scale)...............................................................................

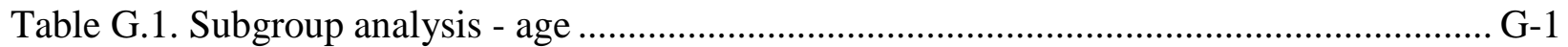

Table G.2. Subgroup analysis - comorbidity ................................................................. G-2

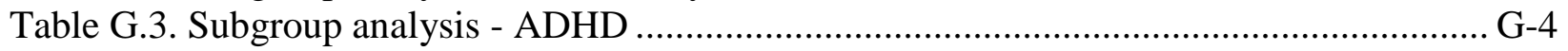

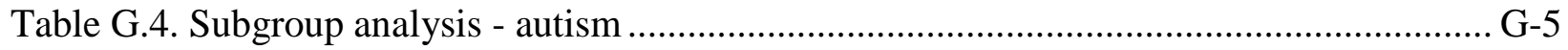

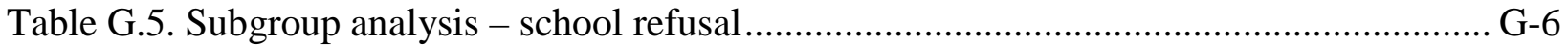

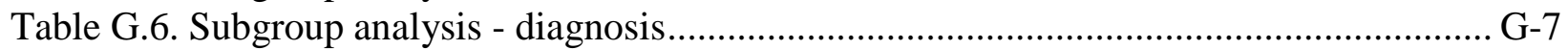

Table G.7. Subgroup analysis - treatment settings ..........................................................9

Table G.8. Subgroup analysis - follow up less than 6 months ......................................... G-11

Table G.9. Subgroup analysis - follow up longer than 6 months ..................................... G-12

Table G.10. Subgroup analysis - therapy components.................................................... G-13

Table G.11. Subgroup analysis - CBT delivery mode ................................................... G-14

Table G.12. Subgroup analysis - CBT intensity ............................................................ G-1

\section{Figures}

Figure A.1. Flow Chart .......................................................................................... A-1

Figure H.1. Funnel plot CBT versus waitlisting or no treatment for primary anxiety clinician

report ...................................................................................................

Figure H.2. Funnel plot CBT versus waitlisting or no treatment for primary anxiety child reportH-2 Figure H.3. Funnel plot for CBT versus waitlisting or no treatment for primary anxiety parent

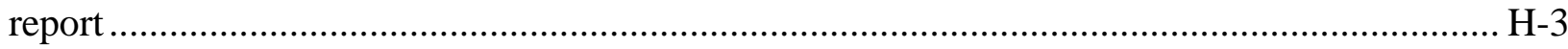




\section{Appendix A. Flow Chart}

Figure A.1. Flow chart

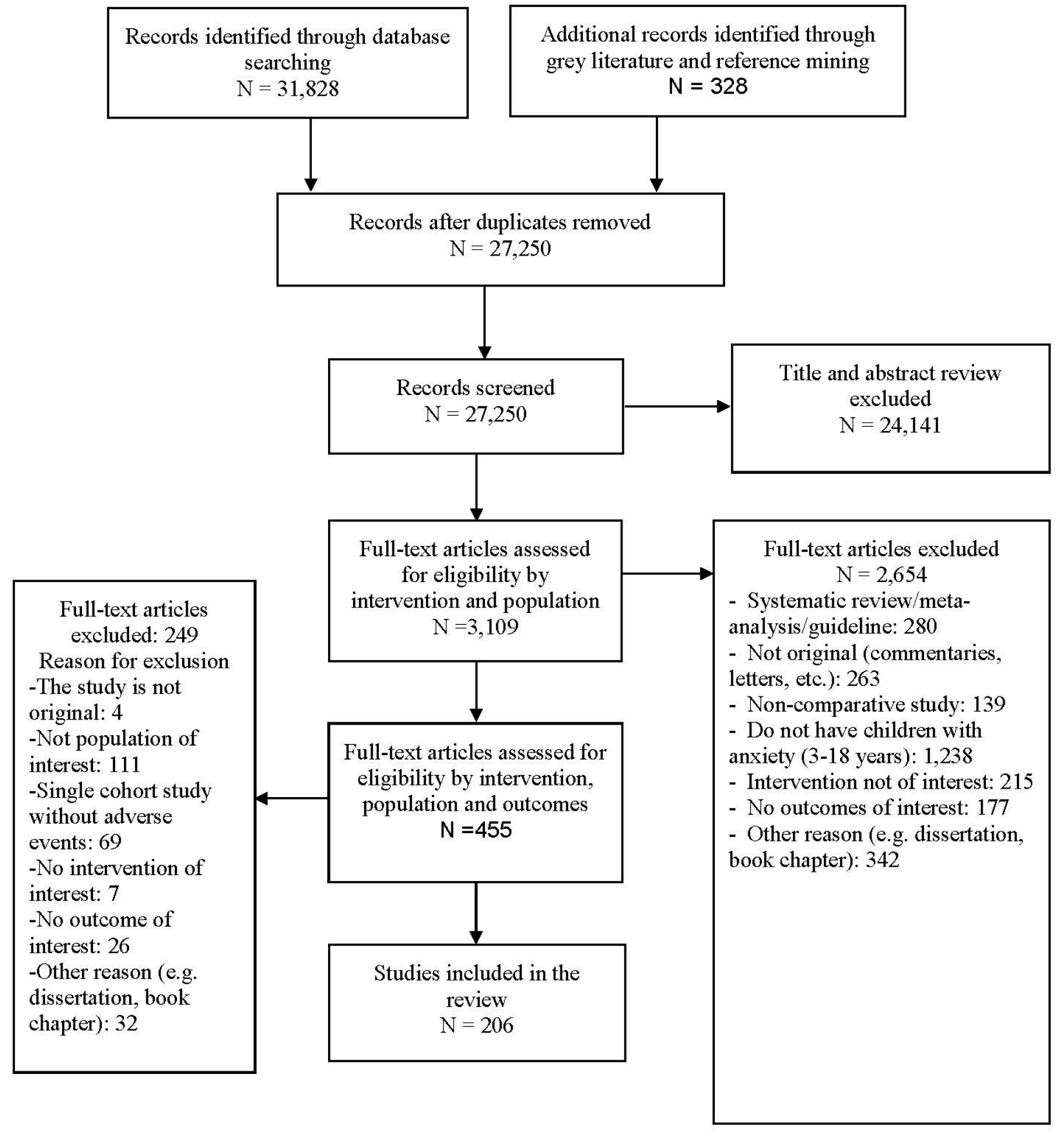




\section{Appendix B. Search Strategy}

Ovid

Database(s): Embase 1988 to 2017 Week 05, Ovid MEDLINE(R) In-Process \& Other NonIndexed Citations and Ovid MEDLINE(R) 1946 to Present, PsycINFO 1806 to January Week 4 2017, EBM Reviews - Cochrane Central Register of Controlled Trials November 2016, EBM

Reviews - Cochrane Database of Systematic Reviews 2005 to January 25, 2017 Search Strategy:

\#

1 Anxiety Disorders/dh, dt, su, th

Searches

2 anxiety disorder/dm, dt, rt, su, th [Disease Management, Drug Therapy,

2 Radiotherapy, Surgery, Therapy]

3 exp Panic Disorder/dt, su, th [Drug Therapy, Surgery, Therapy]

4 exp panic/dm, dt, su, th [Disease Management, Drug Therapy, Surgery, Therapy]

5 exp Phobic Disorders/dh, dt, su, th [Diet Therapy, Drug Therapy, Surgery, Therapy]

6 exp phobia/dm, dt, su, th [Disease Management, Drug Therapy, Surgery, Therapy]

7 exp Anxiety, Separation/dt, th [Drug Therapy, Therapy]

8 exp separation anxiety/dm, dt, th [Disease Management, Drug Therapy, Therapy]

9 exp generalized anxiety disorder/dm, dt, su, th [Disease Management, Drug Therapy, Surgery, Therapy]

((("social anxiet*" or "generalized anxiet*" or overanxious) adj3 (disorder* or neuroses or neurosis or neurotic or phobia* or phobic)) or ((anxiety or anxieties) adj3 (disorder* or neuroses or neurosis or neurotic)) or (panic adj3 (disorder* or attack*)) or Acrophobia* or agoraphobia* or claustrophobia* or homophobia* or neophobia* or Ophidiophobia* or phobia* or phobic or "separation anxiet*" or xenophobia*).mp.

11 exp Psychotherapy/

12 exp Electroconvulsive Shock Therapy/

13 exp Electroconvulsive Therapy/

14 exp brain depth stimulation/

15 exp Deep Brain Stimulation/

16 exp transcranial magnetic stimulation/

17 exp Vagus Nerve/

18 exp Vagus Nerve Stimulation/

19 exp electrostimulation therapy/

20 exp Electric Stimulation Therapy/

21 exp electrical brain stimulation/

22 exp alternative medicine/

23 exp phototherapy/
Results

9492

13722

7765

5422

3954

5441

724

425

2415

244817

20518

27336

30937

39654

34619

40508

9498

181773

254786

38192

268544

102362 
((brain adj2 excitation) or (brain adj2 stimulat*) or "12 step program*" or abreaction or acupressure* or acupuncture or "age regression" or agent* or "alternative medicine" or aromatherap* or Aromatherapy or auriculotherap* or "Balint group*" or "behavior contracting" or "behavior modification" or bibliotherapy or biofeedback or "breathing exercise*" or catharsis or chemotherap* or Chronotherapy or "cognitive rehabilitation" or "cognitive restructuring" or "combined modalit*" or "complementary medicine*" or "consciousness raising" or "contingency management" or cotherap* or counseling or countercondition* or Countertransference or "crisis intervention*" or Desensitization or drug* or "electric stimulat*" or "electrical stimulat*" or Electroacupuncture or electrosleep or electrostimulat* or electrotherap* or "empty chair" or exercise or fading or "fatty acid*" or "flower remed*" or "free association*" or gestalt or "group development" or "group dynamics" or "group intervention*" or heliotherap* or holistic or homeopathy or "human potential*" or humanis* or hypnosis or Hypnotherapy or imagery or intervention* or kinesiotherap* or kinesitherap* or Logotherapy or manag* or massage or medication* or "mental healing" or microbicid* or "mind-body" or neurofeedback or neurosurger* or operat* or overcorrection or "paradoxical technique*" or pharmacotherap* or phototherap* or phytotherap* or prevent* or Psychoanaly* or psychodrama or psychodrama* or psychotherap* or Psychotherapeutic* or radiotherap* or reflexotherap* or relaxation or resect* or "response cost" or "role play*" or "role playing" or "sensory feedback" or sociotherapy or spiritual* or "stress management" or suggestion* or "support group*" or surg* or "tai ji" or therap* or "therapeutic communit*" or "therapeutic touch*" or therapies or therapy or timeout* or training or "Transactional Analysis" or "transcranial magnetic stimulat*" or transference or treat* or treatment* or "twelve step program*" or "vagal nerve" or "vagal stimulat*" or "vagus nerve" or "vagus stimulat*" or yoga).mp.

32 or $/ 11-31$

29519244 168615 37562 170412

3533 or 34 140150 Embase,PsycINFO,CCTR,CDSR; records were retained] limit 36 to (childhood or adolescence $<13$ to 17 years $>$ ) [Limit not valid in Embase,Ovid MEDLINE(R),Ovid MEDLINE(R) In-Process,CCTR,CDSR; 
records were retained]

limit 37 to (preschool child $<1$ to 6 years $>$ or school child $<7$ to 12 years $>$ or

38 adolescent $<13$ to 17 years $>$ ) [Limit not valid in Ovid MEDLINE(R),Ovid

34306

MEDLINE(R) In-Process,PsycINFO,CCTR,CDSR; records were retained]

(toddler* or child* or adolescent* or paediatric* or pediatric* or girl or girls or

39 boy or boys or teen or teens or teenager* or preschooler* or "pre-schooler*" or preteen or preteens or "pre-teen" or "pre-teens" or youth or youths).mp.

$40 \quad 35$ and 39

6640078

41 from 38 keep 1-26193

41617

26193

4240 or 41

42800

43 exp meta analysis/

234764

44 exp Meta-Analysis as Topic/

53463

45 exp "systematic review"/

153050

46 ((meta adj analys*) or (systematic* adj3 review*)).mp,pt.

550689

4743 or 44 or 45 or 46

550689

48 exp controlled study/

5658493

49 exp Randomized Controlled Trial/

905465

50 exp triple blind procedure/

204

51 exp Double-Blind Method/

390501

52 exp Single-Blind Method/

68129

53 exp latin square design/

570

((control* adj3 study) or (control* adj3 trial) or (randomized adj3 study) or (randomized adj3 trial) or (randomised adj3 study) or (randomised adj3 trial) or

54 "pragmatic clinical trial" or (doubl* adj blind*) or (doubl* adj mask*) or (singl*

7148487 adj blind*) or (singl* adj mask*) or (tripl* adj blind*) or (tripl* adj mask*) or (trebl* adj blind*) or (trebl* adj mask*) or "latin square").mp,pt.

55 or $/ 48-54$

7148556

56 controlled study/

5390344

57 exp comparative study/

2718783

58 exp Cross-Sectional Studies/

447921

59 exp Cohort Studies/

2043883

60 exp longitudinal study/

327400

61 exp retrospective study/

1141189

62 exp prospective study/

905077

63 exp population research/

90005

64 exp observational study/

158991

65 clinical study/

223234

66 exp Evaluation Studies/

259715

67 exp quantitative study/

59289

68 exp validation studies/

146273 
71 in vivo study/

73 exp prevention study/

((control* adj3 study) or "comparative study" or "comparative survey" or "comparative analysis" or "cross-sectional study" or "cross-sectional analysis" or "cross-sectional survey" or "cross-sectional design" or "prevalence study" or "prevalence analysis" or "prevalence survey" or "disease frequency study" or "disease frequency analysis" or "disease frequency survey" or cohort* or longitudinal* or retrospectiv* or prospectiv* or (population adj3 (stud* or survey* or analys* or research)) or (("follow-up" or followup) adj (stud* or survey or analysis)) or ((observation or observational) adj (study or survey or analysis)) or "clinical study" or "evaluation study" or "evaluation survey" or "evaluation analysis" or "quantitative study" or "quantitative analys*" or "numerical study" or "validation study" or "validation survey" or "validation analysis" or "quasi experimental study" or "quasi experimental analysis" or "quasiexperimental study" or "quasiexperimental analysis" or "field study" or "field survey" or "field analysis" or "in vivo study" or "in vivo analysis" or "panel study" or "panel survey" or "panel analysis" or ((prevention or preventive) adj3 (trial or study or analysis or survey)) or "replication study" or "replication analysis " or "replication trial" or "feasibility study" or "feasibility analysis" or "trend study" or "trend survey" or "trend analysis" or ((correlation* adj2 study) or (correlation* adj2 analys*)) or "case control study" or "case base study" or "case referrent study" or "case referent study" or "case referent study" or "case compeer study" or "case comparison study" or "matched case control" or "confidence interval" or "regression analysis" or "least square" or "least squares" or (hazard* adj (model or analys* or regression or ratio or ratios)) or "Cox model" or "Cox multivariate analyses" or "Cox multivariate analysis" or "Cox regression" or "Cox survival analyses" or "Cox survival analysis" or "Cox survival model" or ((study or trial or random* or control*) and compar*)).mp,pt.

83 or $/ 56-82$ 
limit 86 to (clinical study or clinical trial, all or clinical trial, phase i or clinical trial, phase ii or clinical trial, phase iii or clinical trial, phase iv or clinical trial or controlled clinical trial or multicenter study or observational study or randomized controlled trial or pragmatic clinical trial or comparative study or controlled clinical trial or evaluation studies or meta analysis or multicenter study or observational study or randomized controlled trial or pragmatic clinical trial or systematic reviews or validation studies) [Limit not valid in Embase,PsycINFO,CCTR,CDSR; records were retained]

8885 or 87

limit 88 to (editorial or erratum or letter or note or addresses or autobiography or bibliography or biography or blogs or comment or dictionary or directory or interactive tutorial or interview or lectures or legal cases or legislation or news or newspaper article or overall or patient education handout or periodical index or portraits or published erratum or video-audio media or webcasts) [Limit not valid in Embase,Ovid MEDLINE(R),Ovid MEDLINE(R) InProcess,PsycINFO,CCTR,CDSR; records were retained]

90 from 89 keep 1-234

9188 not 90

92 limit 91 to $\mathrm{yr}=" 2015$-Current"

93 remove duplicates from 92

94 limit 91 to $\mathrm{yr}=" 2012-2014 "$

95 remove duplicates from 94

96 limit 91 to $\mathrm{yr}=" 2008-2011 "$

97 remove duplicates from 96

98 limit 91 to $\mathrm{yr}=" 2001-2007 "$

99 remove duplicates from 98

100 limit 91 to $\mathrm{yr}=" 1806-2000 "$

$\underline{\text { Scopus }}$

1 TITLE-ABS-KEY((("social anxiet*" or "generalized anxiet*" or overanxious) W/3 (disorder* or neuroses or neurosis or neurotic or phobia* or phobic)) OR ((anxiety or anxieties) W/3 (disorder* or neuroses or neurosis or neurotic)) OR (panic W/3 (disorder* or attack*)) OR Acrophobia* OR agoraphobia* OR claustrophobia* OR homophobia* OR neophobia* OR Ophidiophobia* OR phobia* OR phobic OR "separation anxiet*" OR xenophobia*)

2 TITLE-ABS-KEY((brain W/2 excitation) or (brain W/2 stimulat*) or "12 step program*" or abreaction or acupressure* or acupuncture or "age regression" or agent* or "alternative medicine" or aromatherap* or Aromatherapy or auriculotherap* or "Balint group*" or "behavior contracting" or "behavior modification" or bibliotherapy or biofeedback or 
"breathing exercise*" or catharsis or chemotherap* or Chronotherapy or "cognitive rehabilitation" or "cognitive restructuring" or "combined modalit*" or "complementary medicine*" or "consciousness raising" or "contingency management" or cotherap* or counseling or countercondition* or Countertransference or "crisis intervention*" or Desensitization or drug* or "electric stimulat*" or "electrical stimulat*" or

Electroacupuncture or electrosleep or electrostimulat* or electrotherap* or "empty chair" or exercise or fading or "fatty acid*" or "flower remed*" or "free association*" or gestalt or "group development" or "group dynamics" or "group intervention*" or heliotherap* or holistic or homeopathy or "human potential*" or humanis* or hypnosis or Hypnotherapy or imagery or intervention* or kinesiotherap* or kinesitherap* or Logotherapy or manag* or massage or medication* or "mental healing" or microbicid* or "mind-body" or neurofeedback or neurosurger* or operat* or overcorrection or "paradoxical technique*" or pharmacotherap* or phototherap* or phytotherap* or prevent* or Psychoanaly* or psychodrama or psychodrama* or psychotherap* or Psychotherapeutic* or radiotherap* or reflexotherap* or relaxation or resect* or "response cost" or "role play*" or "role playing" or "sensory feedback" or sociotherapy or spiritual* or "stress management" or suggestion* or "support group*" or surg* or "tai ji" or therap* or "therapeutic communit*" or "therapeutic touch*" or therapies or therapy or timeout* or training or "Transactional Analysis" or "transcranial magnetic stimulat*" or transference or treat* or treatment* or "twelve step program*" or "vagal nerve" or "vagal stimulat*" or "vagus nerve" or "vagus stimulat*" or yoga)

3 TITLE-ABS-KEY(newborn* or neonat* or infant* or toddler* or child* or adolescent* or paediatric* or pediatric* or girl or girls or boy or boys or teen or teens or teenager* or preschooler* or "pre-schooler*" or preteen or preteens or "pre-teen" or "pre-teens" or youth or youths)

4 TITLE-ABS-KEY((meta W/1 analys*) OR (systematic* W/3 review*) OR guideline* OR (control* W/3 study) OR (control* W/3 trial) OR (randomized W/3 study) OR (randomized W/3 trial) OR (randomised W/3 study) OR (randomised W/3 trial) OR "pragmatic clinical trial" OR (doubl* W/1 blind*) OR (doubl* W/1 mask*) OR (singl* W/1 blind*) OR (singl* W/1 mask*) OR (tripl* W/1 blind*) OR (tripl* W/1 mask*) OR (trebl* W/1 blind*) OR (trebl* W/1 mask*) OR "latin square" OR placebo* OR nocebo*)

5 TITLE-ABS-KEY((control* W/3 study) OR "comparative study" OR "comparative survey" OR "comparative analysis" OR "cross-sectional study" OR "cross-sectional analysis" OR "cross-sectional survey" OR "cross-sectional design" OR "prevalence study" OR "prevalence analysis" OR "prevalence survey" OR "disease frequency study" OR "disease frequency analysis" OR "disease frequency survey" OR cohort* OR longitudinal* OR retrospectiv* OR prospectiv* OR (population W/3 (stud* or survey* or analys* or research)) OR (("follow-up" or followup) W/1 (stud* or survey or analysis)) OR ((observation or observational) W/1 (study or survey or analysis)) OR "clinical study" OR "evaluation study" OR "evaluation survey" OR "evaluation analysis" OR "quantitative 
study" OR "quantitative analys*" OR "numerical study" OR "validation study" OR "validation survey" OR "validation analysis" OR "quasi experimental study" OR "quasi experimental analysis" OR "quasiexperimental study" OR "quasiexperimental analysis" OR "field study" OR "field survey" OR "field analysis" OR "in vivo study" OR "in vivo analysis" OR "panel study" OR "panel survey" OR "panel analysis" OR ((prevention or preventive) W/3 (trial or study or analysis or survey)) OR "replication study" OR "replication analysis " OR "replication trial" OR "feasibility study" OR "feasibility analysis" OR "trend study" OR "trend survey" OR "trend analysis" OR ((correlation* W/2 study) OR (correlation* W/2 analys*)) OR "case control study" OR "case base study" OR "case referrent study" OR "case referent study" OR "case referent study" OR "case compeer study" OR "case comparison study" OR "matched case control" OR "confidence interval" OR "regression analysis" OR "least square" OR "least squares" OR (hazard* W/1 (model OR analys* OR regression or ratio or ratios)) OR "Cox model" OR "Cox multivariate analyses" OR "Cox multivariate analysis" OR "Cox regression" OR "Cox survival analyses" OR "Cox survival analysis" OR "Cox survival model" OR ((study OR trial OR random* OR control*) AND compar*))

$6 \quad 1$ and 2 and 3 and (4 or 5 )

7 DOCTYPE(le) OR DOCTYPE(ed) OR DOCTYPE(bk) OR DOCTYPE(er) OR DOCTYPE(no) OR DOCTYPE(sh)

86 and not 7

$9 \quad \mathrm{PMID}\left(0^{*}\right)$ OR PMID(1*) OR PMID(2*) OR PMID(3*) OR PMID(4*) OR PMID(5*) OR $\operatorname{PMID}\left(6^{*}\right)$ OR PMID(7*) OR PMID(8*) OR PMID(9*)

$10 \quad 8$ and not 9

\section{ClinicalTrials.Gov}

Open Studies | anxiety OR overanxious OR phobia OR acrophobia OR agoraphobia OR claustrophobia OR homophobia OR neophobia OR ophidiophobia OR xenophobia | Child Active, not recruiting | anxiety OR overanxious OR phobia OR acrophobia OR agoraphobia OR claustrophobia OR homophobia OR neophobia OR ophidiophobia OR xenophobia | Child Enrolling by invitation | anxiety OR overanxious OR phobia OR acrophobia OR agoraphobia OR claustrophobia OR homophobia OR neophobia OR ophidiophobia OR xenophobia | Child

\section{Health Canada}

Any of these words: anxiety overanxious phobia acrophobia agoraphobia claustrophobia homophobia neophobia ophidiophobia xenophobia

All of these words: child

Any of these words: anxiety overanxious phobia acrophobia agoraphobia claustrophobia homophobia neophobia ophidiophobia xenophobia

All of these words: children

Any of these words: anxiety overanxious phobia acrophobia agoraphobia claustrophobia homophobia neophobia ophidiophobia xenophobia

All of these words: adolescent 
Any of these words: anxiety overanxious phobia acrophobia agoraphobia claustrophobia homophobia neophobia ophidiophobia xenophobia

All of these words: teen

Medicines and Healthcare Products Regulatory Agency

Any of these words: anxiety overanxious phobia acrophobia agoraphobia claustrophobia homophobia neophobia ophidiophobia xenophobia

\section{AHRQ’s Horizon Scanning System}

Anxiety OR overanxious OR phobia OR acrophobia OR agoraphobia OR claustrophobia OR homophobia OR neophobia OR ophidiophobia OR xenophobia 


\section{Appendix C. Criteria for Inclusion/Exclusion of Studies}

Table C.1. Inclusion and exclusion criteria

\begin{tabular}{|c|c|c|}
\hline PICOTS Elements & Inclusion Criteria & Exclusion Criteria \\
\hline Populations & $\begin{array}{l}\text { Humans } \\
\text { Children and adolescents between } 3 \\
\text { and } 18 \text { years old } \\
\text { Patients with confirmed diagnosis of } \\
\text { panic disorder, social anxiety disorder, } \\
\text { specific phobias, generalized anxiety } \\
\text { disorder, or separation anxiety }\end{array}$ & $\begin{array}{l}\text { Animals } \\
\text { Adults (age }>=18 \text { years) } \\
\text { Infants (age }<3 \text { years) } \\
\text { Patients without confirmed diagnosis } \\
\text { of panic disorder, social anxiety } \\
\text { disorder, specific phobias, generalized } \\
\text { anxiety disorder, or separation anxiety }\end{array}$ \\
\hline Interventions & $\begin{array}{l}\text { Any psychotherapy, } \\
\text { pharmacotherapy, alone or } \\
\text { combined: } \\
\text { Pharmacological treatments will } \\
\text { include all formulations of: } \\
\text { Selective reuptake inhibitor (SRI): } \\
\text { Citalopram (Celexa), Escitalopram } \\
\text { (Lexapro), Fluoxetine (Prozac), } \\
\text { Fluvoxamine (Luvox), Paroxetine } \\
\text { (Paxil), Sertraline (Zoloft) } \\
\text { Serotonin-norepinephrine reuptake } \\
\text { inhibitors (SNRI): Desvenlafaxine } \\
\text { (Pristiq), Duloxetine (Cymbalta), } \\
\text { Venlafaxine (Effexor) } \\
\text { Tricyclic antidepressants (TCA): } \\
\text { Amiptriptyline or Nortriptyline (Elavil or } \\
\text { Aventyl HCI), Clomipramine } \\
\text { (Anafranil) } \\
\text { Benzodiazepines: Alprazolam (Xanax, } \\
\text { Niravam), Clonazepam (Klonopin), } \\
\text { Lorazepam (Ativan) } \\
\text { Atypical Antipsychotics: Aripiprazole } \\
\text { (Abilify), } \\
\text { Olanzapine (Zyprexa Zydis), } \\
\text { Quetiapine (Seroquel), } \\
\text { Risperidone (Risperdal), } \\
\text { Ziprasidone (Geodon, Zeldox, or } \\
\text { Zipwell) } \\
\text { Monoamine oxidase inhibitor: } \\
\text { Phenelzine (Nardil) } \\
\text { Others: Bupropion (Wellbutrin), } \\
\text { Mirtazapine (Remeron), D-Cycloserine } \\
\text { (Seromycin), N-Acetylcysteine, } \\
\text { Methylphenidate (Ritalin, Daytrana, } \\
\text { Concerta, Methylin, or Aptensio), } \\
\text { Riluzole (Rilutek), Buspirone (Buspar), } \\
\text { Propranolol (Inderal, Hemangeol, or } \\
\text { Innopran), Prazosin (Minipress), } \\
\text { Cyproheptadine (Periactin or Peritol), } \\
\text { Carbamazepine (Tegretol, Carbatrol, } \\
\text { Equetro, or Epitol), Divalproex (Alti- } \\
\text { Valproic, Depakote, Depakote DR, } \\
\text { Depakote ER, or Depakote Sprinkles) } \\
\text { Psychotherapies: } \\
\text { Cognitive and behavioral therapies } \\
\text { (CBT) } \\
\text { Exposure Therapy/Systematic } \\
\text { Desensitization }\end{array}$ & None \\
\hline
\end{tabular}




\begin{tabular}{|c|c|c|}
\hline PICOTS Elements & Inclusion Criteria & Exclusion Criteria \\
\hline & $\begin{array}{l}\text { Contingency Management Exposure } \\
\text { Therapy } \\
\text { Self-Control Exposure Therapy } \\
\text { Family Focused Cognitive Behavior } \\
\text { Therapy } \\
\text { Child Focused Cognitive Behavior } \\
\text { Therapy } \\
\text { Parent Child Interaction Therapy } \\
\text { Problem solving therapy (PST) } \\
\text { Third wave (Mindfulness) therapies } \\
\text { Acceptance and Commitment Therapy } \\
\text { Mindfulness Based Cognitive } \\
\text { Therapy/Mindfulness Based Stress } \\
\text { Reduction } \\
\text { Psychodynamic psychotherapy } \\
\text { Interpersonal psychotherapy (IPT) } \\
\text { Play therapy } \\
\text { Family therapy } \\
\text { Behavioral Systems Family therapy } \\
\text { Narrative Family Therapy } \\
\text { Solution Focused Family Therapy } \\
\text { Strategic Family Therapy } \\
\text { Attention modification program } \\
\text { Motivational interviewing } \\
\text { Eye movement desensitization } \\
\text { reprocessing therapy (EMDR) } \\
\text { Complementary psychotherapy } \\
\text { techniques } \\
\text { Exercise } \\
\text { Biofeedback } \\
\text { Relaxation Therapies } \\
\text { Progressive muscle relaxation } \\
\text { Diaphramatic breathing } \\
\text { Visualization } \\
\text { Meditation techniques } \\
\text { Hypnosis } \\
\text { Or any combined of the listed } \\
\text { treatment }\end{array}$ & \\
\hline Comparators & Other treatment or no treatment & None \\
\hline Outcomes & $\begin{array}{l}\text { KQ 1: } \\
\text { Intermediate outcomes: Standardized } \\
\text { measures (child, parent, school, and } \\
\text { clinician report) such as the Screen for } \\
\text { Anxiety-Related Emotional Disorders } \\
\text { (SCARED), the Revised Children's } \\
\text { Manifest Anxiety Scale (RCMAS), the } \\
\text { Beck Anxiety Inventory, the } \\
\text { Multidimensional Anxiety Scale for } \\
\text { Children (MASC), the Liebowitz Social } \\
\text { Anxiety Scale, the Social Phobia and } \\
\text { Anxiety Inventory for Children, the } \\
\text { Spence Children's Anxiety Scale } \\
\text { (child and parent report) (SCAS), Fear } \\
\text { Survey Schedule for Children - } \\
\text { Revised, Stait Trait Anxiety Inventory - } \\
\text { Child (STAIC), Anxiety Disorder } \\
\text { Interview Schedule - Child report, } \\
\text { Pediatric Anxiety Rating Scale } \\
\text { (PARS), Child Behavior Checklist } \\
\text { (CBCL), Revised Child Anxiety and } \\
\text { Depression Scale (RCADS), Pre- }\end{array}$ & None \\
\hline
\end{tabular}




\begin{tabular}{|c|c|c|}
\hline PICOTS Elements & Inclusion Criteria & Exclusion Criteria \\
\hline & $\begin{array}{l}\text { School Anxiety Scale, Clinical Global } \\
\text { Impression Scale (CGI), Children's } \\
\text { Anxiety Meter-State (CAM-S) } \\
\text { Patient centered outcomes: } \\
\text { Remission, relapse, anxiety } \\
\text { symptoms, behavioral problems } \\
\text { (Behavior Assessment System for } \\
\text { Children, Achenbach Child Behavior } \\
\text { Checklist), parental overprotection, } \\
\text { accommodation, parent distress, } \\
\text { therapeutic alliance, school } \\
\text { attendance, reduction in impairment } \\
\text { (Child Sheehan Disability Scale), } \\
\text { quality of life (Multidimensional Child } \\
\text { Health Questionnaire, and Youth } \\
\text { Quality of Life Instrument - Research } \\
\text { Version), avoiding hospitalization, } \\
\text { length of treatment, availability of } \\
\text { treatment, peer relationship, functional } \\
\text { impairment (Child Anxiety Impact } \\
\text { Scale (CAIS), Children's Global } \\
\text { Assessment Scale (CGAS), and Child } \\
\text { Anxiety Life Interference Scale } \\
\text { (CALIS)), avoidance behavior in } \\
\text { children. } \\
\text { KQ 2: } \\
\text { Safety outcomes such as incidence of } \\
\text { any adverse events, GI adverse } \\
\text { effects/discomfort, withdrawal } \\
\text { symptoms, dropouts due to adverse } \\
\text { events, neurological complaints, } \\
\text { increase motor activity, suicidal } \\
\text { ideation, homicidal behavior, } \\
\text { treatment emergent suicidality, } \\
\text { addiction, self-injurious behaviors, } \\
\text { activation issues (e.g. sleep, motor } \\
\text { activity), agitation, akathisia, mania, } \\
\text { aggression, and psychosis. }\end{array}$ & \\
\hline Timing & Any & None \\
\hline Settings & Any & None \\
\hline Study design & $\begin{array}{l}\text { Original data } \\
\text { Any sample size } \\
\text { RCTs, nonrandomized comparative } \\
\text { studies (prospective and } \\
\text { retrospective) } \\
\text { Relevant systematic reviews, or meta- } \\
\text { analyses (used for identifying } \\
\text { additional studies) }\end{array}$ & $\begin{array}{l}\text { In vitro studies } \\
\text { Non-original data (e.g. narrative } \\
\text { reviews, editorials, letters, or erratum) } \\
\text { Non-comparative observational } \\
\text { studies, case series }\end{array}$ \\
\hline Publications & Any & None \\
\hline
\end{tabular}

$\mathrm{KQ}$ = key question; PICOTS = populations, interventions, comparators, outcomes, timing, and settings; RCT = randomized controlled trial 


\section{Appendix D. Excluded Studies}

1. Al-Namankany A, Petrie A, Ashley P. Video modelling and reducing anxiety related to dental injections a randomised clinical trial. $\mathrm{Br}$ Dent J. 2014 Jun;216(12):675-9. doi: 10.1038/sj.bdj.2014.497 PMID: 24970519. The study does not have children with anxiety (3-18 yrs).

2. Alfano CA, Pina AA, Villalta IK, et al. Mediators and moderators of outcome in the behavioral treatment of childhood social phobia. J Am Acad Child Adolesc Psychiatry. 2009 Sep;48(9):945-53. doi: 10.1097/CHI.0b013e3181af8216 PMID: 19625981.The study is not a comparative study (case reports only included for side effects/ harms).

3. Anbar RD, Hummell KE. Teamwork approach to clinical hypnosis at a pediatric pulmonary center.

American Journal of Clinical Hypnosis. 2005;48(1):45-9 doi:10.1080/00029157.2005.104014 89 PMID: 2005408928. The study does not have children with anxiety (3-18 yrs).

4. Anderson RE, Spence SH, Donovan $\mathrm{CL}$, et al. Working alliance in online cognitive behavior therapy for anxiety disorders in youth: comparison with clinic delivery and its role in predicting outcome. J Med Internet Res. 2012 Jun 28;14(3):e88. doi:10.1080/00029157.2005.104014 89 PMID: 2012-32354-008. The study does not report anxiety outcomes (symptom severity and scales, behavioral outcomes, adverse effects, etc).
5. Andrzejewska E, Bogucka A, Losiowski Z. [Effectiveness of psychotherapy in the treatment of adolescents]. Psychiatr Pol. 1979 JulAug;13(4):373-6 PMID: 515252. Other reason for exclusion.

6. Araya R, Fritsch R, Spears M, et al. School intervention to improve mental health of students in Santiago, Chile: a randomized clinical trial. JAMA Pediatr. 2013 Nov;167(11):1004-10. doi: 10.1001/jamapediatrics.2013.2361 PMID: 2013761184. The study does not have children with anxiety (3-18 yrs).

7. Attwood M, Meadows S, Stallard P, et al. Universal and targeted computerised cognitive behavioural therapy (Think, Feel, Do) for emotional health in schools: Results from two exploratory studies. Child and Adolescent Mental Health.

2012;17(3):173-8

doi:10.1111/j.14753588.2011.00627.x. PMID: WOS:000306402400008. The study does not have children with anxiety (3-18 yrs).

8. Aydin A, Tekinsav-Sütçü S, Sorias O. Evaluation of the effectiveness of a cognitive-behavioral therapy program for alleviating the symptoms of social anxiety in adolescents. Turk Psikiyatri Dergisi. 2010;21(1):1. PMID: 20204902. Turkish study. 
9. Bar-Haim Y, Morag I, Glickman S.

Training anxious children to

disengage attention from threat: a

randomized controlled trial. J Child

Psychol Psychiatry. 2011

Aug;52(8):861-9. doi:

10.1111/j.1469-7610.2011.02368.x

PMID: 21250993.The study does not

have children with anxiety (3-18

yrs).

10. Barnes VA, Johnson MH, Williams

$\mathrm{RB}$, et al. Impact of Williams

Lifeskills(R) Training on Anger, Anxiety and Ambulatory Blood Pressure in Adolescents. Transl Behav Med. 2012 Dec 01;2(4):401-

10. doi: 10.1007/s13142-012-0162-3

PMID: 23482659. The study does not have children with anxiety (3-18 yrs).

11. Barrett PM, Duffy AL, Dadds MR, et al. Cognitive-behavioral treatment of anxiety disorders in children: long-term (6-year) follow-up. J Consult Clin Psychol. 2001 Feb;69(1):135-41. PMID: 11302272. Other reason.

12. Barrett, P M, Lock, et al. Developmental differences in universal preventive intervention for child anxiety. Clinical Child Psychology and Psychiatry. 2005 October;10(4):539-55. doi: 10.1177/1359104505056317. The study does not have children with anxiety (3-18 yrs).
13. Barrett, P M, Sonderegger, et al. Using FRIENDS to combat anxiety and adjustment problems among young migrants to Australia: A national trial. Clinical Child Psychology and Psychiatry. 2003 April;8(2):241-60. doi: 10.1177/1359104503008002008. The study does not have children with anxiety (3-18 yrs).

14. Barrington, J, Prior, et al. Effectiveness of CBT versus standard treatment for childhood anxiety disorders in a community clinic setting. Behaviour Change. 2005;22(1):29-43. doi:10.1375/bech.22.1.29.66786. Other reason.

15. Baumgartner JL, Emslie GJ, Crismon ML. Citalopram in children and adolescents with depression or anxiety. Ann Pharmacother. 2002 Nov;36(11):1692-7. doi:10.1345/aph.1C078 PMID: 12398561. The study does not have children with anxiety (3-18 yrs).

16. Becker, Emily M, Becker, et al. Modular cognitive behavioral therapy for youth with anxiety disorders: A closer look at the use of specific modules and their relation to treatment process and response. School Mental Health. 2012 Dec;4(4):243-53. doi:10.1007/s12310-012-9080-2. The study is not a comparative study (case reports only included for side effects/ harms).

17. Beidel DC, Turner SM, Young BJ. Social effectiveness therapy for children: five years later. Behav Ther. 2006 Dec;37(4):416-25. doi: 10.1016/j.beth.2006.06.002 PMID: 17071218. Other reason. 
18. Beidel DC, Turner SM, Young B, et al. Social effectiveness therapy for children: three-year follow-up. J Consult Clin Psychol. 2005 Aug;73(4):721-5. doi:10.1037/0022006X.73.4.721 PMID: 16173859.

The study is not a comparative study (case reports only included for side effects/ harms).

19. Benjamin CL, Harrison JP, Settipani $\mathrm{CA}$, et al. Anxiety and related outcomes in young adults 7 to 19 years after receiving treatment for child anxiety. J Consult Clin Psychol. 2013 Oct;81(5):865-76. doi: 10.1037/a0033048 PMID: 23688146. The study is not a comparative study (case reports only included for side effects/ harms).

20. Benjamin CL, O'Neil KA, Crawley SA, et al. Patterns and predictors of subjective units of distress in anxious youth. Behav Cogn Psychother. 2010 Jul;38(4):497-504. doi:10.1017/S1352465810000287 PMID: 20509987. The study is not a comparative study (case reports only included for side effects/ harms).

21. Berg I, Fielding D. An evaluation of hospital in-patient treatment in adolescent school phobia. Br J Psychiatry. 1978 May;132:500-5. doi: 10.1192/bjp.132.5.500 PMID:656715.The study does not include any of the interventions listed above (pharmacotherapy or psychotherapy)
22. Berman, S L, Weems, et al. Predictors of outcome in exposurebased cognitive and behavioral treatments for phobic and anxiety disorders in children. Behavior Therapy. 2000;31(4):713-31. doi:10.1016/S0005-7894(00)800404. The study does not report anxiety outcomes (symptom severity and scales, behavioral outcomes, adverse effects, etc).

23. Berney T, Kolvin I, Bhate SR, et al. School phobia: a therapeutic trial with clomipramine and short-term outcome. Br J Psychiatry. 1981 Feb;138:110-8. doi:10.1192/bjp.138.2.110 PMID: 7020816. The study does not have children with anxiety (3-18 yrs).

24. Bernstein GA, Anderson LK, Hektner JM, et al. Imipramine compliance in adolescents. J Am Acad Child Adolesc Psychiatry. 2000 Mar;39(3):284-91. doi:10.1097/00004583-20000300000009 PMID: 10714047. The study is not a comparative study (case reports only included for side effects/ harms).

25. Bernstein GA, Hektner JM, Borchardt CM, et al. Treatment of school refusal: one-year follow-up. J Am Acad Child Adolesc Psychiatry. 2001 Feb;40(2):206-13. doi:10.1097/00004583-20010200000015 PMID: 11211369.The study does not have children with anxiety (3-18 yrs). 
26. Bernstein GA, Bernat DH, Victor AM, et al. School-based interventions for anxious children: 3, 6-, and 12-month follow-ups. J Am Acad Child Adolesc Psychiatry. 2008 Sep;47(9):1039-47. doi:10.1097/CHI.ob013e31817eecco PMID: 18665000. The study does not have children with anxiety (3-18 yrs).

27. Bernstein GA, Layne AE, Egan EA, et al. School-based interventions for anxious children. J Am Acad Child Adolesc Psychiatry. 2005 Nov;44(11):1118-27. doi:10.1097/01.chi.0000177323.400 05.a1 PMID: 16239860. The study does not have children with anxiety (3-18 yrs).

28. Berry K, Hunt CJ. Evaluation of an Intervention Program for Anxious Adolescent Boys Who Are Bullied at School. Journal of Adolescent Health. 2009 Oct;45(4):376-82. doi:10.1016/j.jadohealth.2009.04.02 3 PMID: 19766942. The study does not have children with anxiety (3-18 yrs).

29. Bilek EL, Ehrenreich-May J. An open trial investigation of a transdiagnostic group treatment for children with anxiety and depressive symptoms. Behav Ther. 2012 Dec;43(4):887-97. doi:10.1016/j.beth.2012.04.007 PMID: 23046789. The study is not a comparative study (case reports only included for side effects/ harms).
30. Bjaastad JF, Haugland BS, Fjermestad KW, et al. Competence and Adherence Scale for Cognitive Behavioral Therapy (CAS-CBT) for anxiety disorders in youth: Psychometric properties. Psychol Assess. 2016 Aug;28(8):908-16. doi:10.1037/pas0000230 PMID:26460894 . The study does not report anxiety outcomes (symptom severity and scales, behavioral outcomes, adverse effects, etc).

31. Blagg NR, Yule W. The behavioural treatment of school refusal--a comparative study. Behav Res Ther. 1984;22(2):119-27. doi:10.1016/0005-7967(84)90100-1 PMID:6712554. The study does not have children with anxiety (3-18 yrs).

32. Blatter M, Judith, Schneider, et al. Cognitive behavioral therapy for children suffering from separation anxiety. Journal de Therapie Comportementale et Cognitive. 2011 Sep;21(3):84-9. doi:10.1016/j.jtcc.2011.07.011. The study is not original (commentaries, letters, etc.)

33. Bodden DH, Bögels SM, Nauta MH, et al. Child versus family cognitivebehavioral therapy in clinically anxious youth: an efficacy and partial effectiveness study. Journal of the American Academy of Child \& Adolescent Psychiatry. 2008;47(12):1384-94. doi:10.1097/CHI.0b013e318189148e PMID: 18981932. The study does not report anxiety outcomes (symptom severity and scales, behavioral outcomes, adverse effects, etc). 
34. Bogels SM, Siqueland L. Family cognitive behavioral therapy for children and adolescents with clinical anxiety disorders. J Am Acad Child Adolesc Psychiatry. 2006 Feb;45(2):134-41.

doi:10.1097/01.chi.0000190467.010 72.ee PMID: 16429083. The study is not a comparative study (case reports only included for side effects/ harms).

35. Byrne SP, Rapee RM, Richardson R, et al. D-cycloserine enhances generalization of fear extinction in children. Depress Anxiety. 2015 Jun;32(6):408-14. doi:10.1002/da.22356 PMID: 25775435. The study does not include any of the interventions listed above (pharmacotherapy or psychotherapy)

36. Calear AL, Batterham PJ, Poyser $\mathrm{CT}$, et al. Cluster randomised controlled trial of the e-couch Anxiety and Worry program in schools. J Affect Disord. 2016 May 15;196:210-7. doi:10.1016/j.jad.2016.02.049 PMID: 26926660. The study does not have children with anxiety (3-18 yrs).

37. Caporino, N E, Herres, et al. Dysregulation in Youth with Anxiety Disorders: Relationship to Acute and 7- to 19- Year Follow-Up Outcomes of Cognitive-Behavioral Therapy. Child Psychiatry and Human Development. 2015. doi:10.1007/s10578-015-0587-2 PMID: 26384978. Child Psychiatry and Human Development. 2015. The study is not a comparative study (case reports only included for side effects/ harms).
38. Caporino NE, Brodman DM, Kendall PC, et al. Defining treatment response and remission in child anxiety: signal detection analysis using the pediatric anxiety rating scale. J Am Acad Child Adolesc Psychiatry. 2013 Jan;52(1):57-67. doi:10.1016/j.jaac.2012.10.006 PMID: 23265634. The study does not report anxiety outcomes (symptom severity and scales, behavioral outcomes, adverse effects, etc).

39. Cederblad, M, Bodén, et al. Barnpsykiatrisk slutenvård i två iän reduktion av platsantalet $\mathrm{i}$ östergötland, effekt på klientelsammansättdng och vårdkonsumtion. Nordic Journal of Psychiatry. 1988;42(5):361-7.The study does not have children with anxiety (3-18 yrs).

40. Chambers, J A, Power, et al. Parental styles and long-term outcome following treatment for anxiety disorders. Clinical Psychology and Psychotherapy. 2004 May/June;11(3):187-98. doi:10.1002/cpp.406. Clinical Psychology and Psychotherapy. 2004 May/June;11(3):187-98.

PMID:2004453864. The study does not have children with anxiety (3-18 yrs).

41. Chutko LS, Surushkina S, Nikishena IS, et al. [Adaptol in the treatment of anxiety disorders in children with school maladaptation]. Zh Nevrol Psikhiatr Im S S Korsakova. 2010;110(2):45-9. doi:10.1007/s11055-011-9448-z PMID: 20436449 The study does not have children with anxiety (3-18 yrs). 
42. Clark DB, Birmaher B, Axelson D, et al. Fluoxetine for the treatment of childhood anxiety disorders: openlabel, long-term extension to a controlled trial. J Am Acad Child Adolesc Psychiatry. 2005

Dec;44(12):1263-70.

doi:10.1097/01.chi.0000183464.417

77.c1 PMID: 16292118. Other

reason.

43. Comer JS, Puliafico AC, Aschenbrand SG, et al. A pilot feasibility evaluation of the CALM Program for anxiety disorders in early childhood. J Anxiety Disord. 2012 Jan;26(1):409.doi:10.1016/j.janxdis.2011.08.011 PMID: 21917417. The study is not a comparative study (case reports only included for side effects/ harms).

44. Compton SN, Peris TS, Almirall D, et al. Predictors and moderators of treatment response in childhood anxiety disorders: results from the CAMS trial. J Consult Clin Psychol. 2014 Apr;82(2):212-24. doi:10.1037/a0035458 PMID: 24417601. The study does not report anxiety outcomes (symptom severity and scales, behavioral outcomes, adverse effects, etc).

45. Compton SN, Walkup JT, Albano AM, et al. Child/Adolescent Anxiety Multimodal Study (CAMS): rationale, design, and methods. Child Adolesc Psychiatry Ment Health. 2010 Jan 05;4:1.2010;4:1. doi: 10.1186/1753-2000-4-1 PMID: 20051130. The study does not report anxiety outcomes (symptom severity and scales, behavioral outcomes, adverse effects, etc).
46. Cooper, P J, Gallop, et al. Treatment response in child anxiety is differentially related to the form of maternal anxiety disorder. Behavioural and Cognitive Psychotherapy. 2008 January;36(1):41-8. doi:10.1017/S1352465807003943. The study does not report anxiety outcomes (symptom severity and scales, behavioral outcomes, adverse effects, etc).

47. Cotton, S, Luberto, et al.

Mindfulness-based cognitive therapy for youth with anxiety disorders at risk for bipolar disorder: a pilot trial. doi:10.1111/eip.12216

PMID:25582800 Early Intervention in Psychiatry. 2015. The study is not a comparative study (case reports only included for side effects/ harms).

48. Crawford AM, Manassis K. Familial predictors of treatment outcome in childhood anxiety disorders. J Am Acad Child Adolesc Psychiatry. 2001 Oct;40(10):1182-9. doi:10.1097/00004583-20011000000012 PMID: 11589531. The study is not a comparative study (case reports only included for side effects/ harms).

49. Crawley, S A, Beidas, et al. Treating socially phobic youth with CBT: Differential outcomes and treatment considerations. Behavioural and Cognitive Psychotherapy. 2008 July;36(4):379-89. doi:10.1017/S1352465808004542 . The study is not a comparative study (case reports only included for side effects/ harms). 
50. Crawley SA, Kendall PC, Benjamin CL, et al. Brief Cognitive-Behavioral Therapy for Anxious Youth: Feasibility and Initial Outcomes. Cogn Behav Pract. 2013 May 01;20(2):123-33. doi:10.1016/j.cbpra.2012.07.003 PMID:24244089. The study is not a comparative study (case reports only included for side effects/ harms).

51. Creswell C, Willetts L, Murray L, et al. Treatment of child anxiety: an exploratory study of the role of maternal anxiety and behaviours in treatment outcome. Clin Psychol Psychother. 2008 doi:10.1002/cpp.559

PMID:19115426. The study is not a comparative study (case reports only included for side effects/ harms).

52. Cummings CM, Caporino NE, Settipani CA, et al. The therapeutic relationship in cognitive-behavioral therapy and pharmacotherapy for anxious youth. J Consult Clin Psychol. 2013 Oct;81(5):859-64. doi:10.1037/a0033294

PMID:23750468. The study does not report anxiety outcomes (symptom severity and scales, behavioral outcomes, adverse effects, etc).

53. Cummings CM, Fristad MA. Anxiety in children with mood disorders: a treatment help or hindrance? J Abnorm Child Psychol. 2012 Apr;40(3):339-51. doi:10.1007/s10802-011-9568-5 PMID: 21912843. The study does not have children with anxiety (3-18 yrs).
54. Cunningham MJ, Wuthrich V. Examination of barriers to treatment and user preferences with computerbased therapy using the Cool Teens $\mathrm{CD}$ for adolescent anxiety. Sensoria: A Journal of Mind, Brain \& Culture. 2008;4(2):12-7 doi:10.7790/ejap.v4i2.115. The study does not report anxiety outcomes (symptom severity and scales, behavioral outcomes, adverse effects, etc).

55. Cunningham NR, Jagpal A, Tran ST, et al. Anxiety Adversely Impacts Response to Cognitive Behavioral Therapy in Children with Chronic Pain. J Pediatr. 2016 Apr;171:22733. doi:10.1016/j.jpeds.2016.01.018 PMID: 26879812. The study does not have children with anxiety (3-18 yrs).

56. Dadds MR, Holland DE, Laurens $\mathrm{KR}$, et al. Early intervention and prevention of anxiety disorders in children: results at 2-year follow-up. J Consult Clin Psychol. 1999 Feb;67(1):145-50. PMID:10028219. The study does not have children with anxiety (3-18 yrs).

57. Dadds MR, Spence SH, Holland DE, et al. Prevention and early intervention for anxiety disorders: a controlled trial. J Consult Clin Psychol. 1997 Aug;65(4):627-35. doi: 10.1037/0022-006X.65.4.627 PMID: 9256564. The study does not have children with anxiety (3-18 yrs).

58. Dadsetan, Parirokh, Anari, et al. Social anxiety disorders and dramatherapy. Journal of Iranian Psychologists. 2008;4(14):115-23. Persian study. 
59. Dahlstrom H, Fedor-Freybergh P, Kareland H, et al. Benzoctamine and medazepam in treatment of anxiety of children and adolescents: a comparative study. Acta Psychiatr Scand. 1973 Jul;49(6):735-43. doi:10.1111/j.16000447.1973.tb04462.x PMID:4592708. The study does not have children with anxiety (3-18 yrs).

60. De J, P J, Andrea, et al. Spider phobia in children: Disgust and fear before and after treatment. Behaviour Research and Therapy. 1997 June;35(6):559-62. doi:10.1016/S0005-7967(97)00002-8 PMID:9159980. The study is not a comparative study (case reports only included for side effects/ harms).

61. De Los R, Andres, Alfano, et al. Are the clinical characteristics of anxious youths participating in nontreatment-related research comparable to those of youths receiving treatment? Child \& Youth Care Forum. 2016 Apr:No Pagination Specified. doi:10.1007/s10566-016-9355-0. The study does not include any of the interventions listed above (pharmacotherapy or psychotherapy)

62. Díaz, Cristina. Evaluación y tratamiento cognitivo-conductual de un caso de fobia social. Psicologia. com. 1997;1(1). The study is not a comparative study (case reports only included for side effects/ harms).
63. Diomsina B, Vyciniene D. [Anxiety disorders in children and adolescents. Psychotherapeutic interventions]. Medicina (Kaunas). 2002;38(4):466-70.

PMID:12474798. The study does not have children with anxiety (3-18 yrs).

64. Diukova G, Vorob'eva O, Petrova E, et al. The efficacy of alprazolam in the therapy of panic disorders. Zhurnal nevrologii i psikhiatrii imeni SS Korsakova. 1995;95(4):9-13. PMID:8533521. Other reason for exclusion

65. Dour, H J, Chorpita, et al. Sudden gains as a long-term predictor of treatment improvement among children in community mental health organizations. Behaviour Research and Therapy. 2013 September;51(9):564-72. doi:10.1016/j.brat.2013.05.012 PMID:23856657. The study does not have children with anxiety (3-18 yrs).

66. Drahota A, Wood JJ, Sze KM, et al. Effects of cognitive behavioral therapy on daily living skills in children with high-functioning autism and concurrent anxiety disorders. J Autism Dev Disord. 2011 Mar;41(3):257-65. doi:10.1007/s10803-010-1037-4 PMID: 20508979. The study does not have children with anxiety (3-18 yrs).

67. Drtílková, I, Blažek, et al. Retrospective evaluation of the effect of sertraline in different indications in children and adolescents. Ceska a Slovenska Psychiatrie. 2001;97(4):157-61.The study does not have children with anxiety (3-18 yrs). 
68. Duan YE. [Treatment of child extensive anxiety disorder with catgut implantation of point plus western medicine]. Zhongguo Zhen Jiu. 2007 May;27(5):341-3. PMID:17645255. The study does not have children with anxiety (3-18 yrs).

69. Eckmann, F, Hoeppner, et al. Sulpiride treatment of children with behavior disturbances. Fortschritte der Medizin. 1975;93(9):464-5. The study does not have children with anxiety (3-18 yrs).

70. Eisen AR, Raleigh H, Neuhoff CC. The unique impact of parent training for separation anxiety disorder in children. Behav Ther. 2008 Jun;39(2):195-206. doi:10.1016/j.beth.2007.07.004 PMID:18502252. The study is not a comparative study (case reports only included for side effects/ harms).

71. Eisenberg L, Gilbert A, Cytryn L, et al. The effectiveness of psychotherapy alone and in confunction with perphenazine or placebo in the treatment of neurotic and hyperkinetic children. Am J Psychiatry. 1961 Jun;117:1088-93. doi:10.1176/ajp.117.12.1088 PMID:13726172. The study does not have children with anxiety (3-18 yrs).

72. Emslie, G J. Combination of cognitive behavioral therapy and sertraline is more effective than monotherapy for pediatric anxiety disorders. Journal of Pediatrics. 2009 May;154(5):775-6. doi:10.1016/j.jpeds.2009.02.045 PMID:19364568. Conference procceeding without full text.
73. Farrell, L J, Barrett, et al. Community trial of an evidencebased anxiety intervention for children and adolescents (the FRIENDS program): A pilot study. Behaviour Change. 2005;22(4):23648. doi:10.1375/bech.22.4.236 The study does not have children with anxiety (3-18 yrs).

74. Fathi A, A, Salimi, et al. Testanxiety in Iranian students: Cognitive therapy vs. systematic desensitisation. Archives of Medical Science. 2006 September;2(3):199204. The study does not have children with anxiety (3-18 yrs).

75. Festen H, Hartman CA, Hogendoorn $\mathrm{S}$, et al. Temperament and parenting predicting anxiety change in cognitive behavioral therapy: the role of mothers, fathers, and children. J Anxiety Disord. 2013 Apr;27(3):289-97. doi:10.1016/j.janxdis.2013.03.001 PMID:23602942. The study is not a comparative study (case reports only included for side effects/ harms).

76. Fitzgerald A, Rawdon C, Dooley B. A randomized controlled trial of attention bias modification training for socially anxious adolescents. Behav Res Ther. 2016 Sep;84:1-8. doi:10.1016/j.brat.2016.06.003 PMID: 27379745. Behaviour Research and Therapy. 2016;84:1-8. The study does not have children with anxiety (3-18 yrs). 
77. Fjermestad KW, Lerner MD, McLeod BD, et al. Therapist-youth agreement on alliance change predicts long-term outcome in CBT for anxiety disorders. J Child Psychol Psychiatry. 2016 May;57(5):625-32. doi:10.1111/jcpp.12485 PMID:26647901. The study is not a comparative study (case reports only included for side effects/ harms).

78. Forbes EE, Stepp SD, Dahl RE, et al. Real-world affect and social context as predictors of treatment response in child and adolescent depression and anxiety: an ecological momentary assessment study. J Child Adolesc Psychopharmacol. 2012 Feb;22(1):37-47. doi:10.1089/cap.2011.0085 PMID:22339611. The study does not have children with anxiety (3-18 yrs).

79. Fox E, Zougkou K, Ashwin C, et al. Investigating the efficacy of attention bias modification in reducing high spider fear: The role of individual differences in initial bias. Journal of behavior therapy and experimental psychiatry. 2015;49:84-93 doi:10.1016/j.jbtep.2015.05.001 PMID:26060177. The study does not have children with anxiety (3-18 yrs).
80. Fu X, Du Y, Au S, et al. Reducing negative interpretations in adolescents with anxiety disorders: a preliminary study investigating the effects of a single session of cognitive bias modification training. Dev Cogn Neurosci. 2013 Apr;4:2937. doi:10.1016/j.dcn.2012.11.003 PMID:23219491. The study does not report anxiety outcomes (symptom severity and scales, behavioral outcomes, adverse effects, etc).

81. Galla BM, Wood JJ, Chiu AW, et al. One year follow-up to modular cognitive behavioral therapy for the treatment of pediatric anxiety disorders in an elementary school setting. Child Psychiatry Hum Dev. 2012 Apr;43(2):219-26. doi:10.1007/s10578-011-0258-x PMID:21987227. The study is not a comparative study (case reports only included for side effects/ harms).

82. Garcia L, L J, Olivares, et al. A pilot study on sensitivity of outcome measures for treatments of generalized social phobia in Spanish adolescents. International journal of clinical and health psychology. 2005;5(2):385-92. The study does not report anxiety outcomes (symptom severity and scales, behavioral outcomes, adverse effects, etc).

83. Garcia L, L J, Olivares, et al. Results at long-term among three psychological treatments for adolescents with generalized social phobia (II): Clinical significance and effect size. Psicologia Conductual. 2002;10(2):371-85. Other reason. 
84. García L, L J, Ruiz, et al.

Transporting a school-based multicomponent treatment for adolescents to young adults with social anxiety: A pilot study. Psicologia Conductual. 2006;14(1):63-73. The study is not a comparative study (case reports only included for side effects/ harms).

85. Gil-Bernal F, Hernández-Guzmán L. Tratamiento cognitivo-conductual para niños mexicanos con fobia social. Anuario de Psicología. 2009;40(1). The study does not have children with anxiety (3-18 yrs).

86. Girling B, R D, Ronan, et al. Brief cognitive-behavioural therapy for children with anxiety disorders: Initial evaluation of a program designed for clinic settings. Behaviour Change. 2009 April;26(1):27-53. doi:10.1375/bech.26.1.27. The study is not a comparative study (case reports only included for side effects/ harms).

87. Gittelman K, R, Klein, et al. Controlled Imipramine Treatment of School Phobia. Archives of General Psychiatry. 1971;25(3):2047.PMID:18730587. The study does not have children with anxiety (3-18 yrs).

88. GlaxoSmithKline. A 16 Week Double-Blind, Placebo Controlled Study to Investigate the Efficacy and Tolerability of Paroxetine in the Treatment of Children and Adolescents with Social Anxiety Disorder/Social Phobia (29060/676). GSK Clinical Study Register [www.gsk clinicalstudyregister.com]. 2001 Other reason.
89. Gonzalez A, Peris TS, Vreeland A, et al. Parental anxiety as a predictor of medication and CBT response for anxious youth. Child psychiatry and human development. 2015;46(1):84 doi:10.1007/s10578-014-0454-6 PMID:24610431. The study does not have children with anxiety (3-18 yrs).

90. Graca, M. Clinical trial with RO 53350 (Lexotan) in child psychiatry. Folha Medica. 1976;72(4):399-402. The study does not have children with anxiety (3-18 yrs).

91. Gutierrez M, J, Magallon N, et al. Virtual reality exposure therapy for school phobia. Anuario de Psicologia. 2009;40(2):223-36. The study does not have children with anxiety (3-18 yrs).

92. Hagopian, L P, Slifer, et al. Treatment of separation anxiety disorder with graduated exposure and reinforcement targeting school attendance: A controlled case study. Journal of Anxiety Disorders. 1993;7(3):271-80. doi:10.1016/08876185(93)90007-8. The study is not a comparative study (case reports only included for side effects/ harms).

93. Hedman E, Andersson E, Ljótsson B, et al. Cost-effectiveness of Internetbased cognitive behavior therapy vs. cognitive behavioral group therapy for social anxiety disorder: results from a randomized controlled trial. Behaviour research and therapy. 2011;49(11):729-36. doi:10.1016/j.brat.2011.07.009 PMID:21851929. The study does not have children with anxiety (3-18 yrs). 
94. Hepburn SL, Blakeley-Smith A, Wolff B, et al. Telehealth delivery of cognitive-behavioral intervention to youth with autism spectrum disorder and anxiety: A pilot study. Autism. 2016 Feb;20(2):207-18. doi:10.1177/1362361315575164 PMID:25896267. The study does not have children with anxiety (3-18 yrs).

95. Heyne D, King NJ, Tonge BJ, et al. Evaluation of child therapy and caregiver training in the treatment of school refusal. J Am Acad Child Adolesc Psychiatry. 2002 Jun;41(6):687-95. doi:10.1097/00004583-20020600000008 PMID:12049443. The study does not have children with anxiety (3-18 yrs).

96. Hilton RC, Rengasamy M, Mansoor $\mathrm{B}$, et al. Impact of treatments for depression on comorbid anxiety, attentional, and behavioral symptoms in adolescents with selective serotonin reuptake inhibitor-resistant depression. J Am Acad Child Adolesc Psychiatry. 2013 May;52(5):482-92. doi:10.1016/j.jaac.2013.02.013 PMID:23622849. The study does not have children with anxiety (3-18 yrs).

97. Hoek W, Schuurmans J, Koot HM, et al. Effects of Internet-based guided self-help problem-solving therapy for adolescents with depression and anxiety: a randomized controlled trial. PLoS One. 2012 Aug;7(8):e43485. doi:10.1371/journal.pone.0043485 PMID:22952691. The study does not have children with anxiety (3-18 yrs).
98. Hogendoorn SM, Prins PJ, Boer F, et al. Mediators of cognitive behavioral therapy for anxiety-disordered children and adolescents: Cognition, perceived control, and coping. Journal of Clinical Child \& Adolescent Psychology. 2014;43(3):486-500 doi:10.1080/15374416.2013.807736 PMID:23795885. The study is not a comparative study (case reports only included for side effects/ harms).

99. Howard, B L, Kendall, et al. Cognitive-behavioral family therapy for anxiety-disordered children: a multiple-baseline evaluation. Cognitive therapy and research. 1996;20(5):423-43. doi:10.1007/BF02227906. The study is not a comparative study (case reports only included for side effects/ harms).

100. Hrdlicka, M, Goetz, et al. Panic Disorder in Paedopsychiatry. [Czech]. Ceska a Slovenska Psychiatrie. 2004;100(1):4-8.The study does not include any of the interventions listed above (pharmacotherapy or psychotherapy)

101. Hrdlička, M, Goetz, et al. Panic Disorder in Paedopsychiatry. Ceska a Slovenska Psychiatrie. 2004;100(1):4-8. The study is not a comparative study (case reports only included for side effects/ harms). 
102. Huang X, Li C, Li WH, et al. Clinical evaluation of the efficacy and safety of tandospirone versus sertraline monotherapy for social anxiety disorder: a randomized openlabel trial. Hum Psychopharmacol. 2013 Nov;28(6):594-9. doi:10.1002/hup.2361 PMID:24519693. The study does not have children with anxiety (3-18 yrs).

103. Ishikawa Si, Okajima I, Matsuoka H, et al. Cognitive behavioural therapy for anxiety disorders in children and adolescents: A meta-analysis. Child and Adolescent Mental Health. 2007;12(4):164-72 doi:0.1111/j.14753588.2006.00433.x. A systematic review/meta-analysis/guideline.

104. Jansen M, van Doorn MM, Lichtwarck-Aschoff A, et al. Effectiveness of a cognitivebehavioral therapy (CBT) manualized program for clinically anxious children: study protocol of a randomized controlled trial. BMC Psychiatry. 2012 Mar 12;12:16. doi:10.1186/1471-244X-12-16 PMID: 22404798. Other reason.

105. Johnco CJ, Salloum A, Lewin AB, et al. Refining Clinical Judgment of Treatment Response and Symptom Remission Identification in Childhood Anxiety Using a Signal Detection Analysis on the Pediatric Anxiety Rating Scale. J Child Adolesc Psychopharmacol. 2015 Nov;25(9):674-83. doi:10.1089/cap.2015.0102 PMID:26579629. The study does not report anxiety outcomes (symptom severity and scales, behavioral outcomes, adverse effects, etc).
106. Johnstone KA, Page AC. Attention to phobic stimuli during exposure: The effect of distraction on anxiety reduction, self-efficacy and perceived control. Behaviour research and therapy. 2004;42(3):249-75 doi:10.1016/S0005-7967(03)00137-2 PMID:14975769. The study does not have children with anxiety (3-18 yrs).

107. Jones JE, Blocher JB, Jackson DC, et al. Social anxiety and self-concept in children with epilepsy: a pilot intervention study. Seizure. 2014;23(9):780-5 doi:10.1016/j.seizure.2014.06.011 PMID:25053153. The study is not a comparative study (case reports only included for side effects/ harms).

108. Jongerden, Loes, Bogels, et al. Parenting, family functioning and anxiety-disordered children: Comparisons to controls, changes after family versus child CBT. Journal of Child and Family Studies. 2015 Jul;24(7):2046-59. doi:10.1007/s10826-014-0005-6 The study does not report anxiety outcomes (symptom severity and scales, behavioral outcomes, adverse effects, etc).

109. Kammerer, Emil, Mattejat, et al. Inpatient treatment of severe school phobia: A follow-up study. Zeitschrift fur Kinder- und Jugendpsychiatrie und Psychotherapie. 1981;9(3):273-87. The study is not a comparative study (case reports only included for side effects/ harms). 
110. Kearney, Christopher A, Silverman, et al. Functionally Based Prescriptive and Nonprescriptive Treatment for Children and Adolescents With School Refusal Behavior. Behavior Therapy. 1999 Aut;30(4):673-95. doi:10.1016/S0005-7894(99)80032$\mathrm{X}$. The study does not have children with anxiety (3-18 yrs).

111. Kelly D, Guirguis W, Frommer E, et al. Tratamiento de los estados fóbicos con antidepresivos. Un estudio retrospectivo de 246 pacientes. Psiquiatría Biológica. 2005;12(4):166-76. The study is not a comparative study (case reports only included for side effects/ harms).

112. Kelly D, Guirguis W, Frommer E, et al. Treatment of phobic states with antidepressants. A retrospective study of 246 patients. Br J Psychiatry. 1970 Apr;116(533):38798. doi:10.1192/bjp.116.533.387 PMID:4909796. The study does not have children with anxiety (3-18 yrs).

113. Kendall PC, Brady EU, Verduin TL. Comorbidity in childhood anxiety disorders and treatment outcome. J Am Acad Child Adolesc Psychiatry. 2001 Jul;40(7):787-94. doi:10.1097/00004583-20010700000013 PMID:11437017. The study does not report anxiety outcomes (symptom severity and scales, behavioral outcomes, adverse effects, etc).

114. Kendall PC, Sugarman A. Attrition in the treatment of childhood anxiety disorders. J Consult Clin Psychol. 1997 Oct;65(5):883-8. PMID:9337507. The study does not have children with anxiety (3-18 yrs).
115. Kendall, P C, Treadwell, et al. The Role of Self-Statements as a Mediator in Treatment for Youth With Anxiety Disorders. Journal of Consulting and Clinical Psychology. 2007 June;75(3):380-9. doi:10.1037/0022-006X.75.3.380 PMID:17563155. Other reason.

116. Kendall PC, Comer JS, Marker CD, et al. In-session exposure tasks and therapeutic alliance across the treatment of childhood anxiety disorders. J Consult Clin Psychol. 2009 Jun;77(3):517-25. doi:10.1037/a0013686 PMID:19485592. The study does not report anxiety outcomes (symptom severity and scales, behavioral outcomes, adverse effects, etc).

117. Kendall PC, Cummings CM, Villabo $\mathrm{MA}$, et al. Mediators of change in the Child/Adolescent Anxiety Multimodal Treatment Study. J Consult Clin Psychol. 2016 Jan;84(1):1-14. doi:10.1037/a0039773 PMID:26460572. The study is not a comparative study (case reports only included for side effects/ harms).

118. Kendall PC, Safford S, FlannerySchroeder E, et al. Child anxiety treatment: outcomes in adolescence and impact on substance use and depression at 7.4-year follow-up. J Consult Clin Psychol. 2004 Apr;72(2):276-87. doi:10.1037/0022-006X.72.2.276 PMID:15065961. The study is not a comparative study (case reports only included for side effects/ harms). 
119. Kerns CM, Read KL, Klugman J, et al. Cognitive behavioral therapy for youth with social anxiety: differential short and long-term treatment outcomes. J Anxiety Disord. 2013 Mar;27(2):210-5. doi:10.1016/j.janxdis.2013.01.009 PMID: 23474911. The study is not a comparative study (case reports only included for side effects/ harms).

120. Klein AM, Rapee RM, Hudson JL, et al. Interpretation modification training reduces social anxiety in clinically anxious children. Behav Res Ther. 2015 Dec;75:78-84. doi:10.1016/j.brat.2015.10.006 PMID:26580081. Other reason.

121. Kley H, Heinrichs N, Bender C, et al. Predictors of outcome in a cognitive-behavioral group program for children and adolescents with social anxiety disorder. J Anxiety Disord. 2012 Jan;26(1):79-87. doi:10.1016/j.janxdis.2011.09.002 PMID:21975266. The study is not a comparative study (case reports only included for side effects/ harms).

122. Klingman A. Biblioguidance with kindergartners: Evaluation of a primary prevention program to reduce fear of the dark. Journal of Clinical Child Psychology. 1988;17(3):237-41. doi:10.1207/s15374424jccp1703_7 The study does not have children with anxiety (3-18 yrs).

123. Knox M, Lentini J, Cummings T, et al. Game-based biofeedback for paediatric anxiety and depression. Ment Health Fam Med. 2011 Sep;8(3):195-203. PMID:22942901. The study does not have children with anxiety (3-18 yrs).
124. Kronenberg, S, Apter, et al. Serotonin transporter polymorphism (5-HTTLPR) and citalopram effectiveness and side effects in children with depression and/or anxiety disorders. Journal of Child and Adolescent Psychopharmacology. 200701 Dec;17(6):741-50. doi:10.1089/cap.2006.0144 PMID:18315446. The study does not have children with anxiety (3-18 yrs).

125. Kronmuller KT, Postelnicu I, Hartmann M, et al. [Efficacy of psychodynamic short-term psychotherapy for children and adolescents with anxiety disorders]. Prax Kinderpsychol Kinderpsychiatr. 2005 Sep;54(7):559-77. PMID:16180526. The study does not have children with anxiety (3-18 yrs).

126. Lau WY, Chan CK, Li JC, et al. Effectiveness of group cognitivebehavioral treatment for childhood anxiety in community clinics. Behav Res Ther. 2010 Nov;48(11):1067-77. doi:10.1016/j.brat.2010.07.007 PMID:20696421. The study does not have children with anxiety (3-18 yrs).

127. Layne AE, Bernstein GA, Egan EA, et al. Predictors of treatment response in anxious-depressed adolescents with school refusal. J Am Acad Child Adolesc Psychiatry. 2003 Mar;42(3):319-26. doi:10.1097/00004583-20030300000012 PMID:12595785. The study does not have children with anxiety (3-18 yrs). 
128. Lee SW, Kwon JH. The efficacy of imagery rescripting (IR) for social phobia: a randomized controlled trial. J Behav Ther Exp Psychiatry. 2013 Dec;44(4):351-60. doi:10.1016/j.jbtep.2013.03.001 PMID:23563218. The study does not have children with anxiety (3-18 yrs).

129. Lee SS, Victor AM, James MG, et al. School-based interventions for anxious children: long-term followup. Child psychiatry and human development. 2016;47(2):183. doi:10.1007/s10578-015-0555-X PMID:26003419 The study does not have children with anxiety (3-18 yrs)

130. Leger E, Ladouceur R, Dugas MJ, et al. Cognitive-behavioral treatment of generalized anxiety disorder among adolescents: A case series. Journal of the American Academy of Child and Adolescent Psychiatry. 2003 Mar;42(3):327-30. doi:10.1097/00004583-20030300000013 PMID:12595786. The study is not a comparative study (case reports only included for side effects/ harms).

131. Legerstee JS, Garnefski N, Jellesma FC, et al. Cognitive coping and childhood anxiety disorders. Eur Child Adolesc Psychiatry. 2010 Feb;19(2):143-50. doi:10.1007/s00787-009-0051-6 PMID:19727903. The study is not a comparative study (case reports only included for side effects/ harms).
132. Legerstee JS, Huizink AC, van Gastel W, et al. Maternal anxiety predicts favourable treatment outcomes in anxiety-disordered adolescents. Acta Psychiatr Scand. 2008 Apr;117(4):289-98.

doi:10.1111/j.1600-

0447.2008.01161.x

PMID:18321354. The study is not a comparative study (case reports only included for side effects/ harms).

133. Legerstee JS, Tulen JH, Kallen VL, et al. Threat-related selective attention predicts treatment success in childhood anxiety disorders. J Am Acad Child Adolesc Psychiatry. 2009 Feb;48(2):196-205. doi:10.1097/CHI.0b013e31819176e4 PMID:19127173. The study is not a comparative study (case reports only included for side effects/ harms).

134. Lessard, Lyse, Coutu, et al. Efficacy of a social skills program for children presenting with heterogeneous psychiatric diagnoses. Canadian Journal of Behavioural Science/Revue canadienne des sciences du comportement. 2011 Jan;43(1):30-9. doi:10.1037/a0020227. The study does not have children with anxiety (3-18 yrs).

135. Levy K, Hunt C, Heriot S. Treating comorbid anxiety and aggression in children. J Am Acad Child Adolesc Psychiatry. 2007 Sep;46(9):1111-8. doi:10.1097/chi.0b013e318074eb32P MID:17712234. The study is not a comparative study (case reports only included for side effects/ harms). 
136. Lewis PJ, James NM. Haloperidol and chlorpromazine: a double-blind cross-over trial and clinical study in children and adolescents. Aust N Z J Psychiatry. 1973 Mar;7(1):59-65. doi:10.3109/00048677309161478 PMID: 4579394. The study does not have children with anxiety (3-18 yrs).

137. Liber, J M, van W, et al. Parenting and Parental Anxiety and Depression as Predictors of Treatment Outcome for Childhood Anxiety Disorders: Has the Role of Fathers Been Underestimated? Journal of clinical child and adolescent psychology. 2008;37(4):747-58. doi:10.1080/15374410802359692 PMID:18991126. The study is not a comparative study (case reports only included for side effects/ harms).

138. Liber JM, van Widenfelt BM, van der Leeden AJ, et al. The relation of severity and comorbidity to treatment outcome with Cognitive Behavioral Therapy for childhood anxiety disorders. J Abnorm Child Psychol. 2010 Jul;38(5):683-94. doi:10.1007/s10802-010-9394-1 PMID: 20180011. The study is not a comparative study (case reports only included for side effects/ harms).

139. Liehr P, Diaz N. A pilot study examining the effect of mindfulness on depression and anxiety for minority children. Archives of Psychiatric Nursing. 2010;24(1):6971. doi:10.1016/j.apnu.2009.10.001 PMID: 20117691. The study does not have children with anxiety (3-18 yrs).
140. Livheim F, Hayes L, Ghaderi A, et al. The effectiveness of acceptance and commitment therapy for adolescent mental health: Swedish and Australian pilot outcomes. Journal of Child and Family Studies. 2015;24(4):1016. doi:10.1007/s10826-014-9912-9. The study does not have children with anxiety (3-18 yrs).

141. Love, Steven R, Matson, et al. Mothers as effective therapists for autistic children's phobias. Journal of Applied Behavior Analysis. 1990 Fal;23(3):379-85. doi:10.1901/jaba.1990.23-379 PMID: 2249973. The study is not a comparative study (case reports only included for side effects/ harms).

142. Lu DP, Lu GP, Lu WI. Anxiety control of dental patients by clinical combination of acupuncture, bidigital O-ring test, and eye movement desensitization with sedation via submucosal route. Acupuncture \& electro-therapeutics research. 2007;32(1-2):15-30. PMID:18077936. The study does not have children with anxiety (3-18 yrs).

143. Lundkvist H, Irene, Thastum, et al. Anxious children and adolescents non-responding to cbt: Clinical predictors and families' experiences of therapy. Clinical Psychology \& Psychotherapy. 2015 Oct:No Pagination Specified. doi:10.1002/cpp.1982. The study is not a comparative study (case reports only included for side effects/ harms). 
144. Manassis K, Avery D, Butalia S, et al. Cognitive-behavioral therapy with childhood anxiety disorders: functioning in adolescence. Depress Anxiety. 2004;19(4):209-16. doi:10.1002/da.10133 PMID:15274169. The study is not a comparative study (case reports only included for side effects/ harms).

145. Maskey M, Lowry J, Rodgers J, et al. Reducing specific phobia/fear in young people with autism spectrum disorders (ASDs) through a virtual reality environment intervention. PLoS One. 2014;9(7):e100374. doi:10.1371/journal.pone.0100374 PMID: 24987957. The study does not have children with anxiety (3-18 yrs).

146. Masia W, Carrie, Colognori, et al. Can school counselors deliver cognitive-behavioral treatment for social anxiety effectively? A randomized controlled trial. Journal of Child Psychology and Psychiatry. 2016 Mar:No Pagination Specified. doi: 10.1111/jcpp.12550 PMID:27002215. Other reason.

147. McMENAMY C, Katz RC. Brief parent-assisted treatment for children's nighttime fears. Journal of Developmental \& Behavioral Pediatrics. 1989;10(3):145-8. doi:10.1017/bec.2014.19 PMID:2663926. The study does not have children with anxiety (3-18 yrs).

148. Mcshane G, Walter G, Rey JM. Functional outcome of adolescents with 'school refusal'. Clinical Child Psychology and Psychiatry. 2004;9(1):53-60. doi:10.1177/1359104504039172 . The study does not have children with anxiety (3-18 yrs).
149. Medvedev VE, Tereshchenko ON, Kost NV, et al. [Optimization of the treatment of anxiety disorders with selank]. Zh Nevrol Psikhiatr Im S S Korsakova. 2015;115(6):33-40. doi:10.17116/jnevro20151156133-40 PMID: 26356395. The study does not have children with anxiety (3-18 yrs).

150. Menatti AR, Weeks JW, Carleton $\mathrm{RN}$, et al. The Social Interaction Phobia Scale: Continued support for the psychometric validity of the SIPS using clinical and non-clinical samples. Journal of anxiety disorders. 2015;32:46-55. doi:10.1016/j.janxdis.2015.03.003 PMID: 25855057. The study does not have children with anxiety (3-18 yrs).

151. Micco, J A, Choate S, et al. Identifying efficacious treatment components of panic control treatment for adolescents: A preliminary examination. Child and Family Behavior Therapy. 2007;29(4):1-23. doi:10.1300/J019v29n04_01. The study is not a comparative study (case reports only included for side effects/ harms).

152. Mifsud C, Rapee RM. Early intervention for childhood anxiety in a school setting: outcomes for an economically disadvantaged population. J Am Acad Child Adolesc Psychiatry. 2005 Oct;44(10):996-1004. doi:10.1097/01.chi.0000173294.134 41.87 PMID: 16175104. Other reason. 
153. Milos ME, Reiss S. Effects of three play conditions on separation anxiety in young children. J Consult Clin Psychol. 1982 Jun;50(3):389-95. doi:0.1037//0022-006X.50.3.389 PMID:7096740. The study does not have children with anxiety (3-18 yrs).

154. Mitchell JH, Newall C, Broeren S, et al. The role of perfectionism in cognitive behaviour therapy outcomes for clinically anxious children. Behav Res Ther. 2013 Sep;51(9):547-54. doi:10.1016/j.brat.2013.05.015 PMID: 23850630. The study is not a comparative study (case reports only included for side effects/ harms).

155. Moniot M, Mises R. [Comparative double blind study of doxepine and medazepam in adolescents]. Ann Med Psychol (Paris). 1971 Mar;1(3):431-4. PMID: 4934283. The study does not have children with anxiety (3-18 yrs).

156. Morgan AJ, Rapee RM, Bayer JK. Prevention and early intervention of anxiety problems in young children: a pilot evaluation of Cool Little Kids Online. Internet Interventions. 2016;4:105-12. doi:10.1186/s13063015-1022-5 PMID:26541812. The study does not have children with anxiety (3-18 yrs).

157. Muratori, F, Picchi, et al. Efficacy of brief dynamic psychotherapy for children with emotional disorders. Psychotherapy and Psychosomatics. 2001;71(1):28-38. doi:10.1159/000049341 PMID:11740166. The study does not have children with anxiety (3-18 yrs).
158. Muris P, Merckelbach H, Van Haaften H, et al. Eye movement desensitisation and reprocessing versus exposure in vivo. A singlesession crossover study of spiderphobic children. Br J Psychiatry. 1997 Jul;171(JULY):82-6. doi:10.1002/jclp.10100 PMID:9328502. The study is not a comparative study (case reports only included for side effects/ harms).

159. Muris P, Mayer B, Bartelds E, et al. The revised version of the screen for child anxiety related emotional disorders (SCARED-R): Treatment sensitivity in an early intervention trial for childhood anxiety disorders. British Journal of Clinical Psychology. 2001;40(3):323-36. doi:10.1348/014466501163724 PMID: 11593959 Other reason.

160. Murphy, Cynthia M, Bootzin, et al. Active and passive participation in the contact desensitization of snake fear in children. Behavior Therapy. 1973 Mar;4(2):203-11. doi:10.1016/S0005-7894(73)800292. The study does not have children with anxiety (3-18 yrs).

161. Nakamura, B J, Pestle, et al. Differential sequencing of cognitivebehavioral techniques for reducing child and adolescent anxiety. Journal of Cognitive Psychotherapy. 2009;23(2):114-35. doi:10.1891/0889-8391.23.2.114. The study is not a comparative study (case reports only included for side effects/ harms). 
162. Nauta, M H, Scholing, et al. Cognitive-behavioural therapy for anxiety disordered children in a clinical setting: does additional cognitive parent training enhance treatment effectiveness? Clinical psychology \& psychotherapy. 2001;8(5):330-40.

doi:10.1097/01.chi.0000085752.710

02.93 PMID:14566163 Other reason.

163. Nishitsuji K, To H, Murakami Y, et al. Tandospirone in the treatment of generalised anxiety disorder and mixed anxiety-depression: results of a comparatively high dosage trial. Clinical drug investigation. 2004;24(2):121-7. doi:10.2165/00044011-20042402000007 PMID:17516698. The study does not have children with anxiety (3-18 yrs).

164. Oar EL, Farrell LJ, Waters AM, et al. One session treatment for pediatric blood-injection-injury phobia: A controlled multiple baseline trial. Behav Res Ther. 2015 Oct;73:131-42. doi:10.1016/j.brat.2015.08.002 PMID: 26313620. The study is not a comparative study (case reports only included for side effects/ harms).

165. Ohmann S, Schuch B, Sackl P, et al. Cognitive behavioral group therapy for adolescents with school refusal. An observational study. Verhaltenstherapie. 2007;17(3):17581. doi: 10.1159/000104353 The study does not have children with anxiety (3-18 yrs).
166. Olivares O, P J, Rosa A, et al. Social validity of adolescent intervention in social phobia: Parents vs. teachers. Terapia Psicologica. 2007;25(1):6371. doi:10.4067/S071848082007000100005 Terapia Psicologica. 2007;25(1):63-71. Other reason.

167. Olivares, J, García L, et al. Application of the Spanish version of Social Effectiveness Therapy for adolescents (SET-Asv) to the treatment of an adolescent with generalized social phobia. Psicologia Conductual. 2002;10(2):409-19. The study does not have children with anxiety (3-18 yrs).

168. Olivares, J, Rosa A, et al. Transmisión de información cualificada frente a tratamiento psicológico estructurado de adolescentes con fobia social generalizada. International Journal of Clinical and Health Psychology. 2009;9(2):241-58. Other reason.

169. Pantazatos SP, Talati A, Schneier FR, et al. Reduced anterior temporal and hippocampal functional connectivity during face processing discriminates individuals with social anxiety disorder from healthy controls and panic disorder, and increases following treatment. Neuropsychopharmacology. 2014;39(2):425-34. doi:10.1038/npp.2013.211 PMID:24084831. The study does not have children with anxiety (3-18 yrs). 
170. Payne, S, Bolton, et al. A pilot investigation of cognitive therapy for generalized anxiety disorder in children aged 7-17 years. Cognitive Therapy and Research. 2011 April;35(2):171-8. doi:10.1007/s10608-010-9341-z. The study is not a comparative study (case reports only included for side effects/ harms).

171. Pennant ME, Loucas CE, Whittington $\mathrm{C}$, et al. Computerised therapies for anxiety and depression in children and young people: a systematic review and meta-analysis. Behav Res Ther. 2015 Apr;67:1-18. doi:10.1016/j.brat.2015.01.009 PMID: 25727678. A systematic review/meta-analysis/guideline.

172. Peris TS, Compton SN, Kendall PC, et al. Trajectories of change in youth anxiety during cognitive-behavior therapy. J Consult Clin Psychol. 2015 Apr;83(2):239-52. doi:10.1037/a0038402 PMID:25486372. The study does not report anxiety outcomes (symptom severity and scales, behavioral outcomes, adverse effects, etc).

173. Peterman JS, Carper MM, Elkins RM, et al. The effects of cognitivebehavioral therapy for youth anxiety on sleep problems. Journal of anxiety disorders. 2016;37:78-88.

doi:10.1016/j.janxdis.2015.11.006 PMID: 26735330. The study is not a comparative study (case reports only included for side effects/ harms).
174. Pettit JW, Silverman WK, Rey Y, et al. Moving to Second-Stage Treatments Faster: Identifying Midtreatment Tailoring Variables for Youth with Anxiety Disorders. J Clin Child Adolesc Psychol. 2016 JulAug;45(4):457-68. doi:10.1080/15374416.2015.103882 4 PMID:25984794. The study is not a comparative study (case reports only included for side effects/ harms).

175. Phelan JR. Parent, teacher, or analyst: the adolescent-group therapist's trilemma. Int J Group Psychother. 1974 Apr;24(2):238-44. doi:10.1080/00207284.1974.114918 22 PMID: 4821467. The study is not original (commentaries, letters, etc.)

176. Pina AA, Zerr AA, Villalta IK, et al. Indicated prevention and early intervention for childhood anxiety: a randomized trial with Caucasian and Hispanic/Latino youth. J Consult Clin Psychol. 2012 Oct;80(5):940-6. doi:10.1037/a0029460

PMID:22823856. The study does not have children with anxiety (3-18 yrs).

177. Pliszka S, Borcherding S. The stop signal task in children with attention deficit hyperactivity disorder and anxiety. Unpublished manuscript. 1995. Other reason for exclusion.

178. Prince J, Bostic J, Monuteaux M, et al. Citalopram for the treatment of adolescent anxiety disorders: a pilot study. Psychopharmacology bulletin. 2001;36(3):100-7. PMID:12473968. Other reason. 
179. Propper, L, Hrdlicka, et al. Mianserin in the treatment of depression and anxiety in childhood and adolescence. [Czech]. Ceska a Slovenska Psychiatrie. 2000;96(7):376-80. The study does not have children with anxiety (3-18 yrs).

180. Puleo, C M, Conner, et al. CBT for childhood anxiety and substance use at 7.4-year follow-up: A reassessment controlling for known predictors. Journal of Anxiety Disorders. 2011 June;25(5):690-6. doi:10.1016/j.janxdis.2011.03.005 PMID:21497052. The study is not a comparative study (case reports only included for side effects/ harms).

181. Puleo CM, Kendall PC. Anxiety disorders in typically developing youth: autism spectrum symptoms as a predictor of cognitive-behavioral treatment. J Autism Dev Disord. 2011 Mar;41(3):275-86. doi:10.1007/s10803-010-1047-2 PMID: 20694508. The study does not report anxiety outcomes (symptom severity and scales, behavioral outcomes, adverse effects, etc).

182. Rapee RM, Jones MP, Hudson JL, et al. d-Cycloserine does not enhance the effects of in vivo exposure among young people with broadbased anxiety disorders. Behaviour research and therapy. 2016;87:22531. doi:10.1016/j.brat.2016.10.004 PMID:27771572. The study does not include any of the interventions listed above (pharmacotherapy or psychotherapy)
183. Reaven J, Blakeley-Smith A, Culhane-Shelburne K, et al. Group cognitive behavior therapy for children with high-functioning autism spectrum disorders and anxiety: a randomized trial. J Child Psychol Psychiatry. 2012 Apr;53(4):410-9. doi:10.1111/j.14697610.2011.02486.x PMID:22435114. The study does not have children with anxiety (3-18 yrs).

184. Reigada LC, Benkov KJ, Bruzzese $\mathrm{JM}$, et al. Integrating illness concerns into cognitive behavioral therapy for children and adolescents with inflammatory bowel disease and cooccurring anxiety. Journal for Specialists in Pediatric Nursing. 2013;18(2):133-43. doi:10.1111/jspn.12019 PMID:23560585. The study is not a comparative study (case reports only included for side effects/ harms).

185. Reinholdt D, M L, Mogg, et al. Attention Control and Attention to Emotional Stimuli in Anxious Children Before and After Cognitive Behavioral Therapy. Cognitive Therapy and Research. 201519 Jul;39(6):785-96. doi:10.1007/s10608-015-9708-2.The study is not a comparative study (case reports only included for side effects/ harms). 
186. Riahi F, Tashakori A, Izadi-Mazidi S. Effectiveness of reboxetine in treatment of outpatient children and adolescents with attention deficithyperactivity disorder with comorbid anxiety disorders. Iranian journal of psychiatry. 2013;8(4):195.

PMID:25628714. The study does not include any of the interventions listed above (pharmacotherapy or psychotherapy)

187. Riemann BC, Kuckertz JM, Rozenman M, et al. Augmentation of youth cognitive behavioral and pharmacological interventions with attention modification: a preliminary investigation. Depress Anxiety. 2013 Sep;30(9):822-8. doi:10.1002/da.22127 PMID:23658147. The study does not have children with anxiety (3-18 yrs).

188. Roberts CL, Farrell LJ, Waters AM, et al. Parents' Perceptions of Novel Treatments for Child and Adolescent Specific Phobia and Anxiety Disorders. Child Psychiatry Hum Dev. 2016 Jun;47(3):459-71. doi:10.1007/s10578-015-0579-2 PMID:26349600 The study does not report anxiety outcomes (symptom severity and scales, behavioral outcomes, adverse effects, etc).

189. Rodgers A, Dunsmuir S. A controlled evaluation of the 'FRIENDS for Life' emotional resiliency programme on overall anxiety levels, anxiety subtype levels and school adjustment. Child and Adolescent Mental Health. 2015 Feb;20(1):13-9. doi:10.1111/camh.12030. The study does not have children with anxiety (3-18 yrs).
190. Ruggiero, L. Clinical trial of medazepam in children. Clinica Pediatrica. 1975;57(7):318-31. The study does not have children with anxiety (3-18 yrs).

191. Ruini C, Belaise C, Brombin C, et al. Well-being therapy in school settings: a pilot study. Psychother Psychosom. 2006 October;75(6):331-6. doi:10.1159/000095438 PMID:17053333. The study does not have children with anxiety (3-18 yrs).

192. Saavedra LM, Silverman WK, Morgan-Lopez AA, et al. Cognitive behavioral treatment for childhood anxiety disorders: long-term effects on anxiety and secondary disorders in young adulthood. J Child Psychol Psychiatry. 2010 Aug;51(8):924-34. doi:10.1111/j.14697610.2010.02242.x PMID:20345838. Other reason.

193. Sadjadi, S A, Hashemian, et al. Sadjadi, S A, Hashemian, et al. Effectiveness of neurofeedback therapy in children with separation anxiety disorder. African Journal of Psychiatry (South Africa). 2014;17 (6) (no pagination)(1000149) doi:10.4172/Psychiatry.1000149 . The study does not include any of the interventions listed above (pharmacotherapy or psychotherapy)

194. Sallee FR, Sethuraman G, Sine L, et al. Yohimbine challenge in children with anxiety disorders. American Journal of Psychiatry. 2000;157(8):1236-42. doi:10.1176/appi.ajp.157.8.1236 PMID: 10910785. Other reason. 
195. Sanchez, B, Pedreira, et al.

Separation anxiety disorders in children: Comorbidity and followup. Revista de Psiquiatria InfantoJuvenil. 1998;2:87-93. The study does not report anxiety outcomes (symptom severity and scales, behavioral outcomes, adverse effects, etc).

196. Saraf KR, Klein DF, GittelmanKlein R, et al. Imipramine side effects in children.

Psychopharmacologia. 1974 Jul 11;37(3):265-74. doi:10.1007/BF00421540. The study does not have children with anxiety (3-18 yrs).

197. Wong Sarver N, Beidel DC, Spitalnick JS. The feasibility and acceptability of virtual environments in the treatment of childhood social anxiety disorder. Journal of Clinical Child \& Adolescent Psychology. 2014;43(1):63-73. doi:10.1080/15374416.2013.843461 PMID: 24144182. The study is not a comparative study (case reports only included for side effects/ harms).

198. Schirman S, Kronenberg S, Apter A, et al. Effectiveness and tolerability of citalopram for the treatment of depression and anxiety disorders in children and adolescents: an openlabel study. J Neural Transm (Vienna). 2010 Jan;117(1):139-45. doi:10.1007/s00702-009-0330-x PMID:19851705. The study does not have children with anxiety (3-18 yrs).
199. Schleider JL, Ginsburg GS, Keeton $\mathrm{CP}$, et al. Parental psychopathology and treatment outcome for anxious youth: roles of family functioning and caregiver strain. J Consult Clin Psychol. 2015 Feb;83(1):213-24. doi:10.1037/a0037935 PMID:25222799. The study is not a comparative study (case reports only included for side effects/ harms).

200. Schmidtchen S, Hobrucker B. [Efficiency testing of client-centered play therapy in children from educational guidance centers]. Prax Kinderpsychol Kinderpsychiatr. 1978 Jun;27(4):117-25.

PMID: 683949. The study does not have children with anxiety (3-18 yrs).

201. Semple RJ, Reid EF, Miller L. Treating anxiety with mindfulness: An open trial of mindfulness training for anxious children. Journal of Cognitive Psychotherapy. 2005;19(4):379-92. doi:10.1891/088983905780907702. The study is not a comparative study (case reports only included for side effects/ harms).

202. Settipani CA, Kendall PC. Social functioning in youth with anxiety disorders: association with anxiety severity and outcomes from cognitive-behavioral therapy. Child Psychiatry Hum Dev. 2013 Feb;44(1):1-18. doi:10.1007/s10578-012-0307-0 PMID:22581270. The study does not report anxiety outcomes (symptom severity and scales, behavioral outcomes, adverse effects, etc). 
203. Sheykhan, R, Mohammadkhani, et al. Sheykhan R, Mohamadkhani S, Hasanabadi H. Self-Focused Attention in Treatment of Social Anxiety: A Controlled Clinical Trial. Journal of Mazandaran University of Medical Sciences. 2013;23(106):120-8. Persian article.

204. Simeon JG, Ferguson HB, Knott V, et al. Clinical, cognitive, and neurophysiological effects of alprazolam in children and adolescents with overanxious and avoidant disorders. J Am Acad Child Adolesc Psychiatry. 1992 Jan;31(1):29-33. doi:10.1097/00004583-19920100000006 PMID:1537778. The study does not have children with anxiety (3-18 yrs).

205. Simon E, Bogels SM, Voncken JM. Efficacy of child-focused and parentfocused interventions in a child anxiety prevention study. J Clin Child Adolesc Psychol. 2011;40(2):204-19. doi:10.1080/15374416.2011.546039 PMID: 21391018. The study does not have children with anxiety (3-18 yrs).

206. Silverman WK, Kurtines WM, Ginsburg GS, et al. Treating anxiety disorders in children with group cognitive-behavioral therapy: A randomized clinical trial. Journal of consulting and clinical psychology. 1999;67(6):995. doi:10.1037/0022006X.67.6.995 PMID:10596522 The study does not have children with anxiety (3-18 yrs).
207. Sofronoff K, Attwood T, Hinton S. A randomised controlled trial of a CBT intervention for anxiety in children with Asperger syndrome. J Child Psychol Psychiatry. 2005 Nov;46(11):1152-60. doi:10.1111/j.14697610.2005.00411.x PMID:16238662. The study does not have children with anxiety (3-18 yrs).

208. Spence SH, Donovan C, BrechmanToussaint M. The treatment of childhood social phobia: The effectiveness of a social skills training-based, cognitive-behavioural intervention, with and without parental involvement. The Journal of Child Psychology and Psychiatry and Allied Disciplines. 2000;41(6):71326. doi:10.1111/1469-7610.00659 PMID:11039684 Other reason.

209. Spence, S H, Donovan, et al. Online CBT in the treatment of child and adolescent anxiety disorders: Issues in the development of BRAVEONLINE and two case illustrations. Behavioural and Cognitive Psychotherapy. 2008 July;36(4):41130. doi:10.1017/S135246580800444X. The study is not a comparative study (case reports only included for side effects/ harms).

210. Spiegelberg U, Petrilowitsch N, Betz B. Medazepam. A new tranquilizer: simple test, intraindividual comparisons and combination therapy. Arzneimittel-Forschung. 1968;18(12):1559.PMID:5756249. The study does not have children with anxiety (3-18 yrs). 
211. Sportel BE, de Hullu E, de Jong PJ, et al. Cognitive bias modification versus CBT in reducing adolescent social anxiety: a randomized controlled trial. PLoS One. 201314 May;8(5):e64355. doi:10.1371/journal.pone.0064355 PMID:23691203. The study does not have children with anxiety (3-18 yrs).

212. Stallard P, Richardson T, Velleman S, et al. Computerized CBT (Think, Feel, Do) for depression and anxiety in children and adolescents: outcomes and feedback from a pilot randomized controlled trial. Behav Cogn Psychother. 2011 May;39(3):273-84. doi:10.1017/S135246581000086X PMID: 21272393. The study does not have children with anxiety (3-18 yrs).

213. Starkova, L, Nemeckova, et al. Fluvoxamine in child and adolescent psychiatry (Retrospective study). [Czech]. Ceska a Slovenska Psychiatrie. 2002;98(5):278-82. The study does not have children with anxiety (3-18 yrs).

214. St-Jacques J, Bouchard S, Bélanger C. Is virtual reality effective to motivate and raise interest in phobic children toward therapy? A clinical trial study of in vivo with in virtuo versus in vivo only treatment exposure. The Journal of clinical psychiatry. 2010;71(7):924-31. doi:10.4088/JCP.08m04822blu PMID:20441721 Other reason.

215. Storch, E A. Computer- Assisted Cognitive-Behavioral Treatment for Anxiety Disorders in Children With Autism Spectrum Disorders. Http://clinicaltrials.gov/show/NCT01 565629. 2012. Other reason.
216. Storch EA, Lewin AB, Collier AB, et al. A randomized controlled trial of cognitive-behavioral therapy versus treatment as usual for adolescents with autism spectrum disorders and comorbid anxiety. Depress Anxiety. 2015 Mar;32(3):174-81. doi:10.1002/da.22332 PMID:25424398. The study does not have children with anxiety (3-18 yrs).

217. Stulmaker, Hayley L, Ray, et al. Child-centered play therapy with young children who are anxious: A controlled trial. Children and Youth Services Review. 2015 Oct;57:12733.

doi:10.1016/j.childyouth.2015.08.00 5 . The study does not have children with anxiety (3-18 yrs).

218. Sung M, Ooi YP, Goh TJ, et al. Effects of cognitive-behavioral therapy on anxiety in children with autism spectrum disorders: A randomized controlled trial. Child Psychiatry \& Human Development. 2011;42(6):634-49. doi:10.1007/s10578-011-0238-1. PMID: 21660428. Other reason.

219. Suveg, C, Kendall, et al. Emotionfocused cognitive-behavioral therapy for anxious youth: A multiplebaseline evaluation. Journal of Contemporary Psychotherapy. 2006 June;36(2):77-85. doi:10.1007/s10879-006-9010-4. The study is not a comparative study (case reports only included for side effects/ harms). 
220. Suveg C, Sood E, Comer JS, et al. Changes in emotion regulation following cognitive-behavioral therapy for anxious youth. J Clin Child Adolesc Psychol. 2009 May;38(3):390-401. doi:10.1080/15374410902851721 PMID: 19437299. The study is not a comparative study (case reports only included for side effects/ harms).

221. Svedin, Carl G, Arvidsson, et al. Symptom changes after family therapy: A follow-up study of 56 cases treated with family therapy in an outpatient child psychiatric clinic. Nordisk Psykiatrisk Tidsskrift. 1990;44(1):31-40. doi:10.3109/08039489009096542 . The study is not a comparative study (case reports only included for side effects/ harms).

222. Svensson L, Larsson A, Ost L-G. How children experience briefexposure treatment of specific phobias. Journal of Clinical Child and Adolescent Psychology. 2002;31(1):80-9. doi:10.1207/S15374424JCCP3101_1 0 PMID:11845654. The study is not a comparative study (case reports only included for side effects/ harms).

223. Taboas, W, Ojserkis, et al. Change in disgust reactions following cognitive-behavioral therapy for childhood anxiety disorders. International Journal of Clinical and Health Psychology. 2015;15(1):1-7. doi:10.1016/j.ijchp.2014.06.002 The study does not have children with anxiety (3-18 yrs).
224. Katschnig H. The International Multicenter Clinical Trial Group on Moclobemide in Social Phobia. Moclobemide in social anxiety disorder. A double-blind, placebocontrolled clinical study. Eur Arch Psychiatry Clin Neurosci. 1997;247:71-80. PMID: 9177952. Other reason for exclusion.

225. Thienemann M, Moore P, Tompkins K. A parent-only group intervention for children with anxiety disorders: pilot study. Journal of the American Academy of Child \& Adolescent Psychiatry. 2006;45(1):37-46. doi:10.1097/01.chi.0000186404.902 17.02 PMID: 16327579. The study is not a comparative study (case reports only included for side effects/ harms).

226. Tishby, O, Raitchick, et al. Changes in interpersonal conflicts among adolescents during psychodynamic therapy. Psychotherapy Research. 2007 May;17(3):301-9. doi:10.1080/10503300600607944 . The study does not have children with anxiety (3-18 yrs).

227. Torma S, Halsti A. Outcome in truancy and school phobias. Psychiatria Fennica. 1976. The study is not a comparative study (case reports only included for side effects/ harms).

228. Ultee, C A, Griffioen, et al. The reduction of anxiety in children: a comparison of the effects of 'systematic desensitization in vitro' and 'systematic desensitization in vivo'. Behaviour research and therapy. 1982;20(1):61-7. PMID:6121554. The study does not have children with anxiety (3-18 yrs). 
229. van der Leeden AJ, van Widenfelt $\mathrm{BM}$, van der Leeden $\mathrm{R}$, et al. Stepped care cognitive behavioural therapy for children with anxiety disorders: a new treatment approach. Behav Cogn Psychother. 2011 Jan;39(1):55-75.

doi:10.1017/S1352465810000500

PMID: 20932360. The study is not a comparative study (case reports only included for side effects/ harms).

230. Vassilopoulos SP, Banerjee R, Prantzalou C. Experimental modification of interpretation bias in socially anxious children: Changes in interpretation, anticipated interpersonal anxiety, and social anxiety symptoms. Behav Res Ther. 2009 Dec;47(12):1085-9. doi:10.1016/j.brat.2009.07.018 PMID:19679299. The study does not have children with anxiety (3-18 yrs).

231. Victor AM, Bernat DH, Bernstein GA, et al. Effects of parent and family characteristics on treatment outcome of anxious children. $\mathrm{J}$ Anxiety Disord. 2007;21(6):835-48. doi:10.1016/j.janxdis.2006.11.005 PMID:17161582. The study does not have children with anxiety (3-18 yrs).

232. Vitiello B, Davis M, Greenhill LL, et al. Blindness of clinical evaluators, parents, and children in a placebocontrolled trial of fluvoxamine. $\mathrm{J}$ Child Adolesc Psychopharmacol. 2006 Feb-Apr;16(1-2):219-25. doi:0.1089/cap.2006.16.219 PMID: 16553542. The study does not report anxiety outcomes (symptom severity and scales, behavioral outcomes, adverse effects, etc).
233. Walkup JT, Albano AM, Piacentini $\mathrm{J}$, et al. Cognitive behavioral therapy, sertraline, or a combination in childhood anxiety. N Engl J Med. 2008 Dec 25;359(26):2753-66. doi:10.1056/NEJMoa0804633 PMID: 18974308. The study is not original (commentaries, letters, etc.)

234. Vitiello B, Group RUoPPAS. Searching for moderators and mediators of pharmacological treatment effects in children and adolescents with anxiety disorders. Journal of the American Academy of Child \& Adolescent Psychiatry. 2003;42(1):13-21. doi:10.1097/00004583-20030100000006 PMID: 12500072. The study does not report anxiety outcomes (symptom severity and scales, behavioral outcomes, adverse effects, etc).

235. Waters, A M, Potter, et al. Predictors of treatment outcomes in anxious children receiving group cognitivebehavioural therapy: Pretreatment attention bias to threat and emotional variability during exposure tasks. Behaviour Change. 201527 Jul;32(3):143-58. doi:10.1017/bec.2015.6. The study is not a comparative study (case reports only included for side effects/ harms).

236. Weisz JR, Chorpita BF, Palinkas LA, et al. Testing standard and modular designs for psychotherapy treating depression, anxiety, and conduct problems in youth: a randomized effectiveness trial. Arch Gen Psychiatry. 2012 Mar;69(3):274-82. doi:10.1001/archgenpsychiatry.2011. 147 PMID:22065252. The study does not have children with anxiety (3-18 yrs). 
237. Wergeland GJ, Fjermestad KW, Marin CE, et al. Predictors of treatment outcome in an effectiveness trial of cognitive behavioral therapy for children with anxiety disorders. Behav Res Ther. 2016 Jan;76:1-12. doi:10.1016/j.brat.2015.11.001 PMID: 26583954. The study is not a comparative study (case reports only included for side effects/ harms).

238. Wettig, H. H G, Coleman, et al. Evaluating the effectiveness of theraplay in treating shy, socially withdrawn children. International Journal of Play Therapy. 2011;20(1):26-37. The study is not a comparative study (case reports only included for side effects/ harms).

239. Wijnhoven LA, Creemers DH, Engels RC, et al. The effect of the video game Mindlight on anxiety symptoms in children with an Autism Spectrum Disorder. BMC Psychiatry. 2015 Jul 01;15:138. doi:10.1186/s12888-015-0522-x PMID:26129831. The study does not have children with anxiety (3-18 yrs).

240. Wolk CB, Kendall PC, Beidas RS. Cognitive-behavioral therapy for child anxiety confers long-term protection from suicidality. J Am Acad Child Adolesc Psychiatry. 2015 Mar;54(3):175-9. doi:10.1016/j.jaac.2014.12.004 PMID: 25721182. The study does not report anxiety outcomes (symptom severity and scales, behavioral outcomes, adverse effects, etc).
241. Wood JJ, Ehrenreich-May J, Alessandri M, et al. Cognitive behavioral therapy for early adolescents with autism spectrum disorders and clinical anxiety: a randomized, controlled trial. Behav Ther. 2015 Jan;46(1):7-19. doi:10.1016/j.beth.2014.01.002 PMID: 25526831. The study does not have children with anxiety (3-18 yrs).

242. Wood JJ, McLeod BD, Piacentini JC, et al. One-year follow-up of family versus child CBT for anxiety disorders: Exploring the roles of child age and parental intrusiveness. Child Psychiatry Hum Dev. 2009 Jun;40(2):301-16. doi:10.1007/s10578-009-0127-z PMID: 19165592. Other reason.

243. Wood JJ, Drahota A, Sze K, et al. Brief report: Effects of cognitive behavioral therapy on parentreported autism symptoms in schoolage children with high-functioning autism. Journal of autism and developmental disorders. 2009;39(11):1608-12. doi:10.1007/s10803-009-0791-7 PMID:19562475 Other reason.

244. Wright H, Hall S, Hames A, et al. Pet Dogs Improve Family Functioning and Reduce Anxiety in Children with Autism Spectrum Disorder. Anthrozoos. 2015;28(4):611-24. doi:10.1080/08927936.2015.107000 3 The study does not have children with anxiety (3-18 yrs). 
245. Wu X, Liu F, Cai H, et al. Cognitive Behaviour Therapy Combined Fluoxetine Treatment Superior to Cognitive Behaviour Therapy Alone for School Refusal. International Journal of Pharmacology. 2013 Apr 1;9(3):197-203. doi:10.3923/ijp.2013.197.203. The study does not have children with anxiety (3-18 yrs).

246. Yan, Yu L, Wang, et al. Effects of group cognitive-behavioral therapy on adolescent anxiety symptoms. Chinese Mental Health Journal. 2015 Jan;29(1):10-5. The study does not have children with anxiety (3-18 yrs).

247. Zarghami, Firouzeh, Heydarinasab, et al. The effectiveness of cognitive behavior treatment based on Kendall's Coping Program on anxiety disorders: A transdiagnostic approach. Journal of Iranian Psychologists. 2015 Fal;12(45):3750. Persian article.
248. Zozulia AA, Neznamov GG, Siuniakov TS, et al. [Efficacy and possible mechanisms of action of a new peptide anxiolytic selank in the therapy of generalized anxiety disorders and neurasthenia]. Zh Nevrol Psikhiatr Im S S Korsakova. 2008;108(4):38-48.

PMID:18454096. The study does not have children with anxiety (3-18 yrs).

249. Zwaanswijk, M, Kösters, et al. Children's and parents' evaluations of 'FRIENDS for life', an indicated school-based prevention program for children with symptoms of anxiety and depression. Behaviour Change. 2015;32(4):243-54.

doi:10.1017/bec.2015.13. The study does not have children with anxiety (3-18 yrs). 


\section{Appendix E. Description of Included Studies}

Table E.1. Characteristics of the included studies comparing drugs versus pill placebo

\begin{tabular}{|c|c|c|c|c|c|c|}
\hline Author, Year & $\begin{array}{c}\text { Study Country, } \\
\text { Study Design, } \\
\text { Type of Study } \\
\text { (Efficacyl } \\
\text { Effectiveness), } \\
\text { Study Settings }\end{array}$ & $\begin{array}{c}\text { Type of } \\
\text { AnxietylSeverity } \\
\text { (CGI) }\end{array}$ & $\begin{array}{l}\text { Intervention } \\
\text { and } \\
\text { Comparison } \\
\text { s (N of } \\
\text { Patients) }\end{array}$ & $\begin{array}{l}\text { Characteristics of Interventions } \\
\text { (Psychotherapy: Components, } \\
\text { Delivery Model)/Pharm: Drug) } \\
\text { Intensity, Duration (Weeks)) }\end{array}$ & $\begin{array}{c}\text { Patient Characteristics Mean } \\
\text { Age (Range), Male (\%), } \\
\text { Race/Ethnicity, Comorbidity, } \\
\text { Household Income, Parent } \\
\text { Education, Family } \\
\text { Dysfunction/Stressor, } \\
\text { Treatment Sequence, } \\
\text { Insurance, History of } \\
\text { Maltreatment) }\end{array}$ & $\begin{array}{l}\text { Length } \\
\text { of } \\
\text { Follow } \\
\text { up } \\
\text { (Weeks } \\
\text { ) }\end{array}$ \\
\hline \multirow[t]{2}{*}{ Abikoff, 2005} & \multirow{2}{*}{$\begin{array}{l}\text { United States } \\
\text { RCT } \\
\text { Efficacy } \\
\text { Mental health } \\
\text { clinic }\end{array}$} & \multirow[t]{2}{*}{ Anxiety disorder } & $\begin{array}{l}\text { SSRI: } \\
\text { Fluvoxamine, } \\
(\mathrm{N}=15)\end{array}$ & $\begin{array}{l}\text { Maximum of } 300 \mathrm{mg} \text { in adolescents } \\
\text { and } 250 \mathrm{mg} \text { in children younger than } \\
13 \text { years of age. }\end{array}$ & \multirow[t]{2}{*}{ Mean age: 10 (Range $6-17)$} & \multirow[t]{2}{*}{ NR } \\
\hline & & & $\begin{array}{c}\text { Control, } \\
(\mathrm{N}=10)\end{array}$ & Pill placebo & & \\
\hline \multirow[t]{2}{*}{ Alfano, $2007^{2}$} & \multirow{2}{*}{$\begin{array}{l}\text { United States } \\
\text { RCT } \\
\text { Efficacy } \\
\text { Outpatient }\end{array}$} & \multirow[t]{2}{*}{ GAD, SAD, SoP } & $\begin{array}{l}\text { SSRI: } \\
\text { Fluvoxamine, } \\
(\mathrm{N}=54)\end{array}$ & & \multirow{2}{*}{$\begin{array}{l}\text { Age; } 6-17 \\
\text { Male: } 70 \% \\
\text { Caucasian: } 77.1 \% \text {, African } \\
\text { American: } 8.5 \% \text {, Hispanic: } 22.8 \% \\
\text { Other: } 13.3 \%\end{array}$} & \multirow[t]{2}{*}{ NR } \\
\hline & & & $\begin{array}{l}\text { Control, } \\
(\mathrm{N}=51)\end{array}$ & Pill placebo & & \\
\hline \multirow[t]{3}{*}{ Beidel, $2007^{3}$} & \multirow{3}{*}{$\begin{array}{l}\text { United States } \\
\text { RCT } \\
\text { Efficacy } \\
\text { Mental health } \\
\text { clinic }\end{array}$} & \multirow[t]{3}{*}{$\begin{array}{l}\text { GAD, SAD, SP, } \\
\text { SoP }\end{array}$} & $\begin{array}{l}\text { SSRI: } \\
\text { Fluoxetine, } \\
(\mathrm{N}=43)\end{array}$ & $\begin{array}{l}10 \mathrm{mg} \text { per day during week } 1 \text { and } 2 \text {. } \\
\text { Increasing dose up to } 40 \mathrm{mg} / \text { day for up } \\
\text { to } 12 \text { weeks. }\end{array}$ & \multirow{3}{*}{$\begin{array}{l}\text { Mean age:11.56 (Range } 7-17 \text { ) } \\
\text { Male: } 53.23 \% \\
\text { Caucasian: } 74.1 \% \\
\text { African American: } 15.1 \% \\
\text { Hispanic: } 2.1 \% \\
\text { Asian: } 2.8 \% \\
\text { Other: } 3.5 \%\end{array}$} & \multirow[t]{3}{*}{52} \\
\hline & & & $\begin{array}{l}\text { Child CBT, } \\
(\mathrm{N}=59)\end{array}$ & $\begin{array}{l}\text { Social Effectiveness Therapy (SET-C) } \\
\text { Child CBT (Parents included }<20 \% \text { ) } \\
\text { Group and Individual based, exposure, } \\
\text { relaxation, and cognitive problem } \\
\text { solving. } \\
60 \text { min individual session and one } 150 \\
\text { min group session twice a week for } 12 \\
\text { weeks. }\end{array}$ & & \\
\hline & & & $\begin{array}{l}\text { Control, } \\
(\mathrm{N}=37)\end{array}$ & Pill placebo & & \\
\hline \multirow[t]{2}{*}{ Black, $1994^{4}$} & \multirow{2}{*}{$\begin{array}{l}\text { United States } \\
\text { RCT } \\
\text { Efficacy } \\
\text { Mental health } \\
\text { clinic }\end{array}$} & \multirow[t]{2}{*}{$\begin{array}{l}\text { GAD, SAD, SoP } \\
\text { CGI>=6: NR }\end{array}$} & $\begin{array}{l}\text { SSRI: } \\
\text { Fluoxetine, } \\
(\mathrm{N}=6)\end{array}$ & $\begin{array}{l}0.2 \mathrm{mg} / \mathrm{kg} \text { for } 1 \text { week, then } 0.4 \mathrm{mg} / \mathrm{kg} \\
\text { for } 1 \text { week, then } 0.6 \mathrm{mg} / \mathrm{kg} \text { for } 10 \\
\text { weeks. }\end{array}$ & $\begin{array}{l}\text { Mean age: } 9.1 \\
\text { Male: } 50 \%\end{array}$ & \multirow[t]{2}{*}{0} \\
\hline & & & $\begin{array}{l}\text { Control: } \\
(\mathrm{N}=9)\end{array}$ & $\begin{array}{l}\text { Placebo syrup, } 0.08 \mathrm{~mL} / \mathrm{kg} / \text { day for } 2 \\
\text { weeks }\end{array}$ & $\begin{array}{l}\text { Mean age: } 8.1 \\
\text { Male: } 33.3 \%\end{array}$ & \\
\hline
\end{tabular}




\begin{tabular}{|c|c|c|c|c|c|c|}
\hline Author, Year & $\begin{array}{l}\text { Study Country, } \\
\text { Study Design, } \\
\text { Type of Study } \\
\text { (Efficacyl } \\
\text { Effectiveness), } \\
\text { Study Settings }\end{array}$ & $\begin{array}{c}\text { Type of } \\
\text { AnxietylSeverity } \\
\text { (CGI) }\end{array}$ & $\begin{array}{l}\text { Intervention } \\
\text { and } \\
\text { Comparison } \\
\text { s (N of } \\
\text { Patients) }\end{array}$ & $\begin{array}{l}\text { Characteristics of Interventions } \\
\text { (Psychotherapy: Components, } \\
\text { Delivery Model)/Pharm: Drug) } \\
\text { Intensity, Duration (Weeks)) }\end{array}$ & $\begin{array}{c}\text { Patient Characteristics Mean } \\
\text { Age (Range), Male (\%), } \\
\text { Race/Ethnicity, Comorbidity, } \\
\text { Household Income, Parent } \\
\text { Education, Family } \\
\text { Dysfunction/Stressor, } \\
\text { Treatment Sequence, } \\
\text { Insurance, History of } \\
\text { Maltreatment) } \\
\end{array}$ & $\begin{array}{l}\text { Length } \\
\text { of } \\
\text { Follow } \\
\text { up } \\
\text { (Weeks } \\
\text { ) }\end{array}$ \\
\hline \multirow[t]{2}{*}{$\begin{array}{l}\text { Birmaher, } \\
2003^{5}\end{array}$} & \multirow[t]{2}{*}{$\begin{array}{l}\text { United States } \\
\text { RCT } \\
\text { Efficacy } \\
\text { Mental health } \\
\text { clinic }\end{array}$} & \multirow[t]{2}{*}{$\begin{array}{l}\text { GAD, SAD, SoP, } \\
\text { SP }\end{array}$} & $\begin{array}{l}\text { SSRI: } \\
\text { Fluoxetine, } \\
(\mathrm{N}=37)\end{array}$ & Up to $200 \mathrm{mg}$ per day for 12 weeks & $\begin{array}{l}\text { Mean age: } 11.6 \\
\text { Male : } 46 \% \\
\text { Caucasian: } 97.2 \% \text {, Asian: } 2.8 \% \\
\text { Low income: } 27.6 \% \\
\text { ADHD: } 5 \% \text {, Depression: } 5 \%, \\
\text { dysthymia: } 8 \% \text {, enuresis: } 5 \%\end{array}$ & \multirow[t]{2}{*}{52} \\
\hline & & & $\begin{array}{l}\text { Control, } \\
(\mathrm{N}=37)\end{array}$ & Pill placebo & $\begin{array}{l}\text { Mean age: } 11.9 \\
\text { Male: } 46 \% \\
\text { Caucasian: } 95 \% \text {, Asian: } 5 \% \\
\text { ODD: } 8 \% \text {, enuresis:8, tics: } 5 \%\end{array}$ & \\
\hline \multirow[t]{3}{*}{$\begin{array}{l}\text { da Costa, } \\
2013^{6}\end{array}$} & \multirow{3}{*}{$\begin{array}{l}\text { Brazil } \\
\text { RCT } \\
\text { Efficacy } \\
\text { Mental health } \\
\text { clinic }\end{array}$} & \multirow[t]{3}{*}{$\begin{array}{l}\text { GAD, SAD, SP } \\
\text { Mean CGI= } 4.9\end{array}$} & $\begin{array}{l}\text { TCA: } \\
\text { Clomipramine } \\
(\mathrm{N}=9)\end{array}$ & $\begin{array}{l}\text { Clomipramine } \\
118.75 \mathrm{mg} / \text { day average dose, } 12 \\
\text { weeks }\end{array}$ & $\begin{array}{l}\text { Mean age: } 11.2 \text { (range: } 7-17 \text { ) } \\
\text { Males: } 33 \% \\
\text { Lower class: } 58.7 \% \\
\text { Upper/Middle class: } 14.3 \%\end{array}$ & \multirow[t]{3}{*}{0} \\
\hline & & & $\begin{array}{l}\text { SSRI: } \\
\text { Fluoxetine, } \\
(\mathrm{N}=10)\end{array}$ & $\begin{array}{l}\text { SRI, SSRI, fluoxetine } \\
35 \mathrm{mg} / \text { day average dose for } 12 \\
\text { weeks. }\end{array}$ & $\begin{array}{l}\text { Mean age: } 11.6 \text { (range: } 7-17 \text { ) } \\
\text { Males: } 50 \% \\
\text { Lower class: } 50 \% \\
\text { Upper/Middle class: } 50 \%\end{array}$ & \\
\hline & & & $\begin{array}{l}\text { Control, } \\
(\mathrm{N}=11)\end{array}$ & Pill placebo & $\begin{array}{l}\text { Mean age: } 11.4 \text { (range: } 7-17 \text { ) } \\
\text { Males: } 54 \% \\
\text { Lower class: } 45.4 \% \\
\text { Upper/Middle class: } 45.4 \%\end{array}$ & \\
\hline \multirow[t]{2}{*}{ Geller, $2007^{7}$} & \multirow[t]{2}{*}{$\begin{array}{l}\text { United States } \\
\text { RCT } \\
\text { Efficacy } \\
\text { Outpatient }\end{array}$} & \multirow[t]{2}{*}{ Anxiety disorder } & $\begin{array}{l}\text { SNRI: } \\
\text { Atomoxetine, } \\
(\mathrm{N}=87)\end{array}$ & & $\begin{array}{l}\text { Mean age: } 12.2 \text { (Range } 8-17) \\
\text { Male: } 62 \% \\
\text { Caucasian: } 77 \% \\
\text { ADHD: } 100 \%\end{array}$ & \multirow[t]{2}{*}{0} \\
\hline & & & $\begin{array}{l}\text { Control, } \\
(\mathrm{N}=89)\end{array}$ & $\begin{array}{l}\text { Pill placebo } \\
\text { Patients completing } 9^{\text {th }} \text { visit could } \\
\text { participate in an open-label } \\
\text { Atomoxetine extension period. }\end{array}$ & $\begin{array}{l}\text { Mean age: } 11.8(8-17) \\
\text { Male: } 67.4 \% \\
\text { Caucasian: } 82 \% \\
\text { ADHD: } 100 \% \\
\end{array}$ & \\
\hline \multirow[t]{2}{*}{$\begin{array}{l}\text { Gittelman- } \\
\text { Klein, } 1973^{8}\end{array}$} & \multirow{2}{*}{$\begin{array}{l}\text { United States } \\
\text { RCT } \\
\text { Efficacy } \\
\text { Outpatient }\end{array}$} & \multirow[t]{2}{*}{$\mathrm{SP}$} & $\begin{array}{l}\text { TCA: } \\
\text { Imipramine, } \\
(\mathrm{N}=19) \\
\end{array}$ & Up to $200 \mathrm{mg} /$ day for 6 weeks & \multirow[t]{2}{*}{ Mean age: 10.8 (range: 6-14) } & \multirow[t]{2}{*}{0} \\
\hline & & & $\begin{array}{l}\text { Control, } \\
(\mathrm{N}=15)\end{array}$ & Pill placebo & & \\
\hline
\end{tabular}




\begin{tabular}{|c|c|c|c|c|c|c|}
\hline Author, Year & $\begin{array}{l}\text { Study Country, } \\
\text { Study Design, } \\
\text { Type of Study } \\
\text { (Efficacyl } \\
\text { Effectiveness), } \\
\text { Study Settings }\end{array}$ & $\begin{array}{c}\text { Type of } \\
\text { Anxiety/Severity } \\
\text { (CGI) }\end{array}$ & $\begin{array}{l}\text { Intervention } \\
\text { and } \\
\text { Comparison } \\
\text { s (N of } \\
\text { Patients) }\end{array}$ & $\begin{array}{l}\text { Characteristics of Interventions } \\
\text { (Psychotherapy: Components, } \\
\text { Delivery Model)/Pharm: Drug) } \\
\text { Intensity, Duration (Weeks)) }\end{array}$ & $\begin{array}{c}\text { Patient Characteristics Mean } \\
\text { Age (Range), Male (\%), } \\
\text { Race/Ethnicity, Comorbidity, } \\
\text { Household Income, Parent } \\
\text { Education, Family } \\
\text { Dysfunction/Stressor, } \\
\text { Treatment Sequence, } \\
\text { Insurance, History of } \\
\text { Maltreatment) }\end{array}$ & $\begin{array}{l}\text { Length } \\
\text { of } \\
\text { Follow } \\
\text { up } \\
\text { (Weeks } \\
\text { ) }\end{array}$ \\
\hline \multirow[t]{2}{*}{ Graae, $1994^{9}$} & \multirow{2}{*}{$\begin{array}{l}\text { United States } \\
\text { RCT } \\
\text { Efficacy } \\
\text { Mental health } \\
\text { clinic }\end{array}$} & \multirow[t]{2}{*}{$\begin{array}{l}\text { GAD,SAD, SoP, } \\
\text { SP } \\
\text { CGI>=6: NR }\end{array}$} & $\begin{array}{l}\text { Benzodiazepi } \\
\text { nes: } \\
\text { Clonazepam, } \\
(\mathrm{N}=8)\end{array}$ & $\begin{array}{l}\text { One tablet of up to } 2 \mathrm{mg} / \text { day for } 4 \\
\text { weeks. }\end{array}$ & \multirow{2}{*}{$\begin{array}{l}\text { Mean age: } 9.8 \text { (range: } 7-13 \text { ) } \\
\text { Male: } 53.3 \% \\
\text { Caucasian: } 100 \% \\
\text { ADHD: } 20 \% \text {, ODD : } 20 \% \text {, Conduct } \\
\text { problems: } 7 \%\end{array}$} & \multirow[t]{2}{*}{0} \\
\hline & & & $\begin{array}{l}\text { Control, } \\
(\mathrm{N}=7)\end{array}$ & $\begin{array}{l}\text { Pill placebo } \\
\text { One tablet a day for } 4 \text { weeks }\end{array}$ & & \\
\hline \multirow[t]{2}{*}{ March, $2007^{10}$} & \multirow[t]{2}{*}{$\begin{array}{l}\text { United States } \\
\text { RCT } \\
\text { Effectivness } \\
\text { Outpatient }\end{array}$} & \multirow[t]{2}{*}{ SoP } & $\begin{array}{l}\text { SSRI: } \\
\text { Venlafaxine, } \\
(\mathrm{N}=141)\end{array}$ & $\begin{array}{l}37.5 \mathrm{mg} / \text { day to a maximum dose of } \\
225 \mathrm{mg} / \text { day over } 16 \text { weeks. }\end{array}$ & $\begin{array}{l}\text { Mean age: } 13.6 \text { (Range } 8-18) \\
\text { Male: } 42.1 \% \\
\text { Caucasian: } 74.28, \text { African: } \\
14.28 \% \\
\text { Hispanic: } 5 \% \text {, Asian: } 1.4 \% \text {, Other: } \\
2.85 \% \\
\mathrm{GCl}<6 \mathrm{n}=155 \\
\mathrm{GCl}>6 \mathrm{n}=22\end{array}$ & \multirow[t]{2}{*}{0} \\
\hline & & & $\begin{array}{l}\text { Control, } \\
(\mathrm{N}=152)\end{array}$ & Pill placebo & $\begin{array}{l}\text { Mean age: } 13.6 \text { (Range } 8-16) \\
\text { Male: } 43.3 \% \\
\text { Caucasian: } 78.5 \% \text {, African: } 10 \% \text {, } \\
\text { Hispanic: } 11.3 \% \text {, Asian: } 1.3 \% \text {, } \\
\text { Other: } 2.6 \% \\
\mathrm{GCl}<6 \mathrm{n}=119 \\
\mathrm{GCl}>6 \mathrm{n}=29\end{array}$ & \\
\hline \multirow[t]{2}{*}{$\begin{array}{l}\text { Pine, } 2001^{11,} \\
12\end{array}$} & \multirow[t]{2}{*}{$\begin{array}{l}\text { United States } \\
\text { RCT } \\
\text { Efficacy } \\
\text { Outpatient }\end{array}$} & \multirow[t]{2}{*}{ GAD,SAD, SoP } & $\begin{array}{l}\text { SNRI: } \\
\text { Fluoxetine, } \\
(\mathrm{N}=63)\end{array}$ & Up to $250 \mathrm{mg}$ per day for 8 weeks & $\begin{array}{l}\text { Male: } 51 \% \\
\text { Caucasian: } 63 \% \text {, African: } 10 \% \text {, } \\
\text { Hispanic : } 20 \% \text {, other: } 7 \% \\
\text { Low income (less than } 25 \mathrm{k}): 16 \% \text {, } \\
\text { Medium income (25k-60K): } 30 \% \\
\text { High income (>60K): 46\% } \\
\text { ADHD: } 17.4 \%, \text { Depression: } 4 \% \text {, } \\
\text { OCD: } 4 \%, \text { ODD: } 6 \%\end{array}$ & \multirow[t]{2}{*}{0} \\
\hline & & & $\begin{array}{l}\text { Control, } \\
(\mathrm{N}=65)\end{array}$ & Pill placebo & $\begin{array}{l}\text { Male:52\% } \\
\text { Caucasian: } 62 \% \text {, African: 5\%, } \\
\text { Hispanic :18\%, other: } 15 \% \\
\text { Low income (less than } 25 \mathrm{k}): 15 \% \text {, } \\
\text { Medium income (25k-60K): } 29 \% \\
\text { High income (> 60K): } 42 \%\end{array}$ & \\
\hline
\end{tabular}




\begin{tabular}{|c|c|c|c|c|c|c|}
\hline Author, Year & $\begin{array}{l}\text { Study Country, } \\
\text { Study Design, } \\
\text { Type of Study } \\
\text { (Efficacyl } \\
\text { Effectiveness), } \\
\text { Study Settings }\end{array}$ & $\begin{array}{c}\text { Type of } \\
\text { AnxietylSeverity } \\
\text { (CGI) }\end{array}$ & $\begin{array}{l}\text { Intervention } \\
\text { and } \\
\text { Comparison } \\
\text { s (N of } \\
\text { Patients) }\end{array}$ & $\begin{array}{l}\text { Characteristics of Interventions } \\
\text { (Psychotherapy: Components, } \\
\text { Delivery Model)/Pharm: Drug) } \\
\text { Intensity, Duration (Weeks)) }\end{array}$ & $\begin{array}{c}\text { Patient Characteristics Mean } \\
\text { Age (Range), Male (\%), } \\
\text { Race/Ethnicity, Comorbidity, } \\
\text { Household Income, Parent } \\
\text { Education, Family } \\
\text { Dysfunction/Stressor, } \\
\text { Treatment Sequence, } \\
\text { Insurance, History of } \\
\text { Maltreatment) } \\
\end{array}$ & $\begin{array}{l}\text { Length } \\
\text { of } \\
\text { Follow } \\
\text { up } \\
\text { (Weeks } \\
\text { ) }\end{array}$ \\
\hline & & & & & $\begin{array}{l}\text { ADHD: } 13 \% \text {, Depression: } 5 \% \text {, } \\
\text { OCD: } 5 \% \text {, ODD: } 5 \% \text {, conduct } \\
\text { disorder: } 3 \%\end{array}$ & \\
\hline \multirow[t]{2}{*}{$\begin{array}{l}\text { Reinblatt, } \\
2009^{13}\end{array}$} & \multirow{2}{*}{$\begin{array}{l}\text { United States } \\
\text { RCT } \\
\text { Efficacy } \\
\text { Mental health } \\
\text { clinic }\end{array}$} & \multirow[t]{2}{*}{ GAD,SAD, SoP } & $\begin{array}{l}\text { SSRI: } \\
\text { Fluvoxamine, } \\
(\mathrm{N}=22)\end{array}$ & $\begin{array}{l}\text { One tablet of up to } 300 \mathrm{mg} / \text { day for } 8 \\
\text { weeks }\end{array}$ & $\begin{array}{l}\text { Mean age: } 10 \text { ( range: } 6-17 \text { ) } \\
\text { Male: } 54.5 \% \\
\text { Caucasian: } 95.4 \%\end{array}$ & \multirow[t]{2}{*}{0} \\
\hline & & & $\begin{array}{l}\text { Control, } \\
(\mathrm{N}=23)\end{array}$ & Pill placebo for 8 weeks & $\begin{array}{l}\text { Mean age: } 9.7 \text { ( range: } 6-17 \text { ) } \\
\text { Male: } 52.2 \% \\
\text { Caucasian: } 95.6 \%\end{array}$ & \\
\hline \multirow[t]{2}{*}{ Rynn, $2001^{14}$} & \multirow{2}{*}{$\begin{array}{l}\text { United States } \\
\text { RCT } \\
\text { Efficacy } \\
\text { Mental health } \\
\text { clinic }\end{array}$} & \multirow[t]{2}{*}{ GAD } & $\begin{array}{l}\text { SSRI: } \\
\text { Sertraline, } \\
(\mathrm{N}=11)\end{array}$ & $\begin{array}{l}25 \mathrm{mg} / \text { day for the first week, } 50 \mathrm{mg} \text { for } \\
\text { weeks } 2-9 .\end{array}$ & $\begin{array}{l}\text { Mean age: } 11.7 \text { ( Range } 5-17 \text { ) } \\
\text { Male: } 77.2 \% \\
\text { Caucasian: } 81.8 \%\end{array}$ & \multirow[t]{2}{*}{0} \\
\hline & & & $\begin{array}{l}\text { Control, } \\
(\mathrm{N}=11)\end{array}$ & Pill placebo & & \\
\hline \multirow[t]{2}{*}{ Rynn, $2007^{15}$} & \multirow{2}{*}{$\begin{array}{l}\text { United States } \\
\text { RCT } \\
\text { Efficacy } \\
\text { Mental health } \\
\text { clinic }\end{array}$} & \multirow[t]{2}{*}{ Anxiety disorder } & $\begin{array}{l}\text { SSRI: } \\
\text { Venlafaxine. } \\
(\mathrm{N}=157)\end{array}$ & $\begin{array}{l}37.5 \mathrm{mg} / \text { day during the first week. } \\
\text { Doses thereafter ranged from } 112.5 \mathrm{mg} \\
-225 \mathrm{mg} \text {. }\end{array}$ & \multirow[t]{2}{*}{$\begin{array}{l}\text { Age: } 6-17 \\
\text { Male: } 57.5 \%\end{array}$} & \multirow[t]{2}{*}{0} \\
\hline & & & $\begin{array}{l}\text { Control, } \\
(\mathrm{N}=163)\end{array}$ & Pill placebo & & \\
\hline \multirow[t]{3}{*}{$\begin{array}{l}\text { Scharfstein, } \\
2011^{16}\end{array}$} & \multirow[t]{3}{*}{$\begin{array}{l}\text { United States } \\
\text { RCT } \\
\text { Effectiveness } \\
\text { Outpatient }\end{array}$} & \multirow[t]{3}{*}{ SoP } & $\begin{array}{l}\text { Child CBT, } \\
(\mathrm{N}=46)\end{array}$ & $\begin{array}{l}\text { Social Effectiveness Therapy (SET-C) } \\
\text { Child CBT (parents included }<20 \%) \\
\text { Exposure and cognitive problem } \\
\text { solving. } \\
\text { One individual and one group session } \\
\text { per week for } 12 \text { weeks. }\end{array}$ & \multirow[t]{3}{*}{ Male: $50 \%$} & \multirow[t]{3}{*}{0} \\
\hline & & & $\begin{array}{l}\text { SSRI: } \\
\text { Fluoxetine, } \\
(\mathrm{N}=22)\end{array}$ & $\begin{array}{l}\text { One tablet of up to } 40 \mathrm{mg} / \text { day for } 12 \\
\text { weeks }\end{array}$ & & \\
\hline & & & $\begin{array}{l}\text { Control, } \\
(\mathrm{N}=22)\end{array}$ & $\begin{array}{l}\text { Pill placebo } \\
\text { Identically appearing placebo capsules } \\
\text { once a week for } 12 \text { weeks. }\end{array}$ & & \\
\hline $\begin{array}{l}\text { Strawn, } \\
2015^{17}\end{array}$ & $\begin{array}{l}\text { United States, } \\
\text { Mexico, South } \\
\text { Africa } \\
\text { RCT }\end{array}$ & $\begin{array}{l}\text { SAD, SoP } \\
\text { Mean CGI: } 4.5\end{array}$ & $\begin{array}{l}\text { SNRI: } \\
\text { Duloxetine, } \\
(\mathrm{N}=135)\end{array}$ & & $\begin{array}{l}\text { Mean age: } 12.6 \text { (range: } 7-17 \text { ) } \\
\text { Male: } 65 \% \\
\text { Caucasian: } 83 \% \\
\text { African American: } 6.7 \%\end{array}$ & 10 \\
\hline
\end{tabular}




\begin{tabular}{|c|c|c|c|c|c|c|}
\hline Author, Year & $\begin{array}{c}\text { Study Country, } \\
\text { Study Design, } \\
\text { Type of Study } \\
\text { (Efficacyl } \\
\text { Effectiveness), } \\
\text { Study Settings }\end{array}$ & $\begin{array}{c}\text { Type of } \\
\text { AnxietylSeverity } \\
\text { (CGI) }\end{array}$ & $\begin{array}{l}\text { Intervention } \\
\text { and } \\
\text { Comparison } \\
\mathrm{s} \text { (N of } \\
\text { Patients) }\end{array}$ & $\begin{array}{l}\text { Characteristics of Interventions } \\
\text { (Psychotherapy: Components, } \\
\text { Delivery Model)/Pharm: Drug) } \\
\text { Intensity, Duration (Weeks)) }\end{array}$ & $\begin{array}{c}\text { Patient Characteristics Mean } \\
\text { Age (Range), Male (\%), } \\
\text { Race/Ethnicity, Comorbidity, } \\
\text { Household Income, Parent } \\
\text { Education, Family } \\
\text { Dysfunction/Stressor, } \\
\text { Treatment Sequence, } \\
\text { Insurance, History of } \\
\text { Maltreatment) } \\
\end{array}$ & $\begin{array}{l}\text { Length } \\
\text { of } \\
\text { Follow } \\
\text { up } \\
\text { (Weeks } \\
\text { ) }\end{array}$ \\
\hline & \multirow[t]{2}{*}{$\begin{array}{l}\text { Efficacy } \\
\text { Outpatient }\end{array}$} & & & & $\begin{array}{l}\text { Asian: } 0.7 \% \\
\text { Other:9.6\% }\end{array}$ & \\
\hline & & & $\begin{array}{l}\text { Control, } \\
(\mathrm{N}=137)\end{array}$ & Pill placebo & $\begin{array}{l}\text { Mean age: } 12.2 \text { (range: } 7-17 \text { ) } \\
\text { Male: } 62 \% \\
\text { Caucasian: } 81 \% \\
\text { African American: } 7.3 \% \\
\text { Asian: } 0.7 \% \\
\text { Other:11\% }\end{array}$ & \\
\hline \multirow[t]{2}{*}{$\begin{array}{l}\text { Wagner, } \\
2004^{18}\end{array}$} & \multirow{2}{*}{$\begin{array}{l}\text { United States, } \\
\text { South Africa, } \\
\text { Canada and } \\
\text { Belgium } \\
\text { RCT } \\
\text { Efficacy } \\
\text { Mental health } \\
\text { clinic }\end{array}$} & SoP & $\begin{array}{l}\text { SSRI: } \\
\text { Paroxetine, } \\
(\mathrm{N}=165)\end{array}$ & $10-50$ mg/day for 16 weeks. & $\begin{array}{l}\text { Mean age: } 13 \\
\text { Male: } 43 \% \\
\text { Caucasian: } 79.4 \% \text {, other: } 21 \%\end{array}$ & \multirow[t]{2}{*}{16} \\
\hline & & & $\begin{array}{l}\text { Control, } \\
(\mathrm{N}=157)\end{array}$ & $\begin{array}{l}\text { Pill placebo } \\
\text { Matching placebo pill, once per day. }\end{array}$ & $\begin{array}{l}\text { Mean age: } 13.3 \\
\text { Male: } 56.6 \% \\
\text { Caucasian: } 83.4 \% \text {, other: } 16.6 \%\end{array}$ & \\
\hline \multirow[t]{3}{*}{$\begin{array}{l}\text { Walkup, } \\
2002^{19}\end{array}$} & \multirow[t]{3}{*}{$\begin{array}{l}\text { United States } \\
\text { RCT } \\
\text { Efficacy } \\
\text { Outpatient }\end{array}$} & \multirow[t]{3}{*}{ GAD, SAD, SoP } & $\begin{array}{l}\text { SSRI: } \\
\text { Fluvoxamine( } \\
\mathrm{N}=35)\end{array}$ & $\begin{array}{l}\text { Up to } 250 \mathrm{mg} / \text { day for children and } 300 \\
\mathrm{mg} / \text { day for } 32 \text { weeks }\end{array}$ & $\begin{array}{l}\text { Mean age: } 10.2 \\
\text { Male: } 43 \% \\
\text { Caucasian: } 66 \% \text {, African } \\
\text { American:8\%, Hispanic: } 20 \% \text {, } \\
\text { other: } 6 \% \\
\text { ADHD: } 14 \% \text {, ODD: } 6\end{array}$ & \multirow[t]{3}{*}{0} \\
\hline & & & $\begin{array}{l}\text { SSRI: } \\
\text { Fluvoxamine } \\
\text { + Fluoxetine, } \\
(\mathrm{N}=14)\end{array}$ & $\begin{array}{l}\text { Fluvoxamine was tapered off during } \\
\text { the first } 2 \text { weeks with Fluoxetine } 10-40 \\
\text { mg/day. for } 32 \text { weeks }\end{array}$ & $\begin{array}{l}\text { Mean age: } 14.1 \\
\text { Male: } 57 \% \\
\text { Caucasian: } 64 \% \text {, African } \\
\text { American:22\%, Hispanic: } 7 \% \text {, } \\
\text { other: } 7 \% \\
\text { ADHD: } 7 \% \text {, ODD:0\% } \\
\text { Fluvoxamine non-responder } \\
\text { patients }\end{array}$ & \\
\hline & & & $\begin{array}{l}\text { Pill Placebo + } \\
\text { SSRI: } \\
\text { Fluvoxamine, } \\
(\mathrm{N}=48)\end{array}$ & $\begin{array}{l}\text { Fluvoxamine was increased by } 50 \\
\text { mg/week up to } 300 \mathrm{mg} / \mathrm{day} \text { in } \\
\text { adolescents and } 250 \mathrm{mg} / \mathrm{day} \text { for } \\
\text { children }\end{array}$ & $\begin{array}{l}\text { Mean age: } 10.3 \\
\text { Male: } 48 \% \\
\text { Caucasian: } 65 \% \text {, African } \\
\text { American: } 6 \% \text {, Hispanic: } 12 \% \text {, }\end{array}$ & \\
\hline
\end{tabular}




\begin{tabular}{|c|c|c|c|c|c|c|}
\hline Author, Year & $\begin{array}{l}\text { Study Country, } \\
\text { Study Design, } \\
\text { Type of Study } \\
\text { (Efficacyl } \\
\text { Effectiveness), } \\
\text { Study Settings }\end{array}$ & $\begin{array}{c}\text { Type of } \\
\text { AnxietylSeverity } \\
\text { (CGI) }\end{array}$ & $\begin{array}{l}\text { Intervention } \\
\text { and } \\
\text { Comparison } \\
\mathrm{s} \text { (N of } \\
\text { Patients) }\end{array}$ & $\begin{array}{l}\text { Characteristics of Interventions } \\
\text { (Psychotherapy: Components, } \\
\text { Delivery Model)/Pharm: Drug) } \\
\text { Intensity, Duration (Weeks)) }\end{array}$ & $\begin{array}{c}\text { Patient Characteristics Mean } \\
\text { Age (Range), Male (\%), } \\
\text { Race/Ethnicity, Comorbidity, } \\
\text { Household Income, Parent } \\
\text { Education, Family } \\
\text { Dysfunction/Stressor, } \\
\text { Treatment Sequence, } \\
\text { Insurance, History of } \\
\text { Maltreatment) }\end{array}$ & $\begin{array}{l}\text { Length } \\
\text { of } \\
\text { Follow } \\
\text { up } \\
\text { (Weeks } \\
\text { ) }\end{array}$ \\
\hline & & & & & $\begin{array}{l}\text { other: } 8 \% \\
\text { ADHD: } 8 \% \text {, ODD: } 2 \% \\
\text { Placebo non-responder patients }\end{array}$ & \\
\hline \multirow[t]{4}{*}{$\begin{array}{l}\text { Walkup, } \\
2008^{20-26}\end{array}$} & \multirow[t]{4}{*}{$\begin{array}{l}\text { United States } \\
\text { RCT } \\
\text { Efficacy } \\
\text { Outpatient }\end{array}$} & \multirow[t]{4}{*}{ GAD,SAD, SoP } & $\begin{array}{l}\text { Child CBT, } \\
(\mathrm{N}=139)\end{array}$ & $\begin{array}{l}\text { Coping cat } \\
\text { Child CBT (parents included }<20 \% \text { ) } \\
\text { Individual-based, exposure, relaxation, } \\
\text { cognitive problem solving. } \\
60 \text {-minute session once a week for } 12 \\
\text { weeks. }\end{array}$ & $\begin{array}{l}\text { Mean age: } 10.5 \\
\text { Male: } 49.2 \% \\
\text { Caucasian: } 76.3 \% \text {, African } \\
\text { American:10.1\%, Hispanic: } 9.2 \% \text {, } \\
\text { other: } 4.5 \% \\
\text { Low income: } 23.7 \% \\
\text { ADHD: } 11.5 \%, \text { ODD:13.8\%, Tic } \\
\text { disorder and other internalizing } \\
\text { disorders: } 41.7 \%\end{array}$ & \multirow[t]{4}{*}{0} \\
\hline & & & $\begin{array}{l}\text { SSRI: } \\
\text { Sertraline, } \\
(\mathrm{N}=133)\end{array}$ & $\begin{array}{l}\text { Beginning with } 25 \mathrm{mg} / \text { day Up to } 200 \\
\mathrm{mg} / \text { day by } 8^{\text {th }} \text { week, for } 12 \text { weeks. }\end{array}$ & $\begin{array}{l}\text { Mean age: } 10.8 \\
\text { Male: } 51.1 \% \\
\text { Caucasian: } 77.4 \% \text {, African } \\
\text { American: } 9 \% \text {, Hispanic: } 11.3 \% \text {, } \\
\text { other: } 2.3 \% \\
\text { Low income: } 26.3 \% \\
\text { ADHD: } 12.7 \%, \text { ODD:8.2\%, Tic } \\
\text { disorder and other internalizing } \\
\text { disorders: } 55.6 \%\end{array}$ & \\
\hline & & & $\begin{array}{l}\text { Combination } \\
\text { therapy: } \\
\text { CBT+ SSRI: } \\
\text { Child CBT+ } \\
\text { Sertraline, } \\
(\mathrm{N}=140)\end{array}$ & $\begin{array}{l}\text { Coping cat, } \\
\text { Child CBT (parents included <20\%) } \\
\text { Individual-based, exposure, relaxation } \\
\text { and cognitive problem solving plus } \\
\text { Sertraline. } \\
60 \text {-minute session once a week for } 12 \\
\text { weeks plus up to } 200 \text { mg/day for } 12 \\
\text { weeks. }\end{array}$ & $\begin{array}{l}\text { Mean age: } 10.7 \\
\text { Male: } 49.6 \% \\
\text { Caucasian: } 82.9 \% \text {, African } \\
\text { American: } 7.9 \% \text {, Hispanic: } 5.6 \% \text {, } \\
\text { other: } 3.6 \% \\
\text { Low income: } 25.0 \% \\
\text { ADHD: } 11.4 \%, \text { ODD:10\%, Tic } \\
\text { disorder and other internalizing } \\
\text { disorders: } 42.8 \%\end{array}$ & \\
\hline & & & $\begin{array}{l}\text { Control, } \\
(\mathrm{N}=76)\end{array}$ & Pill Placebo & $\begin{array}{l}\text { Mean age: } 10.6 \\
\text { Male : } 51.3 \% \\
\text { Caucasian: } 79 \% \text {, African } \\
\text { American: } 9 \% \text {, Hispanic: } 9 \% \text {, } \\
\text { other: } 3 \%\end{array}$ & \\
\hline
\end{tabular}




\begin{tabular}{|c|c|c|c|c|c|c|}
\hline Author, Year & $\begin{array}{c}\text { Study Country, } \\
\text { Study Design, } \\
\text { Type of Study } \\
\text { (Efficacyl } \\
\text { Effectiveness), } \\
\text { Study Settings }\end{array}$ & $\begin{array}{l}\text { Type of } \\
\text { AnxietylSeverity } \\
\text { (CGI) }\end{array}$ & $\begin{array}{c}\text { Intervention } \\
\text { and } \\
\text { Comparison } \\
\text { s (N of } \\
\text { Patients) }\end{array}$ & $\begin{array}{l}\text { Characteristics of Interventions } \\
\text { (Psychotherapy: Components, } \\
\text { Delivery Model)/Pharm: Drug) } \\
\text { Intensity, Duration (Weeks)) }\end{array}$ & $\begin{array}{c}\text { Patient Characteristics Mean } \\
\text { Age (Range), Male (\%), } \\
\text { Race/Ethnicity, Comorbidity, } \\
\text { Household Income, Parent } \\
\text { Education, Family } \\
\text { Dysfunction/Stressor, } \\
\text { Treatment Sequence, } \\
\text { Insurance, History of } \\
\text { Maltreatment) }\end{array}$ & $\begin{array}{l}\text { Length } \\
\text { of } \\
\text { Follow } \\
\text { up } \\
\text { (Weeks } \\
\text { ) }\end{array}$ \\
\hline & & & & & $\begin{array}{l}\text { Low income: } 27.6 \% \\
\text { ADHD: } 118 \% \text {, ODD: } 9.2 \% \text {, Tic } \\
\text { disorder and other internalizing } \\
\text { disorders: } 44.7 \%\end{array}$ & \\
\hline
\end{tabular}

ADHD: attention deficit hyperactivity disorder, CBT: cognitive behavioral therapy, CGI: clinical global impression scale. GAD: generalized anxiety disorder, NR: not reported,

OCD: obsessive compulsive disorder, ODD: oppositional defiant disorder, RCT: randomized control trial, SAD: separation anxiety disorder, SoP: social anxiety, SP: specific

phobia, SRI: serotonin reuptake inhibitor, SSRI: selective serotonin reuptake inhibitor 
Table E.2. Characteristics of the included studies comparing drugs versus drugs

\begin{tabular}{|c|c|c|c|c|c|c|}
\hline Author, Year & $\begin{array}{c}\text { Study Country, } \\
\text { Study Design, } \\
\text { Type of Study } \\
\text { (Efficacyl } \\
\text { Effectiveness), } \\
\text { Study Settings }\end{array}$ & $\begin{array}{c}\text { Type of } \\
\text { AnxietylSeverity } \\
\text { (CGI) }\end{array}$ & $\begin{array}{l}\text { Intervention } \\
\text { and } \\
\text { Comparison } \\
\text { s (N of } \\
\text { Patients) }\end{array}$ & $\begin{array}{l}\text { Characteristics of Interventions } \\
\text { (Psychotherapy: Components, } \\
\text { Delivery Model)/Pharm: Drug) } \\
\text { Intensity, Duration (Weeks)) }\end{array}$ & $\begin{array}{c}\text { Patient Characteristics Mean Age } \\
\text { (Range), Male (\%), } \\
\text { Race/Ethnicity, Comorbidity, } \\
\text { Household Income, Parent } \\
\text { Education, Family } \\
\text { Dysfunction/Stressor, Treatment } \\
\text { Sequence, Insurance, History of } \\
\text { Maltreatment) }\end{array}$ & $\begin{array}{c}\text { Length } \\
\text { of } \\
\text { Follow } \\
\text { up } \\
\text { (Weeks } \\
\text { ) }\end{array}$ \\
\hline \multirow[t]{3}{*}{$\begin{array}{l}\text { da Costa, } \\
2013^{6}\end{array}$} & \multirow{3}{*}{$\begin{array}{l}\text { Brazil } \\
\text { RCT } \\
\text { Efficacy } \\
\text { Mental health } \\
\text { clinic }\end{array}$} & \multirow[t]{3}{*}{$\begin{array}{l}\text { GAD, SAD, SP } \\
\text { Mean CGI }=4.9\end{array}$} & $\begin{array}{l}\text { TCA: } \\
\text { Clomipramine } \\
,(\mathrm{N}=9)\end{array}$ & $\begin{array}{l}\text { Clomipramine } \\
118.75 \mathrm{mg} / \text { day average dose, } 12 \\
\text { weeks }\end{array}$ & $\begin{array}{l}\text { Mean age: } 11.2 \text { (range: } 7-17 \text { ) } \\
\text { Males: } 33 \% \\
\text { Lower class: } 58.7 \% \\
\text { Upper/Middle class: } 14.3 \%\end{array}$ & \multirow[t]{3}{*}{0} \\
\hline & & & $\begin{array}{l}\text { SSRI: } \\
\text { Fluoxetine, } \\
(\mathrm{N}=10)\end{array}$ & $\begin{array}{l}\text { SRI, SSRI, Fluoxetine } \\
35 \text { mg/ day average dose for } 12 \\
\text { weeks. }\end{array}$ & $\begin{array}{l}\text { Mean age: } 11.6 \text { (range: } 7-17 \text { ) } \\
\text { Males: } 50 \% \\
\text { Lower class: } 50 \% \\
\text { Upper/Middle class: } 50 \%\end{array}$ & \\
\hline & & & $\begin{array}{l}\text { Control, } \\
(\mathrm{N}=11)\end{array}$ & Pill Placebo & $\begin{array}{l}\text { Mean age: } 11.4 \text { (range: } 7-17 \text { ) } \\
\text { Males: } 54 \% \\
\text { Lower class: } 45.4 \% \\
\text { Upper/Middle class: } 45.4 \%\end{array}$ & \\
\hline \multirow[t]{2}{*}{ Rynn, $2007^{15}$} & \multirow{2}{*}{$\begin{array}{l}\text { United States } \\
\text { RCT } \\
\text { Efficacy } \\
\text { Mental health } \\
\text { clinic }\end{array}$} & \multirow[t]{2}{*}{ Anxiety disorder } & $\begin{array}{l}\text { SSRI: } \\
\text { Venlafaxine. } \\
(\mathrm{N}=157)\end{array}$ & $\begin{array}{l}37.5 \mathrm{mg} / \text { day during the first week. } \\
\text { Doses thereafter ranged from } \\
112.5 \mathrm{mg}-225 \mathrm{mg} \text {. }\end{array}$ & \multirow[t]{2}{*}{$\begin{array}{l}\text { Age: } 6-17 \\
\text { Male: } 57.5 \%\end{array}$} & \multirow[t]{2}{*}{0} \\
\hline & & & $\begin{array}{l}\text { Control, } \\
(\mathrm{N}=163)\end{array}$ & Pill placebo & & \\
\hline
\end{tabular}

CGI: clinical global impression scale, GAD: generalized anxiety disorder, NR: not reported, OCD: obsessive compulsive disorder, RCT: randomized controlled trial, SAD: separation anxiety disorder, SNRI: serotonin-norepinephrine reuptake inhibitor, SoP: social anxiety, SP: specific phobia, SRI: serotonin reuptake inhibitor, SSRI: selective serotonin reuptake inhibitor. 
Table E.3. Characteristics of the included studies comparing CBT versus drugs

\begin{tabular}{|c|c|c|c|c|c|c|}
\hline Author, Year & $\begin{array}{l}\text { Study Country, } \\
\text { Study Design, } \\
\text { Type of Study } \\
\text { (Efficacyl } \\
\text { Effectiveness), } \\
\text { Study Settings }\end{array}$ & $\begin{array}{c}\text { Type of } \\
\text { Anxiety/Severity } \\
\text { (CGI) }\end{array}$ & $\begin{array}{l}\text { Intervention } \\
\text { and } \\
\text { Comparison } \\
\text { s (N of } \\
\text { Patients) }\end{array}$ & $\begin{array}{l}\text { Characteristics of Interventions } \\
\text { (Psychotherapy: Components, } \\
\text { Delivery Model)/Pharm: Drug) } \\
\text { Intensity, Duration (Weeks)) }\end{array}$ & $\begin{array}{c}\text { Patient Characteristics Mean } \\
\text { Age (Range), Male (\%), } \\
\text { Race/Ethnicity, Comorbidity, } \\
\text { Household Income, Parent } \\
\text { Education, Family } \\
\text { Dysfunction/Stressor, } \\
\text { Treatment Sequence, } \\
\text { Insurance, History of } \\
\text { Maltreatment) }\end{array}$ & $\begin{array}{l}\text { Length } \\
\text { of } \\
\text { Follow } \\
\text { up } \\
\text { (Weeks } \\
\text { ) }\end{array}$ \\
\hline \multirow[t]{3}{*}{ Beidel, $2007^{3}$} & \multirow{3}{*}{$\begin{array}{l}\text { United States } \\
\text { RCT } \\
\text { Efficacy } \\
\text { Mental health } \\
\text { clinic }\end{array}$} & \multirow[t]{3}{*}{$\begin{array}{l}\text { GAD, SAD, SP, } \\
\text { SoP }\end{array}$} & $\begin{array}{l}\text { SSRI: } \\
\text { Fluoxetine, } \\
(\mathrm{N}=43)\end{array}$ & $\begin{array}{l}10 \mathrm{mg} \text { per day during week } 1 \text { and } 2 \text {. } \\
\text { Increasing dose up to } 40 \mathrm{mg} / \text { day for up } \\
\text { to } 12 \text { weeks. }\end{array}$ & \multirow{3}{*}{$\begin{array}{l}\text { Mean age:11.56 (Range } 7-17 \text { ) } \\
\text { Male: } 53.23 \% \\
\text { Caucasian: } 74.1 \% \\
\text { African American: } 15.1 \% \\
\text { Hispanic: } 2.1 \% \\
\text { Asian: } 2.8 \% \\
\text { Other: } 3.5 \%\end{array}$} & \multirow[t]{3}{*}{52} \\
\hline & & & $\begin{array}{l}\text { Child CBT, } \\
(\mathrm{N}=59)\end{array}$ & $\begin{array}{l}\text { Social Effectiveness Therapy (SET-C) } \\
\text { Child CBT (Parents included <20\%) } \\
\text { Group and individual based, exposure, } \\
\text { relaxation, and cognitive problem } \\
\text { solving. } \\
60 \text { min individual session and one } 150 \\
\text { min group session twice a week for } 12 \\
\text { weeks. }\end{array}$ & & \\
\hline & & & $\begin{array}{l}\text { Control, } \\
(\mathrm{N}=37)\end{array}$ & Pill placebo & & \\
\hline \multirow[t]{3}{*}{$\begin{array}{l}\text { Scharfstein, } \\
2011^{16}\end{array}$} & \multirow[t]{3}{*}{$\begin{array}{l}\text { United States } \\
\text { RCT } \\
\text { Effectiveness } \\
\text { Outpatient }\end{array}$} & \multirow[t]{3}{*}{ SoP } & $\begin{array}{l}\text { Child CBT, } \\
(\mathrm{N}=46)\end{array}$ & $\begin{array}{l}\text { Social Effectiveness Therapy (SET-C) } \\
\text { Child CBT (parents included }<20 \% \text { ) } \\
\text { Exposure and cognitive problem } \\
\text { solving. } \\
\text { One individual and one group session } \\
\text { per week for } 12 \text { weeks. }\end{array}$ & \multirow[t]{3}{*}{ Male: $50 \%$} & \multirow[t]{3}{*}{0} \\
\hline & & & $\begin{array}{l}\text { SSRI: } \\
\text { Fluoxetine, } \\
(\mathrm{N}=22)\end{array}$ & $\begin{array}{l}\text { One tablet of up to } 40 \mathrm{mg} / \text { day for } 12 \\
\text { weeks }\end{array}$ & & \\
\hline & & & $\begin{array}{l}\text { Control, } \\
(\mathrm{N}=22)\end{array}$ & $\begin{array}{l}\text { Pill placebo } \\
\text { Identically appearing placebo capsules } \\
\text { once a week for } 12 \text { weeks. }\end{array}$ & & \\
\hline $\begin{array}{l}\text { Walkup, } \\
2008^{20-26}\end{array}$ & $\begin{array}{l}\text { United States } \\
\text { RCT } \\
\text { Efficacy } \\
\text { Outpatient }\end{array}$ & GAD,SAD, SoP & $\begin{array}{l}\text { Child CBT, } \\
(\mathrm{N}=139)\end{array}$ & $\begin{array}{l}\text { Coping cat } \\
\text { Child CBT (parents included }<20 \% \text { ) } \\
\text { Individual-based, exposure, relaxation, } \\
\text { cognitive problem solving. } \\
60 \text {-minute session once a week for } 12 \\
\text { weeks. }\end{array}$ & $\begin{array}{l}\text { Mean age: } 10.5 \\
\text { Male: } 49.2 \% \\
\text { Caucasian: } 76.3 \% \text {, African } \\
\text { American: } 10.1 \% \text {, Hispanic: } \\
\text { 9.2\%, other: } 4.5 \% \\
\text { Low income: } 23.7 \% \\
\text { ADHD: } 11.5 \%, \text { ODD:13.8\%, Tic } \\
\text { disorder and other internalizing } \\
\text { disorders: } 41.7 \%\end{array}$ & 0 \\
\hline
\end{tabular}




\begin{tabular}{|c|c|c|c|c|c|c|}
\hline Author, Year & $\begin{array}{c}\text { Study Country, } \\
\text { Study Design, } \\
\text { Type of Study } \\
\text { (Efficacyl } \\
\text { Effectiveness), } \\
\text { Study Settings }\end{array}$ & $\begin{array}{c}\text { Type of } \\
\text { Anxiety/Severity } \\
\text { (CGI) }\end{array}$ & $\begin{array}{c}\text { Intervention } \\
\text { and } \\
\text { Comparison } \\
\text { s (N of } \\
\text { Patients) }\end{array}$ & $\begin{array}{l}\text { Characteristics of Interventions } \\
\text { (Psychotherapy: Components, } \\
\text { Delivery Model)/Pharm: Drug) } \\
\text { Intensity, Duration (Weeks)) }\end{array}$ & $\begin{array}{c}\text { Patient Characteristics Mean } \\
\text { Age (Range), Male (\%), } \\
\text { Race/Ethnicity, Comorbidity, } \\
\text { Household Income, Parent } \\
\text { Education, Family } \\
\text { Dysfunction/Stressor, } \\
\text { Treatment Sequence, } \\
\text { Insurance, History of } \\
\text { Maltreatment) } \\
\end{array}$ & $\begin{array}{c}\text { Length } \\
\text { of } \\
\text { Follow } \\
\text { up } \\
\text { (Weeks } \\
\text { ) }\end{array}$ \\
\hline & & & $\begin{array}{l}\text { SSRI: } \\
\text { Sertraline, } \\
(\mathrm{N}=133)\end{array}$ & $\begin{array}{l}\text { Beginning with } 25 \mathrm{mg} / \text { day Up to } 200 \\
\mathrm{mg} / \text { day by } 8^{\text {th }} \text { week, for } 12 \text { weeks. }\end{array}$ & $\begin{array}{l}\text { Mean age: } 10.8 \\
\text { Male: } 51.1 \% \\
\text { Caucasian: } 77.4 \% \text {, African } \\
\text { American: } 9 \% \text {, Hispanic: } \\
\text { 11.3\%, other: } 2.3 \% \\
\text { Low income: } 26.3 \% \\
\text { ADHD: } 12.7 \%, \text { ODD:8.2\%, Tic } \\
\text { disorder and other internalizing } \\
\text { disorders: } 55.6 \%\end{array}$ & \\
\hline & & & $\begin{array}{l}\text { Combination } \\
\text { therapy: } \\
\text { CBT+ SSRI: } \\
\text { Child CBT+ } \\
\text { Sertraline, } \\
(\mathrm{N}=140)\end{array}$ & $\begin{array}{l}\text { Coping cat, } \\
\text { Child CBT (parents included <20\%) } \\
\text { Individual-based, exposure, relaxation } \\
\text { and cognitive problem solving plus } \\
\text { Sertraline. } \\
60 \text {-minute session once a week for } 12 \\
\text { weeks plus up to } 200 \mathrm{mg} / \text { day for } 12 \\
\text { weeks. }\end{array}$ & $\begin{array}{l}\text { Mean age: } 10.7 \\
\text { Male: } 49.6 \% \\
\text { Caucasian: } 82.9 \% \text {, African } \\
\text { American: } 7.9 \% \text {, Hispanic: } \\
\text { 5.6\%, other: } 3.6 \% \\
\text { Low income: } 25.0 \% \\
\text { ADHD: } 11.4 \%, \text { ODD:10\%, Tic } \\
\text { disorder and other internalizing } \\
\text { disorders: } 42.8 \%\end{array}$ & \\
\hline & & & $\begin{array}{l}\text { Control, } \\
(\mathrm{N}=76)\end{array}$ & Pill placebo & $\begin{array}{l}\text { Mean age: } 10.6 \\
\text { Male : } 51.3 \% \\
\text { Caucasian: } 79 \% \text {, African } \\
\text { American: } 9 \% \text {, Hispanic: } 9 \% \text {, } \\
\text { other: } 3 \% \\
\text { Low income: } 27.6 \% \\
\text { ADHD: } 118 \%, \text { ODD:9.2\%, Tic } \\
\text { disorder and other internalizing } \\
\text { disorders: } 44.7 \%\end{array}$ & \\
\hline
\end{tabular}

cognitive behavioral therapy, ODD: oppositional defiant disorder, RCT: randomized controlled trial, SAD: separation anxiety disorder, SoP: social anxiety, SP: specific phobia, SSRI: selective serotonin reuptake inhibitor. 
Table E.4. Characteristics of the included studies comparing CBT versus waitlisting or no treatment

\begin{tabular}{|c|c|c|c|c|c|c|}
\hline $\begin{array}{l}\text { Author, } \\
\text { Year }\end{array}$ & $\begin{array}{l}\text { Study Country, } \\
\text { Study Design, } \\
\text { Type of Study } \\
\text { (Efficacyl } \\
\text { Effectiveness), } \\
\text { Study Settings }\end{array}$ & $\begin{array}{c}\text { Type of } \\
\text { Anxiety/Severit } \\
\text { y (CGI) }\end{array}$ & $\begin{array}{l}\text { Intervention } \\
\text { and } \\
\text { Comparison } \\
\text { s (N of } \\
\text { Patients) }\end{array}$ & $\begin{array}{l}\text { Characteristics of Interventions } \\
\text { (Psychotherapy: Components, } \\
\text { Delivery Model)/Pharm: Drug) } \\
\text { Intensity, Duration (Weeks)) }\end{array}$ & $\begin{array}{c}\text { Patient Characteristics Mean } \\
\text { Age (Range), Male (\%), } \\
\text { Race/Ethnicity, Comorbidity, } \\
\text { Household Income, Parent } \\
\text { Education, Family } \\
\text { Dysfunction/Stressor, } \\
\text { Treatment Sequence, } \\
\text { Insurance, History of } \\
\text { Maltreatment) }\end{array}$ & $\begin{array}{l}\text { Length } \\
\text { of } \\
\text { Follow } \\
\text { up } \\
\text { (Weeks } \\
\text { ) }\end{array}$ \\
\hline \multirow[t]{3}{*}{$\underset{27}{\text { Abbasi, } 2016}$} & \multirow[t]{3}{*}{$\begin{array}{l}\text { Iran } \\
\text { RCT } \\
\text { Efficacy } \\
\text { Mental health } \\
\text { clinic }\end{array}$} & \multirow[t]{3}{*}{ SAD } & $\begin{array}{l}\text { Child CBT, } \\
(\mathrm{N}=15)\end{array}$ & $\begin{array}{l}\text { Modular CBT } \\
\text { Child CBT- (parents included }<20 \% \text { ) } \\
\text { Individual based } \\
\text { Exposure } \\
\text { Cognitive problem solving } \\
4-20 \text { sessions, } 1 \text { hour sessions, with }\end{array}$ & $\begin{array}{l}\text { Age range : } 6-7 \text { years } \\
\text { Male: } 53 \%\end{array}$ & \multirow[t]{3}{*}{13} \\
\hline & & & $\begin{array}{l}\text { Other } \\
\text { Therapy, } \\
(\mathrm{N}=15)\end{array}$ & $\begin{array}{l}\text { Other: Child parent relationship training } \\
\text { Individual based } \\
10 \text { weekly, } 1 \text { hour sessions }\end{array}$ & $\begin{array}{l}\text { Age range : } 6-7 \text { years } \\
\text { Male: } 33.3 \%\end{array}$ & \\
\hline & & & $\begin{array}{l}\text { Control, } \\
(\mathrm{N}=16)\end{array}$ & Waitlisting or no treatment & $\begin{array}{l}\text { Age range : } 6-7 \text { years } \\
\text { Male: } 48 \%\end{array}$ & \\
\hline \multirow[t]{2}{*}{$\begin{array}{l}\text { Adler Nevo, } \\
2014^{28}\end{array}$} & \multirow[t]{2}{*}{$\begin{array}{l}\text { Canada } \\
\text { RCT }\end{array}$} & \multirow[t]{2}{*}{$\begin{array}{l}\text { GAD, PD,SAD, } \\
\text { SP, SoP }\end{array}$} & $\begin{array}{l}\text { Child CBT } \\
\text { plus separate } \\
\text { parent } \\
\text { intervention, } \\
(\mathrm{N}=60)\end{array}$ & $\begin{array}{l}\text { Coping Bear } \\
\text { Individual based } \\
\text { Exposure } \\
\text { Relaxation } \\
\text { Cognitive Problem Solving. } \\
12 \text { sessions of group or individual with } \\
12 \text { concurrent parent groups }\end{array}$ & $\begin{array}{l}\text { Mean age:9.6 (Range } 8-12) \\
\text { Male: } 46.50 \% \\
\text { OCD: } 4 \% \\
\text { ADHD: } 3 \% \\
\text { ODD: } 3 \%\end{array}$ & \multirow[t]{2}{*}{0} \\
\hline & & & $\begin{array}{l}\text { Control, } \\
(\mathrm{N}=60)\end{array}$ & Waitlisting or no treatment & $\begin{array}{l}\text { Mean age:9.6 (Range } 8-12) \\
\text { Male: } 58.60 \% \\
\text { OCD: } 5 \% \\
\text { ADHD: } 5 \% \\
\text { ODD: } 5 \% \\
\text { Depression: } 2 \%\end{array}$ & \\
\hline $\begin{array}{l}\text { Afshari, } \\
2014^{29}\end{array}$ & $\begin{array}{l}\text { Iran } \\
\text { RCT } \\
\text { Efficacy } \\
\text { Outpatient } \\
\text { Mental health } \\
\text { clinic }\end{array}$ & SAD & $\begin{array}{l}\text { Child CBT, } \\
(\mathrm{N}=12)\end{array}$ & $\begin{array}{l}\text { Coping Cat } \\
\text { Child CBT- (parents included < 20\%) } \\
\text { Group based } \\
\text { Exposure } \\
\text { Relaxation } \\
\text { Cognitive problem solving } \\
10,60 \text { min weekly sessions } \\
\text { Delivered by student/trainee }\end{array}$ & Mean age: 10.4 (range: 9-13) & 12 \\
\hline
\end{tabular}




\begin{tabular}{|c|c|c|c|c|c|c|}
\hline \multirow[t]{3}{*}{$\begin{array}{l}\text { Author, } \\
\text { Year }\end{array}$} & \multirow[t]{3}{*}{$\begin{array}{l}\text { Study Country, } \\
\text { Study Design, } \\
\text { Type of Study } \\
\text { (Efficacyl } \\
\text { Effectiveness), } \\
\text { Study Settings }\end{array}$} & \multirow[t]{3}{*}{$\begin{array}{c}\text { Type of } \\
\text { Anxiety/Severit } \\
\text { y (CGI) }\end{array}$} & $\begin{array}{l}\text { Intervention } \\
\text { and } \\
\text { Comparison } \\
\text { s (N of } \\
\text { Patients) }\end{array}$ & $\begin{array}{l}\text { Characteristics of Interventions } \\
\text { (Psychotherapy: Components, } \\
\text { Delivery Model)/Pharm: Drug) } \\
\text { Intensity, Duration (Weeks)) }\end{array}$ & $\begin{array}{c}\text { Patient Characteristics Mean } \\
\text { Age (Range), Male (\%), } \\
\text { Race/Ethnicity, Comorbidity, } \\
\text { Household Income, Parent } \\
\text { Education, Family } \\
\text { Dysfunction/Stressor, } \\
\text { Treatment Sequence, } \\
\text { Insurance, History of } \\
\text { Maltreatment) }\end{array}$ & $\begin{array}{l}\text { Length } \\
\text { of } \\
\text { Follow } \\
\text { up } \\
\text { (Weeks } \\
\text { ) }\end{array}$ \\
\hline & & & $\begin{array}{l}\text { Child CBT, } \\
(\mathrm{N}=12)\end{array}$ & $\begin{array}{l}\text { Other: Emotion-focused CBT } \\
\text { Child CBT- (parents included <20\%) } \\
\text { Group based } \\
\text { Cognitive problem solving } \\
12 \text { one hour weekly sessions } \\
\text { Delivered by student/trainee }\end{array}$ & Mean age: 11 (range: 9-13) & \\
\hline & & & $\begin{array}{l}\text { Control, } \\
(\mathrm{N}=10)\end{array}$ & Waitlisting or no treatment & Mean age: 10.3 (range: 9-13) & \\
\hline \multirow[t]{2}{*}{$\underset{30}{\text { Arendt, } 2015}$} & \multirow[t]{2}{*}{$\begin{array}{l}\text { Denmark } \\
\text { RCT } \\
\text { Efficacy } \\
\text { Mental health } \\
\text { clinic }\end{array}$} & \multirow[t]{2}{*}{$\begin{array}{l}\text { GAD, PD with } \\
\text { agoraphobia, PD } \\
\text { without } \\
\text { agoraphobia, } \\
\text { SAD, SoP, SP }\end{array}$} & $\begin{array}{l}\text { Child and } \\
\text { parent } \mathrm{CBT}, \\
(\mathrm{N}=56)\end{array}$ & $\begin{array}{l}\text { Cool Kids } \\
\text { Group-based } \\
\text { Exposure } \\
\text { Cognitive problem solving } \\
10 \text { sessions, } 2 \text { hour weekly sessions } \\
\text { Delivered by psychologist and student }\end{array}$ & $\begin{array}{l}\text { Mean age: } 11.82 \text { (SD: } 2.49) \\
\text { Male: } 45 \% \\
\text { Low income:(<\$93,109): } 21.4 \% \\
\text { Medium income:(\$93,1009- } \\
\$ 130,353): 71.5 \% \\
\text { High income:(>\$167,597): 7.1\% } \\
\text { Less than high school or high } \\
\text { school graduate(parent):4.5\% } \\
\text { Some college(parent): } 24.45 \% \\
\text { College graduate(parent): } \\
71.05 \% \\
\text { OCD: } 7.1 \% \\
\text { Externalizing disorders: } 10.7 \% \\
\text { Mood disorders: } 7.1 \% \\
\text { Other comorbidities: } 5.4 \%\end{array}$ & \multirow[t]{2}{*}{52} \\
\hline & & & $\begin{array}{l}\text { Control, } \\
(\mathrm{N}=53)\end{array}$ & Waitlisting or no treatment & $\begin{array}{l}\text { Mean age: } 11.73 \text { (SD: } 2.47) \\
\text { Male: } 42 \% \\
\text { Low income:(<\$93,109): } 37.7 \% \\
\text { Medium income:(\$93,1009- } \\
\$ 130,353): 52.9 \% \\
\text { High income:(>\$167,597): } 9.4 \% \\
\text { Less than high school or high } \\
\text { school graduate(parent):12.4\% } \\
\text { Some college(parent): } 29.1 \% \\
\text { College graduate(parent): } \\
58.5 \%\end{array}$ & \\
\hline
\end{tabular}




\begin{tabular}{|c|c|c|c|c|c|c|}
\hline $\begin{array}{l}\text { Author, } \\
\text { Year }\end{array}$ & $\begin{array}{c}\text { Study Country, } \\
\text { Study Design, } \\
\text { Type of Study } \\
\text { (Efficacyl } \\
\text { Effectiveness), } \\
\text { Study Settings }\end{array}$ & $\begin{array}{c}\text { Type of } \\
\text { AnxietylSeverit } \\
\text { y (CGI) }\end{array}$ & $\begin{array}{c}\text { Intervention } \\
\text { and } \\
\text { Comparison } \\
\text { s (N of } \\
\text { Patients) }\end{array}$ & $\begin{array}{l}\text { Characteristics of Interventions } \\
\text { (Psychotherapy: Components, } \\
\text { Delivery Model)/Pharm: Drug) } \\
\text { Intensity, Duration (Weeks)) }\end{array}$ & $\begin{array}{c}\text { Patient Characteristics Mean } \\
\text { Age (Range), Male (\%), } \\
\text { Race/Ethnicity, Comorbidity, } \\
\text { Household Income, Parent } \\
\text { Education, Family } \\
\text { Dysfunction/Stressor, } \\
\text { Treatment Sequence, } \\
\text { Insurance, History of } \\
\text { Maltreatment) }\end{array}$ & $\begin{array}{c}\text { Length } \\
\text { of } \\
\text { Follow } \\
\text { up } \\
\text { (Weeks } \\
\text { ) }\end{array}$ \\
\hline & & & & & $\begin{array}{l}\text { OCD: } 7.6 \% \\
\text { Externalizing disorders: } 13.2 \% \\
\text { Mood disorders: } 11.3 \% \\
\text { Other comorbidities: } 7.5 \%\end{array}$ & \\
\hline \multirow[t]{2}{*}{ Baer, $2005^{31}$} & \multirow[t]{2}{*}{$\begin{array}{l}\text { Canada } \\
\text { RCT } \\
\text { Efficacy } \\
\text { Mental health } \\
\text { clinic }\end{array}$} & \multirow[t]{2}{*}{ SoP } & $\begin{array}{l}\text { Child CBT, } \\
(\mathrm{N}=6)\end{array}$ & $\begin{array}{l}\text { Social Effectiveness Therapy (SET-C) } \\
\text { Child CBT- (parents included }<20 \% \text { ) } \\
\text { Group based } \\
\text { Exposure } \\
\text { Cognitive problem solving } \\
12 \text { weekly } 1.5 \text {-hour child sessions plus } \\
\text { one parent session } \\
\text { Delivered by } 2 \text { psychiatrists }\end{array}$ & $\begin{array}{l}\text { Mean age: } 14.5 \text { (Range } 13- \\
\text { 18) } \\
\text { Male: } 50 \%\end{array}$ & \multirow[t]{2}{*}{ NR } \\
\hline & & & $\begin{array}{l}\text { Control, } \\
(\mathrm{N}=6)\end{array}$ & Waitlisting or no treatment & $\begin{array}{l}\text { Mean age: } 16.5 \text { (Range } 13-18) \\
\text { Male: } 66.6 \%\end{array}$ & \\
\hline \multirow[t]{3}{*}{ Barrett, 1996} & \multirow[t]{3}{*}{$\begin{array}{l}\text { Australia } \\
\text { RCT } \\
\text { Efficacy } \\
\text { Mental health } \\
\text { clinic }\end{array}$} & \multirow[t]{3}{*}{ GAD, SAD, SoP } & $\begin{array}{l}\text { Child CBT, (N } \\
=28)\end{array}$ & $\begin{array}{l}\text { Coping Koala } \\
\text { Child CBT- (parents included < 20\%) } \\
\text { Individual based } \\
\text { Exposure, relaxation and cognitive } \\
\text { problem solving } \\
12 \text { sessions, } 60-80 \text { minute weekly; } 4 \\
\text { sessions on anxiety management } \\
\text { Delivered by doctoral level } \\
\text { psychologists. }\end{array}$ & \multirow[t]{3}{*}{ Age range: $7-14$ years } & \multirow[t]{3}{*}{52} \\
\hline & & & $\begin{array}{l}\text { Child and } \\
\text { parent } \mathrm{CBT} \text {, } \\
(\mathrm{N}=25)\end{array}$ & $\begin{array}{l}\text { Coping Koala } \\
\text { Individual based } \\
\text { Exposure ,relaxation and cognitive } \\
\text { problem solving } \\
12 \text { session, } 70 \text { minute weekly sessions } \\
\text { ( } 30 \text { minutes for CBTand } 40 \text { minutess for } \\
\text { family intervention) } \\
\text { Delivered by doctoral level } \\
\text { psychologists. }\end{array}$ & & \\
\hline & & & $\begin{array}{l}\text { Control, } \\
(\mathrm{N}=26)\end{array}$ & Waitlisting or no treatment & & \\
\hline Barrett, 1998 & Australia & GAD, SAD, SP, & Child CBT, & Coping Koala & Age range: $7-14$ years & 52 \\
\hline
\end{tabular}




\begin{tabular}{|c|c|c|c|c|c|c|}
\hline $\begin{array}{l}\text { Author, } \\
\text { Year }\end{array}$ & $\begin{array}{c}\text { Study Country, } \\
\text { Study Design, } \\
\text { Type of Study } \\
\text { (Efficacyl } \\
\text { Effectiveness), } \\
\text { Study Settings }\end{array}$ & $\begin{array}{c}\text { Type of } \\
\text { Anxiety/Severit } \\
\text { y (CGI) }\end{array}$ & $\begin{array}{c}\text { Intervention } \\
\text { and } \\
\text { Comparison } \\
\text { s (N of } \\
\text { Patients) }\end{array}$ & $\begin{array}{l}\text { Characteristics of Interventions } \\
\text { (Psychotherapy: Components, } \\
\text { Delivery Model)/Pharm: Drug) } \\
\text { Intensity, Duration (Weeks)) }\end{array}$ & $\begin{array}{c}\text { Patient Characteristics Mean } \\
\text { Age (Range), Male (\%), } \\
\text { Race/Ethnicity, Comorbidity, } \\
\text { Household Income, Parent } \\
\text { Education, Family } \\
\text { Dysfunction/Stressor, } \\
\text { Treatment Sequence, } \\
\text { Insurance, History of } \\
\text { Maltreatment) }\end{array}$ & $\begin{array}{c}\text { Length } \\
\text { of } \\
\text { Follow } \\
\text { up } \\
\text { (Weeks } \\
\text { ) }\end{array}$ \\
\hline \multirow[t]{3}{*}{33} & \multirow[t]{3}{*}{$\begin{array}{l}\text { RCT } \\
\text { Efficacy } \\
\text { Mental health } \\
\text { clinic }\end{array}$} & \multirow[t]{3}{*}{ SoP. } & $(\mathrm{N}=23)$ & $\begin{array}{l}\text { Child CBT- (parents included < 20\%) } \\
\text { Group based } \\
\text { Exposure } \\
\text { Relaxation } \\
\text { Cognitive problem solving } \\
12 \text { sessions, } 2 \text { hours weekly sessions } \\
\text { Delivered by } 4 \text { clinical psychologists. }\end{array}$ & \multirow[t]{3}{*}{ Male: $53.3 \%$} & \\
\hline & & & $\begin{array}{l}\text { Child and } \\
\text { parent } \\
\text { together } \mathrm{CBT} \text {, } \\
(\mathrm{N}=17)\end{array}$ & $\begin{array}{l}\text { Coping koala } \\
\text { Group-CBT and family management } \\
\text { training } \\
\text { Group based } \\
\text { Exposure } \\
\text { Relaxation } \\
\text { Cognitive problem solving } \\
12 \text { sessions, } 2 \text { hour weekly sessions } \\
\text { Delivered by therapists }\end{array}$ & & \\
\hline & & & $\begin{array}{l}\text { Control, } \\
(\mathrm{N}=20)\end{array}$ & Waitlisting or no treatment & & \\
\hline \multirow[t]{2}{*}{$\begin{array}{l}\text { Chalfant, } \\
2007^{34}\end{array}$} & \multirow[t]{2}{*}{$\begin{array}{l}\text { Australia } \\
\text { RCT } \\
\text { Effectiveness } \\
\text { Mental health } \\
\text { clinic }\end{array}$} & \multirow[t]{2}{*}{$\begin{array}{l}\text { GAD ,PD } \\
\text { (agoraphobia is } \\
\text { not specified) } \\
\text { SAD, SP, SoP. }\end{array}$} & $\begin{array}{l}\text { Child CBT } \\
\text { plus separate } \\
\text { parent } \\
\text { intervention, } \\
(\mathrm{N}=28)\end{array}$ & $\begin{array}{l}\text { Cool Kids } \\
\text { Adaptation of the program for children } \\
\text { with autism } \\
\text { Group based } \\
\text { Exposure } \\
\text { Relaxation } \\
\text { Cognitive problem solving } \\
12 \text { sessions, } 9 \text { weekly plus } 3 \text { booster } \\
\text { monthly sessions } \\
\text { Delivered by a doctoral level } \\
\text { psychologist and Masters level } \\
\text { clinicians. }\end{array}$ & \multirow[t]{2}{*}{ Age: 10.8 ( Range $8-13$ ) } & \multirow[t]{2}{*}{ NR } \\
\hline & & & $\begin{array}{l}\text { Control, } \\
(\mathrm{N}=19)\end{array}$ & Waitlisting or no treatment & & \\
\hline
\end{tabular}




\begin{tabular}{|c|c|c|c|c|c|c|}
\hline $\begin{array}{l}\text { Author, } \\
\text { Year }\end{array}$ & $\begin{array}{l}\text { Study Country, } \\
\text { Study Design, } \\
\text { Type of Study } \\
\text { (Efficacyl } \\
\text { Effectiveness), } \\
\text { Study Settings }\end{array}$ & $\begin{array}{c}\text { Type of } \\
\text { AnxietylSeverit } \\
\text { y (CGI) }\end{array}$ & $\begin{array}{c}\text { Intervention } \\
\text { and } \\
\text { Comparison } \\
\mathrm{s} \text { (N of } \\
\text { Patients) }\end{array}$ & $\begin{array}{l}\text { Characteristics of Interventions } \\
\text { (Psychotherapy: Components, } \\
\text { Delivery Model)/Pharm: Drug) } \\
\text { Intensity, Duration (Weeks)) }\end{array}$ & $\begin{array}{c}\text { Patient Characteristics Mean } \\
\text { Age (Range), Male (\%), } \\
\text { Race/Ethnicity, Comorbidity, } \\
\text { Household Income, Parent } \\
\text { Education, Family } \\
\text { Dysfunction/Stressor, } \\
\text { Treatment Sequence, } \\
\text { Insurance, History of } \\
\text { Maltreatment) } \\
\end{array}$ & $\begin{array}{l}\text { Length } \\
\text { of } \\
\text { Follow } \\
\text { up } \\
\text { (Weeks } \\
\quad \text { ) }\end{array}$ \\
\hline \multirow[t]{2}{*}{ Chiu, $2013^{35}$} & \multirow[t]{2}{*}{$\begin{array}{l}\text { United States } \\
\text { RCT } \\
\text { Effectiveness } \\
\text { School }\end{array}$} & \multirow[t]{2}{*}{ GAD, SAD, SoP } & $\begin{array}{l}\text { Child CBT, } \\
(\mathrm{N}=22)\end{array}$ & $\begin{array}{l}\text { Building confidence } \\
\text { Child CBT- (parents included < 20\%) } \\
\text { Individual based } \\
\text { Exposure } \\
\text { Cognitive problem solving } \\
10 \text { to } 1660 \text {-minute sessions } \\
\text { Delivered by student/trainee }\end{array}$ & \multirow{2}{*}{$\begin{array}{l}\text { Mean age: } 8.51 \text { (range: 5-12) } \\
\text { Males: } 55 \% \\
\text { Caucasian: } 40 \% \\
\text { African American: } 15 \% \\
\text { Hispanic: } 18 \% \\
\text { Asian: } 5 \% \\
\text { Other: } 23 \% \\
\text { Low income }(<\$ 40,000)=17.5 \% \\
\text { Medium income }(\$ 40,000- \\
\$ 70,000)=17.5 \% \\
\text { High income }(>\$ 90,000): 67.5 \% \\
\text { ADHD: } 15 \% \\
\text { OCD: } 5 \% \\
\text { ODD: } 7.5 \%\end{array}$} & \multirow[t]{2}{*}{0} \\
\hline & & & $\begin{array}{l}\text { Control, } \\
(N=18)\end{array}$ & Waitlisting or no treatment & & \\
\hline \multirow[t]{2}{*}{$\begin{array}{l}\text { Cobham, } \\
2012^{36}\end{array}$} & \multirow[t]{2}{*}{$\begin{array}{l}\text { Australia } \\
\text { RCT } \\
\text { Efficacy } \\
\text { Mental health } \\
\text { clinic }\end{array}$} & \multirow[t]{2}{*}{$\begin{array}{l}\text { GAD, PD, PD } \\
\text { with } \\
\text { agoraphobia, } \\
\text { SAD, SoP, SP }\end{array}$} & $\begin{array}{l}\text { Child CBT } \\
\text { plus separate } \\
\text { parent } \\
\text { intervention, } \\
(\mathrm{N}=23)\end{array}$ & $\begin{array}{l}\text { Do as I do } \\
\text { Individual-based } \\
\text { Exposure } \\
\text { Cognitive problem solving } \\
690 \text {-minutes sessions for parent and } 6 \\
60 \text {-minutes for child, weekly Delivered } \\
\text { by Masters level clinicians }\end{array}$ & $\begin{array}{l}\text { Mean age: } 9.70 \text { (range: } 7-14 \text { ) } \\
\text { Males: } 50 \% \\
\text { Caucasian } 92 \% \\
\text { Asian: } 8 \% \\
\text { PTSD: } 4 \% \\
\text { ADHD: } 7 \% \\
\text { Dysthymia: } 4 \% \\
\text { Enuresis: } 4 \%\end{array}$ & \multirow[t]{2}{*}{26} \\
\hline & & & $\begin{array}{l}\text { Distance } \\
\text { Therapy, } \\
(\mathrm{N}=20)\end{array}$ & $\begin{array}{l}\text { Do as I do } \\
\text { "Do as I Do" and "Facing your Fears" } \\
\text { bibliotherapy programs } \\
\text { Exposure } \\
\text { Cognitive problem solving } \\
2 \text { hour parent group, every other week } \\
12 \text { min phone calls for } 12 \text { weeks } \\
\text { Delivered by parent and therapist }\end{array}$ & $\begin{array}{l}\text { Mean age: } 10.20 \text { (range: } 7-14 \text { ) } \\
\text { Males: } 55 \% \\
\text { Caucasian } 92 \% \\
\text { Asian: } 8 \% \\
\text { ADHD: } 5 \% \\
\text { PTSD: } 5 \% \\
\text { Dysthymia: } 5 \% \\
\text { Sleep terrors: } 5 \%\end{array}$ & \\
\hline
\end{tabular}




\begin{tabular}{|c|c|c|c|c|c|c|}
\hline $\begin{array}{l}\text { Author, } \\
\text { Year }\end{array}$ & $\begin{array}{l}\text { Study Country, } \\
\text { Study Design, } \\
\text { Type of Study } \\
\text { (Efficacyl } \\
\text { Effectiveness), } \\
\text { Study Settings }\end{array}$ & $\begin{array}{c}\text { Type of } \\
\text { Anxiety/Severit } \\
\text { y (CGI) }\end{array}$ & $\begin{array}{l}\text { Intervention } \\
\text { and } \\
\text { Comparison } \\
\text { s (N of } \\
\text { Patients) }\end{array}$ & $\begin{array}{l}\text { Characteristics of Interventions } \\
\text { (Psychotherapy: Components, } \\
\text { Delivery Model)/Pharm: Drug) } \\
\text { Intensity, Duration (Weeks)) }\end{array}$ & $\begin{array}{c}\text { Patient Characteristics Mean } \\
\text { Age (Range), Male (\%), } \\
\text { Race/Ethnicity, Comorbidity, } \\
\text { Household Income, Parent } \\
\text { Education, Family } \\
\text { Dysfunction/Stressor, } \\
\text { Treatment Sequence, } \\
\text { Insurance, History of } \\
\text { Maltreatment) }\end{array}$ & $\begin{array}{l}\text { Length } \\
\text { of } \\
\text { Follow } \\
\text { up } \\
\text { (Weeks } \\
\text { ) }\end{array}$ \\
\hline & & & $\begin{array}{l}\text { Control, } \\
(\mathrm{N}=12)\end{array}$ & Waitlisting or no treatment & $\begin{array}{l}\text { Mean age: } 9.83 \text { (range: } 7-14 \text { ) } \\
\text { Males: } 57 \% \\
\text { Caucasian } 92 \% \\
\text { Asian: } 8 \% \\
\text { PTSD: } 4 \%\end{array}$ & \\
\hline \multirow[t]{3}{*}{$\begin{array}{l}\text { Dewis, } \\
2001^{37}\end{array}$} & \multirow[t]{3}{*}{$\begin{array}{l}\text { Australia } \\
\text { RCT } \\
\text { Efficacy } \\
\text { Mental health } \\
\text { clinic }\end{array}$} & \multirow[t]{3}{*}{ SP } & $\begin{array}{l}\text { Child CBT, } \\
(\mathrm{N}=9)\end{array}$ & $\begin{array}{l}\text { Generic CBT } \\
\text { Live graded exposure } \\
\text { Child CBT- (parents included }<20 \% \text { ) } \\
\text { Individual based } \\
\text { Exposure } \\
\text { Three } 45-\text { min treatment sessions every } \\
\text { 3-4 days } \\
\text { Provided by clinical psychologists }\end{array}$ & $\begin{array}{l}\text { Male: } 35.7 \% \\
\text { Caucasian: } 100 \% \\
\text { Mean age: } 12.3 \text { (Range } 10-17 \text { ) }\end{array}$ & \multirow[t]{3}{*}{4} \\
\hline & & & $\begin{array}{l}\text { Distance } \\
\text { Therapy, } \\
(\mathrm{N}=10)\end{array}$ & $\begin{array}{l}\text { Other: Computer-aided vicarious } \\
\text { Exposure } \\
\text { Individual computer based } \\
\text { Three 45-min treatment sessions every } \\
\text { 3-4 days }\end{array}$ & $\begin{array}{l}\text { Male: } 35.7 \% \\
\text { Caucasian: } 100 \% \\
\text { Mean age: } 13.8 \text { (Range } 10-17 \text { ) }\end{array}$ & \\
\hline & & & $\begin{array}{l}\text { Control, } \\
(\mathrm{N}=9)\end{array}$ & Waitlisting or no treatment & $\begin{array}{l}\text { Male: } 35.7 \% \\
\text { Caucasian: } 100 \% \\
\text { Mean age: } 13.3 \text { ( Range } 10 \text { - } \\
\text { 17) }\end{array}$ & \\
\hline \multirow[t]{2}{*}{$\begin{array}{l}\text { Donovan, } \\
2015^{38}\end{array}$} & \multirow[t]{2}{*}{$\begin{array}{l}\text { Australia } \\
\text { RCT } \\
\text { Efficacy } \\
\text { Mental health } \\
\text { clinic }\end{array}$} & \multirow[t]{2}{*}{$\begin{array}{l}\text { GAD, SAD, SoP, } \\
\text { SP }\end{array}$} & $\begin{array}{l}\text { Child and } \\
\text { parent } \\
\text { together } \mathrm{CBT} \text {, } \\
(\mathrm{N}=21)\end{array}$ & $\begin{array}{l}\text { Other: SHY } \\
\text { Group based } \\
\text { Exposure } \\
\text { Relaxation } \\
\text { Cognitive problem solving } \\
4 \text { 3-hour sessions over } 3 \text { consecutive } \\
\text { weekends } \\
\text { Delivered by psychologist, } \\
\text { student/trainee }\end{array}$ & \multirow[t]{2}{*}{$\begin{array}{l}\text { Mean age: } 9.43 \text { (range: } 7-12 \text { ) } \\
\text { Males: } 37.5 \% \\
\text { Caucasian: } 97.5 \% \\
\text { Asian: } 2.5 \% \\
\text { Low income(<74,000): } 45 \% \\
\text { High income(>74,000): } 55 \% \\
\text { ADHD: } 5 \% \\
\text { OCD: } 5 \% \\
\text { ODD: } 5 \% \\
\text { PTSD: } 2.5 \%\end{array}$} & \multirow[t]{2}{*}{26} \\
\hline & & & $\begin{array}{l}\text { Control, } \\
(\mathrm{N}=19)\end{array}$ & Waitlisting or no treatment & & \\
\hline $\begin{array}{l}\text { Flannery- } \\
\text { Schroeder, }\end{array}$ & $\begin{array}{l}\text { United States } \\
\text { RCT }\end{array}$ & $\begin{array}{l}\text { GAD,SAD, SoP, } \\
\text { SP }\end{array}$ & $\begin{array}{l}\text { Child CBT, } \\
(\mathrm{N}=18)\end{array}$ & $\begin{array}{l}\text { Coping Cat } \\
\text { Child CBT- (parents included }<20 \% \text { ) }\end{array}$ & $\begin{array}{l}\text { Male: } 33.3 \% \\
\text { Caucasian: } 94.4 \% \text {, Other: } 5.6 \%\end{array}$ & 13 \\
\hline
\end{tabular}




\begin{tabular}{|c|c|c|c|c|c|c|}
\hline $\begin{array}{l}\text { Author, } \\
\text { Year }\end{array}$ & $\begin{array}{l}\text { Study Country, } \\
\text { Study Design, } \\
\text { Type of Study } \\
\text { (Efficacyl } \\
\text { Effectiveness), } \\
\text { Study Settings }\end{array}$ & $\begin{array}{c}\text { Type of } \\
\text { Anxiety/Severit } \\
\text { y (CGI) }\end{array}$ & $\begin{array}{l}\text { Intervention } \\
\text { and } \\
\text { Comparison } \\
\text { s (N of } \\
\text { Patients) }\end{array}$ & $\begin{array}{l}\text { Characteristics of Interventions } \\
\text { (Psychotherapy: Components, } \\
\text { Delivery Model)/Pharm: Drug) } \\
\text { Intensity, Duration (Weeks)) }\end{array}$ & $\begin{array}{c}\text { Patient Characteristics Mean } \\
\text { Age (Range), Male (\%), } \\
\text { Race/Ethnicity, Comorbidity, } \\
\text { Household Income, Parent } \\
\text { Education, Family } \\
\text { Dysfunction/Stressor, } \\
\text { Treatment Sequence, } \\
\text { Insurance, History of } \\
\text { Maltreatment) }\end{array}$ & $\begin{array}{l}\text { Length } \\
\text { of } \\
\text { Follow } \\
\text { up } \\
\text { (Weeks } \\
\text { ) }\end{array}$ \\
\hline \multirow[t]{3}{*}{$2000^{39,40}$} & \multirow[t]{3}{*}{$\begin{array}{l}\text { Efficacy } \\
\text { Outpatient }\end{array}$} & & & $\begin{array}{l}\text { Individual based } \\
\text { Exposure } \\
\text { Relaxation } \\
\text { Cognitive problem solving } \\
18 \text { sessions, } 50-60 \text { minute weekly } \\
\text { sessions } \\
\text { Delivered by Mastersstudents }\end{array}$ & ADHD: $11 \%$, Depression: $5.6 \%$ & \\
\hline & & & $\begin{array}{l}\text { Child CBT, } \\
(\mathrm{N}=13)\end{array}$ & $\begin{array}{l}\text { Coping Cat } \\
\text { Child CBT- (parents included < 20\%) } \\
\text { Individual based } \\
\text { Exposure } \\
\text { Relaxation } \\
\text { Cognitive problem solving } \\
18 \text { sessions, } 90 \text { minute weekly sessions } \\
\text { Delivered by Mastersstudents }\end{array}$ & $\begin{array}{l}\text { Male: } 61.5 \% \\
\text { Caucasian: } 84.6 \% \text {, Other: } \\
\text { 15.4\% } \\
\text { ADHD: } 30.7 \% \text {, Depression: } \\
\text { 15.3\%, ODD: } 23 \%\end{array}$ & \\
\hline & & & $\begin{array}{l}\text { Control, } \\
(\mathrm{N}=14)\end{array}$ & Waitlisting or no treatment & $\begin{array}{l}\text { Male: } 42.8 \% \\
\text { Caucasian: } 92.8 \% \text {, Other: } 7.2 \% \\
\text { ADHD: } 21.4 \%\end{array}$ & \\
\hline \multirow[t]{2}{*}{$\begin{array}{l}\text { Gallagher, } \\
2004^{41}\end{array}$} & \multirow[t]{2}{*}{$\begin{array}{l}\text { United States } \\
\text { RCT } \\
\text { Efficacy } \\
\text { Mental health } \\
\text { clinic }\end{array}$} & \multirow[t]{2}{*}{$\begin{array}{l}\text { GAD, SP, SAD, } \\
\text { SoP. }\end{array}$} & $\begin{array}{l}\text { Child CBT, } \\
(\mathrm{N}=12)\end{array}$ & $\begin{array}{l}\text { Generic CBT } \\
\text { Child CBT-(parents included }<20 \% \text { ) } \\
\text { Group based } \\
\text { Exposure } \\
\text { Cognitive problem solving } \\
3 \text { sessions, 3-hour weekly sessions }\end{array}$ & Age (range $8-11$ ) & \multirow[t]{2}{*}{3} \\
\hline & & & $\begin{array}{l}\text { Control, } \\
(\mathrm{N}=11)\end{array}$ & Waitlisting or no treatment & Age (range $8-11$ ) & \\
\hline \multirow[t]{2}{*}{ Gallo, $2012^{42}$} & \multirow[t]{2}{*}{$\begin{array}{l}\text { United States } \\
\text { RCT } \\
\text { Efficacy } \\
\text { Mental health } \\
\text { clinic }\end{array}$} & \multirow[t]{2}{*}{$\begin{array}{l}\text { PD with } \\
\text { agoraphobia, PD } \\
\text { without } \\
\text { agoraphobia }\end{array}$} & $\begin{array}{l}\text { Child CBT, } \\
(\mathrm{N}=39)\end{array}$ & $\begin{array}{l}\text { Other: Immediate 8-day intensive } \\
\text { treatment } \\
\text { Child CBT- (parents included }<20 \% \text { ) } \\
\text { Individual based } \\
\text { Exposure and cognitive problem solving } \\
8 \text { days of } 2 \text { to } 6 \text { hours of treatment }(20 \\
\text { hours total) followed by } 4 \text { weeks of } \\
\text { phone contact }\end{array}$ & \multirow[t]{2}{*}{$\begin{array}{l}\text { Mean age: } 15.1 \text { (range } 12-17 \text { ) } \\
\text { Male: } 40 \% \\
\text { Caucasian: } 49 \% \\
\text { Hispanic: } 4 \%\end{array}$} & \\
\hline & & & Control, & Waitlisting or no treatment & & \\
\hline
\end{tabular}




\begin{tabular}{|c|c|c|c|c|c|c|}
\hline $\begin{array}{l}\text { Author, } \\
\text { Year }\end{array}$ & $\begin{array}{l}\text { Study Country, } \\
\text { Study Design, } \\
\text { Type of Study } \\
\text { (Efficacyl } \\
\text { Effectiveness), } \\
\text { Study Settings }\end{array}$ & $\begin{array}{c}\text { Type of } \\
\text { AnxietylSeverit } \\
\text { y (CGI) }\end{array}$ & $\begin{array}{l}\text { Intervention } \\
\text { and } \\
\text { Comparison } \\
\text { s (N of } \\
\text { Patients) }\end{array}$ & $\begin{array}{l}\text { Characteristics of Interventions } \\
\text { (Psychotherapy: Components, } \\
\text { Delivery Model)/Pharm: Drug) } \\
\text { Intensity, Duration (Weeks)) }\end{array}$ & $\begin{array}{c}\text { Patient Characteristics Mean } \\
\text { Age (Range), Male (\%), } \\
\text { Race/Ethnicity, Comorbidity, } \\
\text { Household Income, Parent } \\
\text { Education, Family } \\
\text { Dysfunction/Stressor, } \\
\text { Treatment Sequence, } \\
\text { Insurance, History of } \\
\text { Maltreatment) }\end{array}$ & $\begin{array}{l}\text { Length } \\
\text { of } \\
\text { Follow } \\
\text { up } \\
\text { (Weeks } \\
\text { ) }\end{array}$ \\
\hline & & & $(\mathrm{N}=16)$ & & & \\
\hline \multirow[t]{3}{*}{$\begin{array}{l}\text { Gil-Bernal, } \\
2009^{43}\end{array}$} & \multirow[t]{3}{*}{$\begin{array}{l}\text { Mexico } \\
\text { RCT } \\
\text { Efficacy } \\
\text { Public schools } \\
\text { in low income } \\
\text { district }\end{array}$} & \multirow[t]{3}{*}{ SoP } & $\begin{array}{l}\text { Child CBT, } \\
(\mathrm{N}=6)\end{array}$ & $\begin{array}{l}\text { IAFS } \\
\text { Child CBT- (parents included }<20 \% \text { ) } \\
\text { Group based } \\
\text { Exposure and cognitive problem solving } \\
\text { Nine } 90-\text { minutes sessions during } 5 \\
\text { weeks } \\
\text { Delivered by therapists }\end{array}$ & \multirow[t]{3}{*}{$\begin{array}{l}\text { Age: Range } 7-12 \\
\text { Male: } 36.36 \%\end{array}$} & \multirow[t]{3}{*}{36} \\
\hline & & & $\begin{array}{l}\text { Child CBT } \\
\text { plus separate } \\
\text { parent } \\
\text { intervention, } \\
(\mathrm{N}=5)\end{array}$ & $\begin{array}{l}\text { IAFS } \\
\text { Combined therapy: IAFS + Parent } \\
\text { education } \\
\text { Group based } \\
\text { Exposure } \\
\text { Relaxation } \\
\text { Cognitive problem solving } \\
\text { Nine } 90-\text { minutes sessions during } 5 \\
\text { weeks } \\
\text { Delivered by therapists }\end{array}$ & & \\
\hline & & & $\begin{array}{l}\text { Control, } \\
(\mathrm{N}=6)\end{array}$ & Waitlisting or no treatment & & \\
\hline \multirow[t]{3}{*}{$\begin{array}{l}\text { Hancock, } \\
2016^{44}\end{array}$} & \multirow[t]{3}{*}{$\begin{array}{l}\text { Australia } \\
\text { RCT } \\
\text { Effectiveness } \\
\text { Mental health } \\
\text { clinic }\end{array}$} & \multirow[t]{3}{*}{ GAD, SAD } & $\mathrm{ACT},(\mathrm{N}=68)$ & $\begin{array}{l}\text { Acceptance and commitment therapy } \\
\text { (ACT) } \\
\text { Group based } \\
\text { Relaxation } \\
10 \text { sessions, } 90-\text { minute weekly sessions } \\
\text { Delivered by doctoral level psychologist }\end{array}$ & $\begin{array}{l}\text { Mean age: } 11.15 \text { ( range: } 7-17 \text { ) } \\
\text { Male: } 45.5 \% \\
\text { Caucasian: } 87 \% \text {, Asian: } 3 \% \text {, } \\
\text { Other: } 10 \% \\
\text { ADHD: } 6 \% \text {, Depression, } 18 \% \text {, } \\
\text { OCD: } 7.3 \% \\
\text { Treatment naïve: } 27.9 \%\end{array}$ & \multirow[t]{3}{*}{13} \\
\hline & & & $\begin{array}{l}\text { Child and } \\
\text { parent } \\
\text { together } \mathrm{CBT} \text {, } \\
(\mathrm{N}=63)\end{array}$ & $\begin{array}{l}\text { Cool Kids } \\
\text { Group based } \\
\text { Exposure } \\
\text { Cognitive problem solving } \\
10 \text { sessions, } 90-\text { minute weekly sessions } \\
\text { Delivered by doctoral level psychologist }\end{array}$ & $\begin{array}{l}\text { Mean age: } 10.81 \text { ( range: } 7-17 \text { ) } \\
\text { Male: } 39.6 \% \\
\text { Caucasian: } 94.4 \% \text {, Other: } 5.6 \% \\
\text { ADHD: } 10 \% \text {, Depression, } 13 \% \text {, } \\
\text { OCD: } 3 \% \\
\text { Treatment naïve: } 22.2 \%\end{array}$ & \\
\hline & & & $\begin{array}{l}\text { Control, } \\
(\mathrm{N}=62)\end{array}$ & Waitlisting or no treatment & $\begin{array}{l}\text { Mean age: } 11.66 \text { ( range: } 7-17 \text { ) } \\
\text { Male: } 41.9 \%\end{array}$ & \\
\hline
\end{tabular}




\begin{tabular}{|c|c|c|c|c|c|c|}
\hline $\begin{array}{l}\text { Author, } \\
\text { Year }\end{array}$ & $\begin{array}{l}\text { Study Country, } \\
\text { Study Design, } \\
\text { Type of Study } \\
\text { (Efficacyl } \\
\text { Effectiveness), } \\
\text { Study Settings }\end{array}$ & $\begin{array}{c}\text { Type of } \\
\text { Anxiety/Severit } \\
\text { y (CGI) }\end{array}$ & $\begin{array}{l}\text { Intervention } \\
\text { and } \\
\text { Comparison } \\
\mathrm{s} \text { (N of } \\
\text { Patients) }\end{array}$ & $\begin{array}{l}\text { Characteristics of Interventions } \\
\text { (Psychotherapy: Components, } \\
\text { Delivery Model)/Pharm: Drug) } \\
\text { Intensity, Duration (Weeks)) }\end{array}$ & $\begin{array}{c}\text { Patient Characteristics Mean } \\
\text { Age (Range), Male (\%), } \\
\text { Race/Ethnicity, Comorbidity, } \\
\text { Household Income, Parent } \\
\text { Education, Family } \\
\text { Dysfunction/Stressor, } \\
\text { Treatment Sequence, } \\
\text { Insurance, History of } \\
\text { Maltreatment) }\end{array}$ & $\begin{array}{l}\text { Length } \\
\text { of } \\
\text { Follow } \\
\text { up } \\
\text { (Weeks } \\
\text { ) }\end{array}$ \\
\hline & & & & & $\begin{array}{l}\text { Caucasian: } 84 \% \text {, Other: } 16 \% \\
\text { Depression: } 24 \%, \text { OCD: } 8 \% \\
\text { Treatment naïve: } 70.9\end{array}$ & \\
\hline \multirow[t]{2}{*}{$\begin{array}{l}\text { Hayward, } \\
2000^{45}\end{array}$} & \multirow[t]{2}{*}{$\begin{array}{l}\text { United States } \\
\text { RCT } \\
\text { Efficacy } \\
\text { Mental health } \\
\text { clinic }\end{array}$} & \multirow[t]{2}{*}{ SoP } & $\begin{array}{l}\text { Child CBT- } \\
\text { (parents } \\
\text { included }< \\
20 \%),(N=12)\end{array}$ & $\begin{array}{l}\text { Generic CBT } \\
\text { Group based } \\
\text { Exposure } \\
\text { Cognitive problem solving } \\
1690-\text { minute weekly sessions } \\
\text { Delivered by } 2 \text { doctoral level } \\
\text { psychologist and } 2 \text { students/trainee }\end{array}$ & \multirow[t]{2}{*}{$\begin{array}{l}\text { Mean age: } 15.8 \\
\text { Low income: } n=29 \\
\text { Medium income: } n=23 \\
\text { High income: } n=11\end{array}$} & \multirow[t]{2}{*}{52} \\
\hline & & & $\begin{array}{l}\text { Control, } \\
(\mathrm{N}=3)\end{array}$ & Waitlisting or no treatment & & \\
\hline \multirow[t]{2}{*}{$\begin{array}{l}\text { Holmes, } \\
2014^{46}\end{array}$} & \multirow[t]{2}{*}{$\begin{array}{l}\text { Australia } \\
\text { RCT } \\
\text { Efficacy } \\
\text { Mental health } \\
\text { clinic }\end{array}$} & \multirow[t]{2}{*}{$\begin{array}{l}\text { GAD, SAD, SoP, } \\
\text { SP }\end{array}$} & $\begin{array}{l}\text { Child CBT } \\
\text { plus separate } \\
\text { parent } \\
\text { intervention, } \\
(\mathrm{N}=20)\end{array}$ & $\begin{array}{l}\text { No worries } \\
\text { Group based } \\
\text { Relaxation } \\
\text { Cognitive problem solving } \\
10 \text { weekly } 90 \text {-min child sessions plus } \\
\text { two boosters, and } 790 \text {-minute parent } \\
\text { sessions with } 2 \text { boosters } \\
\text { Delivered by Masters level clinician }\end{array}$ & $\begin{array}{l}\text { Mean age: } 9.65 \text { (range: } 7-12) \\
\text { Males: } 25 \% \\
\text { Caucasian: } 100 \% \\
\text { Low income (<\$29,875): } 0 \% \\
\text { Medium income (\$30,622-\$ } \\
59750): 10 \% \\
\text { High income (>\$60,497): } 90 \% \\
\text { Less than high school or high } \\
\text { school graduate (parent): } 35 \% \\
\text { Some college (parent): } 25 \% \\
\text { College graduate (parent): } 40 \% \\
\text { ADHD: } 45 \% \\
\text { Depression: } 25 \% \\
\text { ODD: } 30 \%\end{array}$ & \multirow[t]{2}{*}{13} \\
\hline & & & $\begin{array}{l}\text { Control, } \\
(\mathrm{N}=22)\end{array}$ & Waitlisting or no treatment & $\begin{array}{l}\text { Mean age: } 9.64 \text { (range: } 7-12) \\
\text { Males: } 40.9 \% \\
\text { Caucasian: } 95.5 \% \\
\text { African American: } 4.5 \\
\text { Low income }(<\$ 29,875): 9.1 \% \\
\text { Medium income }(\$ 30,622-\$\end{array}$ & \\
\hline
\end{tabular}




\begin{tabular}{|c|c|c|c|c|c|c|}
\hline $\begin{array}{l}\text { Author, } \\
\text { Year }\end{array}$ & $\begin{array}{c}\text { Study Country, } \\
\text { Study Design, } \\
\text { Type of Study } \\
\text { (Efficacyl } \\
\text { Effectiveness), } \\
\text { Study Settings }\end{array}$ & $\begin{array}{c}\text { Type of } \\
\text { AnxietylSeverit } \\
\text { y (CGI) }\end{array}$ & $\begin{array}{c}\text { Intervention } \\
\text { and } \\
\text { Comparison } \\
\text { s (N of } \\
\text { Patients) }\end{array}$ & $\begin{array}{l}\text { Characteristics of Interventions } \\
\text { (Psychotherapy: Components, } \\
\text { Delivery Model)/Pharm: Drug) } \\
\text { Intensity, Duration (Weeks)) }\end{array}$ & $\begin{array}{c}\text { Patient Characteristics Mean } \\
\text { Age (Range), Male (\%), } \\
\text { Race/Ethnicity, Comorbidity, } \\
\text { Household Income, Parent } \\
\text { Education, Family } \\
\text { Dysfunction/Stressor, } \\
\text { Treatment Sequence, } \\
\text { Insurance, History of } \\
\text { Maltreatment) }\end{array}$ & $\begin{array}{c}\text { Length } \\
\text { of } \\
\text { Follow } \\
\text { up } \\
\text { (Weeks } \\
\text { ) }\end{array}$ \\
\hline & & & & & $\begin{array}{l}\text { 59750): } 13.6 \% \\
\text { High income ( }>\$ 60,497): 77.3 \% \\
\text { Less than high school or high } \\
\text { school graduate (parent): } 34 \% \\
\text { Some college (parent): } 31.8 \% \\
\text { College graduate (parent): } \\
31.8 \% \\
\text { ADHD: } 45 \% \\
\text { Depression: } 25 \% \\
\text { ODD: } 30 \%\end{array}$ & \\
\hline \multirow[t]{2}{*}{$\begin{array}{l}\text { Hirshfeld- } \\
\text { Becker, } \\
2010^{47}\end{array}$} & \multirow[t]{2}{*}{$\begin{array}{l}\text { United States } \\
\text { RCT } \\
\text { Efficacy } \\
\text { Outpatient }\end{array}$} & \multirow[t]{2}{*}{$\begin{array}{l}\text { GAD, PD with } \\
\text { agoraphobia, } \\
\text { SAD, SoP, SP }\end{array}$} & $\begin{array}{l}\text { Child and } \\
\text { parent } \\
\text { together } \mathrm{CBT} \text {, } \\
(\mathrm{N}=34)\end{array}$ & $\begin{array}{l}\text { Being Brave } \\
\text { Individual based } \\
\text { Exposure } \\
\text { Relaxation } \\
\text { Cognitive problem solving } \\
\text { Up to } 20 \text { weekly sessions } \\
\text { Delivered by psychologist, student/ } \\
\text { trainee }\end{array}$ & $\begin{array}{l}\text { Mean age: } 5.4 \text { (range: } 4-7 \text { ) } \\
\text { Males:50\% } \\
\text { Caucasian: } 79 \% \\
\text { Hispanic:3\% } \\
\text { Asian: } 8.8 \% \\
\text { Other: } 8.8 \% \\
\text { Less than high school or high } \\
\text { school graduate (parent): } \\
6.55 \% \\
\text { Some college (parent): } 15.5 \% \\
\text { College graduate (parent): } 78 \%\end{array}$ & \multirow[t]{2}{*}{12} \\
\hline & & & $\begin{array}{l}\text { Control, } \\
(\mathrm{N}=30)\end{array}$ & Waitlisting or no treatment & $\begin{array}{l}\text { Mean age: } 6.2 \text { (range: } 4-7 \text { ) } \\
\text { Males: } 43 \% \\
\text { Caucasian: } 80 \% \\
\text { Hispanic:3.3\% } \\
\text { Asian: } 6.6 \% \\
\text { Other: } 10 \% \\
\text { Less than high school or high } \\
\text { school graduate (parent): } \\
6.55 \% \\
\text { Some college (parent): } 15.5 \% \\
\text { College graduate (parent): } 78 \%\end{array}$ & \\
\hline Kendall, & $\begin{array}{l}\text { United States } \\
\text { RCT }\end{array}$ & $\begin{array}{l}\text { GAD,SAD, SoP, } \\
\text { SP }\end{array}$ & $\begin{array}{l}\text { Child CBT, } \\
(\mathrm{N}=27)\end{array}$ & $\begin{array}{l}\text { Coping Cat } \\
\text { Child CBT- (parents included < } 20 \% \text { ) }\end{array}$ & $\begin{array}{l}\text { Age range: } 9-13 \text { years } \\
\text { Male: } 51.8 \%\end{array}$ & 52 \\
\hline
\end{tabular}




\begin{tabular}{|c|c|c|c|c|c|c|}
\hline $\begin{array}{l}\text { Author, } \\
\text { Year }\end{array}$ & $\begin{array}{l}\text { Study Country, } \\
\text { Study Design, } \\
\text { Type of Study } \\
\text { (Efficacyl } \\
\text { Effectiveness), } \\
\text { Study Settings }\end{array}$ & $\begin{array}{c}\text { Type of } \\
\text { Anxiety/Severit } \\
\text { y (CGI) }\end{array}$ & $\begin{array}{l}\text { Intervention } \\
\text { and } \\
\text { Comparison } \\
\text { s (N of } \\
\text { Patients) }\end{array}$ & $\begin{array}{l}\text { Characteristics of Interventions } \\
\text { (Psychotherapy: Components, } \\
\text { Delivery Model)/Pharm: Drug) } \\
\text { Intensity, Duration (Weeks)) }\end{array}$ & $\begin{array}{c}\text { Patient Characteristics Mean } \\
\text { Age (Range), Male (\%), } \\
\text { Race/Ethnicity, Comorbidity, } \\
\text { Household Income, Parent } \\
\text { Education, Family } \\
\text { Dysfunction/Stressor, } \\
\text { Treatment Sequence, } \\
\text { Insurance, History of } \\
\text { Maltreatment) }\end{array}$ & $\begin{array}{l}\text { Length } \\
\text { of } \\
\text { Follow } \\
\text { up } \\
\text { (Weeks } \\
\text { ) }\end{array}$ \\
\hline \multirow[t]{2}{*}{$1995^{48}$} & \multirow[t]{2}{*}{$\begin{array}{l}\text { Effectiveness } \\
\text { Mental health } \\
\text { clinic }\end{array}$} & & & $\begin{array}{l}\text { Individual based } \\
\text { Exposure } \\
\text { Relaxation } \\
\text { Cognitive problem solving } \\
1750-60-\text { minute weekly sessions } \\
\text { Delivered by student }\end{array}$ & $\begin{array}{l}\text { Caucasian: } 78 \% \text {, African } \\
\text { American: } 22 \%\end{array}$ & \\
\hline & & & $\begin{array}{l}\text { Control, } \\
(N=20)\end{array}$ & Waitlisting or no treatment & $\begin{array}{l}\text { Age range: } 9-13 \text { years } \\
\text { Male: } 60 \% \\
\text { Caucasian: } 80 \% \text {, African } \\
\text { American: } 20 \%\end{array}$ & \\
\hline \multirow[t]{2}{*}{$\begin{array}{l}\text { Kendall, } \\
1997^{49}\end{array}$} & \multirow[t]{2}{*}{$\begin{array}{l}\text { United States } \\
\text { RCT } \\
\text { Effectiveness } \\
\text { Mental health } \\
\text { clinic }\end{array}$} & \multirow[t]{2}{*}{$\begin{array}{l}\text { GAD, SAD, SP, } \\
\text { SoP }\end{array}$} & $\begin{array}{l}\text { Child CBT, } \\
(\mathrm{N}=60)\end{array}$ & $\begin{array}{l}\text { Coping Cat } \\
\text { Child CBT- (parents included < 20\%) } \\
\text { Individual based } \\
\text { Exposure } \\
\text { Relaxation } \\
\text { Cognitive problem solving } \\
1660 \text {-minute weekly sessions } \\
\text { Delivered by doctoral level } \\
\text { psychologists }\end{array}$ & $\begin{array}{l}\text { Age range: } 9-13 \text { years } \\
\text { Low income: } 32 \% \\
\text { Medium income } 31 \% \\
\text { High income: } 28 \% \\
\text { Male: } 58.3 \% \\
\text { Caucasian: } 86.6 \% \\
\text { African American: } 6.6 \\
\text { Hispanic: } 1.6 \\
\text { Asian: } 1.6\end{array}$ & \multirow[t]{2}{*}{52} \\
\hline & & & $\begin{array}{l}\text { Control, } \\
(\mathrm{N}=34)\end{array}$ & Waitlisting or no treatment & $\begin{array}{l}\text { Age range: } 9-13 \text { years } \\
\text { Low income: } 32 \% \\
\text { Medium income } 31 \% \\
\text { High income: } 28 \% \\
\text { Male: } 67.6 \% \\
\text { Caucasian: } 82.35 \% \\
\text { African American: } 2.9 \% \\
\text { Hispanic: } 2.9 \% \\
\text { Asians: } 5.8 \\
\text { Others: } 5.8 \%\end{array}$ & \\
\hline $\begin{array}{l}\text { Leutgeb, } \\
2011^{50}\end{array}$ & $\begin{array}{l}\text { Austria } \\
\text { RCT } \\
\text { Efficacy } \\
\text { Mental health } \\
\text { clinic }\end{array}$ & SP & $\begin{array}{l}\text { Child CBT, } \\
(\mathrm{N}=16)\end{array}$ & $\begin{array}{l}\text { OST } \\
\text { Child CBT- (parents included }<20 \% \text { ) } \\
\text { Individual based } \\
\text { Exposure } \\
\text { Relaxation } \\
\text { Cognitive problem solving }\end{array}$ & Mean age: 11.44 (range: 8-14) & 0 \\
\hline
\end{tabular}




\begin{tabular}{|c|c|c|c|c|c|c|}
\hline \multirow[t]{3}{*}{$\begin{array}{l}\text { Author, } \\
\text { Year }\end{array}$} & \multirow[t]{3}{*}{$\begin{array}{l}\text { Study Country, } \\
\text { Study Design, } \\
\text { Type of Study } \\
\text { (Efficacyl } \\
\text { Effectiveness), } \\
\text { Study Settings }\end{array}$} & \multirow[t]{3}{*}{$\begin{array}{c}\text { Type of } \\
\text { Anxiety/Severit } \\
\text { y (CGI) }\end{array}$} & \multirow[t]{2}{*}{$\begin{array}{l}\text { Intervention } \\
\text { and } \\
\text { Comparison } \\
\text { s (N of } \\
\text { Patients) }\end{array}$} & \multirow[t]{2}{*}{$\begin{array}{l}\text { Characteristics of Interventions } \\
\text { (Psychotherapy: Components, } \\
\text { Delivery Model)/Pharm: Drug) } \\
\text { Intensity, Duration (Weeks)) }\end{array}$} & \multirow[t]{2}{*}{$\begin{array}{c}\text { Patient Characteristics Mean } \\
\text { Age (Range), Male (\%), } \\
\text { Race/Ethnicity, Comorbidity, } \\
\text { Household Income, Parent } \\
\text { Education, Family } \\
\text { Dysfunction/Stressor, } \\
\text { Treatment Sequence, } \\
\text { Insurance, History of } \\
\text { Maltreatment) } \\
\end{array}$} & \multirow[t]{3}{*}{$\begin{array}{l}\text { Length } \\
\text { of } \\
\text { Follow } \\
\text { up } \\
\text { (Weeks } \\
\text { ) }\end{array}$} \\
\hline & & & & & & \\
\hline & & & $\begin{array}{l}\text { Control, } \\
(\mathrm{N}=14)\end{array}$ & Waitlisting or no treatment & Mean age: 11.54 (range: 8-14) & \\
\hline \multirow[t]{2}{*}{$\begin{array}{l}\text { Masia- } \\
\text { Warner, } \\
2005^{51}\end{array}$} & \multirow[t]{2}{*}{$\begin{array}{l}\text { United States } \\
\text { RCT } \\
\text { Efficacy } \\
\text { School }\end{array}$} & \multirow[t]{2}{*}{$\begin{array}{l}\text { GAD, PD with } \\
\text { agoraphobia, } \\
\text { SoP }\end{array}$} & $\begin{array}{l}\text { Child CBT, } \\
(\mathrm{N}=21)\end{array}$ & $\begin{array}{l}\text { Skills for Social and Academic Success } \\
\text { Child CBT- (parents included < 20\%) } \\
\text { Group based } \\
\text { Exposure } \\
\text { Cognitive problem solving } \\
\text { School settings for about } 3 \text { months. } 12 \\
40 \text {-minutes weekly session, } 2 \text { brief } \\
\text { individual meetings (15 minutes), } 2 \\
\text { group boosters; } 4 \text { weekend social } \\
\text { events (90 minutes); } 2 \text { Parents groups } \\
\text { (45 minutes); } 2 \text { teacher groups (30 } \\
\text { minutes) } \\
\text { Delivered by a doctoral level } \\
\text { psychologist and a student/trainee }\end{array}$ & $\begin{array}{l}\text { Mean age: } 15 \text { ( Range } 13-17 \text { ) } \\
\text { Male: } 19 \% \\
\text { Caucasian: } 76.19 \% \\
\text { African Americans: } 9.5 \%\end{array}$ & \multirow[t]{2}{*}{ NR } \\
\hline & & & $\begin{array}{l}\text { Control, } \\
(\mathrm{N}=21)\end{array}$ & Waitlisting or no treatment & $\begin{array}{l}\text { Mean age: } 14.5 \text { ( Range 13-17) } \\
\text { Male: } 23.8 \% \\
\text { Caucasian: } 61.9 \% \\
\text { African Americans: } 4.7 \% \\
\text { Hispanics: } 4.7 \% \\
\text { Asians: } 4.7 \% \\
\text { Others: } 4.7 \% \\
\end{array}$ & \\
\hline $\begin{array}{l}\text { McConachie, } \\
2014^{52}\end{array}$ & $\begin{array}{l}\text { United Kingdom } \\
\text { RCT } \\
\text { Effectiveness } \\
\text { Mental health } \\
\text { clinic }\end{array}$ & $\begin{array}{l}\text { GAD, PD with } \\
\text { agoraphobia, } \\
\text { SAD SoP, SP }\end{array}$ & $\begin{array}{l}\text { Child CBT } \\
\text { plus separate } \\
\text { parent } \\
\text { intervention, } \\
(\mathrm{N}=17)\end{array}$ & $\begin{array}{l}\text { Exploring feelings } \\
\text { Group based } \\
7 \text { 2-hours sessions with separate parent } \\
\text { and child groups } \\
\text { Delivered by psychologist }\end{array}$ & $\begin{array}{l}\text { Mean age: } 11.7 \text { (range: 9-13) } \\
\text { Males: } 88 \% \\
\text { College graduate (parent): 47\% } \\
\text { ADHD: } 30 \% \\
\text { Depression: } 12 \% \\
\text { Autism: } 100 \% \\
\text { OCD: } 18 \% \\
\text { ODD:6\% }\end{array}$ & 39 \\
\hline
\end{tabular}




\begin{tabular}{|c|c|c|c|c|c|c|}
\hline $\begin{array}{l}\text { Author, } \\
\text { Year }\end{array}$ & $\begin{array}{c}\text { Study Country, } \\
\text { Study Design, } \\
\text { Type of Study } \\
\text { (Efficacyl } \\
\text { Effectiveness), } \\
\text { Study Settings }\end{array}$ & $\begin{array}{c}\text { Type of } \\
\text { Anxiety/Severit } \\
\text { y (CGI) }\end{array}$ & $\begin{array}{c}\text { Intervention } \\
\text { and } \\
\text { Comparison } \\
\mathrm{s} \text { (N of } \\
\text { Patients) }\end{array}$ & $\begin{array}{l}\text { Characteristics of Interventions } \\
\text { (Psychotherapy: Components, } \\
\text { Delivery Model)/Pharm: Drug) } \\
\text { Intensity, Duration (Weeks)) }\end{array}$ & $\begin{array}{c}\text { Patient Characteristics Mean } \\
\text { Age (Range), Male (\%), } \\
\text { Race/Ethnicity, Comorbidity, } \\
\text { Household Income, Parent } \\
\text { Education, Family } \\
\text { Dysfunction/Stressor, } \\
\text { Treatment Sequence, } \\
\text { Insurance, History of } \\
\text { Maltreatment) }\end{array}$ & $\begin{array}{c}\text { Length } \\
\text { of } \\
\text { Follow } \\
\text { up } \\
\text { (Weeks } \\
\text { ) }\end{array}$ \\
\hline & & & $\begin{array}{l}\text { Control, } \\
(\mathrm{N}=15)\end{array}$ & Waitlisting or no treatment & $\begin{array}{l}\text { Mean age: } 11.8 \text { (range: } 9-13 \text { ) } \\
\text { Males: } 87 \% \\
\text { College graduate (parent): 80\% } \\
\text { ADHD: } 33 \% \\
\text { Autism: } 100 \% \\
\text { OCD: } 7 \% \\
\text { ODD: } 7 \%\end{array}$ & \\
\hline \multirow[t]{2}{*}{$\begin{array}{l}\text { McNally } \\
\text { Keehn, } \\
2013^{53}\end{array}$} & \multirow[t]{2}{*}{$\begin{array}{l}\text { United States } \\
\text { RCT } \\
\text { Effectiveness } \\
\text { Mental health } \\
\text { clinic }\end{array}$} & \multirow[t]{2}{*}{$\begin{array}{l}\text { GAD, SAD, SoP, } \\
\text { SP }\end{array}$} & $\begin{array}{l}\text { Child CBT-: } \\
(\mathrm{N}=12)\end{array}$ & $\begin{array}{l}\text { Coping Cat } \\
\text { Child CBT- (parents included }<20 \% \text { ) } \\
\text { Individual based } \\
\text { Exposure } \\
\text { Relaxation } \\
\text { Cognitive problem solving } \\
\text { Delivered by psychologist } \\
16 \text { sessions, } 60 \text { to } 90 \text {-minute weekly } \\
\text { sessions }\end{array}$ & $\begin{array}{l}\text { Mean age: } 11.65 \text { (range: } 8-14 \text { ) } \\
\text { Males: } 100 \% \\
\text { Caucasian: } 66 \% \\
\text { Hispanic: } 17 \% \\
\text { Others: } 17 \% \\
\text { Less than high school or high } \\
\text { school graduate (parent): } 33 \% \\
\text { College graduate (parent): } 67 \% \\
\text { Depression: } 8 \% \\
\text { Autism: } 100 \% \\
\text { OCD:17\% } \\
\text { ADHD: } 67 \% \\
\text { ODD: } 33 \%\end{array}$ & \multirow[t]{2}{*}{8} \\
\hline & & & $\begin{array}{l}\text { Control, } \\
(\mathrm{N}=10)\end{array}$ & Waitlisting or no treatment & $\begin{array}{l}\text { Mean age; } 11.02 \text { (range: } 8-14 \text { ) } \\
\text { Males: } 90 \% \\
\text { Caucasian: } 40 \% \\
\text { Hispanic: } 10 \% \\
\text { Others: } 17 \% \\
\text { Less than high school or high } \\
\text { school graduate (parent): 10\% } \\
\text { College graduate (parent): } 90 \% \\
\text { Autism: } 90 \% \\
\text { ADHD: } 80 \% \\
\text { ODD: } 50 \%\end{array}$ & \\
\hline $\begin{array}{l}\text { Melfsen, } \\
2011^{54}\end{array}$ & $\begin{array}{l}\text { Germany } \\
\text { RCT } \\
\text { Effectiveness } \\
\text { Mental health } \\
\end{array}$ & SoP & $\begin{array}{l}\text { Child CBT, } \\
(\mathrm{N}=21)\end{array}$ & $\begin{array}{l}\text { Generic CBT } \\
\text { Child CBT- (parents included }<20 \% \text { ) } \\
\text { Individual based } \\
\text { Exposure }\end{array}$ & $\begin{array}{l}\text { Mean age: } 10.6 \text { (range } 8-14 \text { ) } \\
\text { Males: } 62 \% \\
\text { Caucasian: } 100 \% \\
\text { Sleeping disorder: } 9.5 \%\end{array}$ & 43 \\
\hline
\end{tabular}




\begin{tabular}{|c|c|c|c|c|c|c|}
\hline $\begin{array}{l}\text { Author, } \\
\text { Year }\end{array}$ & $\begin{array}{l}\text { Study Country, } \\
\text { Study Design, } \\
\text { Type of Study } \\
\text { (Efficacyl } \\
\text { Effectiveness), } \\
\text { Study Settings }\end{array}$ & $\begin{array}{c}\text { Type of } \\
\text { Anxiety/Severit } \\
\text { y (CGI) }\end{array}$ & $\begin{array}{l}\text { Intervention } \\
\text { and } \\
\text { Comparison } \\
\text { s (N of } \\
\text { Patients) }\end{array}$ & $\begin{array}{l}\text { Characteristics of Interventions } \\
\text { (Psychotherapy: Components, } \\
\text { Delivery Model)/Pharm: Drug) } \\
\text { Intensity, Duration (Weeks)) }\end{array}$ & $\begin{array}{c}\text { Patient Characteristics Mean } \\
\text { Age (Range), Male (\%), } \\
\text { Race/Ethnicity, Comorbidity, } \\
\text { Household Income, Parent } \\
\text { Education, Family } \\
\text { Dysfunction/Stressor, } \\
\text { Treatment Sequence, } \\
\text { Insurance, History of } \\
\text { Maltreatment) }\end{array}$ & $\begin{array}{l}\text { Length } \\
\text { of } \\
\text { Follow } \\
\text { up } \\
\text { (Weeks } \\
\text { ) }\end{array}$ \\
\hline & \multirow[t]{2}{*}{ clinic } & & & $\begin{array}{l}\text { Cognitive problem solving } \\
2050 \text {-minute weekly sessions and } 4 \\
\text { parent sessions } \\
\text { Delivered by student/trainee }\end{array}$ & $\begin{array}{l}\text { ODD: } 4.7 \% \\
\text { Tic disorder: } 4.7 \%\end{array}$ & \\
\hline & & & $\begin{array}{l}\text { Control, } \\
(\mathrm{N}=23)\end{array}$ & Waitlisting or no treatment & $\begin{array}{l}\text { Mean age: } 10.76 \text { (range } 8-14 \text { ) } \\
\text { Males: } 43 \% \\
\text { Caucasian: } 100 \% \\
\text { Affective disorder: } 4.3 \% \\
\text { Sleeping disorder: } 4.3 \% \\
\text { ADHD: } 4.3 \% \\
\text { ODD: } 4.3 \% \\
\text { Elimination disorder: } 8.6 \%\end{array}$ & \\
\hline \multirow[t]{3}{*}{$\begin{array}{l}\text { Mendez, } \\
2003^{55}\end{array}$} & \multirow[t]{3}{*}{$\begin{array}{l}\text { Spain } \\
\text { RCT } \\
\text { Efficacy } \\
\text { Schools }\end{array}$} & \multirow[t]{3}{*}{ SP } & $\begin{array}{l}\text { Child and } \\
\text { Parent } \\
\text { Together CBT } \\
(\mathrm{N}=\mathrm{NR})\end{array}$ & $\begin{array}{l}\text { Emotive staging } \\
\text { Exposure } \\
\text { Individual based } \\
\text { Delivered by psychologist } \\
12,30 \text { min sessions over } 3 \text { weeks }\end{array}$ & \multirow[t]{3}{*}{$\begin{array}{l}\text { Total number of patients: } 64 \\
\text { Male: } 50 \%\end{array}$} & \multirow[t]{3}{*}{0} \\
\hline & & & $\begin{array}{l}\text { Child and } \\
\text { Parent } \\
\text { Together CBT } \\
(\mathrm{N}=\mathrm{NR})\end{array}$ & $\begin{array}{l}\text { Emotive staging } \\
\text { Exposure, cognitive problem solving } \\
\text { Individual based } \\
12,30 \text { min sessions over } 3 \text { weeks }\end{array}$ & & \\
\hline & & & $\begin{array}{l}\text { Control, } \\
(\mathrm{N}=\mathrm{NR})\end{array}$ & Waitlisting or no treatment & & \\
\hline \multirow[t]{2}{*}{$\begin{array}{l}\text { Mendlowitz, } \\
199956\end{array}$} & \multirow[t]{2}{*}{$\begin{array}{l}\text { Canada } \\
\text { RCT } \\
\text { Efficacy } \\
\text { Outpatient }\end{array}$} & & $\begin{array}{l}\text { Child CBT, } \\
(\mathrm{N}=23)\end{array}$ & $\begin{array}{l}\text { Coping Bear } \\
\text { Child CBT- (parents included < 20\%) } \\
\text { Group based } \\
\text { Relaxation, cognitive problem solving } \\
12 \text { 1.5-hour weekly sessions } \\
\text { Delivered by } 3 \text { psychologists, } 1 \\
\text { student/trainee, } 1 \text { youth worker }\end{array}$ & \multirow[t]{2}{*}{$\begin{array}{l}\text { Mean age: } 9.5 \text { (Range } 7-12 \text { ) } \\
\text { Male: } 28.4 \%\end{array}$} & \multirow[t]{2}{*}{ NR } \\
\hline & & & $\begin{array}{l}\text { Parent only } \\
\text { intervention, } \\
(\mathrm{N}=21)\end{array}$ & $\begin{array}{l}\text { Generic CBT } \\
\text { Group based } \\
121.5 \text {-hour weekly sessions } \\
\text { Delivered by doctoral level psychologist, } \\
\text { and student/trainee }\end{array}$ & & \\
\hline
\end{tabular}




\begin{tabular}{|c|c|c|c|c|c|c|}
\hline $\begin{array}{c}\text { Author, } \\
\text { Year }\end{array}$ & $\begin{array}{l}\text { Study Country, } \\
\text { Study Design, } \\
\text { Type of Study } \\
\text { (Efficacyl } \\
\text { Effectiveness), } \\
\text { Study Settings }\end{array}$ & $\begin{array}{c}\text { Type of } \\
\text { AnxietylSeverit } \\
\text { y (CGI) }\end{array}$ & $\begin{array}{l}\text { Intervention } \\
\text { and } \\
\text { Comparison } \\
\text { s (N of } \\
\text { Patients) }\end{array}$ & $\begin{array}{l}\text { Characteristics of Interventions } \\
\text { (Psychotherapy: Components, } \\
\text { Delivery Model)/Pharm: Drug) } \\
\text { Intensity, Duration (Weeks)) }\end{array}$ & $\begin{array}{c}\text { Patient Characteristics Mean } \\
\text { Age (Range), Male (\%), } \\
\text { Race/Ethnicity, Comorbidity, } \\
\text { Household Income, Parent } \\
\text { Education, Family } \\
\text { Dysfunction/Stressor, } \\
\text { Treatment Sequence, } \\
\text { Insurance, History of } \\
\text { Maltreatment) }\end{array}$ & $\begin{array}{l}\text { Length } \\
\text { of } \\
\text { Follow } \\
\text { up } \\
\text { (Weeks } \\
\text { ) }\end{array}$ \\
\hline & & & $\begin{array}{l}\text { Child CBT } \\
\text { plus separate } \\
\text { parent } \\
\text { intervention, } \\
(\mathrm{N}=18)\end{array}$ & $\begin{array}{l}\text { Coping bear } \\
\text { Group based } \\
\text { Relaxation } \\
\text { Cognitive problem solving } \\
121.5 \text {-hour weekly sessions (one for } \\
\text { kids, one for parents) } \\
\text { Delivered by doctoral level psychologist, } \\
\text { student/trainee, youth worker }\end{array}$ & & \\
\hline & & & $\begin{array}{l}\text { Control, } \\
(\mathrm{N}=40)\end{array}$ & Waitlisting or no treatment & & \\
\hline \multirow[t]{4}{*}{$\begin{array}{l}\text { Menzies, } \\
1993^{57}\end{array}$} & \multirow[t]{4}{*}{$\begin{array}{l}\text { Australia } \\
\text { RCT } \\
\text { Efficacy } \\
\text { Outpatient }\end{array}$} & \multirow[t]{4}{*}{$\mathrm{SP}$} & $\begin{array}{l}\text { Child CBT, } \\
(\mathrm{N}=13)\end{array}$ & $\begin{array}{l}\text { In vivo exposure plus vicarious } \\
\text { exposure } \\
\text { Child CBT- (parents included < 20\%) } \\
\text { Individual based } \\
\text { Delivered by student therapist } \\
3 \text { 15-minute weekly session }\end{array}$ & \multirow[t]{4}{*}{$\begin{array}{l}\text { Mean age: } 5.5 \text { (range:3-8) } \\
\text { Male: } 50.7 \% \\
\text { Caucasian: } 96 \% \text {, Hispanic: } 4 \% \\
\text { Depression: } 10 \% \\
\text { Treatment non responder: } \\
100 \%\end{array}$} & \multirow[t]{4}{*}{12} \\
\hline & & & $\begin{array}{l}\text { Control, } \\
(\mathrm{N}=13)\end{array}$ & $\begin{array}{l}\text { Attention control or treatment as usual } \\
\text { Only vicarious exposure } \\
330 \text {-minute weekly session } \\
\text { Delivered by student therapist }\end{array}$ & & \\
\hline & & & $\begin{array}{l}\text { Child CBT, } \\
(\mathrm{N}=13)\end{array}$ & $\begin{array}{l}\text { In vivo exposure } \\
\text { Child CBT- (parents included < 20\%) } \\
\text { Individual based } \\
\text { Exposure } 330 \text {-minute weekly session } \\
\text { Delivered by student }\end{array}$ & & \\
\hline & & & $\begin{array}{l}\text { Control, } \\
(\mathrm{N}=12)\end{array}$ & $\begin{array}{l}\text { Waitlisting or no treatment Only } \\
\text { assessment }\end{array}$ & & \\
\hline $\begin{array}{l}\text { Miller, } \\
1972^{58,59}\end{array}$ & $\begin{array}{l}\text { United States } \\
\text { RCT } \\
\text { Efficacy } \\
\text { Outpatient }\end{array}$ & $\mathrm{SP}$ & $\begin{array}{l}\text { Child CBT, } \\
(\mathrm{N}=\mathrm{NR})\end{array}$ & $\begin{array}{l}\text { Total number of patients: } 67 \\
\text { Reciprocal inhibition: individual-based } \\
\text { relaxation, exposure } \\
\text { Delivered by doctoral psychologist } \\
60 \text { min session } 3 \text { times per week for } 8 \\
\text { weeks }\end{array}$ & $\begin{array}{l}\text { Mean age: } 10.8 \text { ( range: } 6-14 \text { ) } \\
\text { Male: } 55 \% \\
\text { Caucasian: } 95.5 \% \text {, African } \\
\text { American: } 4.5 \% \\
\text { Socioeconomic status: } \\
\text { Lower: } 7 \% \\
\text { Middle: } 75 \% \\
\text { High: } 8 \%\end{array}$ & 104 \\
\hline
\end{tabular}




\begin{tabular}{|c|c|c|c|c|c|c|}
\hline $\begin{array}{l}\text { Author, } \\
\text { Year }\end{array}$ & $\begin{array}{l}\text { Study Country, } \\
\text { Study Design, } \\
\text { Type of Study } \\
\text { (Efficacyl } \\
\text { Effectiveness), } \\
\text { Study Settings }\end{array}$ & $\begin{array}{c}\text { Type of } \\
\text { Anxiety/Severit } \\
\text { y (CGI) }\end{array}$ & $\begin{array}{l}\text { Intervention } \\
\text { and } \\
\text { Comparison } \\
\text { s (N of } \\
\text { Patients) }\end{array}$ & $\begin{array}{l}\text { Characteristics of Interventions } \\
\text { (Psychotherapy: Components, } \\
\text { Delivery Model)/Pharm: Drug) } \\
\text { Intensity, Duration (Weeks)) }\end{array}$ & $\begin{array}{c}\text { Patient Characteristics Mean } \\
\text { Age (Range), Male (\%), } \\
\text { Race/Ethnicity, Comorbidity, } \\
\text { Household Income, Parent } \\
\text { Education, Family } \\
\text { Dysfunction/Stressor, } \\
\text { Treatment Sequence, } \\
\text { Insurance, History of } \\
\text { Maltreatment) }\end{array}$ & $\begin{array}{l}\text { Length } \\
\text { of } \\
\text { Follow } \\
\text { up } \\
\text { (Weeks } \\
\text { ) }\end{array}$ \\
\hline & & & $\begin{array}{l}\text { Other } \\
\text { therapy, } \\
(\mathrm{N}=\mathrm{NR})\end{array}$ & $\begin{array}{l}\text { Individual, play psychotherapy directed } \\
\text { toward inner experiences } \\
60 \text { min session } 3 \text { times per week for } 8 \\
\text { weeks }\end{array}$ & & \\
\hline & & & $\begin{array}{l}\text { Control, } \\
(\mathrm{N}=\mathrm{NR})\end{array}$ & Waitlisting or no treatment & & \\
\hline \multirow[t]{2}{*}{$\begin{array}{l}\text { Obler, } \\
1970^{60}\end{array}$} & \multirow[t]{2}{*}{$\begin{array}{l}\text { United States } \\
\text { RCT } \\
\text { Efficacy } \\
\text { Mental health } \\
\text { clinic }\end{array}$} & \multirow[t]{2}{*}{ SP } & $\begin{array}{l}\text { Child CBT, } \\
(\mathrm{N}=15)\end{array}$ & $\begin{array}{l}\text { Reciprocal inhibition } \\
\text { Child CBT- (parents included <20\%) } \\
\text { Individual based } \\
\text { Exposure } \\
105 \text {-hour weekly sessions } \\
\text { Delivered by therapist }\end{array}$ & Mean age: 9.5 (range: $7-12$ ) & \multirow[t]{2}{*}{ NR } \\
\hline & & & $\begin{array}{l}\text { Control, } \\
(\mathrm{N}=15)\end{array}$ & Waitlisting or no treatment & Mean age: 9.3 (range: 7-12) & \\
\hline \multirow[t]{3}{*}{$\begin{array}{l}\text { Olivares, } \\
2002^{61}\end{array}$} & \multirow[t]{3}{*}{$\begin{array}{l}\text { Spain } \\
\text { Non- } \\
\text { Randomized } \\
\text { comparative } \\
\text { studies } \\
\text { Efficacy } \\
\text { School }\end{array}$} & \multirow[t]{3}{*}{$\begin{array}{l}\text { GAD, PD with } \\
\text { agoraphobia, } \\
\text { SoP,SP }\end{array}$} & $\begin{array}{l}\text { Child CBT, } \\
(\mathrm{N}=14)\end{array}$ & $\begin{array}{l}\text { SET-C Spanish } \\
\text { Child CBT- (parents included <20\%) } \\
\text { Exposure } \\
29 \text { treatment sessions over a period of } \\
17 \text { weeks, generally twice weekly }\end{array}$ & $\begin{array}{l}\text { mean age: } 15.57 \text { (range: } 15-17 \text { ) } \\
\text { Male: } 28.5 \% \\
\text { Depression: } 35.7 \% \text {, OCD: } 7 \% \text {, } \\
\text { Substance abuse : } 7 \%, \text { PTSD: } \\
\text { 7\%, avoidant personality } \\
\text { disorder: } 100 \% \text {, selective } \\
\text { mutism: } 7 \%\end{array}$ & \multirow[t]{3}{*}{52} \\
\hline & & & $\begin{array}{l}\text { Child CBT, } \\
(\mathrm{N}=15)\end{array}$ & $\begin{array}{l}\text { Group based } \\
\text { Child CBT- (parents included < 20\%) } \\
\text { Exposure } \\
\text { Cognitive problem solving } \\
1690 \text {-minute sessions over } 14 \text { weeks }\end{array}$ & $\begin{array}{l}\text { mean age: } 16.07 \text { (range: } 15-17 \text { ) } \\
\text { Male: } 35.7 \% \\
\text { Depression: } 60 \%, \text { OCD: } 6 \% \text {, } \\
\text { Substance abuse : } 6 \%, \text { PTSD: } \\
6 \%, \text { avoidant personality } \\
\text { disorder: } 94 \% \text {, selective } \\
\text { mutism: } 12 \%\end{array}$ & \\
\hline & & & $\begin{array}{l}\text { Child CBT, } \\
(\mathrm{N}=15)\end{array}$ & $\begin{array}{l}\text { IAFS } \\
\text { Child CBT- (parents included }<20 \% \text { ) } \\
\text { Exposure, cognitive problem solving } \\
1290-\text { minute weekly group sessions, } \\
\text { and optional individual sessions }\end{array}$ & $\begin{array}{l}\text { mean age: } 15.87 \text { (range: } 15-17 \text { ) } \\
\text { Male: } 26.6 \% \\
\text { Depression: } 40 \%, \text { OCD: } 6 \% \text {, } \\
\text { Substance abuse : 6\%, PTSD: } \\
6 \%, \text { avoidant personality } \\
\text { disorder: } 100 \% \text {, selective }\end{array}$ & \\
\hline
\end{tabular}




\begin{tabular}{|c|c|c|c|c|c|c|}
\hline $\begin{array}{l}\text { Author, } \\
\text { Year }\end{array}$ & $\begin{array}{l}\text { Study Country, } \\
\text { Study Design, } \\
\text { Type of Study } \\
\text { (Efficacyl } \\
\text { Effectiveness), } \\
\text { Study Settings }\end{array}$ & $\begin{array}{c}\text { Type of } \\
\text { Anxiety/Severit } \\
\text { y (CGI) }\end{array}$ & $\begin{array}{l}\text { Intervention } \\
\text { and } \\
\text { Comparison } \\
\text { s (N of } \\
\text { Patients) }\end{array}$ & $\begin{array}{l}\text { Characteristics of Interventions } \\
\text { (Psychotherapy: Components, } \\
\text { Delivery Model)/Pharm: Drug) } \\
\text { Intensity, Duration (Weeks)) }\end{array}$ & $\begin{array}{c}\text { Patient Characteristics Mean } \\
\text { Age (Range), Male (\%), } \\
\text { Race/Ethnicity, Comorbidity, } \\
\text { Household Income, Parent } \\
\text { Education, Family } \\
\text { Dysfunction/Stressor, } \\
\text { Treatment Sequence, } \\
\text { Insurance, History of } \\
\text { Maltreatment) }\end{array}$ & $\begin{array}{c}\text { Length } \\
\text { of } \\
\text { Follow } \\
\text { up } \\
\text { (Weeks } \\
\text { ) }\end{array}$ \\
\hline & & & & & mutism: $6 \%$ & \\
\hline & & & $\begin{array}{l}\text { Control, } \\
(\mathrm{N}=15)\end{array}$ & Waitlisting or no treatment & $\begin{array}{l}\text { mean age: } 15.87 \text { (range: } 15-17 \text { ) } \\
\text { Male: } 35.7 \% \\
\text { Depression: } 46 \%, \text { OCD: } 6 \% \text {, } \\
\text { Substance abuse : } 12 \%, \text { PTSD: } \\
6 \% \text {, avoidant personality } \\
\text { disorder: } 100 \% \text {, selective } \\
\text { mutism: } 12 \%\end{array}$ & \\
\hline \multirow[t]{3}{*}{$\begin{array}{l}\text { Olivares, } \\
2014^{62}\end{array}$} & \multirow[t]{3}{*}{$\begin{array}{l}\text { Spain } \\
\text { RCT } \\
\text { Efficacy } \\
\text { Mental health } \\
\text { clinic }\end{array}$} & \multirow[t]{3}{*}{ SoP } & $\begin{array}{l}\text { Child CBT, } \\
(\mathrm{N}=38)\end{array}$ & $\begin{array}{l}\text { IAFS } \\
\text { Child CBT- (parents included }<20 \% \text { ) } \\
\text { Delivered by experienced psychologist } \\
\text { Group based } \\
\text { Exposure } \\
\text { Cognitive problem solving } \\
1290 \text {-minute weekly sessions }\end{array}$ & $\begin{array}{l}\text { Mean age: } 15.58 \text { (SD: } 0.76) \\
\text { Males: } 36.81 \%\end{array}$ & \multirow[t]{3}{*}{52} \\
\hline & & & $\begin{array}{l}\text { Child CBT, } \\
(\mathrm{N}=37)\end{array}$ & $\begin{array}{l}\text { IAFS } \\
\text { Child CBT- (parents included }<20 \% \text { ) } \\
\text { Delivered by inexperienced psychologist } \\
\text { Group based } \\
\text { Exposure } \\
\text { Cognitive problem solving } \\
1290-\text { minute weekly sessions } \\
\end{array}$ & $\begin{array}{l}\text { Mean age: } 15.30 \text { (SD: } 0.81) \\
\text { Males: } 29.74 \%\end{array}$ & \\
\hline & & & $\begin{array}{l}\text { Control, } \\
(\mathrm{N}=35)\end{array}$ & Waitlisting or no treatment & $\begin{array}{l}\text { Mean age: } 15.23 \text { (SD: } 1.26) \\
\text { Males: } 37.1 \%\end{array}$ & \\
\hline \multirow[t]{2}{*}{$\begin{array}{l}\text { Ollendick, } \\
2009^{63}\end{array}$} & \multirow[t]{2}{*}{$\begin{array}{l}\text { United States } \\
\text { and Sweden } \\
\text { RCT } \\
\text { Efficacy } \\
\text { Outpatient } \\
\text { Mental health } \\
\text { clinic }\end{array}$} & \multirow[t]{2}{*}{$\begin{array}{l}\text { SP, SoP, SAD, } \\
\text { GAD }\end{array}$} & $\begin{array}{l}\text { Child CBT, } \\
(\mathrm{N}=85)\end{array}$ & $\begin{array}{l}\text { OST } \\
\text { Child CBT- (parents included <20\%) } \\
\text { One session treatment } \\
\text { Individual based } \\
\text { Exposure } \\
1 \text { session of } 3 \text { hours } \\
\text { Delivered by Masters level clinicians }\end{array}$ & $\begin{array}{l}\text { Caucasian: } 90 \% \text {, } \\
\text { African American: } 2.5 \% \\
\text { Hispanic:: } 2 \% \\
\text { Other: } 4.5 \% \\
\text { Age range } 7 \text {-16 years } \\
\text { Male: } 45.8 \%\end{array}$ & \multirow[t]{2}{*}{36} \\
\hline & & & $\begin{array}{l}\text { Control, } \\
(\mathrm{N}=70)\end{array}$ & $\begin{array}{l}\text { Attention control or treatment as usual } \\
\text { Education support treatment } \\
1,3 \text { hour session of } \\
\text { Delivered by Master level clinicians }\end{array}$ & $\begin{array}{l}\text { Caucasian: } 90 \% \text {, } \\
\text { African American: } 2.5 \% \\
\text { Hispanic:: } 2 \% \\
\text { Other: } 4.5 \%\end{array}$ & \\
\hline
\end{tabular}




\begin{tabular}{|c|c|c|c|c|c|c|}
\hline $\begin{array}{l}\text { Author, } \\
\text { Year }\end{array}$ & $\begin{array}{l}\text { Study Country, } \\
\text { Study Design, } \\
\text { Type of Study } \\
\text { (Efficacyl } \\
\text { Effectiveness), } \\
\text { Study Settings }\end{array}$ & $\begin{array}{c}\text { Type of } \\
\text { AnxietylSeverit } \\
\text { y (CGI) }\end{array}$ & $\begin{array}{l}\text { Intervention } \\
\text { and } \\
\text { Comparison } \\
\text { s (N of } \\
\text { Patients) }\end{array}$ & $\begin{array}{l}\text { Characteristics of Interventions } \\
\text { (Psychotherapy: Components, } \\
\text { Delivery Model)/Pharm: Drug) } \\
\text { Intensity, Duration (Weeks)) }\end{array}$ & $\begin{array}{c}\text { Patient Characteristics Mean } \\
\text { Age (Range), Male (\%), } \\
\text { Race/Ethnicity, Comorbidity, } \\
\text { Household Income, Parent } \\
\text { Education, Family } \\
\text { Dysfunction/Stressor, } \\
\text { Treatment Sequence, } \\
\text { Insurance, History of } \\
\text { Maltreatment) }\end{array}$ & $\begin{array}{l}\text { Length } \\
\text { of } \\
\text { Follow } \\
\text { up } \\
\text { (Weeks } \\
\text { ) }\end{array}$ \\
\hline & & & & & $\begin{array}{l}\text { Range } 7-16 \\
\text { Male: } 44.2 \%\end{array}$ & \\
\hline & & & $\begin{array}{l}\text { Control, }(\mathrm{N}= \\
41)\end{array}$ & Waitlisting or no treatment & $\begin{array}{l}\text { Age range } 7 \text {-16 years } \\
\text { Male: } 46.3 \%\end{array}$ & \\
\hline \multirow[t]{2}{*}{$\begin{array}{l}\text { Ortbandt, } \\
2009^{64,65}\end{array}$} & \multirow[t]{2}{*}{$\begin{array}{l}\text { Germany } \\
\text { RCT } \\
\text { Efficacy } \\
\text { Mental health } \\
\text { clinic }\end{array}$} & \multirow[t]{2}{*}{ GAD,SAD, SoP } & $\begin{array}{l}\text { Child CBT } \\
\text { plus separate } \\
\text { parent } \\
\text { intervention, } \\
(\mathrm{N}=10)\end{array}$ & $\begin{array}{l}\text { Generic CBT } \\
\text { Individual training is at least } 850 \text {-minute } \\
\text { Weekly sessions or } 4100 \text {-minute } \\
\text { weekly sessions } \\
\text { Group training is at least } 1250 \text {-minutes } \\
\text { weekly sessions or } 6100 \text {-minute } \\
\text { weekly sessions }\end{array}$ & $\begin{array}{l}\text { Mean age: } 9.25 \text { ( range: } 7.2- \\
12.7 \text { ) } \\
\text { Male: } 50 \%\end{array}$ & \multirow[t]{2}{*}{26} \\
\hline & & & $\begin{array}{l}\text { Control, } \\
(\mathrm{N}=9)\end{array}$ & Waitlisting or no treatment & $\begin{array}{l}\text { Mean age: } 9.96 \text { ( range: } 7.9- \\
11.1 \text { ) } \\
\text { Male: } 44.4 \%\end{array}$ & \\
\hline \multirow[t]{3}{*}{ Ost, $2001^{66}$} & \multirow[t]{3}{*}{$\begin{array}{l}\text { Sweden } \\
\text { RCT } \\
\text { Efficacy } \\
\text { Mental health } \\
\text { clinic }\end{array}$} & \multirow[t]{3}{*}{$\begin{array}{l}\text { GAD,SAD, SoP, } \\
\text { SP }\end{array}$} & $\begin{array}{l}\text { Child CBT, } \\
(\mathrm{N}=21)\end{array}$ & $\begin{array}{l}\text { OST } \\
\text { Child CBT- (parents included }<20 \% \text { ) } \\
\text { One session treatment - Child alone } \\
\text { Individual based } \\
\text { Exposure } 1 \text { session of } 3 \text { hours } \\
\text { Delivered by doctoral level Psychologist }\end{array}$ & $\begin{array}{l}\text { mean age: } 11.7 \text { (range: } 7-17 \text { ) } \\
\text { Male: } 33\end{array}$ & \multirow[t]{3}{*}{52} \\
\hline & & & $\begin{array}{l}\text { Child and } \\
\text { parent } \\
\text { together } \mathrm{CBT} \text {, } \\
(\mathrm{N}=20)\end{array}$ & $\begin{array}{l}\text { OST } \\
\text { One session exposure - Parent present } \\
\text { Individual based } \\
\text { Exposure } \\
1 \text { session of } 3 \text { hours } \\
\text { Delivered by doctoral level Psychologist }\end{array}$ & $\begin{array}{l}\text { mean age: } 11.7 \text { (range: } 7-17 \text { ) } \\
\text { Male: } 45 \%\end{array}$ & \\
\hline & & & $\begin{array}{l}\text { Control, } \\
(\mathrm{N}=19)\end{array}$ & Waitlisting or no treatment & $\begin{array}{l}\text { mean age: } 11.7 \text { (range: } 7-17 \text { ) } \\
\text { Male: } 36 \%\end{array}$ & \\
\hline Ost, $2015^{67}$ & $\begin{array}{l}\text { Sweden } \\
\text { RCT } \\
\text { Efficacy } \\
\text { Mental health } \\
\text { clinic }\end{array}$ & $\begin{array}{l}\text { GAD, PD, SAD, } \\
\text { SP }\end{array}$ & $\begin{array}{l}\text { Child CBT, } \\
(\mathrm{N}=16)\end{array}$ & $\begin{array}{l}\text { SET-C } \\
\text { Child CBT- (parents included < 20\%) } \\
\text { Exposure } \\
12 \text { individual weekly sessions plus } 12 \\
\text { social skills group weekly session } \\
\text { Delivered by Psychologist }\end{array}$ & $\begin{array}{l}\text { Mean age: } 11.6 \text { (range: } 8-14 \text { ) } \\
\text { Depression: } 15 \% \\
\text { OCD: } 5 \% \\
\text { ODD: } 2 \% \\
\text { Neurodevelopmental } \\
\text { Disorder:9\% }\end{array}$ & 52 \\
\hline
\end{tabular}




\begin{tabular}{|c|c|c|c|c|c|c|}
\hline $\begin{array}{l}\text { Author, } \\
\text { Year }\end{array}$ & $\begin{array}{l}\text { Study Country, } \\
\text { Study Design, } \\
\text { Type of Study } \\
\text { (Efficacyl } \\
\text { Effectiveness), } \\
\text { Study Settings }\end{array}$ & $\begin{array}{c}\text { Type of } \\
\text { Anxiety/Severit } \\
\text { y (CGI) }\end{array}$ & $\begin{array}{l}\text { Intervention } \\
\text { and } \\
\text { Comparison } \\
\text { s (N of } \\
\text { Patients) }\end{array}$ & $\begin{array}{l}\text { Characteristics of Interventions } \\
\text { (Psychotherapy: Components, } \\
\text { Delivery Model)/Pharm: Drug) } \\
\text { Intensity, Duration (Weeks)) }\end{array}$ & $\begin{array}{c}\text { Patient Characteristics Mean } \\
\text { Age (Range), Male (\%), } \\
\text { Race/Ethnicity, Comorbidity, } \\
\text { Household Income, Parent } \\
\text { Education, Family } \\
\text { Dysfunction/Stressor, } \\
\text { Treatment Sequence, } \\
\text { Insurance, History of } \\
\text { Maltreatment) }\end{array}$ & $\begin{array}{l}\text { Length } \\
\text { of } \\
\text { Follow } \\
\text { up } \\
\text { (Weeks } \\
\text { ) }\end{array}$ \\
\hline & & & $\begin{array}{l}\text { Child CBT } \\
\text { plus separate } \\
\text { parent } \\
\text { intervention, } \\
(\mathrm{N}=16)\end{array}$ & $\begin{array}{l}\text { SET-C } \\
\text { Exposure } \\
12 \text { individual weekly sessions plus } 12 \\
\text { social skills group weekly session; plus } \\
890 \text {-minute parent group sessions } \\
\text { Delivered by psychologist }\end{array}$ & & \\
\hline & & & $\begin{array}{l}\text { Control, } \\
(\mathrm{N}=23)\end{array}$ & Waitlisting or no treatment & & \\
\hline \multirow[t]{2}{*}{$\begin{array}{l}\text { Rapee, } \\
2000^{68}\end{array}$} & \multirow[t]{2}{*}{$\begin{array}{l}\text { Australia } \\
\text { non randomized } \\
\text { comparative } \\
\text { Efficacy } \\
\text { Outpatient }\end{array}$} & \multirow[t]{2}{*}{ NR } & $\begin{array}{l}\text { Child and } \\
\text { parent } \\
\text { together } \mathrm{CBT} \text {, } \\
(\mathrm{N}=95)\end{array}$ & $\begin{array}{l}\text { Other: Family CBT } \\
\text { Group based } \\
\text { Exposure } \\
\text { Cognitive problem solving } \\
9,90 \text { minute treatment sessions, over } \\
11 \text { weeks } \\
\text { Delivered by student/trainee }\end{array}$ & $\begin{array}{l}\text { Mean age: } 10.46 \text { (range: } 7-16) \\
\text { Males: } 41 \%\end{array}$ & \multirow[t]{2}{*}{$\begin{array}{l}52 \text { (only } \\
\text { for CBT } \\
\text { arm) }\end{array}$} \\
\hline & & & $\begin{array}{l}\text { Control, } \\
(\mathrm{N}=15)\end{array}$ & Waitlisting or no treatment & $\begin{array}{l}\text { Mean age: } 11.1 \text { (range: } 7-16) \\
\text { Males: } 33.3 \%\end{array}$ & \\
\hline \multirow[t]{3}{*}{$\begin{array}{l}\text { Rapee, } \\
2006^{69}\end{array}$} & \multirow[t]{3}{*}{$\begin{array}{l}\text { Australia } \\
\text { RCT } \\
\text { Efficacy } \\
\text { Mental health } \\
\text { clinic }\end{array}$} & \multirow[t]{3}{*}{$\begin{array}{l}\text { GAD, PD } \\
\text { (agoraphobia is } \\
\text { not specified), } \\
\text { SAD, SP, SoP. }\end{array}$} & $\begin{array}{l}\text { Child and } \\
\text { parent } \\
\text { together } \mathrm{CBT} \text {, } \\
(\mathrm{N}=90)\end{array}$ & $\begin{array}{l}\text { Cool Kids } \\
\text { Group based } \\
\text { Exposure } \\
\text { Cognitive problem solving } \\
92 \text {-hour sessions over } 12 \text { weeks } \\
\text { Delivered by student trainee. }\end{array}$ & $\begin{array}{l}\text { Mean age: } 9.475 \text { (Range: } 6-12) \\
\text { Male: } 66.6 \% \\
\text { Low income: } n=26(<\$ 30,000)\end{array}$ & \multirow[t]{3}{*}{36} \\
\hline & & & $\begin{array}{l}\text { Distance } \\
\text { Therapy, } \\
(\mathrm{N}=90)\end{array}$ & $\begin{array}{l}\text { Other: Bibliotherapy } \\
\text { Individual based } \\
\text { Exposure } \\
\text { Relaxation } \\
\text { Cognitive problem solving } \\
\text { Treatment duration is } 12 \text { weeks at own } \\
\text { pace }\end{array}$ & $\begin{array}{l}\text { Mean age: } 9.558 \text { (Range: } 6- \\
\text { 12) } \\
\text { Male: } 64.44 \% \\
\text { Low income: } n=9(<\$ 30,000)\end{array}$ & \\
\hline & & & $\begin{array}{l}\text { Control, } \\
(\mathrm{N}=87)\end{array}$ & Waitlisting or no treatment & $\begin{array}{l}\text { Mean age: } 9.5 \text { (Range: } 6-12) \\
\text { Male: } 48.2 \% \\
\text { Low income: } n=15(<\$ 30,000)\end{array}$ & \\
\hline
\end{tabular}




\begin{tabular}{|c|c|c|c|c|c|c|}
\hline $\begin{array}{l}\text { Author, } \\
\text { Year }\end{array}$ & $\begin{array}{l}\text { Study Country, } \\
\text { Study Design, } \\
\text { Type of Study } \\
\text { (Efficacyl } \\
\text { Effectiveness), } \\
\text { Study Settings }\end{array}$ & $\begin{array}{c}\text { Type of } \\
\text { Anxiety/Severit } \\
\text { y (CGI) }\end{array}$ & $\begin{array}{l}\text { Intervention } \\
\text { and } \\
\text { Comparison } \\
\text { s (N of } \\
\text { Patients) }\end{array}$ & $\begin{array}{l}\text { Characteristics of Interventions } \\
\text { (Psychotherapy: Components, } \\
\text { Delivery Model)/Pharm: Drug) } \\
\text { Intensity, Duration (Weeks)) }\end{array}$ & $\begin{array}{c}\text { Patient Characteristics Mean } \\
\text { Age (Range), Male (\%), } \\
\text { Race/Ethnicity, Comorbidity, } \\
\text { Household Income, Parent } \\
\text { Education, Family } \\
\text { Dysfunction/Stressor, } \\
\text { Treatment Sequence, } \\
\text { Insurance, History of } \\
\text { Maltreatment) } \\
\end{array}$ & $\begin{array}{c}\text { Length } \\
\text { of } \\
\text { Follow } \\
\text { up } \\
\text { (Weeks } \\
\text { ) }\end{array}$ \\
\hline \multirow[t]{2}{*}{$\begin{array}{l}\text { Reaven, } \\
2009^{70}\end{array}$} & \multirow[t]{2}{*}{$\begin{array}{l}\text { United States } \\
\text { RCT } \\
\text { Efficacy } \\
\text { Outpatient }\end{array}$} & \multirow[t]{2}{*}{ GAD,SAD, SoP } & $\begin{array}{l}\text { Child and } \\
\text { parent } \\
\text { together } \mathrm{CBT} \text {, } \\
(\mathrm{N}=10)\end{array}$ & $\begin{array}{l}\text { Generic CBT } \\
\text { Exposure } \\
\text { Relaxation } \\
\text { Cognitive problem solving } \\
121.5 \text {-hour weekly sessions (included } \\
\text { large group time, separate parent and } \\
\text { child group meetings, and parent-child } \\
\text { dyads). } \\
\text { Delivered by doctoral level psychologist }\end{array}$ & $\begin{array}{l}\text { Mean age: } 11 \text { ( range: } 8-14 \text { ) } \\
\text { Male: } 70 \% \\
\text { Caucasian: } 80 \% \text {, African } \\
\text { American:10\%, Hispanic: } 10 \% \\
\text { Parent education level: } \\
\text { Some college:30\%, collage } \\
\text { grade: } 40 \% \\
\text { Autism: } 100 \%\end{array}$ & \multirow[t]{2}{*}{0} \\
\hline & & & $\begin{array}{l}\text { Control, } \\
(\mathrm{N}=23)\end{array}$ & Waitlisting or no treatment & $\begin{array}{l}\text { Mean age: } 11 \text { ( range: } 8-14 \text { ) } \\
\text { Male: } 83 \% \\
\text { Caucasian: } 83 \% \text {, African } \\
\text { American:4.5\%, Hispanic: } \\
\text { 4.5\%, Other: } 8 \\
\text { Some college:26\%, collage } \\
\text { grade: } 35 \% \\
\text { Autism: } 100 \%\end{array}$ & \\
\hline \multirow[t]{3}{*}{ Ritter, $1968^{71}$} & \multirow[t]{3}{*}{$\begin{array}{l}\text { United States } \\
\text { RCT } \\
\text { Efficacy } \\
\text { Outpatient }\end{array}$} & \multirow[t]{3}{*}{ SP } & $\begin{array}{l}\text { Child CBT, } \\
(\mathrm{N}=7)\end{array}$ & $\begin{array}{l}\text { Other: Only contact desensitization } \\
\text { Child CBT- (parents included < } 20 \% \text { ) } \\
\text { Group based } \\
\text { Exposure } \\
2,35 \text {-minute weekly sessions } \\
\text { Delivered by psychiatrist }\end{array}$ & \multirow[t]{3}{*}{ Age range: $5-11$ years } & \multirow[t]{3}{*}{0} \\
\hline & & & $\begin{array}{l}\text { Control, } \\
(\mathrm{N}=8)\end{array}$ & $\begin{array}{l}\text { Attention control or treatment as usual } \\
\text { Only vicarious desensitization } \\
\text { Group based } \\
2,35-\text {-minute weekly sessions } \\
\text { Delivered by psychiatrist }\end{array}$ & & \\
\hline & & & $\begin{array}{l}\text { Control, } \\
(\mathrm{N}=7)\end{array}$ & Waitlisting or no treatment & & \\
\hline $\begin{array}{l}\text { Rosa- } \\
\text { Alcazar, } \\
2009^{72}\end{array}$ & $\begin{array}{l}\text { Spain } \\
\text { RCT } \\
\text { Efficacy } \\
\text { Schools }\end{array}$ & $\begin{array}{l}\text { GAD, PD without } \\
\text { agoraphobia, PD } \\
\text { (agoraphobia is } \\
\text { not specified) SP }\end{array}$ & $\begin{array}{l}\text { Child CBT, } \\
(N=20)\end{array}$ & $\begin{array}{l}\text { IAFS } \\
\text { Child CBT- (parents included < 20\%) } \\
\text { Group based } \\
\text { Exposure } \\
\text { Cognitive problem solving }\end{array}$ & $\begin{array}{l}\text { Mean age } 15 \text { (Range } 14-17 \text { ) } \\
\text { Male: } 25 \%\end{array}$ & 52 \\
\hline
\end{tabular}




\begin{tabular}{|c|c|c|c|c|c|c|}
\hline \multirow[t]{5}{*}{$\begin{array}{l}\text { Author, } \\
\text { Year }\end{array}$} & \multirow[t]{5}{*}{$\begin{array}{l}\text { Study Country, } \\
\text { Study Design, } \\
\text { Type of Study } \\
\text { (Efficacyl } \\
\text { Effectiveness), } \\
\text { Study Settings }\end{array}$} & \multirow[t]{5}{*}{$\begin{array}{c}\text { Type of } \\
\text { Anxiety/Severit } \\
\text { y (CGI) }\end{array}$} & $\begin{array}{l}\text { Intervention } \\
\text { and } \\
\text { Comparison } \\
\text { s (N of } \\
\text { Patients) }\end{array}$ & $\begin{array}{l}\text { Characteristics of Interventions } \\
\text { (Psychotherapy: Components, } \\
\text { Delivery Model)/Pharm: Drug) } \\
\text { Intensity, Duration (Weeks)) }\end{array}$ & $\begin{array}{c}\text { Patient Characteristics Mean } \\
\text { Age (Range), Male (\%), } \\
\text { Race/Ethnicity, Comorbidity, } \\
\text { Household Income, Parent } \\
\text { Education, Family } \\
\text { Dysfunction/Stressor, } \\
\text { Treatment Sequence, } \\
\text { Insurance, History of } \\
\text { Maltreatment) }\end{array}$ & $\begin{array}{l}\text { Length } \\
\text { of } \\
\text { Follow } \\
\text { up } \\
\text { (Weeks } \\
\text { ) }\end{array}$ \\
\hline & & & & $\begin{array}{l}12 \text { 90-minute weekly sessions } \\
\text { Delivered by practicing clinician }\end{array}$ & & \\
\hline & & & $\begin{array}{l}\text { Control, } \\
(\mathrm{N}=19)\end{array}$ & $\begin{array}{l}\text { Attention Control or Treatment as Usual } \\
\text { Educational Treatment on anxiety and } \\
\text { relaxation } \\
1290 \text {-minute weekly sessions }\end{array}$ & $\begin{array}{l}\text { Mean age } 14.94(14-17) \\
\text { Male: } 31.5 \%\end{array}$ & \\
\hline & & & $\begin{array}{l}\text { Control, } \\
(\mathrm{N}=18)\end{array}$ & $\begin{array}{l}\text { Attention Control or Treatment as Usual } \\
\text { Education as Placebo } \\
12 \text { sessions of health education }\end{array}$ & $\begin{array}{l}\text { Mean age } 14.75 \text { (14-17) } \\
\text { Male: } 16.6 \%\end{array}$ & \\
\hline & & & $\begin{array}{l}\text { Control, } \\
(\mathrm{N}=20)\end{array}$ & Waitlisting or no treatment & $\begin{array}{l}\text { Mean age } 14.77 \\
\text { Male: } 40 \%\end{array}$ & \\
\hline \multirow[t]{2}{*}{$\begin{array}{l}\text { Rodriguez, } \\
2005^{73}\end{array}$} & \multirow[t]{2}{*}{$\begin{array}{l}\text { Spain } \\
\text { RCT } \\
\text { Efficacy } \\
\text { High school }\end{array}$} & \multirow[t]{2}{*}{$\begin{array}{l}\text { GAD, PD without } \\
\text { agoraphobia, SP } \\
\text {,SoP, social } \\
\text { anxiety disorder }\end{array}$} & $\begin{array}{l}\text { Child CBT, } \\
(\mathrm{N}=17)\end{array}$ & $\begin{array}{l}\text { IAFS } \\
\text { Child CBT- (parents included < 20\%) } \\
\text { Group based } \\
\text { Exposure } \\
\text { Cognitive problem solving } \\
1290-\text { minute weekly sessions } \\
\text { Delivered by two experienced } \\
\text { psychologists }\end{array}$ & $\begin{array}{l}\text { Mean age: } 15 \\
\text { Male: } 41.17 \%\end{array}$ & \multirow[t]{2}{*}{6} \\
\hline & & & $\begin{array}{l}\text { Control, } \\
(\mathrm{N}=17)\end{array}$ & Waitlisting or no treatment & $\begin{array}{l}\text { Mean age: } 15.06 \\
\text { Male: } 41.17 \%\end{array}$ & \\
\hline \multirow[t]{2}{*}{$\begin{array}{l}\text { Sanchez- } \\
\text { Garcia, } 2009\end{array}$} & \multirow[t]{2}{*}{$\begin{array}{l}\text { Spain } \\
\text { RCT } \\
\text { Efficacy } \\
\text { Schools }\end{array}$} & \multirow[t]{2}{*}{ SoP } & $\begin{array}{l}\text { Child CBT, } \\
(\mathrm{N}=\mathrm{NR})\end{array}$ & $\begin{array}{l}\text { IAFS } \\
\text { Child CBT- (parents included < 20\%) } \\
\text { Group based } \\
\text { Exposure } \\
\text { Cognitive problem solving } \\
1290 \text {-minute weekly sessions }\end{array}$ & $\begin{array}{l}\text { Total number of patients: } 45 \\
\text { Mean age: } 12 \\
\text { Male: } 24.4 \%\end{array}$ & \multirow[t]{2}{*}{26} \\
\hline & & & $\begin{array}{l}\text { Control, } \\
(\mathrm{N}=\mathrm{NR})\end{array}$ & Waitlisting or no treatment & & \\
\hline $\begin{array}{l}\text { Sánchez- } \\
\text { García, } 2009 \\
75\end{array}$ & $\begin{array}{l}\text { Spain } \\
\text { RCT } \\
\text { Efficacy } \\
\text { Schools }\end{array}$ & SAD & $\begin{array}{l}\text { Child CBT, } \\
(\mathrm{N}=28)\end{array}$ & $\begin{array}{l}\text { IAFS } \\
\text { Child CBT- (parents included < 20\%) } \\
\text { Group based } \\
\text { Exposure } \\
\text { Cognitive problem solving } \\
1290-\text { minute weekly sessions }\end{array}$ & $\begin{array}{l}\text { Mean age: } 11.91 \\
\text { Male: } 38 \% \\
\text { White: } 82 \%\end{array}$ & 52 \\
\hline
\end{tabular}




\begin{tabular}{|c|c|c|c|c|c|c|}
\hline $\begin{array}{l}\text { Author, } \\
\text { Year }\end{array}$ & $\begin{array}{c}\text { Study Country, } \\
\text { Study Design, } \\
\text { Type of Study } \\
\text { (Efficacyl } \\
\text { Effectiveness), } \\
\text { Study Settings }\end{array}$ & $\begin{array}{c}\text { Type of } \\
\text { AnxietylSeverit } \\
\text { y (CGI) }\end{array}$ & $\begin{array}{c}\text { Intervention } \\
\text { and } \\
\text { Comparison } \\
\text { s (N of } \\
\text { Patients) }\end{array}$ & $\begin{array}{l}\text { Characteristics of Interventions } \\
\text { (Psychotherapy: Components, } \\
\text { Delivery Model)/Pharm: Drug) } \\
\text { Intensity, Duration (Weeks)) }\end{array}$ & $\begin{array}{c}\text { Patient Characteristics Mean } \\
\text { Age (Range), Male (\%), } \\
\text { Race/Ethnicity, Comorbidity, } \\
\text { Household Income, Parent } \\
\text { Education, Family } \\
\text { Dysfunction/Stressor, } \\
\text { Treatment Sequence, } \\
\text { Insurance, History of } \\
\text { Maltreatment) }\end{array}$ & $\begin{array}{c}\text { Length } \\
\text { of } \\
\text { Follow } \\
\text { up } \\
\text { (Weeks } \\
\text { ) }\end{array}$ \\
\hline & & & & Delivered by Practicing clinician & & \\
\hline & & & $\begin{array}{l}\text { Child CBT, } \\
(\mathrm{N}=29)\end{array}$ & $\begin{array}{l}\text { IAFS } \\
\text { Child CBT- (parents included < 20\%) } \\
\text { Incomplete (IAFS without Cognitive } \\
\text { restructuring) } \\
\text { Group based } \\
\text { Exposure } \\
1290 \text {-minute weekly sessions }\end{array}$ & & \\
\hline & & & $\begin{array}{l}\text { Control, } \\
(\mathrm{N}=25)\end{array}$ & Waitlisting or no treatment & & \\
\hline \multirow[t]{2}{*}{$\begin{array}{l}\text { Santucci, } \\
2013^{76}\end{array}$} & \multirow[t]{2}{*}{$\begin{array}{l}\text { United States } \\
\text { RCT } \\
\text { Efficacy } \\
\text { Mental health } \\
\text { clinic }\end{array}$} & \multirow[t]{2}{*}{ SAD } & $\begin{array}{l}\text { Child CBT, } \\
(\mathrm{N}=15)\end{array}$ & $\begin{array}{l}\text { Generic CBT } \\
\text { Child CBT- (parents included <20\%) } \\
\text { Group based } \\
\text { Exposure } \\
\text { Relaxation } \\
\text { Cognitive problem solving } \\
7 \text { sessions, } 3 \text { to } 5 \text { hour daily sessions. } \\
\text { Plus } 2 \text { additional } 60 \text { to } 90 \text { minute parent } \\
\text { sessions } \\
\text { Delivered by psychologist and } \\
\text { student/trainee }\end{array}$ & $\begin{array}{l}\text { Mean age: } 9.43 \text { (range: } 7-12 \text { ) } \\
\text { Males: } 0 \% \\
\text { Caucasian: } 80 \% \\
\text { Asian: } 13 \%\end{array}$ & \multirow[t]{2}{*}{6} \\
\hline & & & $\begin{array}{l}\text { Control, } \\
(\mathrm{N}=14)\end{array}$ & Waitlisting or no treatment & $\begin{array}{l}\text { Mean age: } 8.92 \text { (range: } 7-12 \text { ) } \\
\text { Males: } 0 \% \\
\text { Caucasian: } 93 \% \\
\text { Asian: } 7 \%\end{array}$ & \\
\hline $\begin{array}{l}\text { Schneider, } \\
2011^{77}\end{array}$ & $\begin{array}{l}\text { Germany } \\
\text { RCT } \\
\text { Efficacy } \\
\text { Mental health } \\
\text { clinic }\end{array}$ & SAD & $\begin{array}{l}\text { Child and } \\
\text { parent } \\
\text { together } \mathrm{CBT} \text {, } \\
(\mathrm{N}=21)\end{array}$ & $\begin{array}{l}\text { Other: Parent coached exposure } \\
\text { Individual based } \\
\text { Exposure } \\
\text { Cognitive problem solving } \\
4 \text { weekly 50-min sessions with the child } \\
\text { alone and 50-min parents alone. Then } 8 \\
\text { weekly 50-min family sessions, each } \\
\text { split into two parts: one with parents and }\end{array}$ & Mean age: 6.29 (range: 5-7) & 4 \\
\hline
\end{tabular}




\begin{tabular}{|c|c|c|c|c|c|c|}
\hline $\begin{array}{l}\text { Author, } \\
\text { Year }\end{array}$ & $\begin{array}{l}\text { Study Country, } \\
\text { Study Design, } \\
\text { Type of Study } \\
\text { (Efficacyl } \\
\text { Effectiveness), } \\
\text { Study Settings }\end{array}$ & $\begin{array}{c}\text { Type of } \\
\text { AnxietylSeverit } \\
\text { y (CGI) }\end{array}$ & $\begin{array}{c}\text { Intervention } \\
\text { and } \\
\text { Comparison } \\
\mathrm{s} \text { (N of } \\
\text { Patients) }\end{array}$ & $\begin{array}{l}\text { Characteristics of Interventions } \\
\text { (Psychotherapy: Components, } \\
\text { Delivery Model)/Pharm: Drug) } \\
\text { Intensity, Duration (Weeks)) }\end{array}$ & $\begin{array}{c}\text { Patient Characteristics Mean } \\
\text { Age (Range), Male (\%), } \\
\text { Race/Ethnicity, Comorbidity, } \\
\text { Household Income, Parent } \\
\text { Education, Family } \\
\text { Dysfunction/Stressor, } \\
\text { Treatment Sequence, } \\
\text { Insurance, History of } \\
\text { Maltreatment) }\end{array}$ & $\begin{array}{c}\text { Length } \\
\text { of } \\
\text { Follow } \\
\text { up } \\
\text { (Weeks } \\
\text { ) }\end{array}$ \\
\hline & & & & $\begin{array}{l}\text { child together, and a second with the } \\
\text { parents only } \\
\text { Delivered by psychologist }\end{array}$ & & \\
\hline & & & $\begin{array}{l}\text { Control, } \\
(\mathrm{N}=22)\end{array}$ & Waitlisting or no treatment & Mean age: 6.18 (range:5-7) & \\
\hline \multirow[t]{2}{*}{$\begin{array}{l}\text { Shortt, } \\
2001^{78}\end{array}$} & \multirow[t]{2}{*}{$\begin{array}{l}\text { Australia } \\
\text { RCT } \\
\text { Efficacy } \\
\text { NR }\end{array}$} & \multirow[t]{2}{*}{$\begin{array}{l}\text { GAD, SAD, SP, } \\
\text { SoP. }\end{array}$} & $\begin{array}{l}\text { Child CBT } \\
\text { plus separate } \\
\text { parent } \\
\text { intervention, } \\
(\mathrm{N}=54)\end{array}$ & $\begin{array}{l}\text { Friends } \\
\text { Group based, Exposure } \\
\text { Relaxation } \\
\text { Cognitive problem solving } \\
10 \text { weekly sessions and } 2 \text { booster } \\
\text { sessions; and } 10 \text { parent sessions (each } \\
\text { of about } 40 \text { minutes) }\end{array}$ & $\begin{array}{l}\text { Male: } 40.8 \% \\
\text { Caucasian: } 25.3 \% \\
\text { Asian: } 1.4 \% \\
\text { Mean age: } 7.83 \text { (Range } 6.5-10 \text { ) }\end{array}$ & \multirow[t]{2}{*}{52} \\
\hline & & & $\begin{array}{l}\text { Control, } \\
(\mathrm{N}=17)\end{array}$ & Waitlisting or no treatment & $\begin{array}{l}\text { Male: } 40.8 \% \\
\text { Caucasian: } 25.3 \% \\
\text { Asian: } 1.4 \% \\
\text { Mean age: } 7.88 \text { (Range } 6.5-10 \text { ) }\end{array}$ & \\
\hline \multirow[t]{2}{*}{$\begin{array}{l}\text { Silverman, } \\
1999^{79}\end{array}$} & \multirow[t]{2}{*}{$\begin{array}{l}\text { United States } \\
\text { RCT } \\
\text { Efficacy } \\
\text { Mental health } \\
\text { clinic }\end{array}$} & \multirow[t]{2}{*}{ GAD, SoP } & $\begin{array}{l}\text { Child CBT } \\
\text { plus separate } \\
\text { parent } \\
\text { intervention, } \\
(\mathrm{N}=37)\end{array}$ & $\begin{array}{l}\text { Generic CBT } \\
\text { Group based } \\
\text { Exposure } \\
\text { Cognitive problem solving } \\
\text { Unclear number of sessions, } 65 \text { minutes } \\
\text { Delivered by doctoral level psychologist } \\
\text { and student trainee }\end{array}$ & $\begin{array}{l}\text { Mean age: } 10.14 \text { (range: } 6-16) \\
\text { Males: } 54 \% \\
\text { Caucasian: } 47 \% \\
\text { Hispanic: } 40 \% \\
\text { Other: } 4 \% \\
\text { Low income }(<\$ 15,000): 27 \% \\
\text { Medium income: }(\$ 15,000- \\
\$ 30,000): 27 \% \\
\text { High income: }(>\$ 30,000): 34 \%\end{array}$ & \multirow[t]{2}{*}{52} \\
\hline & & & $\begin{array}{l}\text { Control, } \\
(\mathrm{N}=19)\end{array}$ & Waitlisting or no treatment & $\begin{array}{l}\text { Mean age: } 9.63 \text { (range: } 6-16) \\
\text { Males: } 74 \% \\
\text { Caucasian: } 44 \% \\
\text { Hispanic: } 58 \% \\
\text { Low income }(<\$ 15,000): 5 \% \\
\text { Medium income: }(\$ 15,000- \\
\$ 30,000): 32 \% \\
\text { High income: }(>\$ 30,000): 63 \%\end{array}$ & \\
\hline Spence, & $\begin{array}{l}\text { Australia } \\
\text { RCT }\end{array}$ & $\begin{array}{l}\text { GAD, SAD, SP, } \\
\text { SoP }\end{array}$ & $\begin{array}{l}\text { Child CBT } \\
\text { plus separate }\end{array}$ & $\begin{array}{l}\text { Generic CBT } \\
\text { CBT with parent Involvement }\end{array}$ & $\begin{array}{l}\text { Mean age: } 10.49 \text { (range: } 7-14 \text { ) } \\
\text { Males: } 59 \%\end{array}$ & 52 \\
\hline
\end{tabular}




\begin{tabular}{|c|c|c|c|c|c|c|}
\hline $\begin{array}{l}\text { Author, } \\
\text { Year }\end{array}$ & $\begin{array}{c}\text { Study Country, } \\
\text { Study Design, } \\
\text { Type of Study } \\
\text { (Efficacyl } \\
\text { Effectiveness), } \\
\text { Study Settings }\end{array}$ & $\begin{array}{c}\text { Type of } \\
\text { AnxietylSeverit } \\
\text { y (CGI) }\end{array}$ & $\begin{array}{c}\text { Intervention } \\
\text { and } \\
\text { Comparison } \\
\text { s (N of } \\
\text { Patients) }\end{array}$ & $\begin{array}{l}\text { Characteristics of Interventions } \\
\text { (Psychotherapy: Components, } \\
\text { Delivery Model)/Pharm: Drug) } \\
\text { Intensity, Duration (Weeks)) }\end{array}$ & $\begin{array}{c}\text { Patient Characteristics Mean } \\
\text { Age (Range), Male (\%), } \\
\text { Race/Ethnicity, Comorbidity, } \\
\text { Household Income, Parent } \\
\text { Education, Family } \\
\text { Dysfunction/Stressor, } \\
\text { Treatment Sequence, } \\
\text { Insurance, History of } \\
\text { Maltreatment) }\end{array}$ & $\begin{array}{c}\text { Length } \\
\text { of } \\
\text { Follow } \\
\text { up } \\
\text { (Weeks } \\
\text { ) }\end{array}$ \\
\hline \multirow[t]{3}{*}{$2000^{80}$} & \multirow[t]{3}{*}{$\begin{array}{l}\text { Efficacy } \\
\text { Mental health } \\
\text { clinic }\end{array}$} & & $\begin{array}{l}\text { parent } \\
\text { intervention, } \\
(\mathrm{N}=17)\end{array}$ & $\begin{array}{l}\text { Group based } \\
\text { Exposure } \\
\text { Relaxation } \\
\text { Cognitive problem solving } \\
121.5 \text {-hour weekly sessions, } 2 \text { 1.5-hour } \\
\text { boosters; parents observe } 60 \text { minutes of } \\
\text { child group, then have } 30 \text { minute } \\
\text { sessions } \\
\text { Delivered by } 2 \text { doctoral level } \\
\text { psychologists }\end{array}$ & $\begin{array}{l}\text { ODD: } 12 \% \\
\text { ADHD: } 6 \%\end{array}$ & \\
\hline & & & $\begin{array}{l}\text { Child CBT, } \\
(\mathrm{N}=19)\end{array}$ & $\begin{array}{l}\text { Generic CBT } \\
\text { Child CBT- (parents included < 20\%) } \\
\text { CBT without parent involvement Group } \\
\text { based } \\
\text { Exposure } \\
\text { Relaxation } \\
\text { Cognitive problem solving } \\
121.5 \text {-hour weekly sessions, } 2 \text { 1.5-hour } \\
\text { boosters } \\
\text { Delivered by } 2 \text { doctoral level } \\
\text { psychologists. }\end{array}$ & $\begin{array}{l}\text { Mean age: } 11 \text { (range: } 7-14 \text { ) } \\
\text { Males: } 53 \% \\
\text { ODD: } 10 \% \\
\text { Dysthymia: } 5 \%\end{array}$ & \\
\hline & & & $\begin{array}{l}\text { Control, } \\
(\mathrm{N}=14)\end{array}$ & Waitlisting or no treatment & $\begin{array}{l}\text { Mean age: } 9.93 \text { (range: } 7-14 \text { ) } \\
\text { Males: } 79 \% \\
\text { Dysthymia: } 7 \%\end{array}$ & \\
\hline $\begin{array}{l}\text { Spence, } \\
2006^{81}\end{array}$ & $\begin{array}{l}\text { Australia } \\
\text { RCT } \\
\text { Efficacy } \\
\text { Mental health } \\
\text { clinic }\end{array}$ & $\begin{array}{l}\text { GAD, SAD, SP } \\
\text { SoP }\end{array}$ & $\begin{array}{l}\text { Child CBT } \\
\text { plus separate } \\
\text { parent } \\
\text { intervention, } \\
(\mathrm{N}=22)\end{array}$ & $\begin{array}{l}\text { Generic CBT } \\
\text { Group based } \\
\text { Exposure } \\
\text { Relaxation } \\
\text { Cognitive problem solving } \\
1060 \text {-minute weekly child sessions and } \\
660 \text {-minute weekly parent sessions, } \\
\text { plus booster sessions at } 1 \text { and } 3 \\
\text { months } \\
\text { Delivered by } 5 \text { doctoral level } \\
\text { psychologists. }\end{array}$ & $\begin{array}{l}\text { Mean age: } 10.26 \text { (Range 7-14) } \\
\text { Male: } 59 \%\end{array}$ & 12 \\
\hline
\end{tabular}




\begin{tabular}{|c|c|c|c|c|c|c|}
\hline $\begin{array}{l}\text { Author, } \\
\text { Year }\end{array}$ & $\begin{array}{c}\text { Study Country, } \\
\text { Study Design, } \\
\text { Type of Study } \\
\text { (Efficacyl } \\
\text { Effectiveness), } \\
\text { Study Settings }\end{array}$ & $\begin{array}{c}\text { Type of } \\
\text { Anxiety/Severit } \\
\text { y (CGI) }\end{array}$ & $\begin{array}{c}\text { Intervention } \\
\text { and } \\
\text { Comparison } \\
\text { s (N of } \\
\text { Patients) }\end{array}$ & $\begin{array}{l}\text { Characteristics of Interventions } \\
\text { (Psychotherapy: Components, } \\
\text { Delivery Model)/Pharm: Drug) } \\
\text { Intensity, Duration (Weeks)) }\end{array}$ & $\begin{array}{c}\text { Patient Characteristics Mean } \\
\text { Age (Range), Male (\%), } \\
\text { Race/Ethnicity, Comorbidity, } \\
\text { Household Income, Parent } \\
\text { Education, Family } \\
\text { Dysfunction/Stressor, } \\
\text { Treatment Sequence, } \\
\text { Insurance, History of } \\
\text { Maltreatment) }\end{array}$ & $\begin{array}{c}\text { Length } \\
\text { of } \\
\text { Follow } \\
\text { up } \\
\text { (Weeks } \\
\text { ) }\end{array}$ \\
\hline & & & $\begin{array}{l}\text { Distance } \\
\text { Therapy, } \\
(\mathrm{N}=27)\end{array}$ & $\begin{array}{l}\text { Generic CBT } \\
\text { Internet CBT } \\
\text { Group based } \\
\text { Exposure } \\
\text { Relaxation } \\
\text { Cognitive problem solving } \\
5 \text { of the } 10 \text { child sessions plus the 3- } \\
\text { month booster via Internet, with the } \\
\text { remaining sessions being conducted in } \\
\text { the clinic; } 3 \text { of the } 6 \text { parents sessions } \\
\text { and the } 3 \text {-month via Internet } \\
\text { Delivered through the internet }\end{array}$ & $\begin{array}{l}\text { Mean age: } 9.8 \text { (Range } 7-14) \\
\text { Male: } 59.2 \%\end{array}$ & \\
\hline & & & $\begin{array}{l}\text { Control, } \\
(\mathrm{N}=23)\end{array}$ & Waitlisting or no treatment & $\begin{array}{l}\text { Mean age: } 9.8 \text { (Range } 7-14) \\
\text { Male: } 56.5 \%\end{array}$ & \\
\hline \multirow[t]{2}{*}{$\begin{array}{l}\text { Spence, } \\
2011^{82}\end{array}$} & \multirow[t]{2}{*}{$\begin{array}{l}\text { Australia } \\
\text { RCT } \\
\text { Efficacy } \\
\text { Mental health } \\
\text { clinic }\end{array}$} & \multirow[t]{2}{*}{$\begin{array}{l}\text { GAD, SAD, SoP, } \\
\text { SP }\end{array}$} & $\begin{array}{l}\text { Distance } \\
\text { Therapy, } \\
(\mathrm{N}=44)\end{array}$ & $\begin{array}{l}\text { Brave online } \\
\text { Technology-based } \\
\text { Individual based } \\
\text { Exposure } \\
\text { Relaxation } \\
\text { Cognitive problem solving } \\
10 \text { adolescents weekly sessions and } 5 \\
\text { parent sessions ( } 60 \text { minutes each) over } \\
12 \text { weeks; } 1 \text { 15-minute phone call, email } \\
\text { feedback after each session } \\
\text { Delivered by psychologist, Masters level } \\
\text { clinician }\end{array}$ & \multirow[t]{2}{*}{$\begin{array}{l}\text { Mean age: } 13.98 \text { (range: } 12-18 \text { ) } \\
\text { Males: } 41 \% \\
\text { High income(>\$76,910): } 47 \% \\
\text { College graduate (parent): } 58 \% \\
\text { Depression: } 2.6 \% \\
\text { ODD: } 1.7 \% \\
\text { Dysthymic disorder: } 9.7 \%\end{array}$} & \multirow[t]{2}{*}{52} \\
\hline & & & $\begin{array}{l}\text { Child CBT } \\
\text { plus separate } \\
\text { parent } \\
\text { intervention, } \\
(\mathrm{N}=44)\end{array}$ & $\begin{array}{l}\text { Individual based } \\
\text { Exposure } \\
\text { Relaxation } \\
\text { Cognitive problem solving } \\
10 \text { adolescents weekly sessions and } 5 \\
\text { parent sessions ( } 60 \text { minutes each) over } \\
12 \text { weeks } \\
\text { Delivered by psychologist, Masters level } \\
\text { clinician }\end{array}$ & & \\
\hline
\end{tabular}




\begin{tabular}{|c|c|c|c|c|c|c|}
\hline $\begin{array}{l}\text { Author, } \\
\text { Year }\end{array}$ & $\begin{array}{l}\text { Study Country, } \\
\text { Study Design, } \\
\text { Type of Study } \\
\text { (Efficacyl } \\
\text { Effectiveness), } \\
\text { Study Settings }\end{array}$ & $\begin{array}{c}\text { Type of } \\
\text { AnxietylSeverit } \\
\text { y (CGI) }\end{array}$ & $\begin{array}{l}\text { Intervention } \\
\text { and } \\
\text { Comparison } \\
\text { s (N of } \\
\text { Patients) }\end{array}$ & $\begin{array}{l}\text { Characteristics of Interventions } \\
\text { (Psychotherapy: Components, } \\
\text { Delivery Model)/Pharm: Drug) } \\
\text { Intensity, Duration (Weeks)) }\end{array}$ & $\begin{array}{c}\text { Patient Characteristics Mean } \\
\text { Age (Range), Male (\%), } \\
\text { Race/Ethnicity, Comorbidity, } \\
\text { Household Income, Parent } \\
\text { Education, Family } \\
\text { Dysfunction/Stressor, } \\
\text { Treatment Sequence, } \\
\text { Insurance, History of } \\
\text { Maltreatment) }\end{array}$ & $\begin{array}{l}\text { Length } \\
\text { of } \\
\text { Follow } \\
\text { up } \\
\text { (Weeks } \\
\text { ) }\end{array}$ \\
\hline & & & $\begin{array}{l}\text { Control, } \\
(\mathrm{N}=27)\end{array}$ & Waitlisting or no treatment & & \\
\hline \multirow[t]{2}{*}{$\begin{array}{l}\text { Treadwell, } \\
1996^{83}\end{array}$} & \multirow[t]{2}{*}{$\begin{array}{l}\text { United States } \\
\text { RCT } \\
\text { Efficacy } \\
\text { Outpatient } \\
\text { Mental health } \\
\text { clinic }\end{array}$} & \multirow[t]{2}{*}{ GAD, SAD } & $\begin{array}{l}\text { Child CBT, } \\
(\mathrm{N}=35)\end{array}$ & $\begin{array}{l}\text { Coping Cat } \\
\text { Child CBT- (parents included }<20 \% \text { ) } \\
\text { Individual based } \\
\text { Exposure } \\
\text { Relaxation } \\
\text { Cognitive problem solving } \\
16 \text { sessions, } 50-60 \text { minute weekly } \\
\text { sessions } \\
\text { Delivered by Masters level clinicians }\end{array}$ & \multirow[t]{2}{*}{$\begin{array}{l}\text { Mean age: } 11.7 \\
\text { Male: } 67.6 \% \\
\text { Caucasian: } 76 \% \\
\text { African Americans: } 23.9 \% \\
\text { Low income: } n=23 \\
\text { Medium income: } n=14 \\
\text { High income: } n=33\end{array}$} & \multirow[t]{2}{*}{ NR } \\
\hline & & & $\begin{array}{l}\text { Control, } \\
(\mathrm{N}=36)\end{array}$ & Waitlisting or no treatment & & \\
\hline \multirow[t]{3}{*}{$\begin{array}{l}\text { Valles- } \\
\text { Arandiga, } \\
2014^{84}\end{array}$} & \multirow[t]{3}{*}{$\begin{array}{l}\text { Spain } \\
\text { RCT } \\
\text { Efficacy } \\
\text { Schools }\end{array}$} & \multirow[t]{3}{*}{ SoP } & $\begin{array}{l}\text { Child CBT, } \\
(\mathrm{N}=17)\end{array}$ & $\begin{array}{l}\text { IAFS } \\
\text { Child CBT- (parents included < 20\%) } \\
\text { Group based } \\
\text { 12, } 90 \text {-minute weekly sessions } \\
\text { Delivered by therapist }\end{array}$ & \multirow[t]{3}{*}{$\begin{array}{l}\text { Mean age: } 14.9 \text { (range: } 14-16) \\
\text { Males:25\% }\end{array}$} & \multirow[t]{3}{*}{26} \\
\hline & & & $\begin{array}{l}\text { Control, } \\
(\mathrm{N}=17)\end{array}$ & $\begin{array}{l}\text { Attention Control or Treatment as Usual } \\
\text { Education Support } \\
\text { Individual based } \\
12 \text { 90-minute weekly sessions }\end{array}$ & & \\
\hline & & & $\begin{array}{l}\text { Control, } \\
(\mathrm{N}=17)\end{array}$ & Waitlisting or no treatment & & \\
\hline \multirow[t]{2}{*}{$\begin{array}{l}\text { van } \\
\text { Steensel, } \\
2015^{85}\end{array}$} & \multirow[t]{2}{*}{$\begin{array}{l}\text { Netherlands } \\
\text { Non- } \\
\text { Randomized } \\
\text { comparative } \\
\text { studies } \\
\text { Effectiveness } \\
\text { Outpatient }\end{array}$} & \multirow[t]{2}{*}{ NR } & $\begin{array}{l}\text { Child and } \\
\text { parent } \\
\text { together } \mathrm{CBT} \text {, } \\
(\mathrm{N}=62)\end{array}$ & $\begin{array}{l}\text { Discussing plus Doing } \\
\text { Individual based } \\
\text { Exposure } \\
\text { Relaxation } \\
\text { Cognitive problem solving } \\
12 \text { weekly sessions } \\
\text { Delivered by Masters level clinicians }\end{array}$ & \multirow[t]{2}{*}{ Age range: $7-18$ years } & \multirow[t]{2}{*}{0} \\
\hline & & & $\begin{array}{l}\text { Control, } \\
(\mathrm{N}=17)\end{array}$ & Waitlisting or no treatment & & \\
\hline
\end{tabular}




\begin{tabular}{|c|c|c|c|c|c|c|}
\hline $\begin{array}{l}\text { Author, } \\
\text { Year }\end{array}$ & $\begin{array}{c}\text { Study Country, } \\
\text { Study Design, } \\
\text { Type of Study } \\
\text { (Efficacyl } \\
\text { Effectiveness), } \\
\text { Study Settings }\end{array}$ & $\begin{array}{c}\text { Type of } \\
\text { AnxietylSeverit } \\
\text { y (CGI) }\end{array}$ & $\begin{array}{c}\text { Intervention } \\
\text { and } \\
\text { Comparison } \\
\mathrm{s} \text { (N of } \\
\text { Patients) }\end{array}$ & $\begin{array}{l}\text { Characteristics of Interventions } \\
\text { (Psychotherapy: Components, } \\
\text { Delivery Model)/Pharm: Drug) } \\
\text { Intensity, Duration (Weeks)) }\end{array}$ & $\begin{array}{c}\text { Patient Characteristics Mean } \\
\text { Age (Range), Male (\%), } \\
\text { Race/Ethnicity, Comorbidity, } \\
\text { Household Income, Parent } \\
\text { Education, Family } \\
\text { Dysfunction/Stressor, } \\
\text { Treatment Sequence, } \\
\text { Insurance, History of } \\
\text { Maltreatment) }\end{array}$ & $\begin{array}{c}\text { Length } \\
\text { of } \\
\text { Follow } \\
\text { up } \\
\text { (Weeks } \\
\text { ) }\end{array}$ \\
\hline \multirow[t]{3}{*}{$\begin{array}{l}\text { Waters, } \\
2009^{86}\end{array}$} & \multirow[t]{3}{*}{$\begin{array}{l}\text { Australia } \\
\text { RCT } \\
\text { Efficacy } \\
\text { Outpatient }\end{array}$} & \multirow[t]{3}{*}{$\begin{array}{l}\text { GAD, SAD, SoP, } \\
\text { SP }\end{array}$} & $\begin{array}{l}\text { Child CBT } \\
\text { plus separate } \\
\text { parent } \\
\text { intervention, } \\
(\mathrm{N}=38)\end{array}$ & $\begin{array}{l}\text { Take action } \\
\text { Group based } \\
\text { Exposure } \\
\text { Relaxation } \\
\text { Cognitive problem solving } \\
10 \text { weekly 1-hour child and one hour } \\
\text { parents sessions } \\
\text { Delivered by psychologist }\end{array}$ & $\begin{array}{l}\text { Mean age: } 6.89 \text { (range: } 4-8) \\
\text { Males: } 37 \% \\
\text { Caucasian: } 97 \%\end{array}$ & \multirow[t]{3}{*}{52} \\
\hline & & & $\begin{array}{l}\text { Parent only } \\
\text { intervention, } \\
(\mathrm{N}=31)\end{array}$ & $\begin{array}{l}\text { Take action } \\
\text { Group based } \\
\text { Exposure } \\
\text { Relaxation } \\
\text { Cognitive problem solving } \\
10 \text { weekly 1-hour child and one hour } \\
\text { parents sessions } \\
\text { Delivered by psychologist }\end{array}$ & $\begin{array}{l}\text { Mean age: } 6.68 \text { (range: } 4-8) \\
\text { Males: } 58 \% \\
\text { Caucasian: } 97 \%\end{array}$ & \\
\hline & & & $\begin{array}{l}\text { Control, } \\
(\mathrm{N}=11)\end{array}$ & Waitlisting or no treatment & $\begin{array}{l}\text { Mean age: } 6.79 \text { (range } 4-8 \text { ) } \\
\text { Males: } 55 \% \\
\text { Caucasian: } 91 \%\end{array}$ & \\
\hline \multirow[t]{2}{*}{$\begin{array}{l}\text { Warner, } \\
2011^{87}\end{array}$} & \multirow[t]{2}{*}{$\begin{array}{l}\text { United States } \\
\text { RCT } \\
\text { Efficacy } \\
\text { Outpatient }\end{array}$} & \multirow[t]{2}{*}{$\begin{array}{l}\text { GAD, SAD, SoP, } \\
\text { SP }\end{array}$} & $\begin{array}{l}\text { Child CBT, } \\
(\mathrm{N}=20)\end{array}$ & $\begin{array}{l}\text { TAPS } \\
\text { Child CBT- (parents included }<20 \% \text { ) } \\
\text { Individual based } \\
\text { Exposure } \\
\text { Relaxation } \\
\text { Cognitive problem solving } \\
12 \text { individual sessions ( } 45-60 \text { minutes } \\
\text { each) with } 3 \text { parent meetings ( } 45 \\
\text { minutes each) over } 10 \text { weeks } \\
\text { Delivered by psychologist }\end{array}$ & \multirow[t]{2}{*}{$\begin{array}{l}\text { Mean age: } 12.4 \text { (range: 8-16) } \\
\text { Males: } 35 \% \\
\text { Caucasian: } 73.5 \% \\
\text { African American: } 2.5 \% \\
\text { Hispanic: } 15 \% \\
\text { Other: } 10 \% \\
\text { Income range: } \$ 31,000- \\
\$ 120,000\end{array}$} & \multirow[t]{2}{*}{13} \\
\hline & & & $\begin{array}{l}\text { Control, } \\
(\mathrm{N}=20)\end{array}$ & Waitlisting or no treatment & & \\
\hline $\begin{array}{l}\text { Wergeland, } \\
2014^{88,89}\end{array}$ & $\begin{array}{l}\text { Norway } \\
\text { RCT } \\
\text { Efficacy }\end{array}$ & GAD, SAD, SoP & $\begin{array}{l}\text { Child CBT, } \\
(\mathrm{N}=91)\end{array}$ & $\begin{array}{l}\text { Friends } \\
\text { Child CBT- (parents included }<20 \% \text { ) } \\
\text { Individual based }\end{array}$ & $\begin{array}{l}\text { Mean age: } 11.4 \text { (range: 8-15) } \\
\text { Males: } 48 \% \\
\text { Caucasian: } 76 \%\end{array}$ & 52 \\
\hline
\end{tabular}




\begin{tabular}{|c|c|c|c|c|c|c|}
\hline $\begin{array}{l}\text { Author, } \\
\text { Year }\end{array}$ & $\begin{array}{c}\text { Study Country, } \\
\text { Study Design, } \\
\text { Type of Study } \\
\text { (Efficacyl } \\
\text { Effectiveness), } \\
\text { Study Settings }\end{array}$ & $\begin{array}{c}\text { Type of } \\
\text { AnxietylSeverit } \\
\text { y (CGI) }\end{array}$ & $\begin{array}{c}\text { Intervention } \\
\text { and } \\
\text { Comparison } \\
\text { s (N of } \\
\text { Patients) }\end{array}$ & $\begin{array}{l}\text { Characteristics of Interventions } \\
\text { (Psychotherapy: Components, } \\
\text { Delivery Model)/Pharm: Drug) } \\
\text { Intensity, Duration (Weeks)) }\end{array}$ & $\begin{array}{c}\text { Patient Characteristics Mean } \\
\text { Age (Range), Male (\%), } \\
\text { Race/Ethnicity, Comorbidity, } \\
\text { Household Income, Parent } \\
\text { Education, Family } \\
\text { Dysfunction/Stressor, } \\
\text { Treatment Sequence, } \\
\text { Insurance, History of } \\
\text { Maltreatment) }\end{array}$ & $\begin{array}{c}\text { Length } \\
\text { of } \\
\text { Follow } \\
\text { up } \\
\text { (Weeks } \\
\text { ) }\end{array}$ \\
\hline & \multirow[t]{3}{*}{ Outpatient } & & & $\begin{array}{l}\text { Exposure } \\
\text { Relaxation } \\
\text { Cognitive problem solving } \\
10 \text { weekly sessions, lasting } 60 \mathrm{~min} \\
\text { (ICBT), plus } 2 \text { parent only sessions } \\
\text { Delivered by psychologist, Masters level } \\
\text { clinician }\end{array}$ & $\begin{array}{l}\text { Hispanic: } 0.5 \% \\
\text { Asian: } 3 \% \\
\text { ADHD: } 5 \% \\
\text { Depression: } 8 \% \\
\text { ODD: } 9 \% \\
\text { Tic disorder: } 7 \%\end{array}$ & \\
\hline & & & $\begin{array}{l}\text { Child CBT, } \\
(\mathrm{N}=88)\end{array}$ & $\begin{array}{l}\text { Friends } \\
\text { Child CBT- (parents included }<20 \% \text { ) } \\
\text { Group based } \\
\text { Exposure } \\
\text { Relaxation } \\
\text { Cognitive problem solving } \\
10 \text { weekly sessions, lasting } 90 \text { minutes, } \\
\text { plus } 2 \text { parents sessions } \\
\text { Delivered by psychologist, Masters level } \\
\text { clinician }\end{array}$ & $\begin{array}{l}\text { Mean age: } 11.7 \text { (range: } 8-15 \text { ) } \\
\text { Males: } 45 \% \\
\text { Caucasian: } 76 \% \\
\text { Hispanic: } 0.5 \% \\
\text { Asian: } 3 \% \\
\text { ADHD: } 6 \% \\
\text { Depression: } 16 \% \\
\text { ODD: } 2 \% \\
\text { Tic disorder: } 7 \%\end{array}$ & \\
\hline & & & $\begin{array}{l}\text { Control, } \\
(\mathrm{N}=38)\end{array}$ & Waitlisting or no treatment & $\begin{array}{l}\text { Mean age: } 11.4 \text { (range: } 8-15 \text { ) } \\
\text { Males: } 50 \% \\
\text { Caucasian: } 76 \% \\
\text { Hispanic: } 0.5 \% \\
\text { Asian: } 3 \% \\
\text { ADHD: } 3 \% \\
\text { Depression: } 11 \% \\
\text { ODD: } 8 \% \\
\text { Tic disorder: } 5 \%\end{array}$ & \\
\hline $\begin{array}{l}\text { White, } \\
2013^{90}\end{array}$ & $\begin{array}{l}\text { United States } \\
\text { RCT } \\
\text { Effectiveness } \\
\text { Mental health } \\
\text { clinic }\end{array}$ & $\begin{array}{l}\text { GAD, PD with } \\
\text { agoraphobia, } \\
\text { SAD, SoP, SP }\end{array}$ & $\begin{array}{l}\text { Child CBT } \\
\text { plus separate } \\
\text { parent } \\
\text { intervention, } \\
(\mathrm{N}=15)\end{array}$ & $\begin{array}{l}\text { Social Skills training } \\
\text { Exposure } \\
\text { Cognitive problem solving } \\
\text { Individual therapy (up to } 13 \text { sessions), } \\
\text { group therapy (skills practice, } 7 \\
\text { sessions), and parent education and } \\
\text { coaching (after each individual therapy } \\
\text { session) } \\
\text { Delivered by student/trainee }\end{array}$ & $\begin{array}{l}\text { Mean age: } 14 \text { (range: } 12-17 \text { ) } \\
\text { Males: } 73 \% \\
\text { Caucasian: } 80 \% \\
\text { Asian: } 7 \% \\
\text { African American: } 7 \% \\
\text { Other: } 7 \% \\
\text { Autism: } 100 \% \\
\text { OCD: } 20 \%\end{array}$ & 0 \\
\hline
\end{tabular}




\begin{tabular}{|c|c|c|c|c|c|c|}
\hline \multirow[t]{2}{*}{$\begin{array}{c}\text { Author, } \\
\text { Year }\end{array}$} & $\begin{array}{c}\text { Study Country, } \\
\text { Study Design, } \\
\text { Type of Study } \\
\text { (Efficacyl } \\
\text { Effectiveness), } \\
\text { Study Settings }\end{array}$ & $\begin{array}{c}\text { Type of } \\
\text { Anxiety/Severit } \\
\text { y (CGI) }\end{array}$ & $\begin{array}{c}\text { Intervention } \\
\text { and } \\
\text { Comparison } \\
\text { s (N of } \\
\text { Patients) }\end{array}$ & $\begin{array}{l}\text { Characteristics of Interventions } \\
\text { (Psychotherapy: Components, } \\
\text { Delivery Model)/Pharm: Drug) } \\
\text { Intensity, Duration (Weeks)) }\end{array}$ & $\begin{array}{c}\text { Patient Characteristics Mean } \\
\text { Age (Range), Male (\%), } \\
\text { Race/Ethnicity, Comorbidity, } \\
\text { Household Income, Parent } \\
\text { Education, Family } \\
\text { Dysfunction/Stressor, } \\
\text { Treatment Sequence, } \\
\text { Insurance, History of } \\
\text { Maltreatment) }\end{array}$ & $\begin{array}{c}\text { Length } \\
\text { of } \\
\text { Follow } \\
\text { up } \\
\text { (Weeks } \\
\text { ) }\end{array}$ \\
\hline & & & $\begin{array}{l}\text { Control, } \\
(\mathrm{N}=15)\end{array}$ & Waitlisting or no treatment & $\begin{array}{l}\text { Mean age: } 15 \text { (range: } 12-17 \text { ) } \\
\text { Males: } 80 \% \\
\text { Caucasian: } 93 \% \\
\text { African American: } 7 \% \\
\text { Autism: } 100 \% \\
\text { OCD: } 20 \% \\
\text { PTSD: } 7 \%\end{array}$ & \\
\hline \multirow[t]{2}{*}{$\begin{array}{l}\text { Wood, } 2009 \\
91\end{array}$} & \multirow[t]{2}{*}{$\begin{array}{l}\text { United States } \\
\text { RCT } \\
\text { Efficacy } \\
\text { Outpatient }\end{array}$} & \multirow[t]{2}{*}{ GAD, SAD, SoP } & $\begin{array}{l}\text { Child and } \\
\text { parent } \\
\text { together } \mathrm{CBT} \text {, } \\
(\mathrm{N}=17)\end{array}$ & $\begin{array}{l}\text { Building confidence } \\
\text { Individual based } \\
\text { Exposure } \\
\text { Cognitive problem solving } \\
16 \text { session } 90 \text { minutes (about } 30 \\
\text { minutes with the child and } 60 \text { minutes } \\
\text { with the parents/family } \\
\text { Delivered by psychologist, } \\
\text { student/trainee }\end{array}$ & $\begin{array}{l}\text { Mean age: } 9.2 \text { (Range 7-11) } \\
\text { Males: } 71 \% \\
\text { Caucasian: } 47 \% \\
\text { Hispanic: } 12 \% \\
\text { Asian: } 24 \% \\
\text { Others: } 18 \% \\
\text { Low income (<\$40,000):22\% } \\
\text { Medium Income ( } \$ 40,000- \\
\$ 90,000): 25 \% \\
\text { High Income (>\$90,000):45\% } \\
\text { College Graduate (parent); } 71 \% \\
\text { Autism: } 100 \% \\
\text { ADHD: } 53 \% \\
\text { OCD: } 47 \% \\
\text { ODD: } 12 \% \\
\text { Dysthymia: } 18 \%\end{array}$ & \multirow[t]{2}{*}{0} \\
\hline & & & $\begin{array}{l}\text { Control, } \\
(\mathrm{N}=23)\end{array}$ & Waitlisting or no treatment & $\begin{array}{l}\text { Mean age: } 9.18 \text { (Range } 7-11) \\
\text { Males: } 65 \% \\
\text { Caucasian: } 48 \% \\
\text { African American: } 4 \% \\
\text { Hispanic: } 13 \% \\
\text { Low income (<\$40,000):22\% } \\
\text { Medium Income ( } \$ 40,000- \\
\$ 90,000): 25 \% \\
\text { High Income (>\$90,000):45\% } \\
\text { Asian:9\% } \\
\text { Others: } 26 \% \\
\text { College Graduate (parent): } 60 \%\end{array}$ & \\
\hline
\end{tabular}




\begin{tabular}{|c|c|c|c|c|c|c|}
\hline $\begin{array}{l}\text { Author, } \\
\text { Year }\end{array}$ & $\begin{array}{l}\text { Study Country, } \\
\text { Study Design, } \\
\text { Type of Study } \\
\text { (Efficacyl } \\
\text { Effectiveness), } \\
\text { Study Settings }\end{array}$ & $\begin{array}{c}\text { Type of } \\
\text { Anxiety/Severit } \\
\text { y (CGI) }\end{array}$ & $\begin{array}{l}\text { Intervention } \\
\text { and } \\
\text { Comparison } \\
\text { s (N of } \\
\text { Patients) }\end{array}$ & $\begin{array}{l}\text { Characteristics of Interventions } \\
\text { (Psychotherapy: Components, } \\
\text { Delivery Model)/Pharm: Drug) } \\
\text { Intensity, Duration (Weeks)) }\end{array}$ & $\begin{array}{c}\text { Patient Characteristics Mean } \\
\text { Age (Range), Male (\%), } \\
\text { Race/Ethnicity, Comorbidity, } \\
\text { Household Income, Parent } \\
\text { Education, Family } \\
\text { Dysfunction/Stressor, } \\
\text { Treatment Sequence, } \\
\text { Insurance, History of } \\
\text { Maltreatment) } \\
\end{array}$ & 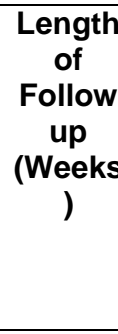 \\
\hline & & & & & $\begin{array}{l}\text { Autism: } 100 \% \\
\text { ADHD: } 65 \% \\
\text { OCD: } 39 \% \\
\text { ODD: } 26 \% \\
\text { PTSD: } 4 \%\end{array}$ & \\
\hline
\end{tabular}

ACT: acceptance and commitment theory, ADHD: attention deficit hyperactivity disorder, IAFS: intervencion en adolescents con fobia social (treatment for adolescents with social phobia), CBT: cognitive behavioral therapy, CGI: clinical global impression scale, GAD: generalized anxiety disorder, NR: not reported, OCD: obsessive compulsive disorder, ODD: oppositional defiant disorder, OST: one session treatment, PD: panic disorder, PTSD: post-traumatic stress disorder, RCT: randomized controlled trial, SAD: separation anxiety disorder, SET-C: social effectiveness therapy, SHY: the SHY manual for social anxiety, SoP: social anxiety, SP: specific phobia. TAPS: treatment of anxiety and physical symptoms 
Table E.5. Characteristics of the included studies comparing CBT versus pill placebo

\begin{tabular}{|c|c|c|c|c|c|c|}
\hline Author, Year & $\begin{array}{c}\text { Study Country, } \\
\text { Study Design, } \\
\text { Type of Study } \\
\text { (Efficacyl } \\
\text { Effectiveness), } \\
\text { Study Settings }\end{array}$ & $\begin{array}{c}\text { Type of } \\
\text { Anxiety/Severity } \\
\text { (CGI) }\end{array}$ & $\begin{array}{l}\text { Intervention } \\
\text { and } \\
\text { Comparison } \\
\text { s (N of } \\
\text { Patients) }\end{array}$ & $\begin{array}{l}\text { Characteristics of Interventions } \\
\text { (Psychotherapy: Components, } \\
\text { Delivery Model)/Pharm: Drug) } \\
\text { Intensity, Duration (Weeks)) }\end{array}$ & $\begin{array}{c}\text { Patient Characteristics Mean Age } \\
\text { (Range), Male (\%), Race/Ethnicity, } \\
\text { Comorbidity, Household Income, } \\
\text { Parent Education, Family } \\
\text { Dysfunction/Stressor, Treatment } \\
\text { Sequence, Insurance, History of } \\
\text { Maltreatment) }\end{array}$ & $\begin{array}{l}\text { Length } \\
\text { of } \\
\text { Follow } \\
\text { up } \\
\text { (Weeks) }\end{array}$ \\
\hline \multirow[t]{3}{*}{ Beidel, $2007^{3}$} & \multirow{3}{*}{$\begin{array}{l}\text { United States } \\
\text { RCT } \\
\text { Efficacy } \\
\text { Mental health } \\
\text { clinic }\end{array}$} & \multirow[t]{3}{*}{$\begin{array}{l}\text { GAD, SAD, SP, } \\
\text { SoP }\end{array}$} & $\begin{array}{l}\text { SSRI: } \\
\text { Fluoxetine, } \\
(\mathrm{N}=43)\end{array}$ & $\begin{array}{l}\text { 10mg per day during week } 1 \text { and } 2 \text {. } \\
\text { Increasing dose up to } 40 \mathrm{mg} / \text { day for } \\
\text { up to } 12 \text { weeks. }\end{array}$ & \multirow{3}{*}{$\begin{array}{l}\text { Mean age:11.56 (Range } 7-17) \\
\text { Male: } 53.23 \% \\
\text { Caucasian: } 74.1 \% \\
\text { African American: } 15.1 \% \\
\text { Hispanic: } 2.1 \% \\
\text { Asian: } 2.8 \% \\
\text { Other: } 3.5 \%\end{array}$} & \multirow[t]{3}{*}{52} \\
\hline & & & $\begin{array}{l}\text { Child CBT, } \\
(\mathrm{N}=59)\end{array}$ & $\begin{array}{l}\text { Social effectiveness therapy (SET- } \\
\text { C) } \\
\text { Child CBT (Parents included <20\%) } \\
\text { Group and Individual based, } \\
\text { Exposure } \\
\text { Relaxation } \\
\text { Cognitive Problem Solving. } \\
60 \text { min individual session and one } \\
150 \text { min group session twice a week } \\
\text { for } 12 \text { weeks. }\end{array}$ & & \\
\hline & & & $\begin{array}{l}\text { Control, } \\
(\mathrm{N}=37)\end{array}$ & Pill Placebo & & \\
\hline \multirow[t]{3}{*}{$\begin{array}{l}\text { Scharfstein, } \\
2011^{16}\end{array}$} & \multirow[t]{3}{*}{$\begin{array}{l}\text { United States } \\
\text { RCT } \\
\text { Effectiveness } \\
\text { Outpatient }\end{array}$} & \multirow[t]{3}{*}{ SoP } & $\begin{array}{l}\text { Child CBT, } \\
(\mathrm{N}=46)\end{array}$ & $\begin{array}{l}\text { Social Effectiveness Therapy (SET- } \\
\text { C) } \\
\text { Child CBT (parents included <20\%) } \\
\text { Exposure } \\
\text { Cognitive Problem Solving. } \\
\text { One individual and one group } \\
\text { session per week for } 12 \text { weeks. }\end{array}$ & \multirow[t]{3}{*}{ Male: $50 \%$} & \multirow[t]{3}{*}{0} \\
\hline & & & $\begin{array}{l}\text { SSRI: } \\
\text { Fluoxetine, } \\
(\mathrm{N}=22)\end{array}$ & $\begin{array}{l}\text { One tablet of up to } 40 \mathrm{mg} / \text { day for } 12 \\
\text { weeks }\end{array}$ & & \\
\hline & & & $\begin{array}{l}\text { Control, } \\
(\mathrm{N}=22)\end{array}$ & $\begin{array}{l}\text { Pill Placebo } \\
\text { Identically appearing placebo } \\
\text { capsules once a week for } 12 \text { weeks. }\end{array}$ & & \\
\hline $\begin{array}{l}\text { Walkup, } \\
2008^{20-26}\end{array}$ & $\begin{array}{l}\text { United States } \\
\text { RCT } \\
\text { Efficacy } \\
\text { Outpatient }\end{array}$ & GAD,SAD, SoP & $\begin{array}{l}\text { Child CBT, } \\
(\mathrm{N}=139)\end{array}$ & $\begin{array}{l}\text { Coping Cat } \\
\text { Child CBT (parents included <20\%) } \\
\text { Individual-based } \\
\text { Exposure, relaxation, cognitive } \\
\text { problem solving. } \\
60 \text {-minute session once a week for } \\
12 \text { weeks. }\end{array}$ & $\begin{array}{l}\text { Mean age: } 10.5 \\
\text { Male: } 49.2 \% \\
\text { Caucasian: } 76.3 \% \text {, African } \\
\text { American: } 10.1 \% \text {, Hispanic: } 9.2 \% \text {, } \\
\text { other: } 4.5 \% \\
\text { Low income: } 23.7 \% \\
\text { ADHD: } 11.5 \%, \text { ODD:13.8\%, Tic }\end{array}$ & 0 \\
\hline
\end{tabular}




\begin{tabular}{|c|c|c|c|c|c|c|}
\hline Author, Year & $\begin{array}{c}\text { Study Country, } \\
\text { Study Design, } \\
\text { Type of Study } \\
\text { (Efficacyl } \\
\text { Effectiveness), } \\
\text { Study Settings }\end{array}$ & $\begin{array}{c}\text { Type of } \\
\text { AnxietylSeverity } \\
\text { (CGI) }\end{array}$ & $\begin{array}{l}\text { Intervention } \\
\text { and } \\
\text { Comparison } \\
\text { s (N of } \\
\text { Patients) }\end{array}$ & $\begin{array}{l}\text { Characteristics of Interventions } \\
\text { (Psychotherapy: Components, } \\
\text { Delivery Model)/Pharm: Drug) } \\
\text { Intensity, Duration (Weeks)) }\end{array}$ & $\begin{array}{c}\text { Patient Characteristics Mean Age } \\
\text { (Range), Male (\%), Race/Ethnicity, } \\
\text { Comorbidity, Household Income, } \\
\text { Parent Education, Family } \\
\text { Dysfunction/Stressor, Treatment } \\
\text { Sequence, Insurance, History of } \\
\text { Maltreatment) }\end{array}$ & $\begin{array}{l}\text { Length } \\
\text { of } \\
\text { Follow } \\
\text { up } \\
\text { (Weeks) }\end{array}$ \\
\hline & & & & & $\begin{array}{l}\text { disorder and other internalizing } \\
\text { disorders: } 41.7 \%\end{array}$ & \\
\hline & & & $\begin{array}{l}\text { SSRI: } \\
\text { Sertraline, } \\
(\mathrm{N}=133)\end{array}$ & $\begin{array}{l}\text { Beginning with } 25 \mathrm{mg} / \text { day Up to } 200 \\
\text { mg/day by } 8^{\text {th }} \text { week, for } 12 \text { weeks. }\end{array}$ & $\begin{array}{l}\text { Mean age: } 10.8 \\
\text { Male: } 51.1 \% \\
\text { Caucasian: } 77.4 \% \text {, African American: } \\
\text { 9\%, Hispanic: } 11.3 \% \text {, other: } 2.3 \% \\
\text { Low income: } 26.3 \% \\
\text { ADHD: } 12.7 \%, \text { ODD:8.2\%, Tic } \\
\text { disorder and other internalizing } \\
\text { disorders: } 55.6 \%\end{array}$ & \\
\hline & & & $\begin{array}{l}\text { Combination } \\
\text { therapy: } \\
\text { CBT+ SSRI: } \\
\text { Child CBT+ } \\
\text { Sertraline, } \\
(\mathrm{N}=140)\end{array}$ & $\begin{array}{l}\text { Coping Cat, } \\
\text { Child CBT (parents included <20\%) } \\
\text { Individual-based } \\
\text { Exposure, relaxation and cognitive } \\
\text { problem solving plus Sertraline. } \\
60 \text {-minute session once a week for } \\
12 \text { weeks plus up to } 200 \text { mg/day for } \\
12 \text { weeks. }\end{array}$ & $\begin{array}{l}\text { Mean age: } 10.7 \\
\text { Male: } 49.6 \% \\
\text { Caucasian: } 82.9 \% \text {, African American: } \\
\text { 7.9\%, Hispanic: } 5.6 \% \text {, other: } 3.6 \% \\
\text { Low income: } 25.0 \% \\
\text { ADHD: } 11.4 \% \text {, ODD:10\%, Tic } \\
\text { disorder and other internalizing } \\
\text { disorders: } 42.8 \%\end{array}$ & \\
\hline & & & $\begin{array}{l}\text { Controil, } \\
(N=76)\end{array}$ & Pill Placebo & $\begin{array}{l}\text { Mean age: } 10.6 \\
\text { Male : } 51.3 \% \\
\text { Caucasian: } 79 \% \text {, African American: } \\
\text { 9\%, Hispanic: } 9 \% \text {, other: } 3 \% \\
\text { Low income: } 27.6 \% \\
\text { ADHD: } 118 \%, \text { ODD:9.2\%, Tic } \\
\text { disorder and other internalizing } \\
\text { disorders: } 44.7 \%\end{array}$ & \\
\hline
\end{tabular}

ACT: acceptance and commitment theory, ADHD: attention deficit hyperactivity disorder, IAFS: intervencion en adolescents con fobia social (treatment for adolescents with social phobia), CBT: cognitive behavioral therapy, CGI: clinical global impression scale, GAD: generalized anxiety disorder, NR: not reported, OCD: obsessive compulsive disorder, ODD: oppositional defiant disorder, OST: one session treatment, PD: panic disorder, PTSD: post-traumatic stress disorder, RCT: randomized controlled trial, SAD: separation anxiety disorder, SET-C: social effectiveness therapy, SHY: the SHY manual for social anxiety, SoP: social anxiety, SP: specific phobia. TAPS: treatment of anxiety and physical symptoms 
Table E.6. Characteristics of the included studies comparing CBT versus attention control or treatment as usual

\begin{tabular}{|c|c|c|c|c|c|c|}
\hline $\begin{array}{l}\text { Author, } \\
\text { Year }\end{array}$ & $\begin{array}{c}\text { Study Country, } \\
\text { Study Design, } \\
\text { Type of Study } \\
\text { (Efficacyl } \\
\text { Effectiveness), } \\
\text { Study Settings }\end{array}$ & $\begin{array}{c}\text { Type of } \\
\text { Anxiety/Severity } \\
\text { (CGI) }\end{array}$ & $\begin{array}{l}\text { Intervention } \\
\text { and } \\
\text { Comparison } \\
\text { s (N of } \\
\text { Patients) }\end{array}$ & $\begin{array}{l}\text { Characteristics of Interventions } \\
\text { (Psychotherapy: Components, } \\
\text { Delivery Model)/Pharm: Drug) } \\
\text { Intensity, Duration (Weeks)) }\end{array}$ & $\begin{array}{c}\text { Patient Characteristics Mean } \\
\text { Age (Range), Male (\%), } \\
\text { Race/Ethnicity, Comorbidity, } \\
\text { Household Income, Parent } \\
\text { Education, Family } \\
\text { Dysfunction/Stressor, } \\
\text { Treatment Sequence, } \\
\text { Insurance, History of } \\
\text { Maltreatment) }\end{array}$ & $\begin{array}{c}\text { Length } \\
\text { of } \\
\text { Follow } \\
\text { up } \\
\text { (Weeks } \\
\text { ) }\end{array}$ \\
\hline \multirow[t]{2}{*}{$\begin{array}{l}\text { Beidel, } 2000 \\
92\end{array}$} & \multirow[t]{2}{*}{$\begin{array}{l}\text { United States } \\
\text { RCT } \\
\text { Eficacy } \\
\text { Mental health } \\
\text { clinic }\end{array}$} & \multirow[t]{2}{*}{$\begin{array}{l}\text { GAD, PD } \\
\text { (agoraphobia is } \\
\text { not specified), } \\
\text { SAD, SP, SoP }\end{array}$} & $\begin{array}{l}\text { Child CBT, } \\
(\mathrm{N}=36)\end{array}$ & $\begin{array}{l}\text { Social effectiveness yherapy for } \\
\text { Children (SET-C) } \\
\text { Individual and group based } \\
\text { Exposure } \\
\text { Cognitive problem solving } \\
\text { Two weekly sessions (one group } \\
\text { session and one individual session) for } \\
12 \text { weeks. Group sessions could be } 60 \\
\text { minutes (social skill training) or } 90 \\
\text { minutes (peer generalization } \\
\text { experiences). Individual sessions were } \\
60 \text { minutes }\end{array}$ & $\begin{array}{l}\text { Mean age: } 10.5 \\
\text { Male: } 38.8 \% \\
\text { Caucasian: } 97.7 \% \\
\text { African American: } 30.5 \% \\
\text { Hispanic: } 5.5 \% \\
\text { GCI: } 5.5\end{array}$ & \multirow[t]{2}{*}{26} \\
\hline & & & $\begin{array}{l}\text { Control, } \\
(\mathrm{N}=31)\end{array}$ & $\begin{array}{l}\text { Attention control or treatment as usual } \\
\text { Testbusters program for study skills and } \\
\text { test taking strategy }\end{array}$ & $\begin{array}{l}\text { Mean age: } 10.5 \\
\text { Male: } 19.3 \% \\
\text { Caucasian: } 58 \% \\
\text { African American: } 25 \% \\
\text { Hispanic: } 9.6 \% \\
\text { Biracial: } 5.5 \% \\
\text { CGI: } 5.6 \\
\end{array}$ & \\
\hline \multirow[t]{2}{*}{ Fujii, $2013^{93}$} & \multirow[t]{2}{*}{$\begin{array}{l}\text { United States } \\
\text { RCT } \\
\text { Efficacy } \\
\text { Mental health } \\
\text { clinic }\end{array}$} & \multirow[t]{2}{*}{ GAD, SAD, SoP } & $\begin{array}{l}\text { Child and } \\
\text { parent } \\
\text { together } \mathrm{CBT} \text {, } \\
(\mathrm{N}=7)\end{array}$ & $\begin{array}{l}\text { Other: Coping skills exposure } \\
\text { Individual based } \\
\text { Exposure } \\
\text { Cognitive problem solving } \\
3290 \text {-minute weekly sessions, first } 16 \\
\text { sessions, modular CBT, second } 16 \\
\text { sessions social skills } \\
\text { Delivered by student/trainee }\end{array}$ & $\begin{array}{l}\text { Mean age: } 8.7 \text { (range: } 7-11 \text { ) } \\
\text { Males: } 71 \% \\
\text { Caucasian: } 86 \% \\
\text { Asian: } 14 \% \\
\text { College graduate (parent): } 71 \% \\
\text { Autism: } 57 \% \\
\text { OCD: } 14 \%\end{array}$ & \multirow[t]{2}{*}{0} \\
\hline & & & $\begin{array}{l}\text { Control, } \\
(\mathrm{N}=5)\end{array}$ & Attention Control or Treatment as Usual & $\begin{array}{l}\text { Mean age: } 9 \text { (range: } 7-11 \text { ) } \\
\text { Males: } 80 \% \\
\text { Caucasian: } 60 \% \\
\text { African American: } 20 \% \\
\text { Other: } 20 \% \\
\text { College graduate (parent): } 60 \% \\
\text { Autism: } 100 \% \\
\end{array}$ & \\
\hline
\end{tabular}




\begin{tabular}{|c|c|c|c|c|c|c|}
\hline $\begin{array}{l}\text { Author, } \\
\text { Year }\end{array}$ & $\begin{array}{l}\text { Study Country, } \\
\text { Study Design, } \\
\text { Type of Study } \\
\text { (Efficacyl } \\
\text { Effectiveness), } \\
\text { Study Settings }\end{array}$ & $\begin{array}{c}\text { Type of } \\
\text { AnxietylSeverity } \\
\text { (CGI) }\end{array}$ & $\begin{array}{l}\text { Intervention } \\
\text { and } \\
\text { Comparison } \\
\text { s (N of } \\
\text { Patients) }\end{array}$ & $\begin{array}{l}\text { Characteristics of Interventions } \\
\text { (Psychotherapy: Components, } \\
\text { Delivery Model)/Pharm: Drug) } \\
\text { Intensity, Duration (Weeks)) }\end{array}$ & $\begin{array}{c}\text { Patient Characteristics Mean } \\
\text { Age (Range), Male (\%), } \\
\text { Race/Ethnicity, Comorbidity, } \\
\text { Household Income, Parent } \\
\text { Education, Family } \\
\text { Dysfunction/Stressor, } \\
\text { Treatment Sequence, } \\
\text { Insurance, History of } \\
\text { Maltreatment) }\end{array}$ & $\begin{array}{l}\text { Length } \\
\text { of } \\
\text { Follow } \\
\text { up } \\
\text { (Weeks } \\
\text { ) }\end{array}$ \\
\hline \multirow[t]{2}{*}{$\begin{array}{l}\text { Ginsburg, } \\
2002^{94}\end{array}$} & \multirow[t]{2}{*}{$\begin{array}{l}\text { United States } \\
\text { RCT } \\
\text { Efficacy } \\
\text { School }\end{array}$} & \multirow[t]{2}{*}{$\begin{array}{l}\text { GAD, SP, SoP, } \\
\text { PD } \\
\text { (agoraphobia) }\end{array}$} & $\begin{array}{l}\text { Child CBT, } \\
(\mathrm{N}=6)\end{array}$ & $\begin{array}{l}\text { Group-based } \\
\text { Exposure } \\
\text { Relaxation } \\
\text { Cognitive problem solving. } \\
45 \text { min session over } 10 \text { weeks delivered } \\
\text { by psychiatrists. No parent involvement. }\end{array}$ & \multirow[t]{2}{*}{$\begin{array}{l}\text { Mean age: } 15.6 \text { (Range 14-17) } \\
\text { Male: } 16.6 \% \\
\text { African Americans: } 100 \%\end{array}$} & \multirow[t]{2}{*}{10} \\
\hline & & & $\begin{array}{l}\text { Control, } \\
(\mathrm{N}=6)\end{array}$ & $\begin{array}{l}\text { Attention control or treatment as usual } \\
\text { Group based. } \\
45-50 \text { min session, one session a week, } \\
10 \text { sessions delivered by student } \\
\text { trainee. }\end{array}$ & & \\
\hline \multirow[t]{2}{*}{$\begin{array}{l}\text { Ginsburg, } \\
2012^{95}\end{array}$} & \multirow[t]{2}{*}{$\begin{array}{l}\text { United States } \\
\text { RCT } \\
\text { Effectiveness } \\
\text { School-based } \\
\text { Mental health } \\
\text { clinics }\end{array}$} & \multirow[t]{2}{*}{$\begin{array}{l}\text { GAD,SAD, SoP, } \\
\text { SP }\end{array}$} & $\begin{array}{l}\text { Child CBT, } \\
(\mathrm{N}=17)\end{array}$ & $\begin{array}{l}\text { Modular CBT } \\
\text { Child CBT- (parents included }<20 \% \text { ) } \\
\text { Individual based } \\
\text { Exposure } \\
\text { Relaxation } \\
\text { Cognitive problem solving } \\
8 \text { modules over } 12 \text { weeks (average } \\
7.29 \text { ); } 20-45 \text { min sessions in school; } \\
\text { efforts to involve parents in at least } 3 \\
\text { sessions } \\
\text { Delivered by doctoral psychologist }\end{array}$ & $\begin{array}{l}\text { Mean age: } 11.12 \\
\text { Male: } 29.4 \% \\
\text { African American: } 82 \% \text {, other: } \\
18 \% \\
\text { Low income: } 23.5 \% \\
\text { Family stress: } 100 \%\end{array}$ & \multirow[t]{2}{*}{4} \\
\hline & & & $\begin{array}{l}\text { Control, } \\
(\mathrm{N}=15)\end{array}$ & Attention control or treatment as usual & $\begin{array}{l}\text { Mean age: } 9.33 \\
\text { Male: } 46.6 \% \\
\text { African American: } 87 \% \text {, other: } \\
13 \% \\
\text { Low income: } 40 \% \\
\text { Family stress: } 100 \%\end{array}$ & \\
\hline \multirow[t]{2}{*}{$\begin{array}{l}\text { Halldorsdotti } \\
\text { r, } 2016^{96}\end{array}$} & \multirow[t]{2}{*}{$\begin{array}{l}\text { United States } \\
\text { RCT } \\
\text { Efficacy } \\
\text { Outpatient }\end{array}$} & \multirow[t]{2}{*}{ GAD, SoP } & $\begin{array}{l}\text { Child CBT, } \\
(N=50)\end{array}$ & $\begin{array}{l}\text { OST } \\
\text { Exposure } \\
\text { Relaxation } \\
\text { Cognitive problem solving } \\
\text { Individual-based } \\
180 \text { minute one session only }\end{array}$ & $\begin{array}{l}\text { Mean age: } 9.24 \\
\text { Male: } 88 \% \\
\text { Mean income: } 71.450\end{array}$ & \multirow[t]{2}{*}{208} \\
\hline & & & Control, & Attention control or treatment as usual & Mean age: 8.97 & \\
\hline
\end{tabular}




\begin{tabular}{|c|c|c|c|c|c|c|}
\hline $\begin{array}{l}\text { Author, } \\
\text { Year }\end{array}$ & $\begin{array}{l}\text { Study Country, } \\
\text { Study Design, } \\
\text { Type of Study } \\
\text { (Efficacyl } \\
\text { Effectiveness), } \\
\text { Study Settings }\end{array}$ & $\begin{array}{c}\text { Type of } \\
\text { AnxietylSeverity } \\
\text { (CGI) }\end{array}$ & $\begin{array}{l}\text { Intervention } \\
\text { and } \\
\text { Comparison } \\
\text { s (N of } \\
\text { Patients) }\end{array}$ & $\begin{array}{l}\text { Characteristics of Interventions } \\
\text { (Psychotherapy: Components, } \\
\text { Delivery Model)/Pharm: Drug) } \\
\text { Intensity, Duration (Weeks)) }\end{array}$ & $\begin{array}{c}\text { Patient Characteristics Mean } \\
\text { Age (Range), Male (\%), } \\
\text { Race/Ethnicity, Comorbidity, } \\
\text { Household Income, Parent } \\
\text { Education, Family } \\
\text { Dysfunction/Stressor, } \\
\text { Treatment Sequence, } \\
\text { Insurance, History of } \\
\text { Maltreatment) }\end{array}$ & $\begin{array}{l}\text { Length } \\
\text { of } \\
\text { Follow } \\
\text { up } \\
\text { (Weeks } \\
\text { ) }\end{array}$ \\
\hline & & & $(\mathrm{N}=33)$ & Individual-based & $\begin{array}{l}\text { Male: } 90 \% \\
\text { Mean income: } \$ 73,232\end{array}$ & \\
\hline \multirow[t]{3}{*}{$\begin{array}{l}\text { Herbert, } \\
2009^{97}\end{array}$} & \multirow[t]{3}{*}{$\begin{array}{l}\text { United States } \\
\text { RCT } \\
\text { Efficacy } \\
\text { Mental health } \\
\text { clinic }\end{array}$} & \multirow[t]{3}{*}{$\begin{array}{l}\text { GAD , PD } \\
\text { (agoraphobia is } \\
\text { not specified), } \\
\text { SAD, SP, SoP }\end{array}$} & $\begin{array}{l}\text { Child CBT, } \\
(\mathrm{N}=23)\end{array}$ & $\begin{array}{l}\text { Generic CBT } \\
\text { Group based } \\
\text { Relaxation, exposure, } \\
\text { Cognitive problem solving } \\
\text { Delivered by Masters level clinicians. } \\
120 \text { min session per week for } 12 \text { weeks }\end{array}$ & $\begin{array}{l}\text { Mean age: } 14.6 \text { (range } 12-17 \text { ) } \\
\text { Male : } 56.5 \% \\
\text { Caucasian: } 52 \% \text {, African } \\
\text { Americans: } 39 \% \text {, Asian: } 8.6 \%\end{array}$ & \multirow[t]{3}{*}{52} \\
\hline & & & $\begin{array}{l}\text { Child CBT, } \\
(\mathrm{N}=24)\end{array}$ & $\begin{array}{l}\text { Generic CBT } \\
\text { Individual based } \\
\text { Relaxation, exposure, cognitive problem } \\
\text { solving } \\
\text { Delivered by Masters level clinicians. } \\
60 \text { min session per week for } 12 \text { weeks. }\end{array}$ & $\begin{array}{l}\text { Mean age: } 14.3 \text { (range } 12-17 \text { ) } \\
\text { Male: } 25 \% \\
\text { Caucasian: } 54.2 \% \text {, African } \\
\text { Americans: } 45.8 \%\end{array}$ & \\
\hline & & & $\begin{array}{l}\text { Control, } \\
(N=26)\end{array}$ & $\begin{array}{l}\text { Attention control or treatment as usual } \\
\text { Psychoeducational-supportive therapy } \\
\text { Group based } \\
\text { Delivered by Masters level clinicians } \\
120 \text { min session per week for } 12 \text { weeks }\end{array}$ & $\begin{array}{l}\text { Mean age: } 15.1 \text { (range } 12-17 \text { ) } \\
\text { Male: } 53.8 \% \\
\text { Caucasian: } 34.6 \% \text {, African } \\
\text { American: } 50 \%, \text { Hispanics: } \\
7.69 \% \\
\text { Asians: } 7.69 \%\end{array}$ & \\
\hline \multirow[t]{2}{*}{$\begin{array}{l}\text { Hudson, } \\
2009^{98}\end{array}$} & \multirow[t]{2}{*}{$\begin{array}{l}\text { Australia } \\
\text { RCT } \\
\text { Efficacy } \\
\text { Mental health } \\
\text { clinic }\end{array}$} & \multirow[t]{2}{*}{$\begin{array}{l}\text { GAD ,SAD, PD, } \\
\text { SP, SoP }\end{array}$} & $\begin{array}{l}\text { Child and } \\
\text { parent } \\
\text { together } \mathrm{CBT} \text {, } \\
(\mathrm{N}=60)\end{array}$ & $\begin{array}{l}\text { Cool kids } \\
\text { Group based } \\
\text { Exposure } \\
\text { Cognitive problem solving. } \\
120 \text { min session per week for } 10 \text { weeks. }\end{array}$ & $\begin{array}{l}\text { Mean age; 10.2 (SD 2.4) } \\
\text { (Range 7-16) } \\
\text { Male: } 53.3 \% \\
\text { Caucasian: } 75 \% \text {, Asian } 6.6 \% \text {, } \\
\text { other:3.3\% } \\
\text { Low income: } n=8 \\
\text { Medium income: } n=21 \\
\text { High income: } n=22\end{array}$ & \multirow[t]{2}{*}{13} \\
\hline & & & $\begin{array}{l}\text { Control, } \\
(\mathrm{N}=52)\end{array}$ & $\begin{array}{l}\text { Attention control or treatment as usual } \\
\text { Group support and attention, group } \\
\text { based } \\
120 \text { min session per week for } 10 \text { weeks }\end{array}$ & $\begin{array}{l}\text { Mean age: } 10.2 \text { (SD 2.7) } \\
\text { (Range } 7-16) \\
\text { Male: } 40.3 \% \\
\text { Caucasian: } 65.3 \% \% \text {, Asian: } \\
\text { 11.5\%, others } 5.7 \% \\
\text { Low income: } n=16 \\
\text { Medium income: } n=11 \\
\end{array}$ & \\
\hline
\end{tabular}




\begin{tabular}{|c|c|c|c|c|c|c|}
\hline $\begin{array}{l}\text { Author, } \\
\text { Year }\end{array}$ & $\begin{array}{l}\text { Study Country, } \\
\text { Study Design, } \\
\text { Type of Study } \\
\text { (Efficacyl } \\
\text { Effectiveness), } \\
\text { Study Settings }\end{array}$ & $\begin{array}{c}\text { Type of } \\
\text { AnxietylSeverity } \\
\text { (CGI) }\end{array}$ & $\begin{array}{l}\text { Intervention } \\
\text { and } \\
\text { Comparison } \\
\text { s (N of } \\
\text { Patients) }\end{array}$ & $\begin{array}{l}\text { Characteristics of Interventions } \\
\text { (Psychotherapy: Components, } \\
\text { Delivery Model)/Pharm: Drug) } \\
\text { Intensity, Duration (Weeks)) }\end{array}$ & $\begin{array}{c}\text { Patient Characteristics Mean } \\
\text { Age (Range), Male (\%), } \\
\text { Race/Ethnicity, Comorbidity, } \\
\text { Household Income, Parent } \\
\text { Education, Family } \\
\text { Dysfunction/Stressor, } \\
\text { Treatment Sequence, } \\
\text { Insurance, History of } \\
\text { Maltreatment) }\end{array}$ & $\begin{array}{l}\text { Length } \\
\text { of } \\
\text { Follow } \\
\text { up } \\
\text { (Weeks } \\
\text { ) }\end{array}$ \\
\hline & & & & & High income: $\mathrm{n}=17$ & \\
\hline \multirow[t]{3}{*}{ Ingul, $2014^{99}$} & \multirow[t]{3}{*}{$\begin{array}{l}\text { Norway } \\
\text { RCT } \\
\text { Efficacy } \\
\text { Mental health } \\
\text { clinic }\end{array}$} & \multirow[t]{3}{*}{ SoP } & $\begin{array}{l}\text { Child CBT, } \\
(\mathrm{N}=36)\end{array}$ & $\begin{array}{l}\text { Other CBT } \\
\text { Exposure } \\
\text { Cognitive problem solving } \\
\text { Individual-based } \\
\text { Delivered by psychologist and Masters } \\
\text { level clinician } \\
\text { 12, } 50 \text { min weekly sessions }\end{array}$ & $\begin{array}{l}\text { Age mean: } 14.98 \text { (SD:0.94) } \\
\text { Males: } 43 \% \\
\text { ADHD: } 14.29 \% \\
\text { Depression: } 9.52 \% \\
\text { PTSD: } 4.76 \%\end{array}$ & \multirow[t]{3}{*}{52} \\
\hline & & & $\begin{array}{l}\text { Child CBT, } \\
(\mathrm{N}=58)\end{array}$ & $\begin{array}{l}\text { Cat Project } \\
\text { Exposure } \\
\text { Cognitive problem solving } \\
\text { Group based } \\
10,90 \text { min sessions }\end{array}$ & $\begin{array}{l}\text { Age mean: 14.30(SD:0.89) } \\
\text { Males: } 40 \% \\
\text { ADHD: } 5 \% \\
\text { Depression: } 10 \%\end{array}$ & \\
\hline & & & $\begin{array}{l}\text { Control, } \\
(\mathrm{N}=34)\end{array}$ & $\begin{array}{l}\text { Attention control or treatment as usual } \\
10,90 \text { min sessions }\end{array}$ & $\begin{array}{l}\text { Age mean: } 14.16 \text { (SD:1.08) } \\
\text { Males: } 43 \% \\
\text { ADHD: } 6.25 \% \\
\text { Depression: } 6.25 \% \\
\text { OCD: } 6.25 \% \\
\text { PTSD: } 6.25 \%\end{array}$ & \\
\hline \multirow[t]{2}{*}{$\begin{array}{l}\text { Kendall, } \\
2008^{100,101}\end{array}$} & \multirow[t]{2}{*}{$\begin{array}{l}\text { United States } \\
\text { RCT } \\
\text { Efficacy } \\
\text { Mental health } \\
\text { clinic }\end{array}$} & \multirow[t]{2}{*}{$\begin{array}{l}\text { GAD,SAD, } \\
\text { SoP,SP }\end{array}$} & $\begin{array}{l}\text { Child CBT, } \\
(\mathrm{N}=55)\end{array}$ & $\begin{array}{l}\text { Coping Cat: } \\
\text { xposure } \\
\text { Relaxation } \\
\text { Cognitive problem solving } \\
\text { Individual-based } \\
\text { Weekly for } 16 \text { weeks, } 60 \text { min each } \\
\text { session, parents at two }\end{array}$ & $\begin{array}{l}\text { Age mean (years): } 10.37 \text { range } \\
(7-14) \\
\text { Caucasian: } 83 \% \\
\text { Other:16\% } \\
\text { Low income }(<\$ 40,000): 20 \% \\
\text { Medium income }(\$ 40,000- \\
\$ 90,000): 34 \% \\
\text { High income }(>\$ 90,000): 38 \%\end{array}$ & \multirow[t]{2}{*}{52} \\
\hline & & & $\begin{array}{l}\text { Child and } \\
\text { parent } \\
\text { together } \mathrm{CBT} \text {, } \\
(\mathrm{N}=56)\end{array}$ & $\begin{array}{l}\text { CC derivative } \\
\text { Exposure } \\
\text { Relaxation } \\
\text { Cognitive problem solving } \\
\text { Individual-based, family based } \\
\text { Weekly for } 16 \text { weeks, } 60 \text { min each }\end{array}$ & $\begin{array}{l}\text { Age mean (years): } 10.41 \text { range } \\
\text { (7-14) } \\
\text { Caucasian: } 80 \% \\
\text { Other: } 16 \% \\
\text { Low income }(<\$ 40,000): 14 \% \\
\text { Medium income }(\$ 40,000-\end{array}$ & \\
\hline
\end{tabular}




\begin{tabular}{|c|c|c|c|c|c|c|}
\hline $\begin{array}{l}\text { Author, } \\
\text { Year }\end{array}$ & $\begin{array}{c}\text { Study Country, } \\
\text { Study Design, } \\
\text { Type of Study } \\
\text { (Efficacyl } \\
\text { Effectiveness), } \\
\text { Study Settings }\end{array}$ & $\begin{array}{c}\text { Type of } \\
\text { Anxiety/Severity } \\
\text { (CGI) }\end{array}$ & $\begin{array}{c}\text { Intervention } \\
\text { and } \\
\text { Comparison } \\
\text { s (N of } \\
\text { Patients) }\end{array}$ & $\begin{array}{l}\text { Characteristics of Interventions } \\
\text { (Psychotherapy: Components, } \\
\text { Delivery Model)/Pharm: Drug) } \\
\text { Intensity, Duration (Weeks)) }\end{array}$ & $\begin{array}{c}\text { Patient Characteristics Mean } \\
\text { Age (Range), Male (\%), } \\
\text { Race/Ethnicity, Comorbidity, } \\
\text { Household Income, Parent } \\
\text { Education, Family } \\
\text { Dysfunction/Stressor, } \\
\text { Treatment Sequence, } \\
\text { Insurance, History of } \\
\text { Maltreatment) }\end{array}$ & $\begin{array}{c}\text { Length } \\
\text { of } \\
\text { Follow } \\
\text { up } \\
\text { (Weeks } \\
\text { ) }\end{array}$ \\
\hline & & & & session & $\begin{array}{l}\$ 90,000): 46 \% \\
\text { High income (>\$90,000):32\% }\end{array}$ & \\
\hline & & & $\begin{array}{l}\text { Control, } \\
(\mathrm{N}=50)\end{array}$ & $\begin{array}{l}\text { Attention control or treatment as usual } \\
\text { Family education, support, and attention } \\
\text { Weekly for } 16 \text { weeks, } 60 \text { min each } \\
\text { session }\end{array}$ & $\begin{array}{l}\text { Age mean (years): } 10.03 \text { range } \\
(7-14) \\
\text { Caucasian: } 88 \% \\
\text { Other: } 12 \% \\
\text { Low income }(<\$ 40,000): 10 \% \\
\text { Medium income }(\$ 40,000- \\
\$ 90,000): 50 \% \\
\text { High income }(>\$ 90,000): 30 \%\end{array}$ & \\
\hline \multirow[t]{3}{*}{$\begin{array}{l}\text { Khanna, } \\
2010^{102}\end{array}$} & \multirow[t]{3}{*}{$\begin{array}{l}\text { United States } \\
\text { RCT } \\
\text { Efficacy } \\
\text { Mental health } \\
\text { clinic }\end{array}$} & \multirow[t]{3}{*}{$\begin{array}{l}\text { GAD, PD, SAD, } \\
\text { SoP, SP }\end{array}$} & $\begin{array}{l}\text { Child CBT, } \\
(\mathrm{N}=17)\end{array}$ & $\begin{array}{l}\text { Coping cat } \\
\text { Exposure } \\
\text { Relaxation } \\
\text { Cognitive problem solving } \\
\text { Individual-based } \\
\text { Delivered by psychologist, student/ } \\
\text { trainee } \\
\text { Weekly for } 12 \text { weeks, } 50 \text { minute } \\
\text { sessions }\end{array}$ & \multirow[t]{3}{*}{$\begin{array}{l}\text { Age mean (years): } 10.1 \text { (range: } \\
\text { 7-13) } \\
\text { Males: } 67 \% \\
\text { Caucasian: } 83 \% \\
\text { African American: } 14 \% \\
\text { Hispanic: } 2 \% \\
\text { ADHD: } 16 \% \\
\text { ODD:4\% } \\
\text { Tic disorder: } 2 \%\end{array}$} & \multirow[t]{3}{*}{13} \\
\hline & & & $\begin{array}{l}\text { Distance, } \\
(\mathrm{N}=16)\end{array}$ & $\begin{array}{l}\text { Camp cope a lot } \\
\text { Exposure } \\
\text { Relaxation } \\
\text { Cognitive problem solving } \\
\text { Individual based } \\
\text { Delivered by psychologist, student/ } \\
\text { trainee } \\
\text { Weekly for } 12 \text { weeks }\end{array}$ & & \\
\hline & & & $\begin{array}{l}\text { Control, } \\
(N=16)\end{array}$ & $\begin{array}{l}\text { Attention control or treatment as usual } \\
\text { Individual-based, technology-based } \\
\text { Delivered by psychologist, student/ } \\
\text { trainee } \\
\text { Weekly for } 12 \text { weeks, } 60 \text { minute } \\
\text { sessions. } 30 \text { minutes of support and } 30 \\
\text { minutes of computer. }\end{array}$ & & \\
\hline Last, $1998^{103}$ & United States & SoP & Child and & Generic CBT & Age mean (years): 11.67 & 4 \\
\hline
\end{tabular}




\begin{tabular}{|c|c|c|c|c|c|c|}
\hline $\begin{array}{l}\text { Author, } \\
\text { Year }\end{array}$ & $\begin{array}{l}\text { Study Country, } \\
\text { Study Design, } \\
\text { Type of Study } \\
\text { (Efficacyl } \\
\text { Effectiveness), } \\
\text { Study Settings }\end{array}$ & $\begin{array}{c}\text { Type of } \\
\text { Anxiety/Severity } \\
\text { (CGI) }\end{array}$ & $\begin{array}{l}\text { Intervention } \\
\text { and } \\
\text { Comparison } \\
\text { s (N of } \\
\text { Patients) }\end{array}$ & $\begin{array}{l}\text { Characteristics of Interventions } \\
\text { (Psychotherapy: Components, } \\
\text { Delivery Model)/Pharm: Drug) } \\
\text { Intensity, Duration (Weeks)) }\end{array}$ & $\begin{array}{c}\text { Patient Characteristics Mean } \\
\text { Age (Range), Male (\%), } \\
\text { Race/Ethnicity, Comorbidity, } \\
\text { Household Income, Parent } \\
\text { Education, Family } \\
\text { Dysfunction/Stressor, } \\
\text { Treatment Sequence, } \\
\text { Insurance, History of } \\
\text { Maltreatment) }\end{array}$ & $\begin{array}{l}\text { Length } \\
\text { of } \\
\text { Follow } \\
\text { up } \\
\text { (Weeks } \\
\text { ) }\end{array}$ \\
\hline & \multirow[t]{2}{*}{$\begin{array}{l}\text { RCT } \\
\text { Efficacy } \\
\text { Mental health } \\
\text { clinic }\end{array}$} & & $\begin{array}{l}\text { Parent } \\
\text { together } \mathrm{CBT} \text {, } \\
(\mathrm{N}=32)\end{array}$ & $\begin{array}{l}\text { Exposure } \\
\text { Cognitive problem solving } \\
\text { Delivered by therapists and school } \\
\text { contact person. } \\
12,60 \text { min weekly sessions }\end{array}$ & $\begin{array}{l}\text { Male: } 59.3 \% \\
\text { Caucasian: } 65.6 \% \\
\text { Hispanic: } 3.1 \% \\
\text { African American: } 3.1 \%\end{array}$ & \\
\hline & & & $\begin{array}{l}\text { Control, } \\
(\mathrm{N}=24)\end{array}$ & $\begin{array}{l}\text { Attention control or treatment as usual } \\
12,60 \text { min weekly sessions }\end{array}$ & $\begin{array}{l}\text { Age mean (years): } 12.4 \\
\text { Male: } 37.5 \% \\
\text { Caucasian: } 87.5 \% \\
\text { African American: } 4.1 \% \\
\text { Hispanic: } 8.2 \%\end{array}$ & \\
\hline \multirow[t]{2}{*}{$\begin{array}{l}\text { Masia- } \\
\text { Warner, } \\
2007^{104}\end{array}$} & \multirow[t]{2}{*}{$\begin{array}{l}\text { United States } \\
\text { RCT } \\
\text { School }\end{array}$} & \multirow[t]{2}{*}{ GAD, SAD, SoP } & $\begin{array}{l}\text { Child CBT, } \\
(\mathrm{N}=19)\end{array}$ & $\begin{array}{l}\text { SASS: skills for academic and social } \\
\text { success, } \\
\text { Individual-based, group-based, } \\
\text { Exposure } \\
\text { Cognitive problem solving, } \\
12 \text { group sessions ( } 40 \text { minutes) and } 2 \\
\text { individuals delivered by } 2 \text { doctoral level } \\
\text { psychologists }\end{array}$ & $\begin{array}{l}\text { Age mean (years): } 15 \text { (Range } \\
14-16) \\
\text { Male: } 15.7 \% \\
\text { Caucasian: } 73.6 \%, \\
\text { African: } 5.2 \% \\
\text { African: } 15.78 \% \text {, other: } 5.2 \%\end{array}$ & \multirow[t]{2}{*}{6} \\
\hline & & & $\begin{array}{l}\text { Control, } \\
(\mathrm{N}=17)\end{array}$ & $\begin{array}{l}\text { Attention control or treatment as usual } \\
\text { Educational supportive group function } \\
\text { (ESGF), } \\
\text { Individual-based, group-based, } \\
\text { Relaxation } \\
\text { Cognitive strategies } \\
12 \text { group sessions and } 2 \text { individual } \\
\text { delivered by } 2 \text { doctoral level } \\
\text { psychologists. }\end{array}$ & $\begin{array}{l}\text { Age mean (years): } 15.1 \text { (Range } \\
\text { 14-16) } \\
\text { Male: } 17.64 \\
\text { Caucasian: } 70.5 \% \text {, African: } \\
5.88 \% \\
\text { Hispanic: } 17.6 \% \text {, other: } 5.88 \%\end{array}$ & \\
\hline \multirow[t]{2}{*}{$\begin{array}{l}\text { Menzies, } \\
1993^{57}\end{array}$} & \multirow[t]{2}{*}{$\begin{array}{l}\text { Australia } \\
\text { RCT } \\
\text { Efficacy } \\
\text { Outpatient }\end{array}$} & \multirow[t]{2}{*}{ SP } & $\begin{array}{l}\text { Child CBT, } \\
(\mathrm{N}=13)\end{array}$ & $\begin{array}{l}\text { In vivo exposure plus vicarious } \\
\text { exposure } \\
\text { Child CBT- (parents included < 20\%) } \\
\text { Individual based } \\
\text { Delivered by student therapist } \\
3 \text { 15-minute weekly session }\end{array}$ & \multirow[t]{2}{*}{$\begin{array}{l}\text { Age mean (years): } 5.5 \text { (range:3- } \\
\text { 8) } \\
\text { Male: } 50.7 \% \\
\text { Caucasian: } 96 \% \text {, Hispanic:4\% } \\
\text { Depression: } 10 \% \\
\text { Treatment non responder: } \\
100 \%\end{array}$} & \multirow[t]{2}{*}{12} \\
\hline & & & $\begin{array}{l}\text { Control, } \\
(\mathrm{N}=13)\end{array}$ & $\begin{array}{l}\text { Attention control or treatment as usual } \\
\text { Only vicarious exposure }\end{array}$ & & \\
\hline
\end{tabular}




\begin{tabular}{|c|c|c|c|c|c|c|}
\hline \multirow[t]{4}{*}{$\begin{array}{l}\text { Author, } \\
\text { Year }\end{array}$} & \multirow[t]{4}{*}{$\begin{array}{l}\text { Study Country, } \\
\text { Study Design, } \\
\text { Type of Study } \\
\text { (Efficacyl } \\
\text { Effectiveness), } \\
\text { Study Settings }\end{array}$} & \multirow[t]{4}{*}{$\begin{array}{c}\text { Type of } \\
\text { Anxiety/Severity } \\
\text { (CGI) }\end{array}$} & $\begin{array}{l}\text { Intervention } \\
\text { and } \\
\text { Comparison } \\
\mathrm{s} \text { (N of } \\
\text { Patients) }\end{array}$ & $\begin{array}{l}\text { Characteristics of Interventions } \\
\text { (Psychotherapy: Components, } \\
\text { Delivery Model)/Pharm: Drug) } \\
\text { Intensity, Duration (Weeks)) }\end{array}$ & $\begin{array}{c}\text { Patient Characteristics Mean } \\
\text { Age (Range), Male (\%), } \\
\text { Race/Ethnicity, Comorbidity, } \\
\text { Household Income, Parent } \\
\text { Education, Family } \\
\text { Dysfunction/Stressor, } \\
\text { Treatment Sequence, } \\
\text { Insurance, History of } \\
\text { Maltreatment) }\end{array}$ & $\begin{array}{l}\text { Length } \\
\text { of } \\
\text { Follow } \\
\text { up } \\
\text { (Weeks } \\
\text { ) }\end{array}$ \\
\hline & & & & $\begin{array}{l}3 \text { 30-minute weekly session } \\
\text { Delivered by student therapist }\end{array}$ & & \\
\hline & & & $\begin{array}{l}\text { Child CBT, } \\
(\mathrm{N}=13)\end{array}$ & $\begin{array}{l}\text { In vivo exposure } \\
\text { Child CBT- (parents included }<20 \% \text { ) } \\
\text { Individual based } \\
\text { Exposure } 330 \text {-minute weekly session } \\
\text { Delivered by student }\end{array}$ & & \\
\hline & & & $\begin{array}{l}\text { Control, } \\
(\mathrm{N}=12)\end{array}$ & Waitlisting or no treatment & & \\
\hline \multirow[t]{2}{*}{$\underset{105}{\text { Muris, } 2002}$} & \multirow[t]{2}{*}{$\begin{array}{l}\text { Netherlands } \\
\text { RCT } \\
\text { Efficacy } \\
\text { School }\end{array}$} & \multirow[t]{2}{*}{ GAD, SAD, SoP } & $\begin{array}{l}\text { Child CBT, } \\
(N=10)\end{array}$ & $\begin{array}{l}\text { Coping Koala } \\
\text { Group based } \\
\text { Exposure } \\
\text { Relaxation } \\
\text { Cognitive problem solving } \\
1230 \text {-minute sessions. } 2 \text { sessions per } \\
\text { week delivered by student/trainee }\end{array}$ & \multirow[t]{2}{*}{$\begin{array}{l}\text { Age range (9-12) years } \\
\text { Caucasian: } 90 \% \\
\text { Other: } 10 \% \\
\text { Low income: } 13 \\
\text { Medium income: } 6 \\
\text { High income: } 1 \\
\text { Male int1 ; } 30 \% \\
\text { Male Int } 2: 40 \%\end{array}$} & \multirow[t]{2}{*}{13} \\
\hline & & & $\begin{array}{l}\text { Control, } \\
(\mathrm{N}=10)\end{array}$ & $\begin{array}{l}\text { Attention control or treatment as usual } \\
\text { Emotional disclosure treatment } \\
\text { program. Group based. } 12 \text { 30-minute } \\
\text { sessions over } 6 \text { weeks }\end{array}$ & & \\
\hline \multirow[t]{2}{*}{$\begin{array}{l}\text { O'Brien, } \\
2007^{106}\end{array}$} & \multirow[t]{2}{*}{$\begin{array}{l}\text { Ireland } \\
\text { RCT } \\
\text { Efficacy } \\
\text { Mental health } \\
\text { clinic }\end{array}$} & \multirow[t]{2}{*}{ Anxiety disorder } & $\begin{array}{l}\text { Child CBT, } \\
(\mathrm{N}=7)\end{array}$ & $\begin{array}{l}\text { Friends } \\
\text { Child CBT- (parents included < 20\%) } \\
\text { Group based } \\
\text { Exposure } \\
\text { Relaxation } \\
\text { Cognitive problem solving } \\
1090-\text { minute weekly sessions, plus } \\
\text { three parent session } \\
\text { Delivered by } 2 \text { Masters level clinicians }\end{array}$ & $\begin{array}{l}\text { Age mean (years): } 13.8 \text { (Range } \\
7-15) \\
\text { Male: } 28.57 \%\end{array}$ & \multirow[t]{2}{*}{4} \\
\hline & & & $\begin{array}{l}\text { Control, } \\
(\mathrm{N}=7)\end{array}$ & Attention Control or Treatment as Usual & $\begin{array}{l}\text { Age mean (years): } 12.5 \text { (Range } \\
7-15) \\
\text { Male: } 57.14 \%\end{array}$ & \\
\hline $\begin{array}{l}\text { Ollendick, } \\
2009^{63}\end{array}$ & $\begin{array}{l}\text { United States } \\
\text { and Sweden } \\
\text { RCT }\end{array}$ & $\begin{array}{l}\text { SP, SoP, SAD, } \\
\text { GAD }\end{array}$ & $\begin{array}{l}\text { Child CBT, } \\
(\mathrm{N}=85)\end{array}$ & $\begin{array}{l}\text { OST } \\
\text { Child CBT- (parents included }<20 \% \text { ) } \\
\text { One session treatment }\end{array}$ & $\begin{array}{l}\text { Caucasian: } 90 \%, \\
\text { African American: } 2.5 \% \\
\text { Hispanic:: } 2 \%\end{array}$ & 36 \\
\hline
\end{tabular}




\begin{tabular}{|c|c|c|c|c|c|c|}
\hline $\begin{array}{l}\text { Author, } \\
\text { Year }\end{array}$ & $\begin{array}{c}\text { Study Country, } \\
\text { Study Design, } \\
\text { Type of Study } \\
\text { (Efficacyl } \\
\text { Effectiveness), } \\
\text { Study Settings }\end{array}$ & $\begin{array}{c}\text { Type of } \\
\text { Anxiety/Severity } \\
\text { (CGI) }\end{array}$ & $\begin{array}{c}\text { Intervention } \\
\text { and } \\
\text { Comparison } \\
\text { s (N of } \\
\text { Patients) }\end{array}$ & $\begin{array}{l}\text { Characteristics of Interventions } \\
\text { (Psychotherapy: Components, } \\
\text { Delivery Model)/Pharm: Drug) } \\
\text { Intensity, Duration (Weeks)) }\end{array}$ & $\begin{array}{c}\text { Patient Characteristics Mean } \\
\text { Age (Range), Male (\%), } \\
\text { Race/Ethnicity, Comorbidity, } \\
\text { Household Income, Parent } \\
\text { Education, Family } \\
\text { Dysfunction/Stressor, } \\
\text { Treatment Sequence, } \\
\text { Insurance, History of } \\
\text { Maltreatment) }\end{array}$ & $\begin{array}{c}\text { Length } \\
\text { of } \\
\text { Follow } \\
\text { up } \\
\text { (Weeks } \\
\text { ) }\end{array}$ \\
\hline & \multirow[t]{3}{*}{$\begin{array}{l}\text { Efficacy } \\
\text { Outpatient } \\
\text { Mental health } \\
\text { clinic }\end{array}$} & & & $\begin{array}{l}\text { Individual based } \\
\text { Exposure } \\
1 \text { session of } 3 \text { hours } \\
\text { Delivered by Masters level clinicians }\end{array}$ & $\begin{array}{l}\text { Other: } 4.5 \% \\
\text { Age range } 7-16 \text { years } \\
\text { Male: } 45.8 \%\end{array}$ & \\
\hline & & & $\begin{array}{l}\text { Control, } \\
(N=70)\end{array}$ & $\begin{array}{l}\text { Attention control or treatment as usual } \\
\text { Education support treatment } \\
1 \text { session of } 3 \text { hours } \\
\text { Delivered by Masters level clinicians }\end{array}$ & $\begin{array}{l}\text { Caucasian: } 90 \%, \\
\text { African American: } 2.5 \% \\
\text { Hispanic:: } 2 \% \\
\text { Other: } 4.5 \% \\
\text { Range } 7-16 \\
\text { Male: } 44.2 \%\end{array}$ & \\
\hline & & & $\begin{array}{l}\text { Control, }(\mathrm{N}= \\
41)\end{array}$ & Waitlisting or no treatment & $\begin{array}{l}\text { Age range } 7-16 \text { years } \\
\text { Male: } 46.3 \%\end{array}$ & \\
\hline \multirow[t]{2}{*}{$\begin{array}{l}\text { Pincus, } \\
2010^{107}\end{array}$} & \multirow[t]{2}{*}{$\begin{array}{l}\text { United States } \\
\text { RCT } \\
\text { Efficacy } \\
\text { Mental health } \\
\text { clinic }\end{array}$} & \multirow[t]{2}{*}{ PD } & $\begin{array}{l}\text { Child CBT, } \\
(\mathrm{N}=13)\end{array}$ & $\begin{array}{l}\text { Panic control treatment } \\
\text { Exposure } \\
\text { Relaxation } \\
\text { Cognitive problem solving } \\
\text { Individual-based } \\
\text { Delivered by psychologist } \\
11 \text { sessions over } 12 \text { weeks, } 50 \text { min }\end{array}$ & \multirow[t]{2}{*}{$\begin{array}{l}\text { Age mean (years): } 15.75 \\
\text { (range: } 14-17) \\
\text { Males: } 23 \% \\
\text { Caucasian: } 100 \% \\
\text { Mean income: } \$ 97,500 \text { (SD: } \\
\$ 65,486)\end{array}$} & \multirow[t]{2}{*}{26} \\
\hline & & & $\begin{array}{l}\text { Control, } \\
(\mathrm{N}=13)\end{array}$ & Attention control or treatment as usual & & \\
\hline \multirow[t]{2}{*}{$\begin{array}{l}\text { Reigada, } \\
2015^{108}\end{array}$} & \multirow[t]{2}{*}{$\begin{array}{l}\text { United States } \\
\text { RCT } \\
\text { Efficacy } \\
\text { Mental health } \\
\text { clinic }\end{array}$} & \multirow[t]{2}{*}{$\begin{array}{l}\text { GAD,PD with } \\
\text { agoraphobia, PD } \\
\text { without } \\
\text { agoraphobia, } \\
\text { SAD, SoP }\end{array}$} & $\begin{array}{l}\text { Child CBT } \\
\text { plus separate } \\
\text { parent } \\
\text { intervention, } \\
(\mathrm{N}=11)\end{array}$ & $\begin{array}{l}\text { TAPS } \\
\text { Individual based } \\
\text { Exposure } \\
\text { Relaxation } \\
\text { Cognitive problem solving } 15 \text { sessions; } \\
13 \text { 1-hour weekly sessions and } 2 \\
\text { boosters; parents received three 1-hr } \\
\text { sessions. } \\
\text { Delivered by doctoral psychologist }\end{array}$ & $\begin{array}{l}\text { Age mean (years): 13.65( } \\
\text { range: } 9-17) \\
\text { Caucasian: } 82 \%, \text { Other: } 18 \% \\
\text { Low income (Less than } \$ 30,000 \\
\text { ): } 10 \% \\
\text { Medium income (\$30,000- } \\
\$ 90,000): 20 \% \\
\text { High income (more than } \\
\$ 90,000): 70 \% \\
\text { Depression: } 18 \%\end{array}$ & \multirow[t]{2}{*}{13} \\
\hline & & & $\begin{array}{l}\text { Control, } \\
(\mathrm{N}=11)\end{array}$ & $\begin{array}{l}\text { Attention control or treatment as usual } \\
\text { Offered social and emotional support }\end{array}$ & $\begin{array}{l}\text { Age mean (years): } 13.65( \\
\text { range: } 9-17) \\
\text { Caucasian: } 55 \% \text {, African } \\
\text { American: } 9 \% \text {, Hispanic: } 18 \% \text {, }\end{array}$ & \\
\hline
\end{tabular}




\begin{tabular}{|c|c|c|c|c|c|c|}
\hline $\begin{array}{l}\text { Author, } \\
\text { Year }\end{array}$ & $\begin{array}{l}\text { Study Country, } \\
\text { Study Design, } \\
\text { Type of Study } \\
\text { (Efficacyl } \\
\text { Effectiveness), } \\
\text { Study Settings }\end{array}$ & $\begin{array}{c}\text { Type of } \\
\text { AnxietylSeverity } \\
\text { (CGI) }\end{array}$ & $\begin{array}{l}\text { Intervention } \\
\text { and } \\
\text { Comparison } \\
\text { s (N of } \\
\text { Patients) }\end{array}$ & $\begin{array}{l}\text { Characteristics of Interventions } \\
\text { (Psychotherapy: Components, } \\
\text { Delivery Model)/Pharm: Drug) } \\
\text { Intensity, Duration (Weeks)) }\end{array}$ & $\begin{array}{c}\text { Patient Characteristics Mean } \\
\text { Age (Range), Male (\%), } \\
\text { Race/Ethnicity, Comorbidity, } \\
\text { Household Income, Parent } \\
\text { Education, Family } \\
\text { Dysfunction/Stressor, } \\
\text { Treatment Sequence, } \\
\text { Insurance, History of } \\
\text { Maltreatment) }\end{array}$ & $\begin{array}{c}\text { Length } \\
\text { of } \\
\text { Follow } \\
\text { up } \\
\text { (Weeks } \\
\text { ) }\end{array}$ \\
\hline & & & & & $\begin{array}{l}\text { other : } 18 \% \\
\text { Low income (Less than } \$ 30,000 \\
\text { ): } 9 \% \\
\text { Medium income }(\$ 30,000- \\
\$ 90,000): 36 \% \\
\text { High income ( more than } \\
\$ 90,000): 55 \% \\
\text { Depression: } 27 \%\end{array}$ & \\
\hline \multirow[t]{3}{*}{ Ritter, $1968^{71}$} & \multirow[t]{3}{*}{$\begin{array}{l}\text { United States } \\
\text { RCT } \\
\text { Efficacy } \\
\text { Outpatient }\end{array}$} & \multirow[t]{3}{*}{$\mathrm{SP}$} & $\begin{array}{l}\text { Child CBT, } \\
(\mathrm{N}=7)\end{array}$ & $\begin{array}{l}\text { Other: Only contact desensitization } \\
\text { Child CBT- (parents included < 20\%) } \\
\text { Group based } \\
\text { Exposure } \\
2,35-\text { minute weekly sessions } \\
\text { Delivered by psychiatrist }\end{array}$ & \multirow[t]{3}{*}{ Age range: 5-11 years } & \multirow[t]{3}{*}{0} \\
\hline & & & $\begin{array}{l}\text { Control, } \\
(\mathrm{N}=8)\end{array}$ & $\begin{array}{l}\text { Attention control or treatment as usual } \\
\text { Only vicarious desensitization } \\
\text { Group based } \\
2,35 \text {-minute weekly sessions } \\
\text { Delivered by psychiatrist }\end{array}$ & & \\
\hline & & & $\begin{array}{l}\text { Control, } \\
(\mathrm{N}=7)\end{array}$ & Waitlisting or no treatment & & \\
\hline \multirow[t]{2}{*}{$\begin{array}{l}\text { Rosa- } \\
\text { Alcazar, } \\
2007^{109}\end{array}$} & \multirow[t]{2}{*}{$\begin{array}{l}\text { Spain } \\
\text { RCT } \\
\text { Efficacy } \\
\text { Schools }\end{array}$} & \multirow[t]{2}{*}{ SoP } & $\begin{array}{l}\text { Child CBT, } \\
(\mathrm{N}=12)\end{array}$ & $\begin{array}{l}\text { IAFS } \\
\text { Group based } \\
\text { Exposure } \\
\text { Cognitive problem solving } \\
\text { Delivered by practicing clinician, } \\
12 \text { weekly sessions for } 90 \text { minutes each }\end{array}$ & \multirow[t]{2}{*}{$\begin{array}{l}\text { Age mean (years) } 15 \\
\text { Male:29\% }\end{array}$} & \multirow[t]{2}{*}{26} \\
\hline & & & $\begin{array}{l}\text { Control, } \\
(\mathrm{N}=13)\end{array}$ & $\begin{array}{l}\text { Attention control or treatment as usual } \\
\text { Educational treatment, individual } \\
\text { treatment-based } \\
12 \text { weekly sessions for } 90 \text { minutes each }\end{array}$ & & \\
\hline $\begin{array}{l}\text { Rosa- } \\
\text { Alcazar, } \\
2009^{72}\end{array}$ & $\begin{array}{l}\text { Spain } \\
\text { RCT } \\
\text { Efficacy } \\
\text { schools }\end{array}$ & $\begin{array}{l}\text { GAD, PD without } \\
\text { agoraphobia, PD } \\
\text { (agoraphobia is } \\
\text { not specified) SP }\end{array}$ & $\begin{array}{l}\text { Child CBT, } \\
(\mathrm{N}=20)\end{array}$ & $\begin{array}{l}\text { IAFS } \\
\text { Child CBT- (parents included }<20 \% \text { ) } \\
\text { Group based } \\
\text { Exposure }\end{array}$ & $\begin{array}{l}\text { Age mean (years) } 15 \text { (Range } \\
14-17) \\
\text { Male:25\% }\end{array}$ & 52 \\
\hline
\end{tabular}




\begin{tabular}{|c|c|c|c|c|c|c|}
\hline $\begin{array}{l}\text { Author, } \\
\text { Year }\end{array}$ & $\begin{array}{c}\text { Study Country, } \\
\text { Study Design, } \\
\text { Type of Study } \\
\text { (Efficacyl } \\
\text { Effectiveness), } \\
\text { Study Settings }\end{array}$ & $\begin{array}{c}\text { Type of } \\
\text { Anxiety/Severity } \\
\text { (CGI) }\end{array}$ & $\begin{array}{l}\text { Intervention } \\
\text { and } \\
\text { Comparison } \\
\text { s (N of } \\
\text { Patients) }\end{array}$ & $\begin{array}{l}\text { Characteristics of Interventions } \\
\text { (Psychotherapy: Components, } \\
\text { Delivery Model)/Pharm: Drug) } \\
\text { Intensity, Duration (Weeks)) }\end{array}$ & $\begin{array}{c}\text { Patient Characteristics Mean } \\
\text { Age (Range), Male (\%), } \\
\text { Race/Ethnicity, Comorbidity, } \\
\text { Household Income, Parent } \\
\text { Education, Family } \\
\text { Dysfunction/Stressor, } \\
\text { Treatment Sequence, } \\
\text { Insurance, History of } \\
\text { Maltreatment) }\end{array}$ & $\begin{array}{c}\text { Length } \\
\text { of } \\
\text { Follow } \\
\text { up } \\
\text { (Weeks } \\
\text { ) }\end{array}$ \\
\hline & & & & $\begin{array}{l}\text { Cognitive problem solving } \\
1290-\text { minute weekly sessions } \\
\text { Delivered by practicing clinician }\end{array}$ & & \\
\hline & & & $\begin{array}{l}\text { Control, } \\
(\mathrm{N}=19)\end{array}$ & $\begin{array}{l}\text { Attention control or treatment as usual } \\
\text { Educational treatment on anxiety and } \\
\text { relaxation } \\
12 \text { 90-minute weekly sessions }\end{array}$ & $\begin{array}{l}\text { Age mean (years) } 14.94(14- \\
17) \\
\text { Male: } 31.5 \%\end{array}$ & \\
\hline & & & $\begin{array}{l}\text { Control, } \\
(\mathrm{N}=18)\end{array}$ & $\begin{array}{l}\text { Attention control or treatment as usual } \\
\text { Education as placebo } \\
12 \text { sessions of health education }\end{array}$ & $\begin{array}{l}\text { Age mean (years) } 14.75(14-17) \\
\text { Male: } 16.6 \%\end{array}$ & \\
\hline & & & $\begin{array}{l}\text { Control, } \\
(\mathrm{N}=20)\end{array}$ & Waitlisting or no treatment & $\begin{array}{l}\text { Age mean (years) } 14.77 \\
\text { Male: } 40 \%\end{array}$ & \\
\hline \multirow[t]{2}{*}{$\begin{array}{l}\text { Southam- } \\
\text { Gerow, } \\
2010^{110}\end{array}$} & \multirow[t]{2}{*}{$\begin{array}{l}\text { United States } \\
\text { RCT } \\
\text { Effectiveness } \\
\text { Mental health } \\
\text { clinic }\end{array}$} & \multirow[t]{2}{*}{$\begin{array}{l}\text { GAD, PD without } \\
\text { agoraphobia, } \\
\text { SAD, SoP, SP }\end{array}$} & $\begin{array}{l}\text { Child CBT, } \\
(\mathrm{N}=24)\end{array}$ & $\begin{array}{l}\text { Coping Cat } \\
\text { Child CBT- (parents included <20\%) } \\
\text { Individual based } \\
\text { Exposure } \\
\text { Relaxation } \\
\text { Cognitive problem solving } \\
14 \text { sessions, } 1 \text { hour sessions over } 12 \\
\text { weeks } \\
\text { Delivered by psychologist, Masters level } \\
\text { clinicians, social workers }\end{array}$ & \multirow{2}{*}{$\begin{array}{l}\text { Total population } \mathrm{N}=48 \\
\text { Age mean (years): } 10.9 \text { (range: } \\
\text { 8-15) } \\
\text { Males: } 44 \% \\
\text { Caucasian: } 48 \% \\
\text { African American: } 12.5 \% \\
\text { Hispanic: } 27 \% \\
\text { Other: } 10 \% \\
\text { Low income (<30,000): } 73 \% \\
\text { Medium income (30,000- } \\
\text { 90,000): } 16 \% \\
\text { High income (>90,000): } 10 \% \\
\text { ADHD: } 42 \% \\
\text { Depression: } 8 \% \\
\text { OCD:4.2\% } \\
\text { ODD:37.5\% } \\
\text { PTSD:6.25\% } \\
\text { Dysthymic disorder: } 2 \%\end{array}$} & \multirow[t]{2}{*}{0} \\
\hline & & & $\begin{array}{l}\text { Control, } \\
(\mathrm{N}=24)\end{array}$ & Attention control or treatment as usual & & \\
\hline Silk, $2016^{111}$ & $\begin{array}{l}\text { United States } \\
\text { RCT } \\
\text { Efficacy } \\
\text { Outpatient }\end{array}$ & GAD,SAD, SoP & $\begin{array}{l}\text { Child CBT, } \\
(\mathrm{N}=90)\end{array}$ & $\begin{array}{l}\text { Coping Cat } \\
\text { Individual-based } \\
\text { Exposure } \\
\text { Relaxation } \\
\text { Cognitive problem solving }\end{array}$ & $\begin{array}{l}\text { Age mean (years): } 10.94 \\
\text { Male: } 45 \% \\
\text { Caucasian: } 91 \% \text {, African } \\
\text { American :2\%, Hispanic: } 1 \% \text {, } \\
\text { Other: } 6 \%\end{array}$ & 52 \\
\hline
\end{tabular}




\begin{tabular}{|c|c|c|c|c|c|c|}
\hline \multirow[t]{3}{*}{$\begin{array}{l}\text { Author, } \\
\text { Year }\end{array}$} & $\begin{array}{l}\text { Study Country, } \\
\text { Study Design, } \\
\text { Type of Study } \\
\text { (Efficacyl } \\
\text { Effectiveness), } \\
\text { Study Settings }\end{array}$ & $\begin{array}{c}\text { Type of } \\
\text { Anxiety/Severity } \\
\text { (CGI) }\end{array}$ & $\begin{array}{l}\text { Intervention } \\
\text { and } \\
\text { Comparison } \\
\text { s (N of } \\
\text { Patients) }\end{array}$ & $\begin{array}{l}\text { Characteristics of Interventions } \\
\text { (Psychotherapy: Components, } \\
\text { Delivery Model)/Pharm: Drug) } \\
\text { Intensity, Duration (Weeks)) }\end{array}$ & $\begin{array}{c}\text { Patient Characteristics Mean } \\
\text { Age (Range), Male (\%), } \\
\text { Race/Ethnicity, Comorbidity, } \\
\text { Household Income, Parent } \\
\text { Education, Family } \\
\text { Dysfunction/Stressor, } \\
\text { Treatment Sequence, } \\
\text { Insurance, History of } \\
\text { Maltreatment) }\end{array}$ & $\begin{array}{c}\text { Length } \\
\text { of } \\
\text { Follow } \\
\text { up } \\
\text { (Weeks } \\
\text { ) }\end{array}$ \\
\hline & & & & One session per week for 16 week & Mean income: 94.155 & \\
\hline & & & $\begin{array}{l}\text { Control } \\
(\mathrm{N}=43)\end{array}$ & $\begin{array}{l}\text { Attention control or treatment as Usual } \\
\text { supportive child centered therapy (CCT) } \\
\text { One session per week for } 16 \text { week }\end{array}$ & $\begin{array}{l}\text { Age mean (years): } 10.98 \\
\text { Male: } 41 \% \\
\text { Caucasian: } 88 \% \text {, African } \\
\text { American :6\%, Hispanic: } 2 \% \text {, } \\
\text { Other:4\% } \\
\text { Mean income: } 78.632\end{array}$ & \\
\hline \multirow[t]{2}{*}{$\begin{array}{l}\text { Storch, } \\
2015^{112}\end{array}$} & \multirow[t]{2}{*}{$\begin{array}{l}\text { United States } \\
\text { RCT } \\
\text { Efficacy } \\
\text { Mental health } \\
\text { clinic }\end{array}$} & \multirow[t]{2}{*}{$\begin{array}{l}\text { GAD, PD, PD } \\
\text { with } \\
\text { agoraphobia, PD } \\
\text { without } \\
\text { agoraphobia, } \\
\text { SAD, SoP, SP } \\
\text { Mean CGI=3.45 }\end{array}$} & $\begin{array}{l}\text { Child CBT, } \\
(\mathrm{N}=49)\end{array}$ & $\begin{array}{l}\text { Camp Cope a Lot } \\
\text { Computerized CBT } \\
\text { Child CBT- (parents included }<20 \% \text { ) } \\
\text { Individual based } \\
\text { Exposure } \\
\text { Relaxation } \\
\text { Cognitive problem solving } \\
\text { Technology based } \\
1260 \text {-minute weekly sessions } \\
\text { Delivered by Masters level clinicians }\end{array}$ & $\begin{array}{l}\text { Age mean (years): } 9.4 \text { (range: } \\
7-13) \\
\text { Male: } 53.1 \% \\
\text { College graduate(parent): 51\% } \\
\text { Caucasian: } 77.6 \% \\
\text { Hispanic: } 10.2 \% \\
\text { African American: } 8.2 \% \\
\text { Low income (<\$40,000): 44.4\% } \\
\text { Medium income (\$40,000- } \\
\$ 90,000): 33.3 \% \\
\text { High income: (>\$90,000): } \\
22.2 \% \\
\text { OCD: } 4.1 \% \\
\text { PTSD: } 4.1 \% \\
\text { Depression: } 6.1 \% \\
\text { ADHD: } 34.2 \% \\
\text { ODD: } 6.1 \% \\
\text { Selective mutism: } 4.1 \% \\
\text { Enuresis: } 4.1 \%\end{array}$ & \multirow[t]{2}{*}{110} \\
\hline & & & $\begin{array}{l}\text { Control, } \\
(\mathrm{N}=51)\end{array}$ & Attention control or treatment as usual & $\begin{array}{l}\text { Age mean (years): } 10.2 \text { (range: } \\
7-13 \text { ) } \\
\text { Male: } 58.8 \% \\
\text { College graduate(parent): } 51 \% \\
\text { Caucasian: } 66.7 \% \\
\text { Hispanic: } 13.7 \% \\
\text { African American: } 13.7 \% \\
\text { Low income }(<\$ 40,000): 62.2 \% \\
\text { Medium income }(\$ 40,000-\end{array}$ & \\
\hline
\end{tabular}




\begin{tabular}{|c|c|c|c|c|c|c|}
\hline $\begin{array}{c}\text { Author, } \\
\text { Year }\end{array}$ & $\begin{array}{c}\text { Study Country, } \\
\text { Study Design, } \\
\text { Type of Study } \\
\text { (Efficacyl } \\
\text { Effectiveness), } \\
\text { Study Settings }\end{array}$ & $\begin{array}{c}\text { Type of } \\
\text { Anxiety/Severity } \\
\text { (CGI) }\end{array}$ & $\begin{array}{c}\text { Intervention } \\
\text { and } \\
\text { Comparison } \\
\text { s (N of } \\
\text { Patients) }\end{array}$ & $\begin{array}{l}\text { Characteristics of Interventions } \\
\text { (Psychotherapy: Components, } \\
\text { Delivery Model)/Pharm: Drug) } \\
\text { Intensity, Duration (Weeks)) }\end{array}$ & $\begin{array}{c}\text { Patient Characteristics Mean } \\
\text { Age (Range), Male (\%), } \\
\text { Race/Ethnicity, Comorbidity, } \\
\text { Household Income, Parent } \\
\text { Education, Family } \\
\text { Dysfunction/Stressor, } \\
\text { Treatment Sequence, } \\
\text { Insurance, History of } \\
\text { Maltreatment) } \\
\end{array}$ & $\begin{array}{c}\text { Length } \\
\text { of } \\
\text { Follow } \\
\text { up } \\
\text { (Weeks } \\
\text { ) }\end{array}$ \\
\hline & & & & & $\begin{array}{l}\text { \$90,000): } 20 \% \\
\text { High income: }(>\$ 90,000): 18 \% \\
\text { OCD: } 7.8 \% \\
\text { Dysthymia: } 5.9 \% \\
\text { Depression: } 5.9 \% \\
\text { ADHD: } 31.4 \% \\
\text { Conduct disorder: } 2 \% \\
\text { ODD: } 7.8 \% \\
\text { Selective mutism: } 5.9 \% \\
\text { Enuresis: } 4.1 \%\end{array}$ & \\
\hline \multirow[t]{2}{*}{$\begin{array}{l}\text { Storch, } \\
2013^{113}\end{array}$} & \multirow[t]{2}{*}{$\begin{array}{l}\text { United States } \\
\text { RCT } \\
\text { Efficacy } \\
\text { Outpatient }\end{array}$} & \multirow[t]{2}{*}{$\begin{array}{l}\text { GAD,SAD, } \\
\text { SoP,SP }\end{array}$} & $\begin{array}{l}\text { Child CBT } \\
\text { plus separate } \\
\text { parent } \\
\text { intervention, } \\
(\mathrm{N}=24)\end{array}$ & $\begin{array}{l}\text { Other: Behavioral interventions for } \\
\text { anxiety in children with autism (BIACA) } \\
\text { program } \\
\text { Individual based } \\
\text { Exposure } \\
\text { Relaxation } \\
\text { Cognitive problem solving } \\
1660-90 \text { minute weekly sessions over } \\
12 \text { weeks } \\
\text { Delivered by psychologist, } \\
\text { student/trainee }\end{array}$ & $\begin{array}{l}\text { Age mean (years): } 8.83 \text { (range: } \\
\text { 7-11) } \\
\text { Male: } 79 \% \\
\text { Caucasian: } 92 \% \\
\text { Hispanic: } 4 \% \\
\text { Asian: } 4 \% \\
\text { Low income (<\$40,000): 4\% } \\
\text { Medium income }(\$ 40,000- \\
\text { \$90,000):25\% } \\
\text { High income: }(>\$ 90,000): 71 \% \\
\text { ADHD: } 71 \% \\
\text { Depression: } 4 \% \\
\text { Autism: } 100 \% \\
\text { OCD: } 46 \% \\
\text { ODD: } 37.5 \%\end{array}$ & \multirow[t]{2}{*}{13} \\
\hline & & & $\begin{array}{l}\text { Control, } \\
(\mathrm{N}=21)\end{array}$ & Attention control or treatment as usual & $\begin{array}{l}\text { Age mean (years): } 8.89 \text { (range: } \\
\text { 7-11) } \\
\text { Males: } 81 \% \\
\text { Caucasian: } 76 \% \\
\text { Hispanic: } 19 \% \\
\text { Asian: } 5 \% \\
\text { ADHD: } 76 \% \\
\text { Depression: } 9 \% \\
\text { Autism: } 100 \% \\
\text { OCD: } 62 \% \\
\end{array}$ & \\
\hline
\end{tabular}




\begin{tabular}{|c|c|c|c|c|c|c|}
\hline $\begin{array}{l}\text { Author, } \\
\text { Year }\end{array}$ & $\begin{array}{l}\text { Study Country, } \\
\text { Study Design, } \\
\text { Type of Study } \\
\text { (Efficacyl } \\
\text { Effectiveness), } \\
\text { Study Settings }\end{array}$ & $\begin{array}{c}\text { Type of } \\
\text { Anxiety/Severity } \\
\text { (CGI) }\end{array}$ & $\begin{array}{l}\text { Intervention } \\
\text { and } \\
\text { Comparison } \\
\text { s (N of } \\
\text { Patients) }\end{array}$ & $\begin{array}{l}\text { Characteristics of Interventions } \\
\text { (Psychotherapy: Components, } \\
\text { Delivery Model)/Pharm: Drug) } \\
\text { Intensity, Duration (Weeks)) }\end{array}$ & $\begin{array}{c}\text { Patient Characteristics Mean } \\
\text { Age (Range), Male (\%), } \\
\text { Race/Ethnicity, Comorbidity, } \\
\text { Household Income, Parent } \\
\text { Education, Family } \\
\text { Dysfunction/Stressor, } \\
\text { Treatment Sequence, } \\
\text { Insurance, History of } \\
\text { Maltreatment) }\end{array}$ & $\begin{array}{l}\text { Length } \\
\text { of } \\
\text { Follow } \\
\text { up } \\
\text { (Weeks } \\
\text { ) }\end{array}$ \\
\hline & & & & & $\begin{array}{l}\text { ODD: } 52 \% \\
\text { Low income }(<\$ 40,000): 14 \% \\
\text { Medium income }(\$ 40,000- \\
\$ 90,000): 28 \% \\
\text { High income: }(>\$ 90,000): 52 \%\end{array}$ & \\
\hline \multirow[t]{3}{*}{$\begin{array}{l}\text { Suveg, } \\
2009^{114}\end{array}$} & \multirow[t]{3}{*}{$\begin{array}{l}\text { United States } \\
\text { RCT } \\
\text { Outpatient }\end{array}$} & \multirow[t]{3}{*}{$\begin{array}{l}\text { GAD, SAD, SoP, } \\
\text { SP }\end{array}$} & $\begin{array}{l}\text { Child CBT, } \\
(\mathrm{N}=55)\end{array}$ & $\begin{array}{l}\text { Coping Cat } \\
\text { Exposure } \\
\text { Relaxation } \\
\text { Cognitive problem solving } \\
\text { Individual based } \\
\text { Delivered by psychologist, Masters level } \\
\text { clinician } \\
16,60 \text { min weekly sessions }\end{array}$ & \multirow[t]{3}{*}{$\begin{array}{l}\text { Age range: } 7-14 \text { years } \\
\text { ADHD: } 32 \% \\
\text { Depression: } 11 \% \\
\text { ODD: } 14 \% \\
\text { Conduct disorder: } 1 \%\end{array}$} & \multirow[t]{3}{*}{52} \\
\hline & & & $\begin{array}{l}\text { Child and } \\
\text { parent } \\
\text { together CBT, } \\
(\mathrm{N}=56)\end{array}$ & $\begin{array}{l}\text { Coping Cat } \\
\text { Exposure } \\
\text { Relaxation } \\
\text { Cognitive problem solving } \\
\text { Individual based } \\
\text { Delivered by psychologist, Masters level } \\
\text { clinician } \\
16,60 \text { min weekly }\end{array}$ & & \\
\hline & & & $\begin{array}{l}\text { Control, } \\
(\mathrm{N}=50)\end{array}$ & $\begin{array}{l}\text { Attention control or treatment as usual } \\
\text { Weekly for } 16 \text { weeks }\end{array}$ & & \\
\hline \multirow[t]{3}{*}{$\begin{array}{l}\text { Valles- } \\
\text { Arandiga, } \\
2014^{84}\end{array}$} & \multirow[t]{3}{*}{$\begin{array}{l}\text { Spain } \\
\text { RCT } \\
\text { Efficacy } \\
\text { Schools }\end{array}$} & \multirow[t]{3}{*}{ SoP } & $\begin{array}{l}\text { Child CBT, } \\
(\mathrm{N}=17)\end{array}$ & $\begin{array}{l}\text { IAFS } \\
\text { Child CBT- (parents included <20\%) } \\
\text { Group based } \\
1290-\text { minute weekly sessions } \\
\text { Delivered by therapist }\end{array}$ & \multirow[t]{3}{*}{$\begin{array}{l}\text { Age mean (years): } 14.9 \text { (range: } \\
\text { 14-16) } \\
\text { Males:25\% }\end{array}$} & \multirow[t]{3}{*}{26} \\
\hline & & & $\begin{array}{l}\text { Control, } \\
(\mathrm{N}=17)\end{array}$ & $\begin{array}{l}\text { Attention control or treatment as usual } \\
\text { Education Support } \\
\text { Individual based } \\
12 \text { 90-minute weekly sessions }\end{array}$ & & \\
\hline & & & $\begin{array}{l}\text { Control, } \\
(\mathrm{N}=17)\end{array}$ & Waitlisting or no treatment & & \\
\hline
\end{tabular}




\begin{tabular}{|c|c|c|c|c|c|c|}
\hline $\begin{array}{l}\text { Author, } \\
\text { Year }\end{array}$ & $\begin{array}{l}\text { Study Country, } \\
\text { Study Design, } \\
\text { Type of Study } \\
\text { (Efficacyl } \\
\text { Effectiveness), } \\
\text { Study Settings }\end{array}$ & $\begin{array}{c}\text { Type of } \\
\text { AnxietylSeverity } \\
\text { (CGI) }\end{array}$ & $\begin{array}{l}\text { Intervention } \\
\text { and } \\
\text { Comparison } \\
\text { s (N of } \\
\text { Patients) }\end{array}$ & $\begin{array}{l}\text { Characteristics of Interventions } \\
\text { (Psychotherapy: Components, } \\
\text { Delivery Model)/Pharm: Drug) } \\
\text { Intensity, Duration (Weeks)) }\end{array}$ & $\begin{array}{c}\text { Patient Characteristics Mean } \\
\text { Age (Range), Male (\%), } \\
\text { Race/Ethnicity, Comorbidity, } \\
\text { Household Income, Parent } \\
\text { Education, Family } \\
\text { Dysfunction/Stressor, } \\
\text { Treatment Sequence, } \\
\text { Insurance, History of } \\
\text { Maltreatment) } \\
\end{array}$ & $\begin{array}{l}\text { Length } \\
\text { of } \\
\text { Follow } \\
\text { up } \\
\text { (Weeks } \\
\text { ) }\end{array}$ \\
\hline \multirow[t]{3}{*}{$\begin{array}{l}\text { Van } \\
\text { Steensel, } \\
2014^{115}\end{array}$} & \multirow[t]{3}{*}{$\begin{array}{l}\text { Netherlands } \\
\text { RCT } \\
\text { Effectiveness } \\
\text { Outpatient }\end{array}$} & \multirow[t]{3}{*}{$\begin{array}{l}\text { GAD, SAD, SoP, } \\
\text { SP }\end{array}$} & $\begin{array}{l}\text { Child and } \\
\text { parent } \\
\text { together } \mathrm{CBT} \text {, } \\
(\mathrm{N}=24)\end{array}$ & $\begin{array}{l}\text { Discussing plus doing } \\
\text { Individual based } \\
15 \text { sessions over } 3 \text { months }\end{array}$ & $\begin{array}{l}\text { Age mean (years): } 11 \text { (range:8- } \\
\text { 18) } \\
\text { Males: } 83.3 \% \\
\text { Autism: } 100 \%\end{array}$ & \multirow[t]{3}{*}{26} \\
\hline & & & $\begin{array}{l}\text { Control, } \\
(\mathrm{N}=25)\end{array}$ & Attention control or treatment as usual & $\begin{array}{l}\text { Age mean (years): } 10.72 \\
\text { (range:8-18) } \\
\text { Males: } 80 \% \\
\text { Autism: } 100 \%\end{array}$ & \\
\hline & & & $\begin{array}{l}\text { Pill Placebo, } \\
(\mathrm{N}=76)\end{array}$ & Pill placebo & $\begin{array}{l}\text { Age mean (years): } 10.6 \\
\text { Male : } 51.3 \% \\
\text { Caucasian: } 79 \% \text {, African } \\
\text { American: } 9 \% \text {, Hispanic: } 9 \% \text {, } \\
\text { other: } 3 \% \\
\text { Low income: } 27.6 \% \\
\text { ADHD: } 118 \%, \text { ODD:9.2\%, Tic } \\
\text { disorder and other internalizing } \\
\text { disorders: } 44.7 \%\end{array}$ & \\
\hline \multirow[t]{3}{*}{$\begin{array}{l}\text { Warner, } \\
2016^{116}\end{array}$} & \multirow[t]{3}{*}{$\begin{array}{l}\text { United States } \\
\text { RCT } \\
\text { Efficacy } \\
\text { Outpatient }\end{array}$} & \multirow[t]{3}{*}{$\begin{array}{l}\text { GAD, PD, SAD, } \\
\text { SP, SoP }\end{array}$} & $\begin{array}{l}\text { Child CBT, } \\
(\mathrm{N}=46)\end{array}$ & $\begin{array}{l}\text { SASS: Group-based, exposure, } \\
\text { cognitive problem solving } \\
\text { (Skills for academic and social success } \\
\text { provided by psychologists) } \\
\text { Delivered by doctoral level psychologist } \\
12 \text { in school group sessions ( ranged } \\
\text { from } 50-90 \text { mints) }\end{array}$ & $\begin{array}{l}\text { Age mean (years): } 15.5 \\
\text { Male: } 30.4 \% \\
\text { Caucasian: } 74 \% \text {, African } \\
\text { American }: 4 \%, \text { Hispanic: } 4 \% \text {, } \\
\text { Asian: } 12 \%, \text { Other: } 4 \% \\
\text { Mean income: } 94.155\end{array}$ & \multirow[t]{3}{*}{20} \\
\hline & & & $\begin{array}{l}\text { Child CBT, } \\
(\mathrm{N}=47)\end{array}$ & $\begin{array}{l}\text { SASS: Group-based, exposure, } \\
\text { cognitive problem solving } \\
\text { Delivered by doctoral level psychologist } \\
12 \text { in school group sessions ( ranged } \\
\text { from } 50-90 \text { mints) }\end{array}$ & $\begin{array}{l}\text { Age mean (years): } 15.34 \\
\text { Male: } 29.7 \% \\
\text { Caucasian: } 75 \% \text {, African } \\
\text { American :8\%, Hispanic: } 5 \% \text {, } \\
\text { Asian: } 6 \%, \text { Other: } 6 \%\end{array}$ & \\
\hline & & & $\begin{array}{l}\text { Control, } \\
(\mathrm{N}=43)\end{array}$ & $\begin{array}{l}\text { Attention control or treatment as usual } \\
\text { Relaxation } \\
\text { Cognitive problem solving. }\end{array}$ & $\begin{array}{l}\text { Age mean (years): } 15.37 \\
\text { Male: } 37 \% \\
\text { Caucasian: } 67 \% \text {, African }\end{array}$ & \\
\hline
\end{tabular}




\begin{tabular}{|c|c|c|c|c|c|c|}
\hline $\begin{array}{l}\text { Author, } \\
\text { Year }\end{array}$ & $\begin{array}{c}\text { Study Country, } \\
\text { Study Design, } \\
\text { Type of Study } \\
\text { (Efficacyl } \\
\text { Effectiveness), } \\
\text { Study Settings }\end{array}$ & $\begin{array}{c}\text { Type of } \\
\text { Anxiety/Severity } \\
\text { (CGI) }\end{array}$ & $\begin{array}{c}\text { Intervention } \\
\text { and } \\
\text { Comparison } \\
\text { s (N of } \\
\text { Patients) }\end{array}$ & $\begin{array}{l}\text { Characteristics of Interventions } \\
\text { (Psychotherapy: Components, } \\
\text { Delivery Model)/Pharm: Drug) } \\
\text { Intensity, Duration (Weeks)) }\end{array}$ & $\begin{array}{c}\text { Patient Characteristics Mean } \\
\text { Age (Range), Male (\%), } \\
\text { Race/Ethnicity, Comorbidity, } \\
\text { Household Income, Parent } \\
\text { Education, Family } \\
\text { Dysfunction/Stressor, } \\
\text { Treatment Sequence, } \\
\text { Insurance, History of } \\
\text { Maltreatment) }\end{array}$ & $\begin{array}{c}\text { Length } \\
\text { of } \\
\text { Follow } \\
\text { up } \\
\text { (Weeks } \\
\text { ) }\end{array}$ \\
\hline & & & & $\begin{array}{l}\text { A nonspecific counseling program, } \\
\text { SFL, controlled for the attention and } \\
\text { group involvement. }\end{array}$ & $\begin{array}{l}\text { American :2\%, Hispanic: } 14 \%, \\
\text { Asian: } 7 \% \text {, Other: } 9 \%\end{array}$ & \\
\hline \multirow[t]{2}{*}{ Yen, $2014^{117}$} & \multirow[t]{2}{*}{$\begin{array}{l}\text { Taiwan } \\
\text { Non- } \\
\text { Randomized } \\
\text { comparative } \\
\text { studies } \\
\text { Efficacy } \\
\text { Outpatient }\end{array}$} & \multirow[t]{2}{*}{ GAD, SAD, SoP } & $\begin{array}{l}\text { Child CBT, } \\
(\mathrm{N}=30)\end{array}$ & $\begin{array}{l}\text { Coping cat } \\
\text { Child CBT- (parents included <20\%) } \\
\text { Individual based } \\
\text { Exposure } \\
\text { Relaxation } \\
\text { Cognitive problem solving } \\
17 \text { weekly sessions } \\
\text { Delivered by Psychologist }\end{array}$ & $\begin{array}{l}\text { Age mean (years): } 9.1 \text { (range: } \\
7-12) \backslash \\
\text { Males: } 40 \%\end{array}$ & \multirow[t]{2}{*}{0} \\
\hline & & & $\begin{array}{l}\text { Control, } \\
(\mathrm{N}=32)\end{array}$ & Attention control or treatment as usual & $\begin{array}{l}\text { Age mean (years): } 9.5 \text { (range: } \\
7-12 \text { ) } \\
\text { Males: } 38 \%\end{array}$ & \\
\hline
\end{tabular}

ADHD: attention deficit hyperactivity disorder, CC: coping cat, CCC: child centered therapy, IAFS: intervencion en adolescents con fobia social (treatment for adolescents with social phobia), CBT: cognitive behavioral therapy, CGI: clinical global impression scale, GAD: generalized anxiety disorder, NR: not reported, OCD: obsessive compulsive disorder, ODD: oppositional defiant disorder, PD: panic disorder, PTSD: post-traumatic stress disorder, RCT: randomized controlled trial, SAD: separation anxiety disorder, SASS: skills for academic social success, SET-C: social effectiveness therapy, SFL: skills for life, SoP: social anxiety, SP: specific phobia, SSRI: selective serotonin reuptake inhibitor. TAPS: treatment of anxiety and physical symptoms. 
Table E.7. Characteristics of studies evaluating combination of CBT with drugs versus CBT

\begin{tabular}{|c|c|c|c|c|c|c|}
\hline Author, Year & $\begin{array}{l}\text { Study Country, } \\
\text { Study Design, } \\
\text { Type of Study } \\
\text { (Efficacyl } \\
\text { Effectiveness), } \\
\text { Study Settings }\end{array}$ & $\begin{array}{c}\text { Type of } \\
\text { Anxiety/Severity } \\
\text { (CGI) }\end{array}$ & $\begin{array}{l}\text { Intervention } \\
\text { and } \\
\text { Comparison } \\
\mathrm{s} \text { (N of } \\
\text { Patients) }\end{array}$ & $\begin{array}{l}\text { Characteristics of Interventions } \\
\text { (Psychotherapy: Components, } \\
\text { Delivery Model)/Pharm: Drug) } \\
\text { Intensity, Duration (Weeks)) }\end{array}$ & $\begin{array}{c}\text { Patient Characteristics Mean Age } \\
\text { (Range), Male (\%), Race/Ethnicity, } \\
\text { Comorbidity, Household Income, } \\
\text { Parent Education, Family } \\
\text { Dysfunction/Stressor, Treatment } \\
\text { Sequence, Insurance, History of } \\
\text { Maltreatment) }\end{array}$ & $\begin{array}{l}\text { Length } \\
\text { of } \\
\text { Follow } \\
\text { up } \\
\text { (Weeks) }\end{array}$ \\
\hline \multirow[t]{2}{*}{$\begin{array}{l}\text { Bernstein, } \\
2000^{118}\end{array}$} & \multirow[t]{2}{*}{$\begin{array}{l}\text { United States } \\
\text { RCT } \\
\text { Outpatient }\end{array}$} & \multirow[t]{2}{*}{ SP } & $\begin{array}{l}\text { Combination } \\
\text { therapy: } \\
\text { CBT+ } \\
\text { Other } \\
\text { Medication: } \\
\text { imipramine+ } \\
\text { child CBT, } \\
(\mathrm{N}=31)\end{array}$ & $\begin{array}{l}\text { Generic CBT } \\
\text { CBT protocol for school refusal, but } \\
\text { each subject had an anxiety disorder } \\
\text { Exposure } \\
\text { Individual-based } \\
8,45 \text { to } 60 \text { min weekly sessions } \\
25 \mathrm{mg} \text { bid. Delivered by } 2 \text { doctoral } \\
\text { level psychologists a Masters level } \\
\text { clinician }\end{array}$ & \multirow[t]{2}{*}{$\begin{array}{l}\text { Age mean (years); } 13.9 \\
\text { Male: } 39.6 \% \\
\text { Caucasian: } 90 \% \\
\text { African Americans: } 7.9 \% \\
\text { Hispanic: } 1.5 \%\end{array}$} & \\
\hline & & & $\begin{array}{l}\text { Combination } \\
\text { therapy } \\
\text { Placebo Pill } \\
\text { plus child } \\
\text { CBT, }(N=31)\end{array}$ & $\begin{array}{l}\text { Generic CBT } \\
\text { CBT protocol for school refusal, but } \\
\text { each subject had an anxiety disorder } \\
\text { Exposure, Individual-based } \\
8,45 \text { to } 60 \text { min weekly sessions } \\
\text { level psychologists a Masters level } \\
\text { clinician. }\end{array}$ & & \\
\hline \multirow[t]{2}{*}{$\begin{array}{l}\text { Eichstedt, } \\
2011^{119}\end{array}$} & \multirow[t]{2}{*}{$\begin{array}{l}\text { Canada } \\
\text { Non } \\
\text { randomized } \\
\text { comparative } \\
\text { study } \\
\text { Mental health } \\
\text { clinic }\end{array}$} & \multirow[t]{2}{*}{$\begin{array}{l}\text { GAD, SAD, SoP, } \\
\text { SP }\end{array}$} & $\begin{array}{l}\text { Therapy only } \\
\text { Child CBT } \\
\text { plus separate } \\
\text { parent } \\
\text { intervention, } \\
(\mathrm{N}=35)\end{array}$ & $\begin{array}{l}\text { Worry warriors program } \\
\text { Exposure } \\
\text { Relaxation } \\
\text { Cognitive problem solving } \\
\text { Group-based } \\
\text { Delivered by psychologist, } \\
\text { student/trainee, nurse } \\
\text { Weekly } 1.5 \text { hr sessions for } 12 \text { weeks }\end{array}$ & $\begin{array}{l}\text { Age mean (years): } 10.49 \text { (range 8-13) } \\
\text { Males: } 46 \%\end{array}$ & \multirow[t]{2}{*}{182} \\
\hline & & & $\begin{array}{l}\text { Combination } \\
\text { therapy: } \\
\text { CBT+ SSRI: } \\
\text { Child CBT } \\
\text { plus separate } \\
\text { parent } \\
\text { intervention } \\
\text { various SSRI } \\
(\mathrm{N}=13)\end{array}$ & $\begin{array}{l}\text { Worry warriors program } \\
\text { Exposure } \\
\text { Relaxation } \\
\text { Cognitive problem solving } \\
\text { Group-based } \\
\text { Delivered by psychologist, } \\
\text { student/trainee, nurse } \\
\text { Weekly } 1.5 \mathrm{hr} \text { sessions for } 12 \text { weeks }\end{array}$ & $\begin{array}{l}\text { Age mean (years): } 10.21 \text { (range 8-13) } \\
\text { Males: } 92 \%\end{array}$ & \\
\hline
\end{tabular}




\begin{tabular}{|c|c|c|c|c|c|c|}
\hline Author, Year & $\begin{array}{l}\text { Study Country, } \\
\text { Study Design, } \\
\text { Type of Study } \\
\text { (Efficacyl } \\
\text { Effectiveness), } \\
\text { Study Settings }\end{array}$ & $\begin{array}{c}\text { Type of } \\
\text { AnxietylSeverity } \\
\text { (CGI) }\end{array}$ & $\begin{array}{l}\text { Intervention } \\
\text { and } \\
\text { Comparison } \\
\text { s (N of } \\
\text { Patients) }\end{array}$ & $\begin{array}{l}\text { Characteristics of Interventions } \\
\text { (Psychotherapy: Components, } \\
\text { Delivery Model)/Pharm: Drug) } \\
\text { Intensity, Duration (Weeks)) }\end{array}$ & $\begin{array}{c}\text { Patient Characteristics Mean Age } \\
\text { (Range), Male (\%), Race/Ethnicity, } \\
\text { Comorbidity, Household Income, } \\
\text { Parent Education, Family } \\
\text { Dysfunction/Stressor, Treatment } \\
\text { Sequence, Insurance, History of } \\
\text { Maltreatment) }\end{array}$ & $\begin{array}{l}\text { Length } \\
\text { of } \\
\text { Follow } \\
\text { up } \\
\text { (Weeks) }\end{array}$ \\
\hline \multirow[t]{2}{*}{ Klein, $1992^{120}$} & \multirow[t]{2}{*}{$\begin{array}{l}\text { United States } \\
\text { RCT } \\
\text { Efficacy } \\
\text { Mental health } \\
\text { clinic }\end{array}$} & \multirow[t]{2}{*}{ SAD } & $\begin{array}{l}\text { Other } \\
\text { Medication+ } \\
\text { therapy: } \\
\text { Imipramine } \\
\text { plus child } \\
\text { CBT, }(\mathrm{N}=11)\end{array}$ & $\begin{array}{l}\text { Other Medication+ Imipramine } \\
\text { Exposure, cognitive problem solving } \\
\text { max of } 5 \mathrm{mg} / \mathrm{kg} / \text { day plus weekly } \\
\text { therapy session for } 6 \text { weeks }\end{array}$ & \multirow[t]{2}{*}{$\begin{array}{l}\text { Age mean (years): } 9.5 \text { (range:6-15) } \\
\text { Male: } 67 \% \\
\text { Caucasian: } 100 \%\end{array}$} & \multirow[t]{2}{*}{0} \\
\hline & & & $\begin{array}{l}\text { Placebo Pill+ } \\
\text { Child CBT, } \\
(\mathrm{N}=10)\end{array}$ & $\begin{array}{l}\text { Placebo plus exposure, cognitive } \\
\text { problem solving } \\
\text { max of } 5 \mathrm{mg} / \mathrm{kg} / \text { day plus weekly } \\
\text { therapy session for } 6 \text { weeks }\end{array}$ & & \\
\hline \multirow[t]{3}{*}{$\begin{array}{l}\text { Melvin, } \\
2016^{121}\end{array}$} & \multirow[t]{3}{*}{$\begin{array}{l}\text { Australia } \\
\text { RCT } \\
\text { Efficacy } \\
\text { Mental health } \\
\text { clinic }\end{array}$} & \multirow[t]{3}{*}{$\begin{array}{l}\text { GAD } \\
\text { SAD } \\
\text { SoP }\end{array}$} & $\begin{array}{l}\text { Child CBT } \\
\text { plus separate } \\
\text { parent } \\
\text { intervention } \\
:(\mathrm{N}=20)\end{array}$ & $\begin{array}{l}\text { Other Therapy } \\
\text { Exposure } \\
\text { Relaxation } \\
\text { Cognitive problem solving } \\
\text { Individual based } \\
\text { Psychologist, Masters level clinician } \\
\text { and student/trainee } \\
24,50-60 \text { min sessions, bi weekly } \\
\text { and then weekly }\end{array}$ & $\begin{array}{l}\text { Age mean (years): } 14 \text { (Range: } 11- \\
\text { 16.5) } \\
\text { Males: } 50 \% \\
\text { Caucasian: } 94 \% \\
\text { Asian: } 6 \%\end{array}$ & \multirow[t]{3}{*}{52} \\
\hline & & & $\begin{array}{l}\text { Child CBT } \\
\text { plus separate } \\
\text { parent } \\
\text { intervention } \\
\text { + pill } \\
\text { placebo: } \\
(\mathrm{N}=21)\end{array}$ & $\begin{array}{l}\text { Other Therapy + Pill Placebo } \\
\text { Exposure } \\
\text { Relaxation } \\
\text { Cognitive problem solving } \\
\text { Individual based } \\
\text { Psychologist, Masters level clinician } \\
\text { and Student/trainee } \\
24,50-60 \text { min sessions, bi weekly } \\
\text { and then weekly }\end{array}$ & $\begin{array}{l}\text { Age mean (years): } 13.4 \text { (Range:11- } \\
\text { 16.5) } \\
\text { Males: } 48 \% \\
\text { Caucasian: } 94 \% \\
\text { Asian: } 6 \%\end{array}$ & \\
\hline & & & $\begin{array}{l}\text { Child CBT } \\
\text { plus separate } \\
\text { parent } \\
\text { intervention } \\
\text { plus } \\
\text { Fluoxetine } \\
:(\mathrm{N}=21)\end{array}$ & $\begin{array}{l}\text { Other Therapy + SSRI: Fluoxetine } \\
\text { Exposure } \\
\text { Relaxation } \\
\text { Cognitive problem solving } \\
\text { Individual based } \\
\text { Psychologist, Masters level clinician } \\
\text { and student/trainee } \\
24,50-60 \text { min sessions, bi weekly } \\
\text { and then weekly }\end{array}$ & $\begin{array}{l}\text { Age mean (years): } 13.3 \text { (Range:11- } \\
\text { 16.5) } \\
\text { Males: } 66 \% \\
\text { Caucasian: } 94 \% \\
\text { Asian: } 6 \%\end{array}$ & \\
\hline
\end{tabular}




\begin{tabular}{|c|c|c|c|c|c|c|}
\hline Author, Year & $\begin{array}{c}\text { Study Country, } \\
\text { Study Design, } \\
\text { Type of Study } \\
\text { (Efficacyl } \\
\text { Effectiveness), } \\
\text { Study Settings }\end{array}$ & $\begin{array}{c}\text { Type of } \\
\text { AnxietylSeverity } \\
\text { (CGI) }\end{array}$ & $\begin{array}{c}\text { Intervention } \\
\text { and } \\
\text { Comparison } \\
\text { s (N of } \\
\text { Patients) }\end{array}$ & $\begin{array}{l}\text { Characteristics of Interventions } \\
\text { (Psychotherapy: Components, } \\
\text { Delivery Model)/Pharm: Drug) } \\
\text { Intensity, Duration (Weeks)) }\end{array}$ & $\begin{array}{c}\text { Patient Characteristics Mean Age } \\
\text { (Range), Male (\%), Race/Ethnicity, } \\
\text { Comorbidity, Household Income, } \\
\text { Parent Education, Family } \\
\text { Dysfunction/Stressor, Treatment } \\
\text { Sequence, Insurance, History of } \\
\text { Maltreatment) }\end{array}$ & $\begin{array}{l}\text { Length } \\
\text { of } \\
\text { Follow } \\
\text { up } \\
\text { (Weeks) }\end{array}$ \\
\hline \multirow[t]{4}{*}{$\begin{array}{l}\text { Walkup, } \\
2008^{20-26}\end{array}$} & \multirow[t]{4}{*}{$\begin{array}{l}\text { United States } \\
\text { RCT } \\
\text { Efficacy } \\
\text { Outpatient }\end{array}$} & \multirow[t]{4}{*}{ GAD,SAD, SoP } & $\begin{array}{l}\text { Child CBT, } \\
(\mathrm{N}=139)\end{array}$ & $\begin{array}{l}\text { Coping Cat } \\
\text { Child CBT (parents included <20\%) } \\
\text { Individual-based. } \\
\text { Exposure } \\
\text { Relaxation } \\
\text { Cognitive problem solving. } \\
60 \text {-minute session once a week for } \\
12 \text { weeks. }\end{array}$ & $\begin{array}{l}\text { Age mean (years): } 10.5 \\
\text { Male: } 49.2 \% \\
\text { Caucasian: } 76.3 \% \text {, African } \\
\text { American:10.1\%, Hispanic: } 9.2 \% \text {, } \\
\text { other: } 4.5 \% \\
\text { Low income: } 23.7 \% \\
\text { ADHD: } 11.5 \%, \text { ODD:13.8\%, Tic } \\
\text { disorder and other internalizing } \\
\text { disorders: } 41.7 \%\end{array}$ & \multirow[t]{4}{*}{0} \\
\hline & & & $\begin{array}{l}\text { SSRI: } \\
\text { Sertraline, } \\
(N=133)\end{array}$ & $\begin{array}{l}\text { Beginning with } 25 \mathrm{mg} / \text { day Up to } 200 \\
\text { mg/day by } 8^{\text {th }} \text { week, for } 12 \text { weeks. }\end{array}$ & $\begin{array}{l}\text { Age mean (years): } 10.8 \\
\text { Male: } 51.1 \% \\
\text { Caucasian: } 77.4 \% \text {, African American: } \\
\text { 9\%, Hispanic: } 11.3 \% \text {, other: } 2.3 \% \\
\text { Low income: } 26.3 \% \\
\text { ADHD: } 12.7 \%, \text { ODD:8.2\%, Tic } \\
\text { disorder and other internalizing } \\
\text { disorders: } 55.6 \%\end{array}$ & \\
\hline & & & $\begin{array}{l}\text { Combination } \\
\text { therapy: } \\
\text { CBT+ SSRI: } \\
\text { Child CBT+ } \\
\text { Sertraline, } \\
(\mathrm{N}=140)\end{array}$ & $\begin{array}{l}\text { Coping Cat, } \\
\text { Child CBT (parents included <20\%) } \\
\text { Individual-based } \\
\text { Exposure, relaxation and cognitive } \\
\text { problem solving plus Sertraline. } \\
60 \text {-minute session once a week for } \\
12 \text { weeks plus up to } 200 \text { mg/day for } \\
12 \text { weeks. }\end{array}$ & $\begin{array}{l}\text { Age mean (years): } 10.7 \\
\text { Male: } 49.6 \% \\
\text { Caucasian: } 82.9 \% \text {, African American: } \\
\text { 7.9\%, Hispanic: } 5.6 \% \text {, other: } 3.6 \% \\
\text { Low income: } 25.0 \% \\
\text { ADHD: } 11.4 \%, \text { ODD:10\%, Tic } \\
\text { disorder and other internalizing } \\
\text { disorders: } 42.8 \%\end{array}$ & \\
\hline & & & $\begin{array}{l}\text { Control, } \\
(\mathrm{N}=76)\end{array}$ & Pill placebo & $\begin{array}{l}\text { Age mean (years): } 10.6 \\
\text { Male : } 51.3 \% \\
\text { Caucasian: } 79 \% \text {, African American: } \\
\text { 9\%, Hispanic: } 9 \% \text {, other: } 3 \% \\
\text { Low income: } 27.6 \% \\
\text { ADHD: } 118 \%, \text { ODD:9.2\%, Tic } \\
\text { disorder and other internalizing } \\
\text { disorders: } 44.7 \%\end{array}$ & \\
\hline
\end{tabular}

ADHD: attention deficit hyperactivity disorder, CBT: cognitive behavioral therapy, CGI: clinical global impression scale, GAD: generalized anxiety disorder, NR: not reported, ODD: oppositional defiant disorder, RCT: randomized controlled trial, SAD: separation anxiety disorder, SoP: social anxiety, SP: specific phobia, SSRI: selective serotonin reuptake inhibitor. 
Table E.8. Characteristics of studies comparing parent only intervention versus waitlisting

\begin{tabular}{|c|c|c|c|c|c|c|}
\hline Author, Year & $\begin{array}{l}\text { Study Country, } \\
\text { Study Design, } \\
\text { Type of Study } \\
\text { (Efficacyl } \\
\text { Effectiveness), } \\
\text { Study Settings }\end{array}$ & $\begin{array}{c}\text { Type of } \\
\text { AnxietylSeverity } \\
\text { (CGI) }\end{array}$ & $\begin{array}{l}\text { Intervention } \\
\text { and } \\
\text { Comparison } \\
s \text { ( } N \text { of } \\
\text { Patients) }\end{array}$ & $\begin{array}{l}\text { Characteristics of Interventions } \\
\text { (Psychotherapy: Components, } \\
\text { Delivery Model)/Pharm: Drug) } \\
\text { Intensity, Duration (Weeks)) }\end{array}$ & $\begin{array}{c}\text { Patient Characteristics Mean } \\
\text { Age (Range), Male (\%), } \\
\text { Race/Ethnicity, Comorbidity, } \\
\text { Household Income, Parent } \\
\text { Education, Family } \\
\text { Dysfunction/Stressor, } \\
\text { Treatment Sequence, } \\
\text { Insurance, History of } \\
\text { Maltreatment) }\end{array}$ & $\begin{array}{l}\text { Length } \\
\text { of } \\
\text { Follow } \\
\text { up } \\
\text { (Weeks } \\
\text { ) }\end{array}$ \\
\hline \multirow[t]{2}{*}{$\begin{array}{l}\text { Cartwright- } \\
\text { Hatton, } 2011 \\
122\end{array}$} & \multirow[t]{2}{*}{$\begin{array}{l}\text { England } \\
\text { RCT } \\
\text { Effectiveness } \\
\text { Mental health } \\
\text { clinic }\end{array}$} & \multirow[t]{2}{*}{$\begin{array}{l}\text { GAD, PD, PD } \\
\text { with } \\
\text { agoraphobia, PD } \\
\text { without } \\
\text { agoraphobia, } \\
\text { SAD, SoP, SP }\end{array}$} & $\begin{array}{l}\text { Parent only } \\
\text { intervention, } \\
(\mathrm{N}=38)\end{array}$ & $\begin{array}{l}\text { Timid to Tiger } \\
\text { Group based } \\
\text { Exposure } \\
\text { Cognitive problem solving } \\
102 \text {-hour weekly sessions } \\
\text { Delivered by psychologist }\end{array}$ & $\begin{array}{l}\text { Age mean (years): } 6.66 \text { (range: } \\
2.7-9 \text { ) } \\
\text { Males: } 47 \% \\
\text { Caucasian: } 76 \% \\
\text { Other: } 24 \% \\
\text { Struggling financially (parent): } \\
24 \% \\
\text { Managing financially (parent):34\% } \\
\text { Comfortable financially } \\
\text { (parent):34\% } \\
\text { Less than high school or high } \\
\text { school graduate (parent): } 45 \% \\
\text { College graduate (parent): } 42 \% \\
\text { OCD: } 15 \% \\
\text { ODD: } 27 \% \\
\text { PTSD: } 5 \% \\
\text { Selective mutism: } 11 \% \\
\text { Depression: } 23 \%\end{array}$ & \multirow[t]{2}{*}{52} \\
\hline & & & $\begin{array}{l}\text { Control, } \\
(\mathrm{N}=36)\end{array}$ & Waitlisting or no treatment & $\begin{array}{l}\text { Age mean (years): } 6.47 \text { (range: } \\
2.7-9) \\
\text { Males: } 39 \% \\
\text { Caucasian: } 72 \% \\
\text { Other: } 28 \% \\
\text { Struggling financially (parent): } \\
11 \% \\
\text { Managing financially (parent):36\% } \\
\text { Comfortable financially } \\
\text { (parent):28\% } \\
\text { Less than high school or high } \\
\text { school graduate (parent):33\% } \\
\text { College graduate (parent): } 39 \% \\
\text { OCD: } 15 \% \\
\text { ODD: } 27 \%\end{array}$ & \\
\hline
\end{tabular}




\begin{tabular}{|c|c|c|c|c|c|c|}
\hline Author, Year & $\begin{array}{c}\text { Study Country, } \\
\text { Study Design, } \\
\text { Type of Study } \\
\text { (Efficacyl } \\
\text { Effectiveness), } \\
\text { Study Settings }\end{array}$ & $\begin{array}{c}\text { Type of } \\
\text { Anxiety/Severity } \\
\text { (CGI) }\end{array}$ & $\begin{array}{l}\text { Intervention } \\
\text { and } \\
\text { Comparison } \\
\text { s (N of } \\
\text { Patients) }\end{array}$ & $\begin{array}{l}\text { Characteristics of Interventions } \\
\text { (Psychotherapy: Components, } \\
\text { Delivery Model)/Pharm: Drug) } \\
\text { Intensity, Duration (Weeks)) }\end{array}$ & $\begin{array}{l}\text { Patient Characteristics Mean } \\
\text { Age (Range), Male (\%), } \\
\text { Race/Ethnicity, Comorbidity, } \\
\text { Household Income, Parent } \\
\text { Education, Family } \\
\text { Dysfunction/Stressor, } \\
\text { Treatment Sequence, } \\
\text { Insurance, History of } \\
\text { Maltreatment) }\end{array}$ & $\begin{array}{l}\text { Length } \\
\text { of } \\
\text { Follow } \\
\text { up } \\
\text { (Weeks } \\
\text { ) }\end{array}$ \\
\hline & & & & & $\begin{array}{l}\text { PTSD: } 5 \% \\
\text { Selective mutism: } 11 \% \\
\text { Depression: } 23 \%\end{array}$ & \\
\hline \multirow[t]{4}{*}{$\begin{array}{l}\text { Medlowitz, } \\
1999^{56}\end{array}$} & \multirow[t]{4}{*}{$\begin{array}{l}\text { Canada } \\
\text { RCT } \\
\text { Efficacy } \\
\text { Outpatient }\end{array}$} & & $\begin{array}{l}\text { Child CBT, } \\
(\mathrm{N}=23)\end{array}$ & $\begin{array}{l}\text { Coping bear } \\
\text { Child CBT- (parents included }<20 \% \text { ) } \\
\text { Group based } \\
\text { Relaxation } \\
\text { Cognitive problem solving } \\
121.5 \text {-hour weekly sessions } \\
\text { Delivered by } 3 \text { psychologists, } 1 \\
\text { student/trainee, } 1 \text { youth worker }\end{array}$ & \multirow[t]{4}{*}{$\begin{array}{l}\text { Age mean (years): } 9.5 \text { (Range } 7- \\
12 \text { - } \\
\text { Male: } 28.4 \%\end{array}$} & \multirow[t]{4}{*}{ NR } \\
\hline & & & $\begin{array}{l}\text { Parent only } \\
\text { intervention, } \\
(\mathrm{N}=21)\end{array}$ & $\begin{array}{l}\text { Generic CBT } \\
\text { Group based } \\
12 \text { 1.5-hour weekly sessions } \\
\text { Delivered by doctoral level } \\
\text { psychologist, and student/trainee }\end{array}$ & & \\
\hline & & & $\begin{array}{l}\text { Child CBT } \\
\text { plus separate } \\
\text { parent } \\
\text { intervention, } \\
(\mathrm{N}=18)\end{array}$ & $\begin{array}{l}\text { Coping Bear } \\
\text { Group based } \\
\text { Relaxation } \\
\text { Cognitive problem solving } \\
121.5 \text {-hour weekly sessions (one for } \\
\text { kids, one for parents) } \\
\text { Delivered by doctoral level } \\
\text { psychologist, student/trainee, youth } \\
\text { worker }\end{array}$ & & \\
\hline & & & $\begin{array}{l}\text { Control, } \\
(\mathrm{N}=40)\end{array}$ & Waitlisting or no treatment & & \\
\hline \multirow[t]{2}{*}{$\begin{array}{l}\text { Ozyurt, } \\
2015^{123}\end{array}$} & \multirow[t]{2}{*}{$\begin{array}{l}\text { Turkey } \\
\text { RCT } \\
\text { Efficacy } \\
\text { Outpatient }\end{array}$} & \multirow[t]{2}{*}{$\begin{array}{l}\text { GAD, SAD, SoP, } \\
\text { SP }\end{array}$} & $\begin{array}{l}\text { Parent only } \\
\text { intervention, } \\
(\mathrm{N}=37)\end{array}$ & $\begin{array}{l}\text { Triple P } \\
\text { Technology based } \\
\text { Group based } \\
5 \text { group sessions ( } 2 \text { hours), } 3 \\
\text { telephone consultations } \\
\end{array}$ & $\begin{array}{l}\text { Age mean (years): } 9.65 \text { (range: } \\
8-12 \text { ) } \\
\text { Male: } 82 \%\end{array}$ & \multirow[t]{2}{*}{17} \\
\hline & & & $\begin{array}{l}\text { Control, } \\
(\mathrm{N}=37)\end{array}$ & Waitlisting or no treatment & $\begin{array}{l}\text { Age mean (years): } 9.83 \text { (range: 8- } \\
\text { 12) } \\
\text { Male: } 71 \%\end{array}$ & \\
\hline
\end{tabular}




\begin{tabular}{|c|c|c|c|c|c|c|}
\hline Author, Year & $\begin{array}{l}\text { Study Country, } \\
\text { Study Design, } \\
\text { Type of Study } \\
\text { (Efficacyl } \\
\text { Effectiveness), } \\
\text { Study Settings }\end{array}$ & $\begin{array}{c}\text { Type of } \\
\text { Anxiety/Severity } \\
\text { (CGI) }\end{array}$ & $\begin{array}{l}\text { Intervention } \\
\text { and } \\
\text { Comparison } \\
\text { s (N of } \\
\text { Patients) }\end{array}$ & $\begin{array}{l}\text { Characteristics of Interventions } \\
\text { (Psychotherapy: Components, } \\
\text { Delivery Model)/Pharm: Drug) } \\
\text { Intensity, Duration (Weeks)) }\end{array}$ & $\begin{array}{l}\text { Patient Characteristics Mean } \\
\text { Age (Range), Male (\%), } \\
\text { Race/Ethnicity, Comorbidity, } \\
\text { Household Income, Parent } \\
\text { Education, Family } \\
\text { Dysfunction/Stressor, } \\
\text { Treatment Sequence, } \\
\text { Insurance, History of } \\
\text { Maltreatment) }\end{array}$ & $\begin{array}{l}\text { Length } \\
\text { of } \\
\text { Follow } \\
\text { up } \\
\text { (Weeks } \\
\text { ) }\end{array}$ \\
\hline \multirow[t]{3}{*}{$\begin{array}{l}\text { Santacruz, } \\
2006^{124}\end{array}$} & \multirow[t]{3}{*}{$\begin{array}{l}\text { Spain } \\
\text { RCT } \\
\text { Efficacy } \\
\text { Home }\end{array}$} & \multirow[t]{3}{*}{ SP } & $\begin{array}{l}\text { Parent only } \\
\text { intervention, } \\
(\mathrm{N}=27)\end{array}$ & $\begin{array}{l}\text { Uncle lightfoot } \\
\text { Bibliotherapy and games } \\
\text { Individual based } \\
\text { Exposure } \\
545 \text {-minute weekly sessions over a } 1 \\
\text { month period } \\
\text { Delivered by the parents }\end{array}$ & \multirow[t]{3}{*}{$\begin{array}{l}\text { Age mean (years): } 6.49 \% \\
\text { Male patients: } 52.5 \%\end{array}$} & \multirow[t]{3}{*}{12} \\
\hline & & & $\begin{array}{l}\text { Parent only } \\
\text { intervention, } \\
(\mathrm{N}=28)\end{array}$ & $\begin{array}{l}\text { Other: Emotive performances } \\
\text { Individual based } \\
\text { Exposure } \\
545 \text {-minute weekly sessions over a } 1 \\
\text { month period } \\
\text { Delivered by the parents }\end{array}$ & & \\
\hline & & & $\begin{array}{l}\text { Control, } \\
(\mathrm{N}=23)\end{array}$ & Waitlisting or no treatment & & \\
\hline \multirow[t]{2}{*}{$\begin{array}{l}\text { Smith, } \\
2014^{125}\end{array}$} & \multirow[t]{2}{*}{$\begin{array}{l}\text { United States } \\
\text { RCT } \\
\text { Efficacy } \\
\text { Outpatient }\end{array}$} & \multirow[t]{2}{*}{$\begin{array}{l}\text { GAD, SAD, SoP, } \\
\text { SP }\end{array}$} & $\begin{array}{l}\text { Parent only } \\
\text { intervention, } \\
(\mathrm{N}=18)\end{array}$ & $\begin{array}{l}\text { CC derivative } \\
\text { Individual based } \\
\text { Exposure } \\
\text { Relaxation } \\
\text { Cognitive problem solving } \\
10 \text { weekly one hour sessions } \\
\text { Delivered by student/trainee }\end{array}$ & $\begin{array}{l}\text { Age mean (years): } 10.04 \text { (range: } \\
7-13 \text { ) } \\
\text { Males:61\% } \\
\text { Caucasian: } 94 \% \\
\text { Hispanic: } 6 \% \\
\text { Mean income: } \$ 131,000 \text { (SD: } \\
82,417 \text { ) } \\
\text { Externalizing disorder: } 22 \%\end{array}$ & \multirow[t]{2}{*}{13} \\
\hline & & & $\begin{array}{l}\text { Control, } \\
(\mathrm{N}=13)\end{array}$ & Waitlisting or no treatment & $\begin{array}{l}\text { Age mean (years): } 9.46 \text { (range: } 7- \\
\text { 13) } \\
\text { Males: } 62 \% \\
\text { Caucasian: } 100 \% \\
\text { Mean income: } \$ 123,571 \text { (SD: } \\
74,202 \text { ) } \\
\text { Externalizing disorder: } 15 \%\end{array}$ & \\
\hline $\begin{array}{l}\text { Thirlwall, } \\
2013^{126,127}\end{array}$ & $\begin{array}{l}\text { United } \\
\text { Kingdoms } \\
\text { RCT } \\
\text { Efficacy }\end{array}$ & GAD, SAD,SoP & $\begin{array}{l}\text { Parent only } \\
\text { intervention, } \\
(\mathrm{N}=64)\end{array}$ & $\begin{array}{l}\text { Generic CBT } \\
\text { Individual based } \\
\text { Exposure } \\
\text { Cognitive problem solving }\end{array}$ & $\begin{array}{l}\text { Males: } 53 \% \\
\text { Caucasian: } 86 \% \\
\text { Unemployed (parent): } 6.3 \% \\
\text { Other employed (parent): } 26.6 \%\end{array}$ & 26 \\
\hline
\end{tabular}




\begin{tabular}{|c|c|c|c|c|c|c|}
\hline Author, Year & $\begin{array}{c}\text { Study Country, } \\
\text { Study Design, } \\
\text { Type of Study } \\
\text { (Efficacyl } \\
\text { Effectiveness), } \\
\text { Study Settings }\end{array}$ & $\begin{array}{c}\text { Type of } \\
\text { Anxiety/Severity } \\
\text { (CGI) }\end{array}$ & $\begin{array}{c}\text { Intervention } \\
\text { and } \\
\text { Comparison } \\
\mathrm{s} \text { (N of } \\
\text { Patients) }\end{array}$ & $\begin{array}{l}\text { Characteristics of Interventions } \\
\text { (Psychotherapy: Components, } \\
\text { Delivery Model)/Pharm: Drug) } \\
\text { Intensity, Duration (Weeks)) }\end{array}$ & $\begin{array}{c}\text { Patient Characteristics Mean } \\
\text { Age (Range), Male (\%), } \\
\text { Race/Ethnicity, Comorbidity, } \\
\text { Household Income, Parent } \\
\text { Education, Family } \\
\text { Dysfunction/Stressor, } \\
\text { Treatment Sequence, } \\
\text { Insurance, History of } \\
\text { Maltreatment) } \\
\end{array}$ & $\begin{array}{c}\text { Length } \\
\text { of } \\
\text { Follow } \\
\text { up } \\
\text { (Weeks } \\
\text { ) }\end{array}$ \\
\hline & \multirow[t]{3}{*}{ Outpatient } & & & $\begin{array}{l}8 \text { 1-hour face-to-face weekly and } 4 \\
20 \text {-minute telephone sessions } \\
\text { Delivered by psychologist, } \\
\text { student/trainee }\end{array}$ & $\begin{array}{l}\text { Higher professional (parent): } \\
57.8 \% \\
\text { Less than high school or high } \\
\text { school graduate (parent): } 20.3 \% \\
\text { Some college (parent): } 40.6 \% \\
\text { College graduate (parent): } 29.7 \% \\
\text { Depression: } 7.8 \% \\
\text { ADHD: } 7.8 \% \\
\text { ODD: } 14.1 \%\end{array}$ & \\
\hline & & & $\begin{array}{l}\text { Parent only } \\
\text { intervention, } \\
(\mathrm{N}=61)\end{array}$ & $\begin{array}{l}\text { Other: Brief guided parent-delivered } \\
\text { CBT } \\
\text { Individual based } \\
\text { Exposure } \\
\text { Cognitive problem solving } \\
2 \text { 1-hour face-to-face weekly and } 2 \\
20 \text {-minute telephone sessions } \\
\text { Delivered by psychologist, } \\
\text { student/trainee }\end{array}$ & $\begin{array}{l}\text { Males: } 51 \% \\
\text { Caucasian: } 87 \% \\
\text { Unemployed (parent): } 8.2 \% \\
\text { Other employed (parent): } 23 \% \\
\text { Higher professional (parent): } \\
63.9 \% \\
\text { Less than high school or high } \\
\text { school graduate (parent): } 24.6 \% \\
\text { Some college (parent): } 44.3 \% \\
\text { College graduate (parent): } 26.2 \% \\
\text { Depression: } 9.8 \% \\
\text { ADHD: } 11.5 \% \\
\text { ODD: } 14.8 \%\end{array}$ & \\
\hline & & & $\begin{array}{l}\text { Control, } \\
(\mathrm{N}=69)\end{array}$ & Waitlisting or no treatment & $\begin{array}{l}\text { Males: } 51 \% \\
\text { Caucasian: } 84 \% \\
\text { Unemployed (parent): } 2.9 \% \\
\text { Other employed (parent): } 26.1 \% \\
\text { Higher professional (parent): } \\
62.3 \% \\
\text { Less than high school or high } \\
\text { school graduate (parent): } 15.9 \% \\
\text { Some college (parent): } 47.8 \% \\
\text { College graduate (parent): } 28.9 \% \\
\text { Depression:15.9\% } \\
\text { ADHD:11.5\% }\end{array}$ & \\
\hline
\end{tabular}




\begin{tabular}{|c|c|c|c|c|c|c|}
\hline Author, Year & $\begin{array}{c}\text { Study Country, } \\
\text { Study Design, } \\
\text { Type of Study } \\
\text { (Efficacyl } \\
\text { Effectiveness), } \\
\text { Study Settings }\end{array}$ & $\begin{array}{c}\text { Type of } \\
\text { AnxietylSeverity } \\
\text { (CGI) }\end{array}$ & $\begin{array}{c}\text { Intervention } \\
\text { and } \\
\text { Comparison } \\
\text { s (N of } \\
\text { Patients) }\end{array}$ & $\begin{array}{l}\text { Characteristics of Interventions } \\
\text { (Psychotherapy: Components, } \\
\text { Delivery Model)/Pharm: Drug) } \\
\text { Intensity, Duration (Weeks)) }\end{array}$ & $\begin{array}{c}\text { Patient Characteristics Mean } \\
\text { Age (Range), Male (\%), } \\
\text { Race/Ethnicity, Comorbidity, } \\
\text { Household Income, Parent } \\
\text { Education, Family } \\
\text { Dysfunction/Stressor, } \\
\text { Treatment Sequence, } \\
\text { Insurance, History of } \\
\text { Maltreatment) }\end{array}$ & $\begin{array}{c}\text { Length } \\
\text { of } \\
\text { Follow } \\
\text { up } \\
\text { (Weeks } \\
\text { ) }\end{array}$ \\
\hline & & & & & ODD: $15.9 \%$ & \\
\hline \multirow[t]{3}{*}{$\begin{array}{l}\text { Waters, } \\
2009^{86}\end{array}$} & \multirow[t]{3}{*}{$\begin{array}{l}\text { Australia } \\
\text { RCT } \\
\text { Efficacy } \\
\text { Outpatient }\end{array}$} & \multirow[t]{3}{*}{$\begin{array}{l}\text { GAD, SAD, SoP, } \\
\text { SP }\end{array}$} & $\begin{array}{l}\text { Child CBT } \\
\text { plus separate } \\
\text { parent } \\
\text { intervention, } \\
(\mathrm{N}=38)\end{array}$ & $\begin{array}{l}\text { Take Action } \\
\text { Group based } \\
\text { Exposure } \\
\text { Relaxation } \\
\text { Cognitive problem solving } \\
10 \text { weekly 1-hour child and one hour } \\
\text { parents sessions } \\
\text { Delivered by psychologist }\end{array}$ & $\begin{array}{l}\text { Age mean (years): } 6.89 \text { (range: } 4- \\
\text { 8) } \\
\text { Males: } 37 \% \\
\text { Caucasian: } 97 \%\end{array}$ & \multirow[t]{3}{*}{52} \\
\hline & & & $\begin{array}{l}\text { Parent only } \\
\text { intervention, } \\
(\mathrm{N}=31)\end{array}$ & $\begin{array}{l}\text { Take Action } \\
\text { Group based } \\
\text { Exposure } \\
\text { Relaxation } \\
\text { Cognitive problem solving } \\
10 \text { weekly 1-hour child and one hour } \\
\text { parents sessions } \\
\text { Delivered by psychologist }\end{array}$ & $\begin{array}{l}\text { Age mean (years): } 6.68 \text { (range: } 4- \\
\text { 8) } \\
\text { Males: } 58 \% \\
\text { Caucasian: } 97 \%\end{array}$ & \\
\hline & & & $\begin{array}{l}\text { Control, } \\
(\mathrm{N}=11)\end{array}$ & Waitlisting or no treatment & $\begin{array}{l}\text { Age mean (years): } 6.79 \text { (range 4- } \\
\text { 8) } \\
\text { Males: } 55 \% \\
\text { Caucasian: } 91 \%\end{array}$ & \\
\hline
\end{tabular}

ADHD: attention deficit hyperactivity disorder, CBT: cognitive behavioral therapy, CC: coping cat, CGI: clinical global impression scale, GAD: generalized anxiety disorder, OCD: obsessive compulsive disorder, ODD: oppositional defiant disorder, PD: panic disorder, PTSD: posttraumatic stress disorder, RCT: randomized controlled trial, SAD: separation anxiety disorder, SoP: social anxiety, SP: specific phobia, Triple P: positive parenting program. 
Table E.9. Characteristics of studies comparing different components of parent only interventions

\begin{tabular}{|c|c|c|c|c|c|c|}
\hline Author, Year & $\begin{array}{l}\text { Study Country, } \\
\text { Study Design, } \\
\text { Type of Study } \\
\text { (Efficacyl } \\
\text { Effectiveness), } \\
\text { Study Settings }\end{array}$ & $\begin{array}{c}\text { Type of } \\
\text { Anxiety/Severity } \\
\text { (CGI) }\end{array}$ & $\begin{array}{l}\text { Intervention } \\
\text { and } \\
\text { Comparison } \\
\text { s (N of } \\
\text { Patients) }\end{array}$ & $\begin{array}{l}\text { Characteristics of Interventions } \\
\text { (Psychotherapy: Components, } \\
\text { Delivery Model)/Pharm: Drug) } \\
\text { Intensity, Duration (Weeks)) }\end{array}$ & $\begin{array}{c}\text { Patient Characteristics Mean } \\
\text { Age (Range), Male (\%), } \\
\text { Race/Ethnicity, Comorbidity, } \\
\text { Household Income, Parent } \\
\text { Education, Family } \\
\text { Dysfunction/Stressor, } \\
\text { Treatment Sequence, } \\
\text { Insurance, History of } \\
\text { Maltreatment) }\end{array}$ & $\begin{array}{c}\text { Length } \\
\text { of } \\
\text { Follow } \\
\text { up } \\
\text { (Weeks } \\
\text { ) }\end{array}$ \\
\hline \multirow[t]{2}{*}{ Hiller, $2016^{128}$} & \multirow[t]{2}{*}{$\begin{array}{l}\text { United Kingdom } \\
\text { RCT } \\
\text { Efficacy } \\
\text { Mental health } \\
\text { clinic }\end{array}$} & \multirow[t]{2}{*}{$\begin{array}{l}\text { GAD, PD, SAD, } \\
\text { SoP }\end{array}$} & $\begin{array}{l}\text { Parent only } \\
\text { intervention, } \\
(\mathrm{N}=32)\end{array}$ & $\begin{array}{l}\text { Generic CBT } \\
\text { Exposure } \\
\text { Cognitive problem solving } \\
\text { Individual based } \\
9,90 \text { min weekly sessions }\end{array}$ & $\begin{array}{l}\text { Age mean (years): } 9.78 \text { (range: } 7- \\
12 \text { - } \\
\text { Males: } 87.5 \% \\
\text { ODD: } 18.75 \% \\
\text { Agoraphobia: } 3 \%\end{array}$ & \multirow[t]{2}{*}{26} \\
\hline & & & $\begin{array}{l}\text { Parent only } \\
\text { intervention, } \\
(\mathrm{N}=28)\end{array}$ & $\begin{array}{l}\text { Other Therapy } \\
\text { Exposure } \\
\text { Cognitive problem solving } \\
\text { Delivered by parent } \\
9,90 \text { min weekly sessions }\end{array}$ & $\begin{array}{l}\text { Age mean (years): } 9.32 \text { (range: } 7- \\
12 \text { - } \\
\text { Males: } 86 \% \\
\text { ODD: } 21.4 \% \\
\text { Agoraphobia: } 3.6 \%\end{array}$ & \\
\hline \multirow[t]{2}{*}{$\begin{array}{l}\text { Thirlwall, } \\
2013^{126,127}\end{array}$} & \multirow[t]{2}{*}{$\begin{array}{l}\text { United } \\
\text { Kingdoms } \\
\text { RCT } \\
\text { Efficacy } \\
\text { Outpatient }\end{array}$} & \multirow[t]{2}{*}{ GAD, SAD, SoP } & $\begin{array}{l}\text { Parent only } \\
\text { intervention, } \\
(\mathrm{N}=64)\end{array}$ & $\begin{array}{l}\text { Generic CBT } \\
\text { Individual based } \\
\text { Exposure } \\
\text { Cognitive problem solving } \\
81 \text {-hour face-to-face weekly and } 4 \\
\text { 20-minute telephone sessions } \\
\text { Delivered by psychologist, } \\
\text { student/trainee }\end{array}$ & $\begin{array}{l}\text { Males: } 53 \% \\
\text { Caucasian: } 86 \% \\
\text { Unemployed (parent): } 6.3 \% \\
\text { Other employed (parent): } 26.6 \% \\
\text { Higher professional (parent): } \\
57.8 \% \\
\text { Less than high school or high } \\
\text { school graduate (parent): } 20.3 \% \\
\text { Some college (parent): } 40.6 \% \\
\text { College graduate (parent): } 29.7 \% \\
\text { Depression: } 7.8 \% \\
\text { ADHD: } 7.8 \% \\
\text { ODD: } 14.1 \%\end{array}$ & \multirow[t]{2}{*}{26} \\
\hline & & & $\begin{array}{l}\text { Parent only } \\
\text { intervention, } \\
(\mathrm{N}=61)\end{array}$ & $\begin{array}{l}\text { Other: Brief guided parent-delivered } \\
\text { CBT } \\
\text { Individual based } \\
\text { Exposure } \\
\text { Cognitive problem solving } \\
21 \text {-hour face-to-face weekly and } 2 \\
20 \text {-minute telephone sessions } \\
\text { Delivered by psychologist, } \\
\text { student/trainee }\end{array}$ & $\begin{array}{l}\text { Males: } 51 \% \\
\text { Caucasian: } 87 \% \\
\text { Unemployed (parent): } 8.2 \% \\
\text { Other employed (parent): } 23 \% \\
\text { Higher professional (parent): } \\
63.9 \% \\
\text { Less than high school or high } \\
\text { school graduate (parent): } 24.6 \% \\
\text { Some college (parent): } 44.3 \% \\
\text { College graduate (parent): } 26.2 \% \\
\text { Depression: } 9.8 \%\end{array}$ & \\
\hline
\end{tabular}




\begin{tabular}{|c|c|c|c|c|c|c|}
\hline Author, Year & $\begin{array}{l}\text { Study Country, } \\
\text { Study Design, } \\
\text { Type of Study } \\
\text { (Efficacyl } \\
\text { Effectiveness), } \\
\text { Study Settings }\end{array}$ & $\begin{array}{c}\text { Type of } \\
\text { AnxietylSeverity } \\
\text { (CGI) }\end{array}$ & $\begin{array}{l}\text { Intervention } \\
\text { and } \\
\text { Comparison } \\
\text { s (N of } \\
\text { Patients) }\end{array}$ & $\begin{array}{l}\text { Characteristics of Interventions } \\
\text { (Psychotherapy: Components, } \\
\text { Delivery Model)/Pharm: Drug) } \\
\text { Intensity, Duration (Weeks)) }\end{array}$ & $\begin{array}{c}\text { Patient Characteristics Mean } \\
\text { Age (Range), Male (\%), } \\
\text { Race/Ethnicity, Comorbidity, } \\
\text { Household Income, Parent } \\
\text { Education, Family } \\
\text { Dysfunction/Stressor, } \\
\text { Treatment Sequence, } \\
\text { Insurance, History of } \\
\text { Maltreatment) } \\
\end{array}$ & $\begin{array}{l}\text { Length } \\
\text { of } \\
\text { Follow } \\
\text { up } \\
\text { (Weeks } \\
\text { ) }\end{array}$ \\
\hline & & & & & $\begin{array}{l}\text { ADHD: } 11.5 \% \\
\text { ODD: } 14.8 \%\end{array}$ & \\
\hline & & & $\begin{array}{l}\text { Control, } \\
(N=69)\end{array}$ & Waitlisting or no treatment & $\begin{array}{l}\text { Males: } 51 \% \\
\text { Caucasian: } 84 \% \\
\text { Unemployed (parent): } 2.9 \% \\
\text { Other employed (parent): } 26.1 \% \\
\text { Higher professional (parent): } \\
62.3 \% \\
\text { Less than high school or high } \\
\text { school graduate (parent): } 15.9 \% \\
\text { Some college (parent): } 47.8 \% \\
\text { College graduate (parent): } 28.9 \% \\
\text { Depression:15.9\% } \\
\text { ADHD:11.5\% } \\
\text { ODD: } 15.9 \%\end{array}$ & \\
\hline
\end{tabular}

ADHD: attention deficit hyperactivity disorder, CBT: cognitive behavioral therapy, CGI: Clinical Global Impression scale, GAD: Generalized anxiety disorder, ODD: oppositional defiant disorder, PD: panic disorder, RCT: randomized controlled trial, SAD: separation anxiety disorder, SoP: social anxiety, SP: specific phobia. 
Table E.10. Characteristics of studies comparing distance therapy versus waitlisting

\begin{tabular}{|c|c|c|c|c|c|c|}
\hline Author, Year & $\begin{array}{l}\text { Study Country, } \\
\text { Study Design, } \\
\text { Type of Study } \\
\text { (Efficacyl } \\
\text { Effectiveness), } \\
\text { Study Settings }\end{array}$ & $\begin{array}{c}\text { Type of } \\
\text { Anxiety/Severity } \\
\text { (CGI) }\end{array}$ & $\begin{array}{l}\text { Intervention } \\
\text { and } \\
\text { Comparison } \\
\text { s (N of } \\
\text { Patients) }\end{array}$ & $\begin{array}{l}\text { Characteristics of Interventions } \\
\text { (Psychotherapy: Components, } \\
\text { Delivery Model)/Pharm: Drug) } \\
\text { Intensity, Duration (Weeks)) }\end{array}$ & $\begin{array}{c}\text { Patient Characteristics Mean } \\
\text { Age (Range), Male (\%), } \\
\text { Race/Ethnicity, Comorbidity, } \\
\text { Household Income, Parent } \\
\text { Education, Family } \\
\text { Dysfunction/Stressor, } \\
\text { Treatment Sequence, } \\
\text { Insurance, History of } \\
\text { Maltreatment) } \\
\end{array}$ & $\begin{array}{l}\text { Length } \\
\text { of } \\
\text { Follow } \\
\text { up } \\
\text { (Weeks } \\
\text { ) }\end{array}$ \\
\hline \multirow[t]{3}{*}{$\begin{array}{l}\text { Cobham, } \\
2012^{36}\end{array}$} & \multirow[t]{3}{*}{$\begin{array}{l}\text { Australia } \\
\text { RCT } \\
\text { Efficacy } \\
\text { Mental health } \\
\text { clinic }\end{array}$} & \multirow[t]{3}{*}{$\begin{array}{l}\text { GAD, PD, PD } \\
\text { with } \\
\text { agoraphobia, } \\
\text { SAD, SoP, SP }\end{array}$} & $\begin{array}{l}\text { Child CBT } \\
\text { plus separate } \\
\text { parent } \\
\text { intervention, } \\
(\mathrm{N}=23)\end{array}$ & $\begin{array}{l}\text { Do as I do } \\
\text { Individual-based } \\
\text { Exposure } \\
\text { Cognitive problem solving } \\
690 \text {-minutes sessions for parent and } \\
660 \text {-minutes for child, weekly } \\
\text { Delivered by Masters level clinicians }\end{array}$ & $\begin{array}{l}\text { Age mean (years): } 9.70 \text { (range: } 7 \text { - } \\
\text { 14) } \\
\text { Males: } 50 \% \\
\text { Caucasian } 92 \% \\
\text { Asian: } 8 \% \\
\text { PTSD: } 4 \% \\
\text { ADHD: } 7 \% \\
\text { Dysthymia: } 4 \% \\
\text { Enuresis: } 4 \%\end{array}$ & \multirow[t]{3}{*}{26} \\
\hline & & & $\begin{array}{l}\text { Distance } \\
\text { Therapy, } \\
(\mathrm{N}=20)\end{array}$ & $\begin{array}{l}\text { Do as I do } \\
\text { "Do as I Do" and "Facing your Fears" } \\
\text { bibliotherapy programs } \\
\text { Exposure } \\
\text { Cognitive problem solving } \\
2 \text { hour parent group, every other } \\
\text { week } 12 \text { min phone calls for } 12 \\
\text { weeks } \\
\text { Delivered by parent and therapist }\end{array}$ & $\begin{array}{l}\text { Age mean (years): } 10.20 \text { (range: } \\
\text { 7-14) } \\
\text { Males: } 55 \% \\
\text { Caucasian } 92 \% \\
\text { Asian: } 8 \% \\
\text { ADHD: } 5 \% \\
\text { PTSD: } 5 \% \\
\text { Dysthymia: } 5 \% \\
\text { Sleep terrors: } 5 \%\end{array}$ & \\
\hline & & & $\begin{array}{l}\text { Control, } \\
(\mathrm{N}=12)\end{array}$ & Waitlisting or no treatment & $\begin{array}{l}\text { Age mean (years): } 9.83 \text { (range: } 7 \text { - } \\
\text { 14) } \\
\text { Males: } 57 \% \\
\text { Caucasian } 92 \% \\
\text { Asian: } 8 \% \\
\text { PTSD: } 4 \%\end{array}$ & \\
\hline \multirow[t]{2}{*}{ Dewis, $2001^{37}$} & \multirow[t]{2}{*}{$\begin{array}{l}\text { Australia } \\
\text { RCT } \\
\text { Efficacy } \\
\text { Mental health } \\
\text { clinic }\end{array}$} & \multirow[t]{2}{*}{ SP } & $\begin{array}{l}\text { Child CBT, } \\
(\mathrm{N}=9)\end{array}$ & $\begin{array}{l}\text { Generic CBT } \\
\text { Live graded exposure } \\
\text { Child CBT- (parents included < 20\%) } \\
\text { Individual based } \\
\text { Exposure } \\
\text { Three } 45-\text { min treatment sessions } \\
\text { every } 3-4 \text { days } \\
\text { Provided by clinical psychologists }\end{array}$ & $\begin{array}{l}\text { Male: } 35.7 \% \\
\text { Caucasian: } 100 \% \\
\text { Age mean (years): } 12.3 \text { (Range } \\
10-17 \text { ) }\end{array}$ & \multirow[t]{2}{*}{4} \\
\hline & & & $\begin{array}{l}\text { Distance } \\
\text { Therapy, }\end{array}$ & $\begin{array}{l}\text { Other: Computer-aided vicarious } \\
\text { exposure }\end{array}$ & $\begin{array}{l}\text { Male: } 35.7 \% \\
\text { Caucasian: } 100 \%\end{array}$ & \\
\hline
\end{tabular}




\begin{tabular}{|c|c|c|c|c|c|c|}
\hline Author, Year & $\begin{array}{l}\text { Study Country, } \\
\text { Study Design, } \\
\text { Type of Study } \\
\text { (Efficacyl } \\
\text { Effectiveness), } \\
\text { Study Settings }\end{array}$ & $\begin{array}{c}\text { Type of } \\
\text { Anxiety/Severity } \\
\text { (CGI) }\end{array}$ & $\begin{array}{l}\text { Intervention } \\
\text { and } \\
\text { Comparison } \\
\text { s (N of } \\
\text { Patients) }\end{array}$ & $\begin{array}{l}\text { Characteristics of Interventions } \\
\text { (Psychotherapy: Components, } \\
\text { Delivery Model)/Pharm: Drug) } \\
\text { Intensity, Duration (Weeks)) }\end{array}$ & $\begin{array}{c}\text { Patient Characteristics Mean } \\
\text { Age (Range), Male (\%), } \\
\text { Race/Ethnicity, Comorbidity, } \\
\text { Household Income, Parent } \\
\text { Education, Family } \\
\text { Dysfunction/Stressor, } \\
\text { Treatment Sequence, } \\
\text { Insurance, History of } \\
\text { Maltreatment) } \\
\end{array}$ & $\begin{array}{l}\text { Length } \\
\text { of } \\
\text { Follow } \\
\text { up } \\
\text { (Weeks } \\
\text { ) }\end{array}$ \\
\hline & & & $(\mathrm{N}=10)$ & $\begin{array}{l}\text { Individual computer based } \\
\text { Exposure } \\
\text { Three 45-min treatment sessions } \\
\text { every 3-4 days }\end{array}$ & $\begin{array}{l}\text { Age mean (years): } 13.8 \text { (Range } \\
10-17)\end{array}$ & \\
\hline & & & $\begin{array}{l}\text { Control, } \\
(\mathrm{N}=9)\end{array}$ & Waitlisting or no treatment & $\begin{array}{l}\text { Male: } 35.7 \% \\
\text { Caucasian: } 100 \% \\
\text { Age mean (years): } 13.3 \text { (Range } \\
10-17 \text { ) }\end{array}$ & \\
\hline \multirow[t]{2}{*}{$\begin{array}{l}\text { Donovan, } \\
2014^{129}\end{array}$} & \multirow[t]{2}{*}{$\begin{array}{l}\text { Australia } \\
\text { RCT } \\
\text { Efficacy } \\
\text { Mental health } \\
\text { clinic }\end{array}$} & \multirow[t]{2}{*}{$\begin{array}{l}\text { GAD, SAD, SoP, } \\
\text { SP }\end{array}$} & $\begin{array}{l}\text { Distance } \\
\text { Therapy, } \\
(\mathrm{N}=23)\end{array}$ & $\begin{array}{l}\text { Brave online } \\
\text { Individual based } \\
\text { Exposure } \\
\text { Relaxation } \\
\text { Cognitive problem solving } \\
6 \text { 1-hour parent sessions and } 2 \\
\text { boosters, one phone call and weekly } \\
\text { emails }\end{array}$ & \multirow[t]{2}{*}{$\begin{array}{l}\text { Age mean (years): } 4.08 \text { (range: 3- } \\
6 \text { ) } \\
\text { Males: } 46 \% \\
\text { Low income: }(<\$ 29,875): 5.8 \% \\
\text { Medium income: }(\$ 30,622-\$ \\
74,688): 38.5 \% \\
\text { High income: }(>\$ 74,688): 55.8 \% \\
\text { Selective mutism: } 3 \%\end{array}$} & \multirow[t]{2}{*}{26} \\
\hline & & & $\begin{array}{l}\text { Control, } \\
(\mathrm{N}=29)\end{array}$ & Waitlisting or no treatment & & \\
\hline \multirow[t]{2}{*}{$\begin{array}{l}\text { Infantino, } \\
2016^{130}\end{array}$} & \multirow[t]{2}{*}{$\begin{array}{l}\text { Australia } \\
\text { RCT } \\
\text { Efficacy } \\
\text { Mental health } \\
\text { clinic }\end{array}$} & \multirow[t]{2}{*}{$\begin{array}{l}\text { GAD,SAD, SoP, } \\
\text { SP }\end{array}$} & $\begin{array}{l}\text { Distance } \\
\text { Therapy, } \\
(\mathrm{N}=12)\end{array}$ & $\begin{array}{l}\text { Other: Audio Intervention } \\
\text { Technology based } \\
\text { Individual based } \\
\text { Exposure } \\
\text { Relaxation } \\
\text { Cognitive problem solving } \\
10 \text { audio lessons, } 20-30 \text { minutes } \\
\text { each, } 2 \text { lessons a week during } 5 \\
\text { weeks }\end{array}$ & $\begin{array}{l}\text { Age mean (years): } 7.3 \text { (range: } 6 \text { - } \\
12 \text { ) } \\
\text { Males: } 50 \% \\
\text { Caucasian: } 100 \% \\
\text { Low income: } 0 \% \\
\text { Medium income } 33.3 \% \\
\text { High income: } 66.7 \% \\
\text { Less than high school or high } \\
\text { school graduate (parent): } 29 \% \\
\text { Some college (parent): } 4 \% \\
\text { College graduate (parent): } 67 \% \\
\end{array}$ & \multirow[t]{2}{*}{13} \\
\hline & & & $\begin{array}{l}\text { Control, } \\
(\mathrm{N}=12)\end{array}$ & Waitlisting or no treatment & $\begin{array}{l}\text { Age mean (years): } 7.7 \text { (range: } 6- \\
\text { 12) } \\
\text { Males: } 42 \% \\
\text { Caucasian: } 100 \% \\
\text { Low income: } 8 \% \\
\text { Medium income: } 25 \%\end{array}$ & \\
\hline
\end{tabular}




\begin{tabular}{|c|c|c|c|c|c|c|}
\hline Author, Year & $\begin{array}{l}\text { Study Country, } \\
\text { Study Design, } \\
\text { Type of Study } \\
\text { (Efficacyl } \\
\text { Effectiveness), } \\
\text { Study Settings }\end{array}$ & $\begin{array}{c}\text { Type of } \\
\text { Anxiety/Severity } \\
\text { (CGI) }\end{array}$ & $\begin{array}{l}\text { Intervention } \\
\text { and } \\
\text { Comparison } \\
\mathrm{s} \text { (N of } \\
\text { Patients) }\end{array}$ & $\begin{array}{l}\text { Characteristics of Interventions } \\
\text { (Psychotherapy: Components, } \\
\text { Delivery Model)/Pharm: Drug) } \\
\text { Intensity, Duration (Weeks)) }\end{array}$ & $\begin{array}{c}\text { Patient Characteristics Mean } \\
\text { Age (Range), Male (\%), } \\
\text { Race/Ethnicity, Comorbidity, } \\
\text { Household Income, Parent } \\
\text { Education, Family } \\
\text { Dysfunction/Stressor, } \\
\text { Treatment Sequence, } \\
\text { Insurance, History of } \\
\text { Maltreatment) }\end{array}$ & $\begin{array}{c}\text { Length } \\
\text { of } \\
\text { Follow } \\
\text { up } \\
\text { (Weeks } \\
\text { ) }\end{array}$ \\
\hline & & & & & $\begin{array}{l}\text { High income: } 67 \% \\
\text { Less than high school or high } \\
\text { school graduate (parent): } 8 \% \\
\text { Some college (parent): } 17 \% \\
\text { College graduate (parent): } 71 \%\end{array}$ & \\
\hline \multirow[t]{3}{*}{$\begin{array}{l}\text { Khanna, } \\
2010^{102}\end{array}$} & \multirow[t]{3}{*}{$\begin{array}{l}\text { United States } \\
\text { RCT } \\
\text { Efficacy } \\
\text { Mental health } \\
\text { clinic }\end{array}$} & \multirow[t]{3}{*}{$\begin{array}{l}\text { GAD, PD, SAD, } \\
\text { SoP, SP }\end{array}$} & $\begin{array}{l}\text { Child CBT, } \\
(\mathrm{N}=17)\end{array}$ & $\begin{array}{l}\text { Coping Cat } \\
\text { Exposure } \\
\text { Relaxation } \\
\text { Cognitive problem solving } \\
\text { Individual-based } \\
\text { Delivered by psychologist, student/ } \\
\text { trainee } \\
\text { Weekly for } 12 \text { weeks, } 50 \text { minute } \\
\text { sessions }\end{array}$ & & \\
\hline & & & $\begin{array}{l}\text { Distance, } \\
(\mathrm{N}=16)\end{array}$ & $\begin{array}{l}\text { Camp Cope a Lot } \\
\text { Exposure } \\
\text { Relaxation } \\
\text { Cognitive problem solving } \\
\text { Individual based } \\
\text { Delivered by psychologist, student/ } \\
\text { trainee } \\
\text { Weekly for } 12 \text { weeks, }\end{array}$ & & \\
\hline & & & $\begin{array}{l}\text { Control, } \\
(\mathrm{N}=16)\end{array}$ & $\begin{array}{l}\text { Attention control or treatment as } \\
\text { usual } \\
\text { Individual-based } \\
\text { Technology-based } \\
\text { Delivered by psychologist, student/ } \\
\text { trainee } \\
\text { Weekly for } 12 \text { weeks, } 60 \text { minute } \\
\text { sessions. } 30 \text { minutes of support and } \\
30 \text { minutes of computer. }\end{array}$ & & \\
\hline Lyneham, & $\begin{array}{l}\text { Australia } \\
\text { RCT }\end{array}$ & $\begin{array}{l}\text { GAD, PD } \\
\text { (agoraphobia is }\end{array}$ & $\begin{array}{l}\text { Distance } \\
\text { Therapy, }\end{array}$ & $\begin{array}{l}\text { Other: Client initiated } \\
\text { Individual based }\end{array}$ & $\begin{array}{l}\text { Age mean (years): } 9.42 \text { (Range 6- } \\
\text { 12) }\end{array}$ & 12 \\
\hline
\end{tabular}




\begin{tabular}{|c|c|c|c|c|c|c|}
\hline Author, Year & $\begin{array}{l}\text { Study Country, } \\
\text { Study Design, } \\
\text { Type of Study } \\
\text { (Efficacyl } \\
\text { Effectiveness), } \\
\text { Study Settings }\end{array}$ & $\begin{array}{c}\text { Type of } \\
\text { Anxiety/Severity } \\
\text { (CGI) }\end{array}$ & $\begin{array}{l}\text { Intervention } \\
\text { and } \\
\text { Comparison } \\
\mathrm{s} \text { (N of } \\
\text { Patients) }\end{array}$ & $\begin{array}{l}\text { Characteristics of Interventions } \\
\text { (Psychotherapy: Components, } \\
\text { Delivery Model)/Pharm: Drug) } \\
\text { Intensity, Duration (Weeks)) }\end{array}$ & $\begin{array}{c}\text { Patient Characteristics Mean } \\
\text { Age (Range), Male (\%), } \\
\text { Race/Ethnicity, Comorbidity, } \\
\text { Household Income, Parent } \\
\text { Education, Family } \\
\text { Dysfunction/Stressor, } \\
\text { Treatment Sequence, } \\
\text { Insurance, History of } \\
\text { Maltreatment) } \\
\end{array}$ & $\begin{array}{l}\text { Length } \\
\text { of } \\
\text { Follow } \\
\text { up } \\
\text { (Weeks } \\
\text { ) }\end{array}$ \\
\hline \multirow[t]{4}{*}{$2006^{131}$} & \multirow[t]{4}{*}{$\begin{array}{l}\text { Efficacy } \\
\text { Mental health } \\
\text { clinic }\end{array}$} & \multirow[t]{4}{*}{$\begin{array}{l}\text { not specified), } \\
\text { SAD, SP, SoP }\end{array}$} & $(\mathrm{N}=28)$ & $\begin{array}{l}\text { Contact as needed by phone/email } \\
\text { over } 12 \text { weeks work } \\
\text { Delivered by a Masters level clinician }\end{array}$ & \multirow{4}{*}{$\begin{array}{l}\text { Male: } 49 \% \\
\text { Caucasian; } 96 \% \\
\text { Asian: } 1 \% \\
\text { Other: } 3 \% \\
\text { Low income: } n=26 \\
\text { Medium income: } n=42 \\
\text { High income: } n=26\end{array}$} & \\
\hline & & & $\begin{array}{l}\text { Distance } \\
\text { Therapy, } \\
(\mathrm{N}=21)\end{array}$ & $\begin{array}{l}\text { Other: Telephone CBT } \\
\text { Technology based } \\
\text { Individual based } \\
9 \text { scheduled telephone calls; weekly } \\
\text { sessions for the first } 6 \text { weeks and bi- } \\
\text { weekly for the final } 6 \text { weeks } \\
\text { Delivered by a Masters level clinician }\end{array}$ & & \\
\hline & & & $\begin{array}{l}\text { Distance } \\
\text { Therapy, } \\
(\mathrm{N}=29)\end{array}$ & $\begin{array}{l}\text { Other: Email Psychotherapy, } \\
\text { Technology based } \\
\text { Individual based } \\
9 \text { scheduled emails, plus ad hoc } \\
\text { replies; weekly sessions for the first } \\
6 \text { weeks and bi-weekly for the final } 6 \\
\text { weeks } \\
\text { Delivered by a Master level clinician }\end{array}$ & & \\
\hline & & & $\begin{array}{l}\text { Control, } \\
(\mathrm{N}=22)\end{array}$ & Waitlisting or no treatment & & \\
\hline $\begin{array}{l}\text { March, } \\
2009^{132}\end{array}$ & $\begin{array}{l}\text { Australia } \\
\text { RCT } \\
\text { Efficacy } \\
\text { Mental health } \\
\text { clinic }\end{array}$ & $\begin{array}{l}\text { GAD, SAD, SP, } \\
\text { SoP. }\end{array}$ & $\begin{array}{l}\text { Distance } \\
\text { Therapy, } \\
(\mathrm{N}=40)\end{array}$ & $\begin{array}{l}\text { Brave online } \\
\text { Individual based } \\
\text { Technology based } \\
\text { Exposure } \\
\text { Relaxation } \\
\text { Cognitive problem solving } \\
10 \text { weekly, 60-min child sessions and } \\
6 \text { weekly, 60-min parent sessions. } \\
\text { Two booster sessions con- ducted } 1 \\
\text { and } 3 \text { months; weekly online contact, } \\
2 \text { telephone calls } \\
\text { Delivered by a doctoral level } \\
\text { psychologist }\end{array}$ & $\begin{array}{l}\text { Age mean (years): } 9.75 \text { (Range } 7 \\
-12 \text { ) } \\
\text { Male: } 47.5 \% \\
\text { Low income: } n=8 \\
\text { Medium income: } n=17 \\
\text { High income: } n=15\end{array}$ & 36 \\
\hline
\end{tabular}




\begin{tabular}{|c|c|c|c|c|c|c|}
\hline Author, Year & $\begin{array}{l}\text { Study Country, } \\
\text { Study Design, } \\
\text { Type of Study } \\
\text { (Efficacyl } \\
\text { Effectiveness), } \\
\text { Study Settings }\end{array}$ & $\begin{array}{c}\text { Type of } \\
\text { Anxiety/Severity } \\
\text { (CGI) }\end{array}$ & $\begin{array}{l}\text { Intervention } \\
\text { and } \\
\text { Comparison } \\
\text { s (N of } \\
\text { Patients) }\end{array}$ & $\begin{array}{l}\text { Characteristics of Interventions } \\
\text { (Psychotherapy: Components, } \\
\text { Delivery Model)/Pharm: Drug) } \\
\text { Intensity, Duration (Weeks)) }\end{array}$ & $\begin{array}{c}\text { Patient Characteristics Mean } \\
\text { Age (Range), Male (\%), } \\
\text { Race/Ethnicity, Comorbidity, } \\
\text { Household Income, Parent } \\
\text { Education, Family } \\
\text { Dysfunction/Stressor, } \\
\text { Treatment Sequence, } \\
\text { Insurance, History of } \\
\text { Maltreatment) }\end{array}$ & $\begin{array}{l}\text { Length } \\
\text { of } \\
\text { Follow } \\
\text { up } \\
\text { (Weeks } \\
\text { ) }\end{array}$ \\
\hline & & & $\begin{array}{l}\text { Control, } \\
(\mathrm{N}=33)\end{array}$ & Waitlisting or no treatment & $\begin{array}{l}\text { Age mean (years): } 9.09 \text { (Range } 7 \\
-12 \text { ) } \\
\text { Male: } 42.4 \% \\
\text { Low income: } n=4 \\
\text { Medium income: } n=16 \\
\text { High income: } n=13\end{array}$ & \\
\hline \multirow[t]{3}{*}{$\begin{array}{l}\text { Rapee, } \\
2006^{69}\end{array}$} & \multirow[t]{3}{*}{$\begin{array}{l}\text { Australia } \\
\text { RCT } \\
\text { Efficacy } \\
\text { Mental health } \\
\text { clinic }\end{array}$} & \multirow[t]{3}{*}{$\begin{array}{l}\text { GAD, PD } \\
\text { (agoraphobia is } \\
\text { not specified), } \\
\text { SAD, SP, SoP. }\end{array}$} & $\begin{array}{l}\text { Child and } \\
\text { parent } \\
\text { together } \mathrm{CBT} \text {, } \\
(\mathrm{N}=90)\end{array}$ & $\begin{array}{l}\text { Cool Kids } \\
\text { Group based } \\
\text { Exposure } \\
\text { Cognitive problem solving } \\
92 \text {-hour sessions over } 12 \text { weeks } \\
\text { Delivered by student trainee. }\end{array}$ & $\begin{array}{l}\text { Age mean (years): } 9.475 \text { (Range: } \\
6-12) \\
\text { Male: } 66.6 \% \\
\text { Low income: } n=26(<\$ 30,000)\end{array}$ & \multirow[t]{3}{*}{36} \\
\hline & & & $\begin{array}{l}\text { Distance } \\
\text { Therapy, } \\
(\mathrm{N}=90)\end{array}$ & $\begin{array}{l}\text { Other: Bibliotherapy } \\
\text { Individual based } \\
\text { Exposure } \\
\text { Relaxation } \\
\text { Cognitive problem solving } \\
\text { Treatment duration is } 12 \text { weeks at } \\
\text { own pace }\end{array}$ & $\begin{array}{l}\text { Age mean (years): } 9.558 \text { (Range: } \\
6-12) \\
\text { Male: } 64.44 \% \\
\text { Low income: } n=9(<\$ 30,000)\end{array}$ & \\
\hline & & & $\begin{array}{l}\text { Control, } \\
(\mathrm{N}=87)\end{array}$ & Waitlisting or no treatment & $\begin{array}{l}\text { Age mean (years): } 9.5 \text { (Range: } 6 \\
-12 \text { ) } \\
\text { Male: } 48.2 \% \\
\text { Low income: } n=15(<\$ 30,000)\end{array}$ & \\
\hline $\begin{array}{l}\text { Spence, } \\
2006^{81}\end{array}$ & $\begin{array}{l}\text { Australia } \\
\text { RCT } \\
\text { Efficacy } \\
\text { Mental health } \\
\text { clinic }\end{array}$ & $\begin{array}{l}\text { GAD, SAD, SP } \\
\text { SoP }\end{array}$ & $\begin{array}{l}\text { Child CBT } \\
\text { plus separate } \\
\text { parent } \\
\text { intervention, } \\
(\mathrm{N}=22)\end{array}$ & $\begin{array}{l}\text { Generic CBT } \\
\text { Group based } \\
\text { Exposure } \\
\text { Relaxation } \\
\text { Cognitive problem solving } \\
1060 \text {-minute weekly child sessions } \\
\text { and } 6 \text { 60-minute weekly parent } \\
\text { sessions, plus booster sessions at } 1 \\
\text { and } 3 \text { months } \\
\text { Delivered by } 5 \text { doctoral level } \\
\text { psychologists. }\end{array}$ & $\begin{array}{l}\text { Age mean (years): } 10.26 \text { (Range } \\
7-14 \text { ) } \\
\text { Male: } 59 \%\end{array}$ & 12 \\
\hline
\end{tabular}




\begin{tabular}{|c|c|c|c|c|c|c|}
\hline Author, Year & $\begin{array}{l}\text { Study Country, } \\
\text { Study Design, } \\
\text { Type of Study } \\
\text { (Efficacyl } \\
\text { Effectiveness), } \\
\text { Study Settings }\end{array}$ & $\begin{array}{c}\text { Type of } \\
\text { Anxiety/Severity } \\
\text { (CGI) }\end{array}$ & $\begin{array}{l}\text { Intervention } \\
\text { and } \\
\text { Comparison } \\
\mathrm{s} \text { (N of } \\
\text { Patients) }\end{array}$ & $\begin{array}{l}\text { Characteristics of Interventions } \\
\text { (Psychotherapy: Components, } \\
\text { Delivery Model)/Pharm: Drug) } \\
\text { Intensity, Duration (Weeks)) }\end{array}$ & $\begin{array}{c}\text { Patient Characteristics Mean } \\
\text { Age (Range), Male (\%), } \\
\text { Race/Ethnicity, Comorbidity, } \\
\text { Household Income, Parent } \\
\text { Education, Family } \\
\text { Dysfunction/Stressor, } \\
\text { Treatment Sequence, } \\
\text { Insurance, History of } \\
\text { Maltreatment) } \\
\end{array}$ & $\begin{array}{c}\text { Length } \\
\text { of } \\
\text { Follow } \\
\text { up } \\
\text { (Weeks } \\
\text { ) }\end{array}$ \\
\hline & & & $\begin{array}{l}\text { Distance } \\
\text { Therapy, } \\
(\mathrm{N}=27)\end{array}$ & $\begin{array}{l}\text { Generic CBT } \\
\text { Internet CBT } \\
\text { Group based } \\
\text { Exposure } \\
\text { Relaxation } \\
\text { Cognitive problem solving } \\
5 \text { of the } 10 \text { child sessions plus the 3- } \\
\text { month booster via Internet, with the } \\
\text { remaining sessions being conducted } \\
\text { in the clinic; } 3 \text { of the } 6 \text { parents } \\
\text { sessions and the } 3 \text {-month via } \\
\text { Internet } \\
\text { Delivered through the internet }\end{array}$ & $\begin{array}{l}\text { Age mean (years): } 9.8 \text { (Range } 7- \\
\text { 14) } \\
\text { Male: } 59.2 \%\end{array}$ & \\
\hline & & & $\begin{array}{l}\text { Control, } \\
(\mathrm{N}=23)\end{array}$ & Waitlisting or no treatment & $\begin{array}{l}\text { Age mean (years): } 9.8 \text { (Range 7- } \\
\text { 14) } \\
\text { Male: } 56.5 \%\end{array}$ & \\
\hline \multirow[t]{2}{*}{$\begin{array}{l}\text { Spence, } \\
2011^{82}\end{array}$} & \multirow[t]{2}{*}{$\begin{array}{l}\text { Australia } \\
\text { RCT } \\
\text { Efficacy } \\
\text { Mental health } \\
\text { clinic }\end{array}$} & \multirow[t]{2}{*}{$\begin{array}{l}\text { GAD, SAD, SoP, } \\
\text { SP }\end{array}$} & $\begin{array}{l}\text { Distance } \\
\text { Therapy, } \\
(\mathrm{N}=44)\end{array}$ & $\begin{array}{l}\text { Brave online } \\
\text { Technology-based } \\
\text { Individual based } \\
\text { Exposure } \\
\text { Relaxation } \\
\text { Cognitive problem solving } \\
10 \text { adolescents weekly sessions and } \\
5 \text { parent sessions ( } 60 \text { minutes each) } \\
\text { over } 12 \text { weeks; } 115 \text {-minute phone } \\
\text { call, email feedback after each } \\
\text { session } \\
\text { Delivered by psychologist, Masters } \\
\text { level clinician }\end{array}$ & \multirow[t]{2}{*}{$\begin{array}{l}\text { Age mean (years): } 13.98 \text { (range: } \\
\text { 12-18) } \\
\text { Males: } 41 \% \\
\text { High income(>\$76,910): } 47 \% \\
\text { College graduate (parent): } 58 \% \\
\text { Depression: } 2.6 \% \\
\text { ODD: } 1.7 \% \\
\text { Dysthymic disorder: } 9.7 \%\end{array}$} & \multirow[t]{2}{*}{52} \\
\hline & & & $\begin{array}{l}\text { Child CBT } \\
\text { plus separate } \\
\text { parent } \\
\text { intervention, } \\
(\mathrm{N}=44)\end{array}$ & $\begin{array}{l}\text { Individual based } \\
\text { Exposure } \\
\text { Relaxation } \\
\text { Cognitive problem solving } \\
10 \text { adolescents weekly sessions and } \\
5 \text { parent sessions ( } 60 \text { minutes each) }\end{array}$ & & \\
\hline
\end{tabular}




\begin{tabular}{|c|c|c|c|c|c|c|}
\hline Author, Year & $\begin{array}{c}\text { Study Country, } \\
\text { Study Design, } \\
\text { Type of Study } \\
\text { (Efficacyl } \\
\text { Effectiveness), } \\
\text { Study Settings }\end{array}$ & $\begin{array}{c}\text { Type of } \\
\text { Anxiety/Severity } \\
\text { (CGI) }\end{array}$ & $\begin{array}{c}\text { Intervention } \\
\text { and } \\
\text { Comparison } \\
\text { s (N of } \\
\text { Patients) }\end{array}$ & $\begin{array}{l}\text { Characteristics of Interventions } \\
\text { (Psychotherapy: Components, } \\
\text { Delivery Model)/Pharm: Drug) } \\
\text { Intensity, Duration (Weeks)) }\end{array}$ & $\begin{array}{c}\text { Patient Characteristics Mean } \\
\text { Age (Range), Male (\%), } \\
\text { Race/Ethnicity, Comorbidity, } \\
\text { Household Income, Parent } \\
\text { Education, Family } \\
\text { Dysfunction/Stressor, } \\
\text { Treatment Sequence, } \\
\text { Insurance, History of } \\
\text { Maltreatment) }\end{array}$ & $\begin{array}{c}\text { Length } \\
\text { of } \\
\text { Follow } \\
\text { up } \\
\text { (Weeks } \\
\text { ) }\end{array}$ \\
\hline & & & & $\begin{array}{l}\text { over } 12 \text { weeks } \\
\text { Delivered by psychologist, Masters } \\
\text { level clinician }\end{array}$ & & \\
\hline & & & $\begin{array}{l}\text { Control, } \\
(\mathrm{N}=27)\end{array}$ & Waitlisting or no treatment & & \\
\hline \multirow[t]{3}{*}{$\begin{array}{l}\text { Spence, } \\
2017^{133}\end{array}$} & \multirow[t]{3}{*}{$\begin{array}{l}\text { Australia } \\
\text { RCT } \\
\text { Efficacy } \\
\text { Mental health } \\
\text { clinic }\end{array}$} & \multirow[t]{3}{*}{$\begin{array}{l}\text { GAD } \\
\text { SAD } \\
\text { SoP } \\
\text { SP }\end{array}$} & $\begin{array}{l}\text { Distance } \\
\text { Therapy: } \\
(\mathrm{N}=48)\end{array}$ & $\begin{array}{l}\text { BRAVE online } \\
\text { Exposure } \\
\text { Relaxation } \\
\text { Cognitive problem solving } \\
\text { Individual based } \\
\text { Delivered by doctoral level } \\
\text { psychologists } \\
\text { 10, 60min weekly sessions, 5-6 } \\
\text { parent sessions }\end{array}$ & $\begin{array}{l}\text { Age mean (years): } 11.02 \text { (Range } \\
\text { 8-17) } \\
\text { Males:46\% } \\
\text { Caucasian: } 92 \% \\
\text { African Americans: } 4 \% \\
\text { Asian: } 4 \% \\
\text { Low income (<76,761.50): } 58 \% \\
\text { High income (>\$76761.50): } 37.5 \% \\
\text { Other comorbidities: } 10 \%\end{array}$ & \multirow[t]{3}{*}{26} \\
\hline & & & $\begin{array}{l}\text { Distance } \\
\text { Therapy: } \\
(\mathrm{N}=47)\end{array}$ & $\begin{array}{l}\text { Other Therapy } \\
\text { Exposure } \\
\text { Relaxation } \\
\text { Cognitive problem solving } \\
\text { Individual based } \\
\text { Delivered by doctoral level } \\
\text { psychologists } \\
\text { 10, 60min weekly sessions, 5-6 } \\
\text { parent sessions }\end{array}$ & $\begin{array}{l}\text { Age mean (years): } 11.34 \text { (Range } \\
\text { 8-17) } \\
\text { Males: } 30 \% \\
\text { Caucasian: } 98 \% \\
\text { Asian: } 2 \% \\
\text { Low income (<76,761.50): 5\% } \\
\text { High income (>\$76761.50): } 36 \% \\
\text { Dysthymia:11\% } \\
\text { Other comorbidities:9\% }\end{array}$ & \\
\hline & & & $\begin{array}{l}\text { Control: } \\
(\mathrm{N}=30)\end{array}$ & Waitlisting or no treatment & $\begin{array}{l}\text { Age mean (years): } 11.6 \text { (Range 8- } \\
17) \\
\text { Males: } 46 \% \\
\text { Caucasian: } 100 \% \\
\text { Low income }(<76,761.50): 46 \% \\
\text { High income }(>\$ 76761.50): 53 \% \\
\text { Dysthymia:13\% } \\
\text { Other comorbidities:3\% }\end{array}$ & \\
\hline $\begin{array}{l}\text { Tillfors, } \\
2011^{134}\end{array}$ & $\begin{array}{l}\text { Sweden } \\
\text { RCT } \\
\text { Efficacy }\end{array}$ & SoP & $\begin{array}{l}\text { Distance } \\
\text { Therapy, } \\
(\mathrm{N}=10)\end{array}$ & $\begin{array}{l}\text { Generic CBT } \\
\text { Technology based } \\
\text { Individual based }\end{array}$ & $\begin{array}{l}\text { Age mean (years): } 16.5 \\
\text { Male: } 10 \%\end{array}$ & 0 \\
\hline
\end{tabular}




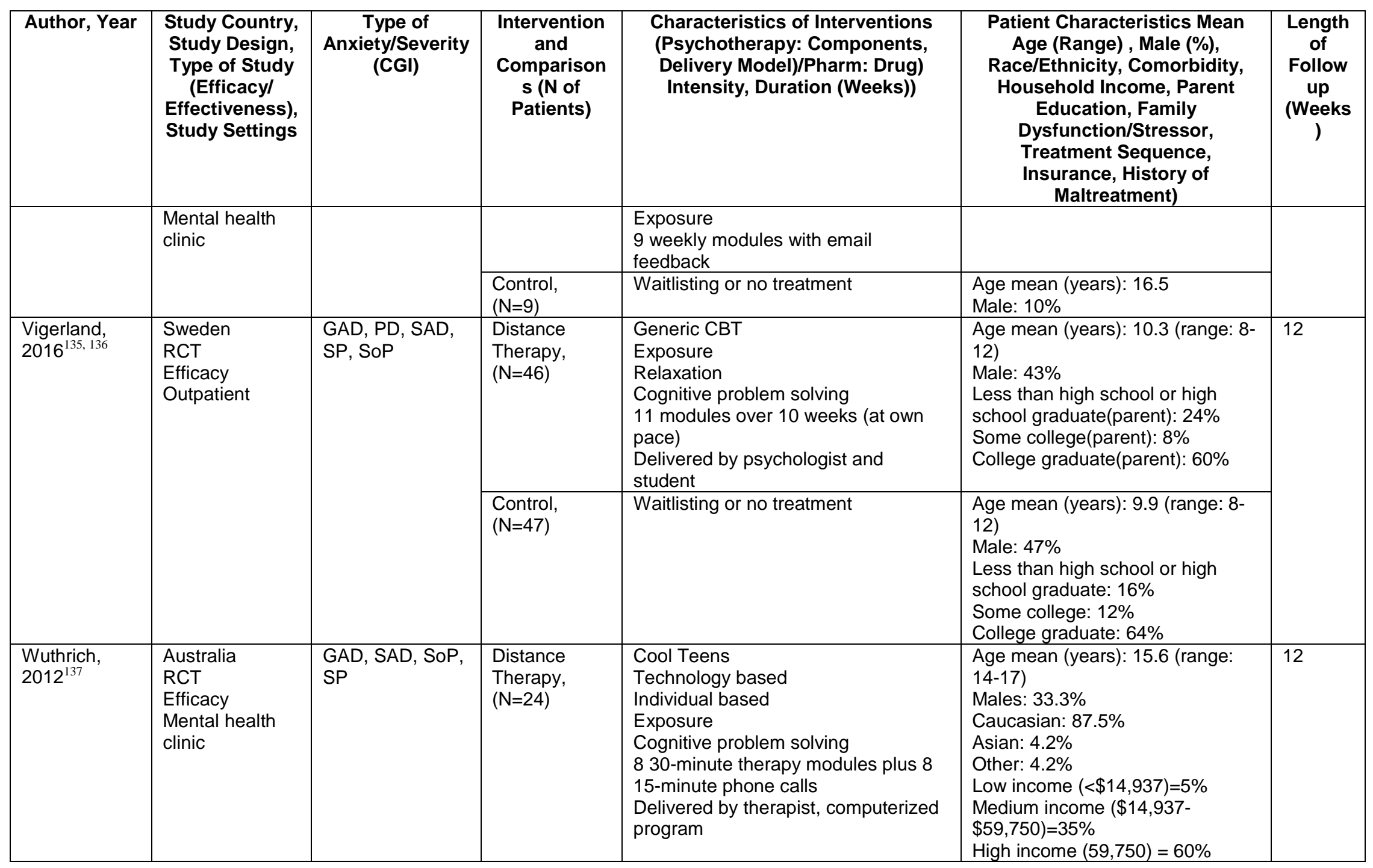




\begin{tabular}{|c|c|c|c|c|c|c|}
\hline Author, Year & $\begin{array}{l}\text { Study Country, } \\
\text { Study Design, } \\
\text { Type of Study } \\
\text { (Efficacyl } \\
\text { Effectiveness), } \\
\text { Study Settings }\end{array}$ & $\begin{array}{c}\text { Type of } \\
\text { AnxietylSeverity } \\
\text { (CGI) }\end{array}$ & $\begin{array}{c}\text { Intervention } \\
\text { and } \\
\text { Comparison } \\
\text { s (N of } \\
\text { Patients) }\end{array}$ & $\begin{array}{l}\text { Characteristics of Interventions } \\
\text { (Psychotherapy: Components, } \\
\text { Delivery Model)/Pharm: Drug) } \\
\text { Intensity, Duration (Weeks)) }\end{array}$ & $\begin{array}{c}\text { Patient Characteristics Mean } \\
\text { Age (Range), Male (\%), } \\
\text { Race/Ethnicity, Comorbidity, } \\
\text { Household Income, Parent } \\
\text { Education, Family } \\
\text { Dysfunction/Stressor, } \\
\text { Treatment Sequence, } \\
\text { Insurance, History of } \\
\text { Maltreatment) }\end{array}$ & $\begin{array}{l}\text { Length } \\
\text { of } \\
\text { Follow } \\
\text { up } \\
\text { (Weeks } \\
\text { ) }\end{array}$ \\
\hline & & & $\begin{array}{l}\text { Control, } \\
(\mathrm{N}=19)\end{array}$ & Waitlisting or no treatment & $\begin{array}{l}\text { Age mean (years): } 15.4 \text { (range: } \\
\text { 14-17) } \\
\text { Males: } 42.1 \% \\
\text { Caucasian: } 84 \% \\
\text { Asian: } 5.3 \% \\
\text { Other: } 5.3 \% \\
\text { Low income }(<\$ 14,937)=5.3 \% \\
\text { Medium income }(\$ 14,937- \\
\$ 59,750)=36.8 \% \\
\text { High income }(>\$ 59,750)=57.9 \%\end{array}$ & \\
\hline
\end{tabular}

behavioral therapy, CGI: clinical global impression scale, EMDR: eye movement desensitization and reprocessing, GAD: generalized anxiety disorder, ODD: oppositional defiant disorder, PD: panic disorder, PTSD: posttraumatic stress disorder, RCT: randomized controlled trial, SAD: separation anxiety disorder, SoP: social anxiety, SP: specific phobia. 
Table E.11. Characteristics of studies comparing different components of distance therapy

\begin{tabular}{|c|c|c|c|c|c|c|}
\hline Author, Year & $\begin{array}{l}\text { Study Country, } \\
\text { Study Design, } \\
\text { Type of Study } \\
\text { (Efficacyl } \\
\text { Effectiveness), } \\
\text { Study Settings }\end{array}$ & $\begin{array}{c}\text { Type of } \\
\text { AnxietylSeverity } \\
\text { (CGI) }\end{array}$ & $\begin{array}{l}\text { Intervention } \\
\text { and } \\
\text { Comparison } \\
\text { s (N of } \\
\text { Patients) }\end{array}$ & $\begin{array}{l}\text { Characteristics of Interventions } \\
\text { (Psychotherapy: Components, } \\
\text { Delivery Model)/Pharm: Drug) } \\
\text { Intensity, Duration (Weeks)) }\end{array}$ & $\begin{array}{l}\text { Patient Characteristics Mean } \\
\text { Age (Range), Male (\%), } \\
\text { Race/Ethnicity, Comorbidity, } \\
\text { Household Income, Parent } \\
\text { Education, Family } \\
\text { Dysfunction/Stressor, } \\
\text { Treatment Sequence, } \\
\text { Insurance, History of } \\
\text { Maltreatment) }\end{array}$ & $\begin{array}{l}\text { Length } \\
\text { of } \\
\text { Follow } \\
\text { up } \\
\text { (Weeks } \\
\text { ) }\end{array}$ \\
\hline \multirow[t]{4}{*}{$\begin{array}{l}\text { Lyneham, } \\
2006^{131}\end{array}$} & \multirow[t]{4}{*}{$\begin{array}{l}\text { Australia } \\
\text { RCT } \\
\text { Efficacy } \\
\text { Outpatient }\end{array}$} & \multirow[t]{4}{*}{$\begin{array}{l}\text { GAD, PD } \\
\text { (agoraphobia is } \\
\text { not specified), } \\
\text { SAD, SP, SoP }\end{array}$} & $\begin{array}{l}\text { Distance } \\
\text { Therapy, } \\
(\mathrm{N}=28)\end{array}$ & $\begin{array}{l}\text { Other: Client initiated } \\
\text { Individual based } \\
\text { Contact as needed by phone/email } \\
\text { over } 12 \text { weeks work } \\
\text { Delivered by a Masters level clinician }\end{array}$ & \multirow{4}{*}{$\begin{array}{l}\text { Age mean (years): } 9.42 \text { (Range 6- } \\
\text { 12) } \\
\text { Male: } 49 \% \\
\text { Caucasian; } 96 \% \\
\text { Asian: } 1 \% \\
\text { Other: } 3 \% \\
\text { Low income: } n=26 \\
\text { Medium income: } n=42 \\
\text { High income: } n=26\end{array}$} & \multirow[t]{4}{*}{12} \\
\hline & & & $\begin{array}{l}\text { Distance } \\
\text { Therapy, } \\
(\mathrm{N}=21)\end{array}$ & $\begin{array}{l}\text { Other: Telephone CBT } \\
\text { Technology based } \\
\text { Individual based } \\
9 \text { scheduled telephone calls; weekly } \\
\text { sessions for the first } 6 \text { weeks and bi- } \\
\text { weekly for the final } 6 \text { weeks } \\
\text { Delivered by a Masters level clinician }\end{array}$ & & \\
\hline & & & $\begin{array}{l}\text { Distance } \\
\text { Therapy, } \\
(\mathrm{N}=29)\end{array}$ & $\begin{array}{l}\text { Other: Email Psychotherapy, } \\
\text { Technology based } \\
\text { Individual based } \\
9 \text { scheduled emails, plus ad hoc } \\
\text { replies; weekly sessions for the first } \\
6 \text { weeks and bi-weekly for the final } 6 \\
\text { weeks } \\
\text { Delivered by a Masters level clinician }\end{array}$ & & \\
\hline & & & $\begin{array}{l}\text { Control, } \\
(\mathrm{N}=22)\end{array}$ & Waitlisting or no treatment & & \\
\hline \multirow[t]{2}{*}{$\begin{array}{l}\text { Spence, } \\
2017^{133}\end{array}$} & \multirow[t]{2}{*}{$\begin{array}{l}\text { Australia } \\
\text { RCT } \\
\text { Efficacy } \\
\text { Mental health } \\
\text { clinic }\end{array}$} & \multirow[t]{2}{*}{$\begin{array}{l}\text { GAD, SAD, SoP, } \\
\text { SP }\end{array}$} & $\begin{array}{l}\text { Distance } \\
\text { Therapy: } \\
(\mathrm{N}=48)\end{array}$ & $\begin{array}{l}\text { BRAVE online } \\
\text { Exposure } \\
\text { Relaxation } \\
\text { Cognitive problem solving } \\
\text { Individual based } \\
\text { Delivered by doctoral level } \\
\text { psychologists } \\
10,60 \text { min weekly sessions, 5-6 } \\
\text { parent sessions }\end{array}$ & $\begin{array}{l}\text { Age mean (years): } 11.02 \text { (Range } \\
\text { 8-17) } \\
\text { Males:46\% } \\
\text { Caucasian: } 92 \% \\
\text { African Americans: } 4 \% \\
\text { Asian: } 4 \% \\
\text { Low income (<76,761.50): } 58 \% \\
\text { High income (>\$76761.50): } 37.5 \% \\
\text { Other comorbidities: } 10 \%\end{array}$ & \multirow[t]{2}{*}{26} \\
\hline & & & $\begin{array}{l}\text { Distance } \\
\text { Therapy: }\end{array}$ & $\begin{array}{l}\text { Other Therapy } \\
\text { Exposure }\end{array}$ & $\begin{array}{l}\text { Age mean (years): } 11.34 \text { (Range } \\
8-17)\end{array}$ & \\
\hline
\end{tabular}




\begin{tabular}{|c|c|c|c|c|c|c|}
\hline Author, Year & $\begin{array}{l}\text { Study Country, } \\
\text { Study Design, } \\
\text { Type of Study } \\
\text { (Efficacyl } \\
\text { Effectiveness), } \\
\text { Study Settings }\end{array}$ & $\begin{array}{c}\text { Type of } \\
\text { AnxietylSeverity } \\
\text { (CGI) }\end{array}$ & $\begin{array}{c}\text { Intervention } \\
\text { and } \\
\text { Comparison } \\
\text { s (N of } \\
\text { Patients) }\end{array}$ & $\begin{array}{l}\text { Characteristics of Interventions } \\
\text { (Psychotherapy: Components, } \\
\text { Delivery Model)/Pharm: Drug) } \\
\text { Intensity, Duration (Weeks)) }\end{array}$ & $\begin{array}{c}\text { Patient Characteristics Mean } \\
\text { Age (Range), Male (\%), } \\
\text { Race/Ethnicity, Comorbidity, } \\
\text { Household Income, Parent } \\
\text { Education, Family } \\
\text { Dysfunction/Stressor, } \\
\text { Treatment Sequence, } \\
\text { Insurance, History of } \\
\text { Maltreatment) } \\
\end{array}$ & 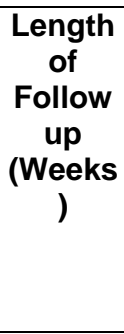 \\
\hline & & & $(\mathrm{N}=47)$ & $\begin{array}{l}\text { Relaxation } \\
\text { Cognitive problem solving } \\
\text { Individual based } \\
\text { Delivered by doctoral level } \\
\text { psychologists } \\
\text { 10, 60min weekly sessions, 5-6 } \\
\text { parent sessions }\end{array}$ & $\begin{array}{l}\text { Males: } 30 \% \\
\text { Caucasian: } 98 \% \\
\text { Asian: } 2 \% \text { Low income } \\
\text { (<76,761.50): } 5 \% \\
\text { High income (>\$76761.50): } 36 \% \\
\text { Dysthymia:11\% } \\
\text { Other comorbidities:9\% }\end{array}$ & \\
\hline & & & $\begin{array}{l}\text { Control: } \\
(\mathrm{N}=30)\end{array}$ & Waitlisting or no treatment & $\begin{array}{l}\text { Age mean (years): } 11.6 \text { (Range 8- } \\
\text { 17) } \\
\text { Males: } 46 \% \\
\text { Caucasian: } 100 \% \\
\text { Low income }(<76,761.50): 46 \% \\
\text { High income (>\$76761.50): 53\% } \\
\text { Dysthymia:13\% } \\
\text { Other comorbidities:3\% }\end{array}$ & \\
\hline
\end{tabular}

BRAVE: body signs, relaxation, active helpful thoughts, victory over your fears, enjoy! reward yourself. CBT: cognitive behavioral therapy, CGI: clinical global impression scale, GAD: generalized anxiety disorder, PD: panic disorder, RCT: randomized controlled trial, SAD: separation anxiety disorder, SoP: social anxiety, SP: specific phobia 
Table E.12. Characteristics of studies comparing attention bias modification versus wait listing or pill placebo

\begin{tabular}{|c|c|c|c|c|c|c|}
\hline Author, Year & $\begin{array}{l}\text { Study Country, } \\
\text { Study Design, } \\
\text { Type of Study } \\
\text { (Efficacyl } \\
\text { Effectiveness), } \\
\text { Study Settings }\end{array}$ & $\begin{array}{c}\text { Type of } \\
\text { AnxietylSeverity } \\
\text { (CGI) }\end{array}$ & $\begin{array}{l}\text { Intervention } \\
\text { and } \\
\text { Comparison } \\
s \text { ( } N \text { of } \\
\text { Patients) }\end{array}$ & $\begin{array}{l}\text { Characteristics of Interventions } \\
\text { (Psychotherapy: Components, } \\
\text { Delivery Model)/Pharm: Drug) } \\
\text { Intensity, Duration (Weeks)) }\end{array}$ & $\begin{array}{c}\text { Patient Characteristics Mean } \\
\text { Age (Range), Male (\%), } \\
\text { Race/Ethnicity, Comorbidity, } \\
\text { Household Income, Parent } \\
\text { Education, Family } \\
\text { Dysfunction/Stressor, } \\
\text { Treatment Sequence, } \\
\text { Insurance, History of } \\
\text { Maltreatment) }\end{array}$ & 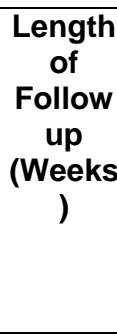 \\
\hline \multirow[t]{3}{*}{ Eldar, $2012^{138}$} & \multirow[t]{3}{*}{$\begin{array}{l}\text { Israel } \\
\text { RCT } \\
\text { Efficacy } \\
\text { Mental health } \\
\text { clinic }\end{array}$} & \multirow[t]{3}{*}{$\begin{array}{l}\text { GAD, SAD, SoP, } \\
\text { SP }\end{array}$} & $\begin{array}{l}\text { ABM plus } \\
\text { therapy, } \\
(\mathrm{N}=15)\end{array}$ & $\begin{array}{l}\text { Attention bias modification plus } \\
\text { therapy } \\
\text { Individual based } \\
\text { Attention bias modification } \\
4 \text { weekly sessions }\end{array}$ & $\begin{array}{l}\text { Age mean (years): } 9.5 \text { (range: 8- } \\
\text { 14) }\end{array}$ & \multirow[t]{3}{*}{ NR } \\
\hline & & & $\begin{array}{l}\text { Control, } \\
(\mathrm{N}=15)\end{array}$ & $\begin{array}{l}\text { Attention control or treatment as } \\
\text { usual } \\
\text { ABM placebo ABM stimuli without } \\
\text { attention training } \\
4 \text { weekly sessions }\end{array}$ & $\begin{array}{l}\text { Age mean (years): } 9.8 \text { (range: 8- } \\
\text { 14) }\end{array}$ & \\
\hline & & & $\begin{array}{l}\text { Control, } \\
(\mathrm{N}=10)\end{array}$ & $\begin{array}{l}\text { Attention control or treatment as } \\
\text { usual } \\
\text { ABM placebo } \\
\text { ABM neutral (only neutral stimuli) } \\
4 \text { weekly sessions }\end{array}$ & $\begin{array}{l}\text { Age mean (years): } 10.5 \text { (range: 8- } \\
\text { 14) }\end{array}$ & \\
\hline \multirow[t]{2}{*}{$\begin{array}{l}\text { Waters, } \\
2015^{139}\end{array}$} & \multirow[t]{2}{*}{$\begin{array}{l}\text { Australia } \\
\text { RCT } \\
\text { Efficacy }\end{array}$} & \multirow[t]{2}{*}{$\begin{array}{l}\text { GAD, SAD, SoP, } \\
\text { SP }\end{array}$} & ABM, $(\mathrm{N}=31)$ & $\begin{array}{l}\text { Attention bias modification } \\
\text { Technology based } \\
\text { Individual based } \\
12 \text { weekly sessions, at home }\end{array}$ & $\begin{array}{l}\text { Age mean (years): } 9 \\
\text { Male: } 39 \%\end{array}$ & \multirow[t]{2}{*}{26} \\
\hline & & & $\begin{array}{l}\text { Control, } \\
(\mathrm{N}=28)\end{array}$ & Waitlisting or no treatment & $\begin{array}{l}\text { Age mean (years): } 8.5 \\
\text { Male: } 47 \%\end{array}$ & \\
\hline
\end{tabular}

ABM: attention bias modification ,GAD: Generalized anxiety disorder, RCT: randomized control trial, SAD: separation anxiety disorder, SoP: social anxiety, SP: specific phobia. 
Table E.13. Characteristics of studies comparing combined attention bias modification intervention and other therapy versus other therapy

\begin{tabular}{|c|c|c|c|c|c|c|}
\hline Author, Year & $\begin{array}{l}\text { Study Country, } \\
\text { Study Design, } \\
\text { Type of Study } \\
\text { (Efficacyl } \\
\text { Effectiveness), } \\
\text { Study Settings }\end{array}$ & $\begin{array}{c}\text { Type of } \\
\text { AnxietylSeverity } \\
\text { (CGI) }\end{array}$ & $\begin{array}{l}\text { Intervention } \\
\text { and } \\
\text { Comparison } \\
\text { s (N of } \\
\text { Patients) }\end{array}$ & $\begin{array}{l}\text { Characteristics of Interventions } \\
\text { (Psychotherapy: Components, } \\
\text { Delivery Model)/Pharm: Drug) } \\
\text { Intensity, Duration (Weeks)) }\end{array}$ & $\begin{array}{c}\text { Patient Characteristics Mean } \\
\text { Age (Range), Male (\%), } \\
\text { Race/Ethnicity, Comorbidity, } \\
\text { Household Income, Parent } \\
\text { Education, Family } \\
\text { Dysfunction/Stressor, } \\
\text { Treatment Sequence, } \\
\text { Insurance, History of } \\
\text { Maltreatment) }\end{array}$ & $\begin{array}{l}\text { Length } \\
\text { of } \\
\text { Follow } \\
\text { up } \\
\text { (Weeks } \\
\text { ) }\end{array}$ \\
\hline \multirow[t]{2}{*}{$\begin{array}{l}\text { Britton, } 2013 \\
140\end{array}$} & \multirow[t]{2}{*}{$\begin{array}{l}\text { United States } \\
\text { RCT } \\
\text { Effectiveness } \\
\text { Mental health } \\
\text { clinic }\end{array}$} & \multirow[t]{2}{*}{$\begin{array}{l}\text { GAD, SAD, SoP, } \\
\text { SP }\end{array}$} & $\begin{array}{l}\text { ABM + CBT, } \\
(\mathrm{N}=18)\end{array}$ & $\begin{array}{l}\text { Other CBT } \\
\text { Exposure } \\
\text { Relaxation } \\
\text { Cognitive problem solving Individual } \\
\text { based } \\
\text { Delivered by psychologist } \\
8 \text { weekly sessions }\end{array}$ & $\begin{array}{l}\text { Age mean (years): } 11.4 \text { (range: 8- } \\
\text { 17) } \\
\text { Males: } 33 \% \\
\text { Depression: } 5.5 \%\end{array}$ & \multirow[t]{2}{*}{0} \\
\hline & & & $\begin{array}{l}\text { ABM control } \\
+\mathrm{CBT} \\
(\mathrm{N}=18)\end{array}$ & $\begin{array}{l}\text { Therapy placebo, Other CBT } \\
\text { Exposure } \\
\text { Relaxation } \\
\text { Cognitive problem solving(8 weekly } \\
\text { sessions }\end{array}$ & $\begin{array}{l}\text { Age mean (years): } 10.9 \text { (range: 8- } \\
\text { 17) } \\
\text { Males: } 33 \% \\
\text { Depression: } 5.5 \%\end{array}$ & \\
\hline \multirow[t]{2}{*}{$\begin{array}{l}\text { Pergamin- } \\
\text { Hight, } 2016^{141}\end{array}$} & \multirow{2}{*}{$\begin{array}{l}\text { Israel } \\
\text { RCT } \\
\text { Efficacy } \\
\text { Outpatient }\end{array}$} & $\begin{array}{l}\text { Anxiety disorder } \\
\text { (Social Anxiety } \\
\text { Disorder) }\end{array}$ & $\begin{array}{l}\text { ABM } \\
(N=36)\end{array}$ & $\begin{array}{l}\text { ABM } \\
\text { Individual based } \\
8, \text { bi weekly sessions }\end{array}$ & Age mean (years): 12.71 & \multirow[t]{2}{*}{12} \\
\hline & & & $\begin{array}{l}\text { Control } \\
(\mathrm{N}=31)\end{array}$ & $\begin{array}{l}\text { Attention control or treatment as } \\
\text { usual } \\
\text { ABM placebo }\end{array}$ & Age mean (years): 12.2 & \\
\hline \multirow[t]{2}{*}{$\begin{array}{l}\text { Waters, } \\
2014^{142}\end{array}$} & \multirow[t]{2}{*}{$\begin{array}{l}\text { Australia } \\
\text { RCT } \\
\text { Efficacy } \\
\text { Outpatient }\end{array}$} & \multirow[t]{2}{*}{ SP } & $\begin{array}{l}\text { ABM + OST, } \\
(N=19)\end{array}$ & $\begin{array}{l}\text { Exposure } \\
\text { Individual based } \\
\text { Delivered by student/trainee } \\
\text { One } 3 \mathrm{hr} \text { session, } 15 \text { min attention } \\
\text { bias modification training }\end{array}$ & $\begin{array}{l}\text { Age mean (years): } 10.06 \text { (range: } \\
6-17) \\
\text { Males: } 58 \% \\
\text { High income (>\$59,750): } 85 \% \\
\text { College graduate (parent): } 53 \%\end{array}$ & \multirow[t]{2}{*}{12} \\
\hline & & & $\begin{array}{l}\text { ABM control } \\
+ \text { OST, } \\
(\mathrm{N}=18)\end{array}$ & $\begin{array}{l}\text { Exposure, } \\
\text { Individual based } \\
\text { Delivered by student/trainee } \\
\text { One } 3 \mathrm{hr} \text { session }\end{array}$ & $\begin{array}{l}\text { Age mean (years): } 11.05 \text { (range: } \\
6-17) \backslash \\
\text { Males: } 72 \% \\
\text { High income }(>\$ 59,750): 88 \% \\
\text { College graduate (parent) : } 72 \%\end{array}$ & \\
\hline
\end{tabular}

ABM: attention bias modification, CBT: cognitive behavioral therapy, CGI: clinical global impression scale, GAD: generalized anxiety disorder, OST: one session treatment,

RCT: randomized controlled trial, SAD: separation anxiety disorder, SoP: social anxiety, SP: specific phobia. 
Table E.14. Characteristics of studies comparing mindfulness based CBT to waitlisting

\begin{tabular}{|c|c|c|c|c|c|c|}
\hline Author, Year & $\begin{array}{l}\text { Study Country, } \\
\text { Study Design, } \\
\text { Type of Study } \\
\text { (Efficacyl } \\
\text { Effectiveness), } \\
\text { Study Settings }\end{array}$ & $\begin{array}{c}\text { Type of } \\
\text { AnxietylSeverity } \\
\text { (CGI) }\end{array}$ & $\begin{array}{l}\text { Intervention } \\
\text { and } \\
\text { Comparison } \\
\text { s (N of } \\
\text { Patients) }\end{array}$ & $\begin{array}{l}\text { Characteristics of Interventions } \\
\text { (Psychotherapy: Components, } \\
\text { Delivery Model)/Pharm: Drug) } \\
\text { Intensity, Duration (Weeks)) }\end{array}$ & $\begin{array}{c}\text { Patient Characteristics Mean } \\
\text { Age (Range), Male (\%), } \\
\text { Race/Ethnicity, Comorbidity, } \\
\text { Household Income, Parent } \\
\text { Education, Family } \\
\text { Dysfunction/Stressor, } \\
\text { Treatment Sequence, } \\
\text { Insurance, History of } \\
\text { Maltreatment) }\end{array}$ & $\begin{array}{l}\text { Length } \\
\text { of } \\
\text { Follow } \\
\text { up } \\
\text { (Weeks } \\
\text { ) }\end{array}$ \\
\hline \multirow[t]{2}{*}{$\begin{array}{l}\text { Ebrahimineja } \\
\text { d, } 2016^{143}\end{array}$} & \multirow[t]{2}{*}{$\begin{array}{l}\text { Iran } \\
\text { RCT } \\
\text { Effectiveness } \\
\text { School }\end{array}$} & \multirow[t]{2}{*}{ SoP } & $\begin{array}{l}\text { Mindfulness } \\
\text { Based CBT } \\
:(N=15)\end{array}$ & $\begin{array}{l}\text { Cognitive problem solving } \\
\text { Group based } \\
\text { Delivered by Masters level clinician } \\
8,120 \text { min weekly sessions }\end{array}$ & $\begin{array}{l}\text { Age mean (years): } 14.5 \text { (Range: } \\
\text { 12-18) } \\
\text { Males: 0\% } \\
\text { Other Race: } 100 \% \\
\text { Medium income (middle class): } \\
\text { 100\% }\end{array}$ & \multirow[t]{2}{*}{ NR } \\
\hline & & & $\begin{array}{l}\text { Control: } \\
(\mathrm{N}=15)\end{array}$ & Waitlisting or no treatment & $\begin{array}{l}\text { Age mean (years): } 14.3 \text { (Range: } \\
\text { 12-18) } \\
\text { Males: } 0 \% \\
\text { Other Race: } 100 \% \\
\text { Medium income (middle class): } \\
\text { 100\% }\end{array}$ & \\
\hline
\end{tabular}

CGI: clinical global impression scale, RCT: randomized controlled trial, SoP: social anxiety 
Table E.15. Characteristics of studies comparing acceptance and commitment therapy versus waitlist or no treatment

\begin{tabular}{|c|c|c|c|c|c|c|}
\hline Author, Year & $\begin{array}{l}\text { Study Country, } \\
\text { Study Design, } \\
\text { Type of Study } \\
\text { (Efficacyl } \\
\text { Effectiveness), } \\
\text { Study Settings }\end{array}$ & $\begin{array}{c}\text { Type of } \\
\text { Anxiety/Severit } \\
\text { y (CGI) }\end{array}$ & $\begin{array}{l}\text { Intervention } \\
\text { and } \\
\text { Comparison } \\
\mathrm{s} \text { (N of } \\
\text { Patients) }\end{array}$ & $\begin{array}{l}\text { Characteristics of Interventions } \\
\text { (Psychotherapy: Components, } \\
\text { Delivery Model)/Pharm: Drug) } \\
\text { Intensity, Duration (Weeks)) }\end{array}$ & $\begin{array}{l}\text { Patient Characteristics Mean } \\
\text { Age (Range), Male (\%), } \\
\text { Race/Ethnicity, Comorbidity, } \\
\text { Household Income, Parent } \\
\text { Education, Family } \\
\text { Dysfunction/Stressor, } \\
\text { Treatment Sequence, } \\
\text { Insurance, History of } \\
\text { Maltreatment) }\end{array}$ & $\begin{array}{l}\text { Length } \\
\text { of } \\
\text { Follow } \\
\text { up } \\
\text { (Weeks } \\
\text { ) }\end{array}$ \\
\hline \multirow[t]{2}{*}{$\begin{array}{l}\text { Azadeh, } \\
2015^{144}\end{array}$} & \multirow{2}{*}{$\begin{array}{l}\text { Iran } \\
\text { RCT } \\
\text { Effectiveness } \\
\text { Mental health } \\
\text { clinic }\end{array}$} & \multirow[t]{2}{*}{ SoP } & $\begin{array}{l}\text { (ACT), } \\
(\mathrm{N}=\mathrm{NR})\end{array}$ & $\begin{array}{l}\text { Acceptance and commitment therapy } \\
\text { Group based } \\
10 \text { sessions, } 90 \text { minute sessions, } \\
\text { weekly }\end{array}$ & \multirow[t]{2}{*}{$\begin{array}{l}\text { Total number of patients: } 30 \\
\text { Age mean (years): } 15.3 \text { (range } \\
: 15-16 \text { ) } \\
\text { Male: } 0 \%\end{array}$} & \multirow[t]{2}{*}{0} \\
\hline & & & $\begin{array}{l}\text { Control, } \\
\mathrm{N}=\mathrm{NR})\end{array}$ & Waitlisting or no treatment & & \\
\hline \multirow[t]{3}{*}{$\begin{array}{l}\text { Hancock, } \\
2016^{44}\end{array}$} & \multirow[t]{3}{*}{$\begin{array}{l}\text { Australia } \\
\text { RCT } \\
\text { Effectiveness } \\
\text { Mental health } \\
\text { clinic }\end{array}$} & \multirow[t]{3}{*}{ GAD, SAD } & $\mathrm{ACT},(\mathrm{N}=68)$ & $\begin{array}{l}\text { Acceptance and commitment therapy } \\
\text { (ACT) } \\
\text { Group based } \\
\text { Relaxation } \\
10 \text { sessions, } 90 \text {-minute weekly } \\
\text { sessions } \\
\text { Delivered by doctoral level } \\
\text { psychologist }\end{array}$ & $\begin{array}{l}\text { Age mean (years): } 11.15 \text { ( range: } \\
7-17 \text { ) } \\
\text { Male: } 45.5 \% \\
\text { Caucasian: } 87 \% \text {, Asian: } 3 \%, \\
\text { Other: } 10 \% \\
\text { ADHD: } 6 \% \text {, Depression, } 18 \%, \\
\text { OCD: } 7.3 \% \\
\text { Treatment naïve: } 27.9 \%\end{array}$ & \multirow[t]{3}{*}{13} \\
\hline & & & $\begin{array}{l}\text { Child and } \\
\text { parent } \\
\text { together } \mathrm{CBT} \text {, } \\
(\mathrm{N}=63)\end{array}$ & $\begin{array}{l}\text { Cool Kids } \\
\text { Group based } \\
\text { Exposure } \\
\text { Cognitive problem solving } \\
10 \text { sessions, } 90 \text {-minute weekly } \\
\text { sessions } \\
\text { Delivered by doctoral level } \\
\text { psychologist }\end{array}$ & $\begin{array}{l}\text { Age mean (years): } 10.81 \text { ( range: } \\
7-17 \text { ) } \\
\text { Male: } 39.6 \% \\
\text { Caucasian: } 94.4 \% \text {, Other: } 5.6 \% \\
\text { ADHD: } 10 \% \text {, Depression, } 13 \% \text {, } \\
\text { OCD: } 3 \% \\
\text { Treatment naïve: } 22.2 \%\end{array}$ & \\
\hline & & & $\begin{array}{l}\text { Control, } \\
(\mathrm{N}=62)\end{array}$ & Waitlisting or no treatment & $\begin{array}{l}\text { Age mean (years): } 11.66 \text { ( range: } \\
7-17 \text { ) } \\
\text { Male: } 41.9 \% \\
\text { Caucasian: } 84 \% \text {, Other: } 16 \% \\
\text { Depression: } 24 \%, \text { OCD: } 8 \% \\
\text { Treatment naïve: } 70.9\end{array}$ & \\
\hline
\end{tabular}

ABM: attention bias modification, ACT: acceptance and commitment therapy, CBT: cognitive behavioral therapy, CGI: clinical global impression scale, GAD: generalized anxiety disorder, RCT: randomized controlled trial, SAD: separation anxiety disorder, SoP: social anxiety. 
Table E.16. Characteristics of studies comparing non-CBT psychoanalysis versus wait listing

\begin{tabular}{|c|c|c|c|c|c|c|}
\hline Author, Year & $\begin{array}{l}\text { Study Country, } \\
\text { Study Design, } \\
\text { Type of Study } \\
\text { (Efficacyl } \\
\text { Effectiveness), } \\
\text { Study Settings }\end{array}$ & $\begin{array}{c}\text { Type of } \\
\text { AnxietylSeverity } \\
\text { (CGI) }\end{array}$ & $\begin{array}{l}\text { Intervention } \\
\text { and } \\
\text { Comparison } \\
\text { s (N of } \\
\text { Patients) }\end{array}$ & $\begin{array}{l}\text { Characteristics of Interventions } \\
\text { (Psychotherapy: Components, } \\
\text { Delivery Model)/Pharm: Drug) } \\
\text { Intensity, Duration (Weeks)) }\end{array}$ & $\begin{array}{l}\text { Patient Characteristics Mean } \\
\text { Age (Range), Male (\%), } \\
\text { Race/Ethnicity, Comorbidity, } \\
\text { Household Income, Parent } \\
\text { Education, Family } \\
\text { Dysfunction/Stressor, } \\
\text { Treatment Sequence, } \\
\text { Insurance, History of } \\
\text { Maltreatment) }\end{array}$ & $\begin{array}{l}\text { Length } \\
\text { of } \\
\text { Follow } \\
\text { up } \\
\text { (Weeks } \\
\text { ) }\end{array}$ \\
\hline \multirow[t]{2}{*}{$\begin{array}{l}\text { Gottken, } \\
2014^{145}\end{array}$} & \multirow[t]{2}{*}{$\begin{array}{l}\text { Germany } \\
\text { RCT } \\
\text { Efficacy } \\
\text { Mental health } \\
\text { clinic }\end{array}$} & \multirow[t]{2}{*}{$\begin{array}{l}\text { GAD, PD, PD } \\
\text { with } \\
\text { agoraphobia, } \\
\text { SoP, SP }\end{array}$} & $\begin{array}{l}\text { Non-CBT } \\
\text { psychoanalysi } \\
\mathrm{s},(\mathrm{N}=18)\end{array}$ & $\begin{array}{l}\text { Short term psychoanalytic child } \\
\text { therapy } \\
\text { Individual based } \\
20-25 \text { weekly sessions } \\
\text { Delivered by psychologist, } \\
\text { psychiatrist }\end{array}$ & $\begin{array}{l}\text { Age mean (years) (years): } 7.07 \\
\text { (range: } 4-10 \text { ) } \\
\text { Males: } 61.1 \% \\
\text { Less than high school or high } \\
\text { school graduate (parent): } 37.5 \% \\
\text { Some college (parent): } 31.3 \% \\
\text { College graduate (parent): } 31.3 \% \\
\text { Depression: } 44.5 \%\end{array}$ & \multirow[t]{2}{*}{6} \\
\hline & & & $\begin{array}{l}\text { Control, } \\
(\mathrm{N}=12)\end{array}$ & Waitlisting or no treatment & $\begin{array}{l}\text { Age mean (years): } 7.06 \text { (range: 4- } \\
\text { 10) } \\
\text { Males: } 58.3 \% \\
\text { Less than high school or high } \\
\text { school graduate (parent): } 60 \% \\
\text { Some college (parent): } 10 \% \\
\text { College graduate (parent): } 30 \% \\
\text { Depression: } 41.7 \% \\
\text { Selective mutism: } 8.3 \%\end{array}$ & \\
\hline
\end{tabular}

CBT: cognitive behavioral therapy, CGI: clinical global impression scale, GAD: generalized anxiety disorder, PD: panic disorder, RCT: randomized controlled trial, SoP: social anxiety, SP: specific phobia. 
Table E.17. Characteristics of studies comparing other therapy versus waitlisting or attention control or treatment as usual

\begin{tabular}{|c|c|c|c|c|c|c|}
\hline Author, Year & $\begin{array}{l}\text { Study Country, } \\
\text { Study Design, } \\
\text { Type of Study } \\
\text { (Efficacyl } \\
\text { Effectiveness), } \\
\text { Study Settings }\end{array}$ & $\begin{array}{c}\text { Type of } \\
\text { Anxiety/Severity } \\
\text { (CGI) }\end{array}$ & $\begin{array}{l}\text { Intervention } \\
\text { and } \\
\text { Comparison } \\
\text { s (N of } \\
\text { Patients) }\end{array}$ & $\begin{array}{l}\text { Characteristics of Interventions } \\
\text { (Psychotherapy: Components, } \\
\text { Delivery Model)/Pharm: Drug) } \\
\text { Intensity, Duration (Weeks)) }\end{array}$ & $\begin{array}{c}\text { Patient Characteristics Mean } \\
\text { Age (Range), Male (\%), } \\
\text { Race/Ethnicity, Comorbidity, } \\
\text { Household Income, Parent } \\
\text { Education, Family } \\
\text { Dysfunction/Stressor, } \\
\text { Treatment Sequence, } \\
\text { Insurance, History of } \\
\text { Maltreatment) }\end{array}$ & $\begin{array}{l}\text { Length } \\
\text { of } \\
\text { Follow } \\
\text { up } \\
\text { (Weeks } \\
\text { ) }\end{array}$ \\
\hline \multirow[t]{3}{*}{$\underset{27}{\text { Abbasi, } 2016}$} & \multirow[t]{3}{*}{$\begin{array}{l}\text { Iran } \\
\text { RCT } \\
\text { Efficacy } \\
\text { Outpatient }\end{array}$} & \multirow[t]{3}{*}{ SAD } & $\begin{array}{l}\text { Child CBT } \\
(\mathrm{N}=15)\end{array}$ & $\begin{array}{l}\text { Modular CBT } \\
\text { Individual based } \\
\text { Exposure } \\
\text { Cognitive problem solving } \\
\text { 4-20 sessions, } 1 \text { hour sessions, with }\end{array}$ & $\begin{array}{l}\text { Age range : } 6-7 \text { years } \\
\text { Male: } 53 \%\end{array}$ & \multirow[t]{3}{*}{13} \\
\hline & & & $\begin{array}{l}\text { Other } \\
\text { Therapy, } \\
(\mathrm{N}=15)\end{array}$ & $\begin{array}{l}\text { Child parent relationship training } \\
\text { Individual based, } \\
10 \text { weekly, } 1 \text { hour sessions }\end{array}$ & $\begin{array}{l}\text { Age range : } 6-7 \text { years } \\
\text { Male: } 33.3 \%\end{array}$ & \\
\hline & & & $\begin{array}{l}\text { Control, } \\
(\mathrm{N}=16)\end{array}$ & Waitlisting or no treatment & $\begin{array}{l}\text { Age range : } 6-7 \text { years } \\
\text { Male: } 48 \%\end{array}$ & \\
\hline \multirow[t]{2}{*}{$\begin{array}{l}\text { Cornwall, } \\
1996^{146}\end{array}$} & \multirow[t]{2}{*}{$\begin{array}{l}\text { Australia } \\
\text { RCT } \\
\text { Effectiveness } \\
\text { Mental health } \\
\text { clinic }\end{array}$} & \multirow[t]{2}{*}{$\begin{array}{l}\text { SP (simple } \\
\text { phobia }\end{array}$} & $\begin{array}{l}\text { Other } \\
\text { Therapy, } \\
(\mathrm{N}=\mathrm{NR})\end{array}$ & $\begin{array}{l}\text { Reciprocal inhibition } \\
\text { Emotive imagery treatment condition } \\
\text { Individual based } \\
640 \text {-minute weekly sessions } \\
\text { Delivered by Masters level clinicians. }\end{array}$ & \multirow[t]{2}{*}{ Age range: $7-10$ years } & \multirow[t]{2}{*}{13} \\
\hline & & & $\begin{array}{l}\text { Control, } \\
\text { (N=NR) }\end{array}$ & Waitlisting or no treatment & & \\
\hline \multirow[t]{2}{*}{$\begin{array}{l}\text { Elkins, } \\
2016^{147}\end{array}$} & \multirow[t]{2}{*}{$\begin{array}{l}\text { United States } \\
\text { RCT } \\
\text { Efficacy } \\
\text { Mental health } \\
\text { clinic }\end{array}$} & \multirow[t]{2}{*}{ PD } & $\begin{array}{l}\text { Other } \\
\text { Therapy, } \\
(\mathrm{N}=37)\end{array}$ & $\begin{array}{l}\text { Panic control treatment } \\
\text { Single intensive CBT } \\
\text { Exposure } \\
\text { Cognitive problem solving } \\
8 \text { daily intensive sessions } \\
\end{array}$ & $\begin{array}{l}\text { Age mean (years): } 15.04 \\
\text { Male: } 45.5 \%\end{array}$ & \multirow[t]{2}{*}{6} \\
\hline & & & $\begin{array}{l}\text { Control, } \\
(\mathrm{N}=17)\end{array}$ & Waitlisting or no treatment & $\begin{array}{l}\text { Age mean (years): } 15.82 \\
\text { Male:35.2 }\end{array}$ & \\
\hline $\begin{array}{l}\text { Goldbeck, } \\
2012^{148}\end{array}$ & $\begin{array}{l}\text { Germany } \\
\text { RCT } \\
\text { Efficacy } \\
\text { Mental health } \\
\text { clinic }\end{array}$ & $\begin{array}{l}\text { GAD, SAD, SoP, } \\
\text { SP }\end{array}$ & $\begin{array}{l}\text { Other } \\
\text { therapy, } \\
(\mathrm{N}=18)\end{array}$ & $\begin{array}{l}\text { Music therapy } \\
\text { Relaxation } \\
3 \text { individual sessions (60mins), } 9 \\
\text { group sessions (100mins), } 2 \text { parent } \\
\text { sessions (50mins) over } 17 \text { weeks }\end{array}$ & $\begin{array}{l}\text { Age mean (years): } 9.94 \text { (range: } 8 \text { - } \\
\text { 12) } \\
\text { Males: } 33.3 \% \\
\text { Caucasian: } 100 \% \\
\text { Less than high school or high } \\
\text { school graduate (parent): } 100 \% \\
\text { ADHD:5.5\% } \\
\text { Depression:5.5\% } \\
\text { Selective mutism:5.5\% }\end{array}$ & 16 \\
\hline
\end{tabular}




\begin{tabular}{|c|c|c|c|c|c|c|}
\hline Author, Year & $\begin{array}{l}\text { Study Country, } \\
\text { Study Design, } \\
\text { Type of Study } \\
\text { (Efficacyl } \\
\text { Effectiveness), } \\
\text { Study Settings }\end{array}$ & $\begin{array}{c}\text { Type of } \\
\text { Anxiety/Severity } \\
\text { (CGI) }\end{array}$ & $\begin{array}{l}\text { Intervention } \\
\text { and } \\
\text { Comparison } \\
\text { s (N of } \\
\text { Patients) }\end{array}$ & $\begin{array}{l}\text { Characteristics of Interventions } \\
\text { (Psychotherapy: Components, } \\
\text { Delivery Model)/Pharm: Drug) } \\
\text { Intensity, Duration (Weeks)) }\end{array}$ & $\begin{array}{c}\text { Patient Characteristics Mean } \\
\text { Age (Range), Male (\%), } \\
\text { Race/Ethnicity, Comorbidity, } \\
\text { Household Income, Parent } \\
\text { Education, Family } \\
\text { Dysfunction/Stressor, } \\
\text { Treatment Sequence, } \\
\text { Insurance, History of } \\
\text { Maltreatment) } \\
\end{array}$ & $\begin{array}{c}\text { Length } \\
\text { of } \\
\text { Follow } \\
\text { up } \\
\text { (Weeks } \\
\text { ) }\end{array}$ \\
\hline & & & $\begin{array}{l}\text { Control, } \\
(\mathrm{N}=18)\end{array}$ & $\begin{array}{l}\text { Attention control or treatment as } \\
\text { usual }\end{array}$ & $\begin{array}{l}\text { Age mean (years): } 9.94 \text { (8-12) } \\
\text { Males: } 66.6 \% \\
\text { Caucasian: } 94.4 \% \\
\text { Other: } 5.5 \% \\
\text { Less than high school or high } \\
\text { school graduate (parent): } 100 \% \\
\text { Depression: } 5.5 \% \\
\text { Encopresis: } 5.5 \%\end{array}$ & \\
\hline \multirow[t]{2}{*}{$\begin{array}{l}\text { Joormann, } \\
2002^{149}\end{array}$} & \multirow{2}{*}{$\begin{array}{l}\text { Germany } \\
\text { RCT } \\
\text { Efficacy } \\
\text { Mental health } \\
\text { clinic }\end{array}$} & \multirow[t]{2}{*}{ SoP } & $\begin{array}{l}\text { Other } \\
\text { Therapy, } \\
(\mathrm{N}=9)\end{array}$ & $\begin{array}{l}\text { Generic CBT } \\
\text { Group based } \\
\text { Two sessions per week for } 8 \text { weeks }\end{array}$ & $\begin{array}{l}\text { Age mean (years): } 13.9 \text { (range: } \\
\text { 11-15) } \\
\text { Male: } 45 \%\end{array}$ & \multirow[t]{2}{*}{52} \\
\hline & & & $\begin{array}{l}\text { Control, } \\
(\mathrm{N}=9)\end{array}$ & Waitlisting or no treatment & $\begin{array}{l}\text { Age mean (years): } 11.33 \text { (range: } \\
\text { 8-15) } \\
\text { Male: } 45 \%\end{array}$ & \\
\hline \multirow[t]{2}{*}{ Klein, $2015^{150}$} & \multirow[t]{2}{*}{$\begin{array}{l}\text { Netherlands } \\
\text { RCT } \\
\text { efficacy } \\
\text { Mental health } \\
\text { clinic }\end{array}$} & \multirow[t]{2}{*}{ GAD, SAD, SoP. } & $\begin{array}{l}\text { Other } \\
\text { Therapy, } \\
(\mathrm{N}=44)\end{array}$ & $\begin{array}{l}\text { Other Therapy. } \\
\text { Individual based } 15 \text { sessions over } 2 \\
\text { weeks }\end{array}$ & Age mean (years): 9.1 & \multirow[t]{2}{*}{2} \\
\hline & & & $\begin{array}{l}\text { Control, } \\
(\mathrm{N}=43)\end{array}$ & $\begin{array}{l}\text { Attention control or treatment as } \\
\text { usual } \\
\text { Therapy Placebo }\end{array}$ & Age mean (years): 9.4 & \\
\hline \multirow[t]{2}{*}{ Lee, $2016^{151}$} & \multirow[t]{2}{*}{$\begin{array}{l}\text { United States } \\
\text { RCT } \\
\text { Efficacy } \\
\text { Mental health } \\
\text { clinic }\end{array}$} & \multirow[t]{2}{*}{ GAD,SAD, SoP } & $\begin{array}{l}\text { Other } \\
\text { Therapy, } \\
(\mathrm{N}=37)\end{array}$ & $\begin{array}{l}\text { Friends } \\
\text { Combines CBT only and CBT plus } \\
\text { parenting } \\
\text { Group based } \\
\text { Exposure } \\
\text { Relaxation } \\
\text { Cognitive problem solving } \\
9 \text { sessions, plus } 2 \text { booster sessions; } \\
\text { half of group also received } 9 \\
\text { concurrent parent sessions }\end{array}$ & \multirow[t]{2}{*}{ Caucasian: $97 \%$} & \multirow[t]{2}{*}{156} \\
\hline & & & $\begin{array}{l}\text { Control, } \\
(\mathrm{N}=24)\end{array}$ & Waitlisting or no treatment & & \\
\hline
\end{tabular}




\begin{tabular}{|c|c|c|c|c|c|c|}
\hline Author, Year & $\begin{array}{l}\text { Study Country, } \\
\text { Study Design, } \\
\text { Type of Study } \\
\text { (Efficacyl } \\
\text { Effectiveness), } \\
\text { Study Settings }\end{array}$ & $\begin{array}{c}\text { Type of } \\
\text { Anxiety/Severity } \\
\text { (CGI) }\end{array}$ & $\begin{array}{l}\text { Intervention } \\
\text { and } \\
\text { Comparison } \\
\text { s (N of } \\
\text { Patients) }\end{array}$ & $\begin{array}{l}\text { Characteristics of Interventions } \\
\text { (Psychotherapy: Components, } \\
\text { Delivery Model)/Pharm: Drug) } \\
\text { Intensity, Duration (Weeks)) }\end{array}$ & $\begin{array}{c}\text { Patient Characteristics Mean } \\
\text { Age (Range), Male (\%), } \\
\text { Race/Ethnicity, Comorbidity, } \\
\text { Household Income, Parent } \\
\text { Education, Family } \\
\text { Dysfunction/Stressor, } \\
\text { Treatment Sequence, } \\
\text { Insurance, History of } \\
\text { Maltreatment) }\end{array}$ & $\begin{array}{c}\text { Length } \\
\text { of } \\
\text { Follow } \\
\text { up } \\
\text { (Weeks } \\
\text { ) }\end{array}$ \\
\hline \multirow[t]{2}{*}{$\begin{array}{l}\text { Yoosefi } \\
\text { Looyeh, } 2014 \\
152\end{array}$} & \multirow[t]{2}{*}{$\begin{array}{l}\text { Iran } \\
\text { RCT } \\
\text { Efficacy } \\
\text { School }\end{array}$} & \multirow[t]{2}{*}{ SoP } & $\begin{array}{l}\text { Other } \\
\text { Therapy, } \\
(\mathrm{N}=12)\end{array}$ & $\begin{array}{l}\text { Other: Narrative group therapy } \\
\text { Group based } \\
\text { Delivered by parent and teacher } \\
14 \text { sessions } 90 \text { minute sessions, } \\
\text { twice per week } \\
\text { Delivered by parent and teacher }\end{array}$ & \multirow[t]{2}{*}{$\begin{array}{l}\text { Age range: }(10-11) \text { years } \\
\text { Male: } 100 \%\end{array}$} & \multirow[t]{2}{*}{0} \\
\hline & & & $\begin{array}{l}\text { Control, } \\
(\mathrm{N}=12)\end{array}$ & Pill Placebo & & \\
\hline \multirow[t]{3}{*}{$\begin{array}{l}\text { Miller, } 1972^{58,} \\
59\end{array}$} & \multirow[t]{3}{*}{$\begin{array}{l}\text { United States } \\
\text { RCT } \\
\text { Efficacy } \\
\text { Outpatient }\end{array}$} & \multirow[t]{3}{*}{ SP } & $\begin{array}{l}\text { Child CBT, } \\
(\mathrm{N}=\mathrm{NR})\end{array}$ & $\begin{array}{l}\text { Reciprocal inhibition: } \\
\text { Individual-based relaxation exposure } \\
\text { Delivered by doctoral psychologist } \\
60 \text { min session } 3 \text { times per week for } \\
8 \text { weeks }\end{array}$ & \multirow{3}{*}{$\begin{array}{l}\text { Age mean (years): } 10.8 \text { ( range: } \\
\text { 6-14) } \\
\text { Male: } 55 \% \\
\text { Caucasian: } 95.5 \% \text {, African } \\
\text { American: } 4.5 \% \\
\text { Socioeconomic status: } \\
\text { Lower: } 7 \% \\
\text { Middle: } 75 \% \\
\text { High: } 8 \%\end{array}$} & \multirow[t]{3}{*}{104} \\
\hline & & & $\begin{array}{l}\text { Other } \\
\text { therapy, } \\
(\mathrm{N}=\mathrm{NR})\end{array}$ & $\begin{array}{l}\text { Individual, play psychotherapy } \\
\text { directed toward inner experiences } \\
60 \text { min session } 3 \text { times per week for } \\
8 \text { weeks }\end{array}$ & & \\
\hline & & & $\begin{array}{l}\text { Control, } \\
(\mathrm{N}=\mathrm{NR})\end{array}$ & $\begin{array}{l}\text { Waitlisting or no treatment } \\
60 \text { min session } 3 \text { times per week for } \\
8 \text { weeks }\end{array}$ & & \\
\hline
\end{tabular}

ADHD: attention deficit hyperactivity disorder, CBT: cognitive behavioral therapy, CGI: clinical global impression scale, GAD: generalized anxiety disorder, NR: not reported, RCT: randomized controlled trial, SAD: separation anxiety disorder, SoP: social anxiety, SP: specific phobia 
Table E.18. Characteristics of studies comparing different non-CBT psychotherapies

\begin{tabular}{|c|c|c|c|c|c|c|}
\hline Author, Year & $\begin{array}{l}\text { Study Country, } \\
\text { Study Design, } \\
\text { Type of Study } \\
\text { (Efficacyl } \\
\text { Effectiveness), } \\
\text { Study Settings }\end{array}$ & $\begin{array}{c}\text { Type of } \\
\text { Anxiety/Severity } \\
\text { (CGI) }\end{array}$ & $\begin{array}{l}\text { Intervention } \\
\text { and } \\
\text { Comparison } \\
\text { s (N of } \\
\text { Patients) }\end{array}$ & $\begin{array}{l}\text { Characteristics of Interventions } \\
\text { (Psychotherapy: Components, } \\
\text { Delivery Model)/Pharm: Drug) } \\
\text { Intensity, Duration (Weeks)) }\end{array}$ & $\begin{array}{c}\text { Patient Characteristics Mean } \\
\text { Age (Range), Male (\%), } \\
\text { Race/Ethnicity, Comorbidity, } \\
\text { Household Income, Parent } \\
\text { Education, Family } \\
\text { Dysfunction/Stressor, } \\
\text { Treatment Sequence, } \\
\text { Insurance, History of } \\
\text { Maltreatment) }\end{array}$ & $\begin{array}{l}\text { Length } \\
\text { of } \\
\text { Follow } \\
\text { up } \\
\text { (Weeks } \\
\text { ) }\end{array}$ \\
\hline \multirow[t]{3}{*}{$\begin{array}{l}\text { Muris, } 1998 \\
153\end{array}$} & \multirow[t]{3}{*}{$\begin{array}{l}\text { Netherland } \\
\text { RCT } \\
\text { Outpatient }\end{array}$} & \multirow[t]{3}{*}{ SP } & $\begin{array}{l}\text { Other } \\
\text { therapy, } \\
(\mathrm{N}=9)\end{array}$ & $\begin{array}{l}\text { EMDR } \\
\text { Delivered by psychotherapist } \\
\text { 1,150min session }\end{array}$ & \multirow[t]{3}{*}{$\begin{array}{l}\text { Age mean (years): } 12.58 \text { ( range: } \\
\text { 8-17) } \\
\text { Caucasian: } 100 \% \\
\text { Medium income: } 100 \%\end{array}$} & \multirow[t]{3}{*}{0} \\
\hline & & & $\begin{array}{l}\text { Child CBT, } \\
(\mathrm{N}=9)\end{array}$ & $\begin{array}{l}\text { Generic CBT } \\
\text { Exposure } \\
\text { Individual- delivered by behavioral } \\
\text { scientist } \\
1,150 \mathrm{~min} \text { session }\end{array}$ & & \\
\hline & & & $\begin{array}{l}\text { Distance } \\
\text { therapy, } \\
(\mathrm{N}=8)\end{array}$ & $\begin{array}{l}\text { Generic CBT } \\
\text { Exposure } \\
\text { Individual-based exposure cognitive } \\
\text { strategies } \\
\text { Delivered by behavioral scientist } \\
1,150 \text { min session }\end{array}$ & & \\
\hline \multirow[t]{2}{*}{$\begin{array}{l}\text { Muris, } 2002 \\
154\end{array}$} & \multirow[t]{2}{*}{$\begin{array}{l}\text { Netherlands } \\
\text { RCT } \\
\text { Efficacy } \\
\text { Mental health } \\
\text { clinic }\end{array}$} & \multirow[t]{2}{*}{ GAD,SAD SoP } & $\begin{array}{l}\text { Non-CBT } \\
(\mathrm{EMDR}) \\
(\mathrm{N}=11)\end{array}$ & $\begin{array}{l}\text { Generic CBT } \\
\text { Cognitive problem solving } \\
\text { Group-based } \\
\text { Delivered by student/trainee } \\
\text { Weekly for } 6 \text { weeks, } 50 \text { min }\end{array}$ & \multirow{2}{*}{$\begin{array}{l}\text { Age mean (years): } 9.3 \text { (range: } 8- \\
\text { 12) } \\
\text { Males: } 37.5 \% \\
\text { Caucasian: } 83 \% \\
\text { Asian: } 17 \% \\
\text { Low income (Dutch Bureau of } \\
\text { Statistics): } 20.8 \% \\
\text { Medium income (Dutch Bureau of } \\
\text { Statistics): } 62.5 \% \\
\text { High income (Dutch Bureau of } \\
\text { Statistics): } 16.7 \%\end{array}$} & \multirow[t]{2}{*}{0} \\
\hline & & & $\begin{array}{l}\text { Other } \\
\text { therapy, } \\
\mathrm{N}=13 \text { ) }\end{array}$ & $\begin{array}{l}\text { Emotional disclosure } \\
\text { Group based } \\
\text { Weekly for } 6 \text { weeks, } 50 \text { min }\end{array}$ & & \\
\hline Parr, $2009^{155}$ & $\begin{array}{l}\text { United Kingdom } \\
\text { RCT } \\
\text { Efficacy } \\
\text { Mental health } \\
\text { clinic }\end{array}$ & SAD, SoP & $\begin{array}{l}\text { Other } \\
\text { therapy, } \\
(\mathrm{N}=18)\end{array}$ & $\begin{array}{l}\text { Other therapy } \\
\text { Video feedback, } \\
\text { Individual based } \\
\text { Delivered by psychology student } \\
\text { One session }\end{array}$ & $\begin{array}{l}\text { Age mean (years): } 15.7 \text { (range } \\
\text { 13-17) } \\
\text { male: } 55.5 \%\end{array}$ & NR \\
\hline
\end{tabular}




\begin{tabular}{|l|l|l|l|l|}
\hline & & & $\begin{array}{l}\text { Other } \\
\text { therapy, } \\
(\mathrm{N}=18)\end{array}$ & $\begin{array}{l}\text { Other therapy } \\
\text { no video feedback } \\
\text { Individual-based } \\
\text { Delivered by psychology student. one } \\
\text { session }\end{array}$ \\
\hline
\end{tabular}

CBT: cognitive behavioral therapy, CGI: clinical global impression scale, EMDR: eye movement desensitization and reprocessing, GAD: generalized anxiety disorder, RCT: randomized controlled trial, SAD: separation anxiety disorder, SoP: social anxiety. 
Table E.19. Characteristics of studies comparing CBT versus other psychotherapy

\begin{tabular}{|c|c|c|c|c|c|c|}
\hline Author, Year & $\begin{array}{c}\text { Study Country, } \\
\text { Study Design, } \\
\text { Type of Study } \\
\text { (Efficacyl } \\
\text { Effectiveness), } \\
\text { Study Settings }\end{array}$ & $\begin{array}{c}\text { Type of } \\
\text { AnxietylSeverity } \\
\text { (CGI) }\end{array}$ & $\begin{array}{l}\text { Intervention } \\
\text { and } \\
\text { Comparison } \\
\text { s (N of } \\
\text { Patients) }\end{array}$ & $\begin{array}{l}\text { Characteristics of Interventions } \\
\text { (Psychotherapy: Components, } \\
\text { Delivery Model)/Pharm: Drug) } \\
\text { Intensity, Duration (Weeks)) }\end{array}$ & $\begin{array}{c}\text { Patient Characteristics Mean } \\
\text { Age (Range), Male (\%), } \\
\text { Race/Ethnicity, Comorbidity, } \\
\text { Household Income, Parent } \\
\text { Education, Family } \\
\text { Dysfunction/Stressor, } \\
\text { Treatment Sequence, } \\
\text { Insurance, History of } \\
\text { Maltreatment) }\end{array}$ & $\begin{array}{l}\text { Length } \\
\text { of } \\
\text { Follow } \\
\text { up } \\
\text { (Weeks } \\
\text { ) }\end{array}$ \\
\hline \multirow[t]{3}{*}{$\begin{array}{l}\text { Abbasi, } \\
2016^{27}\end{array}$} & \multirow[t]{3}{*}{$\begin{array}{l}\text { Iran } \\
\text { RCT } \\
\text { Efficacy } \\
\text { Outpatient }\end{array}$} & \multirow[t]{3}{*}{ SAD } & $\begin{array}{l}\text { Child CBT, } \\
(\mathrm{N}=15)\end{array}$ & $\begin{array}{l}\text { Modular CBT } \\
\text { Individual-based } \\
\text { Exposure cognitive problem solving, } \\
\text { 4-20 } 1 \text { hour sessions. }\end{array}$ & $\begin{array}{l}\text { Age range : } 6-7 \text { years } \\
\text { Male: } 53 \%\end{array}$ & \multirow[t]{3}{*}{13} \\
\hline & & & $\begin{array}{l}\text { Other } \\
\text { therapy, } \\
(\mathrm{N}=15)\end{array}$ & $\begin{array}{l}\text { Other: Child parent relationship } \\
\text { training. } \\
\text { One session a week for } 10 \text { weeks }\end{array}$ & $\begin{array}{l}\text { Age range : } 6-7 \text { years } \\
\text { Male: } 33.3 \%\end{array}$ & \\
\hline & & & $\begin{array}{l}\text { Control, } \\
(\mathrm{N}=16)\end{array}$ & Waitlisting or no treatment & $\begin{array}{l}\text { Age range : } 6-7 \text { years } \\
\text { Male: } 48 \%\end{array}$ & \\
\hline \multirow[t]{2}{*}{$\begin{array}{l}\text { Chavira, } 2014 \\
156\end{array}$} & \multirow[t]{2}{*}{$\begin{array}{l}\text { United States } \\
\text { RCT } \\
\text { Efficacy } \\
\text { Mental health } \\
\text { clinic }\end{array}$} & \multirow[t]{2}{*}{$\begin{array}{l}\text { GAD, SAD, SoP, } \\
\text { SP }\end{array}$} & $\begin{array}{l}\text { Child CBT, } \\
(\mathrm{N}=24)\end{array}$ & $\begin{array}{l}\text { Cool Kids } \\
\text { Exposure } \\
\text { Cognitive problem solving } \\
\text { Individual based } \\
\text { Delivered by primary care physicians } \\
10 \text { sessions over } 12 \text { weeks, } 60- \\
90 \text { mins each }\end{array}$ & $\begin{array}{l}\text { Age mean (years): } 9.75 \text { (range: } 8 \text { - } \\
\text { 13) } \\
\text { Males: } 42 \% \\
\text { Caucasian: } 83.3 \% \\
\text { Hispanic: } 8.3 \% \\
\text { Other: } 12.5 \% \\
\text { Less than high school or high } \\
\text { school graduate (parent): } 16.7 \% \\
\text { Some college (parent): } 16.7 \% \\
\text { College graduate (parent): } 33 \% \\
\text { OCD: } 16.7 \% \\
\text { Depression: } 12.5 \% \\
\text { Disruptive Behavior Disorders: } \\
\text { 12.5\% } \\
\text { Autism: } 4.2 \%\end{array}$ & \multirow[t]{2}{*}{12} \\
\hline & & & $\begin{array}{l}\text { Distance } \\
\text { Therapy, } \\
(\mathrm{N}=24)\end{array}$ & $\begin{array}{l}\text { Cool Kids } \\
\text { Exposure } \\
\text { Cognitive problem solving } \\
10 \text { sessions over } 12 \text { weeks, } 60 \text { - } \\
\text { 90mins each }\end{array}$ & $\begin{array}{l}\text { Age mean (years): } 9.5 \text { (range: } 8 \text { - } \\
\text { 13) } \\
\text { Males: } 46 \% \\
\text { Caucasian: } 62.5 \% \\
\text { Hispanic: } 12.5 \% \\
\text { Other: } 20.8 \% \\
\text { Less than high school or high } \\
\text { school graduate (parent): } 12.5 \% \\
\text { Some college (parent): } 25.0 \%\end{array}$ & \\
\hline
\end{tabular}




\begin{tabular}{|c|c|c|c|c|c|c|}
\hline Author, Year & $\begin{array}{l}\text { Study Country, } \\
\text { Study Design, } \\
\text { Type of Study } \\
\text { (Efficacyl } \\
\text { Effectiveness), } \\
\text { Study Settings }\end{array}$ & $\begin{array}{c}\text { Type of } \\
\text { Anxiety/Severity } \\
\text { (CGI) }\end{array}$ & $\begin{array}{l}\text { Intervention } \\
\text { and } \\
\text { Comparison } \\
\text { s (N of } \\
\text { Patients) }\end{array}$ & $\begin{array}{l}\text { Characteristics of Interventions } \\
\text { (Psychotherapy: Components, } \\
\text { Delivery Model)/Pharm: Drug) } \\
\text { Intensity, Duration (Weeks)) }\end{array}$ & $\begin{array}{l}\text { Patient Characteristics Mean } \\
\text { Age (Range), Male (\%), } \\
\text { Race/Ethnicity, Comorbidity, } \\
\text { Household Income, Parent } \\
\text { Education, Family } \\
\text { Dysfunction/Stressor, } \\
\text { Treatment Sequence, } \\
\text { Insurance, History of } \\
\text { Maltreatment) }\end{array}$ & $\begin{array}{l}\text { Length } \\
\text { of } \\
\text { Follow } \\
\text { up } \\
\text { (Weeks } \\
\text { ) }\end{array}$ \\
\hline & & & & & $\begin{array}{l}\text { College graduate (parent): } 45.8 \% \\
\text { OCD: } 8.3 \% \\
\text { Depression: } 4.2 \% \\
\text { Disruptive Behavior Disorders: } \\
25 \% \\
\text { Autism: } 4.2 \%\end{array}$ & \\
\hline \multirow[t]{3}{*}{$\begin{array}{l}\text { Cobham, } \\
2012^{36}\end{array}$} & \multirow[t]{3}{*}{$\begin{array}{l}\text { Australia } \\
\text { RCT } \\
\text { Efficacy } \\
\text { Mental health } \\
\text { clinic }\end{array}$} & \multirow[t]{3}{*}{$\begin{array}{l}\text { GAD, PD, PD } \\
\text { with } \\
\text { agoraphobia, } \\
\text { SAD, SoP, SP }\end{array}$} & $\begin{array}{l}\text { Child CBT } \\
\text { plus separate } \\
\text { parent } \\
\text { intervention, } \\
(\mathrm{N}=23)\end{array}$ & $\begin{array}{l}\text { Do as I do } \\
\text { Individual-based } \\
\text { Exposure } \\
\text { Cognitive problem solving } \\
690 \text {-minutes sessions for parent and } \\
660 \text {-minutes for child, weekly } \\
\text { Delivered by Masters level clinicians }\end{array}$ & $\begin{array}{l}\text { Age mean (years): } 9.70 \text { (range: } 7- \\
\text { 14) } \\
\text { Males: } 50 \% \\
\text { Caucasian } 92 \% \\
\text { Asian: } 8 \% \\
\text { PTSD: } 4 \% \\
\text { ADHD: } 7 \% \\
\text { Dysthymia: } 4 \% \\
\text { Enuresis: } 4 \%\end{array}$ & \multirow[t]{3}{*}{26} \\
\hline & & & $\begin{array}{l}\text { Distance } \\
\text { Therapy, } \\
(\mathrm{N}=20)\end{array}$ & $\begin{array}{l}\text { Do as I do } \\
\text { "Do as I Do" and "Facing your Fears" } \\
\text { bibliotherapy programs } \\
\text { Exposure } \\
\text { Cognitive problem solving } \\
2 \text { hour parent group, every other } \\
\text { week } 12 \text { min phone calls for } 12 \\
\text { weeks } \\
\text { Delivered by parent and therapist }\end{array}$ & $\begin{array}{l}\text { Age mean (years): } 10.20 \text { (range: } \\
\text { 7-14) } \\
\text { Males: } 55 \% \\
\text { Caucasian } 92 \% \\
\text { Asian: } 8 \% \\
\text { ADHD: } 5 \% \\
\text { PTSD: } 5 \% \\
\text { Dysthymia: } 5 \% \\
\text { Sleep terrors: } 5 \%\end{array}$ & \\
\hline & & & $\begin{array}{l}\text { Control, } \\
(\mathrm{N}=12)\end{array}$ & Waitlisting or no treatment & $\begin{array}{l}\text { Age mean (years): } 9.83 \text { (range: } 7 \text { - } \\
\text { 14) } \\
\text { Males: } 57 \% \\
\text { Caucasian } 92 \% \\
\text { Asian: } 8 \% \\
\text { PTSD: } 4 \%\end{array}$ & \\
\hline Dewis, $2001^{37}$ & $\begin{array}{l}\text { Australia } \\
\text { RCT } \\
\text { Efficacy } \\
\text { Mental health }\end{array}$ & SP & $\begin{array}{l}\text { Child CBT, } \\
(\mathrm{N}=9)\end{array}$ & $\begin{array}{l}\text { Generic CBT } \\
\text { Live graded exposure } \\
\text { Child CBT- (parents included < 20\%) } \\
\text { Individual based }\end{array}$ & $\begin{array}{l}\text { Male: } 35.7 \% \\
\text { Caucasian: } 100 \% \\
\text { Age mean (years): } 12.3 \text { (Range } \\
10-17 \text { ) }\end{array}$ & 4 \\
\hline
\end{tabular}




\begin{tabular}{|c|c|c|c|c|c|c|}
\hline Author, Year & $\begin{array}{l}\text { Study Country, } \\
\text { Study Design, } \\
\text { Type of Study } \\
\text { (Efficacyl } \\
\text { Effectiveness), } \\
\text { Study Settings }\end{array}$ & $\begin{array}{c}\text { Type of } \\
\text { Anxiety/Severity } \\
\text { (CGI) }\end{array}$ & $\begin{array}{l}\text { Intervention } \\
\text { and } \\
\text { Comparison } \\
\text { s (N of } \\
\text { Patients) }\end{array}$ & $\begin{array}{l}\text { Characteristics of Interventions } \\
\text { (Psychotherapy: Components, } \\
\text { Delivery Model)/Pharm: Drug) } \\
\text { Intensity, Duration (Weeks)) }\end{array}$ & $\begin{array}{l}\text { Patient Characteristics Mean } \\
\text { Age (Range), Male (\%), } \\
\text { Race/Ethnicity, Comorbidity, } \\
\text { Household Income, Parent } \\
\text { Education, Family } \\
\text { Dysfunction/Stressor, } \\
\text { Treatment Sequence, } \\
\text { Insurance, History of } \\
\text { Maltreatment) }\end{array}$ & $\begin{array}{l}\text { Length } \\
\text { of } \\
\text { Follow } \\
\text { up } \\
\text { (Weeks } \\
\text { ) }\end{array}$ \\
\hline & \multirow[t]{3}{*}{ clinic } & & & $\begin{array}{l}\text { Exposure } \\
\text { Three } 45-\text { min treatment sessions } \\
\text { every } 3-4 \text { days } \\
\text { Provided by clinical psychologists }\end{array}$ & & \\
\hline & & & $\begin{array}{l}\text { Distance } \\
\text { Therapy, } \\
(\mathrm{N}=10)\end{array}$ & $\begin{array}{l}\text { Other: Computer-aided vicarious } \\
\text { exposure } \\
\text { Individual computer based } \\
\text { Exposure } \\
\text { Three } 45 \text {-min treatment sessions } \\
\text { every } 3-4 \text { days }\end{array}$ & $\begin{array}{l}\text { Male: } 35.7 \% \\
\text { Caucasian: } 100 \% \\
\text { Age mean (years): } 13.8 \text { (Range } \\
\text { 10-17) }\end{array}$ & \\
\hline & & & $\begin{array}{l}\text { Control, } \\
(\mathrm{N}=9)\end{array}$ & Waitlisting or no treatment & $\begin{array}{l}\text { Male: } 35.7 \% \\
\text { Caucasian: } 100 \% \\
\text { Age mean (years): } 13.3 \text { ( Range } \\
10-17 \text { ) }\end{array}$ & \\
\hline \multirow[t]{3}{*}{$\begin{array}{l}\text { Hancock, } \\
2016{ }^{44}\end{array}$} & \multirow[t]{3}{*}{$\begin{array}{l}\text { Australia } \\
\text { RCT } \\
\text { Effectiveness } \\
\text { Mental health } \\
\text { clinic }\end{array}$} & \multirow[t]{3}{*}{ GAD, SAD } & $\mathrm{ACT},(\mathrm{N}=68)$ & $\begin{array}{l}\text { Acceptance and commitment therapy } \\
\text { (ACT) } \\
\text { Group based } \\
\text { Relaxation } \\
10 \text { sessions, } 90 \text {-minute weekly } \\
\text { sessions } \\
\text { Delivered by doctoral level } \\
\text { psychologist }\end{array}$ & $\begin{array}{l}\text { Age mean (years): } 11.15 \text { ( range: } \\
7-17 \text { ) } \\
\text { Male: } 45.5 \% \\
\text { Caucasian: } 87 \% \text {, Asian: } 3 \% \text {, } \\
\text { Other: } 10 \% \\
\text { ADHD: } 6 \% \text {, Depression, } 18 \% \text {, } \\
\text { OCD: } 7.3 \% \\
\text { Treatment naïve: } 27.9 \%\end{array}$ & \multirow[t]{3}{*}{13} \\
\hline & & & $\begin{array}{l}\text { Child and } \\
\text { parent } \\
\text { together } \mathrm{CBT} \text {, } \\
(\mathrm{N}=63)\end{array}$ & $\begin{array}{l}\text { Cool Kids } \\
\text { Group based } \\
\text { Exposure } \\
\text { Cognitive problem solving } \\
10 \text { sessions, } 90 \text {-minute weekly } \\
\text { sessions } \\
\text { Delivered by doctoral level } \\
\text { psychologist }\end{array}$ & $\begin{array}{l}\text { Age mean (years): } 10.81 \text { ( range: } \\
7-17 \text { ) } \\
\text { Male: } 39.6 \% \\
\text { Caucasian: } 94.4 \% \text {, Other: } 5.6 \% \\
\text { ADHD: } 10 \% \text {, Depression, } 13 \% \text {, } \\
\text { OCD: } 3 \% \\
\text { Treatment naïve: } 22.2 \%\end{array}$ & \\
\hline & & & $\begin{array}{l}\text { Control, } \\
(\mathrm{N}=62)\end{array}$ & Waitlisting or no treatment & $\begin{array}{l}\text { Age mean (years): } 11.66 \text { ( range: } \\
7-17 \text { ) } \\
\text { Male: } 41.9 \% \\
\text { Caucasian: } 84 \% \text {, Other: } 16 \% \\
\text { Depression: } 24 \% \text {, OCD: } 8 \%\end{array}$ & \\
\hline
\end{tabular}




\begin{tabular}{|c|c|c|c|c|c|c|}
\hline Author, Year & $\begin{array}{l}\text { Study Country, } \\
\text { Study Design, } \\
\text { Type of Study } \\
\text { (Efficacyl } \\
\text { Effectiveness), } \\
\text { Study Settings }\end{array}$ & $\begin{array}{c}\text { Type of } \\
\text { Anxiety/Severity } \\
\text { (CGI) }\end{array}$ & $\begin{array}{l}\text { Intervention } \\
\text { and } \\
\text { Comparison } \\
\text { s (N of } \\
\text { Patients) }\end{array}$ & $\begin{array}{l}\text { Characteristics of Interventions } \\
\text { (Psychotherapy: Components, } \\
\text { Delivery Model)/Pharm: Drug) } \\
\text { Intensity, Duration (Weeks)) }\end{array}$ & $\begin{array}{c}\text { Patient Characteristics Mean } \\
\text { Age (Range), Male (\%), } \\
\text { Race/Ethnicity, Comorbidity, } \\
\text { Household Income, Parent } \\
\text { Education, Family } \\
\text { Dysfunction/Stressor, } \\
\text { Treatment Sequence, } \\
\text { Insurance, History of } \\
\text { Maltreatment) } \\
\end{array}$ & $\begin{array}{l}\text { Length } \\
\text { of } \\
\text { Follow } \\
\text { up } \\
\text { (Weeks } \\
\text { ) }\end{array}$ \\
\hline & & & & & Treatment naïve: 70.9 & \\
\hline \multirow[t]{2}{*}{$\begin{array}{l}\text { Karbasi, } \\
2010^{157}\end{array}$} & \multirow[t]{2}{*}{$\begin{array}{l}\text { Iran } \\
\text { RCT } \\
\text { Efficacy } \\
\text { Mental health } \\
\text { clinic }\end{array}$} & \multirow[t]{2}{*}{ Anxiety disorder } & $\begin{array}{l}\text { Child CBT } \\
\text { plus parent } \\
\text { involvement, } \\
(\mathrm{N}=22)\end{array}$ & $\begin{array}{l}\text { Being Brave } \\
\text { Exposure, relaxation, Cognitive } \\
\text { Problem Solving } \\
\text { Group-based 8,75min weekly } \\
\text { sessions }\end{array}$ & $\begin{array}{l}\text { Age mean (years): } 14.2 \text { ( range: } \\
12-17 \text { ) }\end{array}$ & \multirow[t]{2}{*}{3} \\
\hline & & & $\begin{array}{l}\text { Distance } \\
\text { therapy, } \\
(\mathrm{N}=22)\end{array}$ & $\begin{array}{l}\text { Being Brave } \\
\text { Exposure } \\
\text { Relaxation } \\
\text { Cognitive problem solving } \\
\text { Individual Based } \\
4,75 \text { min weekly sessions, } 4 \text { sessions } \\
\text { via CD }\end{array}$ & $\begin{array}{l}\text { Age mean (years): } 15.1 \text { ( range: } \\
12-17)\end{array}$ & \\
\hline \multirow[t]{3}{*}{$\begin{array}{l}\text { Khanna, } \\
2010^{102}\end{array}$} & \multirow[t]{3}{*}{$\begin{array}{l}\text { United States } \\
\text { RCT } \\
\text { Efficacy } \\
\text { Mental health } \\
\text { clinic }\end{array}$} & \multirow[t]{3}{*}{$\begin{array}{l}\text { GAD, PD, SAD, } \\
\text { SoP, SP }\end{array}$} & $\begin{array}{l}\text { Child CBT, } \\
(\mathrm{N}=17)\end{array}$ & $\begin{array}{l}\text { Coping Cat } \\
\text { Exposure } \\
\text { Relaxation } \\
\text { Cognitive problem solving } \\
\text { Individual-based } \\
\text { Delivered by psychologist, student/ } \\
\text { trainee } \\
\text { Weekly for } 12 \text { weeks, } 50 \text { minute } \\
\text { sessions }\end{array}$ & \multirow[t]{3}{*}{$\begin{array}{l}\text { Age mean (years): } 10.1 \text { (range: } 7 \text { - } \\
\text { 13) } \\
\text { Males: } 67 \% \\
\text { Caucasian: } 83 \% \\
\text { African American: } 14 \% \\
\text { Hispanic: } 2 \% \\
\text { ADHD: } 16 \% \\
\text { ODD:4\% } \\
\text { Tic disorder: } 2 \%\end{array}$} & \multirow[t]{3}{*}{13} \\
\hline & & & $\begin{array}{l}\text { Distance, } \\
(\mathrm{N}=16)\end{array}$ & $\begin{array}{l}\text { Camp cope a lot } \\
\text { Exposure } \\
\text { Relaxation } \\
\text { Cognitive problem solving } \\
\text { Individual based } \\
\text { Delivered by psychologist, student/ } \\
\text { trainee } \\
\text { Weekly for } 12 \text { weeks, }\end{array}$ & & \\
\hline & & & $\begin{array}{l}\text { Control, } \\
(\mathrm{N}=16)\end{array}$ & $\begin{array}{l}\text { Attention control or treatment as } \\
\text { usual } \\
\text { Individual-based } \\
\text { Technology-based } \\
\text { Delivered by psychologist, student/ }\end{array}$ & & \\
\hline
\end{tabular}




\begin{tabular}{|c|c|c|c|c|c|c|}
\hline Author, Year & $\begin{array}{l}\text { Study Country, } \\
\text { Study Design, } \\
\text { Type of Study } \\
\text { (Efficacyl } \\
\text { Effectiveness), } \\
\text { Study Settings }\end{array}$ & $\begin{array}{c}\text { Type of } \\
\text { Anxiety/Severity } \\
\text { (CGI) }\end{array}$ & $\begin{array}{l}\text { Intervention } \\
\text { and } \\
\text { Comparison } \\
\text { s (N of } \\
\text { Patients) }\end{array}$ & $\begin{array}{l}\text { Characteristics of Interventions } \\
\text { (Psychotherapy: Components, } \\
\text { Delivery Model)/Pharm: Drug) } \\
\text { Intensity, Duration (Weeks)) }\end{array}$ & $\begin{array}{l}\text { Patient Characteristics Mean } \\
\text { Age (Range), Male (\%), } \\
\text { Race/Ethnicity, Comorbidity, } \\
\text { Household Income, Parent } \\
\text { Education, Family } \\
\text { Dysfunction/Stressor, } \\
\text { Treatment Sequence, } \\
\text { Insurance, History of } \\
\text { Maltreatment) }\end{array}$ & $\begin{array}{l}\text { Length } \\
\text { of } \\
\text { Follow } \\
\text { up } \\
\text { (Weeks } \\
\text { ) }\end{array}$ \\
\hline & & & & $\begin{array}{l}\text { trainee } \\
\text { Weekly for } 12 \text { weeks, } 60 \text { minute } \\
\text { sessions. } 30 \text { minutes of support and } \\
30 \text { minutes of computer. }\end{array}$ & & \\
\hline \multirow[t]{2}{*}{ Leong,2009 $9^{158}$} & \multirow[t]{2}{*}{$\begin{array}{l}\text { Australia } \\
\text { Efficacy } \\
\text { RCT }\end{array}$} & \multirow[t]{2}{*}{$\begin{array}{l}\text { GAD, SAD, } \\
\text { SoP,SP }\end{array}$} & $\begin{array}{l}\text { Child CBT } \\
\text { plus parent } \\
\text { Intervention, } \\
(\mathrm{N}=15)\end{array}$ & $\begin{array}{l}\text { Do as I Do } \\
\text { Exposure } \\
\text { Cognitive problem solving } \\
\text { Individual based } \\
\text { Weekly for } 12 \text { weeks }\end{array}$ & \multirow{2}{*}{$\begin{array}{l}\text { Total population: } 27 \\
\text { Age mean (years): } 9.26 \text { (range: } 7 \text { - } \\
\text { 14) } \\
\text { Males: } 63 \% \\
\text { Caucasian: } 100 \% \\
\text { Less than high school or high } \\
\text { school graduate (parent); } 40.7 \% \\
\text { College graduate (parent): } 59.3 \% \\
\text { OCD: } 4 \% \\
\text { Agoraphobia: } 4 \%\end{array}$} & \multirow[t]{2}{*}{20} \\
\hline & & & $\begin{array}{l}\text { Distance } \\
\text { therapy, } \\
(\mathrm{N}=15)\end{array}$ & $\begin{array}{l}\text { Do as I Do } \\
\text { Exposure } \\
\text { Cognitive problem solving } \\
\text { Delivered by parents } \\
\text { Weekly for } 12 \text { weeks } \\
\end{array}$ & & \\
\hline \multirow[t]{3}{*}{$\begin{array}{l}\text { Mendlowitz, } \\
199956\end{array}$} & \multirow[t]{3}{*}{$\begin{array}{l}\text { Canada } \\
\text { RCT } \\
\text { Efficacy } \\
\text { Outpatient }\end{array}$} & & $\begin{array}{l}\text { Child CBT, } \\
(\mathrm{N}=23)\end{array}$ & $\begin{array}{l}\text { Coping Bear } \\
\text { Child CBT- (parents included < 20\%) } \\
\text { Group based } \\
\text { Relaxation } \\
\text { Cognitive problem solving } \\
121.5 \text {-hour weekly sessions } \\
\text { Delivered by } 3 \text { psychologists, } 1 \\
\text { student/trainee, } 1 \text { youth worker }\end{array}$ & \multirow[t]{3}{*}{$\begin{array}{l}\text { Age mean (years): } 9.5 \text { (Range } 7- \\
12 \text { ) } \\
\text { Male: } 28.4 \%\end{array}$} & \multirow[t]{3}{*}{ NR } \\
\hline & & & $\begin{array}{l}\text { Parent only } \\
\text { intervention, } \\
(\mathrm{N}=21)\end{array}$ & $\begin{array}{l}\text { Generic CBT } \\
\text { Group based } \\
12 \text { 1.5-hour weekly sessions } \\
\text { Delivered by doctoral level } \\
\text { psychologist, and student/trainee }\end{array}$ & & \\
\hline & & & $\begin{array}{l}\text { Child CBT } \\
\text { plus separate } \\
\text { parent } \\
\text { intervention, } \\
(\mathrm{N}=18)\end{array}$ & $\begin{array}{l}\text { Coping Bear } \\
\text { Group based } \\
\text { Relaxation } \\
\text { Cognitive problem solving } \\
121.5 \text {-hour weekly sessions (one for } \\
\text { kids, one for parents) } \\
\text { Delivered by doctoral level }\end{array}$ & & \\
\hline
\end{tabular}




\begin{tabular}{|c|c|c|c|c|c|c|}
\hline Author, Year & $\begin{array}{c}\text { Study Country, } \\
\text { Study Design, } \\
\text { Type of Study } \\
\text { (Efficacyl } \\
\text { Effectiveness), } \\
\text { Study Settings }\end{array}$ & $\begin{array}{c}\text { Type of } \\
\text { Anxiety/Severity } \\
\text { (CGI) }\end{array}$ & $\begin{array}{l}\text { Intervention } \\
\text { and } \\
\text { Comparison } \\
\text { s (N of } \\
\text { Patients) }\end{array}$ & $\begin{array}{l}\text { Characteristics of Interventions } \\
\text { (Psychotherapy: Components, } \\
\text { Delivery Model)/Pharm: Drug) } \\
\text { Intensity, Duration (Weeks)) }\end{array}$ & $\begin{array}{c}\text { Patient Characteristics Mean } \\
\text { Age (Range), Male (\%), } \\
\text { Race/Ethnicity, Comorbidity, } \\
\text { Household Income, Parent } \\
\text { Education, Family } \\
\text { Dysfunction/Stressor, } \\
\text { Treatment Sequence, } \\
\text { Insurance, History of } \\
\text { Maltreatment) } \\
\end{array}$ & $\begin{array}{c}\text { Length } \\
\text { of } \\
\text { Follow } \\
\text { up } \\
\text { (Weeks } \\
\text { ) }\end{array}$ \\
\hline & & & & $\begin{array}{l}\text { psychologist, student/trainee, youth } \\
\text { worker }\end{array}$ & & \\
\hline & & & $\begin{array}{l}\text { Control, } \\
(\mathrm{N}=40)\end{array}$ & Waitlisting or no treatment & & \\
\hline \multirow[t]{3}{*}{$\begin{array}{l}\text { Miller, } 1972^{58,} \\
59\end{array}$} & \multirow[t]{3}{*}{$\begin{array}{l}\text { United States } \\
\text { RCT } \\
\text { Efficacy } \\
\text { Outpatient }\end{array}$} & \multirow[t]{3}{*}{ SP } & $\begin{array}{l}\text { Child CBT, } \\
(\mathrm{N}=\mathrm{NR})\end{array}$ & $\begin{array}{l}\text { Reciprocal inhibition } \\
\text { Individual-based } \\
\text { Relaxation } \\
\text { Exposure } \\
\text { Delivered by doctoral psychologist } \\
60 \text { min session } 3 \text { times per week for } \\
8 \text { weeks }\end{array}$ & \multirow{3}{*}{$\begin{array}{l}\text { Age mean (years): } 10.8 \text { (range: 6- } \\
14 \text { ) } \\
\text { Male: } 55 \% \\
\text { Caucasian: } 95.5 \% \\
\text { African American: } 4.5 \% \\
\text { Socioeconomic status: } \\
\text { Low income: } 7 \% \\
\text { Middle income:75\% } \\
\text { High income: } 8 \%\end{array}$} & \multirow[t]{3}{*}{104} \\
\hline & & & $\begin{array}{l}\text { Other } \\
\text { therapy, } \\
(\mathrm{N}=\mathrm{NR})\end{array}$ & $\begin{array}{l}\text { Individual, play psychotherapy } \\
\text { directed toward inner experiences } \\
60 \text { min session } 3 \text { times per week for } \\
8 \text { weeks }\end{array}$ & & \\
\hline & & & $\begin{array}{l}\text { Control, } \\
(\mathrm{N}=\mathrm{NR})\end{array}$ & $\begin{array}{l}\text { Waitlist: } 60 \text { min session } 3 \text { times per } \\
\text { week for } 8 \text { weeks }\end{array}$ & & \\
\hline \multirow[t]{2}{*}{$\begin{array}{l}\text { Monga, } \\
2015^{159}\end{array}$} & \multirow[t]{2}{*}{$\begin{array}{l}\text { Canada } \\
\text { RCT } \\
\text { Efficacy } \\
\text { Outpatient }\end{array}$} & \multirow[t]{2}{*}{ NR } & $\begin{array}{l}\text { Parent Only } \\
\text { intervention, } \\
(\mathrm{N}=32)\end{array}$ & $\begin{array}{l}\text { Taming sneaky fears } \\
\text { Exposure } \\
\text { Relaxation } \\
\text { Cognitive problem solving } \\
\text { Group based } \\
\text { Delivered by psychologist, Masters } \\
\text { level clinician, psychiatrist } \\
60 \text { min parents, } 60 \text { min child } \\
\text { (attention placebo) Weekly for } 11 \\
\text { weeks }\end{array}$ & $\begin{array}{l}\text { Age mean (years): } 7 \text { (range: } 5-7 \text { ) } \\
\text { Male: } 40.6 \% \\
\text { Caucasian: } 90.6 \%\end{array}$ & \multirow[t]{2}{*}{52} \\
\hline & & & $\begin{array}{l}\text { Child CBT + } \\
\text { parent } \\
\text { intervention, } \\
(\mathrm{N}=45)\end{array}$ & $\begin{array}{l}\text { Taming sneaky fears } \\
\text { Exposure } \\
\text { Relaxation } \\
\text { Cognitive problem solving } \\
\text { Group Based } \\
\text { Delivered by psychologist, Masters } \\
\text { level clinician, psychiatrist } \\
60 \text { min parents, 60min child(CBT) }\end{array}$ & $\begin{array}{l}\text { Age mean (years): } 6.6 \text { (range: 5- } \\
\text { 7) } \\
\text { Male: } 35.6 \% \\
\text { Caucasian: } 88.9 \%\end{array}$ & \\
\hline
\end{tabular}




\begin{tabular}{|c|c|c|c|c|c|c|}
\hline Author, Year & $\begin{array}{l}\text { Study Country, } \\
\text { Study Design, } \\
\text { Type of Study } \\
\text { (Efficacyl } \\
\text { Effectiveness), } \\
\text { Study Settings }\end{array}$ & $\begin{array}{c}\text { Type of } \\
\text { Anxiety/Severity } \\
\text { (CGI) }\end{array}$ & $\begin{array}{l}\text { Intervention } \\
\text { and } \\
\text { Comparison } \\
\text { s (N of } \\
\text { Patients) }\end{array}$ & $\begin{array}{l}\text { Characteristics of Interventions } \\
\text { (Psychotherapy: Components, } \\
\text { Delivery Model)/Pharm: Drug) } \\
\text { Intensity, Duration (Weeks)) }\end{array}$ & $\begin{array}{c}\text { Patient Characteristics Mean } \\
\text { Age (Range), Male (\%), } \\
\text { Race/Ethnicity, Comorbidity, } \\
\text { Household Income, Parent } \\
\text { Education, Family } \\
\text { Dysfunction/Stressor, } \\
\text { Treatment Sequence, } \\
\text { Insurance, History of } \\
\text { Maltreatment) } \\
\end{array}$ & $\begin{array}{l}\text { Length } \\
\text { of } \\
\text { Follow } \\
\text { up } \\
\text { (Weeks } \\
\text { ) }\end{array}$ \\
\hline & & & & Weekly, 11 weeks & & \\
\hline \multirow[t]{3}{*}{$\begin{array}{l}\text { Muris, } 1998 \\
153\end{array}$} & \multirow{3}{*}{$\begin{array}{l}\text { Netherland } \\
\text { RCT } \\
\text { Efficacy } \\
\text { Mental health } \\
\text { clinic }\end{array}$} & \multirow[t]{3}{*}{$\mathrm{SP}$} & $\begin{array}{l}\text { Other therapy } \\
,(N=9)\end{array}$ & $\begin{array}{l}\text { EMDR } \\
\text { Delivered by psychotherapist } \\
1,150 \text { min session }\end{array}$ & \multirow{3}{*}{$\begin{array}{l}\text { Age mean (years): } 12.58 \text { ( range: } \\
\text { 8-17) } \\
\text { Caucasian: } 100 \% \\
\text { Medium income: } 100 \%\end{array}$} & \multirow[t]{3}{*}{0} \\
\hline & & & $\begin{array}{l}\text { Child CBT, } \\
(\mathrm{N}=9)\end{array}$ & $\begin{array}{l}\text { Generic CBT } \\
\text { Exposure } \\
\text { Individual } \\
\text { Delivered by behavioral scientist } \\
1,150 \text { min session }\end{array}$ & & \\
\hline & & & $\begin{array}{l}\text { Distance } \\
\text { Therapy, } \\
(\mathrm{N}=8)\end{array}$ & $\begin{array}{l}\text { Generic CBT } \\
\text { Exposure } \\
\text { Individual-based exposure cognitive } \\
\text { strategies } \\
\text { Delivered by behavioral scientist } \\
1,150 \text { min session }\end{array}$ & & \\
\hline \multirow[t]{3}{*}{$\begin{array}{l}\text { Rapee, } \\
2006^{69}\end{array}$} & \multirow[t]{3}{*}{$\begin{array}{l}\text { Australia } \\
\text { RCT } \\
\text { Efficacy } \\
\text { Mental health } \\
\text { clinic }\end{array}$} & \multirow[t]{3}{*}{$\begin{array}{l}\text { GAD, PD } \\
\text { (agoraphobia is } \\
\text { not specified), } \\
\text { SAD, SP, SoP. }\end{array}$} & $\begin{array}{l}\text { Child and } \\
\text { parent } \\
\text { together CBT, } \\
(\mathrm{N}=90)\end{array}$ & $\begin{array}{l}\text { Cool Kids } \\
\text { Group based } \\
\text { Exposure } \\
\text { Cognitive problem solving } \\
92 \text {-hour sessions over } 12 \text { weeks } \\
\text { Delivered by student trainee. }\end{array}$ & $\begin{array}{l}\text { Age mean (years): } 9.475 \text { (Range: } \\
6 \text {-12) } \\
\text { Male: } 66.6 \% \\
\text { Low income: } n=26(<\$ 30,000)\end{array}$ & \multirow[t]{3}{*}{36} \\
\hline & & & $\begin{array}{l}\text { Distance } \\
\text { Therapy, } \\
(\mathrm{N}=90)\end{array}$ & $\begin{array}{l}\text { Other: Bibliotherapy } \\
\text { Individual based } \\
\text { Exposure } \\
\text { Relaxation } \\
\text { Cognitive problem solving } \\
\text { Treatment duration is } 12 \text { weeks at } \\
\text { own pace }\end{array}$ & $\begin{array}{l}\text { Age mean (years): } 9.558 \text { (Range: } \\
6-12) \\
\text { Male: } 64.44 \% \\
\text { Low income: } n=9(<\$ 30,000)\end{array}$ & \\
\hline & & & $\begin{array}{l}\text { Control, } \\
(\mathrm{N}=87)\end{array}$ & Waitlisting or no treatment & $\begin{array}{l}\text { Age mean (years): } 9.5 \text { (Range: } 6 \\
-12 \text { ) } \\
\text { Male: } 48.2 \% \\
\text { Low income: } n=15(<\$ 30,000)\end{array}$ & \\
\hline
\end{tabular}




\begin{tabular}{|c|c|c|c|c|c|c|}
\hline Author, Year & $\begin{array}{c}\text { Study Country, } \\
\text { Study Design, } \\
\text { Type of Study } \\
\text { (Efficacyl } \\
\text { Effectiveness), } \\
\text { Study Settings }\end{array}$ & $\begin{array}{c}\text { Type of } \\
\text { Anxiety/Severity } \\
\text { (CGI) }\end{array}$ & $\begin{array}{l}\text { Intervention } \\
\text { and } \\
\text { Comparison } \\
\text { s (N of } \\
\text { Patients) }\end{array}$ & $\begin{array}{l}\text { Characteristics of Interventions } \\
\text { (Psychotherapy: Components, } \\
\text { Delivery Model)/Pharm: Drug) } \\
\text { Intensity, Duration (Weeks)) }\end{array}$ & $\begin{array}{l}\text { Patient Characteristics Mean } \\
\text { Age (Range), Male (\%), } \\
\text { Race/Ethnicity, Comorbidity, } \\
\text { Household Income, Parent } \\
\text { Education, Family } \\
\text { Dysfunction/Stressor, } \\
\text { Treatment Sequence, } \\
\text { Insurance, History of } \\
\text { Maltreatment) } \\
\end{array}$ & $\begin{array}{l}\text { Length } \\
\text { of } \\
\text { Follow } \\
\text { up } \\
\text { (Weeks } \\
\text { ) }\end{array}$ \\
\hline \multirow[t]{3}{*}{$\begin{array}{l}\text { Spence, } \\
2006^{81}\end{array}$} & \multirow[t]{3}{*}{$\begin{array}{l}\text { Australia } \\
\text { RCT } \\
\text { Efficacy } \\
\text { Mental health } \\
\text { clinic }\end{array}$} & \multirow[t]{3}{*}{$\begin{array}{l}\text { GAD, SAD, SP } \\
\text { SoP }\end{array}$} & $\begin{array}{l}\text { Child CBT } \\
\text { plus separate } \\
\text { parent } \\
\text { intervention, } \\
(\mathrm{N}=22)\end{array}$ & $\begin{array}{l}\text { Generic CBT } \\
\text { Group based } \\
\text { Exposure } \\
\text { Relaxation } \\
\text { Cognitive problem solving } \\
1060 \text {-minute weekly child sessions } \\
\text { and } 660 \text {-minute weekly parent } \\
\text { sessions, plus booster sessions at } 1 \\
\text { and } 3 \text { months } \\
\text { Delivered by } 5 \text { doctoral level } \\
\text { psychologists. }\end{array}$ & $\begin{array}{l}\text { Age mean (years): } 10.26 \text { (Range } \\
7-14) \\
\text { Male: } 59 \%\end{array}$ & \multirow[t]{3}{*}{12} \\
\hline & & & $\begin{array}{l}\text { Distance } \\
\text { Therapy, } \\
(\mathrm{N}=27)\end{array}$ & $\begin{array}{l}\text { Generic CBT } \\
\text { Internet CBT } \\
\text { Group based } \\
\text { Exposure } \\
\text { Relaxation } \\
\text { Cognitive problem solving } \\
5 \text { of the } 10 \text { child sessions plus the } 3 \text { - } \\
\text { month booster via Internet, with the } \\
\text { remaining sessions being conducted } \\
\text { in the clinic; } 3 \text { of the } 6 \text { parents } \\
\text { sessions and the } 3 \text {-month via } \\
\text { Internet } \\
\text { Delivered through the internet }\end{array}$ & $\begin{array}{l}\text { Age mean (years): } 9.8 \text { (Range } 7- \\
\text { 14) } \\
\text { Male: } 59.2 \%\end{array}$ & \\
\hline & & & $\begin{array}{l}\text { Control, } \\
(\mathrm{N}=23)\end{array}$ & Waitlisting or no treatment & $\begin{array}{l}\text { Age mean (years): } 9.8 \text { (Range } 7- \\
\text { 14) } \\
\text { Male: } 56.5 \%\end{array}$ & \\
\hline $\begin{array}{l}\text { Spence, } \\
2011^{82}\end{array}$ & $\begin{array}{l}\text { Australia } \\
\text { RCT } \\
\text { Efficacy } \\
\text { Mental health } \\
\text { clinic }\end{array}$ & $\begin{array}{l}\text { GAD, SAD, SoP, } \\
\text { SP }\end{array}$ & $\begin{array}{l}\text { Distance } \\
\text { Therapy, } \\
(\mathrm{N}=44)\end{array}$ & $\begin{array}{l}\text { Brave online } \\
\text { Technology-based } \\
\text { Individual based } \\
\text { Exposure } \\
\text { Relaxation } \\
\text { Cognitive problem solving } \\
10 \text { adolescents weekly sessions and } \\
5 \text { parent sessions ( } 60 \text { minutes each) }\end{array}$ & $\begin{array}{l}\text { Age mean (years): } 13.98 \text { (range: } \\
\text { 12-18) } \\
\text { Males: } 41 \% \\
\text { High income(>\$76,910): } 47 \% \\
\text { College graduate (parent): } 58 \% \\
\text { Depression: } 2.6 \% \\
\text { ODD: } 1.7 \% \\
\text { Dysthymic disorder: } 9.7 \%\end{array}$ & 52 \\
\hline
\end{tabular}




\begin{tabular}{|c|c|c|c|c|c|c|}
\hline Author, Year & $\begin{array}{l}\text { Study Country, } \\
\text { Study Design, } \\
\text { Type of Study } \\
\text { (Efficacyl } \\
\text { Effectiveness), } \\
\text { Study Settings }\end{array}$ & $\begin{array}{c}\text { Type of } \\
\text { Anxiety/Severity } \\
\text { (CGI) }\end{array}$ & $\begin{array}{l}\text { Intervention } \\
\text { and } \\
\text { Comparison } \\
\text { s (N of } \\
\text { Patients) }\end{array}$ & $\begin{array}{l}\text { Characteristics of Interventions } \\
\text { (Psychotherapy: Components, } \\
\text { Delivery Model)/Pharm: Drug) } \\
\text { Intensity, Duration (Weeks)) }\end{array}$ & $\begin{array}{c}\text { Patient Characteristics Mean } \\
\text { Age (Range), Male (\%), } \\
\text { Race/Ethnicity, Comorbidity, } \\
\text { Household Income, Parent } \\
\text { Education, Family } \\
\text { Dysfunction/Stressor, } \\
\text { Treatment Sequence, } \\
\text { Insurance, History of } \\
\text { Maltreatment) }\end{array}$ & $\begin{array}{c}\text { Length } \\
\text { of } \\
\text { Follow } \\
\text { up } \\
\text { (Weeks } \\
\text { ) }\end{array}$ \\
\hline & & & & $\begin{array}{l}\text { over } 12 \text { weeks; } 1 \text { 15-minute phone } \\
\text { call, email feedback after each } \\
\text { session } \\
\text { Delivered by psychologist, Masters } \\
\text { level clinician }\end{array}$ & & \\
\hline & & & $\begin{array}{l}\text { Child CBT } \\
\text { plus separate } \\
\text { parent } \\
\text { intervention, } \\
(\mathrm{N}=44)\end{array}$ & $\begin{array}{l}\text { Individual based } \\
\text { Exposure } \\
\text { Relaxation } \\
\text { Cognitive problem solving } \\
10 \text { adolescents weekly sessions and } \\
5 \text { parent sessions ( } 60 \text { minutes each) } \\
\text { over } 12 \text { weeks } \\
\text { Delivered by psychologist, Masters } \\
\text { level clinician }\end{array}$ & & \\
\hline & & & $\begin{array}{l}\text { Control, } \\
(\mathrm{N}=27)\end{array}$ & Waitlisting or no treatment & & \\
\hline \multirow[t]{3}{*}{$\begin{array}{l}\text { Waters, } \\
2009^{86}\end{array}$} & \multirow[t]{3}{*}{$\begin{array}{l}\text { Australia } \\
\text { RCT } \\
\text { Efficacy } \\
\text { Outpatient }\end{array}$} & \multirow[t]{3}{*}{$\begin{array}{l}\text { GAD, SAD, SoP, } \\
\text { SP }\end{array}$} & $\begin{array}{l}\text { Child CBT } \\
\text { plus separate } \\
\text { parent } \\
\text { intervention, } \\
(\mathrm{N}=38)\end{array}$ & $\begin{array}{l}\text { Take action } \\
\text { Group based } \\
\text { Exposure } \\
\text { Relaxation } \\
\text { Cognitive problem solving } \\
10 \text { weekly 1-hour child and one hour } \\
\text { parents sessions } \\
\text { Delivered by psychologist }\end{array}$ & $\begin{array}{l}\text { Age mean (years): } 6.89 \text { (range: 4- } \\
\text { 8) } \\
\text { Males: } 37 \% \\
\text { Caucasian: } 97 \%\end{array}$ & \multirow[t]{3}{*}{52} \\
\hline & & & $\begin{array}{l}\text { Parent only } \\
\text { intervention, } \\
(\mathrm{N}=31)\end{array}$ & $\begin{array}{l}\text { Take action } \\
\text { Group based } \\
\text { Exposure } \\
\text { Relaxation } \\
\text { Cognitive problem solving } \\
10 \text { weekly 1-hour child and one hour } \\
\text { parents sessions } \\
\text { Delivered by psychologist }\end{array}$ & $\begin{array}{l}\text { Age mean (years): } 6.68 \text { (range: 4- } \\
\text { 8) } \\
\text { Males: } 58 \% \\
\text { Caucasian: } 97 \%\end{array}$ & \\
\hline & & & $\begin{array}{l}\text { Control, } \\
(\mathrm{N}=11)\end{array}$ & Waitlisting or no treatment & $\begin{array}{l}\text { Age mean (years): } 6.79 \text { (range 4- } \\
\text { 8) }\end{array}$ & \\
\hline
\end{tabular}




\begin{tabular}{|c|c|c|c|c|c|c|}
\hline Author, Year & $\begin{array}{l}\text { Study Country, } \\
\text { Study Design, } \\
\text { Type of Study } \\
\text { (Efficacyl } \\
\text { Effectiveness), } \\
\text { Study Settings }\end{array}$ & $\begin{array}{c}\text { Type of } \\
\text { AnxietylSeverity } \\
\text { (CGI) }\end{array}$ & $\begin{array}{c}\text { Intervention } \\
\text { and } \\
\text { Comparison } \\
\mathrm{s} \text { (N of } \\
\text { Patients) }\end{array}$ & $\begin{array}{l}\text { Characteristics of Interventions } \\
\text { (Psychotherapy: Components, } \\
\text { Delivery Model)/Pharm: Drug) } \\
\text { Intensity, Duration (Weeks)) }\end{array}$ & $\begin{array}{c}\text { Patient Characteristics Mean } \\
\text { Age (Range), Male (\%), } \\
\text { Race/Ethnicity, Comorbidity, } \\
\text { Household Income, Parent } \\
\text { Education, Family } \\
\text { Dysfunction/Stressor, } \\
\text { Treatment Sequence, } \\
\text { Insurance, History of } \\
\text { Maltreatment) }\end{array}$ & $\begin{array}{c}\text { Length } \\
\text { of } \\
\text { Follow } \\
\text { up } \\
\text { (Weeks } \\
\text { ) }\end{array}$ \\
\hline & & & & & $\begin{array}{l}\text { Males: 55\% } \\
\text { Caucasian: 91\% }\end{array}$ & \\
\hline \multirow[t]{2}{*}{$\begin{array}{l}\text { Waters, } \\
2013^{160}\end{array}$} & \multirow[t]{2}{*}{$\begin{array}{l}\text { Australia } \\
\text { RCT } \\
\text { Outpatient }\end{array}$} & \multirow[t]{2}{*}{$\begin{array}{l}\text { GAD, SAD, SoP, } \\
\text { SP }\end{array}$} & AMB, $(\mathrm{N}=18)$ & $\begin{array}{l}\text { Attention bias modification training } \\
\text { Individual based } \\
4 \text { sessions a week for } 3 \text { weeks }\end{array}$ & $\begin{array}{l}\text { Age mean (years): } 9.3 \text { (range: } 7- \\
\text { 13) } \\
\text { Males: } 28 \% \\
\text { Caucasian: } 100 \%\end{array}$ & \multirow[t]{2}{*}{0} \\
\hline & & & CBT, $(\mathrm{N}=16)$ & 4 sessions a week for 3 weeks & $\begin{array}{l}\text { Age mean (years): } 9.9 \text { (range: } 7- \\
\text { 13) } \\
\text { Males: } 44 \% \\
\text { Caucasian: } 100 \%\end{array}$ & \\
\hline
\end{tabular}

ACT: acceptance and commitment therapy, ADHD: attention deficit hyperactivity disorder, BRAVE: body signs, relaxation, active helpful thoughts, victory over your fears, enjoy! reward yourself, CBT: cognitive behavioral therapy, CD: compact disc, CGI: clinical global impression, GAD: generalized anxiety disorder, NR: not reported, OCD: obsessive compulsive disorder, ODD: oppositional defiant disorder, PD: panic disorder, PTSD: posttraumatic stress disorder, RCT: randomized controlled trial, SAD: separation anxiety disorder, SoP: social anxiety, SP: specific phobia 
Table E.20. Characteristics of studies comparing different CBTs

\begin{tabular}{|c|c|c|c|c|c|c|}
\hline Author, Year & $\begin{array}{c}\text { Study Country, } \\
\text { Study Design, } \\
\text { Type of Study } \\
\text { (Efficacyl } \\
\text { Effectiveness), } \\
\text { Study Settings }\end{array}$ & $\begin{array}{c}\text { Type of } \\
\text { AnxietylSeverity } \\
\text { (CGI) }\end{array}$ & $\begin{array}{l}\text { Intervention } \\
\text { and } \\
\text { Comparison } \\
\text { s (N of } \\
\text { Patients) }\end{array}$ & $\begin{array}{l}\text { Characteristics of Interventions } \\
\text { (Psychotherapy: Components, } \\
\text { Delivery Model)/Pharm: Drug) } \\
\text { Intensity, Duration (Weeks)) }\end{array}$ & $\begin{array}{c}\text { Patient Characteristics Mean } \\
\text { Age (Range), Male (\%), } \\
\text { Race/Ethnicity, Comorbidity, } \\
\text { Household Income, Parent } \\
\text { Education, Family } \\
\text { Dysfunction/Stressor, } \\
\text { Treatment Sequence, } \\
\text { Insurance, History of } \\
\text { Maltreatment) }\end{array}$ & $\begin{array}{l}\text { Length } \\
\text { of } \\
\text { Follow } \\
\text { up } \\
\text { (Weeks } \\
\text { ) }\end{array}$ \\
\hline \multirow[t]{3}{*}{$\begin{array}{l}\text { Afshari, } 2014 \\
29\end{array}$} & \multirow[t]{3}{*}{$\begin{array}{l}\text { Iran } \\
\text { RCT } \\
\text { Efficacy } \\
\text { Outpatient } \\
\text { Mental health } \\
\text { clinic }\end{array}$} & \multirow[t]{3}{*}{ SAD } & $\begin{array}{l}\text { Child CBT, } \\
(\mathrm{N}=12)\end{array}$ & $\begin{array}{l}\text { Coping Cat } \\
\text { Exposure, Relaxation, Cognitive } \\
\text { Problem Solving } \\
\text { Group based } \\
\text { Delivered by student/trainee } \\
10,60 \text { min weekly sessions }\end{array}$ & $\begin{array}{l}\text { Age mean (years): } 10.4 \text { (range: 9- } \\
\text { 13) }\end{array}$ & \multirow[t]{3}{*}{12} \\
\hline & & & $\begin{array}{l}\text { Child CBT, } \\
(\mathrm{N}=12)\end{array}$ & $\begin{array}{l}\text { Other CBT } \\
\text { Cognitive problem solving } \\
\text { Group based } \\
\text { Delivered by student/trainee } \\
12,1 \text { hr weekly sessions }\end{array}$ & $\begin{array}{l}\text { Age mean (years): } 11 \text { (range: 9- } \\
\text { 13) }\end{array}$ & \\
\hline & & & $\begin{array}{l}\text { Control, } \\
(\mathrm{N}=10)\end{array}$ & Waitlisting or no treatment & $\begin{array}{l}\text { Age mean (years): } 10.3 \text { (range: 9- } \\
\text { 13) }\end{array}$ & \\
\hline \multirow[t]{2}{*}{$\begin{array}{l}\text { Amoros -Boix, } \\
2011^{161}\end{array}$} & \multirow[t]{2}{*}{$\begin{array}{l}\text { Spain } \\
\text { RCT } \\
\text { Efficacy } \\
\text { School }\end{array}$} & \multirow[t]{2}{*}{$\begin{array}{l}\text { GAD,PD with } \\
\text { agoraphobia, } \\
\text { PD , SP }\end{array}$} & $\begin{array}{l}\text { Child CBT, } \\
(\mathrm{N}=25)\end{array}$ & $\begin{array}{l}\text { IAFS } \\
\text { Exposure } \\
\text { Cognitive problem zolving } \\
\text { Group based } \\
\text { 12, } 90 \text { min weekly sessions }\end{array}$ & $\begin{array}{l}\text { Age mean (years): } 14.88 \\
\text { Male: } 16 \% \\
\text { depression: } 8 \%, \text { PTSD: } 4 \% \text {, } \\
\text { Dysthymia: } 4 \%\end{array}$ & \multirow[t]{2}{*}{26} \\
\hline & & & $\begin{array}{l}\text { Child CBT, } \\
(\mathrm{N}=25)\end{array}$ & $\begin{array}{l}\text { IAFS } \\
\text { Exposure } \\
\text { Cognitive problem zolving } \\
\text { Group based } \\
12,90 \text { min weekly sessions }\end{array}$ & $\begin{array}{l}\text { Age mean (years): } 14.80 \\
\text { Male: } 16 \% \\
\text { OCD: } 4 \%\end{array}$ & \\
\hline \multirow[t]{2}{*}{ Barrett, 1996} & \multirow[t]{2}{*}{$\begin{array}{l}\text { Australia } \\
\text { RCT } \\
\text { Efficacy } \\
\text { Mental health } \\
\text { clinic }\end{array}$} & \multirow[t]{2}{*}{ GAD, SAD, SoP } & $\begin{array}{l}\text { Child CBT, } \\
(\mathrm{N}=28)\end{array}$ & $\begin{array}{l}\text { Coping Koala } \\
\text { Individual based } \\
\text { Exposure } \\
\text { Relaxation } \\
\text { Cognitive problem solving } \\
\text { Delivered by doctoral level } \\
\text { psychologists } \\
12,60-80 \text { min weekly sessions }\end{array}$ & \multirow[t]{2}{*}{ Age range: $7-14$ years } & \multirow[t]{2}{*}{52} \\
\hline & & & $\begin{array}{l}\text { Child and } \\
\text { Parent }\end{array}$ & $\begin{array}{l}\text { Coping Koala } \\
\text { Individual based }\end{array}$ & & \\
\hline
\end{tabular}




\begin{tabular}{|c|c|c|c|c|c|c|}
\hline Author, Year & $\begin{array}{l}\text { Study Country, } \\
\text { Study Design, } \\
\text { Type of Study } \\
\text { (Efficacyl } \\
\text { Effectiveness), } \\
\text { Study Settings }\end{array}$ & $\begin{array}{c}\text { Type of } \\
\text { Anxiety/Severity } \\
\text { (CGI) }\end{array}$ & $\begin{array}{c}\text { Intervention } \\
\text { and } \\
\text { Comparison } \\
\text { s (N of } \\
\text { Patients) }\end{array}$ & $\begin{array}{l}\text { Characteristics of Interventions } \\
\text { (Psychotherapy: Components, } \\
\text { Delivery Model)/Pharm: Drug) } \\
\text { Intensity, Duration (Weeks)) }\end{array}$ & $\begin{array}{c}\text { Patient Characteristics Mean } \\
\text { Age (Range), Male (\%), } \\
\text { Race/Ethnicity, Comorbidity, } \\
\text { Household Income, Parent } \\
\text { Education, Family } \\
\text { Dysfunction/Stressor, } \\
\text { Treatment Sequence, } \\
\text { Insurance, History of } \\
\text { Maltreatment) } \\
\end{array}$ & $\begin{array}{l}\text { Length } \\
\text { of } \\
\text { Follow } \\
\text { up } \\
\text { (Weeks } \\
\quad \text { ) }\end{array}$ \\
\hline & & & $\begin{array}{l}\text { together CBT, } \\
(\mathrm{N}=25)\end{array}$ & $\begin{array}{l}\text { Exposure } \\
\text { Relaxation } \\
\text { Cognitive problem solving } \\
\text { Delivered by doctoral level } \\
\text { psychologists } \\
12,30 \text { min CBT, 40mins for family } \\
\text { intervention weekly sessions }\end{array}$ & & \\
\hline & & & $\begin{array}{l}\text { Control } \\
(\mathrm{N}=26)\end{array}$ & Waitlisting or no treatment & & \\
\hline \multirow[t]{3}{*}{$\begin{array}{l}\text { Barrett, } 1998 \\
33\end{array}$} & \multirow[t]{3}{*}{$\begin{array}{l}\text { Australia } \\
\text { RCT } \\
\text { Efficacy } \\
\text { Mental health } \\
\text { clinic }\end{array}$} & \multirow[t]{3}{*}{$\begin{array}{l}\text { GAD, SAD, SP, } \\
\text { SoP. }\end{array}$} & $\begin{array}{l}\text { Child CBT, } \\
(\mathrm{N}=23)\end{array}$ & $\begin{array}{l}\text { Coping koala } \\
\text { Group therapy, } \\
\text { Exposure } \\
\text { Relaxation } \\
\text { Cognitive problem solving } \\
\text { Delivered by } 4 \text { clinical psychologists. } \\
1 \text { session per week over } 12 \text { weeks. }\end{array}$ & \multirow[t]{3}{*}{$\begin{array}{l}\text { Age range: } 7-14 \text { years } \\
\text { Male: } 53.3 \%\end{array}$} & \multirow[t]{3}{*}{52} \\
\hline & & & $\begin{array}{l}\text { Child and } \\
\text { parent } \\
\text { together CBT, } \\
(\mathrm{N}=17)\end{array}$ & $\begin{array}{l}\text { Group-CBT and family management } \\
\text { training. } \\
\text { Group based } \\
\text { Exposure } \\
\text { Relaxation } \\
\text { Cognitive problem solving } \\
\text { Delivered by therapists } 1 \text { session per } \\
\text { week. }\end{array}$ & & \\
\hline & & & $\begin{array}{l}\text { Control, } \\
(\mathrm{N}=20)\end{array}$ & Waitlisting or no treatment & & \\
\hline $\begin{array}{l}\text { Bodden, } 2008 \\
162,163\end{array}$ & $\begin{array}{l}\text { Netherland s } \\
\text { RCT } \\
\text { Efficacy } \\
\text { Mental health } \\
\text { clinic }\end{array}$ & $\begin{array}{l}\text { PD (agoraphobia } \\
\text { is not specified), } \\
\text { SAD, SP, SoP, } \\
\text { GAD }\end{array}$ & $\begin{array}{l}\text { Child CBT, } \\
(\mathrm{N}=64)\end{array}$ & $\begin{array}{l}\text { Generic CBT } \\
\text { Individual based, } \\
\text { Exposure } \\
\text { Cognitive problem solving } \\
\text { Delivered by psychotherapists. } \\
60-90 \text { min session per week } \\
\text { for } 13 \text { weeks }\end{array}$ & $\begin{array}{l}\text { Age mean (years): } 12.4 \text { (range: } 8- \\
\text { 17) } \\
\text { Males: } 40.6 \% \\
\text { Caucasian: } 100 \% \\
\text { ADHD: } 8 \% \\
\text { Depression: } 24 \% \\
\text { OCD: } 5 \%\end{array}$ & 13 \\
\hline
\end{tabular}




\begin{tabular}{|c|c|c|c|c|c|c|}
\hline Author, Year & $\begin{array}{l}\text { Study Country, } \\
\text { Study Design, } \\
\text { Type of Study } \\
\text { (Efficacyl } \\
\text { Effectiveness), } \\
\text { Study Settings }\end{array}$ & $\begin{array}{c}\text { Type of } \\
\text { Anxiety/Severity } \\
\text { (CGI) }\end{array}$ & $\begin{array}{l}\text { Intervention } \\
\text { and } \\
\text { Comparison } \\
\text { s (N of } \\
\text { Patients) }\end{array}$ & $\begin{array}{l}\text { Characteristics of Interventions } \\
\text { (Psychotherapy: Components, } \\
\text { Delivery Model)/Pharm: Drug) } \\
\text { Intensity, Duration (Weeks)) }\end{array}$ & $\begin{array}{c}\text { Patient Characteristics Mean } \\
\text { Age (Range), Male (\%), } \\
\text { Race/Ethnicity, Comorbidity, } \\
\text { Household Income, Parent } \\
\text { Education, Family } \\
\text { Dysfunction/Stressor, } \\
\text { Treatment Sequence, } \\
\text { Insurance, History of } \\
\text { Maltreatment) }\end{array}$ & $\begin{array}{l}\text { Length } \\
\text { of } \\
\text { Follow } \\
\text { up } \\
\text { (Weeks } \\
\text { ) }\end{array}$ \\
\hline & & & $\begin{array}{l}\text { Child CBT, } \\
(\mathrm{N}=64)\end{array}$ & $\begin{array}{l}\text { Family CBT } \\
60 \text { - } 90 \text { min session per week. } 13 \\
\text { session total; } 3 \text { sessions are with the } \\
\text { child alone, } 2 \text { with child and parents, } \\
5 \text { with parents alone, and } 3 \text { involve } \\
\text { the whole family, including siblings } \\
\text { Delivered by therapists }\end{array}$ & $\begin{array}{l}\text { ODD: } 1 \% \\
\text { Conduct problems: } 1 \% \\
\text { PTSD: } 6 \%\end{array}$ & \\
\hline \multirow[t]{2}{*}{$\begin{array}{l}\text { Chase, } \\
2012^{164}\end{array}$} & \multirow[t]{2}{*}{$\begin{array}{l}\text { United States } \\
\text { Non- } \\
\text { Randomized } \\
\text { comparative } \\
\text { studies } \\
\text { Efficacy }\end{array}$} & \multirow[t]{2}{*}{$\begin{array}{l}\text { PD with } \\
\text { agoraphobia }\end{array}$} & $\begin{array}{l}\text { Child CBT, } \\
(\mathrm{N}=26)\end{array}$ & $\begin{array}{l}\text { Panic control treatment } \\
\text { Exposure } \\
\text { Relaxation, } \\
\text { Cognitive problem solving } \\
\text { Individual-based } \\
\text { Delivered by doctoral psychologist } \\
11,50 \text { min sessions over } 12 \text { weeks }\end{array}$ & \multirow[t]{2}{*}{$\begin{array}{l}\text { Age mean (years): } 15.26 \text { ( range: } \\
11-18) \\
\text { Male: } 31.3 \% \\
\text { Caucasian: } 98 \% \text {, Hispanic: } 2 \%\end{array}$} & \multirow[t]{2}{*}{26} \\
\hline & & & $\begin{array}{l}\text { Child CBT, } \\
(\mathrm{N}=25)\end{array}$ & $\begin{array}{l}\text { Panic control treatment } \\
\text { Exposure cognitive problem solving } \\
\text { Group-based } \\
\text { Delivered by doctoral psychologist } \\
6 \text { consecutive extended-length } \\
\text { sessions over } 8 \text { days: } 3 \text { sessions were } \\
\text { (90min-120min long) } 2 \text { were (360min- } \\
420 \text { min) }\end{array}$ & & \\
\hline \multirow[t]{2}{*}{$\begin{array}{l}\text { Cobham, } \\
1998^{165}\end{array}$} & \multirow[t]{2}{*}{$\begin{array}{l}\text { Australia } \\
\text { RCT } \\
\text { Effectiveness } \\
\text { Mental health } \\
\text { clinic }\end{array}$} & \multirow[t]{2}{*}{$\begin{array}{l}\text { GAD, SAD, SP, } \\
\text { SoP }\end{array}$} & $\begin{array}{l}\text { Child CBT, } \\
(\mathrm{N}=\mathrm{NR})\end{array}$ & $\begin{array}{l}\text { Coping Koala } \\
\text { Exposure } \\
\text { Relaxation } \\
\text { Cognitive problem solving } \\
\text { Group based } \\
\text { Delivered by clinician } \\
10,90 \text { min weekly sessions. }\end{array}$ & \multirow[t]{2}{*}{$\begin{array}{l}\text { Age range: } 7-14 \text { years } \\
\text { Male: } n=34\end{array}$} & \multirow[t]{2}{*}{52} \\
\hline & & & $\begin{array}{l}\text { Child CBT } \\
\text { plus separate } \\
\text { parent } \\
\text { intervention, } \\
(\mathrm{N}=\mathrm{NR}) \\
\end{array}$ & $\begin{array}{l}\text { Coping Koala } \\
\text { Exposure } \\
\text { Relaxation } \\
\text { Cognitive problem solving } \\
\text { Group based. }\end{array}$ & & \\
\hline Creswell, & United Kingdom & GAD,PD with & Child CBT & Cool Kids & Age mean (years): 9.94 ( range: & 52 \\
\hline
\end{tabular}




\begin{tabular}{|c|c|c|c|c|c|c|}
\hline Author, Year & $\begin{array}{l}\text { Study Country, } \\
\text { Study Design, } \\
\text { Type of Study } \\
\text { (Efficacyl } \\
\text { Effectiveness), } \\
\text { Study Settings }\end{array}$ & $\begin{array}{c}\text { Type of } \\
\text { Anxiety/Severity } \\
\text { (CGI) }\end{array}$ & $\begin{array}{l}\text { Intervention } \\
\text { and } \\
\text { Comparison } \\
\text { s (N of } \\
\text { Patients) }\end{array}$ & $\begin{array}{l}\text { Characteristics of Interventions } \\
\text { (Psychotherapy: Components, } \\
\text { Delivery Model)/Pharm: Drug) } \\
\text { Intensity, Duration (Weeks)) }\end{array}$ & $\begin{array}{c}\text { Patient Characteristics Mean } \\
\text { Age (Range), Male (\%), } \\
\text { Race/Ethnicity, Comorbidity, } \\
\text { Household Income, Parent } \\
\text { Education, Family } \\
\text { Dysfunction/Stressor, } \\
\text { Treatment Sequence, } \\
\text { Insurance, History of } \\
\text { Maltreatment) } \\
\end{array}$ & $\begin{array}{l}\text { Length } \\
\text { of } \\
\text { Follow } \\
\text { up } \\
\text { (Weeks } \\
\text { ) }\end{array}$ \\
\hline \multirow[t]{3}{*}{$2015^{166}$} & \multirow[t]{3}{*}{$\begin{array}{l}\text { RCT } \\
\text { Efficacy } \\
\text { Mental health } \\
\text { clinic }\end{array}$} & \multirow[t]{3}{*}{$\begin{array}{l}\text { agoraphobia, PD } \\
\text { without } \\
\text { agoraphobia, } \\
\text { SAD, SoP, SP }\end{array}$} & $\begin{array}{l}\text { plus separate } \\
\text { parent } \\
\text { intervention, } \\
(\mathrm{N}=71)\end{array}$ & $\begin{array}{l}\text { Exposure } \\
\text { Cognitive problem solving } \\
\text { Individual-based } \\
\text { Delivered by doctoral psychotherapist } \\
\text { Mother: } 60 \text { min weekly sessions for } 8 \\
\text { weeks } \\
\text { Child CBT: } 60 \text { min weekly sessions } \\
\text { for } 8 \text { weeks } \\
\text { family health: } 2 \text { sessions for mother } \\
\text { and } 2 \text { child and mother together - } \\
\text { delivered over duration of } 8 \text { weeks }\end{array}$ & $\begin{array}{l}7-13) \\
\text { Male: } 47.9 \% \\
\text { Caucasian: } 96 \%, \text { African: } 2 \% \\
\text { other :2\% }\end{array}$ & \\
\hline & & & $\begin{array}{l}\text { Child CBT } \\
\text { plus separate } \\
\text { parent } \\
\text { intervention, } \\
(\mathrm{N}=69)\end{array}$ & $\begin{array}{l}\text { Cool Kids } \\
\text { Exposure } \\
\text { Cognitive problem solving Individual- } \\
\text { based } \\
\text { Delivered by doctoral psychotherapist } \\
\text { Mother: CBT } 8 \text { sessions } 60 \text { min } \\
\text { weekly sessions } \\
\text { Child CBT } 8,60 \text { min weekly sessions } \\
\text { family health: } 2 \text { sessions for mother } \\
\text { and } 2 \text { child and mother together } \\
\text { delivered over duration of } 16 \text { weeks }\end{array}$ & $\begin{array}{l}\text { Age mean (years): } 9.89 \text { ( range: } \\
6-12 \text { ) } \\
\text { Male: } 50.7 \% \\
\text { Caucasian: } 91 \% \text {, Asian: } 4.5 \% \text {, } \\
\text { other : } 4.5 \%\end{array}$ & \\
\hline & & & CBT, $(\mathrm{N}=71)$ & $\begin{array}{l}\text { Cool Kids } \\
\text { Exposure } \\
\text { Cognitive problem solving } \\
\text { Individual-based } \\
\text { Delivered by doctoral psychotherapist } \\
\text { Mother: Non - specific Intervention 2, } \\
60 \text { Min sessions, } \\
\text { Child CBT: } 8 \mathrm{~s}, 60 \text { Min weekly } \\
\text { sessions } \\
\text { mother-child interaction - } 10 \text { sessions } \\
\text { over } 8\end{array}$ & $\begin{array}{l}\text { Age mean (years): } 9.74 \text { ( range: } \\
7-13 \text { ) } \\
\text { Male: } 45.1 \% \\
\text { Caucasian: } 91 \% \text {, African: } 1 \% \text {, } \\
\text { Asian : } 3 \% \text {, other : } 5 \%\end{array}$ & \\
\hline $\begin{array}{l}\text { De Groot, } \\
2007^{167}\end{array}$ & $\begin{array}{l}\text { Australia } \\
\text { RCT }\end{array}$ & $\begin{array}{l}\text { GAD, PD } \\
\text { (agoraphobia is }\end{array}$ & $\begin{array}{l}\text { Child CBT } \\
\text { plus separate }\end{array}$ & $\begin{array}{l}\text { Do as I Do } \\
\text { Exposure }\end{array}$ & $\begin{array}{l}\text { Age mean (years): } 8.79 \text { (Range } 7 \\
-12 \text { ) }\end{array}$ & 36 \\
\hline
\end{tabular}




\begin{tabular}{|c|c|c|c|c|c|c|}
\hline Author, Year & $\begin{array}{l}\text { Study Country, } \\
\text { Study Design, } \\
\text { Type of Study } \\
\text { (Efficacyl } \\
\text { Effectiveness), } \\
\text { Study Settings }\end{array}$ & $\begin{array}{c}\text { Type of } \\
\text { Anxiety/Severity } \\
\text { (CGI) }\end{array}$ & $\begin{array}{l}\text { Intervention } \\
\text { and } \\
\text { Comparison } \\
\text { s (N of } \\
\text { Patients) }\end{array}$ & $\begin{array}{l}\text { Characteristics of Interventions } \\
\text { (Psychotherapy: Components, } \\
\text { Delivery Model)/Pharm: Drug) } \\
\text { Intensity, Duration (Weeks)) }\end{array}$ & $\begin{array}{c}\text { Patient Characteristics Mean } \\
\text { Age (Range), Male (\%), } \\
\text { Race/Ethnicity, Comorbidity, } \\
\text { Household Income, Parent } \\
\text { Education, Family } \\
\text { Dysfunction/Stressor, } \\
\text { Treatment Sequence, } \\
\text { Insurance, History of } \\
\text { Maltreatment) } \\
\end{array}$ & $\begin{array}{l}\text { Length } \\
\text { of } \\
\text { Follow } \\
\text { up } \\
\text { (Weeks } \\
\text { ) }\end{array}$ \\
\hline & \multirow[t]{2}{*}{$\begin{array}{l}\text { Efficacy } \\
\text { Mental health } \\
\text { clinic }\end{array}$} & \multirow[t]{2}{*}{$\begin{array}{l}\text { not specified), } \\
\text { SP, SAD, SoP. }\end{array}$} & $\begin{array}{l}\text { parent } \\
\text { intervention, } \\
(\mathrm{N}=14)\end{array}$ & $\begin{array}{l}\text { Relaxation } \\
\text { Cognitive problem solving } \\
\text { Individual-based } \\
\text { Delivered by doctoral level } \\
\text { psychologist } \\
60-90 \text { min weekly sessions for } 6 \\
\text { weeks (parents and children) }\end{array}$ & $\begin{array}{l}\text { Male: } 64.2 \% \\
\text { Mean GCI: } 6.93 \text { ( } 1.0)\end{array}$ & \\
\hline & & & $\begin{array}{l}\text { Child CBT } \\
\text { plus separate } \\
\text { parent } \\
\text { intervention, } \\
(\mathrm{N}=15)\end{array}$ & $\begin{array}{l}\text { Exposure } \\
\text { Relaxation } \\
\text { Cognitive problem solving } \\
\text { Delivered by doctoral level } \\
\text { psychologist } \\
60-90 \text { minute weekly sessions for } 6 \\
\text { weeks (parents and children) }\end{array}$ & $\begin{array}{l}\text { Age mean (years): } 8.93 \text { (Range } 7 \\
\text {-12) } \\
\text { Male: } 66.6 \% \\
\text { Mean GCl: } 6.93(0.8)\end{array}$ & \\
\hline \multirow[t]{2}{*}{$\begin{array}{l}\text { Esbjorn, } \\
2014^{168}\end{array}$} & \multirow{2}{*}{$\begin{array}{l}\text { Denmark } \\
\text { RCT } \\
\text { Effectiveness } \\
\text { Mental health } \\
\text { clinic }\end{array}$} & \multirow[t]{2}{*}{$\begin{array}{l}\text { GAD, SAD, SoP, } \\
\text { SP }\end{array}$} & $\begin{array}{l}\text { Child CBT, } \\
(N=N R)\end{array}$ & $\begin{array}{l}\text { Individual based } \\
\text { Delivered by therapists } \\
\text { Weekly for } 14 \text { weeks }\end{array}$ & \multirow{2}{*}{$\begin{array}{l}\text { Total population: } N=54 \\
\text { Age mean (years): } 9.59 \text { (range: } 7 \text { - } \\
12 \text { ) } \\
\text { Males: } 52 \% \\
\text { Caucasian: } 100 \% \\
\text { College graduate (parent): } 35 \%\end{array}$} & \multirow[t]{2}{*}{26} \\
\hline & & & $\begin{array}{l}\text { Child CBT } \\
\text { plus separate } \\
\text { parent } \\
\text { intervention, } \\
(\mathrm{N}=\mathrm{NR})\end{array}$ & $\begin{array}{l}\text { Individual based } \\
\text { Delivered by therapists } \\
\text { Weekly for } 14 \text { weeks }\end{array}$ & & \\
\hline $\begin{array}{l}\text { Flannery- } \\
\text { Schroeder, } \\
2000^{39,40}\end{array}$ & $\begin{array}{l}\text { United States } \\
\text { RCT } \\
\text { Efficacy } \\
\text { Outpatient }\end{array}$ & $\begin{array}{l}\text { GAD,SAD, SoP, } \\
\text { SP }\end{array}$ & $\begin{array}{l}\text { Child CBT, } \\
(\mathrm{N}=18)\end{array}$ & $\begin{array}{l}\text { Coping Cat } \\
\text { Child CBT- (parents included < 20\%) } \\
\text { Individual based } \\
\text { Exposure } \\
\text { Relaxation } \\
\text { Cognitive problem solving } \\
18 \text { sessions, } 50-60 \text { minute weekly } \\
\text { sessions } \\
\text { Delivered by Masters students }\end{array}$ & $\begin{array}{l}\text { Male: } 33.3 \% \\
\text { Caucasian: } 94.4 \% \text {, Other: } 5.6 \% \\
\text { ADHD: } 11 \% \text {, Depression: } 5.6 \%\end{array}$ & 13 \\
\hline
\end{tabular}




\begin{tabular}{|c|c|c|c|c|c|c|}
\hline Author, Year & $\begin{array}{l}\text { Study Country, } \\
\text { Study Design, } \\
\text { Type of Study } \\
\text { (Efficacyl } \\
\text { Effectiveness), } \\
\text { Study Settings }\end{array}$ & $\begin{array}{c}\text { Type of } \\
\text { Anxiety/Severity } \\
\text { (CGI) }\end{array}$ & $\begin{array}{l}\text { Intervention } \\
\text { and } \\
\text { Comparison } \\
\text { s (N of } \\
\text { Patients) }\end{array}$ & $\begin{array}{l}\text { Characteristics of Interventions } \\
\text { (Psychotherapy: Components, } \\
\text { Delivery Model)/Pharm: Drug) } \\
\text { Intensity, Duration (Weeks)) }\end{array}$ & $\begin{array}{c}\text { Patient Characteristics Mean } \\
\text { Age (Range), Male (\%), } \\
\text { Race/Ethnicity, Comorbidity, } \\
\text { Household Income, Parent } \\
\text { Education, Family } \\
\text { Dysfunction/Stressor, } \\
\text { Treatment Sequence, } \\
\text { Insurance, History of } \\
\text { Maltreatment) }\end{array}$ & $\begin{array}{l}\text { Length } \\
\text { of } \\
\text { Follow } \\
\text { up } \\
\text { (Weeks } \\
\text { ) }\end{array}$ \\
\hline & & & $\begin{array}{l}\text { Child CBT, } \\
(\mathrm{N}=13)\end{array}$ & $\begin{array}{l}\text { Coping Cat } \\
\text { Child CBT- (parents included < 20\%) } \\
\text { Individual based } \\
\text { Exposure } \\
\text { Relaxation } \\
\text { Cognitive problem solving } \\
18 \text { sessions, } 90 \text { minute weekly } \\
\text { sessions } \\
\text { Delivered by Masters students }\end{array}$ & $\begin{array}{l}\text { Male: } 61.5 \% \\
\text { Caucasian: } 84.6 \% \text {, Other: } 15.4 \% \\
\text { ADHD: } 30.7 \% \text {, Depression: } \\
\text { 15.3\%, ODD: } 23 \%\end{array}$ & \\
\hline & & & $\begin{array}{l}\text { Control, } \\
(\mathrm{N}=14)\end{array}$ & Waitlisting or no treatment & $\begin{array}{l}\text { Male: } 42.8 \% \\
\text { Caucasian: } 92.8 \% \text {, Other: } 7.2 \% \\
\text { ADHD: } 21.4 \%\end{array}$ & \\
\hline \multirow[t]{2}{*}{$\begin{array}{l}\text { Garcia-Lopez, } \\
2014^{169}\end{array}$} & \multirow[t]{2}{*}{$\begin{array}{l}\text { Spain } \\
\text { RCT } \\
\text { Efficacy } \\
\text { School }\end{array}$} & \multirow[t]{2}{*}{$\begin{array}{l}\text { GAD, SAD, SoP, } \\
\text { SP }\end{array}$} & $\begin{array}{l}\text { Child CBT, } \\
(\mathrm{N}=33)\end{array}$ & $\begin{array}{l}\text { IAFS } \\
\text { Exposure } \\
\text { Cognitive Problem Solving } \\
\text { Group based } \\
\text { Delivered by student/trainee } \\
\text { 12, 90mins weekly sessions }\end{array}$ & \multirow[t]{2}{*}{$\begin{array}{l}\text { Age mean (years): } 15.42 \text { (range: } \\
\text { 13-18) } \\
\text { Males: } 34.6 \%\end{array}$} & \multirow[t]{2}{*}{52} \\
\hline & & & $\begin{array}{l}\text { Child CBT } \\
\text { plus separate } \\
\text { parent } \\
\text { intervention, } \\
(\mathrm{N}=27)\end{array}$ & $\begin{array}{l}\text { IAFS } \\
\text { Exposure } \\
\text { Cognitive Problem Solving } \\
\text { Group based } \\
\text { Delivered by psychologist, } \\
\text { student/trainee } \\
1790 \text { min weekly sessions, and } 5 \\
120 \text { min parent sessions }\end{array}$ & & \\
\hline \multirow[t]{2}{*}{$\begin{array}{l}\text { Gil-Bernal, } \\
2009^{43}\end{array}$} & \multirow[t]{2}{*}{$\begin{array}{l}\text { Mexico } \\
\text { RCT } \\
\text { Efficacy } \\
\text { Public schools } \\
\text { in low income } \\
\text { district }\end{array}$} & \multirow[t]{2}{*}{ SoP } & $\begin{array}{l}\text { Child CBT, } \\
(\mathrm{N}=6)\end{array}$ & $\begin{array}{l}\text { IAFS } \\
\text { Child CBT- (parents included <20\%) } \\
\text { Group based } \\
\text { Exposure } \\
\text { Cognitive problem solving } \\
\text { Nine } 90-\text { minutes sessions during } 5 \\
\text { weeks } \\
\text { Delivered by therapists }\end{array}$ & \multirow[t]{2}{*}{$\begin{array}{l}\text { Age range: } 7-12 \text { years } \\
\text { Male: } 36.4 \%\end{array}$} & \multirow[t]{2}{*}{36} \\
\hline & & & Child CBT & IAFS & & \\
\hline
\end{tabular}




\begin{tabular}{|c|c|c|c|c|c|c|}
\hline Author, Year & $\begin{array}{l}\text { Study Country, } \\
\text { Study Design, } \\
\text { Type of Study } \\
\text { (Efficacyl } \\
\text { Effectiveness), } \\
\text { Study Settings }\end{array}$ & $\begin{array}{c}\text { Type of } \\
\text { Anxiety/Severity } \\
\text { (CGI) }\end{array}$ & $\begin{array}{l}\text { Intervention } \\
\text { and } \\
\text { Comparison } \\
\text { s (N of } \\
\text { Patients) }\end{array}$ & $\begin{array}{l}\text { Characteristics of Interventions } \\
\text { (Psychotherapy: Components, } \\
\text { Delivery Model)/Pharm: Drug) } \\
\text { Intensity, Duration (Weeks)) }\end{array}$ & $\begin{array}{c}\text { Patient Characteristics Mean } \\
\text { Age (Range), Male (\%), } \\
\text { Race/Ethnicity, Comorbidity, } \\
\text { Household Income, Parent } \\
\text { Education, Family } \\
\text { Dysfunction/Stressor, } \\
\text { Treatment Sequence, } \\
\text { Insurance, History of } \\
\text { Maltreatment) }\end{array}$ & $\begin{array}{l}\text { Length } \\
\text { of } \\
\text { Follow } \\
\text { up } \\
\text { (Weeks } \\
\text { ) }\end{array}$ \\
\hline & & & $\begin{array}{l}\text { plus separate } \\
\text { parent } \\
\text { intervention, } \\
(\mathrm{N}=5)\end{array}$ & $\begin{array}{l}\text { Combined therapy: IAFS + parent } \\
\text { education } \\
\text { Group based } \\
\text { Exposure } \\
\text { Relaxation } \\
\text { Cognitive problem solving } \\
\text { Nine } 90 \text {-minutes sessions during } 5 \\
\text { weeks } \\
\text { Delivered by therapists }\end{array}$ & & \\
\hline & & & $\begin{array}{l}\text { Control, } \\
(\mathrm{N}=6)\end{array}$ & Waitlisting or no treatment & & \\
\hline \multirow[t]{3}{*}{$\begin{array}{l}\text { Herbert, } \\
2009^{97}\end{array}$} & \multirow[t]{3}{*}{$\begin{array}{l}\text { United States } \\
\text { RCT } \\
\text { Efficacy } \\
\text { Mental health } \\
\text { clinic }\end{array}$} & \multirow[t]{3}{*}{$\begin{array}{l}\text { GAD , PD } \\
\text { (agoraphobia is } \\
\text { not specified), } \\
\text { SAD, SP, SoP }\end{array}$} & $\begin{array}{l}\text { Child CBT, } \\
(\mathrm{N}=23)\end{array}$ & $\begin{array}{l}\text { Generic CBT } \\
\text { Exposure } \\
\text { Relaxation } \\
\text { Cognitive Problem Solving } \\
\text { Group based } \\
\text { Delivered by Masters level clinicians } \\
12,120 \text { min weekly sessions }\end{array}$ & $\begin{array}{l}\text { Age mean (years): } 14.6 \text { (range } 12 \\
-17 \text { ) } \\
\text { Male : } 56.5 \% \\
\text { Caucasian: } 52 \% \text {, African } \\
\text { Americans: } 39 \% \text {, Asian: } 8.6 \%\end{array}$ & \multirow[t]{3}{*}{52} \\
\hline & & & $\begin{array}{l}\text { Child CBT, } \\
(\mathrm{N}=24)\end{array}$ & $\begin{array}{l}\text { Generic CBT } \\
\text { Exposure } \\
\text { Relaxation } \\
\text { Cognitive Problem Solving } \\
\text { Individual based } \\
\text { Delivered by Masters level clinicians. } \\
12,60 \text { min weekly sessions } \\
\end{array}$ & $\begin{array}{l}\text { Age mean (years): } 14.3 \text { (range } 12 \\
-17 \text { ) } \\
\text { Male: } 25 \% \\
\text { Caucasian: } 54.2 \% \text {, African } \\
\text { Americans: } 45.8 \%\end{array}$ & \\
\hline & & & $\begin{array}{l}\text { Control, } \\
(\mathrm{N}=26)\end{array}$ & $\begin{array}{l}\text { Attention control or treatment as } \\
\text { usual } \\
12,60 \text { min weekly sessions }\end{array}$ & $\begin{array}{l}\text { Age mean (years): } 15.1 \text { (range } \\
\text { 12-17) } \\
\text { Male: } 53.8 \% \\
\text { Caucasian: } 34.6 \% \text {, African } \\
\text { American: } 50 \% \text {, Hispanics: } 7.69 \% \\
\text { Asians: } 7.69 \%\end{array}$ & \\
\hline $\begin{array}{l}\text { Hudson, } \\
2014^{170}\end{array}$ & $\begin{array}{l}\text { Australia } \\
\text { RCT } \\
\text { Efficacy } \\
\text { Mental health }\end{array}$ & $\begin{array}{l}\text { GAD, PD, SAD, } \\
\text { SoP, SP anxiety }\end{array}$ & $\begin{array}{l}\text { Child CBT, } \\
(\mathrm{N}=94)\end{array}$ & $\begin{array}{l}\text { Cool Kids } \\
\text { Exposure } \\
\text { Cognitive problem solving } \\
\text { Group-based }\end{array}$ & Age mean (years): 9.5 & 26 \\
\hline
\end{tabular}




\begin{tabular}{|c|c|c|c|c|c|c|}
\hline Author, Year & $\begin{array}{l}\text { Study Country, } \\
\text { Study Design, } \\
\text { Type of Study } \\
\text { (Efficacyl } \\
\text { Effectiveness), } \\
\text { Study Settings }\end{array}$ & $\begin{array}{c}\text { Type of } \\
\text { Anxiety/Severity } \\
\text { (CGI) }\end{array}$ & $\begin{array}{l}\text { Intervention } \\
\text { and } \\
\text { Comparison } \\
\text { s (N of } \\
\text { Patients) }\end{array}$ & $\begin{array}{l}\text { Characteristics of Interventions } \\
\text { (Psychotherapy: Components, } \\
\text { Delivery Model)/Pharm: Drug) } \\
\text { Intensity, Duration (Weeks)) }\end{array}$ & $\begin{array}{c}\text { Patient Characteristics Mean } \\
\text { Age (Range), Male (\%), } \\
\text { Race/Ethnicity, Comorbidity, } \\
\text { Household Income, Parent } \\
\text { Education, Family } \\
\text { Dysfunction/Stressor, } \\
\text { Treatment Sequence, } \\
\text { Insurance, History of } \\
\text { Maltreatment) }\end{array}$ & $\begin{array}{l}\text { Length } \\
\text { of } \\
\text { Follow } \\
\text { up } \\
\text { (Weeks } \\
\text { ) }\end{array}$ \\
\hline & \multirow[t]{2}{*}{ clinic } & & & $\begin{array}{l}\text { Delivered by psychologist, } \\
\text { student/trainee } \\
10,2 \mathrm{hr} \text { weekly sessions }\end{array}$ & & \\
\hline & & & $\begin{array}{l}\text { Child CBT } \\
\text { plus separate } \\
\text { parent } \\
\text { intervention, } \\
(\mathrm{N}=95)\end{array}$ & $\begin{array}{l}\text { Exposure } \\
\text { Cognitive problem solving } \\
\text { Group-based } \\
\text { Delivered by psychologist, } \\
\text { student/trainee } \\
10,2 \mathrm{hr} \text { weekly sessions, } 5,45 \mathrm{~min} \\
\text { parent sessions }\end{array}$ & & \\
\hline \multirow[t]{3}{*}{ Ingul, $2014^{99}$} & \multirow[t]{3}{*}{$\begin{array}{l}\text { Norway } \\
\text { RCT } \\
\text { Efficacy } \\
\text { Mental health } \\
\text { clinic }\end{array}$} & \multirow[t]{3}{*}{ SoP } & $\begin{array}{l}\text { Child CBT, } \\
(\mathrm{N}=36)\end{array}$ & $\begin{array}{l}\text { Other CBT } \\
\text { Exposure } \\
\text { Cognitive problem solving } \\
\text { Individual-based } \\
\text { Delivered by psychologist and } \\
\text { Masters level clinician } \\
12,50 \text { min weekly sessions }\end{array}$ & $\begin{array}{l}\text { Age mean (years): } 14.98 \\
\text { (SD:0.94) } \\
\text { Male: } 43 \% \\
\text { ADHD: } 14.29 \% \\
\text { Depression: } 9.52 \% \\
\text { PTSD: } 4.76 \%\end{array}$ & \multirow[t]{3}{*}{52} \\
\hline & & & $\begin{array}{l}\text { Child CBT, } \\
(N=58)\end{array}$ & $\begin{array}{l}\text { Cat Project } \\
\text { Exposure } \\
\text { Cognitive problem solving } \\
\text { Group based } \\
10,90 \text { min sessions }\end{array}$ & $\begin{array}{l}\text { Age mean: } 14.30(\text { SD:0.89) } \\
\text { Males: } 40 \% \\
\text { ADHD: } 5 \% \\
\text { Depression: } 10 \%\end{array}$ & \\
\hline & & & $\begin{array}{l}\text { Control, } \\
(\mathrm{N}=34)\end{array}$ & $\begin{array}{l}\text { Attention control or treatment as } \\
\text { usual } \\
10,90 \text { min sessions }\end{array}$ & $\begin{array}{l}\text { Age mean (years): } 14.16 \\
\text { (SD:1.08) } \\
\text { Male: } 43 \% \\
\text { ADHD: } 6.25 \% \\
\text { Depression: } 6.25 \% \\
\text { OCD: } 6.25 \% \\
\text { PTSD: } 6.25 \% \%\end{array}$ & \\
\hline $\begin{array}{l}\text { Ishikawa, } \\
2012^{171}\end{array}$ & $\begin{array}{l}\text { Japan } \\
\text { Non } \\
\text { randomized } \\
\text { comparative }\end{array}$ & $\begin{array}{l}\text { GAD, SAD, SoP, } \\
\text { SP }\end{array}$ & $\begin{array}{l}\text { Child CBT, } \\
(N=N R)\end{array}$ & $\begin{array}{l}\text { Other CBT } \\
\text { Exposure } \\
\text { Cognitive problem solving } \\
\text { Group-based }\end{array}$ & $\begin{array}{l}\text { Total population= } 33 \\
\text { Age mean (years): } 11.24 \\
\text { (range:7-15) } \\
\text { Male: } 39 \%\end{array}$ & 12 \\
\hline
\end{tabular}




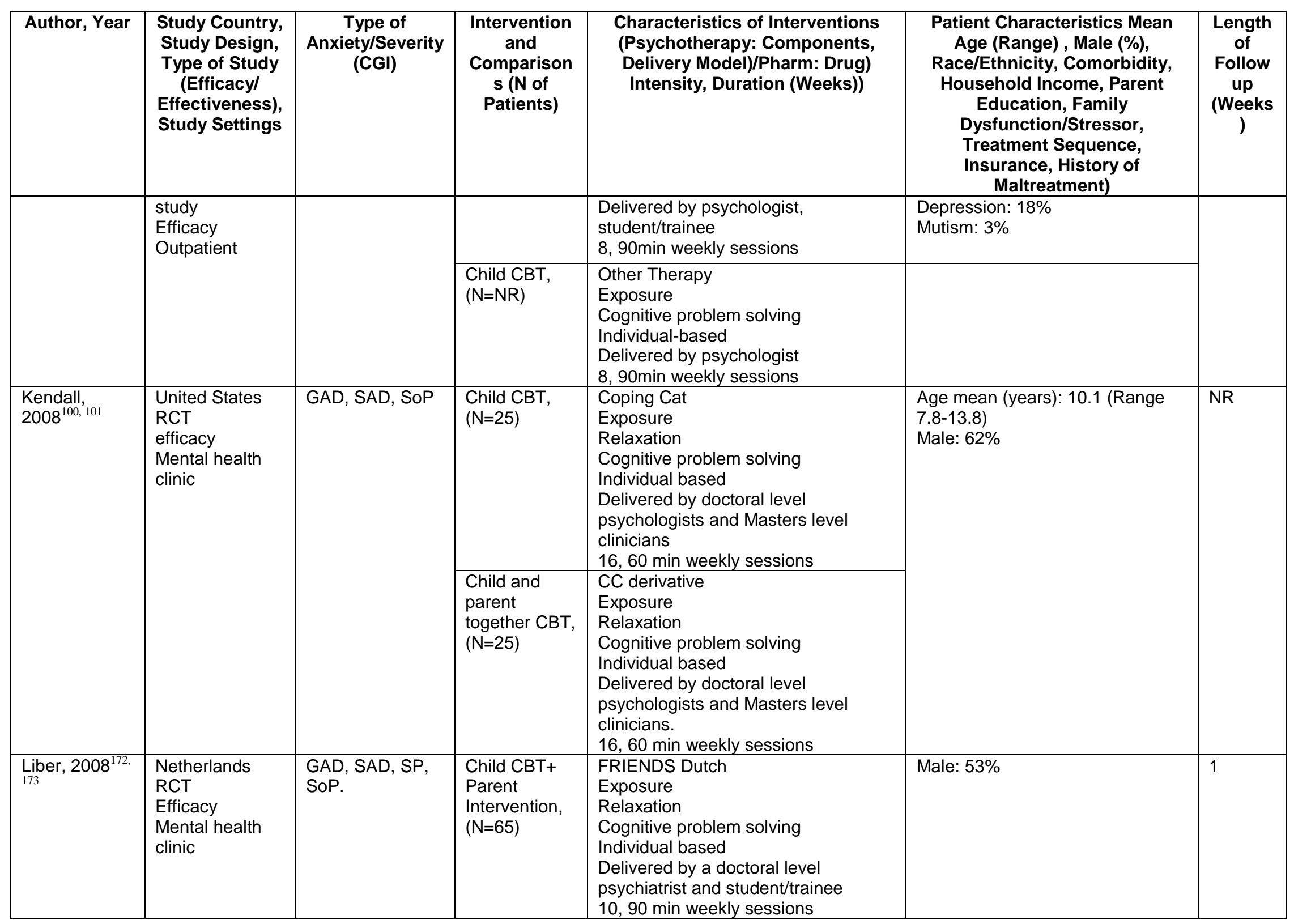




\begin{tabular}{|c|c|c|c|c|c|c|}
\hline Author, Year & $\begin{array}{l}\text { Study Country, } \\
\text { Study Design, } \\
\text { Type of Study } \\
\text { (Efficacyl } \\
\text { Effectiveness), } \\
\text { Study Settings }\end{array}$ & $\begin{array}{c}\text { Type of } \\
\text { Anxiety/Severity } \\
\text { (CGI) }\end{array}$ & $\begin{array}{l}\text { Intervention } \\
\text { and } \\
\text { Comparison } \\
\text { s (N of } \\
\text { Patients) }\end{array}$ & $\begin{array}{l}\text { Characteristics of Interventions } \\
\text { (Psychotherapy: Components, } \\
\text { Delivery Model)/Pharm: Drug) } \\
\text { Intensity, Duration (Weeks)) }\end{array}$ & $\begin{array}{c}\text { Patient Characteristics Mean } \\
\text { Age (Range), Male (\%), } \\
\text { Race/Ethnicity, Comorbidity, } \\
\text { Household Income, Parent } \\
\text { Education, Family } \\
\text { Dysfunction/Stressor, } \\
\text { Treatment Sequence, } \\
\text { Insurance, History of } \\
\text { Maltreatment) }\end{array}$ & $\begin{array}{l}\text { Length } \\
\text { of } \\
\text { Follow } \\
\text { up } \\
\text { (Weeks } \\
\text { ) }\end{array}$ \\
\hline & & & $\begin{array}{l}\text { Child CBT + } \\
\text { Parent } \\
\text { Intervention, } \\
(\mathrm{N}=62)\end{array}$ & $\begin{array}{l}\text { FRIENDS -Dutch } \\
\text { Exposure } \\
\text { Relaxation } \\
\text { Cognitive problem solving } \\
\text { Group based } \\
\text { Delivered by a doctoral level } \\
\text { psychiatrist and student/trainee } \\
\text { 14, 90min weekly sessions } \\
\end{array}$ & Male: $58 \%$ & \\
\hline \multirow[t]{2}{*}{$\begin{array}{l}\text { Manassis, } \\
2002^{174}\end{array}$} & \multirow[t]{2}{*}{$\begin{array}{l}\text { Canada } \\
\text { RCT } \\
\text { Efficacy } \\
\text { Mental health } \\
\text { clinic }\end{array}$} & \multirow[t]{2}{*}{$\begin{array}{l}\text { GAD, PD } \\
\text { (agoraphobia is } \\
\text { not specified) } \\
\text { SP, SAD, SoP }\end{array}$} & $\begin{array}{l}\text { Child CBT + } \\
\text { Parent } \\
\text { Intervention, } \\
(\mathrm{N}=37)\end{array}$ & $\begin{array}{l}\text { Coping bear } \\
\text { Exposure } \\
\text { Relaxation } \\
\text { Cognitive problem solving } \\
\text { Group based } \\
\text { Delivered by primary care physician } \\
\text { and student/trainee. } \\
12,90 \text { min weekly sessions }\end{array}$ & \multirow[t]{2}{*}{$\begin{array}{l}\text { Age: } 9.8 \text { ( Range } 8-12 \text { ) } \\
\text { Caucasian : } 84.6 \%\end{array}$} & \multirow[t]{2}{*}{ NR } \\
\hline & & & $\begin{array}{l}\text { Child CBT + } \\
\text { Parent } \\
\text { Involvement, } \\
(\mathrm{N}=41)\end{array}$ & $\begin{array}{l}\text { Coping bear } \\
\text { Exposure } \\
\text { Relaxation } \\
\text { Cognitive problem solving } \\
\text { Individual based } \\
\text { Delivered by primary care physician } \\
\text { and student/trainee } \\
12,90 \text { min weekly sessions }\end{array}$ & & \\
\hline \multirow[t]{2}{*}{$\begin{array}{l}\text { Mendez, } \\
2003^{55}\end{array}$} & \multirow[t]{2}{*}{$\begin{array}{l}\text { Spain } \\
\text { RCT } \\
\text { Efficacy } \\
\text { Schools }\end{array}$} & \multirow[t]{2}{*}{ SP } & $\begin{array}{l}\text { Child and } \\
\text { Parent } \\
\text { Together CBT } \\
(\mathrm{N}=\mathrm{NR})\end{array}$ & $\begin{array}{l}\text { Emotive staging } \\
\text { Exposure } \\
\text { Individual based } \\
\text { Delivered by psychologist } \\
\text { Individual based } \\
12,30 \text { min sessions over } 3 \text { weeks }\end{array}$ & \multirow[t]{2}{*}{$\begin{array}{l}\text { Total number of patients: } 64 \\
\text { Male: } 50 \%\end{array}$} & \multirow[t]{2}{*}{0} \\
\hline & & & $\begin{array}{l}\text { Child and } \\
\text { Parent } \\
\text { Together CBT } \\
(\mathrm{N}=\mathrm{NR})\end{array}$ & $\begin{array}{l}\text { Emotive staging } \\
\text { Exposure } \\
\text { Cognitive problem solving } \\
\text { Individual based } \\
12,30 \text { min sessions over } 3 \text { weeks }\end{array}$ & & \\
\hline
\end{tabular}




\begin{tabular}{|c|c|c|c|c|c|c|}
\hline Author, Year & $\begin{array}{l}\text { Study Country, } \\
\text { Study Design, } \\
\text { Type of Study } \\
\text { (Efficacyl } \\
\text { Effectiveness), } \\
\text { Study Settings }\end{array}$ & $\begin{array}{c}\text { Type of } \\
\text { AnxietylSeverity } \\
\text { (CGI) }\end{array}$ & $\begin{array}{l}\text { Intervention } \\
\text { and } \\
\text { Comparison } \\
\text { s (N of } \\
\text { Patients) }\end{array}$ & $\begin{array}{l}\text { Characteristics of Interventions } \\
\text { (Psychotherapy: Components, } \\
\text { Delivery Model)/Pharm: Drug) } \\
\text { Intensity, Duration (Weeks)) }\end{array}$ & $\begin{array}{c}\text { Patient Characteristics Mean } \\
\text { Age (Range), Male (\%), } \\
\text { Race/Ethnicity, Comorbidity, } \\
\text { Household Income, Parent } \\
\text { Education, Family } \\
\text { Dysfunction/Stressor, } \\
\text { Treatment Sequence, } \\
\text { Insurance, History of } \\
\text { Maltreatment) }\end{array}$ & $\begin{array}{l}\text { Length } \\
\text { of } \\
\text { Follow } \\
\text { up } \\
\text { (Weeks } \\
\text { ) }\end{array}$ \\
\hline & & & $\begin{array}{l}\text { Control, } \\
(\mathrm{N}=\mathrm{NR})\end{array}$ & Waitlisting or no treatment & & \\
\hline \multirow[t]{4}{*}{$\begin{array}{l}\text { Mendlowitz, } \\
1999^{56}\end{array}$} & \multirow[t]{4}{*}{$\begin{array}{l}\text { Canada } \\
\text { RCT } \\
\text { Efficacy } \\
\text { Outpatient }\end{array}$} & \multirow[t]{4}{*}{ Anxiety disorder } & $\begin{array}{l}\text { Child CBT, } \\
(\mathrm{N}=23)\end{array}$ & $\begin{array}{l}\text { Coping Bear } \\
\text { Child CBT- (parents included < 20\%) } \\
\text { Group based } \\
\text { Relaxation } \\
\text { Cognitive problem solving } \\
121.5 \text {-hour weekly sessions } \\
\text { Delivered by } 3 \text { psychologists, } 1 \\
\text { student/trainee, } 1 \text { youth worker }\end{array}$ & \multirow[t]{4}{*}{$\begin{array}{l}\text { Age mean (years): } 9.5 \text { (Range } 7- \\
12 \text { ) } \\
\text { Male: } 28.4 \%\end{array}$} & \multirow[t]{4}{*}{ NR } \\
\hline & & & $\begin{array}{l}\text { Parent only } \\
\text { intervention, } \\
(\mathrm{N}=21)\end{array}$ & $\begin{array}{l}\text { Generic CBT } \\
\text { Group based } \\
121.5 \text {-hour weekly sessions } \\
\text { Delivered by doctoral level } \\
\text { psychologist, and student/trainee }\end{array}$ & & \\
\hline & & & $\begin{array}{l}\text { Child CBT } \\
\text { plus separate } \\
\text { parent } \\
\text { intervention, } \\
(\mathrm{N}=18)\end{array}$ & $\begin{array}{l}\text { Coping Bear } \\
\text { Group based } \\
\text { Relaxation } \\
\text { Cognitive problem solving } \\
12 \text { 1.5-hour weekly sessions (one for } \\
\text { kids, one for parents) } \\
\text { Delivered by doctoral level } \\
\text { psychologist, student/trainee, youth } \\
\text { worker }\end{array}$ & & \\
\hline & & & $\begin{array}{l}\text { Control, } \\
(\mathrm{N}=40)\end{array}$ & Waitlisting or no treatment & & \\
\hline $\begin{array}{l}\text { Menzies, } \\
1993^{57}\end{array}$ & $\begin{array}{l}\text { Australia } \\
\text { RCT } \\
\text { Efficacy } \\
\text { Outpatient }\end{array}$ & SP & $\begin{array}{l}\text { Child CBT, } \\
(\mathrm{N}=13)\end{array}$ & $\begin{array}{l}\text { In vivo exposure plus vicarious } \\
\text { exposure } \\
\text { Child CBT- (parents included < 20\%) } \\
\text { Individual based } \\
\text { Delivered by student therapist } \\
3 \text { 15-minute weekly session }\end{array}$ & $\begin{array}{l}\text { Age mean (years): } 5.5 \text { (range:3-8) } \\
\text { Male: } 50.7 \% \\
\text { Caucasian: } 96 \% \\
\text { Hispanic: } 4 \% \\
\text { Depression: } 10 \% \\
\text { Treatment non responder: } 100 \%\end{array}$ & 12 \\
\hline
\end{tabular}




\begin{tabular}{|c|c|c|c|c|c|c|}
\hline Author, Year & $\begin{array}{l}\text { Study Country, } \\
\text { Study Design, } \\
\text { Type of Study } \\
\text { (Efficacyl } \\
\text { Effectiveness), } \\
\text { Study Settings }\end{array}$ & $\begin{array}{c}\text { Type of } \\
\text { Anxiety/Severity } \\
\text { (CGI) }\end{array}$ & $\begin{array}{l}\text { Intervention } \\
\text { and } \\
\text { Comparison } \\
\text { s (N of } \\
\text { Patients) }\end{array}$ & $\begin{array}{l}\text { Characteristics of Interventions } \\
\text { (Psychotherapy: Components, } \\
\text { Delivery Model)/Pharm: Drug) } \\
\text { Intensity, Duration (Weeks)) }\end{array}$ & $\begin{array}{c}\text { Patient Characteristics Mean } \\
\text { Age (Range), Male (\%), } \\
\text { Race/Ethnicity, Comorbidity, } \\
\text { Household Income, Parent } \\
\text { Education, Family } \\
\text { Dysfunction/Stressor, } \\
\text { Treatment Sequence, } \\
\text { Insurance, History of } \\
\text { Maltreatment) }\end{array}$ & $\begin{array}{l}\text { Length } \\
\text { of } \\
\text { Follow } \\
\text { up } \\
\text { (Weeks } \\
\quad \text { ) }\end{array}$ \\
\hline & & & $\begin{array}{l}\text { Control, } \\
(\mathrm{N}=13)\end{array}$ & $\begin{array}{l}\text { Attention control or treatment as } \\
\text { usual } \\
\text { Only vicarious exposure } \\
3 \text { 30-minute weekly session } \\
\text { Delivered by student therapist }\end{array}$ & & \\
\hline & & & $\begin{array}{l}\text { Child CBT, } \\
(\mathrm{N}=13)\end{array}$ & $\begin{array}{l}\text { In vivo exposure } \\
\text { Child CBT- (parents included < } 20 \% \text { ) } \\
\text { Individual based } \\
\text { Exposure } 330 \text {-minute weekly session } \\
\text { Delivered by student }\end{array}$ & & \\
\hline & & & $\begin{array}{l}\text { Control, } \\
(\mathrm{N}=12)\end{array}$ & $\begin{array}{l}\text { Waitlisting or no treatment } \\
\text { Assessment only }\end{array}$ & & \\
\hline \multirow[t]{2}{*}{$\begin{array}{l}\text { Muris, } 2001 \\
175\end{array}$} & \multirow[t]{2}{*}{$\begin{array}{l}\text { Netherlands } \\
\text { RCT } \\
\text { Efficacy } \\
\text { Outpatient }\end{array}$} & \multirow[t]{2}{*}{ GAD,SAD, SoP } & $\begin{array}{l}\text { Child CBT, } \\
(\mathrm{N}=19)\end{array}$ & $\begin{array}{l}\text { Coping koala } \\
\text { Exposure } \\
\text { Cognitive problem solving } \\
\text { Group-based } \\
1230-40 \text { min twice weekly sessions }\end{array}$ & \multirow[t]{2}{*}{$\begin{array}{l}\text { Age mean (years): } 9.9 \text { (range: } 8- \\
\text { 13) } \\
\text { Male: } 25 \% \\
\text { Caucasian: } 97 \% \\
\text { Other: } 3 \% \\
\text { ADHD: } 3 \%\end{array}$} & \multirow[t]{2}{*}{0} \\
\hline & & & $\begin{array}{l}\text { Child CBT, } \\
(\mathrm{N}=17)\end{array}$ & $\begin{array}{l}\text { Coping koala } \\
\text { Exposure } \\
\text { Cognitive problem solving } \\
\text { Individual-based } \\
1230-40 \text { min twice weekly sessions }\end{array}$ & & \\
\hline \multirow[t]{2}{*}{$\begin{array}{l}\text { Nauta, } \\
2001^{176}\end{array}$} & \multirow[t]{2}{*}{$\begin{array}{l}\text { Netherlands } \\
\text { RCT } \\
\text { Effectiveness } \\
\text { Mental health } \\
\text { clinic }\end{array}$} & \multirow[t]{2}{*}{ GAD,SAD, SoP, } & $\begin{array}{l}\text { Child CBT, } \\
(\mathrm{N}=9)\end{array}$ & $\begin{array}{l}\text { Coping Cat -Dutch } \\
\text { Exposure } \\
\text { Relaxation } \\
\text { Cognitive problem solving } \\
\text { Individual based } \\
\text { Delivered by student/ trainee } \\
12,60 \text { min sessions }\end{array}$ & $\begin{array}{l}\text { Age mean (years): } 10.8 \\
\text { Male: } 77.7 \%\end{array}$ & \multirow[t]{2}{*}{65} \\
\hline & & & $\begin{array}{l}\text { Child CBT+ } \\
\text { parent } \\
\text { Intervention, } \\
(\mathrm{N}=9)\end{array}$ & $\begin{array}{l}\text { Coping Cat - Dutch Exposure, } \\
\text { Relaxation } \\
\text { Cognitive problem solving } \\
\text { Delivered by doctoral level } \\
\text { psychologists } \\
12,60 \text { min sessions and } 7 \text { parent }\end{array}$ & $\begin{array}{l}\text { Age mean (years): } 9.9 \\
\text { Male: } 33.3 \%\end{array}$ & \\
\hline
\end{tabular}




\begin{tabular}{|c|c|c|c|c|c|c|}
\hline Author, Year & $\begin{array}{l}\text { Study Country, } \\
\text { Study Design, } \\
\text { Type of Study } \\
\text { (Efficacyl } \\
\text { Effectiveness), } \\
\text { Study Settings }\end{array}$ & $\begin{array}{c}\text { Type of } \\
\text { Anxiety/Severity } \\
\text { (CGI) }\end{array}$ & $\begin{array}{l}\text { Intervention } \\
\text { and } \\
\text { Comparison } \\
\text { s (N of } \\
\text { Patients) }\end{array}$ & $\begin{array}{l}\text { Characteristics of Interventions } \\
\text { (Psychotherapy: Components, } \\
\text { Delivery Model)/Pharm: Drug) } \\
\text { Intensity, Duration (Weeks)) }\end{array}$ & $\begin{array}{c}\text { Patient Characteristics Mean } \\
\text { Age (Range), Male (\%), } \\
\text { Race/Ethnicity, Comorbidity, } \\
\text { Household Income, Parent } \\
\text { Education, Family } \\
\text { Dysfunction/Stressor, } \\
\text { Treatment Sequence, } \\
\text { Insurance, History of } \\
\text { Maltreatment) } \\
\end{array}$ & $\begin{array}{l}\text { Length } \\
\text { of } \\
\text { Follow } \\
\text { up } \\
\text { (Weeks } \\
\text { ) }\end{array}$ \\
\hline & & & & sessions. & & \\
\hline \multirow[t]{2}{*}{$\mathrm{N}_{177}$} & \multirow[t]{2}{*}{$\begin{array}{l}\text { Netherlands } \\
\text { RCT } \\
\text { Effectiveness } \\
\text { Mental health } \\
\text { clinic }\end{array}$} & \multirow[t]{2}{*}{$\begin{array}{l}\text { GAD, PD without } \\
\text { agoraphobia, } \\
\text { SoP, SAD }\end{array}$} & $\begin{array}{l}\text { Child CBT } \\
\text { alone, } N=37 \text { ) }\end{array}$ & $\begin{array}{l}\text { Coping Cat -Dutch } \\
\text { Exposure } \\
\text { Cognitive problem solving } \\
\text { Individual based } \\
\text { Delivered by doctoral level } \\
\text { psychologist student/trainee } \\
12,60 \text { min sessions }\end{array}$ & \multirow[t]{2}{*}{$\begin{array}{l}\text { Age mean (years): } 11 \\
\text { Male: } 51.3 \%\end{array}$} & \multirow[t]{2}{*}{12} \\
\hline & & & $\begin{array}{l}\text { Child CBT+ } \\
\text { parent } \\
\text { Intervention, } \\
(\mathrm{N}=39)\end{array}$ & $\begin{array}{l}\text { Coping cat - Dutch Exposure, } \\
\text { Cognitive problem solving } \\
\text { Delivered by doctoral level } \\
\text { psychologists and student/trainee 12, } \\
60 \text { min sessions and } 7 \text { parent } \\
\text { sessions. }\end{array}$ & & \\
\hline \multirow[t]{2}{*}{$\begin{array}{l}\text { Olivares, } \\
2002^{61}\end{array}$} & \multirow[t]{2}{*}{$\begin{array}{l}\text { Spain } \\
\text { Non- } \\
\text { Randomized } \\
\text { comparative } \\
\text { studies } \\
\text { School }\end{array}$} & \multirow[t]{2}{*}{$\begin{array}{l}\text { GAD, PD with } \\
\text { agoraphobia, } \\
\text { SoP,SP }\end{array}$} & $\begin{array}{l}\text { Child CBT, } \\
(\mathrm{N}=14)\end{array}$ & $\begin{array}{l}\text { SET-C Spanish } \\
\text { Child CBT- (parents included < 20\%) } \\
\text { Exposure } \\
29 \text { treatment sessions over a period } \\
\text { of } 17 \text { weeks, generally twice weekly }\end{array}$ & $\begin{array}{l}\text { Age mean (years): } 15.57 \text { (range: } \\
\text { 15-17) } \\
\text { Male: } 28.5 \% \\
\text { Depression: } 35.7 \% \\
\text { OCD: } 7 \% \\
\text { Substance abuse: } 7 \% \\
\text { PTSD: } 7 \% \\
\text { Avoidant personality disorder: } \\
100 \% \\
\text { Selective mutism: } 7 \%\end{array}$ & \multirow[t]{2}{*}{52} \\
\hline & & & $\begin{array}{l}\text { Child CBT, } \\
(\mathrm{N}=15)\end{array}$ & $\begin{array}{l}\text { Group based } \\
\text { Child CBT- (parents included }<20 \% \text { ) } \\
\text { Exposure } \\
\text { Cognitive problem solving } \\
1690 \text {-minute sessions over } 14 \text { weeks }\end{array}$ & $\begin{array}{l}\text { Age mean (years): } 16.07 \text { (range: } \\
\text { 15-17) } \\
\text { Male: } 35.7 \% \\
\text { Depression: } 60 \% \\
\text { OCD: } 6 \% \\
\text { Substance abuse: } 6 \% \\
\text { PTSD: } 6 \% \\
\text { Avoidant personality disorder: } \\
94 \% \\
\text { Selective mutism: } 12 \%\end{array}$ & \\
\hline
\end{tabular}




\begin{tabular}{|c|c|c|c|c|c|c|}
\hline Author, Year & $\begin{array}{l}\text { Study Country, } \\
\text { Study Design, } \\
\text { Type of Study } \\
\text { (Efficacyl } \\
\text { Effectiveness), } \\
\text { Study Settings }\end{array}$ & $\begin{array}{c}\text { Type of } \\
\text { Anxiety/Severity } \\
\text { (CGI) }\end{array}$ & $\begin{array}{l}\text { Intervention } \\
\text { and } \\
\text { Comparison } \\
\text { s (N of } \\
\text { Patients) }\end{array}$ & $\begin{array}{l}\text { Characteristics of Interventions } \\
\text { (Psychotherapy: Components, } \\
\text { Delivery Model)/Pharm: Drug) } \\
\text { Intensity, Duration (Weeks)) }\end{array}$ & $\begin{array}{c}\text { Patient Characteristics Mean } \\
\text { Age (Range), Male (\%), } \\
\text { Race/Ethnicity, Comorbidity, } \\
\text { Household Income, Parent } \\
\text { Education, Family } \\
\text { Dysfunction/Stressor, } \\
\text { Treatment Sequence, } \\
\text { Insurance, History of } \\
\text { Maltreatment) } \\
\end{array}$ & $\begin{array}{l}\text { Length } \\
\text { of } \\
\text { Follow } \\
\text { up } \\
\text { (Weeks } \\
\text { ) }\end{array}$ \\
\hline & & & $\begin{array}{l}\text { Child CBT, } \\
(\mathrm{N}=15)\end{array}$ & $\begin{array}{l}\text { IAFS } \\
\text { Child CBT- (parents included }<20 \% \text { ) } \\
\text { Exposure } \\
\text { Cognitive problem solving } \\
1290 \text {-minute weekly group sessions, } \\
\text { and optional individual sessions }\end{array}$ & $\begin{array}{l}\text { Age mean (years): } 15.87 \text { (range: } \\
\text { 15-17) } \\
\text { Male: } 26.6 \% \\
\text { Depression: } 40 \% \\
\text { OCD: } 6 \% \\
\text { Substance abuse: } 6 \% \\
\text { PTSD: } 6 \% \\
\text { Avoidant personality disorder: } \\
\text { 100\% } \\
\text { Selective mutism: } 6 \%\end{array}$ & \\
\hline & & & $\begin{array}{l}\text { Control, } \\
(\mathrm{N}=15)\end{array}$ & Waitlisting or no treatment & $\begin{array}{l}\text { Age mean (years): } 15.87 \text { (range: } \\
\text { 15-17) } \\
\text { Male: } 35.7 \% \\
\text { Depression: } 46 \% \\
\text { OCD: } 6 \% \\
\text { Substance abuse: } 12 \% \\
\text { PTSD: } 6 \% \\
\text { Avoidant personality disorder: } \\
\text { 100\% } \\
\text { Selective mutism: } 12 \%\end{array}$ & \\
\hline \multirow[t]{2}{*}{$\begin{array}{l}\text { Olivares- } \\
\text { Rodriguez, } \\
2006^{178}\end{array}$} & \multirow[t]{2}{*}{$\begin{array}{l}\text { Spain } \\
\text { RCT } \\
\text { Efficacy } \\
\text { School }\end{array}$} & \multirow[t]{2}{*}{$\begin{array}{l}\text { GAD, PD without } \\
\text { agoraphobia, } \\
\text { SoP. }\end{array}$} & $\begin{array}{l}\text { Child CBT, } \\
(\mathrm{N}=12)\end{array}$ & $\begin{array}{l}\text { IAFS } \\
\text { Exposure } \\
\text { Cognitive problem solving } \\
\text { Group based } \\
12,90 \text { min weekly sessions, and } 6 \\
\text { individual sessions }\end{array}$ & $\begin{array}{l}\text { Age mean (years): } 15.33 \\
\text { Male: } 33.33 \%\end{array}$ & \multirow[t]{2}{*}{36} \\
\hline & & & $\begin{array}{l}\text { Child CBT, } \\
(\mathrm{N}=13)\end{array}$ & $\begin{array}{l}\text { IAFS } \\
\text { Exposure } \\
\text { Cognitive problem solving } \\
\text { Group based } \\
\text { Delivered by therapists. } \\
12,90 \text { min weekly sessions }\end{array}$ & $\begin{array}{l}\text { Age mean (years): } 15.31 \\
\text { Male: } 38.4 \%\end{array}$ & \\
\hline $\begin{array}{l}\text { Olivares- } \\
\text { Olivares, }\end{array}$ & $\begin{array}{l}\text { Spain } \\
\text { RCT } \\
\text { Efficacy }\end{array}$ & $\begin{array}{l}\text { GAD, PD with } \\
\text { agoraphobia, PD } \\
\text { (agoraphobia is }\end{array}$ & $\begin{array}{l}\text { Child CBT, } \\
(\mathrm{N}=18)\end{array}$ & $\begin{array}{l}\text { IAFS } \\
\text { Exposure } \\
\text { Cognitive problem solving }\end{array}$ & $\begin{array}{l}\text { Age mean (years): } 15.7 \text { ( range } 14 \\
\text {-18) } \\
\text { Male: } 18.8 \%\end{array}$ & 52 \\
\hline
\end{tabular}




\begin{tabular}{|c|c|c|c|c|c|c|}
\hline Author, Year & $\begin{array}{c}\text { Study Country, } \\
\text { Study Design, } \\
\text { Type of Study } \\
\text { (Efficacyl } \\
\text { Effectiveness), } \\
\text { Study Settings }\end{array}$ & $\begin{array}{c}\text { Type of } \\
\text { Anxiety/Severity } \\
\text { (CGI) }\end{array}$ & $\begin{array}{l}\text { Intervention } \\
\text { and } \\
\text { Comparison } \\
\text { s (N of } \\
\text { Patients) }\end{array}$ & $\begin{array}{l}\text { Characteristics of Interventions } \\
\text { (Psychotherapy: Components, } \\
\text { Delivery Model)/Pharm: Drug) } \\
\text { Intensity, Duration (Weeks)) }\end{array}$ & $\begin{array}{c}\text { Patient Characteristics Mean } \\
\text { Age (Range), Male (\%), } \\
\text { Race/Ethnicity, Comorbidity, } \\
\text { Household Income, Parent } \\
\text { Education, Family } \\
\text { Dysfunction/Stressor, } \\
\text { Treatment Sequence, } \\
\text { Insurance, History of } \\
\text { Maltreatment) }\end{array}$ & $\begin{array}{l}\text { Length } \\
\text { of } \\
\text { Follow } \\
\text { up } \\
\text { (Weeks } \\
\quad \text { ) }\end{array}$ \\
\hline \multirow[t]{3}{*}{$2008^{179}$} & \multirow[t]{3}{*}{$\begin{array}{l}\text { Mental health } \\
\text { clinic }\end{array}$} & \multirow[t]{3}{*}{$\begin{array}{l}\text { not specified), } \\
\text { SP, SoP. }\end{array}$} & & $\begin{array}{l}\text { Group based } \\
\text { Delivered by doctoral level } \\
\text { psychologists } \\
12,90 \text { min weekly sessions }\end{array}$ & & \\
\hline & & & CBT, $(\mathrm{N}=20)$ & $\begin{array}{l}\text { IAFS } \\
\text { Exposure } \\
\text { Cognitive problem solving, } \\
\text { Group based,= } \\
\text { Delivered by doctoral level } \\
\text { psychologists } \\
\text { 12,90min weekly sessions, } 6 \\
\text { individual sessions }\end{array}$ & $\begin{array}{l}\text { Age mean (years): } 15.15 \text { (Range } \\
14-18) \\
\text { Male: } 35 \%\end{array}$ & \\
\hline & & & $\begin{array}{l}\text { Child CBT, } \\
(\mathrm{N}=19)\end{array}$ & $\begin{array}{l}\text { IAFS } \\
\text { Exposure, Cognitive Problem Solving, } \\
\text { Group based, } \\
\text { Delivered by doctoral level } \\
\text { psychologists } \\
\text { 12,90min weekly sessions, } 12 \\
\text { individual sessions }\end{array}$ & $\begin{array}{l}\text { Age mean (years): } 15.58 \text { (Range } \\
14-18) \\
\text { Male: } 36.8 \%\end{array}$ & \\
\hline \multirow[t]{2}{*}{$\begin{array}{l}\text { Olivares, } \\
2014^{62}\end{array}$} & \multirow[t]{2}{*}{$\begin{array}{l}\text { Spain } \\
\text { Efficacy } \\
\text { Mental health } \\
\text { clinic }\end{array}$} & \multirow[t]{2}{*}{ SoP } & $\begin{array}{l}\text { Child CBT, } \\
(\mathrm{N}=38)\end{array}$ & $\begin{array}{l}\text { IAFS } \\
\text { Child CBT- (parents included <20\%) } \\
\text { Group based } \\
\text { Exposure } \\
\text { Cognitive problem solving } \\
\text { Delivered by experienced } \\
\text { psychologist12 90-minute weekly } \\
\text { sessions }\end{array}$ & $\begin{array}{l}\text { Age mean (years): } 15.58 \text { (SD: } \\
0.76) \\
\text { Males: } 36.81 \%\end{array}$ & \multirow[t]{2}{*}{52} \\
\hline & & & $\begin{array}{l}\text { Child CBT, } \\
(\mathrm{N}=37)\end{array}$ & $\begin{array}{l}\text { IAFS } \\
\text { Child CBT- (parents included < 20\%) } \\
\text { Delivered by inexperienced } \\
\text { psychologist } \\
\text { Group based } \\
\text { Exposure } \\
\text { Cognitive problem solving } \\
1290 \text {-minute weekly sessions }\end{array}$ & $\begin{array}{l}\text { Age mean (years): } 15.30 \text { (SD: } \\
0.81) \\
\text { Males: } 29.74 \%\end{array}$ & \\
\hline
\end{tabular}




\begin{tabular}{|c|c|c|c|c|c|c|}
\hline Author, Year & $\begin{array}{l}\text { Study Country, } \\
\text { Study Design, } \\
\text { Type of Study } \\
\text { (Efficacyl } \\
\text { Effectiveness), } \\
\text { Study Settings }\end{array}$ & $\begin{array}{c}\text { Type of } \\
\text { Anxiety/Severity } \\
\text { (CGI) }\end{array}$ & $\begin{array}{l}\text { Intervention } \\
\text { and } \\
\text { Comparison } \\
\text { s (N of } \\
\text { Patients) }\end{array}$ & $\begin{array}{l}\text { Characteristics of Interventions } \\
\text { (Psychotherapy: Components, } \\
\text { Delivery Model)/Pharm: Drug) } \\
\text { Intensity, Duration (Weeks)) }\end{array}$ & $\begin{array}{c}\text { Patient Characteristics Mean } \\
\text { Age (Range), Male (\%), } \\
\text { Race/Ethnicity, Comorbidity, } \\
\text { Household Income, Parent } \\
\text { Education, Family } \\
\text { Dysfunction/Stressor, } \\
\text { Treatment Sequence, } \\
\text { Insurance, History of } \\
\text { Maltreatment) } \\
\end{array}$ & $\begin{array}{l}\text { Length } \\
\text { of } \\
\text { Follow } \\
\text { up } \\
\text { (Weeks } \\
\text { ) }\end{array}$ \\
\hline & & & $\begin{array}{l}\text { Control, } \\
(\mathrm{N}=35)\end{array}$ & Waitlisting or no treatment & $\begin{array}{l}\text { Age mean (years): } 15.23 \text { (SD: } \\
1.26) \\
\text { Males: } 37.1 \%\end{array}$ & \\
\hline \multirow[t]{2}{*}{$\begin{array}{l}\text { Ollendick } \\
\text { Thomas, } \\
2015^{180}\end{array}$} & \multirow[t]{2}{*}{$\begin{array}{l}\text { United States } \\
\text { RCT } \\
\text { Outpatient }\end{array}$} & \multirow[t]{2}{*}{ SP } & $\begin{array}{l}\text { Child CBT, } \\
(\mathrm{N}=46)\end{array}$ & $\begin{array}{l}\text { OST } \\
\text { Exposure } \\
\text { Individual based } \\
\text { Delivered by Masters level clinicians. } \\
1180 \text { min session } \\
\end{array}$ & $\begin{array}{l}\text { Age mean (years): } 8.79 \text { ( range: } \\
6-15 \text { ) } \\
\text { Male:52.1\% } \\
\text { Caucasian: } 82.6 \% \\
\text { parental over-protection:15.2 }\end{array}$ & \multirow[t]{2}{*}{26} \\
\hline & & & $\begin{array}{l}\text { Child and } \\
\text { Parent } \\
\text { together CBT, } \\
(\mathrm{N}=51)\end{array}$ & $\begin{array}{l}\text { OST } \\
\text { Exposure } \\
\text { Individual based } \\
\text { Delivered by Masters level clinicians } \\
1 \text { 180min session }\end{array}$ & $\begin{array}{l}\text { Age mean (years): } 8.93 \text { ( range: } \\
6-15 \text { ) } \\
\text { Male: } 45 \% \\
\text { Caucasian: } 86.2 \% \\
\text { parental over-protection: } 13.7 \%\end{array}$ & \\
\hline \multirow[t]{3}{*}{ Ost, $2001^{66}$} & \multirow[t]{3}{*}{$\begin{array}{l}\text { Sweden } \\
\text { RCT } \\
\text { Efficacy } \\
\text { Mental health } \\
\text { clinic }\end{array}$} & \multirow[t]{3}{*}{$\begin{array}{l}\text { GAD,SAD, SoP, } \\
\text { SP }\end{array}$} & $\begin{array}{l}\text { Child CBT, } \\
(\mathrm{N}=21)\end{array}$ & $\begin{array}{l}\text { OST } \\
\text { Exposure } \\
\text { Individual-based } \\
\text { Delivered by doctoral level } \\
\text { Psychologist } \\
1,180 \text { min session } \\
\end{array}$ & $\begin{array}{l}\text { Age mean (years): } 11.7 \text { (range: } 7- \\
17) \\
\text { Male: } 33\end{array}$ & \multirow[t]{3}{*}{52} \\
\hline & & & $\begin{array}{l}\text { Child and } \\
\text { Parent } \\
\text { together CBT, } \\
(\mathrm{N}=20)\end{array}$ & $\begin{array}{l}\text { OST } \\
\text { Exposure } \\
\text { Individual based } \\
\text { Delivered by doctoral level } \\
\text { Psychologist } \\
1,180 \text { min session } \\
\end{array}$ & $\begin{array}{l}\text { Age mean (years): } 11.7 \text { (range: } 7- \\
\text { 17) } \\
\text { Male: } 45 \%\end{array}$ & \\
\hline & & & $\begin{array}{l}\text { Control, } \\
(\mathrm{N}=19)\end{array}$ & Waitlisting or no treatment & $\begin{array}{l}\text { Age mean (years): } 11.7 \text { (range: } 7- \\
17) \\
\text { Male: } 36 \%\end{array}$ & \\
\hline Ost, $2015^{67}$ & $\begin{array}{l}\text { Sweden } \\
\text { RCT } \\
\text { Efficacy } \\
\text { Mental health } \\
\text { clinic } \\
\end{array}$ & $\begin{array}{l}\text { GAD, PD, SAD, } \\
\text { SP }\end{array}$ & $\begin{array}{l}\text { Child CBT, } \\
(\mathrm{N}=16)\end{array}$ & $\begin{array}{l}\text { SET-C } \\
\text { Exposure } \\
\text { Delivered by psychologist } \\
12 \text { weekly group sessions and } 12 \\
\text { individual sessions }\end{array}$ & $\begin{array}{l}\text { Age mean (years): } 11.6 \text { (range: } 8- \\
\text { 14) } \\
\text { Depression: } 15 \% \\
\text { OCD: } 5 \% \\
\text { ODD: } 2 \%\end{array}$ & 52 \\
\hline
\end{tabular}




\begin{tabular}{|c|c|c|c|c|c|c|}
\hline Author, Year & $\begin{array}{l}\text { Study Country, } \\
\text { Study Design, } \\
\text { Type of Study } \\
\text { (Efficacyl } \\
\text { Effectiveness), } \\
\text { Study Settings }\end{array}$ & $\begin{array}{c}\text { Type of } \\
\text { Anxiety/Severity } \\
\text { (CGI) }\end{array}$ & $\begin{array}{l}\text { Intervention } \\
\text { and } \\
\text { Comparison } \\
\text { s (N of } \\
\text { Patients) }\end{array}$ & $\begin{array}{l}\text { Characteristics of Interventions } \\
\text { (Psychotherapy: Components, } \\
\text { Delivery Model)/Pharm: Drug) } \\
\text { Intensity, Duration (Weeks)) }\end{array}$ & $\begin{array}{c}\text { Patient Characteristics Mean } \\
\text { Age (Range), Male (\%), } \\
\text { Race/Ethnicity, Comorbidity, } \\
\text { Household Income, Parent } \\
\text { Education, Family } \\
\text { Dysfunction/Stressor, } \\
\text { Treatment Sequence, } \\
\text { Insurance, History of } \\
\text { Maltreatment) }\end{array}$ & $\begin{array}{l}\text { Length } \\
\text { of } \\
\text { Follow } \\
\text { up } \\
\text { (Weeks } \\
\text { ) }\end{array}$ \\
\hline & & & $\begin{array}{l}\text { Child and } \\
\text { Parent } \\
\text { together CBT, } \\
(\mathrm{N}=16)\end{array}$ & $\begin{array}{l}\text { SET-C } \\
\text { Exposure } \\
\text { Delivered by psychologist } \\
24 \text { children, } 8 \text { parent sessions over } \\
12 \text { weeks }\end{array}$ & \multirow[t]{2}{*}{ Neurodevelopmental Disorder:9\% } & \\
\hline & & & $\begin{array}{l}\text { Control, } \\
(\mathrm{N}=23)\end{array}$ & Waitlist/no treatment & & \\
\hline \multirow[t]{2}{*}{$\begin{array}{l}\text { Rosa- } \\
\text { Alcazar } \\
2013^{181}\end{array}$} & \multirow[t]{2}{*}{$\begin{array}{l}\text { Spain } \\
\text { RCT } \\
\text { Efficacy } \\
\text { School }\end{array}$} & \multirow[t]{2}{*}{$\begin{array}{l}\text { GAD, PD, PD } \\
\text { with } \\
\text { agoraphobia, SP }\end{array}$} & $\begin{array}{l}\text { Child CBT, } \\
(\mathrm{N}=25)\end{array}$ & $\begin{array}{l}\text { IAFS } \\
\text { Exposure } \\
\text { Relaxation } \\
\text { Cognitive problem solving } \\
\text { Group based } \\
\text { 12, 90min weekly sessions }\end{array}$ & $\begin{array}{l}\text { Age mean (years): } 14.80 \text { (range: } \\
\text { 13-17) } \\
\text { Males: } 24 \% \\
\text { Depression: } 4 \% \\
\text { PTSD: } 4 \% \\
\text { Dysthymia: } 4 \%\end{array}$ & \multirow[t]{2}{*}{6} \\
\hline & & & $\begin{array}{l}\text { Child CBT, } \\
(\mathrm{N}=25)\end{array}$ & $\begin{array}{l}\text { IAFS } \\
\text { Exposure } \\
\text { Group based } \\
\text { 12, 90min weekly sessions }\end{array}$ & $\begin{array}{l}\text { Age mean (years): } 14.40 \text { (range: } \\
\text { 13-17) } \\
\text { Males: } 28 \% \\
\text { Depression: } 8 \% \\
\text { PTSD: } 4 \% \\
\text { Dysthymia: } 4 \%\end{array}$ & \\
\hline \multirow[t]{3}{*}{$\begin{array}{l}\text { Sánchez- } \\
\text { García, } 2009 \\
75\end{array}$} & \multirow[t]{3}{*}{$\begin{array}{l}\text { Spain } \\
\text { RCT } \\
\text { Efficacy } \\
\text { schools }\end{array}$} & \multirow[t]{3}{*}{ SAD } & $\begin{array}{l}\text { Child CBT, } \\
(\mathrm{N}=28)\end{array}$ & $\begin{array}{l}\text { IAFS } \\
\text { Exposure } \\
\text { Cognitive problem solving } \\
\text { Group based } \\
\text { Delivered by practicing clinician 12, } \\
\text { 90min weekly sessions }\end{array}$ & \multirow[t]{3}{*}{$\begin{array}{l}\text { Age mean (years): } 11.91 \\
\text { Male: } 38 \% \\
\text { White: } 82 \%\end{array}$} & \multirow[t]{3}{*}{52} \\
\hline & & & $\begin{array}{l}\text { Child CBT, } \\
(\mathrm{N}=29)\end{array}$ & $\begin{array}{l}\text { IAFS } \\
\text { Exposure } \\
\text { Group based } \\
\text { Delivered by Practicing clinician 12, } \\
\text { 90min weekly sessions }\end{array}$ & & \\
\hline & & & $\begin{array}{l}\text { Control, } \\
(\mathrm{N}=25)\end{array}$ & Waitlisting or no treatment & & \\
\hline
\end{tabular}




\begin{tabular}{|c|c|c|c|c|c|c|}
\hline Author, Year & $\begin{array}{l}\text { Study Country, } \\
\text { Study Design, } \\
\text { Type of Study } \\
\text { (Efficacyl } \\
\text { Effectiveness), } \\
\text { Study Settings }\end{array}$ & $\begin{array}{c}\text { Type of } \\
\text { AnxietylSeverity } \\
\text { (CGI) }\end{array}$ & $\begin{array}{l}\text { Intervention } \\
\text { and } \\
\text { Comparison } \\
\text { s (N of } \\
\text { Patients) }\end{array}$ & $\begin{array}{l}\text { Characteristics of Interventions } \\
\text { (Psychotherapy: Components, } \\
\text { Delivery Model)/Pharm: Drug) } \\
\text { Intensity, Duration (Weeks)) }\end{array}$ & $\begin{array}{c}\text { Patient Characteristics Mean } \\
\text { Age (Range), Male (\%), } \\
\text { Race/Ethnicity, Comorbidity, } \\
\text { Household Income, Parent } \\
\text { Education, Family } \\
\text { Dysfunction/Stressor, } \\
\text { Treatment Sequence, } \\
\text { Insurance, History of } \\
\text { Maltreatment) }\end{array}$ & $\begin{array}{l}\text { Length } \\
\text { of } \\
\text { Follow } \\
\text { up } \\
\text { (Weeks } \\
\quad \text { ) }\end{array}$ \\
\hline \multirow[t]{2}{*}{$\begin{array}{l}\text { Schneider, } \\
2013^{182}\end{array}$} & \multirow[t]{2}{*}{$\begin{array}{l}\text { Germany } \\
\text { RCT } \\
\text { Efficacy } \\
\text { Mental health } \\
\text { clinic }\end{array}$} & \multirow[t]{2}{*}{ SAD } & $\begin{array}{l}\text { Child and } \\
\text { Parent } \\
\text { together CBT, } \\
(\mathrm{N}=31)\end{array}$ & $\begin{array}{l}\text { Other therapy } \\
\text { Exposure } \\
\text { Cognitive problem solving } \\
\text { Individual based } \\
\text { Delivered by psychologist, Masters } \\
\text { level clinicians } \\
16,50 \text { min weekly sessions }\end{array}$ & \multirow[t]{2}{*}{$\begin{array}{l}\text { Age mean (years): } 10.36 \text { (range: } \\
8-13 \text { ) } \\
\text { Males: } 48 \%\end{array}$} & \multirow[t]{2}{*}{52} \\
\hline & & & $\begin{array}{l}\text { Child CBT, } \\
(\mathrm{N}=33)\end{array}$ & $\begin{array}{l}\text { Coping cat } \\
\text { Exposure } \\
\text { Relaxation } \\
\text { Cognitive problem aolving } \\
\text { Individual based } \\
\text { Delivered by psychologist, Masters } \\
\text { level clinicians } \\
16,50 \text { min weekly sessions }\end{array}$ & & \\
\hline \multirow[t]{2}{*}{$\begin{array}{l}\text { Siqueland, } \\
2005^{183}\end{array}$} & \multirow[t]{2}{*}{$\begin{array}{l}\text { United States } \\
\text { RCT } \\
\text { Efficacy } \\
\text { Outpatient }\end{array}$} & \multirow[t]{2}{*}{$\begin{array}{l}\text { GAD, PD } \\
\text { (agoraphobia is } \\
\text { not specified) } \\
\text { SP, SoP. }\end{array}$} & $\begin{array}{l}\text { Child and } \\
\text { parent } \\
\text { together CBT, } \\
(\mathrm{N}=5)\end{array}$ & $\begin{array}{l}\text { Other Therapy } \\
\text { Exposure } \\
\text { Relaxation, } \\
\text { Cognitive problem solving } \\
\text { Individual based, } \\
\text { Delivered by doctoral level } \\
\text { psychologists, Masters level } \\
\text { psychologists, and graduate students } \\
16 \text { weekly sessions. }\end{array}$ & \multirow[t]{2}{*}{$\begin{array}{l}\text { Age mean (years): } 14.9 \text { (Range } \\
12-17) \\
\text { Male: } 72.7 \% \\
\text { Caucasians: } 90 \% \\
\text { Africans: } 9 \%\end{array}$} & \multirow[t]{2}{*}{9} \\
\hline & & & $\begin{array}{l}\text { Child CBT, } \\
(\mathrm{N}=6)\end{array}$ & $\begin{array}{l}\text { Coping Cat } \\
\text { Exposure } \\
\text { Relaxation } \\
\text { Cognitive problem solving } \\
\text { Individual based, } \\
\text { Delivered by doctoral level } \\
\text { psychologists, Masters level } \\
\text { psychologists, and Masters level } \\
\text { students }\end{array}$ & & \\
\hline
\end{tabular}




\begin{tabular}{|c|c|c|c|c|c|c|}
\hline Author, Year & $\begin{array}{l}\text { Study Country, } \\
\text { Study Design, } \\
\text { Type of Study } \\
\text { (Efficacyl } \\
\text { Effectiveness), } \\
\text { Study Settings }\end{array}$ & $\begin{array}{c}\text { Type of } \\
\text { Anxiety/Severity } \\
\text { (CGI) }\end{array}$ & $\begin{array}{l}\text { Intervention } \\
\text { and } \\
\text { Comparison } \\
\text { s (N of } \\
\text { Patients) }\end{array}$ & $\begin{array}{l}\text { Characteristics of Interventions } \\
\text { (Psychotherapy: Components, } \\
\text { Delivery Model)/Pharm: Drug) } \\
\text { Intensity, Duration (Weeks)) }\end{array}$ & $\begin{array}{c}\text { Patient Characteristics Mean } \\
\text { Age (Range), Male (\%), } \\
\text { Race/Ethnicity, Comorbidity, } \\
\text { Household Income, Parent } \\
\text { Education, Family } \\
\text { Dysfunction/Stressor, } \\
\text { Treatment Sequence, } \\
\text { Insurance, History of } \\
\text { Maltreatment) }\end{array}$ & $\begin{array}{l}\text { Length } \\
\text { of } \\
\text { Follow } \\
\text { up } \\
\text { (Weeks } \\
\text { ) }\end{array}$ \\
\hline & & & & 16 weekly sessions. & & \\
\hline \multirow[t]{2}{*}{$\begin{array}{l}\text { Silverman, } \\
2009^{184}\end{array}$} & \multirow[t]{2}{*}{$\begin{array}{l}\text { United States } \\
\text { RCT } \\
\text { Efficacy } \\
\text { Mental health } \\
\text { clinic }\end{array}$} & \multirow[t]{2}{*}{$\begin{array}{l}\text { GAD, PD } \\
\text { agoraphobia, } \\
\text { SAD, SP, SoP }\end{array}$} & $\begin{array}{l}\text { Child and } \\
\text { parent } \\
\text { together } \mathrm{CBT} \text {, } \\
(\mathrm{N}=59)\end{array}$ & $\begin{array}{l}\text { Generic CBT } \\
\text { Exposure } \\
\text { Cognitive problem solving } \\
\text { Individual based } \\
\text { Delivered by doctoral level } \\
\text { psychologists } \\
12-14,60 \text { min weekly sessions }\end{array}$ & \multirow[t]{2}{*}{$\begin{array}{l}\text { Age mean (years): } 9.93 \text { (range: } 7 \\
\text { - 16)/ No SD } \\
\text { Male: } 40 \% \\
\text { White: } 40 \% \text {, Hispanic } 73 \% \text {, other: } \\
6 \% \\
\text { Mean household income: } \$ 34,312 \\
\text { Low income }<20,000 \mathrm{n}=33\end{array}$} & \multirow[t]{2}{*}{52} \\
\hline & & & $\begin{array}{l}\text { Child CBT, } \\
(\mathrm{N}=60)\end{array}$ & $\begin{array}{l}\text { Generic CBT } \\
\text { Exposure } \\
\text { Cognitive problem solving } \\
\text { Individual-based } \\
\text { Delivered by doctoral level } \\
\text { psychologists } \\
12-14,60 \text { min weekly sessions }\end{array}$ & & \\
\hline \multirow[t]{3}{*}{ Spence, 2000} & \multirow[t]{3}{*}{$\begin{array}{l}\text { Australia } \\
\text { RCT } \\
\text { Effectiveness } \\
\text { Mental health } \\
\text { clinic }\end{array}$} & \multirow[t]{3}{*}{$\begin{array}{l}\text { GAD, SAD, SP, } \\
\text { SoP }\end{array}$} & $\begin{array}{l}\text { Child CBT + } \\
\text { parent } \\
\text { Intervention, } \\
(\mathrm{N}=17)\end{array}$ & $\begin{array}{l}\text { Generic CBT } \\
\text { Exposure } \\
\text { Relaxation } \\
\text { Cognitive problem solving } \\
\text { Group based } \\
\text { Delivered by doctoral level } \\
\text { psychologist. } \\
12 \text { weekly sessions }\end{array}$ & $\begin{array}{l}\text { Age mean (years): } 10.49 \text { (range: } \\
\text { 7-14) } \\
\text { Males: } 59 \% \\
\text { ODD: } 12 \% \\
\text { ADHD: }{ }^{\wedge} \%\end{array}$ & \multirow[t]{3}{*}{52} \\
\hline & & & $\begin{array}{l}\text { Child CBT, } \\
(\mathrm{N}=19)\end{array}$ & $\begin{array}{l}\text { Generic CBT } \\
\text { Exposure } \\
\text { Relaxation } \\
\text { Cognitive problem solving } \\
\text { Group based } \\
\text { Delivered by doctoral level } \\
\text { psychologist. } \\
12 \text { weekly sessions } \\
\end{array}$ & $\begin{array}{l}\text { Age mean (years): } 11 \text { (range: } 7- \\
\text { 14) } \\
\text { Males: } 53 \% \\
\text { ODD: } 10 \% \\
\text { Dysthymia: } 5 \%\end{array}$ & \\
\hline & & & $\begin{array}{l}\text { Control, } \\
(\mathrm{N}=14)\end{array}$ & Waitlisting or no treatment & $\begin{array}{l}\text { Age mean (years): } 9.93 \text { (range: 7- } \\
\text { 14) }\end{array}$ & \\
\hline
\end{tabular}




\begin{tabular}{|c|c|c|c|c|c|c|}
\hline Author, Year & $\begin{array}{l}\text { Study Country, } \\
\text { Study Design, } \\
\text { Type of Study } \\
\text { (Efficacyl } \\
\text { Effectiveness), } \\
\text { Study Settings }\end{array}$ & $\begin{array}{c}\text { Type of } \\
\text { Anxiety/Severity } \\
\text { (CGI) }\end{array}$ & $\begin{array}{l}\text { Intervention } \\
\text { and } \\
\text { Comparison } \\
\text { s (N of } \\
\text { Patients) }\end{array}$ & $\begin{array}{l}\text { Characteristics of Interventions } \\
\text { (Psychotherapy: Components, } \\
\text { Delivery Model)/Pharm: Drug) } \\
\text { Intensity, Duration (Weeks)) }\end{array}$ & $\begin{array}{c}\text { Patient Characteristics Mean } \\
\text { Age (Range), Male (\%), } \\
\text { Race/Ethnicity, Comorbidity, } \\
\text { Household Income, Parent } \\
\text { Education, Family } \\
\text { Dysfunction/Stressor, } \\
\text { Treatment Sequence, } \\
\text { Insurance, History of } \\
\text { Maltreatment) }\end{array}$ & $\begin{array}{l}\text { Length } \\
\text { of } \\
\text { Follow } \\
\text { up } \\
\text { (Weeks } \\
\text { ) }\end{array}$ \\
\hline & & & & & $\begin{array}{l}\text { Males: } 79 \% \\
\text { Dysthymia: } 7 \%\end{array}$ & \\
\hline \multirow[t]{2}{*}{$\begin{array}{l}\text { St-Jacques, } \\
2010^{185}\end{array}$} & \multirow[t]{2}{*}{$\begin{array}{l}\text { Canada } \\
\text { RCT } \\
\text { Efficacy } \\
\text { Mental health } \\
\text { clinic }\end{array}$} & \multirow[t]{2}{*}{ SP } & $\begin{array}{l}\text { Child CBT, } \\
(\mathrm{N}=17)\end{array}$ & $\begin{array}{l}\text { Other Therapy } \\
\text { Exposure } \\
\text { Individual-based } \\
60 \text { min session once a week for } 4 \\
\text { weeks }\end{array}$ & \multirow[t]{2}{*}{$\begin{array}{l}\text { Age mean (years): } 10.16 \\
\text { (range:8-15) } \\
\text { Males: } 16 \%\end{array}$} & \multirow[t]{2}{*}{36} \\
\hline & & & $\begin{array}{l}\text { Child CBT, } \\
(\mathrm{N}=14)\end{array}$ & $\begin{array}{l}\text { Generic CBT } \\
\text { Exposure } \\
\text { Individual-based } \\
60 \text { min weekly sessions for } 4 \text { weeks }\end{array}$ & & \\
\hline \multirow[t]{3}{*}{$\begin{array}{l}\text { Suveg, } \\
2009^{114}\end{array}$} & \multirow[t]{3}{*}{$\begin{array}{l}\text { United States } \\
\text { RCT } \\
\text { Outpatient }\end{array}$} & \multirow[t]{3}{*}{$\begin{array}{l}\text { GAD, SAD, SoP, } \\
\text { SP }\end{array}$} & $\begin{array}{l}\text { Child CBT, } \\
(\mathrm{N}=55)\end{array}$ & $\begin{array}{l}\text { Exposure } \\
\text { Relaxation } \\
\text { Cognitive problem solving } \\
\text { Individual based } \\
\text { Delivered by psychologist, Masters } \\
\text { level clinician } \\
16,60 \text { min weekly sessions } \\
\end{array}$ & \multirow[t]{3}{*}{$\begin{array}{l}\text { Age range: } 7-14 \text { years } \\
\text { ADHD: } 32 \% \\
\text { Depression: } 11 \% \\
\text { ODD: } 14 \% \\
\text { Conduct disorder: } 1 \%\end{array}$} & \multirow[t]{3}{*}{52} \\
\hline & & & $\begin{array}{l}\text { Child and } \\
\text { parent } \\
\text { together } \mathrm{CBT} \text {, } \\
(\mathrm{N}=56)\end{array}$ & $\begin{array}{l}\text { Exposure } \\
\text { Relaxation } \\
\text { Cognitive problem solving } \\
\text { Individual based } \\
\text { Delivered by psychologist, Masters } \\
\text { level clinician } \\
16,60 \text { min weekly }\end{array}$ & & \\
\hline & & & $\begin{array}{l}\text { Control, } \\
(\mathrm{N}=50)\end{array}$ & $\begin{array}{l}\text { Attention control or treatment as } \\
\text { usual } \\
\text { Weekly for } 16 \text { weeks }\end{array}$ & & \\
\hline
\end{tabular}




\begin{tabular}{|c|c|c|c|c|c|c|}
\hline Author, Year & $\begin{array}{l}\text { Study Country, } \\
\text { Study Design, } \\
\text { Type of Study } \\
\text { (Efficacyl } \\
\text { Effectiveness), } \\
\text { Study Settings }\end{array}$ & $\begin{array}{c}\text { Type of } \\
\text { Anxiety/Severity } \\
\text { (CGI) }\end{array}$ & $\begin{array}{l}\text { Intervention } \\
\text { and } \\
\text { Comparison } \\
\text { s (N of } \\
\text { Patients) }\end{array}$ & $\begin{array}{l}\text { Characteristics of Interventions } \\
\text { (Psychotherapy: Components, } \\
\text { Delivery Model)/Pharm: Drug) } \\
\text { Intensity, Duration (Weeks)) }\end{array}$ & $\begin{array}{c}\text { Patient Characteristics Mean } \\
\text { Age (Range), Male (\%), } \\
\text { Race/Ethnicity, Comorbidity, } \\
\text { Household Income, Parent } \\
\text { Education, Family } \\
\text { Dysfunction/Stressor, } \\
\text { Treatment Sequence, } \\
\text { Insurance, History of } \\
\text { Maltreatment) }\end{array}$ & $\begin{array}{l}\text { Length } \\
\text { of } \\
\text { Follow } \\
\text { up } \\
\text { (Weeks } \\
\text { ) }\end{array}$ \\
\hline \multirow[t]{3}{*}{$\begin{array}{l}\text { Wergeland, } \\
2014^{88,89}\end{array}$} & \multirow[t]{3}{*}{$\begin{array}{l}\text { Norway } \\
\text { RCT } \\
\text { Efficacy } \\
\text { Outpatient }\end{array}$} & \multirow[t]{3}{*}{ GAD, SAD, SoP } & $\begin{array}{l}\text { Child CBT, } \\
(\mathrm{N}=91)\end{array}$ & $\begin{array}{l}\text { Friends } \\
\text { Child CBT- (parents included < 20\%) } \\
\text { Individual based } \\
\text { Exposure } \\
\text { Relaxation } \\
\text { Cognitive problem solving } \\
10 \text { weekly sessions, lasting } 60 \text { min } \\
\text { (ICBT), plus } 2 \text { parent only sessions } \\
\text { Delivered by psychologist, Masters } \\
\text { level clinician }\end{array}$ & $\begin{array}{l}\text { Age mean (years): } 11.4 \text { (range: } 8- \\
\text { 15) } \\
\text { Males: } 48 \% \\
\text { Caucasian: } 76 \% \\
\text { Hispanic: } 0.5 \% \\
\text { Asian: } 3 \% \\
\text { ADHD: } 5 \% \\
\text { Depression: } 8 \% \\
\text { ODD: } 9 \% \\
\text { Tic disorder: } 7 \%\end{array}$ & \multirow[t]{3}{*}{52} \\
\hline & & & $\begin{array}{l}\text { Child CBT, } \\
(\mathrm{N}=88)\end{array}$ & $\begin{array}{l}\text { Friends } \\
\text { Child CBT- (parents included < 20\%) } \\
\text { Group based } \\
\text { Exposure } \\
\text { Relaxation } \\
\text { Cognitive problem solving } \\
10 \text { weekly sessions, lasting } 90 \\
\text { minutes, plus } 2 \text { parents sessions } \\
\text { Delivered by psychologist, Masters } \\
\text { level clinician }\end{array}$ & $\begin{array}{l}\text { Age mean (years): } 11.7 \text { (range: } 8- \\
\text { 15) } \\
\text { Males: } 45 \% \\
\text { Caucasian: } 76 \% \\
\text { Hispanic: } 0.5 \% \\
\text { Asian: } 3 \% \\
\text { ADHD: } 6 \% \\
\text { Depression: } 16 \% \\
\text { ODD: } 2 \% \\
\text { Tic disorder: } 7 \%\end{array}$ & \\
\hline & & & $\begin{array}{l}\text { Control, } \\
(\mathrm{N}=38)\end{array}$ & Waitlisting or no treatment & $\begin{array}{l}\text { Age mean (years): } 11.4 \text { (range: } 8- \\
\text { 15) } \\
\text { Males: } 50 \% \\
\text { Caucasian: } 76 \% \\
\text { Hispanic: } 0.5 \% \\
\text { Asian: } 3 \% \\
\text { ADHD: } 3 \% \\
\text { Depression: } 11 \% \\
\text { ODD: } 8 \% \\
\text { Tic disorder: } 5 \%\end{array}$ & \\
\hline $\begin{array}{l}\text { Whiteside, } \\
2015^{186}\end{array}$ & $\begin{array}{l}\text { United States } \\
\text { RCT } \\
\text { Effectiveness } \\
\text { Mental health } \\
\text { clinic }\end{array}$ & $\begin{array}{l}\text { GAD, PD, SAD, } \\
\text { SoP, SP }\end{array}$ & $\begin{array}{l}\text { Child CBT, } \\
(\mathrm{N}=7)\end{array}$ & $\begin{array}{l}\text { Anxiety management strategies } \\
\text { Relaxation } \\
\text { Cognitive problem solving } \\
\text { Individual based } \\
\text { Delivered by psychologist and }\end{array}$ & $\begin{array}{l}\text { Age mean (years): } 9.71 \text { (range: } 7 \text { - } \\
14) \\
\text { Male: } 29 \% \\
\text { Depression: } 14 \% \\
\text { College Graduate(parent): } 100 \%\end{array}$ & 52 \\
\hline
\end{tabular}




\begin{tabular}{|c|c|c|c|c|c|c|}
\hline Author, Year & $\begin{array}{l}\text { Study Country, } \\
\text { Study Design, } \\
\text { Type of Study } \\
\text { (Efficacyl } \\
\text { Effectiveness), } \\
\text { Study Settings }\end{array}$ & $\begin{array}{c}\text { Type of } \\
\text { Anxiety/Severity } \\
\text { (CGI) }\end{array}$ & $\begin{array}{l}\text { Intervention } \\
\text { and } \\
\text { Comparison } \\
\text { s (N of } \\
\text { Patients) }\end{array}$ & $\begin{array}{l}\text { Characteristics of Interventions } \\
\text { (Psychotherapy: Components, } \\
\text { Delivery Model)/Pharm: Drug) } \\
\text { Intensity, Duration (Weeks)) }\end{array}$ & $\begin{array}{l}\text { Patient Characteristics Mean } \\
\text { Age (Range), Male (\%), } \\
\text { Race/Ethnicity, Comorbidity, } \\
\text { Household Income, Parent } \\
\text { Education, Family } \\
\text { Dysfunction/Stressor, } \\
\text { Treatment Sequence, } \\
\text { Insurance, History of } \\
\text { Maltreatment) }\end{array}$ & $\begin{array}{l}\text { Length } \\
\text { of } \\
\text { Follow } \\
\text { up } \\
\text { (Weeks } \\
\text { ) }\end{array}$ \\
\hline & & & & $\begin{array}{l}\text { masters level clinicians } \\
6,50-60 \text { min weekly sessions }\end{array}$ & & \\
\hline & & & $\begin{array}{l}\text { Child and } \\
\text { parent } \\
\text { together } \mathrm{CBT} \\
,(\mathrm{N}=7)\end{array}$ & $\begin{array}{l}\text { Parent coached exposure therapy } \\
\text { Exposure } \\
\text { Delivered by psychologist and } \\
\text { Masters level clinicians }\end{array}$ & $\begin{array}{l}\text { Age mean (years): } 10.71 \text { (range: } \\
7-14) \\
\text { Male: } 29 \% \\
\text { Depression: } 14 \% \\
\text { College Graduate(parent): } 100 \%\end{array}$ & \\
\hline \multirow[t]{2}{*}{$\begin{array}{l}\text { Wood, } \\
2006^{187}\end{array}$} & \multirow[t]{2}{*}{$\begin{array}{l}\text { RCT } \\
\text { Efficacy } \\
\text { Mental health } \\
\text { clinic }\end{array}$} & \multirow[t]{2}{*}{$\begin{array}{l}\text { GAD, SAD, SP, } \\
\text { SoP. }\end{array}$} & $\begin{array}{l}\text { Child CBT, } \\
(N=20)\end{array}$ & $\begin{array}{l}\text { Coping Cat } \\
\text { Exposure } \\
\text { Relaxation } \\
\text { Cognitive problem solving } \\
\text { Individual based } \\
\text { Delivered by student trainee, doctoral } \\
\text { level psychologist and clinical } \\
\text { psychologist } \\
12-16,60-80 \text { min sessions. }\end{array}$ & $\begin{array}{l}\text { Age mean (years): } 9.83 \text { (Range } 6 \\
\text { - 13) } \\
\text { Male: } 65 \% \\
\text { Caucasian: } 65 \% \\
\text { African American: } 5 \% \\
\text { Hispanic: } 15 \% \\
\text { Other: } 15 \%\end{array}$ & \multirow[t]{2}{*}{ NR } \\
\hline & & & $\begin{array}{l}\text { Child and } \\
\text { parent } \\
\text { together } \mathrm{CBT} \\
,(\mathrm{N}=20)\end{array}$ & $\begin{array}{l}\text { Building confidence } \\
\text { Exposure } \\
\text { Relaxation } \\
\text { Cognitive problem solving } \\
\text { Individual based } \\
\text { Delivered by student trainee, doctoral } \\
\text { level psychologist and clinical } \\
\text { psychologist. } \\
12-16,60-80 \text { min sessions }\end{array}$ & $\begin{array}{l}\text { Age mean (years): } 9.83 \text { (Range } 6 \\
\text { - 13) } \\
\text { Male: } 55 \% \\
\text { Caucasian: } 55 \% \\
\text { Hispanic: } 5 \% \\
\text { Asian: } 5 \% \\
\text { Others: } 30 \%\end{array}$ & \\
\hline \multirow[t]{2}{*}{$\begin{array}{l}\text { Walczak, } \\
2016^{188}\end{array}$} & \multirow[t]{2}{*}{$\begin{array}{l}\text { Denmark } \\
\text { RCT } \\
\text { Efficacy } \\
\text { Mental health } \\
\text { xlinic }\end{array}$} & \multirow[t]{2}{*}{$\begin{array}{l}\text { GAD } \\
\text { SAD } \\
\text { SoP } \\
\text { SP }\end{array}$} & $\begin{array}{l}\text { Child CBT } \\
\text { plus separate } \\
\text { parent } \\
\text { intervention } \\
:(\mathrm{N}=28) \\
\end{array}$ & $\begin{array}{l}\text { Generic CBT } \\
\text { Individual based } \\
\text { Delivered by Masters level clinician } \\
14 \text { sessions: two family, } 2 \text { child, } 6 \\
\text { parent }\end{array}$ & $\begin{array}{l}\text { Age mean (years): } 13.95 \text { (Range: } \\
\text { 11-17) } \\
\text { Depression: } 4 \% \\
\text { ODD: } 4 \%\end{array}$ & \multirow[t]{2}{*}{156} \\
\hline & & & $\begin{array}{l}\text { Child CBT: } \\
(\mathrm{N}=26)\end{array}$ & $\begin{array}{l}\text { Generic CBT } \\
\text { Individual based } \\
\text { Delivered by Masters level clinician } \\
14 \text { sessions, two family and } 12 \text { child }\end{array}$ & $\begin{array}{l}\text { Age mean (years): } 13.95 \text { (Range: } \\
\text { 11-17) } \\
\text { Depression:4\% } \\
\text { OCD: } 4 \%\end{array}$ & \\
\hline
\end{tabular}




\begin{tabular}{|c|c|c|c|c|c|c|}
\hline Author, Year & $\begin{array}{l}\text { Study Country, } \\
\text { Study Design, } \\
\text { Type of Study } \\
\text { (Efficacyl } \\
\text { Effectiveness), } \\
\text { Study Settings }\end{array}$ & $\begin{array}{l}\text { Type of } \\
\text { Anxiety/Severity } \\
\text { (CGI) }\end{array}$ & $\begin{array}{l}\text { Intervention } \\
\text { and } \\
\text { Comparison } \\
\text { s (N of } \\
\text { Patients) }\end{array}$ & $\begin{array}{l}\text { Characteristics of Interventions } \\
\text { (Psychotherapy: Components, } \\
\text { Delivery Model)/Pharm: Drug) } \\
\text { Intensity, Duration (Weeks)) }\end{array}$ & $\begin{array}{c}\text { Patient Characteristics Mean } \\
\text { Age (Range), Male (\%), } \\
\text { Race/Ethnicity, Comorbidity, } \\
\text { Household Income, Parent } \\
\text { Education, Family } \\
\text { Dysfunction/Stressor, } \\
\text { Treatment Sequence, } \\
\text { Insurance, History of } \\
\text { Maltreatment) }\end{array}$ & $\begin{array}{l}\text { Length } \\
\text { of } \\
\text { Follow } \\
\text { up } \\
\text { (Weeks } \\
\text { ) }\end{array}$ \\
\hline & & & & only & $\begin{array}{l}\text { ODD: } 4 \% \\
\text { PTSD: } 4 \%\end{array}$ & \\
\hline \multirow[t]{3}{*}{$\begin{array}{l}\text { Warner, } \\
2016^{116}\end{array}$} & \multirow[t]{3}{*}{$\begin{array}{l}\text { United States } \\
\text { RCT } \\
\text { Efficacy } \\
\text { Outpatient }\end{array}$} & \multirow[t]{3}{*}{$\begin{array}{l}\text { GAD, PD, SAD, } \\
\text { SP, SoP }\end{array}$} & $\begin{array}{l}\text { Child CBT, } \\
(\mathrm{N}=46)\end{array}$ & $\begin{array}{l}\text { SASS: Group-based exposure } \\
\text { cognitive problem solving } \\
\text { (Skills for academic and social } \\
\text { success provided by psychologists) } \\
\text { Delivered by doctoral level } \\
\text { psychologist } \\
12 \text { in school group sessions ( ranged } \\
\text { from } 50-90 \text { mints) }\end{array}$ & $\begin{array}{l}\text { Age mean (years): } 15.5 \\
\text { Male: } 30.4 \% \\
\text { Caucasian: } 74 \% \text {, African } \\
\text { American :4\%, Hispanic: 4\%, } \\
\text { Asian: } 12 \%, \text { Other: } 4 \% \\
\text { Mean income: } 94.155\end{array}$ & \multirow[t]{3}{*}{20} \\
\hline & & & $\begin{array}{l}\text { Child CBT, } \\
(\mathrm{N}=47)\end{array}$ & $\begin{array}{l}\text { SASS: Group-based } \\
\text { Exposure } \\
\text { Cognitive problem solving } \\
\text { Delivered by doctoral level } \\
\text { psychologist } \\
12 \text { in school group sessions ( ranged } \\
\text { from } 50-90 \text { mints) }\end{array}$ & $\begin{array}{l}\text { Age mean (years): } 15.34 \\
\text { Male: } 29.7 \% \\
\text { Caucasian: } 75 \% \text {, African } \\
\text { American :8\%, Hispanic: } 5 \% \text {, } \\
\text { Asian: } 6 \%, \text { Other: } 6 \%\end{array}$ & \\
\hline & & & $\begin{array}{l}\text { Control, } \\
(\mathrm{N}=43)\end{array}$ & $\begin{array}{l}\text { Attention control or treatment as } \\
\text { usual } \\
\text { Relaxation } \\
\text { Cognitive problem solving } \\
\text { A nonspecific counseling program, } \\
\text { SFL, controlled for the attention and } \\
\text { group involvement. }\end{array}$ & $\begin{array}{l}\text { Age mean (years): } 15.37 \\
\text { Male: } 37 \% \\
\text { Caucasian: } 67 \% \text {, African } \\
\text { American :2\%, Hispanic: } 14 \% \text {, } \\
\text { Asian: } 7 \% \text {, Other: } 9 \%\end{array}$ & \\
\hline
\end{tabular}

ADHD: attention deficit hyperactivity disorder, CBT: cognitive behavioral therapy, CC: coping cat, CGI: clinical global impression, FRIENDS: feeling worried?; relax and feel good; inner thoughts; explore plans; nice work so reward yourself; don't forget to practice; and stay calm, GAD: generalized anxiety disorder, ICBT: individualized cognitive behavioral therapy, IAFS: intervencion en adolescents con fobia social (Treatment for adolescents with social phobia), NR: not reported, OCD: obsessive compulsive disorder, ODD: oppositional defiant disorder, OST: one session treatment, PD: panic disorder, PTSD: posttraumatic stress disorder, RCT: randomized controlled trial, SAD: separation anxiety disorder, SET-C: social effectiveness therapy, SoP: social anxiety, SP: specific phobia. 
Table E.21. Characteristics of single-cohort observational studies with adverse events

\begin{tabular}{|c|c|c|c|c|c|c|}
\hline Author, Year & $\begin{array}{l}\text { Study Country, } \\
\text { Study Design, } \\
\text { Type of Study } \\
\text { (Efficacyl } \\
\text { Effectiveness), } \\
\text { Study Settings }\end{array}$ & $\begin{array}{c}\text { Type of } \\
\text { AnxietylSeverity } \\
\text { (CGI) }\end{array}$ & $\begin{array}{c}\text { Intervention } \\
\text { and } \\
\text { Comparison } \\
\mathrm{s} \text { (N of } \\
\text { Patients) }\end{array}$ & $\begin{array}{l}\text { Characteristics of Interventions } \\
\text { (Psychotherapy: Components, } \\
\text { Delivery Model)/Pharm: Drug) } \\
\text { Intensity, Duration (Weeks)) }\end{array}$ & $\begin{array}{c}\text { Patient Characteristics Mean Age } \\
\text { (Range), Male (\%), } \\
\text { Race/Ethnicity, Comorbidity, } \\
\text { Household Income, Parent } \\
\text { Education, Family } \\
\text { Dysfunction/Stressor, Treatment } \\
\text { Sequence, Insurance, History of } \\
\text { Maltreatment) }\end{array}$ & $\begin{array}{c}\text { Length } \\
\text { of } \\
\text { Follow } \\
\text { up } \\
\text { (Weeks } \\
\text { ) }\end{array}$ \\
\hline $\begin{array}{l}\text { Biederman, } \\
1987^{189}\end{array}$ & $\begin{array}{l}\text { United States } \\
\text { Case } \\
\text { series/case } \\
\text { report } \\
\text { Outpatient } \\
\end{array}$ & $\begin{array}{l}\text { GAD, PD with } \\
\text { agoraphobia, PD } \\
\text { without } \\
\text { agoraphobia, } \\
\text { SAD, SoP }\end{array}$ & $\begin{array}{l}\text { Clonazepam, } \\
(\mathrm{N}=3)\end{array}$ & $1 \mathrm{mg} / \mathrm{day}$ & $\begin{array}{l}\text { Age mean (years): } 10 \text { (range: } 8-11 \text { ) } \\
\text { Males: } 66.6 \% \\
\text { Caucasian: } 100 \%\end{array}$ & $\begin{array}{l}21.5- \\
156\end{array}$ \\
\hline $\begin{array}{l}\text { Birmaher, } \\
1994^{190}\end{array}$ & $\begin{array}{l}\text { United States } \\
\text { Case series } \\
\text { Outpatient }\end{array}$ & SAD, SoP & $\begin{array}{l}\text { SSRI: } \\
\text { Fluoxetine, } \\
(\mathrm{N}=21)\end{array}$ & $\begin{array}{l}\text { Mean dose of } 25.7 \mathrm{mg} / \text { day for up to } \\
43 \text { weeks }\end{array}$ & $\begin{array}{l}\text { Age Range: ( } 11-17) \text { years } \\
\text { Male: } 55 \% \\
\text { CGI>=6: } 91 \%\end{array}$ & 0 \\
\hline $\begin{array}{l}\text { Chavira, } \\
2002^{191}\end{array}$ & $\begin{array}{l}\text { United States } \\
\text { Case } \\
\text { series/case } \\
\text { report } \\
\text { Outpatient }\end{array}$ & SoP, SP & $\begin{array}{l}\text { SSRI: } \\
\text { Citalopram, } \\
(\mathrm{N}=12)\end{array}$ & $100-40 \mathrm{mg} / \mathrm{day}$ for 12 weeks & $\begin{array}{l}\text { Age mean (years): } 13.42 \text { (range: } 8 \text { - } \\
\text { 17) } \\
\text { Males: } 33.3 \% \\
\text { Caucasian: } 6 \% \\
\text { African American: } 8 \% \\
\text { Hispanic: } 16.6 \% \\
\text { Others: } 25 \% \\
\text { Mean CGI-S=4.82 }\end{array}$ & 0 \\
\hline $\begin{array}{l}\text { Chutko, } \\
2011^{192}\end{array}$ & $\begin{array}{l}\text { Kazakhstan } \\
\text { Case series } \\
\text { Outpatient }\end{array}$ & GAD & $\begin{array}{l}\text { SNRI: } \\
\text { Adaptol, } \\
(\mathrm{N}=32)\end{array}$ & $1000 \mathrm{mg} /$ day for 4 weeks & Age range: $7-14$ years & 0 \\
\hline $\begin{array}{l}\text { Compton, } \\
2001^{193}\end{array}$ & $\begin{array}{l}\text { United States } \\
\text { RCT } \\
\text { Outpatient } \\
\end{array}$ & SoP & $\begin{array}{l}\text { SRI, SSRI: } \\
\text { Sertraline, } \\
(\mathrm{N}=14)\end{array}$ & $\begin{array}{l}\text { Maximum of } 200 \mathrm{mg} / \mathrm{day} \text { for } 8 \\
\text { weeks }\end{array}$ & $\begin{array}{l}\text { Age Range: }(10-17) \text { years } \\
\text { Males: } 57 \%\end{array}$ & 0 \\
\hline $\begin{array}{l}\text { dAmato, } \\
1962^{194}\end{array}$ & $\begin{array}{l}\text { United States } \\
\text { Case } \\
\text { series/case } \\
\text { report } \\
\text { Outpatient }\end{array}$ & SP & $\begin{array}{l}\text { Benzodiazepi } \\
\text { ne: } \\
\text { Chlordiazepo } \\
\text { xide: }(\mathrm{N}=9)\end{array}$ & $10-30 \mathrm{mg} /$ day for $1-4$ weeks & $\begin{array}{l}\text { Age range: } 8-11 \text { years } \\
\text { Males: } 44 \%\end{array}$ & 0 \\
\hline $\begin{array}{l}\text { Dummit, } \\
\text { 1996 }^{195}\end{array}$ & $\begin{array}{l}\text { United States } \\
\text { Case } \\
\text { series/case } \\
\text { report } \\
\text { Outpatient }\end{array}$ & $\begin{array}{l}\text { GAD, SAD, SoP, } \\
\text { SP }\end{array}$ & $\begin{array}{l}\text { SSRI: } \\
\text { Fluoxetine } \\
(\mathrm{N}=21)\end{array}$ & $20-60 \mathrm{mg} / \mathrm{day}$ for 9 weeks & $\begin{array}{l}\text { Age mean (years): } 8.2 \text { (range: } 8- \\
\text { 14) } \\
\text { Males: } 24 \% \\
\text { Caucasian: } 90 \% \\
\text { Asian: } 9.5 \% \\
\text { ODD: } 5 \% \\
\text { Learning disabilities: } 14 \%\end{array}$ & 0 \\
\hline
\end{tabular}




\begin{tabular}{|c|c|c|c|c|c|c|}
\hline Author, Year & $\begin{array}{l}\text { Study Country, } \\
\text { Study Design, } \\
\text { Type of Study } \\
\text { (Efficacyl } \\
\text { Effectiveness), } \\
\text { Study Settings }\end{array}$ & $\begin{array}{c}\text { Type of } \\
\text { Anxiety/Severity } \\
\text { (CGI) }\end{array}$ & $\begin{array}{l}\text { Intervention } \\
\text { and } \\
\text { Comparison } \\
\text { s (N of } \\
\text { Patients) }\end{array}$ & $\begin{array}{l}\text { Characteristics of Interventions } \\
\text { (Psychotherapy: Components, } \\
\text { Delivery Model)/Pharm: Drug) } \\
\text { Intensity, Duration (Weeks)) }\end{array}$ & $\begin{array}{c}\text { Patient Characteristics Mean Age } \\
\text { (Range), Male (\%), } \\
\text { Race/Ethnicity, Comorbidity, } \\
\text { Household Income, Parent } \\
\text { Education, Family } \\
\text { Dysfunction/Stressor, Treatment } \\
\text { Sequence, Insurance, History of } \\
\text { Maltreatment) }\end{array}$ & $\begin{array}{l}\text { Length } \\
\text { of } \\
\text { Follow } \\
\text { up } \\
\text { (Weeks } \\
\text { ) }\end{array}$ \\
\hline & & & & & $\begin{array}{l}\text { Enuresis: 5\% } \\
\text { Trichotillomania: 5\% }\end{array}$ & \\
\hline $\begin{array}{l}\text { Fairbanks, } \\
1997^{196}\end{array}$ & $\begin{array}{l}\text { United States } \\
\text { Case } \\
\text { series/case } \\
\text { report } \\
\text { Outpatient }\end{array}$ & $\begin{array}{l}\text { GAD, PD, PD } \\
\text { with } \\
\text { agoraphobia, } \\
\text { SAD, SoP }\end{array}$ & $\begin{array}{l}\text { SSRI: } \\
\text { Fluoxetine } \\
(\mathrm{N}=18)\end{array}$ & $\begin{array}{l}\text { Oral, } \\
20-40 \mathrm{mg} / \text { day (children) or } 20- \\
80 \mathrm{mg} / \text { day (adolescents) for } 9 \\
\text { weeks. }\end{array}$ & $\begin{array}{l}\text { Age mean (years): } 11.9 \text { (range: } 9- \\
17 \text { ) } \\
\text { Caucasian: } 55 \% \\
\text { African American: } 5 \% \\
\text { Hispanic: } 5 \% \\
\text { Other: } 5 \% \\
\text { Body Dysmorphic Disorder: } 5 \%\end{array}$ & 0 \\
\hline $\begin{array}{l}\text { Isolan, } \\
2007^{197}\end{array}$ & $\begin{array}{l}\text { Brazil } \\
\text { Case series } \\
\text { Mental health } \\
\text { clinic }\end{array}$ & $\begin{array}{l}\text { GAD, SAD, SP, } \\
\text { SoP. }\end{array}$ & $\begin{array}{l}\text { SSRI: } \\
\text { Escitalopram } \\
(\mathrm{N}=20)\end{array}$ & $10-20 \mathrm{mg} /$ day for 12 weeks. & $\begin{array}{l}\text { Age mean (years): } 15 \text { (Range } 10- \\
\text { 17) } \\
\text { Male: } 30 \%\end{array}$ & 0 \\
\hline $\begin{array}{l}\text { Karabekiroglu } \\
, 2011^{198}\end{array}$ & $\begin{array}{l}\text { Turkey } \\
\text { Case series } \\
\text { Outpatient }\end{array}$ & $\begin{array}{l}\text { GAD,SAD, SoP, } \\
\text { SP }\end{array}$ & $\begin{array}{l}\text { SSRI: } \\
\text { Fluoxetine: } \\
(\mathrm{N}=40)\end{array}$ & 12 weeks of treatment. & $\begin{array}{l}\text { Age mean (years): } 10.08 \text { ( range: } 7 \text { - } \\
\text { 17) } \\
\text { Male: } 57 \% \\
\text { ADHD: } 7.5 \% \text {, OCD : } 2.5 \% \text {, } \\
\text { selective mutism: } 2.5 \%\end{array}$ & 0 \\
\hline $\begin{array}{l}\text { Lepola, } \\
1996^{199}\end{array}$ & $\begin{array}{l}\text { Finland } \\
\text { Case series } \\
\text { Outpatient }\end{array}$ & $\begin{array}{l}\text { PD with } \\
\text { agoraphobia }\end{array}$ & $\begin{array}{l}\text { SSRI: } \\
\text { Citalopram, } \\
(\mathrm{N}=3)\end{array}$ & $20 \mathrm{mg} /$ day for $34-64$ weeks & $\begin{array}{l}\text { Age range: } 9-16 \text { years } \\
\text { Males: } 66.6 \%\end{array}$ & 52 \\
\hline \multirow[t]{3}{*}{$\begin{array}{l}\text { Mancini, } \\
1999^{200}\end{array}$} & \multirow[t]{3}{*}{$\begin{array}{l}\text { Canada } \\
\text { Case series/ } \\
\text { case report } \\
\text { Outpatient }\end{array}$} & \multirow[t]{3}{*}{ SoP } & $\begin{array}{l}\text { SSRI: } \\
\text { Paroxetine, } \\
(\mathrm{N}=5)\end{array}$ & $40-80$ mg/day for 5-24 weeks & $\begin{array}{l}\text { Age Range: } 7-18 \text { years } \\
\text { Males: } 20 \% \\
\text { OCD: } 40 \% \\
\text { Dysthymia: } 40 \%\end{array}$ & \multirow[t]{3}{*}{0} \\
\hline & & & $\begin{array}{l}\text { SNRI: } \\
\text { Nefazodone, } \\
(\mathrm{N}=1)\end{array}$ & 350 mg/day for 20 weeks & $\begin{array}{l}\text { Age: } 15 \\
\text { Males: } 0 \%\end{array}$ & \\
\hline & & & $\begin{array}{l}\text { SSRI: } \\
\text { Sertraline, } \\
(\mathrm{N}=1)\end{array}$ & 175 mg/day, & $\begin{array}{l}\text { Age: } 17 \\
\text { Males: } 0 \% \\
\text { Depression: } 100 \% \\
\text { Dysthymia: } 100 \%\end{array}$ & \\
\hline Masi, $2001^{201}$ & $\begin{array}{l}\text { Italy } \\
\text { Case series } \\
\text { Outpatient } \\
\end{array}$ & $\begin{array}{l}\text { GAD, PD with } \\
\text { agoraphobia, PD } \\
\text { without }\end{array}$ & $\begin{array}{l}\text { SSRI: } \\
\text { paroxetine, } \\
(\mathrm{N}=18)\end{array}$ & $\begin{array}{l}\text { Average } 23.9 \mathrm{mg} / \text { day } \\
\text { Daily for } 2-24 \text { weeks }\end{array}$ & $\begin{array}{l}\text { Age mean (years): } 12.3 \text { (range: } 7- \\
\text { 16) } \\
\text { Males: } 66.6 \%\end{array}$ & 0 \\
\hline
\end{tabular}




\begin{tabular}{|c|c|c|c|c|c|c|}
\hline Author, Year & $\begin{array}{l}\text { Study Country, } \\
\text { Study Design, } \\
\text { Type of Study } \\
\text { (Efficacyl } \\
\text { Effectiveness), } \\
\text { Study Settings }\end{array}$ & $\begin{array}{c}\text { Type of } \\
\text { AnxietylSeverity } \\
\text { (CGI) }\end{array}$ & $\begin{array}{l}\text { Intervention } \\
\text { and } \\
\text { Comparison } \\
\text { s (N of } \\
\text { Patients) }\end{array}$ & $\begin{array}{l}\text { Characteristics of Interventions } \\
\text { (Psychotherapy: Components, } \\
\text { Delivery Model)/Pharm: Drug) } \\
\text { Intensity, Duration (Weeks)) }\end{array}$ & $\begin{array}{c}\text { Patient Characteristics Mean Age } \\
\text { (Range), Male (\%), } \\
\text { Race/Ethnicity, Comorbidity, } \\
\text { Household Income, Parent } \\
\text { Education, Family } \\
\text { Dysfunction/Stressor, Treatment } \\
\text { Sequence, Insurance, History of } \\
\text { Maltreatment) }\end{array}$ & $\begin{array}{l}\text { Length } \\
\text { of } \\
\text { Follow } \\
\text { up } \\
\text { (Weeks } \\
\text { ) }\end{array}$ \\
\hline & & $\begin{array}{l}\text { agoraphobia, } \\
\text { SAD, SoP, SP }\end{array}$ & & & $\begin{array}{l}\text { Depression: } 22 \% \\
\text { OCD: } 22 \% \\
\text { Tic Disorder: } 11 \% \\
\end{array}$ & \\
\hline $\begin{array}{l}\text { Mrakotsky, } \\
2008^{202}\end{array}$ & $\begin{array}{l}\text { United States } \\
\text { Open-label pilot } \\
\text { Outpatient }\end{array}$ & SoP & $\begin{array}{l}\text { Tetracyclic } \\
\text { Antidepressa } \\
\text { nt: } \\
\text { Mirtazapine, } \\
(\mathrm{N}=18)\end{array}$ & $15-45 \mathrm{mg} /$ day for 8 weeks & $\begin{array}{l}\text { Age mean (years): } 12.06 \text { (range: } 8- \\
\text { 17) } \\
\text { Males: } 50 \% \\
\text { ODD: } 5 \% \\
\text { Depression: } 10 \%\end{array}$ & 0 \\
\hline $\begin{array}{l}\text { Renaud, } \\
1999^{203}\end{array}$ & $\begin{array}{l}\text { United States } \\
\text { Case series } \\
\text { Outpatient }\end{array}$ & $\begin{array}{l}\text { GAD, PD, SAD, } \\
\text { SoP, SP }\end{array}$ & SSRI, $(\mathrm{N}=12)$ & $\begin{array}{l}9 \text { received Fluoxetine }(34.4 \mathrm{mg} / \text { day }) \\
2 \text { received Paroxetine }(20 \mathrm{mg} / \text { day }) \\
1 \text { received of Sertraline }(125 \\
\text { mg/day) }\end{array}$ & $\begin{array}{l}\text { Age mean (years): } 12 \text { (range: } 7-17 \text { ) } \\
\text { Males: } 42 \% \\
\text { Depression: } 66.6 \% \\
\text { Substance abuse: } 8 \% \\
\text { OCD: } 8 \%\end{array}$ & 26 \\
\hline $\begin{array}{l}\text { Simeon, } \\
1987^{204}\end{array}$ & $\begin{array}{l}\text { Canada } \\
\text { Cross over } \\
\text { study } \\
\text { Outpatient }\end{array}$ & GAD & $\begin{array}{l}\text { Benzodiazepi } \\
\text { ne: } \\
\text { Alprazolam, } \\
(\mathrm{N}=12)\end{array}$ & $0.5 \mathrm{mg}$ to $1.5 \mathrm{mg} / \mathrm{day}$ & $\begin{array}{l}\text { Age mean (years):11.5 (Range: } 8- \\
\text { 14) } \\
\text { Males: } 90 \% \\
\text { Caucasian: } 100 \%\end{array}$ & 4 \\
\hline $\begin{array}{l}\text { Simeon, } \\
1994^{205}\end{array}$ & $\begin{array}{l}\text { Canada } \\
\text { Case series } \\
\text { Outpatient }\end{array}$ & GAD, SAD & $\begin{array}{l}\text { Buspirone: } \\
(\mathrm{N}=15)\end{array}$ & NR & $\begin{array}{l}\text { Age mean (years): } 10 \text { (range: (6- } \\
\text { 14) } \\
\text { Males: } 66.6 \% \\
\text { ADHD: } 27 \% \\
\text { Avoidant disorder: } 7 \%\end{array}$ & 0 \\
\hline Zwier, $1993^{206}$ & $\begin{array}{l}\text { United States } \\
\text { Case } \\
\text { series/case } \\
\text { report } \\
\text { Inpatient }\end{array}$ & SoP & $\begin{array}{l}\text { Buspirone: } \\
(\mathrm{N}=1)\end{array}$ & 20 mg/day for 52 weeks & $\begin{array}{l}\text { Age: } 16 \\
\text { Males: } 100 \% \\
\text { Caucasian } 100 \%\end{array}$ & 0 \\
\hline
\end{tabular}

ADHD: attention deficit hyperactivity disorder, CGI: clinical global impression scale, GAD: generalized anxiety disorder, NR: not reported, OCD: obsessive compulsive disorder, ODD: oppositional defiant disorder, PD: panic disorder, SAD: separation anxiety disorder, SNRI: serotonin-norepinephrine reuptake inhibitor, SoP: social anxiety, SP: specific phobia, SRI: serotonin reuptake inhibitor, SSRI: selective serotonin reuptake inhibitor. 


\section{Appendix F. Risk of Bias}

Table F.1. Risk of bias for randomized controlled trials (Cochrane Risk of Bias tool) ${ }^{207}$

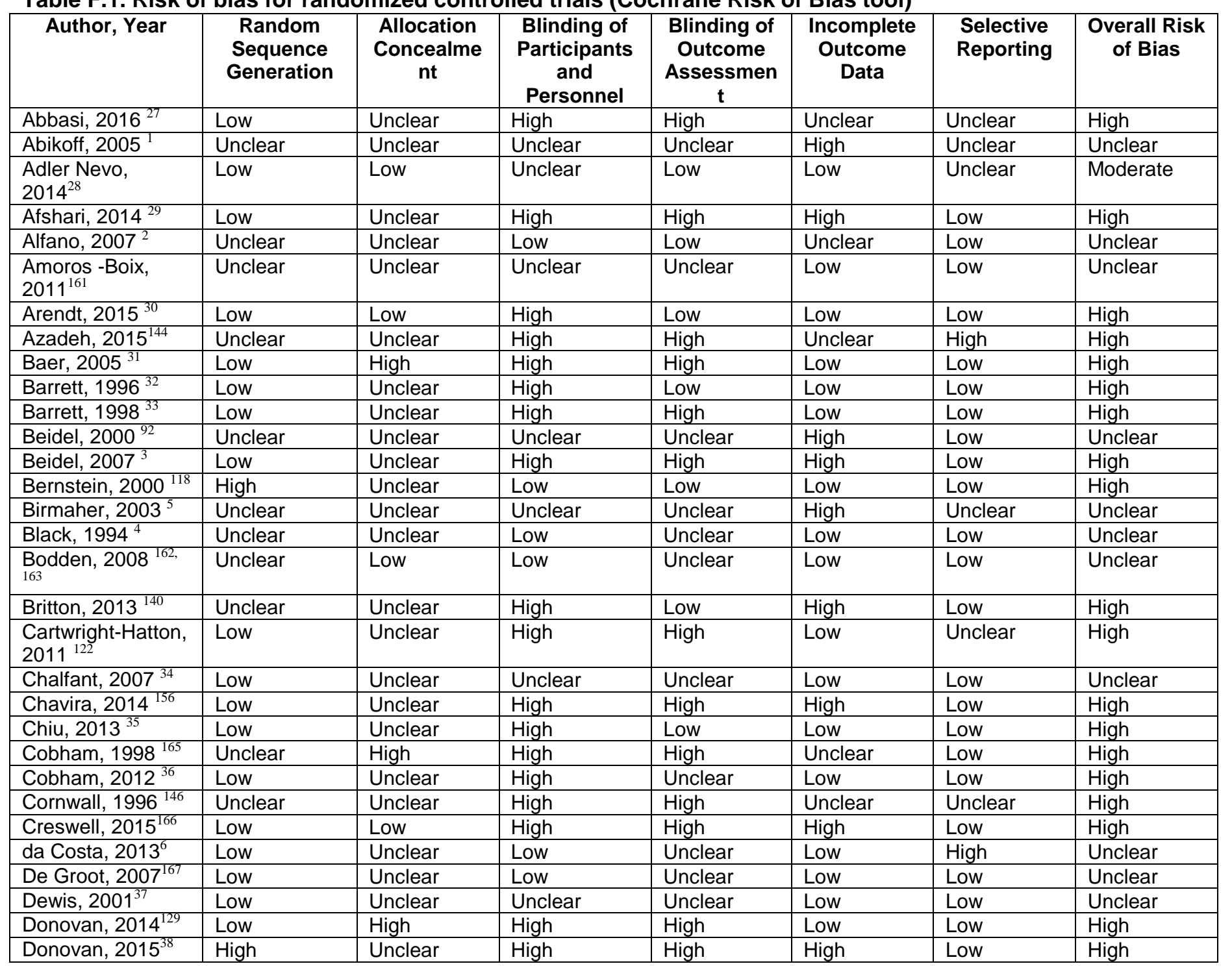




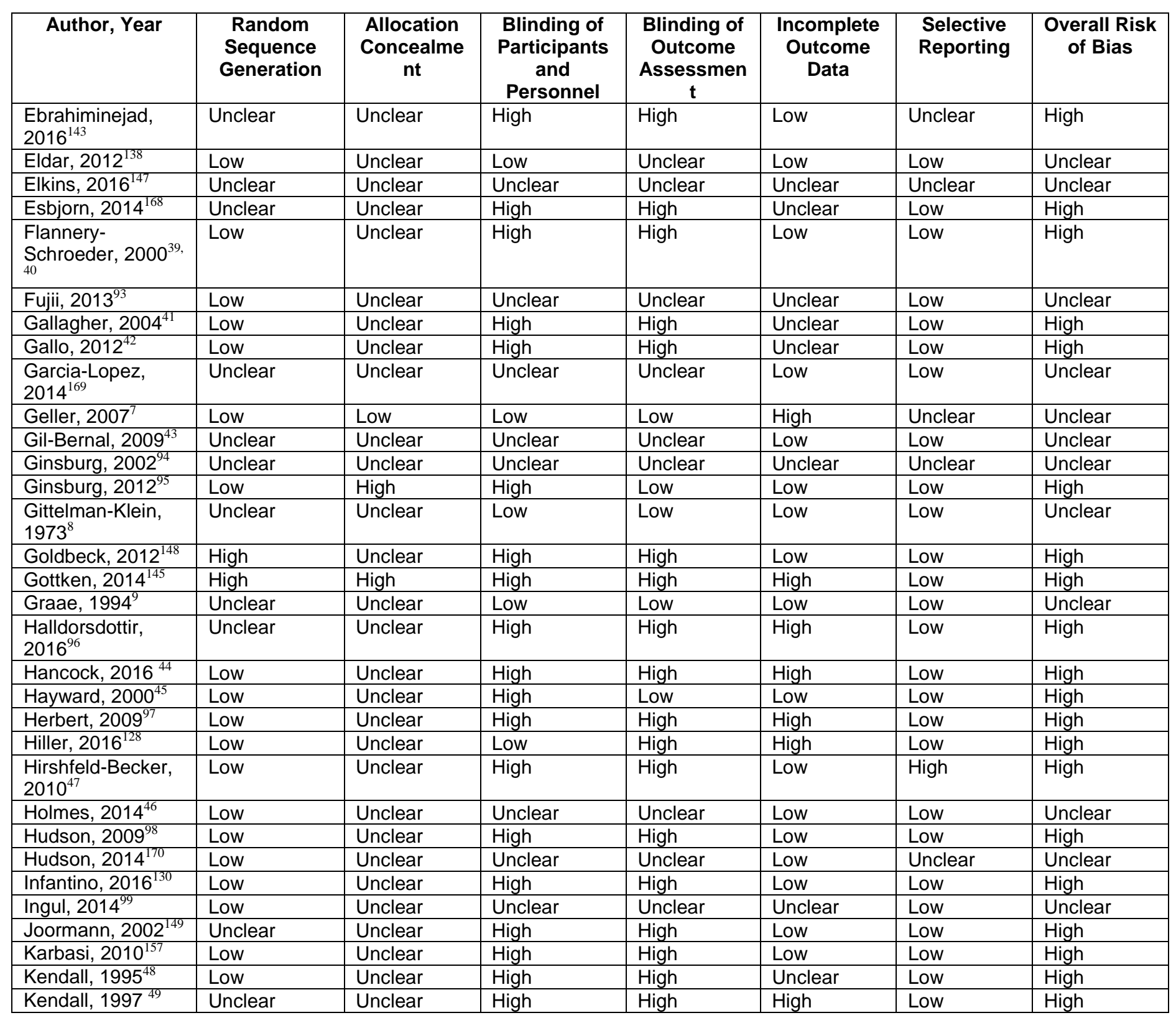




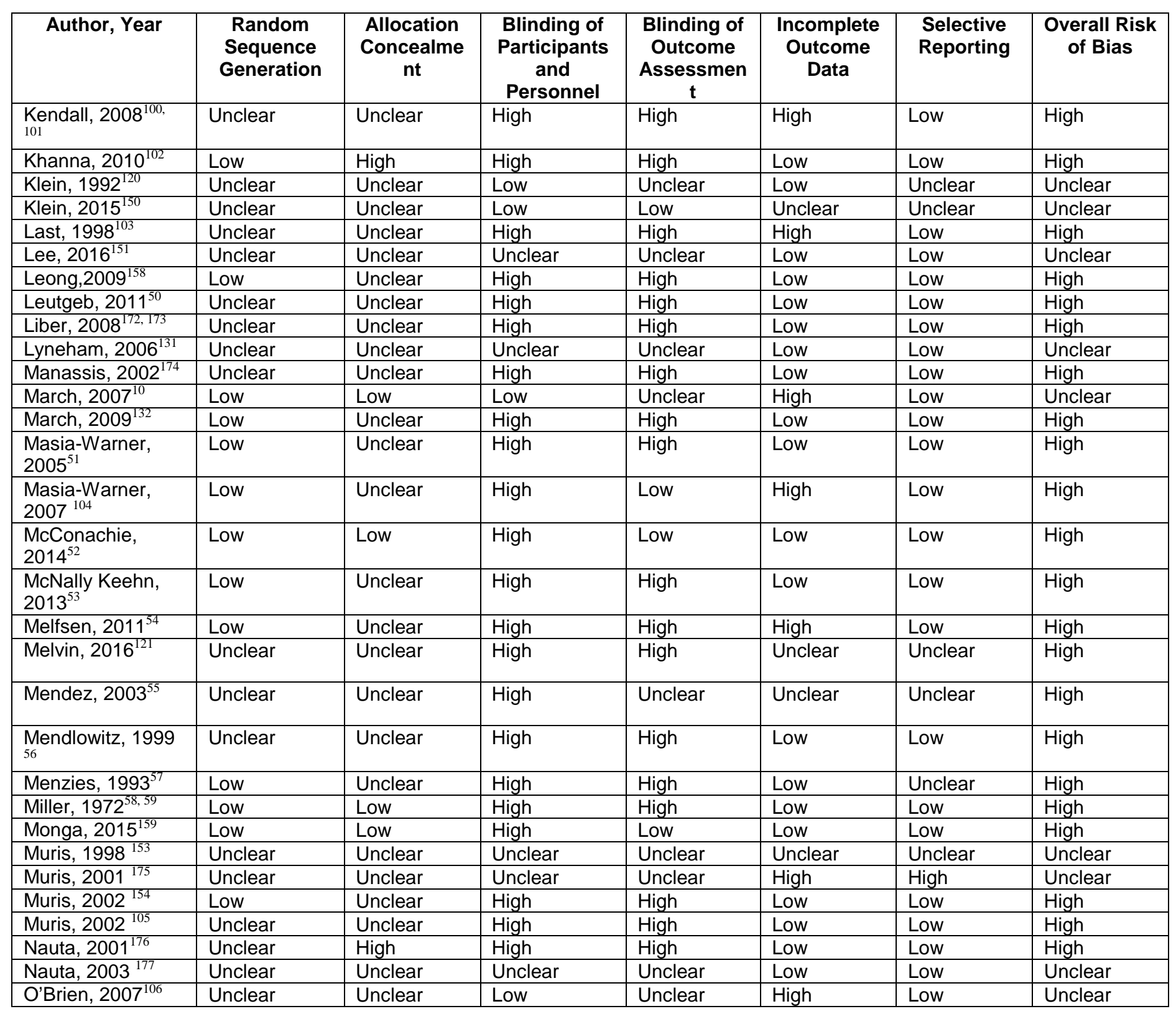




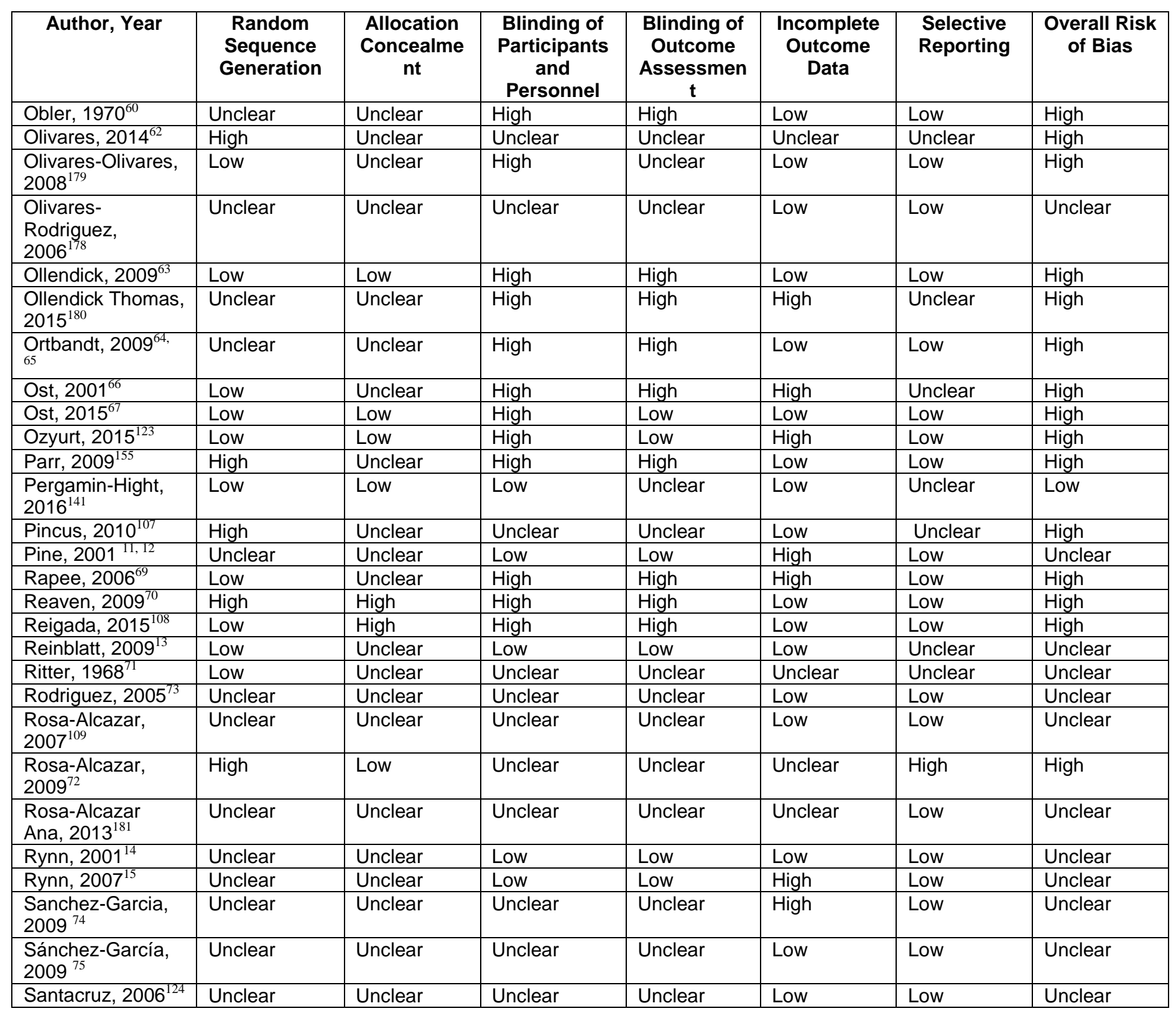




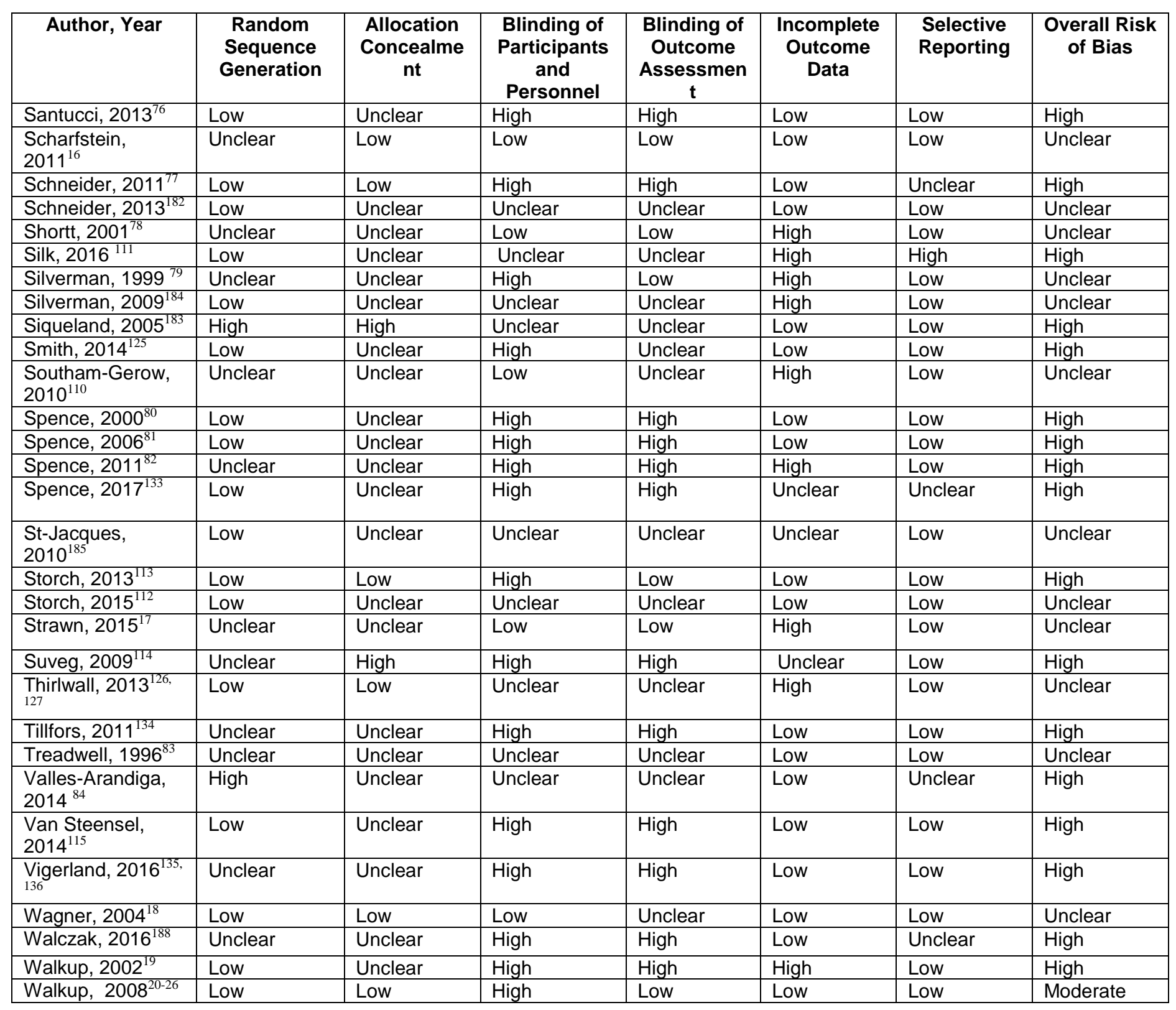




\begin{tabular}{|c|c|c|c|c|c|c|c|}
\hline Author, Year & $\begin{array}{l}\text { Random } \\
\text { Sequence } \\
\text { Generation }\end{array}$ & $\begin{array}{c}\text { Allocation } \\
\text { Concealme } \\
\text { nt }\end{array}$ & $\begin{array}{l}\text { Blinding of } \\
\text { Participants } \\
\text { and } \\
\text { Personnel }\end{array}$ & $\begin{array}{c}\text { Blinding of } \\
\text { Outcome } \\
\text { Assessmen } \\
t\end{array}$ & $\begin{array}{c}\text { Incomplete } \\
\text { Outcome } \\
\text { Data }\end{array}$ & $\begin{array}{l}\text { Selective } \\
\text { Reporting }\end{array}$ & $\begin{array}{c}\text { Overall Risk } \\
\text { of Bias }\end{array}$ \\
\hline Warner, $2016^{116}$ & Low & Unclear & Low & Low & Low & Low & Low \\
\hline Waters, $2009^{86}$ & Low & Unclear & High & High & High & Low & High \\
\hline Waters, $2013^{160}$ & Low & Unclear & Low & Low & High & Low & Unclear \\
\hline $\begin{array}{l}\text { Wergeland, } \\
2014^{88,89}\end{array}$ & Low & Unclear & High & Unclear & Low & Low & High \\
\hline White, $2013^{90}$ & Low & Unclear & High & Unclear & Unclear & Low & High \\
\hline Whiteside, $2015^{186}$ & Low & Unclear & Unclear & Unclear & High & Low & Unclear \\
\hline Wood, $2006^{187}$ & Low & Low & High & High & Low & Low & High \\
\hline Wood, $2009^{91}$ & Low & Low & Low & Unclear & Low & Unclear & Unclear \\
\hline
\end{tabular}

Low: low risk of bias; Moderate: moderate risk of bias; High: high risk of bias; Unclear: unclear risk of bias 
Table F.2. Risk of bias for non-randomized comparative studies (Newcastle-Ottawa Quality Assessment Scale) ${ }^{208}$

\begin{tabular}{|l|l|l|l|l|l|l|l|}
\hline \multicolumn{1}{|c|}{$\begin{array}{c}\text { Author, } \\
\text { Year }\end{array}$} & $\begin{array}{l}\text { Representative } \\
\text { ness of the } \\
\text { Population }\end{array}$ & $\begin{array}{c}\text { Selection } \\
\text { of the } \\
\text { Cohort }\end{array}$ & $\begin{array}{c}\text { Ascertainm } \\
\text { ent of } \\
\text { Exposure }\end{array}$ & $\begin{array}{c}\text { Ascertain } \\
\text { ment of } \\
\text { Outcome }\end{array}$ & $\begin{array}{c}\text { Adequacy } \\
\text { of Follow } \\
\text { Up }\end{array}$ & $\begin{array}{c}\text { Possible } \\
\text { Conflicts } \\
\text { of } \\
\text { Interest }\end{array}$ & $\begin{array}{c}\text { Overall Risk } \\
\text { of Bias }\end{array}$ \\
\hline $\begin{array}{l}\text { Chase, } \\
2012^{164}\end{array}$ & Moderate & High & Low & High & Low & Unclear & High \\
\hline $\begin{array}{l}\text { Eichstedt, } \\
2011^{119}\end{array}$ & Low & Low & Low & High & High & Low & High \\
\hline $\begin{array}{l}\text { Ishikawa, } \\
2012^{171}\end{array}$ & Moderate & Unclear & Low & High & Low & Low & High \\
\hline $\begin{array}{l}\text { Olivares, } \\
2002^{61}\end{array}$ & Moderate & Low & Low & High & Low & Unclear & High \\
\hline $\begin{array}{l}\text { Rapee, } \\
2000^{68}\end{array}$ & Moderate & Low & Low & High & Low & Low & High \\
\hline $\begin{array}{l}\text { van } \\
\text { Steensel, } \\
2015^{55}\end{array}$ & High & High & Low & Low & Moderate & Unclear & Moderate \\
\hline $\begin{array}{l}\text { Yen, } \\
2014^{117}\end{array}$ & Moderate & Low & Low & Low & Unclear & Unclear & Moderate \\
\hline
\end{tabular}

Low: low risk of bias; Moderate: moderate risk of bias; High: high risk of bias; Unclear: unclear risk of bias 


\section{Appendix G. Subgroup Analysis}

Table G.1. Subgroup analysis - age

\begin{tabular}{|c|c|c|c|c|}
\hline Subgroup & Comparison & Outcome & Subgroup Variable & Conclusion \\
\hline \multirow[t]{8}{*}{ Age } & \multirow[t]{2}{*}{$\begin{array}{l}\text { CBT vs. attention control or treatment } \\
\text { as usual }\end{array}$} & \multirow[t]{2}{*}{ Primary anxiety, child report } & $7-12$ years & $\begin{array}{l}\text { SMD: }-1.05 ; 95 \% \mathrm{Cl}:-1.99 \text { to }-0.11 ; I^{2}= \\
\text { N/A }\end{array}$ \\
\hline & & & 13-18 years & $\begin{array}{l}\text { SMD: }-1.04 ; 95 \% \mathrm{Cl}:-1.65 \text { to }-0.42 ; I^{2}= \\
60.7 \%{ }^{94,104}\end{array}$ \\
\hline & \multirow[t]{6}{*}{ CBT vs. waitlisting or no treatment } & \multirow[t]{2}{*}{ Primary anxiety, clinician report } & $7-12$ years & $\begin{array}{l}\text { SMD: }-0.82 ; 95 \% \mathrm{Cl}:-1.34 \text { to }-0.30 ; \mathrm{I}^{2}= \\
58.9 \%{ }^{38,41}\end{array}$ \\
\hline & & & $13-18$ years & $\begin{array}{l}\text { SMD: }-1.19 ; 95 \% \mathrm{Cl}:-1.87 \text { to }-0.52 ; I^{2}= \\
0.0 \%{ }^{31,61}\end{array}$ \\
\hline & & \multirow[t]{2}{*}{ Primary anxiety, child report } & $7-12$ years & $\begin{array}{l}\text { SMD: }-0.37 ; 95 \% \mathrm{Cl}:-1.17 \text { to } 0.43 ; \mathrm{I}^{2}= \\
0.0 \%{ }^{38,41,56}\end{array}$ \\
\hline & & & 13-18 years & $\begin{array}{l}\text { SMD: }-1.22 ; 95 \% \mathrm{Cl}:-1.89 \text { to }-0.55 ; \mathrm{I}^{2}= \\
0.0 \%{ }^{31,61}\end{array}$ \\
\hline & & \multirow[t]{2}{*}{ Function } & $7-12$ years & $\begin{array}{l}\text { SMD: }-0.48 ; 95 \% \mathrm{Cl}:-1.00 \text { to } 0.04 ; I^{2}= \\
88.7 \% 38,41\end{array}$ \\
\hline & & & $13-18$ years & $\begin{array}{l}\text { SMD: }-1.65 ; 95 \% \mathrm{Cl}:-2.50 \text { to }-0.80 ; I^{2}= \\
\text { N/A }^{61}\end{array}$ \\
\hline
\end{tabular}

CBT: cognitive behavioral therapy, CI: confidence interval, N/A: not applicable, SMD: standardized mean difference 
Table G.2. Subgroup analysis - comorbidity

\begin{tabular}{|c|c|c|c|c|}
\hline Subgroup & Comparison & Outcome & $\begin{array}{l}\text { Subgroup } \\
\text { Variable }\end{array}$ & Conclusion \\
\hline \multirow[t]{20}{*}{ Comorbidity } & \multirow[t]{2}{*}{$\begin{array}{l}\text { CBT vs. attention control or treatment } \\
\text { as usual }\end{array}$} & \multirow[t]{2}{*}{ Primary anxiety, child report } & Comorbidity & $\begin{array}{l}\text { SMD: }-0.31 ; 95 \% \mathrm{Cl}:-0.84 \text { to } 0.23 ; \mathrm{I}^{2}= \\
\text { N/A }^{103}\end{array}$ \\
\hline & & & No comorbidity & $\begin{array}{l}\text { SMD: }-0.53 ; 95 \% \mathrm{Cl}:-1.49 \text { to } 0.44 ; I^{2}= \\
74.7 \%{ }^{99,102,104,116}\end{array}$ \\
\hline & \multirow[t]{4}{*}{ CBT vs. Pill Placebo } & \multirow[t]{2}{*}{ Function } & Comorbidity & $\begin{array}{l}\text { SMD: } 0.02 ; 95 \% \mathrm{Cl}:-0.59 \text { to } 0.63 ; I^{2}= \\
\text { N/A }\end{array}$ \\
\hline & & & No comorbidity & $\begin{array}{l}\text { SMD: }-0.60 ; 95 \% \mathrm{Cl}:-0.84 \text { to }-0.36 ; I^{2}= \\
90.5 \%{ }^{3,20-26}\end{array}$ \\
\hline & & \multirow[t]{2}{*}{ Secondary measure } & Comorbidity & $\begin{array}{l}\text { SMD: } 0.30 ; 95 \% \mathrm{Cl}:-0.32 \text { to } 0.91 ; I^{2}= \\
\text { N/A }\end{array}$ \\
\hline & & & No comorbidity & $\begin{array}{l}\text { SMD: }-1.02 ; 95 \% \mathrm{Cl}:-1.45 \text { to }-0.58 ; I^{2}= \\
\text { N/A }\end{array}$ \\
\hline & \multirow[t]{12}{*}{ CBT vs. waitlisting or no treatment } & \multirow[t]{2}{*}{ Primary anxiety, clinician report } & Comorbidity & $\begin{array}{l}\text { SMD: }-1.25 ; 95 \% \mathrm{Cl}:-1.79 \text { to }-0.70 ; I^{2}= \\
93.2 \%{ }^{90,91}\end{array}$ \\
\hline & & & No comorbidity & 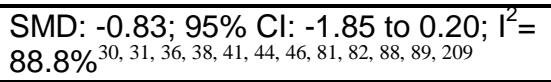 \\
\hline & & \multirow[t]{2}{*}{ Primary anxiety, child report } & Comorbidity & $\begin{array}{l}\text { SMD: }-0.85 ; 95 \% \mathrm{Cl}:-2.82 \text { to } 1.12 ; \mathrm{I}^{2}= \\
90.0 \%{ }^{34,53,70,91}\end{array}$ \\
\hline & & & No comorbidity & 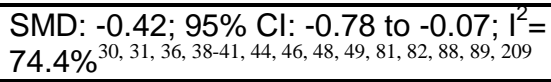 \\
\hline & & \multirow[t]{2}{*}{ Primary anxiety, parent report } & Comorbidity & $\begin{array}{l}\text { SMD: }-1.82 ; 95 \% \mathrm{Cl}:-4.44 \text { to } 0.80 ; I^{2}= \\
0.90 .5 \%{ }^{34,53,70,91}\end{array}$ \\
\hline & & & No comorbidity & $\begin{array}{l}\text { SMD: }-0.63 ; 95 \% \mathrm{Cl}:-1.15 \text { to }-0.12 ; I^{2}= \\
76.7 \%{ }^{30,38-40,46,48,49,81,82,88,89}\end{array}$ \\
\hline & & \multirow[t]{2}{*}{ Function } & Comorbidity & $\begin{array}{l}\text { SMD: }-0.62 ; 95 \% \mathrm{Cl}:-1.19 \text { to }-0.05 ; I^{2}= \\
75.8 \%{ }^{53,210}\end{array}$ \\
\hline & & & No comorbidity & $\begin{array}{l}\text { SMD: }-0.20 ; 95 \% \mathrm{Cl}:-1.07 \text { to } 0.67 ; I^{2}= \\
91.9 \%{ }^{30,38,41,44,46,82}\end{array}$ \\
\hline & & \multirow[t]{2}{*}{ Secondary measure } & Comorbidity & $\begin{array}{l}\text { SMD: }-0.33 ; 95 \% \mathrm{Cl}:-0.92 \text { to } 0.25 ; I^{2}= \\
\text { N/A }\end{array}$ \\
\hline & & & No comorbidity & $\begin{array}{l}\text { SMD: } 0.24 ; 95 \% \mathrm{Cl}:-0.54 \text { to } 1.02 ; \mathrm{I}^{2}= \\
94.5 \%{ }^{39,40,44,46,48,49,209}\end{array}$ \\
\hline & & \multirow[t]{2}{*}{ Response } & Comorbidity & $\begin{array}{l}\text { RR: } 12.69 ; 95 \% \mathrm{Cl}: 0.81 \text { to } 198.10 ; I^{2}= \\
\text { N/A }\end{array}$ \\
\hline & & & No comorbidity & $\begin{array}{l}\text { RR: } 10.16 ; 95 \% \mathrm{Cl}: 2.98 \text { to } 34.66 ; \\
\mathrm{l}^{2}=0.0 \%{ }^{39}, 40,46,49,209\end{array}$ \\
\hline & \multirow[t]{2}{*}{ Fluvoxamine vs. pill placebo } & \multirow[t]{2}{*}{ Primary anxiety, clinician report } & Comorbidity & $\begin{array}{l}\text { SMD: }-0.30 ; 95 \% \mathrm{Cl}:-1.11 \text { to } 0.51 ; I^{2}= \\
\text { N/A }\end{array}$ \\
\hline & & & No comorbidity & SMD: $-1.11 ; 95 \% \mathrm{Cl}:-1.49$ to $-0.74 ; \mathrm{I}^{2}=$ \\
\hline
\end{tabular}




\begin{tabular}{|c|c|c|c|c|}
\hline Subgroup & Comparison & Outcome & $\begin{array}{c}\text { Subgroup } \\
\text { Variable }\end{array}$ & \multicolumn{1}{c|}{ Conclusion } \\
\hline & & & & $\mathrm{N}^{11} \mathrm{~A}^{11}$ \\
\hline
\end{tabular}

CBT: cognitive behavioral therapy, CI: confidence interval, N/A: not applicable, RR: risk ratio, SMD: standardized mean difference 
Table G.3. Subgroup analysis - ADHD

\begin{tabular}{|c|c|c|c|c|}
\hline Subgroup & Comparison & Outcome & $\begin{array}{l}\text { Subgroup } \\
\text { Variable }\end{array}$ & Conclusion \\
\hline \multirow{2}{*}{ ADHD } & \multirow{2}{*}{ Fluvoxamine vs. pill placebo } & \multirow{2}{*}{$\begin{array}{l}\text { Primary anxiety, clinician } \\
\text { report }\end{array}$} & ADHD & $\begin{array}{l}\text { SMD: }-0.30 ; 95 \% \mathrm{Cl}:-1.11 \text { to } 0.51 ; I^{2}= \\
\text { N/A }^{1}\end{array}$ \\
\hline & & & No ADHD & $\begin{array}{l}\text { SMD: }-1.11 ; 95 \% \mathrm{Cl}:-1.49 \text { to }-0.74 ; \mathrm{I}^{2}= \\
\text { N/A } 11\end{array}$ \\
\hline
\end{tabular}

ADHD: attention deficit hyperactivity disorder, CI: confidence interval, N/A: not applicable, SMD: standardized mean difference 
Table G.4. Subgroup analysis - autism

\begin{tabular}{|c|c|c|c|c|}
\hline Subgroup & Comparison & Outcome & $\begin{array}{l}\text { Subgroup } \\
\text { Variable }\end{array}$ & Conclusion \\
\hline \multirow{10}{*}{ Autism } & \multirow{10}{*}{ CBT vs. waitlisting or no treatment } & \multirow{2}{*}{$\begin{array}{l}\text { Primary anxiety, clinician } \\
\text { report }\end{array}$} & Autism & $\begin{array}{l}\text { SMD: }-1.25 ; 95 \% \mathrm{Cl}:-1.79 \text { to }-0.70 ; \mathrm{I}^{2}= \\
93.2 \%{ }^{91,210}\end{array}$ \\
\hline & & & No Autism & $\begin{array}{l}\text { SMD: }-0.83 ; 95 \% \mathrm{Cl}:-1.85 \text { to } 0.20 ; \mathrm{I}^{2}= \\
88.8 \%{ }^{30,31,36,38,41,46,81,82,88}\end{array}$ \\
\hline & & \multirow{2}{*}{ Primary anxiety, child report } & Autism & $\begin{array}{l}\text { SMD: }-0.85 ; 95 \% \mathrm{Cl}:-2.82 \text { to } 1.12 ; I^{2}= \\
90.0 \%{ }^{34,53,70,91}\end{array}$ \\
\hline & & & No Autism & 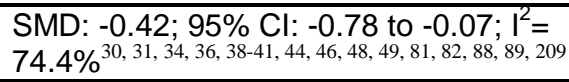 \\
\hline & & \multirow{2}{*}{ Primary anxiety, parent report } & Autism & $\begin{array}{l}\text { SMD: }-1.82 ; 95 \% \mathrm{Cl}:-4.44 \text { to } 0.80 ; I^{2}= \\
90.5 \%{ }^{34,53,70,91}\end{array}$ \\
\hline & & & No Autism & $\begin{array}{l}\text { SMD: }-0.62 ; 95 \% \mathrm{Cl}:-1.14 \text { to }-0.10 \\
I^{2}=74.4 \%{ }^{30,34,38-40,46,48,49,81,82,88,89}\end{array}$ \\
\hline & & \multirow{2}{*}{ Function } & Autism & $\begin{array}{l}\text { SMD: }-0.62 ; 95 \% \text { Cl: }-1.19 \text { to }-0.05 ; I^{2}= \\
75.8 \%{ }^{53,210}\end{array}$ \\
\hline & & & No Autism & $\begin{array}{l}\text { SMD: }-0.20 ; 95 \% \mathrm{Cl}:-1.07 \text { to } 0.67 ; \mathrm{I}^{2}= \\
91.9 \%^{30,38,41,44,46,82}\end{array}$ \\
\hline & & \multirow{2}{*}{ Response } & Autism & $\begin{array}{l}\text { RR: } 12.69 ; 95 \% \mathrm{Cl}: 0.81 \text { to } 198.10 ; I^{2}= \\
\text { N/A }\end{array}$ \\
\hline & & & No Autism & $\begin{array}{l}\text { RR: } 9.91 ; 95 \% \mathrm{Cl}: 2.25 \text { to } 43.65 ; I^{2}= \\
0.0 \%{ }^{39,40,46,49,209}\end{array}$ \\
\hline
\end{tabular}

CBT: cognitive behavioral therapy, CI: confidence interval, N/A: not applicable, RR: risk ratio, SMD: standardized mean difference 
Table G.5. Subgroup analysis - school refusal

\begin{tabular}{|c|c|c|c|c|}
\hline Subgroup & Comparison & Outcome & $\begin{array}{l}\text { Subgroup } \\
\text { Variable }\end{array}$ & Conclusion \\
\hline \multirow{4}{*}{ School Refusal } & \multirow{2}{*}{$\begin{array}{l}\text { CBT vs. attention control or treatment as } \\
\text { usual }\end{array}$} & \multirow{2}{*}{ Primary anxiety, child report } & School refusal & $\begin{array}{l}\text { SMD: }-0.31 ; 95 \% \mathrm{Cl}:-0.84 \text { to } 0.23 ; \mathrm{I}^{2}= \\
\text { N/A }^{103}\end{array}$ \\
\hline & & & No School refusal & $\begin{array}{l}\text { SMD: }-0.53 ; 95 \% \mathrm{Cl}:-1.49 \text { to } 0.44 ; \mathrm{I}^{2}= \\
74.7 \%{ }^{99,}, 102,104,116\end{array}$ \\
\hline & \multirow{2}{*}{ CBT vs. pill placebo } & \multirow{2}{*}{ Secondary measure } & School refusal & $\begin{array}{l}\text { SMD: } 0.30 ; 95 \% \mathrm{Cl}:-0.32 \text { to } 0.91 ; \mathrm{I}^{2}= \\
\text { N/A }\end{array}$ \\
\hline & & & No School refusal & $\begin{array}{l}\text { SMD: }-1.02 ; 95 \% \mathrm{Cl}:-1.45 \text { to }-0.58 ; \mathrm{I}^{2}= \\
\text { N/A }^{3}\end{array}$ \\
\hline
\end{tabular}

CBT: cognitive behavioral therapy, CI: confidence interval, N/A: not applicable, SMD: standardized mean difference 
Table G.6. Subgroup analysis - diagnosis

\begin{tabular}{|c|c|c|c|c|}
\hline Subgroup & Comparison & Outcome & Subgroup Variable & Conclusion \\
\hline \multirow{20}{*}{ Diagnosis } & \multirow{9}{*}{$\begin{array}{l}\text { CBT vs. attention control or yreatment } \\
\text { as usual }\end{array}$} & \multirow{3}{*}{ Primary anxiety, clinician report } & Panic Disorder & $\begin{array}{l}\text { SMD: }-0.97 ; 95 \% \mathrm{Cl}:-1.79 \text { to }-0.15 ; \\
\mathrm{I}^{2}=\mathrm{N} / \mathrm{A}^{107}\end{array}$ \\
\hline & & & $\begin{array}{l}\text { Social Anxiety } \\
\text { Disorder }\end{array}$ & $\begin{array}{l}\text { SMD: }-0.44 ; 95 \% \mathrm{Cl}:-1.95 \text { to } 1.08 ; I^{2}= \\
73.9 \%{ }^{72,}, 97,116\end{array}$ \\
\hline & & & Specific Phobias & $\begin{array}{l}\text { SMD: }-0.00 ; 95 \% \mathrm{Cl}:-0.36 \text { to } 0.35 ; \mathrm{I}^{2}= \\
87.8 \% 96,110\end{array}$ \\
\hline & & \multirow{2}{*}{ Primary anxiety, child report } & Panic Disorder & $\begin{array}{l}\text { SMD: }-0.24 ; 95 \% \mathrm{Cl}:-1.02 \text { to } 0.53 ; I^{2}= \\
\text { N/A } 107\end{array}$ \\
\hline & & & $\begin{array}{l}\text { Social Anxiety } \\
\text { Disorder }\end{array}$ & $\begin{array}{l}\text { SMD: }-0.70 ; 95 \% \mathrm{Cl}:-1.34 \text { to }-0.05 ; \\
\mathrm{I}^{2}=66.4 \%{ }^{72,} 99,104,109,116\end{array}$ \\
\hline & & \multirow{2}{*}{ Primary anxiety, parent report } & $\begin{array}{l}\text { Social Anxiety } \\
\text { Disorder }\end{array}$ & $\begin{array}{l}\text { SMD: }-0.65 ; 95 \% \mathrm{Cl}:-2.67 \text { to } 1.38 ; I^{2}= \\
90.3 \%{ }^{22}, 97,104,116\end{array}$ \\
\hline & & & Specific Phobias & $\begin{array}{l}\text { SMD: } 0.11 ; 95 \% \text { Cl: }-0.45 \text { to } 0.68 ; I^{2}= \\
\text { N/A }\end{array}$ \\
\hline & & \multirow{2}{*}{ Secondary measure } & Panic Disorder & $\begin{array}{l}\text { SMD: }-0.50 ; 95 \% \mathrm{Cl}:-1.28 \text { to } 0.29 ; I^{2}= \\
\text { N/A }\end{array}$ \\
\hline & & & $\begin{array}{l}\text { Social Anxiety } \\
\text { Disorder }\end{array}$ & $\begin{array}{l}\text { SMD: }-1.71 ; 95 \% \mathrm{Cl}:-2.46 \text { to }-0.96 ; \\
\mathrm{I}^{2}=\mathrm{N} / \mathrm{A}^{72}\end{array}$ \\
\hline & \multirow{11}{*}{ CBT vs. waitlisting or no treatment } & \multirow{4}{*}{ Primary anxiety, clinician report } & Generalized Anxiety & $\begin{array}{l}\text { SMD: }-2.42 ; 95 \% \mathrm{Cl}:-3.23 \text { to }-1.62 ; \\
\mathrm{I}^{2}=\mathrm{N} / \mathrm{A}^{46}\end{array}$ \\
\hline & & & Panic Disorder & $\begin{array}{l}\text { SMD: }-1.09 ; 95 \% \mathrm{Cl}:-1.71 \text { to }-0.47 ; \\
\mathrm{I}^{2}=\mathrm{N} / \mathrm{A}^{42}\end{array}$ \\
\hline & & & $\begin{array}{l}\text { Social Anxiety } \\
\text { Disorder }\end{array}$ & $\begin{array}{l}\text { SMD: }-1.59 ; 95 \% \text { Cl: }-2.38 \text { to }-0.80 ; \\
I^{2}=81.0 \%{ }^{31,38,41,45,51,54,61,67,74,80,178}\end{array}$ \\
\hline & & & Specific Phobias & $\begin{array}{l}\text { SMD: }-1.01 ; 95 \% \mathrm{Cl}:-1.35 \text { to }-0.68 ; \\
\mathrm{I}^{2}=83.2 \% 58,63\end{array}$ \\
\hline & & \multirow{4}{*}{ Primary anxiety, Child report } & Generalized Anxiety & $\begin{array}{l}\text { SMD: }-0.30 ; 95 \% \mathrm{Cl}:-0.91 \text { to } 0.31 ; I^{2}= \\
\text { N/A }\end{array}$ \\
\hline & & & Separation Anxiety & $\begin{array}{l}\text { SMD: }-0.29 ; 95 \% \mathrm{Cl}:-0.89 \text { to } 0.32 ; I^{2}= \\
\text { N/A }\end{array}$ \\
\hline & & & $\begin{array}{l}\text { Social Anxiety } \\
\text { Disorder }\end{array}$ & $\begin{array}{l}\text { SMD: }-1.21 ; 95 \% \mathrm{Cl}:-1.91 \text { to }-0.52 ; \\
\mathrm{I}^{2}=87.4 \%{ }^{31}, 38,41,45,51,54,61,62,67,74,80,178\end{array}$ \\
\hline & & & Specific Phobias & $\begin{array}{l}\text { SMD: }-0.08 ; 95 \% \text { Cl: }-0.93 \text { to } 0.77 ; I^{2}= \\
9.4 \%{ }^{50,63,66,124}\end{array}$ \\
\hline & & \multirow{3}{*}{ Primary anxiety, parent report } & Generalized Anxiety & $\begin{array}{l}\text { SMD: }-0.14 ; 95 \% \mathrm{Cl}:-0.75 \text { to } 0.47 ; I^{2}= \\
\text { N/A }\end{array}$ \\
\hline & & & Separation Anxiety & $\begin{array}{l}\text { SMD: }-1.27 ; 95 \% \mathrm{Cl}:-1.90 \text { to }-0.65 ; \\
\mathrm{I}^{2}=50.0 \%{ }^{27,77}\end{array}$ \\
\hline & & & $\begin{array}{l}\text { Social Anxiety } \\
\text { Disorder }\end{array}$ & $\begin{array}{l}\text { SMD: }-0.89 ; 95 \% \mathrm{Cl}:-1.66 \text { to }-0.13 ; \\
\mathrm{I}^{2}=72.9 \% 0^{38,51,62,65,67}\end{array}$ \\
\hline
\end{tabular}




\begin{tabular}{|c|c|c|c|c|}
\hline Subgroup & Comparison & Outcome & Subgroup Variable & Conclusion \\
\hline & & & Specific Phobias & $\begin{array}{l}\text { SMD: }-0.83 ; 95 \% \mathrm{Cl}:-1.45 \text { to }-0.21 ; \\
\mathrm{I}^{2}=\mathrm{N} / \mathrm{A}^{58}\end{array}$ \\
\hline & & \multirow{3}{*}{ Function } & Generalized Anxiety & $\begin{array}{l}\text { SMD: }-0.30 ; 95 \% \mathrm{Cl}:-0.91 \text { to } 0.31 ; I^{2}= \\
\text { N/A }=\end{array}$ \\
\hline & & & Separation Anxiety & $\begin{array}{l}\text { SMD: } 1.41 ; 95 \% \text { Cl: } 0.74 \text { to } 2.08 ; 12= \\
\text { N/A }\end{array}$ \\
\hline & & & $\begin{array}{l}\text { Social Anxiety } \\
\text { Disorder }\end{array}$ & $\begin{array}{l}\text { SMD: }-1.00 ; 95 \% \text { Cl: }-1.74 \text { to }-0.26 \\
1^{2}=83.7 \% \%^{38,41,51,54,61,62,67,178}\end{array}$ \\
\hline & & \multirow{3}{*}{ Secondary measure } & Generalized Anxiety & $\begin{array}{l}\text { SMD: }-0.38 ; 95 \% \mathrm{Cl}:-0.99 \text { to } 0.23 \\
\mathrm{I}^{2}=\mathrm{N} / \mathrm{A}^{46}\end{array}$ \\
\hline & & & $\begin{array}{l}\text { Social Anxiety } \\
\text { Disorder }\end{array}$ & $\begin{array}{l}\text { SMD: }-0.57 ; 95 \% \mathrm{Cl}:-1.53 \text { to } 0.38 ; I^{2}= \\
94.2 \%{ }^{61,62,74,178,209}\end{array}$ \\
\hline & & & Specific Phobias & $\begin{array}{l}\text { SMD: } 1.18 ; 95 \% \text { Cl: }-3.99 \text { to } 6.34 ; I^{2}= \\
93.8 \% \%^{50,63,66}\end{array}$ \\
\hline & & \multirow{2}{*}{ Social function } & Generalized Anxiety & $\begin{array}{l}\text { SMD: }-0.61 ; 95 \% \mathrm{Cl}:-1.24 \text { to } 0.01 ; I^{2}= \\
\text { N/A }^{46}=\end{array}$ \\
\hline & & & $\begin{array}{l}\text { Social Anxiety } \\
\text { Disorder }\end{array}$ & $\begin{array}{l}\text { SMD: } 0.15 ; 95 \% \mathrm{Cl}:-1.27 \text { to } 1.56 ; I^{2}= \\
90.6 \% \%^{38,41,61,80,178}\end{array}$ \\
\hline & & \multirow{2}{*}{ Remission } & Generalized Anxiety & $\begin{array}{l}\text { RR: } 7.67 ; 95 \% \mathrm{Cl}: 0.42 \text { to } 139.83 ; I^{2}= \\
N / A^{46}\end{array}$ \\
\hline & & & $\begin{array}{l}\text { Social Anxiety } \\
\text { Disorder }\end{array}$ & $\begin{array}{l}\text { RR: } 11.38 ; 95 \% \text { Cl: } 1.56 \text { to } 83.22 ; I^{2}= \\
0.0 \% 33,62\end{array}$ \\
\hline & & \multirow{3}{*}{ Response } & Generalized Anxiety & $\begin{array}{l}\text { RR: } 20.81 ; 95 \% \mathrm{Cl}: 1.29 \text { to } 335.97 ; \\
\mathrm{I}^{2}=\mathrm{N} / \mathrm{A}^{46}\end{array}$ \\
\hline & & & $\begin{array}{l}\text { Social Anxiety } \\
\text { Disorder }\end{array}$ & $\begin{array}{l}\text { RR: } 8.42 ; 95 \% \text { Cl: } 3.88 \text { to } 18.25 ; I^{2}= \\
0.0 \%{ }^{45,51,} 67,80,178\end{array}$ \\
\hline & & & Specific Phobias & $\begin{array}{l}\text { RR: } 22.67 ; 95 \% \mathrm{Cl}: 3.24 \text { to } 158.60 ; \\
\mathrm{I}^{2}=\mathrm{N} / \mathrm{A}^{63}\end{array}$ \\
\hline & \multirow{2}{*}{ Venlafaxine vs. pill placebo } & \multirow{2}{*}{ Primary anxiety, child report } & Generalized Anxiety & $\begin{array}{l}\text { SMD: }-0.52 ; 95 \% \text { Cl: }-0.84 \text { to }-0.19 ; \\
\mathrm{I}^{2}=\mathrm{N} / \mathrm{A}^{15}\end{array}$ \\
\hline & & & $\begin{array}{l}\text { Social Anxiety } \\
\text { Disorder }\end{array}$ & $\begin{array}{l}\text { SMD: }-0.47 ; 95 \% \mathrm{Cl}:-0.70 \text { to }-0.24 ; \\
\mathrm{I}^{2}=\mathrm{N} / \mathrm{A}^{10}\end{array}$ \\
\hline
\end{tabular}

CBT: cognitive behavioral therapy, CI: confidence interval, N/A: not applicable, RR: risk ratio, SMD: standardized mean difference 
Table G.7. Subgroup analysis - treatment settings

\begin{tabular}{|c|c|c|c|c|}
\hline Subgroup & Comparison & outcome & Subgroup Variable & Conclusion \\
\hline \multirow{19}{*}{$\begin{array}{l}\text { Treatment } \\
\text { Settings } \\
\text { (School, Mental } \\
\text { Health Clinic, } \\
\text { Outpatient } \\
\text { primary care) }\end{array}$} & \multirow{16}{*}{$\begin{array}{l}\text { CBT vs. attention control or treatment } \\
\text { as usual }\end{array}$} & \multirow{2}{*}{ Primary anxiety, clinician report } & Mental health clinic & $\begin{array}{l}\text { SMD: }-0.11 ; 95 \% \mathrm{Cl}:-0.55 \text { to } 0.33 ; I^{2}= \\
55.2 \%{ }^{96-98,101,106,110}\end{array}$ \\
\hline & & & School & $\begin{array}{l}\text { SMD: }-0.24 ; 95 \% \mathrm{Cl}:-2.46 \text { to } 1.98 ; I^{2}= \\
84.7 \%{ }^{72,} 95,116\end{array}$ \\
\hline & & \multirow{2}{*}{ Primary anxiety, child report } & Mental health clinic & 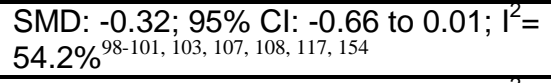 \\
\hline & & & School & $\begin{array}{l}\text { SMD: }-0.49 ; 95 \% \mathrm{Cl}:-1.16 \text { to } 0.17 ; I^{2}= \\
66.2 \%{ }^{34,72,95,109,116}\end{array}$ \\
\hline & & \multirow{2}{*}{ Primary anxiety, parent report } & Mental health clinic & $\begin{array}{l}\text { SMD: } 0.08 ; 95 \% \mathrm{Cl}:-0.20 \text { to } 0.37 ; \mathrm{I}^{2}= \\
0.0 \%{ }^{97,98,100,101,110,117}\end{array}$ \\
\hline & & & School & $\begin{array}{l}\text { SMD: }-0.68 ; 95 \% \mathrm{Cl}:-2.66 \text { to } 1.30 ; I^{2}= \\
89.6^{72,95,104,116}\end{array}$ \\
\hline & & \multirow{2}{*}{ Function } & Mental health clinic & $\begin{array}{l}\text { SMD: }-0.30 ; 95 \% \mathrm{Cl}:-1.26 \text { to } 0.66 ; I^{2}= \\
61.9 \%{ }^{99}, 101,114\end{array}$ \\
\hline & & & School & $\begin{array}{l}\text { SMD: }-1.18 ; 95 \% \mathrm{Cl}:-3.42 \text { to } 1.05 ; I^{2}= \\
79.2 \%{ }^{72,104,109}\end{array}$ \\
\hline & & \multirow{2}{*}{ Secondary measure } & Mental health clinic & $\begin{array}{l}\text { SMD: }-0.50 ; 95 \% \mathrm{Cl}:-1.28 \text { to } 0.29 ; I^{2}= \\
\text { N/A }^{100,101,107}\end{array}$ \\
\hline & & & School & $\begin{array}{l}\text { SMD: }-1.71 ; 95 \% \mathrm{Cl}:-2.46 \text { to }-0.96 ; \\
\mathrm{I}^{2}=\mathrm{N} / \mathrm{A}^{72,109}\end{array}$ \\
\hline & & \multirow{2}{*}{ Social function } & Mental health clinic & $\begin{array}{l}\text { SMD: }-0.36 ; 95 \% \mathrm{Cl}:-1.02 \text { to } 0.30 ; I^{2}= \\
15.7 \% 97,114,117\end{array}$ \\
\hline & & & School & $\begin{array}{l}\text { SMD: }-0.34 ; 95 \% \mathrm{Cl}:-0.72 \text { to } 0.03 ; I^{2}= \\
82.6 \% 109,116,211\end{array}$ \\
\hline & & \multirow{2}{*}{ Remission } & Mental health clinic & $\begin{array}{l}\text { RR: } 1.53 ; 95 \% \mathrm{Cl}: 1.11 \text { to } 2.11 ; I^{2}= \\
0.0 \%{ }^{98,111}\end{array}$ \\
\hline & & & School & $\begin{array}{l}\text { RR: } 2.68 ; 95 \% \text { Cl: } 0.11 \text { to } 64.50 ; I^{2}= \\
64.3 \%^{72,95,116}\end{array}$ \\
\hline & & \multirow{2}{*}{ Response } & Mental health clinic & $\begin{array}{l}\text { RR: } 1.50 ; 95 \% \text { Cl: } 1.07 \text { to } 2.11 ; I^{2}= \\
0.0 \%{ }^{98,100,101}\end{array}$ \\
\hline & & & School & $\begin{array}{l}\text { RR: } 1.95 ; 95 \% \text { Cl: } 0.28 \text { to } 13.39 ; I^{2}= \\
79.1 \%{ }^{95,104,116}\end{array}$ \\
\hline & \multirow{3}{*}{ CBT vs. Waitlisting or No Treatment } & \multirow[t]{2}{*}{ Primary anxiety, clinician report } & Mental health clinic & 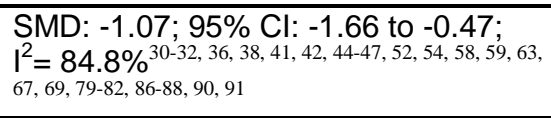 \\
\hline & & & School & $\begin{array}{l}\text { SMD: }-1.97 ; 95 \% \mathrm{Cl}:-3.26 \text { to }-0.68 ; \\
\mathrm{I}^{2}=89.5 \%{ }^{35,51,61,74,151,178}\end{array}$ \\
\hline & & Primary anxiety, child report & Mental health clinic & 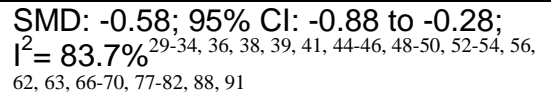 \\
\hline
\end{tabular}




\begin{tabular}{|c|c|c|c|c|}
\hline Subgroup & Comparison & outcome & Subgroup Variable & Conclusion \\
\hline & & & School & $\begin{array}{l}\text { SMD: }-1.32 ; 95 \% \text { Cl: }-2.43 \text { to }-0.21 ; \\
\mathrm{I}^{2}=91.4 \%{ }^{35,61,74,151,178}\end{array}$ \\
\hline & & \multirow{2}{*}{ Primary anxiety, parent report } & Mental health clinic & $\begin{array}{l}\text { SMD: }-0.86 ; 95 \% \mathrm{Cl}:-1.23 \text { to }-0.48 \\
\mathrm{I}^{2}=81.1 \%{ }^{27}, 29,30,34,38,39,46-49,52,53,58,59 \\
62,65,67,69,70,77,79,81,82,88,91\end{array}$ \\
\hline & & & School & $\begin{array}{l}\text { SMD: }-0.50 ; 95 \% \text { Cl: }-1.24 \text { to } 0.24 ; I^{2}= \\
0.0 \%{ }^{35,51,151}\end{array}$ \\
\hline & & \multirow{2}{*}{ Function } & Mental health clinic & 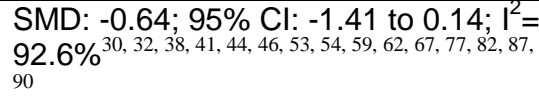 \\
\hline & & & School & $\begin{array}{l}\text { SMD: }-1.27 ; 95 \% \text { Cl: }-3.09 \text { to } 0.55 ; I^{2}= \\
74.2 \%{ }^{51,61,178}\end{array}$ \\
\hline & & \multirow{2}{*}{ Secondary measure } & Mental health clinic & $\begin{array}{l}\text { SMD: } 0.05 ; 95 \% \mathrm{Cl}:-0.44 \text { to } 0.55 ; I^{2}= \\
93.5 \% 32,34,39,44,46-50,56,62,63,66,69,80\end{array}$ \\
\hline & & & School & $\begin{array}{l}\text { SMD: }-0.14 ; 95 \% \mathrm{Cl}:-1.87 \text { to } 1.59 ; \\
\mathrm{I}^{2}=94.7 \% 61,74,178\end{array}$ \\
\hline & & \multirow{2}{*}{ Social function } & Mental Health Clinic & $\begin{array}{l}\text { SMD: }-0.07 ; 95 \% \mathrm{Cl}:-0.69 \text { to } 0.55 ; \\
\mathrm{I} 2=74.8 \%{ }^{38,39,41,44,46,48,80}\end{array}$ \\
\hline & & & School & $\begin{array}{l}\text { SMD: } 0.10 ; 95 \% \mathrm{Cl}:-4.66 \text { to } 4.86 ; \mathrm{I}^{2}= \\
95.1 \%{ }^{61,178}\end{array}$ \\
\hline & & \multirow{2}{*}{ Remission } & Mental health clinic & $\begin{array}{l}\text { RR: } 2.78 ; 95 \% \text { Cl: } 0.24 \text { to } 31.98 ; I^{2}= \\
76.1 \%^{32,46,62,86}\end{array}$ \\
\hline & & & School & $\begin{array}{l}\text { RR: } 5.74 ; 95 \% \text { Cl: } 2.17 \text { to } 15.20 ; I^{2}= \\
0.0 \%{ }^{35,46}\end{array}$ \\
\hline & & \multirow{2}{*}{ Response } & Mental health clinic & $\begin{array}{l}\text { RR: } 3.60 ; 95 \% \mathrm{Cl}: 1.77 \text { to } 7.32 ; I^{2}= \\
83.0 \%{ }^{45-49,52,53,63,67,79,80,86,87}\end{array}$ \\
\hline & & & School & $\begin{array}{l}\text { RR: } 14.45 ; 95 \% \mathrm{Cl}: 2.94 \text { to } 71.01 ; I^{2}= \\
0.0 \%{ }^{51,178}\end{array}$ \\
\hline & \multirow{2}{*}{ Fluvoxamine vs. pill placebo } & \multirow{2}{*}{ Primary anxiety, clinician report } & Mental health clinic & $\begin{array}{l}\text { SMD: }-0.30 ; 95 \% \text { Cl: }-1.11 \text { to } 0.51 ; I^{2}= \\
\text { N/A }\end{array}$ \\
\hline & & & $\begin{array}{l}\text { Outpatient primary } \\
\text { care }\end{array}$ & $\begin{array}{l}\text { SMD: }-1.11 ; 95 \% \mathrm{Cl}:-1.49 \text { to }-0.74 ; \\
\mathrm{I}^{2}=\mathrm{N} / \mathrm{A}^{11}\end{array}$ \\
\hline
\end{tabular}

CBT: cognitive behavioral therapy, CI: confidence interval, N/A: not applicable, RR: risk ratio, SMD: standardized mean difference 
Table G.8. Subgroup analysis - follow up less than 6 months

\begin{tabular}{|c|c|c|c|c|}
\hline Subgroup & Comparison & Outcome & Subgroup Variable & Conclusion \\
\hline \multirow{18}{*}{$\begin{array}{l}\text { Follow up (less } \\
\text { than } 6 \text { months) }\end{array}$} & Benzodiazepine vs. pill placebo & Primary anxiety, clinician report & Less than 6 months & $\begin{array}{l}\text { SMD: }-0.40 ; 95 \% \mathrm{Cl}:-1.43 \text { to } 0.63 ; \\
\mathrm{I}^{2}=\mathrm{N} / \mathrm{A}^{9}\end{array}$ \\
\hline & \multirow{7}{*}{$\begin{array}{l}\text { CBT vs. attention control or treatment } \\
\text { as usual }\end{array}$} & Primary anxiety, clinician report & Less than 6 months & $\begin{array}{l}\text { SMD: }-0.11 ; 95 \% \mathrm{Cl}:-0.52 \text { to } 0.30 ; \\
\mathrm{I}^{2}=49.9 \%{ }^{95-98,101,106,116}\end{array}$ \\
\hline & & Primary anxiety, child report & Less than 6 months & $\begin{array}{l}\text { SMD: }-0.41 ; 95 \% \mathrm{Cl}:-0.88 \text { to } 0.07 \\
\left.\right|^{2}=54.2 \%{ }^{95}, 98,101,104,108,109,116\end{array}$ \\
\hline & & Primary anxiety, parent report & Less than 6 months & $\begin{array}{l}\text { SMD: } 0.16 ; 95 \% \mathrm{Cl}:-0.53 \text { to } 0.85 \\
\mathrm{I}^{2}=76.7 \% \%^{95,97,98,106,116}\end{array}$ \\
\hline & & Function & Less than 6 months & $\begin{array}{l}\text { SMD: }-0.87 ; 95 \% \mathrm{Cl}:-2.98 \text { to } 1.23 ; \\
\mathrm{I}^{2}=79.5 \%{ }^{101}, 109,116\end{array}$ \\
\hline & & Social Function & Less than 6 months & $\begin{array}{l}\text { SMD: } 0.62 ; 95 \% \mathrm{Cl}:-1.03 \text { to } 2.26 ; \\
\mathrm{I}^{2}=82.0 \%{ }^{97,109,116}\end{array}$ \\
\hline & & Remission & Less than 6 months & $\begin{array}{l}\text { RR: } 1.52 ; 95 \% \mathrm{Cl}: 0.22 \text { to } 10.48 ; \\
\mathrm{I}^{2}=74.9 \%{ }^{55,98,116}\end{array}$ \\
\hline & & Response & Less than 6 months & $\begin{array}{l}\text { RR:1.70; 95\% Cl: } 0.34 \text { to } 8.53 ; \\
\mathrm{I}^{2}=77.9 \%{ }^{95,98,116}\end{array}$ \\
\hline & \multirow{7}{*}{ CBT vs. waitlisting or no treatment } & Primary anxiety, clinician report & Less than 6 months & $\begin{array}{l}\text { SMD: }-1.02 ; 95 \% \mathrm{Cl}:-1.65 \text { to }-0.38 ; \\
\mathrm{I}^{2}=86.1 \%^{32,41,46,58,59,63,72,74,76,151,178}\end{array}$ \\
\hline & & Primary anxiety, child report & Less than 6 months & $\begin{array}{l}\text { SMD: }-1.43 ; 95 \% \mathrm{Cl}:-2.72 \text { to }-0.14 ; \\
\mathrm{I}^{2}=94.4 \%{ }^{29,32,41,46,63,72,74,76,151,178}\end{array}$ \\
\hline & & Primary anxiety, parent report & Less than 6 months & $\begin{array}{l}\text { SMD: }-0.93 ; 95 \% \mathrm{Cl}:-2.98 \text { to } 1.13 ; \\
\mathrm{I}^{2}=85.1 \%{ }^{29,46,58,59,72,76,151}\end{array}$ \\
\hline & & Function & Less than 6 months & $\begin{array}{l}\text { SMD: }-0.52,95 \% \mathrm{Cl}:-1.28 \text { to } 0.23 ; \\
1^{2}=73.0 \%{ }^{32,41,59,72,76,178}\end{array}$ \\
\hline & & Social function & Less than 6 months & $\begin{array}{l}\text { SMD: }-1.60 ; 95 \% \mathrm{Cl}:-11.13 \text { to } 7.92 ; \\
\mathrm{I}^{2}=96.1 \%{ }^{41,46,84,178}\end{array}$ \\
\hline & & Remission & Less than 6 months & $\begin{array}{l}\text { RR: } 4.38 ; 95 \% \text { Cl: } 0.03 \text { to } 598.20 ; \\
\mathrm{I}^{2}=78.2 \%{ }^{32,46,72}\end{array}$ \\
\hline & & Response & Less than 6 months & $\begin{array}{l}\text { RR: } 1.50 ; 95 \% \mathrm{Cl}: 0.71 \text { to } 3.17 ; \\
\mathrm{I}^{2}=\mathrm{N} / \mathrm{A}^{178}\end{array}$ \\
\hline & Clonazepam vs. pill placebo & Primary anxiety, clinician report & Less than 6 months & $\begin{array}{l}\text { SMD: }-0.40 ; 95 \% \mathrm{Cl}:-1.43 \text { to } 0.63 ; \\
\mathrm{I}^{2}=\mathrm{N} / \mathrm{A}^{9}\end{array}$ \\
\hline & \multirow{2}{*}{ Fluoxetine plus CBT vs. CBT } & Function & Less than 6 months & $\begin{array}{l}\text { SMD: }-0.53 ; 95 \% \mathrm{Cl}:-0.10 \text { to } 1.15 ; \\
\mathrm{I}^{2}=\mathrm{N} / \mathrm{A}^{121}\end{array}$ \\
\hline & & Secondary aeasure & Less than 6 months & $\begin{array}{l}\text { SMD: } 0.39 ; 95 \% \mathrm{Cl}:-0.23 \text { to } 1.01 ; \\
\mathrm{I}^{2}=\mathrm{N} / \mathrm{A}^{121}\end{array}$ \\
\hline
\end{tabular}

CBT: cognitive behavioral therapy, CI: confidence interval, N/A: not applicable, RR: risk ratio, SMD: standardized mean difference 
Table G.9. Subgroup analysis - follow up longer than 6 months

\begin{tabular}{|c|c|c|c|c|}
\hline Subgroup & Comparison & Outcome & Subgroup Variable & Conclusion \\
\hline \multirow{13}{*}{$\begin{array}{l}\text { Follow up } \\
\text { (longer than } 6 \\
\text { months) }\end{array}$} & \multirow{6}{*}{$\begin{array}{l}\text { CBT vs. attention control or treatment } \\
\text { as usual }\end{array}$} & Primary anxiety, clinician report & Longer than 6 months & $\begin{array}{l}\text { SMD: }-0.06 ; 95 \% \mathrm{Cl}:-0.50 \text { to } 0.38 ; \\
\mathrm{I}^{2}=\mathrm{N} / \mathrm{A}^{96}\end{array}$ \\
\hline & & Primary anxiety, child report & Longer than 6 months & $\begin{array}{l}\text { SMD: }-0.20 ; 95 \% \mathrm{Cl}:-0.48 \text { to }-0.09 ; \\
\mathrm{I}^{2}=83.5 \%{ }^{99-101}\end{array}$ \\
\hline & & Function & Longer than 6 months & $\begin{array}{l}\text { SMD: }-0.31 ; 95 \% \mathrm{Cl}:-0.59 \text { to }-0.02 \\
\mathrm{I}^{2}=89.7 \%{ }^{99,114}\end{array}$ \\
\hline & & Social function & Longer than 6 months & $\begin{array}{l}\text { SMD: }-0.09 ; 95 \% \mathrm{Cl}:-0.47 \text { to } 0.29 \\
\mathrm{I}^{2}=\mathrm{N} / \mathrm{A}^{114}\end{array}$ \\
\hline & & Remission & Longer than 6 months & $\begin{array}{l}\text { RR: } 1.26 ; 95 \% \text { Cl: } 0.99 \text { to } 1.60 ; \\
I^{2}=N / A^{111}\end{array}$ \\
\hline & & Response & Longer than 6 months & $\begin{array}{l}\text { RR: } 1.40 ; 95 \% \text { Cl: } 0.97 \text { to } 2.04 ; \\
I^{2}=N / A^{100,101}\end{array}$ \\
\hline & \multirow[t]{5}{*}{ CBT vs. waitlisting or no treatment } & Primary anxiety, clinician report & Longer than 6 months & $\begin{array}{l}\text { SMD: }-0.59 ; 95 \% \mathrm{Cl}:-1.31 \text { to }-0.13 ; \\
\mathrm{I}^{2}=0.0 \%{ }^{32,72,151}\end{array}$ \\
\hline & & Primary anxiety, child report & Longer than 6 months & $\begin{array}{l}\text { SMD: }-0.08 ; 95 \% \mathrm{Cl}:-0.56 \text { to } 0.39 ; \\
\mathrm{I}^{2}=0.0 \%{ }^{32,45,72,151}\end{array}$ \\
\hline & & Primary anxiety, parent report & Longer than 6 months & $\begin{array}{l}\text { SMD: }-1.55 ; 95 \% \mathrm{Cl}:-8.38 \text { to } 5.28 \\
\mathrm{I}^{2}=96.1 \%{ }^{59,72,151}\end{array}$ \\
\hline & & Function & Longer than 6 months & $\begin{array}{l}\text { SMD: }-0.36,95 \% \mathrm{Cl} ;-2.39 \text { to } 1.67 ; \\
\mathrm{I}^{2}=85.1 \%^{32,59,72}\end{array}$ \\
\hline & & Remission & Longer than 6 months & $\begin{array}{l}\text { RR: } 0.71 ; 95 \% \text { Cl: } 0.57 \text { to } 1.03 ; \\
I^{2}=N / A^{32}\end{array}$ \\
\hline & \multirow{2}{*}{ Fluoxetine plus CBT vs. CBT } & Function & Longer than 6 months & $\begin{array}{l}\text { SMD: }-0.64 ; 95 \% \mathrm{Cl}:-1.26 \text { to }-0.01 ; \\
\mathrm{I}^{2}=\mathrm{N} / \mathrm{A}^{121}\end{array}$ \\
\hline & & Secondary measure & Longer than 6 months & $\begin{array}{l}\text { SMD: } 0.65 ; 95 \% \mathrm{Cl}: 0.02 \text { to } 1.27 ; \\
\mathrm{I}^{2}=\mathrm{N} / \mathrm{A}^{121}\end{array}$ \\
\hline
\end{tabular}

CBT: cognitive behavioral therapy, CI: confidence interval, N/A: not applicable, RR: risk ratio, SMD: standardized mean difference 
Table G.10. Subgroup analysis - therapy components

\begin{tabular}{|c|c|c|c|c|}
\hline Subgroup & Comparison & Outcome & Subgroup Variable & Conclusion \\
\hline \multirow{7}{*}{$\begin{array}{l}\text { CBT with } \\
\text { cognitive } \\
\text { strategies }\end{array}$} & \multirow{7}{*}{$\begin{array}{l}\text { CBT without cognitive strategies vs. } \\
\text { CBT with cognitive strategies }\end{array}$} & Primary anxiety, clinician report & $\begin{array}{l}\text { No cognitive vs. } \\
\text { cognitive }\end{array}$ & $\begin{array}{l}\text { SMD: }-0.30 ; 95 \% \text { Cl: }-1.44 \text { to } 0.83 ; \\
I^{2}=41.3 \%{ }^{74,181,186}\end{array}$ \\
\hline & & Primary anxiety, child report & $\begin{array}{l}\text { No cognitive vs. } \\
\text { cognitive }\end{array}$ & $\begin{array}{l}\text { SMD: } 0.09 ; 95 \% \text { Cl: }-2.25 \text { to } 2.44 ; I^{2}= \\
87.0 \%{ }^{74,181,186}\end{array}$ \\
\hline & & Primary anxiety, parent report & $\begin{array}{l}\text { No cognitive vs. } \\
\text { cognitive }\end{array}$ & $\begin{array}{l}\text { SMD: }-1.29 ; 95 \% \mathrm{Cl}:-2.46 \text { to }-0.13 ; \mathrm{I}^{2}= \\
\text { N/A }\end{array}$ \\
\hline & & Function & $\begin{array}{l}\text { No cognitive vs. } \\
\text { cognitive }\end{array}$ & $\begin{array}{l}\text { SMD: } 0.09 ; 95 \% \text { Cl: }-0.42 \text { to } 0.59 ; I^{2}= \\
82.4 \% 181,186\end{array}$ \\
\hline & & Secondary measure & $\begin{array}{l}\text { No cognitive vs. } \\
\text { cognitive }\end{array}$ & $\begin{array}{l}\text { SMD: }-0.27 ; 95 \% \mathrm{Cl}:-0.83 \text { to } 0.29 ; I^{2}= \\
\text { N/A }\end{array}$ \\
\hline & & Social function & $\begin{array}{l}\text { No cognitive vs. } \\
\text { cognitive }\end{array}$ & $\begin{array}{l}\text { SMD: }-0.36 ; 95 \% \mathrm{Cl}:-0.92 \text { to } 0.20 ; I^{2}= \\
\text { N/A }\end{array}$ \\
\hline & & Response & $\begin{array}{l}\text { No cognitive vs. } \\
\text { cognitive }\end{array}$ & $\begin{array}{l}\text { RR: } 0.62 ; 95 \% \mathrm{Cl}: 0.31 \text { to } 1.22 ; I^{2}= \\
\text { N/A }\end{array}$ \\
\hline \multirow{3}{*}{$\begin{array}{l}\text { CBT with } \\
\text { exposure } \\
\text { sessions }\end{array}$} & \multirow{3}{*}{$\begin{array}{l}\text { CBT without exposure sessions vs. } \\
\text { CBT with exposure sessions }\end{array}$} & Primary anxiety, clinician report & $\begin{array}{l}\text { No exposure vs. } \\
\text { exposure }\end{array}$ & $\begin{array}{l}\text { SMD: } 0.13 ; 95 \% \text { Cl: }-0.74 \text { to } 1.37 ; I^{2}= \\
\text { N/A }\end{array}$ \\
\hline & & Primary anxiety, child report & $\begin{array}{l}\text { No exposure vs. } \\
\text { exposure }\end{array}$ & $\begin{array}{l}\text { SMD: } 0.62 ; 95 \% \text { Cl: }-0.46 \text { to } 1.70 ; I^{2}= \\
\text { N/A }\end{array}$ \\
\hline & & Primary anxiety, parent report & $\begin{array}{l}\text { No exposure vs. } \\
\text { exposure }\end{array}$ & $\begin{array}{l}\text { SMD: } 1.29 ; 95 \% \mathrm{Cl}: 0.13 \text { to } 2.46 ; I^{2}= \\
\text { N/A }\end{array}$ \\
\hline \multirow{7}{*}{$\begin{array}{l}\text { CBT with } \\
\text { relaxation } \\
\text { strategies }\end{array}$} & \multirow{7}{*}{$\begin{array}{l}\text { CBT without relaxation strategies vs. } \\
\text { CBT with relaxation strategies }\end{array}$} & Primary anxiety, clinician report & $\begin{array}{l}\text { No relaxation vs. } \\
\text { relaxation }\end{array}$ & $\begin{array}{l}\text { SMD: }-0.15 ; 95 \% \mathrm{Cl}:-0.64 \text { to } 0.33 ; \mathrm{I}^{2}= \\
0.0 \%{ }^{164,186}\end{array}$ \\
\hline & & Primary anxiety, child report & $\begin{array}{l}\text { No relaxation vs. } \\
\text { relaxation }\end{array}$ & $\begin{array}{l}\text { SMD: }-0.16 ; 95 \% \mathrm{Cl}:-1.08 \text { to } 0.75 ; I^{2}= \\
48.4 \%{ }^{46,164,182,186}\end{array}$ \\
\hline & & Primary anxiety, parent report & $\begin{array}{l}\text { No relaxation vs. } \\
\text { Relaxation }\end{array}$ & $\begin{array}{l}\text { SMD: }-0.16 ; 95 \% \mathrm{Cl}:-2.37 \text { to } 2.05 ; I^{2}= \\
65.3 \%{ }^{46,186}\end{array}$ \\
\hline & & Function & $\begin{array}{l}\text { No relaxation vs. } \\
\text { relaxation }\end{array}$ & $\begin{array}{l}\text { SMD: }-0.01 ; 95 \% \mathrm{Cl}:-0.46 \text { to } 0.44 ; I^{2}= \\
78.3 \%{ }^{182,186}\end{array}$ \\
\hline & & Secondary measure & $\begin{array}{l}\text { No relaxation vs. } \\
\text { relaxation }\end{array}$ & $\begin{array}{l}\text { SMD: } 0.41 ; 95 \% \text { Cl: }-0.14 \text { to } 0.97 ; I^{2}= \\
\text { N/A }\end{array}$ \\
\hline & & Social function & $\begin{array}{l}\text { No relaxation vs. } \\
\text { relaxation }\end{array}$ & $\begin{array}{l}\text { SMD: } 0.88 ; 95 \% \text { Cl: }-0.38 \text { to } 2.13 ; I^{2}= \\
\text { N/A }\end{array}$ \\
\hline & & Remission & $\begin{array}{l}\text { No relaxation vs. } \\
\text { relaxation }\end{array}$ & $\begin{array}{l}\text { RR: } 1.25 ; 95 \% \text { Cl: } 0.33 \text { to } 4.77 ; I^{2}= \\
\text { N/A }\end{array}$ \\
\hline
\end{tabular}

CBT: cognitive behavioral therapy, CI: confidence interval, N/A: not applicable, RR: risk ratio, SMD: standardized mean difference 
Table G.11. Subgroup analysis - CBT delivery mode

\begin{tabular}{|c|c|c|c|c|}
\hline Subgroup & Comparison & Outcome & Subgroup Variable & Conclusion \\
\hline \multirow{8}{*}{$\begin{array}{l}\text { Individual-based } \\
\text { CBT vs Group- } \\
\text { based CBT }\end{array}$} & \multirow{8}{*}{$\begin{array}{l}\text { Individual-based CBT vs group-based } \\
\text { CBT }\end{array}$} & Primary anxiety, clinician report & Individual vs group & $\begin{array}{l}\text { SMD: }-0.07 ; 95 \% \mathrm{Cl}:-0.35 \text { to } 0.22 ; I^{2}= \\
0.0 \%{ }^{88,89,97,164,167,174}\end{array}$ \\
\hline & & Primary anxiety, child report & Individual vs group & 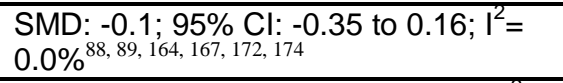 \\
\hline & & Primary anxiety, parent report & Individual vs group & $\begin{array}{l}\text { SMD: }-0.03 ; 95 \% \mathrm{Cl}:-0.81 \text { to } 0.75 ; I^{2}= \\
49.9 \% 88,89,97,174\end{array}$ \\
\hline & & Function & Individual vs group & $\begin{array}{l}\text { SMD: }-0.64 ; 95 \% \mathrm{Cl}:-1.10 \text { to }-0.19 ; I^{2}= \\
\text { N/A }\end{array}$ \\
\hline & & Secondary measure & Individual vs group & $\begin{array}{l}\text { SMD: }-0.41 ; 95 \% \mathrm{Cl}:-0.97 \text { to } 0.14 ; I^{2}= \\
\text { N/A }\end{array}$ \\
\hline & & Social function & Individual vs group & $\begin{array}{l}\text { SMD: } 0.28 ; 95 \% \mathrm{Cl}:-0.30 \text { to } 0.85 ; I^{2}= \\
\text { N/A }{ }^{97}\end{array}$ \\
\hline & & Remission & Individual vs group & $\begin{array}{l}\text { RR: } 0.81 ; 95 \% \mathrm{Cl}: 0.47 \text { to } 1.39 ; I^{2}=\mathrm{N} / \mathrm{A} \\
88,89\end{array}$ \\
\hline & & Response & Individual vs group & $\begin{array}{l}\text { RR: } 0.93 ; 95 \% \mathrm{Cl}: 0.70 \text { to } 1.23 ; \mathrm{I}^{2}= \\
0.0 \%{ }^{88,89,172,173}\end{array}$ \\
\hline
\end{tabular}

CBT: cognitive behavioral therapy, CI: confidence interval, N/A: not applicable, RR: risk ratio, SMD: standardized mean difference 
Table G.12. Subgroup analysis - CBT intensity

\begin{tabular}{|c|c|c|c|c|}
\hline Subgroup & Comparison & Outcome & Subgroup Variable & Conclusion \\
\hline \multirow{8}{*}{$\begin{array}{l}\text { Treatment } \\
\text { Intensity (low, } \\
\text { medium, and } \\
\text { high) }\end{array}$} & \multirow{8}{*}{$\begin{array}{l}\text { CBT with low intensity vs. CBT with } \\
\text { medium intensity CBT vs. CBT with } \\
\text { high intensity }\end{array}$} & Primary anxiety, child report & $\begin{array}{l}\text { Low intensity vs. } \\
\text { medium }\end{array}$ & $\begin{array}{l}\text { SMD: } 0.22 ; 95 \% \mathrm{Cl}:-0.11 \text { to } 0.56 ; I^{2}= \\
\text { N/A }^{164,166}\end{array}$ \\
\hline & & Primary anxiety, parent report & $\begin{array}{l}\text { Low intensity vs. } \\
\text { medium }\end{array}$ & $\begin{array}{l}\text { SMD: } 0.18 ; 95 \% \mathrm{Cl}:-0.15 \text { to } 0.51 ; \mathrm{I}^{2}= \\
\text { N/A }^{164,166}\end{array}$ \\
\hline & & Function & $\begin{array}{l}\text { Low intensity vs. } \\
\text { medium }\end{array}$ & $\begin{array}{l}\text { SMD: }-0.02 ; 95 \% \mathrm{Cl}:-0.35 \text { to } 0.31 ; I^{2}= \\
\text { N/A }\end{array}$ \\
\hline & & Primary anxiety, clinician report & $\begin{array}{l}\text { Medium intensity vs. } \\
\text { high }\end{array}$ & $\begin{array}{l}\text { SMD: } 0.16 ; 95 \% \mathrm{Cl}:-0.24 \text { to } 0.56 ; I^{2}= \\
0.0 \%{ }^{166}\end{array}$ \\
\hline & & Primary anxiety, child report & $\begin{array}{l}\text { Medium intensity vs. } \\
\text { high }\end{array}$ & $\begin{array}{l}\text { SMD: } 0.25 ; 95 \% \mathrm{Cl}:-0.03 \text { to } 0.54 ; I^{2}= \\
84.2 \%{ }^{166}\end{array}$ \\
\hline & & Primary anxiety, parent report & $\begin{array}{l}\text { Medium intensity vs. } \\
\text { high }\end{array}$ & $\begin{array}{l}\text { SMD: } 0.04 ; 95 \% \mathrm{Cl}:-0.24 \text { to } 0.33 ; I^{2}= \\
35.2 \% 166\end{array}$ \\
\hline & & Function & $\begin{array}{l}\text { Medium intensity vs. } \\
\text { high }\end{array}$ & $\begin{array}{l}\text { SMD: }-0.12 ; 95 \% \mathrm{Cl}:-0.46 \text { to } 0.21 ; 12= \\
\text { N/A166 }\end{array}$ \\
\hline & & Secondary measure & $\begin{array}{l}\text { Medium intensity vs. } \\
\text { high }\end{array}$ & $\begin{array}{l}\text { SMD: }-0.41 ; 95 \% \text { Cl: }-0.97 \text { to } 0.14 ; I^{2}= \\
\text { N/A }\end{array}$ \\
\hline
\end{tabular}

Intensity: low: less than 480 minutes in total sessions; medium: 480 minutes to 960 minutes in total sessions; high: greater than 960 minutes in total sessions. CBT: cognitive

behavioral therapy, CI: confidence interval, N/A: not applicable, SMD: standardized mean difference 


\section{Appendix H. Figures}

Figure H.1. Funnel plot CBT versus waitlisting or no treatment for primary anxiety symptoms, clinician report

Funnel plot with pseudo 95\% confidence limits

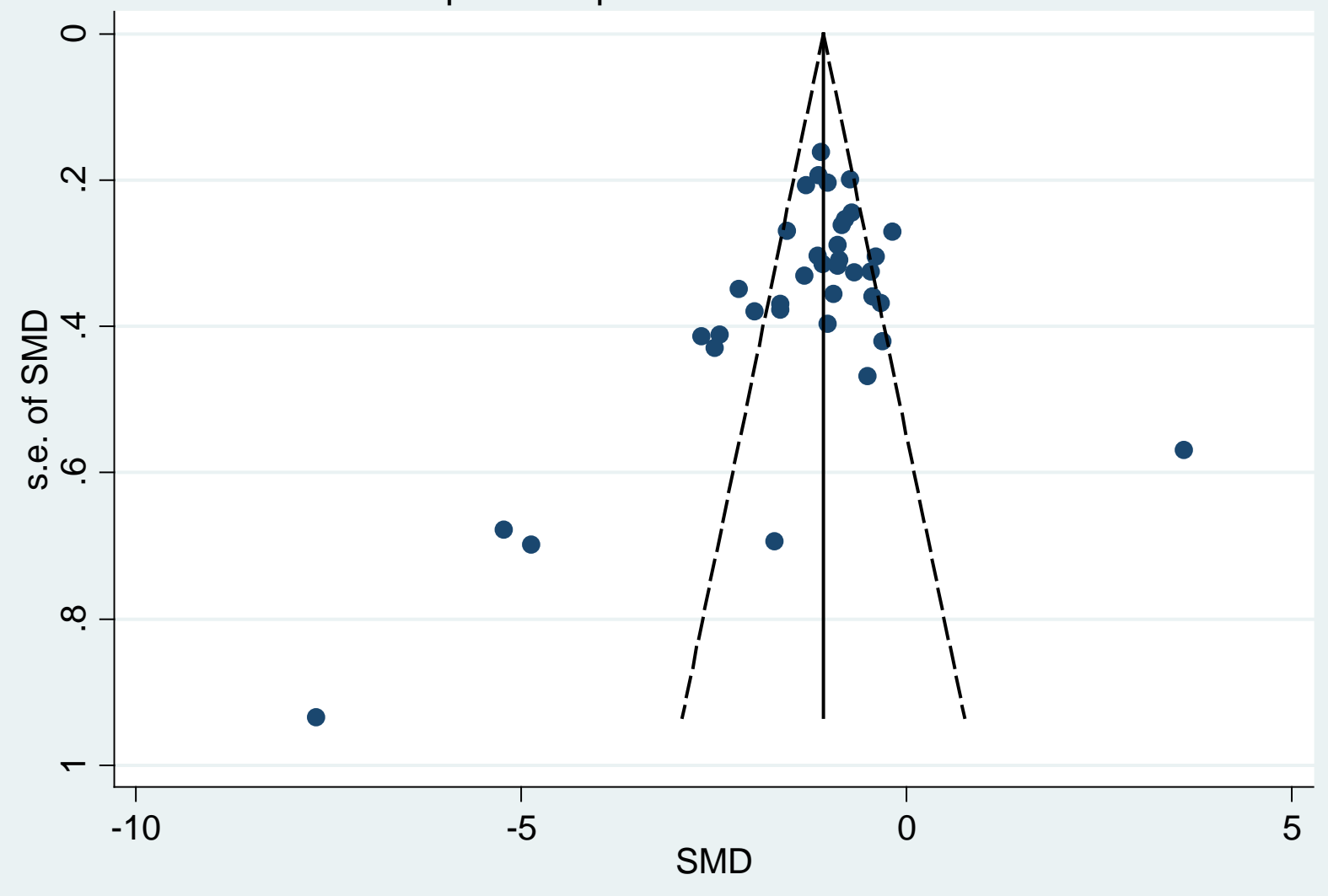


Figure H.2. Funnel plot CBT versus waitlisting or no treatment for primary anxiety symptoms,

Funnel plot with pseudo 95\% confidence limits

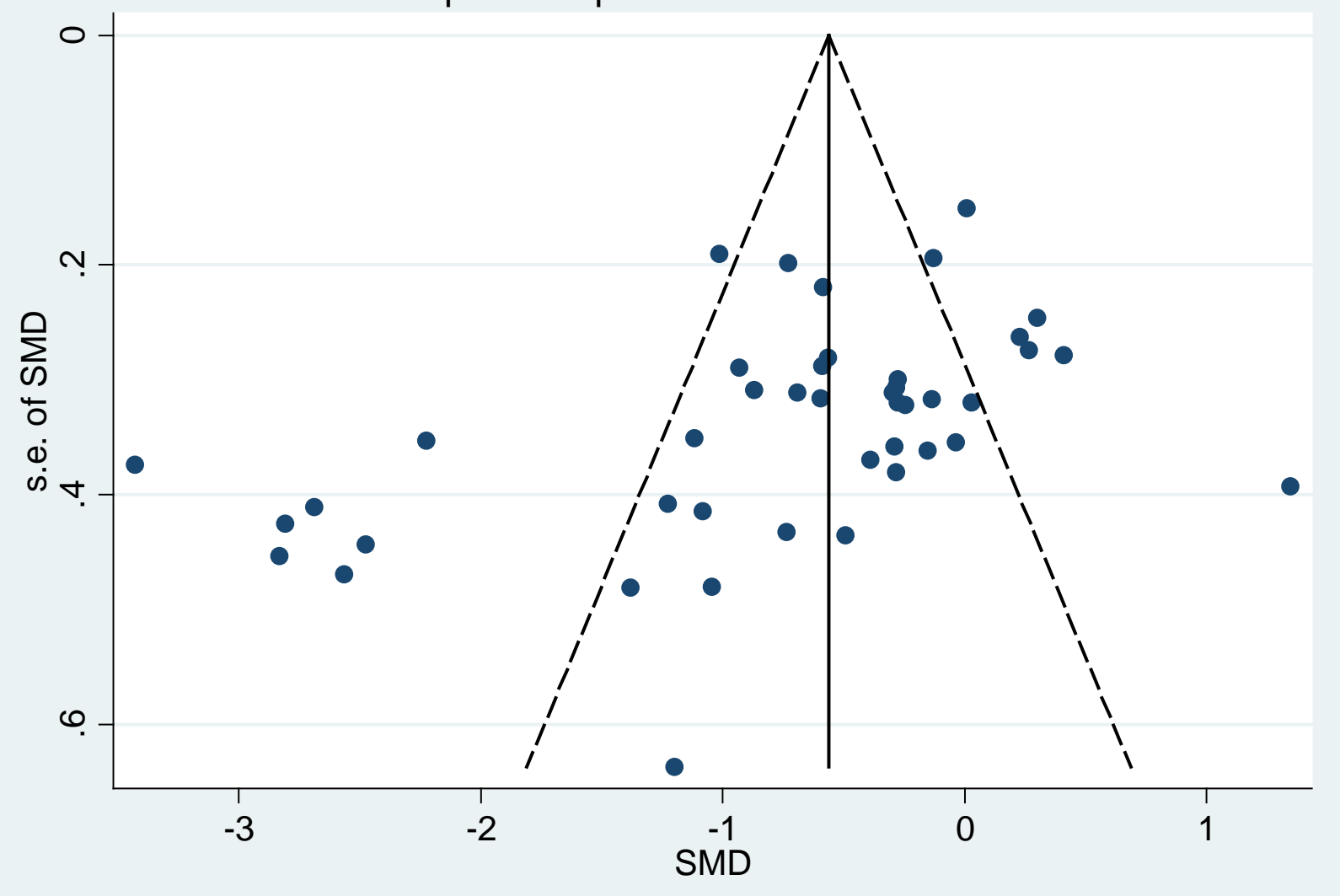


Figure H.3. Funnel plot for CBT versus waitlisting or no treatment for primary anxiety symptoms, Funnel plot with pseudo 95\% confidence limits

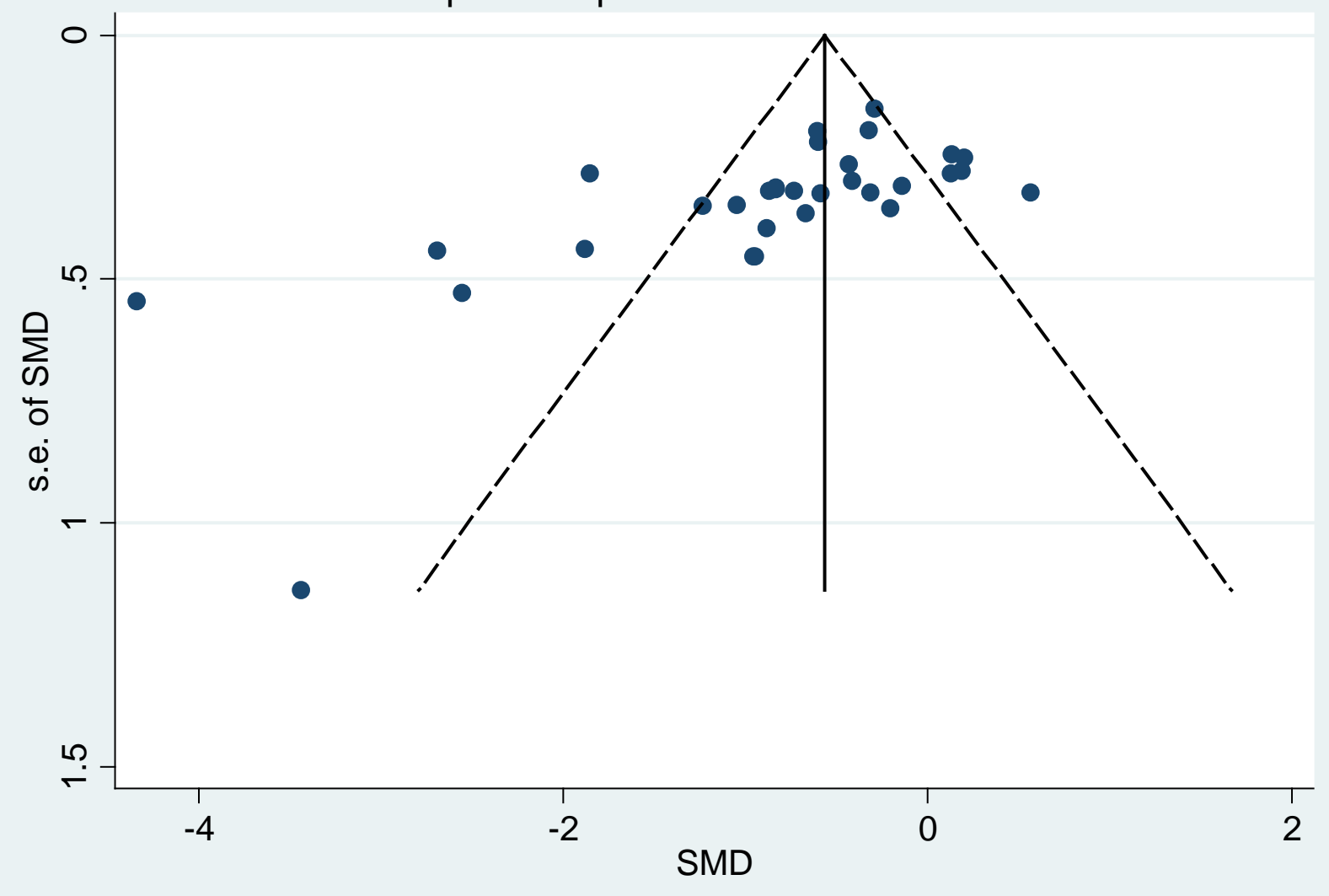




\section{Appendix I. References for Appendixes}

1. Abikoff H, McGough J, Vitiello B, et al. Sequential pharmacotherapy for children with comorbid attentiondeficit/hyperactivity and anxiety disorders. J Am Acad Child Adolesc Psychiatry. 2005 May;44(5):418-27. doi: 10.1097/01.chi.0000155320.52322.37. PMID: 15843763.

2. Alfano CA, Ginsburg GS, Kingery JN. Sleep-related problems among children and adolescents with anxiety disorders. J Am Acad Child Adolesc Psychiatry. 2007 Feb;46(2):224-32. doi: 10.1097/01.chi.0000242233.06011.8e. PMID: 17242626.

3. Beidel DC, Turner SM, Sallee FR, et al. SET-C versus fluoxetine in the treatment of childhood social phobia. J Am Acad Child Adolesc Psychiatry. 2007 Dec;46(12):162232. doi: 10.1097/chi.0b013e318154bb57. PMID: 18030084.

4. Black B, Uhde TW. Treatment of elective mutism with fluoxetine: a double-blind, placebo-controlled study. J Am Acad Child Adolesc Psychiatry. 1994 Sep;33(7):1000-6. doi: 10.1097/00004583-199409000-00010. PMID: 7961338.

5. Birmaher B, Axelson DA, Monk K, et al. Fluoxetine for the treatment of childhood anxiety disorders. J Am Acad Child Adolesc Psychiatry. 2003 Apr;42(4):415-23. doi: 10.1097/01.CHI.0000037049.04952.9F. PMID: 12649628.

6. da Costa CZ, de Morais RM, Zanetta DM, et al. Comparison among clomipramine, fluoxetine, and placebo for the treatment of anxiety disorders in children and adolescents. J Child Adolesc Psychopharmacol. 2013 Dec;23(10):687-92. doi: 10.1089/cap.2012.0110. PMID: 24350814.
7. Geller D, Donnelly C, Lopez F, et al. Atomoxetine treatment for pediatric patients with attention-deficit/hyperactivity disorder with comorbid anxiety disorder. J Am Acad Child Adolesc Psychiatry. 2007

Sep;46(9):1119-27. doi: 10.1097/chi.0b013e3180ca8385. PMID: 17712235.

8. Gittelman K, Rachel, Klein, et al. School phobia: Diagnostic considerations in the light of imipramine effects. Journal of Nervous and Mental Disease. 1973 Mar;156(3):199-215. PMID: 1974-01582001.

9. Graae F, Milner J, Rizzotto L, et al. Clonazepam in childhood anxiety disorders. J Am Acad Child Adolesc Psychiatry. 1994 Mar-Apr;33(3):372-6. doi: 10.1097/00004583-199403000-00011. PMID: 8169182.

10. March JS, Entusah AR, Rynn M, et al. A Randomized controlled trial of venlafaxine ER versus placebo in pediatric social anxiety disorder. Biol Psychiatry. 2007 Nov 15;62(10):1149-54. doi: 10.1016/j.biopsych.2007.02.025. PMID: 17553467.

11. Pine, D S, Walkup, et al. Fluvoxamine for the treatment of anxiety disorders in children and adolescents. New England Journal of Medicine. 200126 Apr;344(17):1279-85. doi: 10.1056/NEJM200104263441703. PMID: 2001155341.

12. Reinblatt SP, Riddle MA. Selective serotonin reuptake inhibitor-induced apathy: a pediatric case series. J Child Adolesc Psychopharmacol. 2006 Feb-Apr;16(12):227-33. doi: 10.1089/cap.2006.16.227. PMID: 16553543. 
13. Reinblatt SP, DosReis S, Walkup JT, et al. Activation adverse events induced by the selective serotonin reuptake inhibitor fluvoxamine in children and adolescents. J Child Adolesc Psychopharmacol. 2009 Apr;19(2):119-26. doi: 10.1089/cap.2008.040. PMID: 19364290.

14. Rynn MA, Siqueland L, Rickels K. Placebocontrolled trial of sertraline in the treatment of children with generalized anxiety

disorder. Am J Psychiatry. 2001

Dec;158(12):2008-14. doi:

10.1176/appi.ajp.158.12.2008. PMID:

11729017.

15. Rynn MA, Riddle MA, Yeung PP, et al. Efficacy and safety of extended-release venlafaxine in the treatment of generalized anxiety disorder in children and adolescents: two placebo-controlled trials. Am J Psychiatry. 2007 Feb;164(2):290-300. doi: 10.1176/ajp.2007.164.2.290. PMID: 17267793.

16. Scharfstein LA, Beidel DC, Finnell LR, et al. Do pharmacological and behavioral interventions differentially affect treatment outcome for children with social phobia? Behav Modif. 2011 Sep;35(5):451-67. doi: 10.1177/0145445511408590. PMID: 21586501.

17. Strawn JR, Prakash A, Zhang Q, et al. A randomized, placebo-controlled study of duloxetine for the treatment of children and adolescents with generalized anxiety disorder. J Am Acad Child Adolesc Psychiatry. 2015 Apr;54(4):283-93. doi: 10.1016/j.jaac.2015.01.008. PMID: 25791145.

18. Wagner, K, Berard, et al. A multicenter, randomized, double-blind, placebocontrolled trial ofparoxetine in children and adolescents with social anxiety disorder. Archives of General Psychiatry.

2004;61(11):1153-62. doi:

10.1001/archpsyc.61.11.1153.
19. Walkup J, Labellarte M, Riddle MA, et al. Treatment of pediatric anxiety disorders: an open-label extension of the research units on pediatric psychopharmacology anxiety study. J Child Adolesc Psychopharmacol. 2002 Fall;12(3):175-88. doi: 10.1089/104454602760386879. PMID: 12427292.

20. Walkup JT, Albano AM, Piacentini J, et al. Cognitive behavioral therapy, sertraline, or a combination in childhood anxiety. N Engl J Med. 2008 Dec 25;359(26):2753-66. doi: 10.1056/NEJMoa0804633. PMID: 18974308.

21. Ginsburg GS, Kendall PC, Sakolsky D, et al. Remission after acute treatment in children and adolescents with anxiety disorders: findings from the CAMS. J Consult Clin Psychol. 2011 Dec;79(6):806-13. doi: 10.1037/a0025933. PMID: 22122292.

22. Gonzalez A, Peris TS, Vreeland A, et al. Parental anxiety as a predictor of medication and CBT response for anxious youth. Child Psychiatry Hum Dev. 2015 Feb;46(1):84-93. doi: 10.1007/s10578-014-0454-6. PMID: 24610431.

23. Keeton CP, Ginsburg GS, Drake KL, et al. Benefits of child-focused anxiety treatments for parents and family functioning. Depress Anxiety. 2013 Sep;30(9):865-72. doi: 10.1002/da.22055. PMID: 23390005.

24. Nail, Jennifer E, Christofferson, et al. Academic impairment and impact of treatments among youth with anxiety disorders. Child \& Youth Care Forum. 2015 Jun;44(3):327-42. doi: 10.1007/s10566-0149290-x. PMID: 2014-51382-001.

25. Piacentini J, Bennett S, Compton SN, et al. 24- and 36-week outcomes for the Child/Adolescent Anxiety Multimodal Study (CAMS). J Am Acad Child Adolesc Psychiatry. 2014 Mar;53(3):297-310. doi: 10.1016/j.jaac.2013.11.010. PMID: 24565357. 
26. Rynn MA, Walkup JT, Compton SN, et al. Child/Adolescent anxiety multimodal study: evaluating safety. J Am Acad Child Adolesc Psychiatry. 2015 Mar;54(3):180-90. doi: 10.1016/j.jaac.2014.12.015. PMID: 25721183.

27. Abbasi, Z, Amiri, et al. The effective comparison between modular cognitive behavioral therapy (MCBT) and child-parent relationship training (CPRT) in children with separation anxiety symptoms. Social Sciences (Pakistan). 2016;11(6):890-902. doi: 10.3923/sscience.2016.890.902.

28. Adler Nevo GW, Avery D, Fiksenbaum L, et al. Eight years later: outcomes of CBTtreated versus untreated anxious children. Brain Behav. 2014 Sep;4(5):765-74. doi: 10.1002/brb3.274. PMID: 25328851.

29. Afshari A, Neshat-Doost HT, Maracy MR, et al. The effective comparison between emotion-focused cognitive behavioral group therapy and cognitive behavioral group therapy in children with separation anxiety disorder. J Res Med Sci. 2014 Mar;19(3):221-7. PMID: 24949029.

30. Arendt K, Thastum M, Hougaard E. Efficacy of a Danish version of the Cool Kids program: a randomized wait-list controlled trial. Acta Psychiatr Scand. 2015 May 27;133(2):109-21. doi: 10.1111/acps.12448. PMID: 26016532.

31. Baer S, Garland EJ. Pilot study of community-based cognitive behavioral group therapy for adolescents with social phobia. J Am Acad Child Adolesc Psychiatry. 2005 Mar;44(3):258-64. doi: 10.1097/00004583-200503000-00010. PMID: 15725970.
32. Barrett PM, Dadds MR, Rapee RM. Family treatment of childhood anxiety: a controlled trial. J Consult Clin Psychol. 1996 Apr;64(2):333-42. doi: 10.1037//0022006X.64.2.333. PMID: 8871418.

33. Barrett PM. Evaluation of cognitivebehavioral group treatments for childhood anxiety disorders. J Clin Child Psychol. 1998 Dec;27(4):459-68. doi: 10.1207/s15374424jccp2704_10. PMID: 9866083.

34. Chalfant AM, Rapee R, Carroll L. Treating anxiety disorders in children with high functioning autism spectrum disorders: a controlled trial. J Autism Dev Disord. 2007 Nov;37(10):1842-57. doi: 10.1007/s10803006-0318-4. PMID: 17171539.

35. Chiu AW, Langer DA, McLeod BD, et al. Effectiveness of modular CBT for child anxiety in elementary schools. Sch Psychol Q. 2013 Jun;28(2):141-53. doi: 10.1037/spq0000017. PMID: 23750860.

36. Cobham VE. Do anxiety-disordered children need to come into the clinic for efficacious treatment? J Consult Clin Psychol. 2012 Jun;80(3):465-76. doi: 10.1037/a0028205. PMID: 22545740.

37. Dewis LM, Kirkby KC, Martin F, et al. Computer-aided vicarious exposure versus live graded exposure for spider phobia in children. J Behav Ther Exp Psychiatry. 2001 Mar;32(1):17-27. doi: 10.1016/S00057916(01)00019-2. PMID: 11729943.

38. Donovan CL, Cobham V, Waters AM, et al. Intensive group-based CBT for child social phobia: a pilot study. Behav Ther. 2015 May;46(3):350-64. doi: 10.1016/j.beth.2014.12.005. PMID: 25892171. 
39. Flannery S, E C, Kendall, et al. Group and individual cognitive-behavioral treatments for youth with anxiety disorders: A randomized clinical trial. Cognitive Therapy and Research. 2000 June;24(3):251-78. doi: 10.1023/A:1005500219286. PMID: 2000223577.

40. Flannery S, E, Choudhury, et al. Group and individual cognitive-behavioral treatments for youth with anxiety disorders: 1-Year follow-up. Cognitive Therapy and Research. 2005 April;29(2):253-9. doi: 10.1007/s10608-005-3168-z. PMID: 2005221485.

41. Gallagher HM, Rabian BA, McCloskey MS. A brief group cognitive-behavioral intervention for social phobia in childhood. J Anxiety Disord. 2004;18(4):459-79. doi: 10.1016/S0887-6185(03)00027-6. PMID: 15149708.

42. Gallo KP, Chan PT, Buzzella BA, et al. The impact of an 8-day intensive treatment for adolescent panic disorder and agoraphobia on comorbid diagnoses. Behav Ther. 2012 Mar;43(1):153-9. doi: 10.1016/j.beth.2011.05.002. PMID: 22304887.

43. Gil B, F, Hernandez G, et al. [Cognitivebehavioural treatment in Mexican children with social phobia]. Anuario de Psicologia. 2009;40(1):89-104. PMID: CN-00753537 UPDATE.

44. Hancock KM, Swain J, Hainsworth CJ, et al. Acceptance and Commitment Therapy versus Cognitive Behavior Therapy for Children With Anxiety: Outcomes of a Randomized Controlled Trial. J Clin Child Adolesc Psychol. 2016 Mar 21:1-16. doi: 10.1080/15374416.2015.1110822. PMID: 26998803.
45. Hayward C, Varady S, Albano AM, et al. Cognitive-behavioral group therapy for social phobia in female adolescents: results of a pilot study. J Am Acad Child Adolesc Psychiatry. 2000 Jun;39(6):721-6. doi: 10.1097/00004583-200006000-00010. PMID: 10846306.

46. Holmes MC, Donovan CL, Farrell LJ, et al. The efficacy of a group-based, disorderspecific treatment program for childhood GAD--a randomized controlled trial. Behav Res Ther. 2014 Oct;61:122-35. doi: 10.1016/j.brat.2014.08.002. PMID: 25193003.

47. Hirshfeld-Becker DR, Masek B, Henin A, et al. Cognitive behavioral therapy for 4- to 7year-old children with anxiety disorders: a randomized clinical trial. J Consult Clin Psychol. 2010 Aug;78(4):498-510. doi: 10.1037/a0019055. PMID: 20658807.

48. Kendall, P C. Treating anxiety disorders in children: results of a randomized clinical trial. Annual Progress in Child Psychiatry and Child Development. 1995doi: 10.1037/0022-006X.62.1.100 · PMID: CN00216211 UPDATE.

49. Kendall PC, Flannery-Schroeder E, Panichelli-Mindel SM, et al. Therapy for youths with anxiety disorders: a second randomized clinical trial. J Consult Clin Psychol. 1997 Jun;65(3):366-80. doi: 10.1037/0022-006X.65.3.366. PMID: 9170760.

50. Leutgeb V, Schienle A. Changes in facial electromyographic activity in spider-phobic girls after psychotherapy. J Psychiatr Res. 2012 Jun;46(6):805-10. doi: 10.1016/j.jpsychires.2012.02.017. PMID: 22424962. 
51. Masia-Warner C, Klein RG, Dent HC, et al. School-based intervention for adolescents with social anxiety disorder: results of a controlled study. J Abnorm Child Psychol. 2005 Dec;33(6):707-22. doi:

10.1007/s10802-005-7649-z. PMID: 16328746.

52. McConachie H, McLaughlin E, Grahame V, et al. Group therapy for anxiety in children with autism spectrum disorder. Autism. 2014 Aug;18(6):723-32. doi: 10.1177/1362361313488839. PMID: 24101715.

53. McNally Keehn RH, Lincoln AJ, Brown $\mathrm{MZ}$, et al. The Coping Cat program for children with anxiety and autism spectrum disorder: a pilot randomized controlled trial. J Autism Dev Disord. 2013 Jan;43(1):57-67. doi: 10.1007/s10803-012-1541-9. PMID: 22588377.

54. Melfsen S, Kuhnemund M, Schwieger J, et al. Cognitive behavioral therapy of socially phobic children focusing on cognition: a randomised wait-list control study. Child Adolesc Psychiatry Ment Health. 2011 Feb 28;5(1):5. doi: 10.1186/1753-2000-5-5. PMID: 21356037.

55. Mendez, Xavier, Orgiles, et al. Psychological treatment of the phobia of the dark in a game situation: A controlled essay. Revista de Psicopatologia y Psicologia Clinica. 2003 Dec;8(3):199-210. PMID: 2004-12003-002.

56. Mendlowitz SL, Manassis K, Bradley S, et al. Cognitive-behavioral group treatments in childhood anxiety disorders: the role of parental involvement. J Am Acad Child Adolesc Psychiatry. 1999 Oct;38(10):12239. doi: 10.1097/00004583-19991000000010. PMID: 10517054.
57. Menzies RG, Clarke JC. A comparison of in vivo and vicarious exposure in the treatment of childhood water phobia. Behav Res Ther. 1993 Jan;31(1):9-15. doi: 10.1016/00057967(93)90037-U. PMID: 8093340.

58. Miller LC, Barrett CL, Hampe E, et al. Comparison of reciprocal inhibition, psychotherapy, and waiting list control for phobic children. J Abnorm Psychol. 1972 Jun;79(3):269-79. PMID: 5033367.

59. Hampe E, Noble H, Miller LC, et al. Phobic children one and two years posttreatment. J Abnorm Psychol. 1973 Dec;82(3):446-53. PMID: 4770914.

60. Obler M, Terwilliger RF. Pilot study on the effectiveness of systematic desensitization with neurologically impaired children with phobic disorders. J Consult Clin Psychol. 1970 Jun;34(3):314-8. doi: 10.1037/h0029367. PMID: 5523436.

61. Olivares, J, Garcia L, et al. Results at longterm among three psychological treatments for adolescents with generalized social phobia (I): Statistical significance. Psicologia Conductual. 2002;10(1):147-64. PMID: 2002236025.

62. Olivares J, Olivares-Olivares PJ, RosaAlcazar AI, et al. The contribution of the therapist's competence in the treatment of adolescents with generalized social phobia. Psicothema. 2014;26(4):483-9. doi: 10.7334/psicothema2014.69. PMID: 25340895.

63. Ollendick TH, Ost LG, Reuterskiold L, et al. One-session treatment of specific phobias in youth: a randomized clinical trial in the United States and Sweden. J Consult Clin Psychol. 2009 Jun;77(3):504-16. doi: 10.1037/a0015158. PMID: 19485591. 
64. Ortbandt, C, Petermann, et al. Effects of a cognitive behavioral training program for children with social anxiety. Kindheit und Entwicklung. 2009;18(1):21-9.

65. Moller, C, Petermann, et al. Short- and longterm effects of a cognitive-behavioural training programme for children with social anxiety. [German]. Verhaltenstherapie. 2011 March;21(1):15-22. PMID: 2011134836.

66. Ost LG, Svensson L, Hellstrom K, et al. One-Session treatment of specific phobias in youths: a randomized clinical trial. J Consult Clin Psychol. 2001 Oct;69(5):814-24. doi: 10.1037/0022-006X.69.5.814. PMID: 11680558.

67. Ost, L G, Cederlund, et al. Behavioral treatment of social phobia in youth: Does parent education training improve the outcome? Behaviour Research and Therapy. 2015 April 01;67:19-29. doi: 10.1016/j.brat.2015.02.001. PMID: 2015788786.

68. Rapee, Ronald M. Group treatment of children with anxiety disorders: Outcome and predictors of treatment response. Australian Journal of Psychology. 2000;52(3):125-9. doi: 10.1080/00049530008255379.

69. Rapee RM, Abbott MJ, Lyneham HJ. Bibliotherapy for children with anxiety disorders using written materials for parents: A randomized controlled trial. J Consult Clin Psychol. 2006 Jun;74(3):436-44. doi: 10.1037/0022-006X.74.3.436. PMID: 16822101.

70. Reaven, J A, Blakeley S, et al. Cognitivebehavioral group treatment for anxiety symptoms in children with high-functioning autism spectrum disorders: A pilot study. Focus on Autism and Other Developmental Disabilities. 2009 March;24(1):27-37. doi: 10.1177/1088357608327666. PMID: 2009069887. 
78. Shortt AL, Barrett PM, Fox TL. Evaluating the FRIENDS program: a cognitivebehavioral group treatment for anxious children and their parents. J Clin Child Psychol. 2001 Dec;30(4):525-35. doi: 10.1207/S15374424JCCP3004_09. PMID: 11708240 .

79. Silverman WK, Kurtines WM, Ginsburg GS, et al. Treating anxiety disorders in children with group cognitive-behaviorial therapy: a randomized clinical trial. J Consult Clin Psychol. 1999 Dec;67(6):9951003. doi: 10.1037/0022-006X.67.6.995 PMID: 10596522.

80. Spence SH, Donovan C, BrechmanToussaint M. The treatment of childhood social phobia: the effectiveness of a social skills training-based, cognitive-behavioural intervention, with and without parental involvement. J Child Psychol Psychiatry. 2000 Sep;41(6):713-26. doi: 10.1111/14697610.00659. PMID: 11039684.

81. Spence SH, Holmes JM, March S, et al. The feasibility and outcome of clinic plus internet delivery of cognitive-behavior therapy for childhood anxiety. J Consult Clin Psychol. 2006 Jun;74(3):614-21. doi: 10.1037/0022-006X.74.3.614. PMID: 16822117.

82. Spence SH, Donovan CL, March S, et al. A randomized controlled trial of online versus clinic-based CBT for adolescent anxiety. J Consult Clin Psychol. 2011 Oct;79(5):62942. doi: 10.1037/a0024512. PMID: 21744945.

83. Treadwell KR, Kendall PC. Self-talk in youth with anxiety disorders: states of mind, content specificity, and treatment outcome. J Consult Clin Psychol. 1996 Oct;64(5):94150. doi: 10.1037//0022-006X.64.5.941 PMID: 8916623.
84. Arándiga, Antonio V, Rodríguez, et al. Competencia social y autoestima en adolescentes con fobia social. Investigar el cambio curricular en el espacio europeo de educación superior. 2014:459-79.

85. Van S, F. J A, Bogels, et al. CBT for anxiety disorders in children with and without autism spectrum disorders. Journal of Consulting and Clinical Psychology. 2015 01 Jun;83(3):512-23. doi: 10.1037/a0039108. PMID: 2015938821.

86. Waters AM, Ford LA, Wharton TA, et al. Cognitive-behavioural therapy for young children with anxiety disorders: Comparison of a Child + Parent condition versus a Parent Only condition. Behav Res Ther. 2009 Aug;47(8):654-62. doi: 10.1016/j.brat.2009.04.008. PMID: 19457471.

87. Warner CM, Colognori D, Kim RE, et al. Cognitive-behavioral treatment of persistent functional somatic complaints and pediatric anxiety: an initial controlled trial. Depress Anxiety. 2011 Jul;28(7):551-9. doi: 10.1002/da.20821. PMID: 21681863.

88. Wergeland GJ, Fjermestad KW, Marin CE, et al. An effectiveness study of individual vs. group cognitive behavioral therapy for anxiety disorders in youth. Behav Res Ther. 2014 Jun;57:1-12. doi: 10.1016/j.brat.2014.03.007. PMID: 24727078.

89. Wergeland GJ, Fjermestad KW, Marin CE, et al. Predictors of treatment outcome in an effectiveness trial of cognitive behavioral therapy for children with anxiety disorders. Behav Res Ther. 2016 Jan;76:1-12. doi: 10.1016/j.brat.2015.11.001. PMID: 26583954. 
90. White SW, Ollendick T, Albano AM, et al. Randomized controlled trial: Multimodal Anxiety and Social Skill Intervention for adolescents with autism spectrum disorder. J Autism Dev Disord. 2013 Feb;43(2):382-94. doi: 10.1007/s10803-012-1577-x. PMID: 22735897.

91. Wood JJ, Drahota A, Sze K, et al. Cognitive behavioral therapy for anxiety in children with autism spectrum disorders: a randomized, controlled trial. J Child Psychol Psychiatry. 2009 Mar;50(3):224-34. doi: 10.1111/j.1469-7610.2008.01948.x. PMID: 19309326.

92. Beidel DC, Turner SM, Morris TL. Behavioral treatment of childhood social phobia. J Consult Clin Psychol. 2000 Dec;68(6):1072-80. doi: 10.1037//0022006X.68.6.1072. PMID: 11142541.

93. Fujii, Cori, Renno, et al. Intensive cognitive behavioral therapy for anxiety disorders in school-aged children with autism: A preliminary comparison with treatment-asusual. School Mental Health. 2013;5(1):2537. doi: 10.1007/s12310-012-9090-0. PMID: CN-01000510 UPDATE.

94. Ginsburg GS, Drake KL. School-based treatment for anxious african-american adolescents: a controlled pilot study. J Am Acad Child Adolesc Psychiatry. 2002 Jul;41(7):768-75. doi: 10.1097/00004583200207000-00007. PMID: 12108800.

95. Ginsburg GS, Becker KD, Drazdowski TK, et al. Treating Anxiety Disorders in Inner City Schools: Results from a Pilot Randomized Controlled Trial Comparing CBT and Usual Care. Child Youth Care Forum. 2012 Feb;41(1):1-19. doi: 10.1007/s10566-011-9156-4. PMID: 22701295.
96. Halldorsdottir T, Ollendick TH. Long-term outcomes of brief, intensive CBT for specific phobias: The negative impact of ADHD symptoms. J Consult Clin Psychol. 2016 May;84(5):465-71. doi: 10.1037/ccp0000088. PMID: 26900895.

97. Herbert JD, Gaudiano BA, Rheingold AA, et al. Cognitive behavior therapy for generalized social anxiety disorder in adolescents: a randomized controlled trial. J Anxiety Disord. 2009 Mar;23(2):167-77. doi: 10.1016/j.janxdis.2008.06.004. PMID: 18653310.

98. Hudson JL, Rapee RM, Deveney C, et al. Cognitive-behavioral treatment versus an active control for children and adolescents with anxiety disorders: a randomized trial. J Am Acad Child Adolesc Psychiatry. 2009 May;48(5):533-44. doi: 10.1097/CHI.0b013e31819c2401. PMID: 19318990.

99. Ingul JM, Aune T, Nordahl HM. A randomized controlled trial of individual cognitive therapy, group cognitive behaviour therapy and attentional placebo for adolescent social phobia. Psychother Psychosom. 2014;83(1):54-61. doi: 10.1159/000354672. PMID: 24281563.

100. Kendall PC, Hudson JL, Gosch E, et al. Cognitive-behavioral therapy for anxiety disordered youth: a randomized clinical trial evaluating child and family modalities. J Consult Clin Psychol. 2008 Apr;76(2):28297. doi: 10.1037/0022-006X.76.2.282. PMID: 18377124.

101. Khanna MS, Kendall PC. Exploring the role of parent training in the treatment of childhood anxiety. J Consult Clin Psychol. 2009 Oct;77(5):981-6. doi: 10.1037/a0016920. PMID: 19803577. 
102. Khanna MS, Kendall PC. Computer-assisted cognitive behavioral therapy for child anxiety: results of a randomized clinical trial. J Consult Clin Psychol. 2010 Oct;78(5):737-45. doi: 10.1037/a0019739. PMID: 20873909.

103. Last CG, Hansen C, Franco N. Cognitivebehavioral treatment of school phobia. J Am Acad Child Adolesc Psychiatry. 1998 Apr;37(4):404-11. doi: 10.1097/00004583199804000-00018. PMID: 9549961.

104. Masia Warner C, Fisher PH, Shrout PE, et al. Treating adolescents with social anxiety disorder in school: an attention control trial. J Child Psychol Psychiatry. 2007 Jul;48(7):676-86. doi: 10.1111/j.14697610.2007.01737.x. PMID: 17593148.

105. Muris, P, Meesters, et al. Cognitive coping vs emotional disclosure in the treatment of anxious children: A pilot-study. Cognitive Behaviour Therapy. 2002;31(2):59-67. doi: 10.1080/16506070252959490. PMID: 2003069119.

106. O'Brien, F, Olden, et al. Group cognitive behavioural therapy for children with anxiety disorder - An evaluation of the 'Friends for Youth' programme. Irish Journal of Psychological Medicine. 2007 March;24(1):5-12. doi: doi.org/10.1017/S0790966700010065. PMID: 2007447394.

107. Pincus DB, May JE, Whitton SW, et al. Cognitive-behavioral treatment of panic disorder in adolescence. J Clin Child Adolesc Psychol. 2010;39(5):638-49. doi: 10.1080/15374416.2010.501288. PMID: 20706917.
108. Reigada, Laura C, Polokowski, et al. Treatment for comorbid pediatric gastrointestinal and anxiety disorders: A pilot study of a flexible health sensitive cognitive-behavioral therapy program. Clinical Practice in Pediatric Psychology. 2015 Dec;3(4):314-26. doi: 10.1037/cpp0000116 PMID: 2015-55574002.

109. Rosa A, Ana I, Olivares R, et al. The role of planned interaction in the treatment of generalized social phobia. Terapia Psicologica. 2007;25(2):205-12. PMID: 2008-02112-012.

110. Southam-Gerow MA, Weisz JR, Chu BC, et al. Does cognitive behavioral therapy for youth anxiety outperform usual care in community clinics? An initial effectiveness test. J Am Acad Child Adolesc Psychiatry. 2010 Oct;49(10):1043-52. doi: 10.1016/j.jaac.2010.06.009. PMID: 20855049.

111. Silk JS, Tan PZ, Ladouceur CD, et al. A Randomized Clinical Trial Comparing Individual Cognitive Behavioral Therapy and Child-Centered Therapy for Child Anxiety Disorders. J Clin Child Adolesc Psychol. 2016 Mar 16:1-13. doi: 10.1080/15374416.2016.1138408. PMID: 26983904.

112. Storch EA, Salloum A, King MA, et al. A Randomized Controlled Trial in Community Mental Health Centers of ComputerAssisted Cognitive Behavioral Therapy Versus Treatment as Usual for Children with Anxiety. Depress Anxiety. 2015 Nov;32(11):843-52. doi: 10.1002/da.22399. PMID: 26366886. 
113. Storch EA, Arnold EB, Lewin AB, et al. The effect of cognitive-behavioral therapy versus treatment as usual for anxiety in children with autism spectrum disorders: a randomized, controlled trial. J Am Acad Child Adolesc Psychiatry. 2013

Feb;52(2):132-42 e2. doi: 10.1016/j.jaac.2012.11.007. PMID: 23357440.

114. Suveg C, Hudson JL, Brewer G, et al. Cognitive-behavioral therapy for anxietydisordered youth: secondary outcomes from a randomized clinical trial evaluating child and family modalities. J Anxiety Disord. 2009 Apr;23(3):341-9. doi: 10.1016/j.janxdis.2009.01.003. PMID: 19216048.

115. Van S, F. J A, Dirksen, et al. Costeffectiveness of cognitive-behavioral therapy versus treatment as usual for anxiety disorders in children with autism spectrum disorder. Research in Autism Spectrum Disorders. 2014 February;8(2):127-37. doi: 10.1016/j.rasd.2013.11.001. PMID: 2013783128.

116. Masia W, Carrie, Colognori, et al. Can school counselors deliver cognitivebehavioral treatment for social anxiety effectively? A randomized controlled trial. Journal of Child Psychology and Psychiatry. 2016 Mar:No Pagination Specified. doi: 10.1111/jcpp.12550. PMID: 2016-14653001.

117. Yen CF, Chen YM, Cheng JW, et al. Effects of cognitive-behavioral therapy on improving anxiety symptoms, behavioral problems and parenting stress in Taiwanese children with anxiety disorders and their mothers. Child Psychiatry Hum Dev. 2014 Jun;45(3):338-47. doi: 10.1007/s10578-0130403-9. PMID: 24002227.
118. Bernstein GA, Borchardt CM, Perwien AR, et al. Imipramine plus cognitive-behavioral therapy in the treatment of school refusal. J Am Acad Child Adolesc Psychiatry. 2000 Mar;39(3):276-83. doi: 10.1097/00004583200003000-00008. PMID: 10714046.

119. Eichstedt JA, Tobon JI, Phoenix E, et al. Worried no more: The effects of medication status on treatment response to a CBT group for children with anxiety in a community setting. Clin Child Psychol Psychiatry. 2011 Apr;16(2):265-77. doi: 10.1177/1359104510366282. PMID: 21059669.

120. Klein RG, Koplewicz HS, Kanner A. Imipramine treatment of children with separation anxiety disorder. J Am Acad Child Adolesc Psychiatry. 1992 Jan;31(1):21-8. doi: 10.1097/00004583199201000-00005. PMID: 1347039.

121. Melvin GA, Dudley AL, Gordon MS, et al. Augmenting Cognitive Behavior Therapy for School Refusal with Fluoxetine: A Randomized Controlled Trial. Child Psychiatry Hum Dev. 2016 Aug 02doi: 10.1007/s10578-016-0675-y. PMID: 27485100 .

122. Cartwright-Hatton S, McNally D, Field AP, et al. A new parenting-based group intervention for young anxious children: results of a randomized controlled trial. $\mathrm{J}$ Am Acad Child Adolesc Psychiatry. 2011 Mar;50(3):242-51 e6. doi: 10.1016/j.jaac.2010.12.015. PMID: 21334564.

123. Ozyurt, Gonca, Gencer, et al. Is triple p positive parenting program effective on anxious children and their parents? 4th month follow up results. Journal of Child and Family Studies. 2015 Dec:No Pagination Specified. doi: s10826-015-0343z. PMID: 2015-57339-001. 
124. Santacruz, I, Mendez, et al. Play therapy applied by parents for children with darkness phobia: comparison of two programmes. Child \& family behavior therapy. 2006;28(1):19-35. doi: 10.1300/J019v28n01_02. PMID: CN00709646 UPDATE.

125. Smith AM, Flannery-Schroeder EC, Gorman KS, et al. Parent cognitive-behavioral intervention for the treatment of childhood anxiety disorders: a pilot study. Behav Res Ther. 2014 Oct;61:156-61. doi: 10.1016/j.brat.2014.08.010. PMID: 25217169.

126. Thirlwall K, Cooper PJ, Karalus J, et al. Treatment of child anxiety disorders via guided parent-delivered cognitivebehavioural therapy: randomised controlled trial. Br J Psychiatry. 2013 Dec;203(6):43644. doi: 10.1192/bjp.bp.113.126698. PMID: 23969483.

127. Brown A, Creswell C, Barker C, et al. Guided parent-delivered cognitive behaviour therapy for children with anxiety disorders: Outcomes at 3- to 5-year follow-up. Br J Clin Psychol. 2017 Jan 09doi: 10.1111/bjc.12127. PMID: 28070889.

128. Hiller, R M, Apetroaia, et al. The effect of targeting tolerance of children's negative emotions among anxious parents of children with anxiety disorders: A pilot randomised controlled trial. Journal of Anxiety Disorders. 201601 Aug;42:52-9. doi: 10.1016/j.janxdis.2016.05.009. PMID: 20160447547.

129. Donovan CL, March S. Online CBT for preschool anxiety disorders: a randomised control trial. Behav Res Ther. 2014 Jul;58:24-35. doi: 10.1016/j.brat.2014.05.001. PMID: 24927471.
130. Infantino A, Donovan CL, March S. A randomized controlled trial of an audiobased treatment program for child anxiety disorders. Behav Res Ther. 2016 Apr;79:3545. doi: 10.1016/j.brat.2016.02.007. PMID: 26950257.

131. Lyneham HJ, Rapee RM. Evaluation of therapist-supported parent-implemented CBT for anxiety disorders in rural children. Behav Res Ther. 2006 Sep;44(9):1287-300. doi: 10.1016/j.brat.2005.09.009. PMID: 16313883.

132. March S, Spence SH, Donovan CL. The efficacy of an internet-based cognitivebehavioral therapy intervention for child anxiety disorders. J Pediatr Psychol. 2009 Jun;34(5):474-87. doi: 10.1093/jpepsy/jsn099. PMID: 18794187.

133. Spence SH, Donovan CL, March S, et al. Generic versus disorder specific cognitive behavior therapy for social anxiety disorder in youth: A randomized controlled trial using internet delivery. Behav Res Ther. 2017 Mar;90:41-57. doi: 10.1016/j.brat.2016.12.003. PMID: 27988427.

134. Tillfors M, Andersson G, Ekselius L, et al. A randomized trial of Internet-delivered treatment for social anxiety disorder in high school students. Cogn Behav Ther. 2011;40(2):147-57. doi: 10.1080/16506073.2011.555486. PMID: 25155815.

135. Vigerland S, Ljotsson B, Thulin U, et al. Internet-delivered cognitive behavioural therapy for children with anxiety disorders: A randomised controlled trial. Behav Res Ther. 2016 Jan;76:47-56. doi: 10.1016/j.brat.2015.11.006. PMID: 26649465. 
136. Vigerland S, Serlachius E, Thulin U, et al. Long-term outcomes and predictors of internet-delivered cognitive behavioral therapy for childhood anxiety disorders. Behav Res Ther. 2017 Mar;90:67-75. doi: 10.1016/j.brat.2016.12.008. PMID: 28012300.

137. Wuthrich VM, Rapee RM, Cunningham MJ, et al. A randomized controlled trial of the Cool Teens CD-ROM computerized program for adolescent anxiety. J Am Acad Child Adolesc Psychiatry. 2012

Mar;51(3):261-70. doi: 10.1016/j.jaac.2011.12.002. PMID: 22365462.

138. Eldar S, Apter A, Lotan D, et al. Attention bias modification treatment for pediatric anxiety disorders: a randomized controlled trial. Am J Psychiatry. 2012

Feb;169(2):213-20. doi: 10.1176/appi.ajp.2011.11060886. PMID: 22423353.

139. Waters AM, Zimmer-Gembeck MJ, Craske MG, et al. Look for good and never give up: A novel attention training treatment for childhood anxiety disorders. Behav Res Ther. 2015 Oct;73:111-23. doi: 10.1016/j.brat.2015.08.005. PMID: 26310362.

140. Britton JC, Bar-Haim Y, Clementi MA, et al. Training-associated changes and stability of attention bias in youth: Implications for Attention Bias Modification Treatment for pediatric anxiety. Dev Cogn Neurosci. 2013 Apr;4:52-64. doi: 10.1016/j.dcn.2012.11.001. PMID: 23200784.

141. Pergamin-Hight L, Pine DS, Fox NA, et al. Attention bias modification for youth with social anxiety disorder. J Child Psychol Psychiatry. 2016 Nov;57(11):1317-25. doi: 10.1111/jcpp.12599. PMID: 27435286.
142. Waters AM, Farrell LJ, Zimmer-Gembeck MJ, et al. Augmenting one-session treatment of children's specific phobias with attention training to positive stimuli. Behav Res Ther. 2014 Nov;62:107-19. doi: 10.1016/j.brat.2014.07.020. PMID: 25156398.

143. Ebrahiminejad S, Poursharifi H, Bakhshiour Roodsari A, et al. The Effectiveness of Mindfulness-Based Cognitive Therapy on Iranian Female Adolescents Suffering From Social Anxiety. Iran Red Crescent Med J. 2016 Nov;18(11):e25116. doi: 10.5812/ircmj.25116. PMID: 28191335.

144. Azadeh SM, Kazemi-Zahrani H, Besharat MA. Effectiveness of Acceptance and Commitment Therapy on Interpersonal Problems and Psychological Flexibility in Female High School Students With Social Anxiety Disorder. Glob J Health Sci. 2015 Jul 12;8(3):131-8. doi: 10.5539/gjhs.v8n3p131. PMID: 26493425.

145. Gottken T, White LO, Klein AM, et al. Short-term psychoanalytic child therapy for anxious children: a pilot study.

Psychotherapy (Chic). 2014 Mar;51(1):14858. doi: 10.1037/a0036026. PMID: 24635002.

146. Cornwall, E, Spence, et al. The effectiveness of emotive imagery in the treatment of darkness phobia in children. Behaviour Change. 1996;13(4):223-9. doi: 10.1017/S0813483900004824. PMID: 1997031833.

147. Elkins, R M, Gallo, et al. Moderators of intensive cognitive behavioral therapy for adolescent panic disorder: The roles of fear and avoidance. Child and Adolescent Mental Health. 2016;21(1):30-6. doi: 10.1111/camh.12122. 
148. Goldbeck L, Ellerkamp T. A randomized controlled trial of multimodal music therapy for children with anxiety disorders. J Music Ther. 2012 Winter;49(4):395-413. doi: 10.1093/jmt/49.4.395. PMID: 23705344.

149. Joormann, J, Unnewehr, et al. The efficacy of a cognitive-behavioral group treatment for children and adolescents with social phobia: A controlled trial. [German]. Zeitschrift fur Klinische Psychologie und Psychotherapie. 2002;31(4):284-90. PMID: 2002363778.

150. Klein AM, Rapee RM, Hudson JL, et al. Interpretation modification training reduces social anxiety in clinically anxious children. Behav Res Ther. 2015 Dec;75:78-84. doi: 10.1016/j.brat.2015.10.006. PMID: 26580081.

151. Lee SS, Victor AM, James MG, et al. School-Based Interventions for Anxious Children: Long-Term Follow-Up. Child Psychiatry Hum Dev. 2016 Apr;47(2):18393. doi: 10.1007/s10578-015-0555-X. PMID: 26003419.

152. Yoosefi L, M, Kamali, et al. Treating social phobia in children through group narrative therapy. Arts in Psychotherapy. 2014 February;41(1):16-20. doi: 10.1016/j.aip.2013.11.005. PMID: 2013786357.

153. Muris P, Merckelbach H, Holdrinet I, et al. Treating phobic children: effects of EMDR versus exposure. J Consult Clin Psychol. 1998 Feb;66(1):193-8. doi: 10.1037//0022006X.66.1.193. PMID: 9489274.

154. Muris P, Meesters C, van Melick M. Treatment of childhood anxiety disorders: a preliminary comparison between cognitivebehavioral group therapy and a psychological placebo intervention. J Behav Ther Exp Psychiatry. 2002 Sep-Dec;33(34):143-58. doi: 10.1016/S00057916(02)00025-3. PMID: 12628633.
155. Parr CJ, Cartwright-Hatton S. Social anxiety in adolescents: the effect of video feedback on anxiety and the self-evaluation of performance. Clin Psychol Psychother. 2009 Jan-Feb;16(1):46-54. doi: 10.1002/cpp.599. PMID: 19123484.

156. Chavira DA, Drahota A, Garland AF, et al. Feasibility of two modes of treatment delivery for child anxiety in primary care. Behav Res Ther. 2014 Sep;60:60-6. doi: 10.1016/j.brat.2014.06.010. PMID: 25075802.

157. Karbasi A, Arman S, Maracy MR. The efficacy of attendance and semi-attendance group cognitive-behavioral therapy (CBT) on the anxiety disorders of adolescent girls. J Res Med Sci. 2010 Sep;15(5):256-63. PMID: 21526093.

158. Leong J, Cobham VE, de Groot J, et al. Comparing different modes of delivery: a pilot evaluation of a family-focused, cognitive-behavioral intervention for anxiety-disordered children. Eur Child Adolesc Psychiatry. 2009 Apr;18(4):231-9. doi: 10.1007/s00787-008-0723-7. PMID: 19165538.

159. Monga S, Rosenbloom BN, Tanha A, et al. Comparison of child-parent and parent-only cognitive-behavioral therapy programs for anxious children aged 5 to 7 years: shortand long-term outcomes. J Am Acad Child Adolesc Psychiatry. 2015 Feb;54(2):138-46. doi: 10.1016/j.jaac.2014.10.008. PMID: 25617254.

160. Waters AM, Pittaway M, Mogg K, et al. Attention training towards positive stimuli in clinically anxious children. Dev Cogn Neurosci. 2013 Apr;4:77-84. doi: 10.1016/j.dcn.2012.09.004. PMID: 23063461. 
161. Amoros-Boix M, Rosa-Alcazar AI, Olivares-Olivares PJ. Role of the focus of attention in the treatment of generalized social phobia in adolescents. Anales De Psicologia. 2011 Oct;27(3):718-28. PMID: WOS:000293716800017.

162. Bodden DH, Dirksen CD, Bogels SM, et al. Costs and cost-effectiveness of family CBT versus individual CBT in clinically anxious children. Clin Child Psychol Psychiatry. 2008 Oct;13(4):543-64. doi: 10.1177/1359104508090602. PMID: 18927140 .

163. Bodden DH, Bogels SM, Nauta MH, et al. Child versus family cognitive-behavioral therapy in clinically anxious youth: an efficacy and partial effectiveness study. J Am Acad Child Adolesc Psychiatry. 2008 Dec;47(12):1384-94. doi: 10.1097/CHI.0b013e318189148e. PMID: 18981932.

164. Chase, Rhea M, Whitton, et al. Treatment of adolescent panic disorder: A nonrandomized comparison of intensive versus weekly CBT. Child \& Family Behavior Therapy. 2012 Oct;34(4):305-23. doi: 10.1080/07317107.2012.732873. PMID: 2012-30128-004.

165. Cobham VE, Dadds MR, Spence SH. The role of parental anxiety in the treatment of childhood anxiety. J Consult Clin Psychol. 1998 Dec;66(6):893-905. doi: 10.1037//0022-006X.66.6.893. PMID: 9874902.

166. Creswell C, Cruddace S, Gerry S, et al. Treatment of childhood anxiety disorder in the context of maternal anxiety disorder: a randomised controlled trial and economic analysis. Health Technol Assess. 2015 May;19(38):1-184, vii-viii. doi: 10.3310/hta19380. PMID: 26004142.
167. de Groot J, Cobham V, Leong J, et al. Individual versus group family-focused cognitive-behaviour therapy for childhood anxiety: pilot randomized controlled trial. Aust N Z J Psychiatry. 2007

Dec;41(12):990-7. doi: 10.1080/00048670701689436. PMID: 17999271.

168. Esbjorn BH, Somhovd MJ, Nielsen SK, et al. Parental changes after involvement in their anxious child's cognitive behavior therapy. J Anxiety Disord. 2014 Oct;28(7):664-70. doi: 10.1016/j.janxdis.2014.07.008. PMID: 25124503.

169. Garcia L, L J, Diaz C, et al. Can parent training for parents with high levels of expressed emotion have a positive effect on their child's social anxiety improvement? Journal of Anxiety Disorders. 2014 December 01;28(8):812-22. doi: 10.1016/j.janxdis.2014.09.001. PMID: 2014880948.

170. Hudson JL, Newall C, Rapee RM, et al. The impact of brief parental anxiety management on child anxiety treatment outcomes: a controlled trial. J Clin Child Adolesc Psychol. 2014;43(3):370-80. doi: 10.1080/15374416.2013.807734. PMID: 23845064.

171. Ishikawa S, Motomura N, Kawabata Y, et al. Cognitive behavioural therapy for Japanese children and adolescents with anxiety disorders: a pilot study. Behav Cogn Psychother. 2012 May;40(3):271-85. doi: 10.1017/S1352465811000713. PMID: 22217534.

172. Liber JM, Van Widenfelt BM, Utens EM, et al. No differences between group versus individual treatment of childhood anxiety disorders in a randomised clinical trial. J Child Psychol Psychiatry. 2008 Aug;49(8):886-93. doi: 10.1111/j.14697610.2008.01877.x. PMID: 18341545. 
173. Liber JM, McLeod BD, Van Widenfelt BM, et al. Examining the relation between the therapeutic alliance, treatment adherence, and outcome of cognitive behavioral therapy for children with anxiety disorders. Behav Ther. 2010 Jun;41(2):172-86. doi: 10.1016/j.beth.2009.02.003. PMID: 20412883.

174. Manassis K, Mendlowitz SL, Scapillato D, et al. Group and individual cognitivebehavioral therapy for childhood anxiety disorders: a randomized trial. J Am Acad Child Adolesc Psychiatry. 2002 Dec;41(12):1423-30. doi: 10.1097/00004583-200212000-00013. PMID: 12447028.

175. Muris P, Mayer B, Bartelds E, et al. The revised version of the Screen for Child Anxiety Related Emotional Disorders (SCARED-R): treatment sensitivity in an early intervention trial for childhood anxiety disorders. Br J Clin Psychol. 2001 Sep;40(Pt 3):323-36. doi: 10.1348/014466501163724. PMID: 11593959.

176. Nauta, Maaike H, Scholing, et al. Cognitivebehavioural therapy for anxiety disordered children in a clinical setting: Does additional cognitive parent training enhance treatment effectiveness? Clinical Psychology \& Psychotherapy. 2001 Sep-Oct;8(5):330-40. doi: 10.1002/cpp.314. PMID: 2011-15198004.

177. Nauta MH, Scholing A, Emmelkamp PM, et al. Cognitive-behavioral therapy for children with anxiety disorders in a clinical setting: no additional effect of a cognitive parent training. J Am Acad Child Adolesc Psychiatry. 2003 Nov;42(11):1270-8. doi: 10.1097/01.chi.0000085752.71002.93. PMID: 14566163.
178. Olivares R, Jose, Rosa-Alcazar A, et al. The relevance of the individualized attention in the treatment with adolescents under generalized social phobia. International journal of clinical and health psychology. 2006;6(3):565-80. PMID: CN-00634079 UPDATE.

179. Olivares O, P J, Rosa A, et al. Does individual attention improve the effect of group treatment of adolescents with social phobia? International journal of clinical and health psychology. 2008;8(2):465-81. PMID: CN-00744423 UPDATE.

180. Ollendick TH, Halldorsdottir T, Fraire MG, et al. Specific phobias in youth: a randomized controlled trial comparing onesession treatment to a parent-augmented one-session treatment. Behav Ther. 2015 Mar;46(2):141-55. doi: 10.1016/j.beth.2014.09.004. PMID: 25645164.

181. Rosa-Alcazar A, I, Boix M, et al. Contributions of cognitive restructuring in the treatment of social phobia in adolescents. Behavioral Psychology / Psicologia Conductual: Revista Internacional Clinica y de la Salud Psicologia Conductual Revista Internacional de Psicologia Clinica de la Salud. 2013;21(1):6-23. PMID: CN-01038693 NEW.

182. Schneider S, Blatter-Meunier J, Herren C, et al. The efficacy of a family-based cognitivebehavioral treatment for separation anxiety disorder in children aged 8-13: a randomized comparison with a general anxiety program. J Consult Clin Psychol. 2013 Oct;81(5):93240. doi: 10.1037/a0032678. PMID: 23607501.

183. Siqueland L, Rynn M, Diamond GS. Cognitive behavioral and attachment based family therapy for anxious adolescents: Phase I and II studies. J Anxiety Disord. 2005;19(4):361-81. doi: 10.1016/j.janxdis.2004.04.006. PMID: 15721570 . 
184. Silverman WK, Kurtines WM, Jaccard J, et al. Directionality of change in youth anxiety treatment involving parents: an initial examination. J Consult Clin Psychol. 2009 Jun;77(3):474-85. doi: 10.1037/a0015761. PMID: 19485589.

185. St-Jacques J, Bouchard S, Belanger C. Is virtual reality effective to motivate and raise interest in phobic children toward therapy? A clinical trial study of in vivo with in virtuo versus in vivo only treatment exposure. J Clin Psychiatry. 2010 Jul;71(7):924-31. doi: 10.4088/JCP.08m04822blu. PMID: 20441721.

186. Whiteside SP, Ale CM, Young B, et al. The feasibility of improving CBT for childhood anxiety disorders through a dismantling study. Behav Res Ther. 2015 Oct;73:83-9. doi: 10.1016/j.brat.2015.07.011. PMID: 26275761.

187. Wood JJ, Piacentini JC, Southam-Gerow M, et al. Family cognitive behavioral therapy for child anxiety disorders. J Am Acad Child Adolesc Psychiatry. 2006 Mar;45(3):314-21. doi: 10.1097/01.chi.0000196425.88341.b0. PMID: 16540816.

188. Walczak M, Esbjorn BH, Breinholst S, et al. Parental Involvement in Cognitive Behavior Therapy for Children with Anxiety Disorders: 3-Year Follow-Up. Child Psychiatry Hum Dev. 2016 Jul 12doi: 10.1007/s10578-016-0671-2. PMID: 27405872.

189. Biederman J. Clonazepam in the treatment of prepubertal children with panic-like symptoms. J Clin Psychiatry. 1987 Oct;48 Suppl:38-42. doi: 10.1097/00004583199403000-00011. PMID: 3667548.
190. Birmaher B, Waterman GS, Ryan N, et al. Fluoxetine for childhood anxiety disorders. J Am Acad Child Adolesc Psychiatry. 1994 Sep;33(7):993-9. doi: 10.1097/00004583199409000-00009. PMID: 7961355.

191. Chavira DA, Stein MB. Combined psychoeducation and treatment with selective serotonin reuptake inhibitors for youth with generalized social anxiety disorder. J Child Adolesc Psychopharmacol. 2002 Spring;12(1):47-54. doi: 10.1089/10445460252943560. PMID: 12014595.

192. Chutko, L S, Surushkina, et al. Treatment of anxiety disorders in school maladaptation with adaptol. Neuroscience and Behavioral Physiology. 2011 June;41(5):520-4. doi: 10.1007/s11055-011-9448-z. PMID: 2011364339.

193. Compton SN, Grant PJ, Chrisman AK, et al. Sertraline in children and adolescents with social anxiety disorder: an open trial. J Am Acad Child Adolesc Psychiatry. 2001 May;40(5):564-71. doi: 10.1097/00004583200105000-00016. PMID: 11349701.

194. D'Amato G. Chlordiazepoxide in management of school phobia. Dis Nerv Syst. 1962 May;23:292-5. PMID: 13882945.

195. Dummit ES, 3rd, Klein RG, Tancer NK, et al. Fluoxetine treatment of children with selective mutism: an open trial. J Am Acad Child Adolesc Psychiatry. 1996 May;35(5):615-21. doi: 10.1097/00004583199605000-00016. PMID: 8935208.

196. Fairbanks JM, Pine DS, Tancer NK, et al. Open fluoxetine treatment of mixed anxiety disorders in children and adolescents. J Child Adolesc Psychopharmacol. 1997 Spring;7(1):17-29. doi: 10.1089/cap.1997.7.17. PMID: 9192539. 
197. Isolan L, Pheula G, Salum GA, Jr., et al. An open-label trial of escitalopram in children and adolescents with social anxiety disorder. J Child Adolesc Psychopharmacol. 2007

Dec;17(6):751-60. doi:

10.1089/cap.2007.0007. PMID: 18315447.

198. Karabekiroglu K, Karakurt MN, Yuce M, et al. Fluoxetine for the Treatment of Childhood and Adolescence Social Phobia: Factors playing a role in Efficacy. Klinik Psikofarmakoloji Bulteni-Bulletin of Clinical Psychopharmacology. 2011 Dec;21(4):317-24. doi: 10.5455/Bcp.20110810012912. PMID: WOS:000297959300004.

199. Lepola U, Leinonen E, Koponen H. Citalopram in the treatment of early-onset panic disorder and school phobia. Pharmacopsychiatry. 1996 Jan;29(1):30-2. doi: 10.1055/s-2007-979539. PMID: 8852532.

200. Mancini C, Van Ameringen M, Oakman JM, et al. Serotonergic agents in the treatment of social phobia in children and adolescents: a case series. Depress Anxiety. 1999;10(1):339. doi: 10.1002/(SICI)15206394(1999)10:1<33::AID-DA6>3.0.CO;2H. PMID: 10499188.

201. Masi G, Toni C, Mucci M, et al. Paroxetine in child and adolescent outpatients with panic disorder. J Child Adolesc Psychopharmacol. 2001 Summer;11(2):1517. doi: $10.1089 / 104454601750284054$. PMID: 11436954.

202. Mrakotsky C, Masek B, Biederman J, et al. Prospective open-label pilot trial of mirtazapine in children and adolescents with social phobia. J Anxiety Disord. 2008;22(1):88-97. doi: 10.1016/j.janxdis.2007.01.005. PMID: 17419001.
203. Renaud J, Birmaher B, Wassick SC, et al. Use of selective serotonin reuptake inhibitors for the treatment of childhood panic disorder: a pilot study. J Child Adolesc Psychopharmacol. 1999;9(2):73-83. doi: 10.1089/cap.1999.9.73. PMID: 10461817.

204. Simeon JG, Ferguson HB. Alprazolam effects in children with anxiety disorders. Can J Psychiatry. 1987 Oct;32(7):570-4. doi: 10.1177/070674378703200712. PMID: 3315169.

205. Simeon JG, Knott VJ, Dubois C, et al. Buspirone Therapy of Mixed Anxiety Disorders in Childhood and Adolescence - a Pilot-Study. Journal of Child and Adolescent Psychopharmacology. 1994 Fal;4(3):159-70. doi: DOI 10.1089/cap.1994.4.159. PMID: WOS:A1994PK77100003.

206. Zwier KJ, Rao U. Buspirone use in an adolescent with social phobia and mixed personality disorder (cluster A type). J Am Acad Child Adolesc Psychiatry. 1994 Sep;33(7):1007-11. doi: 10.1097/00004583199409000-00011. PMID: 7961339.

207. Higgins JPT, Green S, eds. Cochrane handbook for systematic reviews of interventions Version 5.1.0 [updated March 2011]: The Cochrane Collaboration; 2011.

208. Wells G, Shea B, O'connell D, et al. The Newcastle-Ottawa Scale (NOS) for assessing the quality of nonrandomised studies in meta-analyses. 2000.

209. Spence, Susan H, Donovan, et al. The treatment of childhood social phobia: The effectiveness of a social skills trainingbased, cognitive-behavioural intervention, with and without parental involvement. Journal of Child Psychology and Psychiatry. 2000;41(6):713-26. doi: 10.1111/14697610.00659 . 
210. White IR, Barrett JK, Jackson D, et al. Consistency and inconsistency in network meta-analysis: model estimation using multivariate meta-regression. Res Synth Methods. 2012 Jun;3(2):111-25. doi: 10.1002/jrsm.1045. PMID: 26062085.
211. Arándiga, Antonio V, Rodríguez, et al. Competencia social y autoestima en adolescentes con fobia social. Investigar el cambio curricular en el espacio europeo de educación superior. 2007:459-79. 